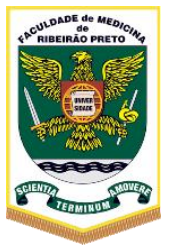

UNIVERSIDADE DE SÃO PAULO

FACULDADE DE MEDICINA DE RIBEIRÃO PRETO

DEPARTAMENTO DE BIOQUÍMICA

VANESSA ELISA PINHEIRO

Potencial biotecnológico da biomassa influência do pré-tratamento enzimático para a digestão anaeróbia e fermentação alcoólica

RIBEIRÃO PRETO - SP 


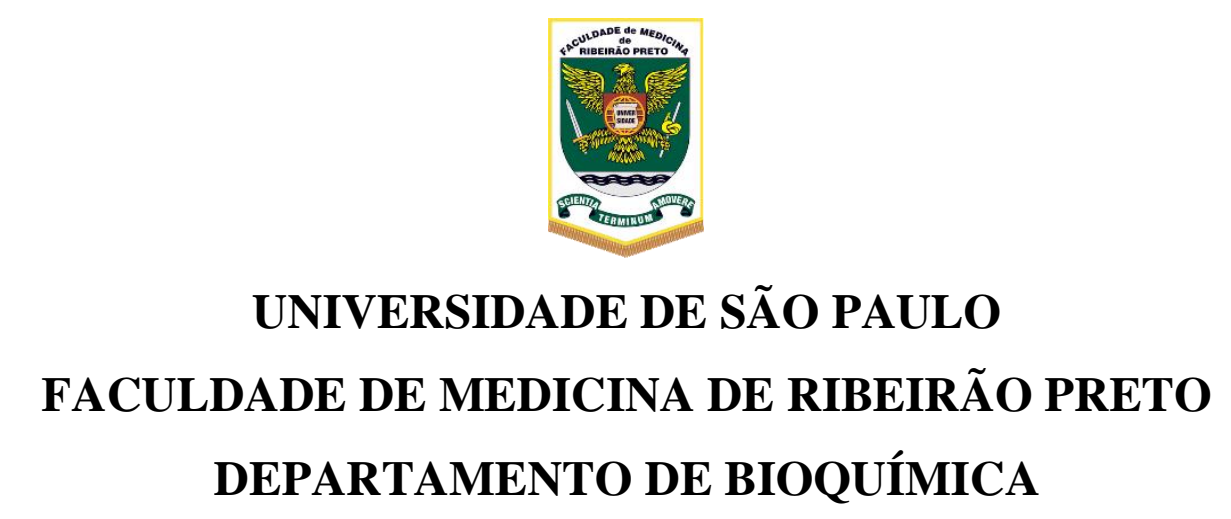

VANESSA ELISA PINHEIRO

\title{
Potencial biotecnológico da biomassa - influência do pré-tratamento enzimático para a digestão anaeróbia e fermentação alcoólica
}

\author{
Versão Original
}

Tese apresentada à Faculdade de Medicina de Ribeirão Preto - Universidade de São Paulo para obtenção do título de Doutor em Ciências - Área de Concentração: Bioquímica

Orientadora: Prof. a . Dra. Maria de Lourdes Teixeira de Moraes Polizeli

$$
\text { RIBEIRÃO PRETO - SP }
$$


Autorizo a reprodução e divulgação total ou parcial deste trabalho, por qualquer meio convencional ou eletrônico, para fins de estudo e pesquisa, desde que citada a fonte.

\section{FICHA CATALOGRÁFICA}

Pinheiro, Vanessa Elisa

Potencial biotecnológico da biomassa - influência do pré-tratamento enzimático para a digestão anaeróbia e fermentação alcoólica. Ribeirão Preto, 2021.

278 f.: il.; $30 \mathrm{~cm}$

Tese de doutorado, apresentada à Faculdade de Medicina de Ribeirão Preto/USP. Área de concentração: Bioquímica.

Orientadora: Polizeli, Maria de Lourdes Teixeira de Moraes.

1. Biomassa 2. Enzimas 3. Farelo de milho

4. Dejeto bovino 5. Digestão anaeróbia

6. Metano 7. Ácidos graxos voláteis

8. Fermentação alcoólica

9. Etanol 
PINHEIRO, V. E. Potencial biotecnológico da biomassa - influência do pré-tratamento enzimático para a digestão anaeróbia e fermentação alcoólica. 2021. 278 p. Tese (Doutorado em Ciências - área de concentração Bioquímica) - Faculdade de Medicina de Ribeirão Preto, Universidade de São Paulo, Ribeirão Preto, 2021.

Aprovado em:

\section{Banca Examinadora}

Prof. Dr.

Instituição:

Julgamento:

Prof. Dr.

Instituição:

Julgamento:

Prof. Dr.

Instituição:

Julgamento:

Prof. Dr.

Instituição:

Julgamento:

Prof. Dr.

Instituição:

Julgamento: 


\section{Agradecimentos}

À Prof ${ }^{a}$. Dra. Maria de Lourdes Teixeira de Moraes Polizeli pela orientação, paciência e apoio durante o desenvolvimento deste trabalho de doutoramento;

À Prof ${ }^{a}$ Dra. Valeria Reginatto Spiller pela colaboração no desenvolvimento dos experimentos de biogás;

A todos os professores do departamento de Bioquímica da Faculdade de Medicina de Ribeirão Preto - USP que auxiliaram em minha formação; e a Maria Ivone Campos Fonseca, secretária do programa de pós-graduação em Bioquímica, pela disponibilidade e paciência em responder todas as minhas dúvidas com competência e dedicação;

À Faculdade de Filosofia, Ciência e Letras de Ribeirão Preto - USP pela estrutura necessária para realização deste trabalho.

A todos os meus amigos e técnicos de laboratório pelas discussões e compartilhamento de conhecimentos durante o desenvolvimento das atividades realizadas, além da companhia diária e dos bons momentos partilhados. Meus sinceros agradecimentos a Alex Graça Contato, Ana Silvia de Almeida Scarcella, Ana Claudia Vici, Emanuelle Neiverth de Freitas, Enrico Spiropulos, Inaiá Ramos Aguiar, José Carlos Salgado, Juliana da Conceição Infante, Malena Martinez Pérez, Mariana Cereia, Monica Stropa Ferreira Nozawa, Paula Zaghetto de Almeida, Robson Carlos Alnoch, Rosymar Coutinho de Lucas e Tássio Brito de Oliveira.

Um agradecimento especial aqueles que além de colegas de trabalho, se tornaram amigos pra uma vida toda: Juliana, Paula, Alex, Emanuelle e Inaiá.

À Universidade de Borås pela recepção e estrutura para realização dos experimentos do Doutorado Sanduíche. Ao Prof. Dr. Mohammad Taherzadeh, chefe do departamento de Resource Recovery, pela aceitação em seu grupo de pesquisa. À Prof ${ }^{a}$. Dra. Ilona H. Sarvath pela orientação no exterior e por todas as sugestões, críticas e apoio para o sucesso deste trabalho.

À minha mãe Ivani e a meu pai Valdecir, pelo amor, compreensão, conselhos e mais do que tudo, por me apoiarem em cada decisão. Vocês estavam presentes em cada etapa de minha jornada acadêmica, sendo de perto ou de longe o meu ponto de retorno, minha base e minha motivação. A vocês continuo agradecendo a absolutamente tudo.

À minha amada irmã Lívia, pelo carinho, amor e companheirismo. Obrigada pelas inúmeras conversas, conselhos, risadas e lágrimas compartilhadas. Você esteve comigo nesta longa jornada e sou imensamente grata por tê-la em minha vida. Amo você. 
À minha inseparável “dearest from Sweden”, Begüm Bilgiç. Uma amizade que foi fundamental para meus dias de laboratório e também de vivência durante o doutorado sanduíche.

Ao Conselho Nacional de Desenvolvimento Científico e Tecnológico (CNPq) pelo apoio financeiro através de bolsa no Brasil.

À Coordenação de Aperfeiçoamento de Pessoal de Ensino Superior (CAPES) pelo apoio financeiro através de bolsa no exterior.

A todos os que contribuíram para a realização deste trabalho, direta ou indiretamente, fica a minha gratidão. 


\section{Apoio e suporte financeiro}

1) CNPq, Conselho Nacional de Desenvolvimento Científico e Tecnológico - Brasil. Número de processo: 142139/2017-3.

2) Programa de Doutorado-sanduíche no Exterior - CAPES/PRINT, Coordenação de Aperfeiçoamento de Pessoal de Nível Superior - Brasil - Edital nº 41/2017, Número de processo: 88887.368240/2019-00.

3) FAPESP, Fundação de Amparo à Pesquisa do Estado de São Paulo - Brasil. Número de processos: 2014/50884-5; 2018/07522-6.

4) Fundação de Apoio ao Ensino, Pesquisa e Assistência - FAEPA (FMRP/USP).

5) Faculdade de Medicina de Ribeirão Preto - FMRP/USP.

6) Faculdade de Filosofia, Ciências e Letras de Ribeirão Preto - FFCLRP/USP. 
Pesquisar é acordar para o mundo... 


\section{Resumo}

PINHEIRO, V. E. Potencial biotecnológico da biomassa - influência do pré-tratamento enzimático para a digestão anaeróbia e fermentação alcoólica. 2021. 278 p. Tese (Doutorado em Ciências - área de concentração Bioquímica) - Faculdade de Medicina de Ribeirão Preto, Universidade de São Paulo, Ribeirão Preto, 2021.

O consumo de energia aumentou à medida que a população mundial cresceu e os países se industrializaram. A energia é vital para praticamente todas as atividades humanas, por exemplo, iluminação, produção alimentícia, aquecimento, cozimento de alimentos, produção industrial e transporte. Atualmente, o bem-estar mundial e a competitividade industrial dependem da sustentabilidade e acessibilidade a energia. Os biocombustíveis são alternativas ecológicas de energia renovável que minimizam a dependência de fontes de energia fóssil. A biomassa pode ser utilizada como substrato para esses combustíveis renováveis, porém o pré-tratamento do substrato é uma etapa útil neste processo, pois facilita e acelera a hidrólise de materiais compostos. O objetivo deste trabalho foi (1) triar, selecionar, estudar e otimizar a formulação de coquetéis enzimáticos para a hidrólise de biomassa, onde as enzimas fornecidas foram tanto de origem comercial (Trichoderma reesei, Novozymes®) quanto de cultivo de microorganismos (Aspergillus brasiliensis e Aspergillus tamarii Kita); (2) estudar a digestão anaeróbia da biomassa selecionada ( $i$ ) quando hidrolisada ou não e (ii) em co-digestão com dejeto bovino; e (3) comparar a fermentação alcoólica da biomassa selecionada quando a hidrólise enzimática e fermentação são simultâneas ou separadas. Planejamentos experimentais de mistura foram realizados para otimizar a conversão de substratos enzimáticos em açúcares simples. O extrato bruto rico em amilase (AMI) teve uma influência positiva significativa na hidrólise do farelo de milho (Zea mays), maximizando a liberação de Açúcar Redutor (AR) $(173 \mu \mathrm{mol} / \mathrm{mL})$. Celluclast ${ }^{\mathrm{TM}}$, rico em celulase, teve um efeito significativo na hidrólise da casca de banana (Musa ssp.), maximizando a produção de AR $(175 \mu \mathrm{mol} / \mathrm{mL})$. Estudos posteriores mostraram que o pré-tratamento enzimático de farelo de milho por AMI, contendo principalmente enzimas degradantes de amido, quando numa carga enzimática de $1: 10 \mathrm{~m} / \mathrm{v}(\mathrm{g}$ de massa seca do substrato/ mL de extrato enzimático adicionado) a $45{ }^{\circ} \mathrm{C}$ por $48 \mathrm{~h}$, resultou na hidrólise de $79 \pm 5 \%$ dos carboidratos do substrato. Além disso, os testes de produção de metano mostraram que houve um aumento significativo na produção específica desse gás durante os ensaios em batelada quando as enzimas foram adicionadas diretamente ao digestor ou quando o hidrolisado de farelo de milho foi digerido. Além disso, foram encontrados efeitos sinérgicos ao co-digerir farelo de milho e dejeto bovino, levando a uma maior produção de metano (280 NmL / g SV) do que (200 NmL / g SV) a calculada com base no potencial de $\mathrm{CH}_{4}$ dos substratos individuais. Com relação aos efeitos a longo prazo, os experimentos semicontínuos em escala laboratorial também demonstraram que a co-digestão de farelo de milho e dejeto bovino (1:1 na base de SV) levou a um processo estável ao longo do período de tempo estudado de 140 dias, atingindo uma taxa de carga orgânica de $3 \mathrm{~g} \mathrm{SV/L/dia} \mathrm{e} \mathrm{atingindo} \mathrm{uma}$ produção diária de metano de 1280,12 \pm 99,4 $\mathrm{NmL} \mathrm{CH}_{4} /$ dia. No entanto, quando o farelo de milho foi investigado em mono-digestão, ou quando AMI foi adicionado diretamente durante a digestão semi-contínua do farelo, o acúmulo de ácidos graxos voláteis foi observado, o que levou a uma redução no $\mathrm{pH}$. Por fim, a fermentação alcoólica a partir do farelo de milho présacarificado com extrato enzimático bruto produzido por fungo filamentoso selvagem apresentou $100 \%$ de potencial etanólico com relação ao potencial teórico, o que mostra a promissora aplicação das enzimas brutas em processos industriais bioenergéticos.

Palavras-chave: biomassa, enzimas, farelo de milho, dejeto bovino, digestão anaeróbia, metano, ácidos graxos voláteis, fermentação alcoólica, etanol 


\begin{abstract}
PINHEIRO, V. E. Potencial biotecnológico da biomassa - influência do pré-tratamento enzimático para a digestão anaeróbia e fermentação alcoólica. 2021. 278 p. Tese (Doutorado em Ciências - área de concentração Bioquímica) - Faculdade de Medicina de Ribeirão Preto, Universidade de São Paulo, Ribeirão Preto, 2021.
\end{abstract}

Energy consumption has enhanced as the world population has grown and countries became industrialized. Energy provides vital power for practically all human activities, e.g., lighting, food production, heating, cooking, industrial production, and transportation. Currently, the overall world well-being and industrial competitiveness are dependent on the sustainability and affordability of energy. Biofuels are environmental-friendly renewable energy alternatives which minimize the dependence on fossil energy sources. Biomass can be used as substrates for renewable fuels, nevertheless the substrate pretreatment is a step useful to this process, since it facilitates and accelerates the hydrolysis of compounded materials. The aim of this work was (1) to screen, select, study and optimize a cocktail formulation for biomass hydrolysis, where the enzymes were provided from both commercial source (Trichoderma reesei, Novozymes ${ }^{\circledR}$ ) and microorganism cultivation (Aspergillus brasiliensis and Aspergillus tamarii Kita); (2) to study the anaerobic digestion of the selected biomass $(i)$ when hydrolyzed or not and (ii) in codigestion with cow manure; and (3) to compare the alcoholic fermentation of the selected biomass when enzymatic hydrolysis and fermentation are simultaneous or separated. Mixture experimental designs were performed to optimize the enzymatic substrates conversion into simple sugars. Crude extract rich in amylase (AMI) had a significant positive influence on cornmeal (Zea mays) hydrolysis by maximizing the Reducing Sugar (RS) yield $(173 \mu \mathrm{mol} / \mathrm{mL})$ and Celluclast ${ }^{\mathrm{TM}}$, rich in cellulase had a significant effect on banana (Musa spp) peel hydrolysis by maximizing the RS yield $(175 \mu \mathrm{mol} / \mathrm{mL})$. Further studies, showed that the enzymatic pretreatment of cornmeal by AMI, containing mainly starch-degrading enzymes, with an enzyme load of $1: 10 \mathrm{w} / \mathrm{v}$ ( $\mathrm{g}$ of dry weight of substrate/ $\mathrm{mL}$ of enzyme extract added) at $45^{\circ} \mathrm{C}$ for $48 \mathrm{~h}$ resulted in the hydrolysis of $79 \pm 5 \%$ of substrate carbohydrates. Furthermore, the methane production tests showed that there was a significant enhancement in the specific gas production observed during the batch assays, both when enzymes were directly added to the digester or when cornmeal hydrolysate was digested. Additionally, synergetic effects were found when co-digesting cornmeal and cow manure, leading to higher methane yield (280 $\mathrm{NmL} / \mathrm{g}$ VS) than that $\left(200 \mathrm{NmL} / \mathrm{g}\right.$ VS) calculated on the basis of $\mathrm{CH}_{4}$ potential of the individual substrates. Concerning long term effects, the laboratory-scale semi-continuous experiments similarly demonstrated that the co-digestion of cornmeal and cow manure (1:1 volatile solid (VS) basis) led to a stable process over the studied time period of 140 days reaching an organic loading rate of $3 \mathrm{~g} \mathrm{VS} / \mathrm{L} /$ day and reaching a daily methane production of $1280.12 \pm 99.4 \mathrm{NmL}$ $\mathrm{CH}_{4} /$ day. Nevertheless, when cornmeal was investigated in mono-digestion, along with when the enzyme extract was directly added during semi-continuous digestion of cornmeal, volatile fatty acids accumulation was observed leading to a reduction in $\mathrm{pH}$. Finally, the alcoholic fermentation from pre-saccharified cornmeal with crude enzymatic extract produced by wild filamentous fungus showed a $100 \%$ ethanolic potential in relation to the theoretical potential, which shows the promising application of crude enzymes in bioenergetic industrial processes.

Keywords: biomass, enzymes, cornmeal, cow manure, anaerobic digestion, methane, volatile fatty acids, alcoholic fermentation, ethanol 


\section{Lista de figuras}

Figura 1. Estrutura da celulose demonstrando o padrão de ligação de hidrogênio inter e intracadeia.

Figura 2. Estruturas representativas das hemiceluloses predominantes. (A) Oacetilgalactoglucomananas, (B) arabino-4-O-metilglucuroxilana, (C) glucomananas e (D) Oacetil-4-O metilglucuranoxilanas.

Figura 3. Precursores da lignina. (A) álcool cumárico, (B) álcool coniferílico e (C) álcool sinapílico .5

Figura 4. Polímeros constituintes do amido. (A) amilose e (B) amilopectina ...........................5

Figura 5. Ação das celulases na estrutura cristalina e amorfa da celulose ..................................7

Figura 6. Representação simplificada da xilana com ramificações e os locais de hidrólise das enzimas .

Figura 7. Representação esquemática do sistema enzimático envolvido na degradação do amido 10

Figura 8. Principais etapas e percursos do processo de DA .14

Figura 9. Esquema do modelo de aparato experimental para medição do volume de metano produzido .38

Figura 10. Seleção de biomassa. Produção de AR ( $\mu \mathrm{mol} / \mathrm{mL})$ após 24 horas de hidrólise a 50 ${ }^{\circ} \mathrm{C}, \mathrm{pH}$ 5,0 com os extratos enzimáticos AMI (A), XIL (B) e CEL (C)

Figura 11. Superfície de resposta obtida pelo design de misturas entre extratos brutos aplicados no farelo de milho (A), casca de banana $(\mathbf{B})$ e farelo de grão de sorgo $(\mathbf{C})$

Figura 12. Superfície de resposta obtida pelo design de misturas entre biomassas quando aplicado AMI (A), XIL (B) e CEL (C)

Figura 13. Eletroforese (azul) e zimograma (marrom) em gel de poliacrilamida em condições não - desnaturantes (PAGE 10\%) do consórcio enzimático produzido por $A$. brasiliensis.

Figura 14. Temperatura ótima de dosagem da amilase bruta no consórcio enzimático AMI ....60

Figura 15. pH ótimo de dosagem da amilase bruta no consórcio enzimático AMI

Figura 16. Hidrólises relativas (\%) referentes a produção de AR variando-se a concentração do farelo de milho .62

Figura 17. Hidrólise (\%) do farelo de milho variando-se o tempo de tratamento .63

Figura 18. Superfície de resposta obtida a partir do modelo de segunda ordem .67 
Figura 19. AR produzido na hidrólise do farelo de milho sob influência somente da temperatura

Figura 20. Produção relativa de AR (\%). (1) farelo de milho puro e (2) é o farelo de milho acrescido de $A$. brasiliensis

Figura 21. Produção acumulativa de metano, onde a é o controle positivo (glucose), • farelo de milho não tratado, $\boldsymbol{\Delta}$ hidrolisado de farelo de milho (pré-tratado com AMI) .72

Figura 22. Configuração experimental dos testes de DA em batelada, que ocorreram em frascos de vidro de $118 \mathrm{~mL}$, sem ajuste inicial do $\mathrm{pH}$ do meio

Figura 23. Diagrama esquemático da configuração experimental dos ensaios em batelada para seleção de substrato e CoDA na razão substrato para inóculo (S/I) de 1:2 na base de SV

Figura 24. Aparato experimental da DA semi-contínua. (A) Reator de vidro 2,2 L, (B) reatores em banho termostatizado, $(\mathbf{C})$ reatores conectados ao instrumento $\mu$-flow on-line (Bioprocess control $\mathrm{AB}$ ) para coleta de dados da produção de metano

Figura 25. Ilustração esquemática do AMPTS II. (A) reator de garrafa de vidro de $2200 \mathrm{~mL}$, (B) frasco de vidro com $\mathrm{NaOH},(\mathbf{C})$ dispositivo de medição da produção de metano, (D) processamento de dados

Figura 26. AR (g/L) liberado seguindo as respectivas proporções entre farelo de milho $(g)$ e AMI (mL) . .95

Figura 27. AR total $(\mu \mathrm{mol} / 11 \mathrm{~mL})$ liberado no sistema a cada 24 horas durante a hidrólise do farelo de milho (na carga de sólidos de 10\%) de acordo com as proporções: $\square$ 1:10 e $\square$ 1:8 (g de farelo: $\mathrm{mL}$ de AMI)

Figura 28. Produção acumulativa de metano utilizando o lodo termofílico como inóculo na proporção S/I de 0,5

Figura 29. Produção acumulativa de metano (NmL/g SV) utilizando o dejeto bovino como inóculo na proporção $\mathrm{S} / \mathrm{I}$ de 0,5 , após a primeira e a segunda alimentação 100

Figura 30. Produção acumulativa de metano (NmL/g SV) nos testes de CoDA sob a proporção S/I de 0,5 utilizando como inóculo o lodo termofílico 103

Figura 31. Resultados semanais da digestão semi-contínua. pH, razão AGV/AT e média diária da produção de metano $\left(\mathrm{NmL} \mathrm{CH} \mathrm{CH}_{4} /\right.$ dia) dos reatores $(\mathbf{A}) \rightarrow \mathrm{M} 1$ e $\cdots \cdot \cdot \cdot \mathrm{M} 2,(\mathbf{B}) \simeq \mathrm{MEx} 1$, .*.*MEx2, (C) $\multimap-$ MDe1 e $\cdot \circ \cdot \operatorname{MDe} 2$ 108

Figura 32. Taxa de degradação dos substratos (\%) durante a DA semi-contínua dos reatores $\rightarrow-M 1$ e $\cdot \cdot \cdot \cdot M 2, \mp$ MEx1, $\cdot \cdots \cdot M E x 2,-\infty$ MDe1 e $\cdot \cdot \circ \cdot \operatorname{MDe} 2$ 116 


\section{Lista de tabelas}

Tabela 1. Resumo das principais enzimas responsáveis pela bioconversão da biomassa vegetal, com destaque para seus respectivos alvos e produtos

Tabela 2. Potencial de aplicação dos AGVs .23

Tabela 3. Valores utilizados no DCCR para a hidrólise do farelo de milho por AMI 36

Tabela 4. Atividades enzimáticas presentes em cada extrato bruto .42

Tabela 5. Design de mistura: hidrólise da biomassa durante 24 horas utilizando extratos das enzimas XIL, AMI e CEL e suas diferentes misturas. A variável de resposta utilizada foi a concentração de $\mathrm{AR}(\mu \mathrm{mol} / \mathrm{mL})$ liberado .....

Tabela 6. Análise de variância (ANOVA) referente ao design de mistura envolvendo a produção de $\mathrm{AR}(\mu \mathrm{mol} / \mathrm{mL})$ obtida pela hidrólise enzimática ocasionada por misturas entre os extratos AMI, XIL e CEL

Tabela 7. Design de mistura: hidrólise da biomassa (farelo de milho, casca de banana, farelo do grão de sorgo) aplicando-se extratos enzimáticos XIL, AMI e CEL e suas diferentes misturas. A variável de resposta utilizada foi a concentração de $\mathrm{AR}(\mu \mathrm{mol} / \mathrm{mL})$ liberado .53

Tabela 8. Análise de variância (ANOVA) referente ao design de mistura envolvendo a produção de $\mathrm{AR}(\mu \mathrm{mol} / \mathrm{mL})$ obtida pela aplicação dos extratos brutos nas misturas das biomassas farelo de milho, casca de banana e farelo de grão de sorgo

Tabela 9. Matriz do DCCR e os valores experimentais avaliados no efeito da temperatura e $\mathrm{pH}$ sobre a hidrólise do farelo de milho pelo consórcio enzimático AMI

Tabela 10. Efeitos e interações calculados para as variáveis estudadas na hidrólise do farelo de milho por AMI

Tabela 11. Análise de variância (ANOVA) do DCCR para estudo das variáveis independentes temperatura e $\mathrm{pH}$ durante a hidrólise do farelo de milho por AMI 66

Tabela 12. Conteúdo de ST e SV dos substratos e inóculo utilizados nos ensaios de produção de metano

Tabela 13. Dados cinéticos obtidos pelo modelo de Gompertz modificado para produção de metano a partir do farelo de milho tratado e não tratado

Tabela 14. Proporções entre o farelo de milho e AMI testadas para maximização da hidrólise

Tabela 15. Configuração experimental da CoDA em batelada para seleção de substrato .84

Tabela 16. Descrição dos parâmetros aplicados na DA semi-contínua .86

Tabela 17. Configuração experimental da digestão semi-contínua .88 
Tabela 18. Proporção entre farelo de milho e extrato enzimático aplicada nos testes de hidrólise, com consequente liberação de AR no sistema

Tabela 19. Conteúdo de ST e SV dos substratos e inóculo utilizados na DA em batelada e semicontínua ..... .98

Tabela 20. Variáveis cinéticas obtidas pelo modelo de Gompertz modificado para o acúmulo de metano a partir dos substratos testados na mono e co-digestão .106

Tabela 21. Concentração de etanol e rendimento etanólico resultante dos processos fermentativos com farelo de milho 


\section{Lista de abreviações e símbolos}

AGV Ácidos graxos voláteis

AMI Extrato bruto otimizado para produção de amilase por Aspergillus brasiliensis

AMPTS Automatic methane potential test system

AR Açúcar redutor

atm Atmosfera

CEL Extrato comercial Celluclast ${ }^{\mathrm{TM}}$ (Novozymes $\left.{ }^{\circledR}\right)$ contento celulases produzidas por Trichoderma reesei diluído dez vezes

CG Cromatografia gasosa

CLAE Cromatografia líquida de alta eficiência

CO Carga orgânica

CoDA Co-digestão anaeróbia

CSTR Continuous stirring tank reactor

d Dias

DA Digestão anaeróbia

DCCR Delineamento composto central rotacional

DO Demanda de oxigênio

EJ Exajoule. Corresponde a 1 quintilhão $\left(10^{18}\right)$ de joules

g Grama

HFSim Hidrólise e fermentação simultâneas

HFSep Hidrólise e fermentação separadas

$\mathbf{H}_{\max } \quad$ Acúmulo máximo de metano

kDa Kilodaltons

L Litros

$\boldsymbol{\mu L} \quad$ Microlitros

M Molar

mg Miligramas

min Minutos

mL Mililitros

MM Massa molecular

$\mathbf{m m}^{2} \quad$ Milímetros quadrados

$\mathbf{m}^{\mathbf{3}} \quad$ Metros cúbicos

MSR Metodologia de superfícies de respostas

$\mathbf{m} / \mathbf{v} \quad$ Massa por volume

NmL Mililitros medido nas condições normais de temperatura e pressão

PAGE Eletroforese em gel de poliacrilamida

pH Potencial hidrogeniônico

pNPG $\quad p$-Nitrofenil- $\beta$-D-glucopiranosídeo

Rm Velocidade máxima de produção de metano

rpm Rotações por minuto 


$\begin{array}{ll}\text { q.s.p. } & \text { Quantidade suficiente para } \\ \mathbf{S} & \text { Segundos } \\ \text { S/I } & \text { Razão entre substrato e inóculo } \\ \mathbf{S T} & \text { Sólidos totais } \\ \text { SV } & \text { Sólidos voláteis } \\ \text { TD } & \text { Taxa de degradação } \\ \text { TEMED } & \text { Tetrametiletilenodiamina } \\ \text { TRH } & \text { Tempo de retenção hidráulica } \\ \text { Tris } & \text { Tris(hidroximetil)aminometano } \\ \mathbf{v} / \mathbf{v} & \text { Volume por volume } \\ \mathbf{X I L} & \text { Extrato bruto otimizado para produção de xilanase por Aspergillus Tamarii Kita } \\ { }^{\circ} \mathbf{C} & \text { Grau Celsius } \\ \boldsymbol{\%} & \text { Por cento } \\ \boldsymbol{\mu} \mathbf{g} & \text { Microgramas } \\ \boldsymbol{\mu} \text { Mol } & \text { Micromolar } \\ \boldsymbol{\alpha} & \text { Alfa } \\ \boldsymbol{\beta} & \text { Beta } \\ \boldsymbol{\lambda} & \text { Fase de latência }\end{array}$




\section{Sumário}

Agradecimentos ........................................................................................................................................i

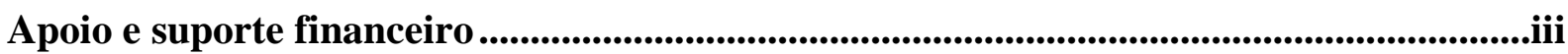

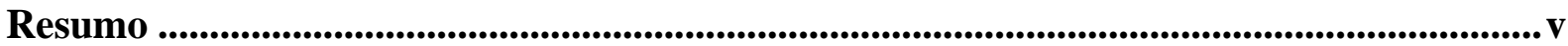

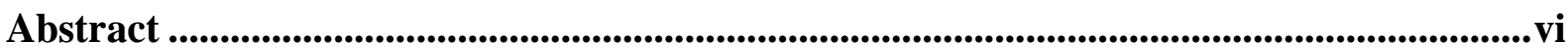

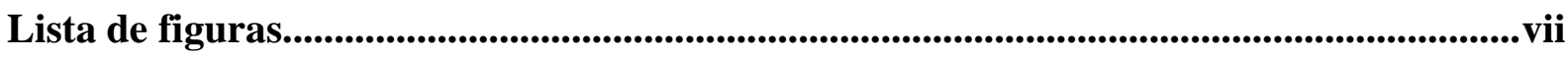

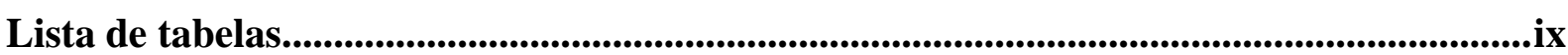

Lista de abreviações e símbolos ...............................................................................................xi

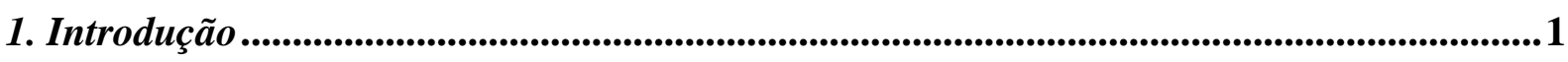

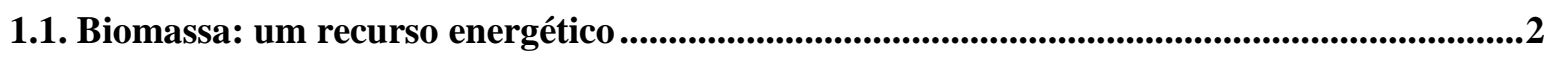

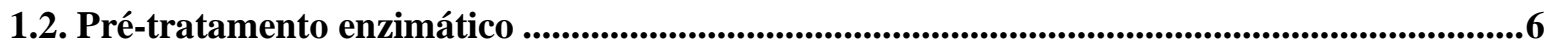

1.2.1. Enzimas degradantes da holocelulose e amido .......................................................

1.3. Otimização de processos por meio da metodologia de superfície de resposta: variáveis de processo e de mistura ..............................................................................................................................11

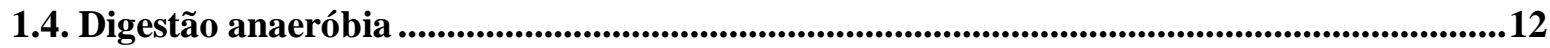

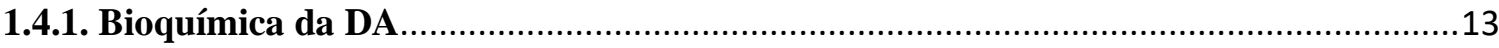

1.4.1.1. Reações básicas envolvidas no processo de DA ….....................................................15

1.4.2. Parâmetros ambientais e operacionais ........................................................................ 16

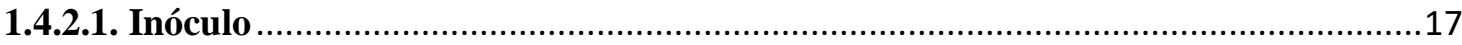

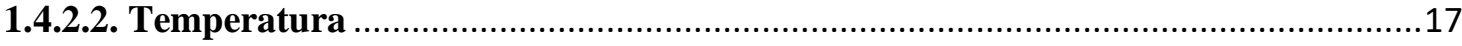

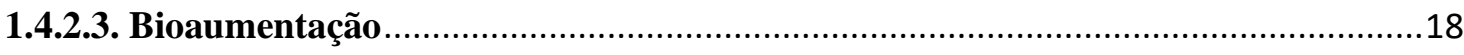

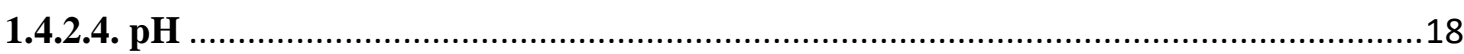

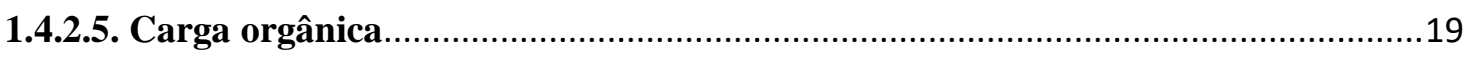

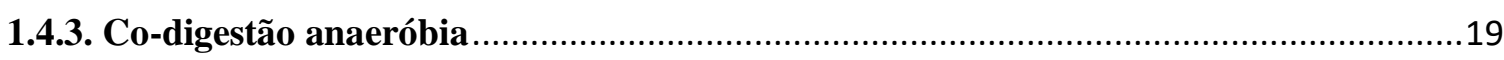

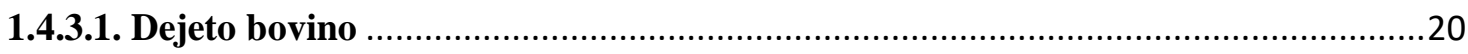

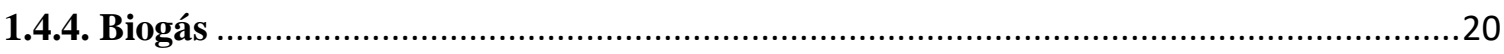

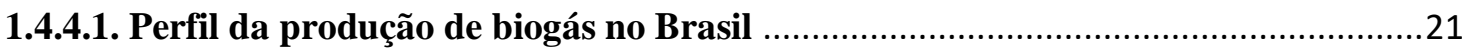

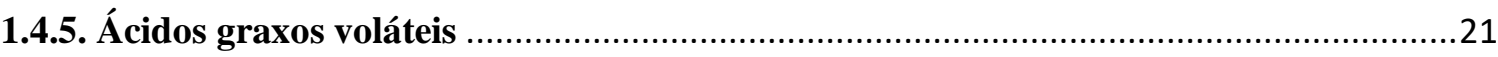

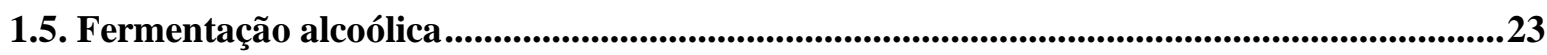

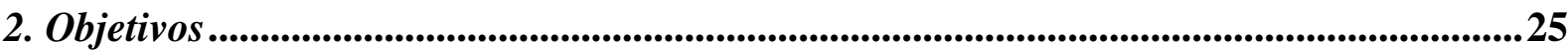

Parte 1. Screening, hidrólise \& aplicação da biomassa .......................................................28

3. Material \& Métodos - Parte 1 ........................................................................................................29

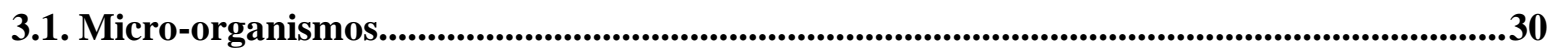

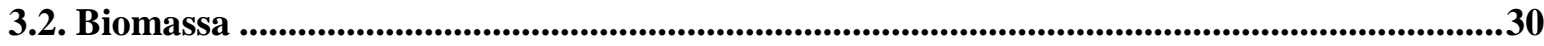

3.3. Produção de enzimas...................................................................................................................................31

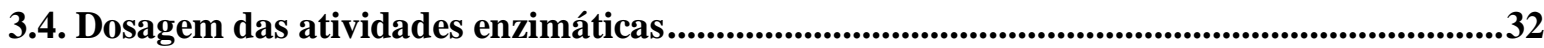


3.5. Determinação de Proteínas .............................................................................................................32

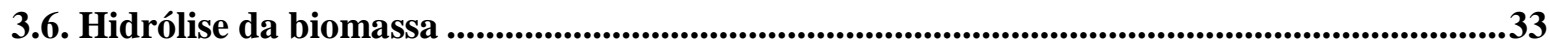

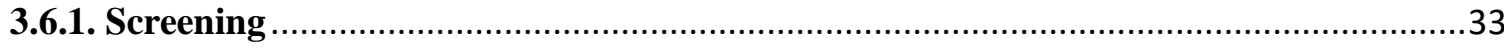

3.6.2. Planejamento de misturas e análises estatísticas ......................................................... 33

3.7. Caracterização do extrato enzimático produzido por $A$. brasiliensis ....................................35

3.7.1. Gel de eletroforese em condições não desnaturantes (PAGE) e zimograma .................35

3.7.2. Caracterização quanto a temperatura e pH ótimos da amilase presente em AMI ..35

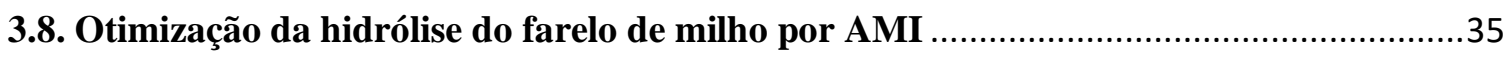

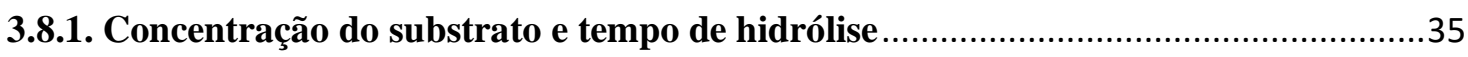

3.8.2. Estudo da temperatura e pH de hidrólise por planejamento experimental e análises

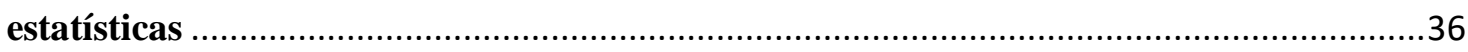

3.9. Efeito da temperatura sobre a hidrólise do farelo de milho ..................................................37

3.10. Hidrólise do farelo de milho acrescido do micélio de $A$. brasiliensis ..................................37

3.11. Ensaios do potencial de produção de metano em modo descontínuo...................................37

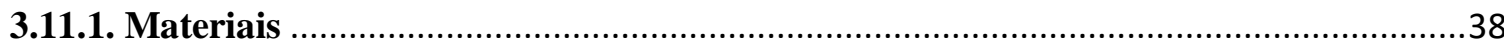

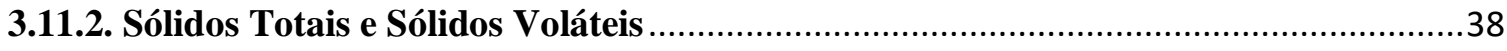

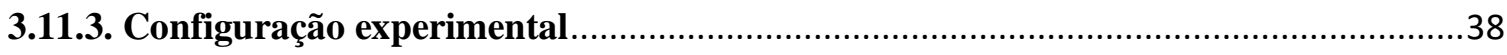

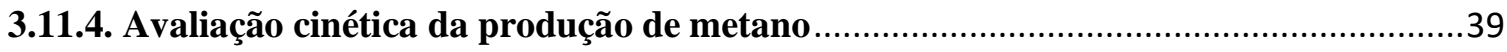

3.12. Análises estatísticas ...........................................................................................................................40

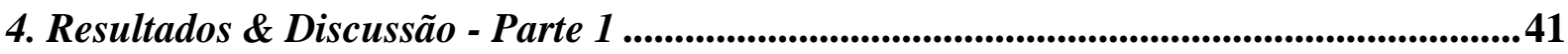

4.1. Produção dos extratos enzimáticos ..........................................................................................42

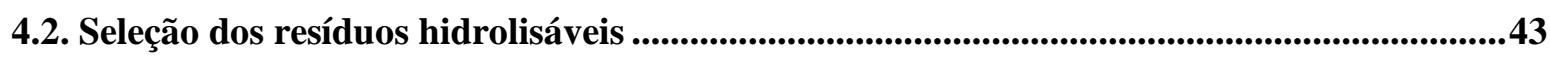

4.3. Variáveis de resposta, ajuste de modelo e análises de regressão ..........................................47

4.3.1. Planejamento de mistura com extratos enzimáticos ...............................................4

4.3.2. Planejamento de misturas com a biomassa ............................................................ 52

4.4. Caracterização do extrato enzimático produzido por $A$. brasiliensis.....................................58

4.4.1. Gel de eletroforese em condições não desnaturantes (PAGE) e zimograma ................58

4.4.2. Caracterização quanto a temperatura e pH ótimos da amilase presente em AMI ......59

4.5. Otimização da hidrólise do farelo de milho por AMI ..................................................................61

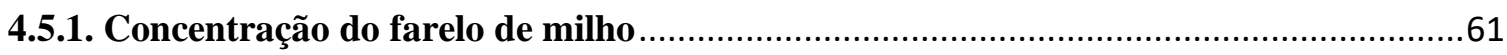

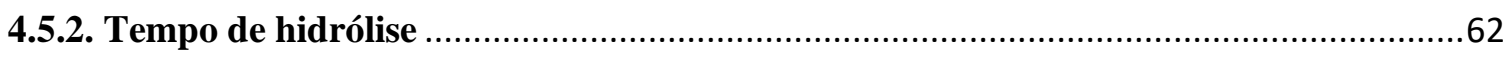

4.5.3. Otimização da temperatura e pH por planejamento experimental e análise de

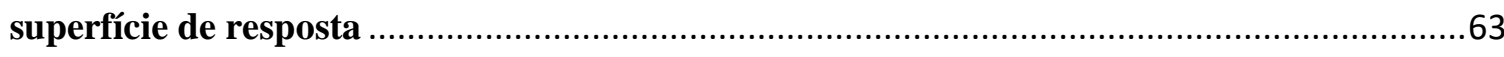

4.5.4. Efeito da temperatura sobre a hidrólise do farelo de milho ...................................67

4.6. Hidrólise do farelo de milho acrescido do micélio de $A$. brasiliensis ..................................68

4.7. Potencial do farelo de milho para a produção de metano .....................................................69

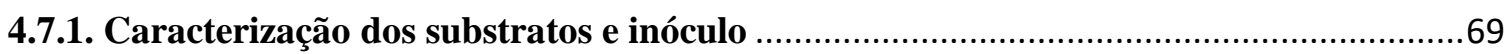


4.7.2. Rendimento e cinética da produção de metano ………………………........................ 71

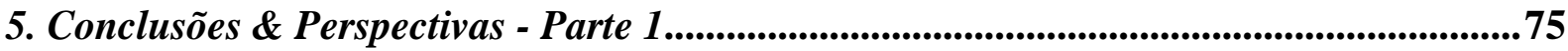

Parte 2. Digestão anaeróbia \& fermentação alcoólica..........................................................77

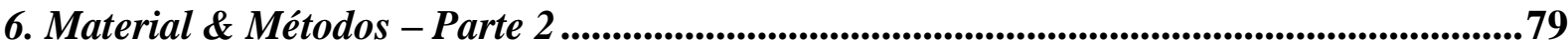

6.1. Substrato e inóculo para DA...........................................................................................................80

6.2. Produção do extrato enzimático AMI e dosagem da atividade amilolítica ...........................80

6.3. Otimização da hidrólise ...................................................................................................................81

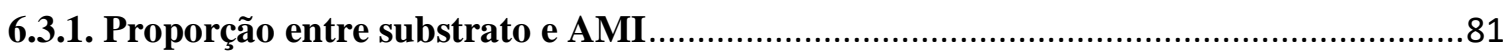

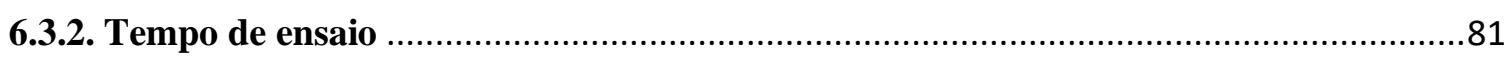

6.4. Configuração experimental em batelada ..............................................................................81

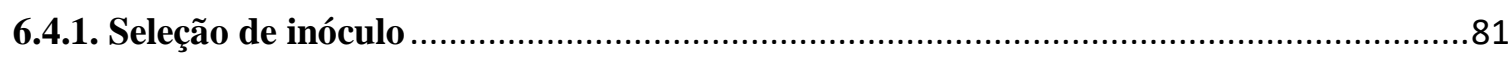

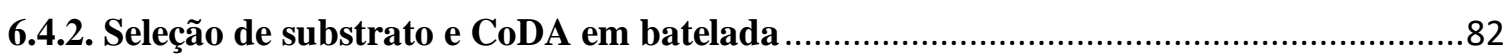

6.4.3. Mensuração do gás nos experimentos em batelada ...................................................... 84

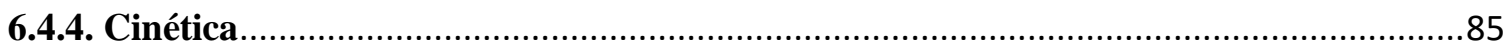

6.5. Configuração experimental dos ensaios em modo semi-contínuo ......................................85

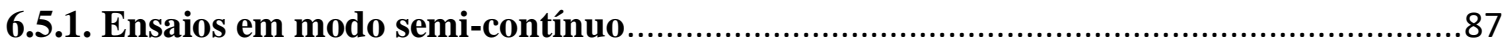

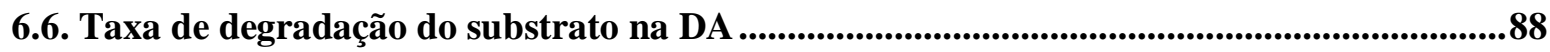

6.7. Métodos analíticos usados nos testes de DA .............................................................................89

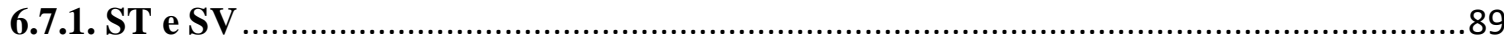

6.7.2. Cromatografia gasosa

6.7.3. Sistema Automático de Teste de Potencial de Metano …............................................ 89

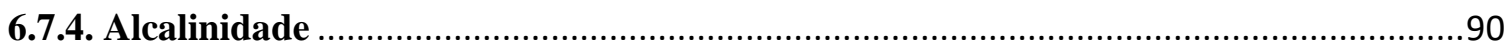

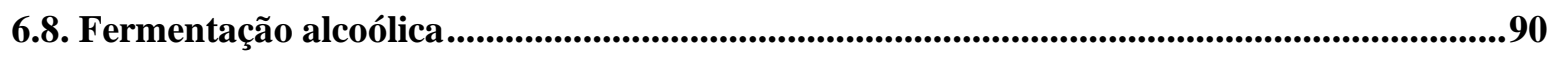

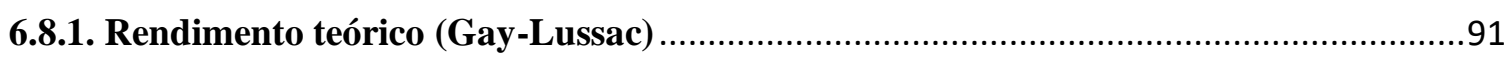

6.8.2. Cromatografia Líquida de Alta Eficiência .......................................................... 91

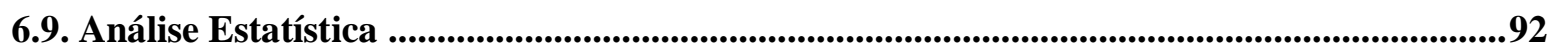

7. Resultados \& Discussão - Parte 2.............................................................................93

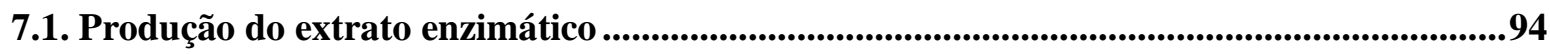

7.2. Otimização da hidrólise ...................................................................................................................94

7.2.1. Proporção entre substrato e extrato enzimático..........................................................94

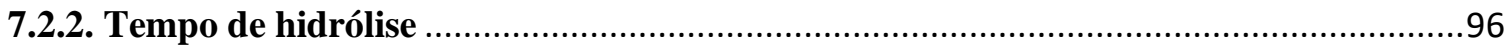

7.3. Caracterização dos substratos e inóculos utilizados na DA...................................................98

7.4. DA em batelada ...........................................................................................................................................98

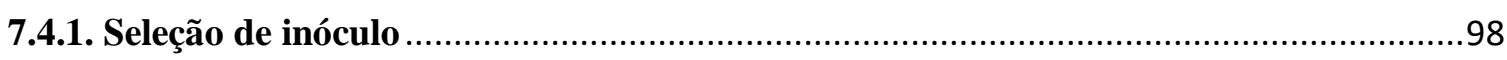

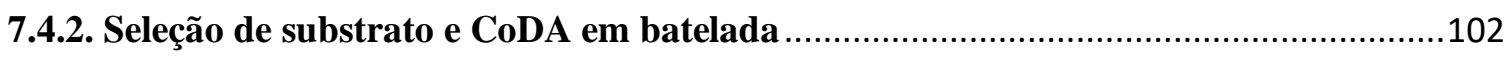

7.4.2.1. Análise estatística e cinética dos testes em batelada ..............................................105 


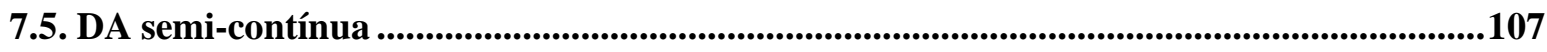

7.5.1. Estabilidade do processo e produção de metano no início do processo …...................107

7.5.2. Estratégias para restaurar o processo de mono-digestão do farelo de milho …..........110

7.5.3. Influência do extrato enzimático na DA semi-contínua do farelo de milho.................111

7.5.4. Influência da co-digestão........................................................................................ 112

7.5.5. Adição de extrato enzimático nos reatores estáveis trabalhando em co-digestão .......113

7.5.6. Mono-digestão do farelo de milho como alternativa para produção de AGVs ..........114

7.6. Fermentação alcoólica...........................................................................................................116

8. Observações finais \& Perspectivas - Parte 2 ............................................................................. 119

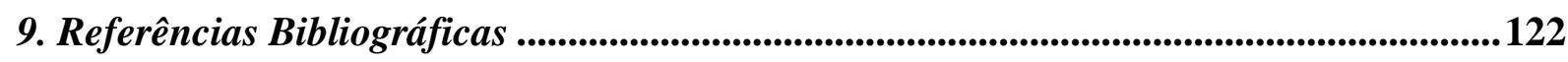

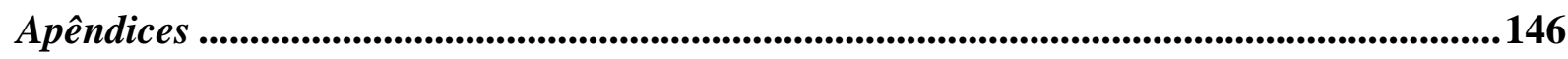

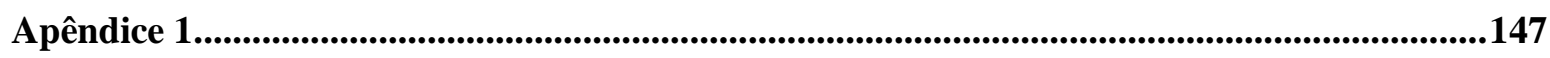

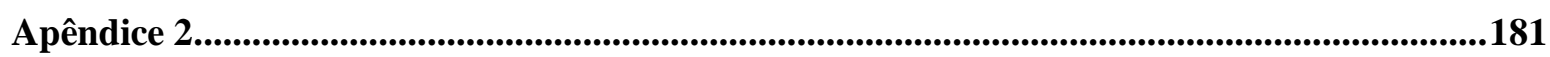

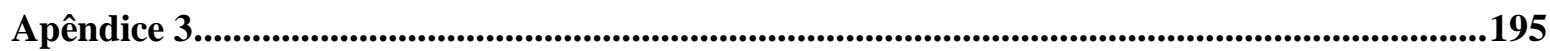

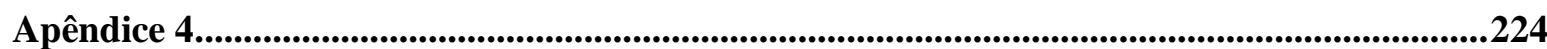




\section{Introducão}

Parte deste item foi publicado como capítulo do livro Wastewater Treatment Reactors: Microbial Community Structure pela editora Elsevier em maio de 2021 - Apêndice 1 


\subsection{Biomassa: um recurso energético}

Com os impactos ambientais e econômicos ocasionados pelas mudanças climáticas originadas principalmente pelo uso extensivo de combustíveis fósseis, mudar as fontes de recursos energéticos constitui um desafio que o mundo deve enfrentar coletivamente. Segundo a World Bioenergy Association (WBA, 2020) as tecnologias de energias renováveis como solar, eólica, hídrica, biomassa, geotérmica etc. tiveram uma participação de 13,8\% no fornecimento de energia primária em 2018. Nesse sentido, reforça-se a necessidade de implantação de uma variedade de medidas focadas na eficiência energética limpa e no uso de fontes de energia sustentáveis de modo a descarbonizar as economias mundiais e alcançar reduções efetivas de emissões de gases de efeito estufa. Inovações tecnológicas, crescimento econômico, condescendência social e das estruturas regulatórias e institucionais são alguns dos fatores proeminentes que podem promover e moldar essa transição entre a energia fóssil e energia renovável (NEOFYTOU; NIKAS; DOUKAS, 2020).

A biomassa vegetal representa uma das mais abundantes e promissoras alternativas de matéria-prima que pode ser processada para fornecer formas bioenergéticas e químicas mais elaboradas e adequadas para o uso final (ALVES, 2019). A biomassa pode ser proveniente de florestas de regeneração natural, plantação florestal, produção anual de safras agrícolas, produção de algas ou também pode ser residual de processos industriais, resíduos domésticos ou operações de limpeza de terras (NUNES; CAUSER; CIOLKOSZ, 2020).

Em 2018, 637 TWh de eletricidade foram gerados a partir de biomassa em todo o mundo. $66 \%$ de toda a energia biológica gerada foi de fontes de biomassa sólida, seguida por 19\% de resíduos municipais e industriais. Adicionalmente, 160 bilhões de litros de biocombustíveis foram produzidos globalmente, sendo destaque o bioetanol, com uma participação de $62 \%$ seguido do biodiesel FAME com 26\%. Juntas, as Américas do Norte e do Sul produziram $75 \%$ de todos os biocombustíveis globais, com a Europa tendo uma participação de 14\%. Quanto ao biogás, em 2018, 59,3 bilhões de $\mathrm{m}^{3}$ deste gás foram produzidos globalmente com um conteúdo de energia equivalente de 1,36 EJ (WBA, 2020).

Segundo a World Bioenergy Association, a agricultura é um setor chave para aumentar o potencial de utilização de bioenergia no futuro. Em termos de rendimentos das principais safras, há um potencial significativo para aumentar as produções em várias regiões globais. Isso permitirá o aumento da produção de alimentos e combustíveis, e desta forma o setor agrícola atuará como um facilitador chave para o aumento do uso de bioenergia em todo o mundo. A geração de energia a partir da silvicultura e agricultura representa, respectivamente, o primeiro 
e segundo maiores setores de matéria-prima para produção bioenergética, seguidos pelos resíduos municipais e industriais (WBA, 2020).

\subsubsection{Composição estrutural}

A biomassa vegetal apresenta em sua estrutura principalmente celulose, hemicelulose e lignina, os quais são polímeros associados entre si. A celulose é um polímero linear, fibroso, resistente e insolúvel em água. Está envolvida com a manutenção estrutural das paredes celulares de plantas, oomicetos e algas (GUPTA et al., 2016; LISPERGUER; PEREZ; URIZAR, 2009). Este polímero tem potencial absorvente, não é tóxico e é de fácil modificação química (GUPTA et al., 2016). Com fórmula molecular $\left(\mathrm{C}_{6} \mathrm{H}_{12} \mathrm{O}_{6}\right)$ n, a celulose é constituída por unidades de D-anidroglucopiranose (glucose) que combinam-se por ligações do tipo $\beta-1,4$ (GUPTA et al., 2016; IOELOVICH; LEYKIN, 2008) (Figura 1). De acordo com o grau de organização das ligações entre as cadeias de celulose, a estrutura pode ser cristalina (altamente ordenada) ou amorfa (menos ordenada). A rigidez deste polímero é devido a muitos grupos hidroxila na molécula de glucose, os quais contribuem para a formação de um grande número de ligações intramoleculares (entre unidades de glucose da mesma molécula) e ligações de hidrogênio intermoleculares (entre unidades de glucose de moléculas diferentes) (PASIN et al., 2020).

Figura 1. Estrutura da celulose demonstrando o padrão de ligação de hidrogênio inter e intracadeia

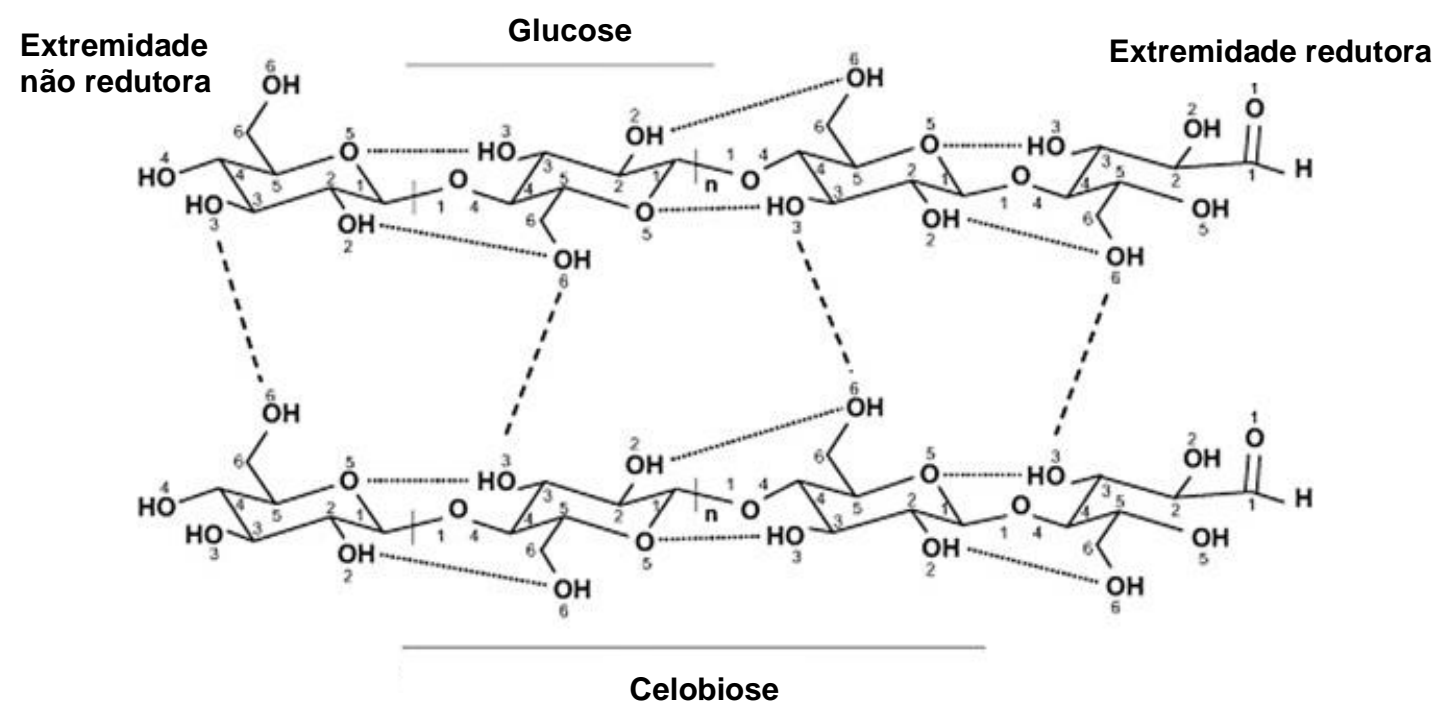

Fonte: adaptado de CIOLACU (2018).

A hemicelulose constitui de 15 a $35 \%$ da biomassa vegetal. Apresenta cadeias mais curtas de baixa massa molecular e está intimamente ligada a celulose na estrutura dos tecidos 
vegetais. É um heteropolímero composto por diferentes monômeros de açúcar (D-xilose, Dmanose, D-arabinose, D-galactose, entre outros) dispostos em cadeias lineares e ramificadas. Dependendo da fonte de biomassa são encontradas em diferentes formas como: Oacetilgalactoglucomananas, arabino-4-O-metilglucuronoxilana, glucomananas e O-acetil-4-O metilglucuranoxilanas (Figura 2). Os ácidos urônicos, como glucurônico e galacturônicos também são encontrados em hemiceluloses (POLIZELI et al., 2016; RAVINDRAN; JAISWAL, 2016). A xilana, localizada principalmente na parede celular secundária e na lamela média das plantas, é o mais abundante heteropolíssacarídeo natural. Sua cadeia principal é composta por resíduos de xilose unidos por ligações glicosídicas do tipo $\beta-1,4$, a partir das quais surgem ramificações laterais de cadeias curtas (FREESE; SCHMIDT; FISCHER, 2005; POLIZELI et al., 2005; POLIZELI et al., 2016).

Figura 2. Estruturas representativas das hemiceluloses predominantes. (A) Oacetilgalactoglucomananas, (B) arabino-4-O-metilglucuronoxilana, (C) glucomananas e (D) Oacetil-4-O metilglucuranoxilanas

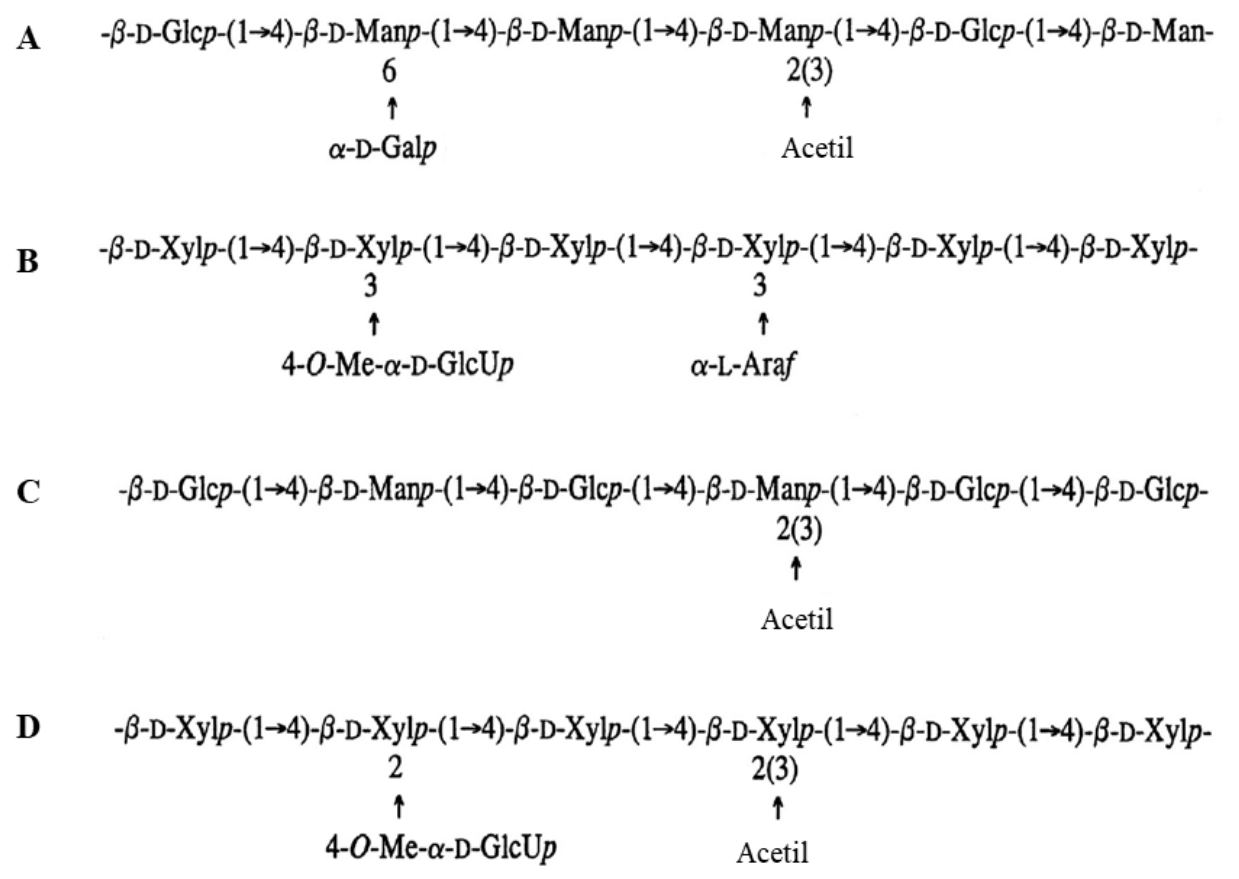

Fonte: adaptado de BAJPAI (2018).

A lignina, por sua vez, é um polímero complexo cuja estrutura e natureza aromática e amorfa variam entre as espécies de plantas. É constituída de unidades de fenilpropano unidas por ligações do tipo C-O-C e C-C, com variados teores de grupos alcóolicos e metoxílicos. O acoplamento das moléculas de fenilpropano ocorre de maneira não repetitiva e irregular devido a polimerização dos monômeros: álcool cumárico, álcool coniferílico e álcool sinapílico 
(Figura 3). Esses grupos unidos formam uma estrutura rígida, que desempenha função estrutural e proteção à parede celular (BAJPAI, 2018; PASIN et al., 2020; RAVINDRAN; JAISWAL, 2016).

Figura 3. Precursores da lignina. (A) álcool cumárico, (B) álcool coniferílico e (C) álcool sinapílico
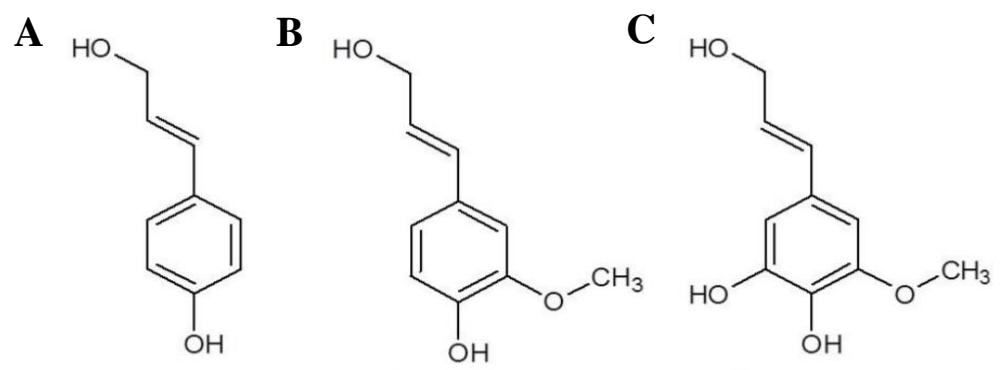

Fonte: SCREMIN (2014).

A estrutura bioquímica da lignina (10-30\% em peso do material lignocelulósico seco) não pode ser relacionada às moléculas de açúcar e não é adequada para bioconversão ou rotas fermentativas. Além disso, o arranjo final entre a lignina, celulose e hemicelulose, desempenha um papel fundamental no sucesso da tecnologia de hidrólise, pois há um bloqueio ao acesso à celulose devido a rede fibrosa que se forma entre os três polímeros mencionados (PASIN et al., 2020).

Adicionalmente, as células vegetais apresentam outros componentes importantes além daqueles na parede celular, como por exemplo, o amido. Este é o principal carboidrato de reserva das plantas, sendo composto por amilose e amilopectina. Ambos componentes são polímeros de cadeia formados por unidades de D-glucose unidas por ligação $\alpha-1,4$. O que os distingue são as ramificações com ligações $\alpha-1,6$ a cada 17-26 resíduos de glucose na amilopectina (BON; GÍRIO; PEREIRA JUNIOR, 2008) (Figura 4).

Figura 4. Polímeros constituintes do amido. (A) amilose e (B) amilopectina
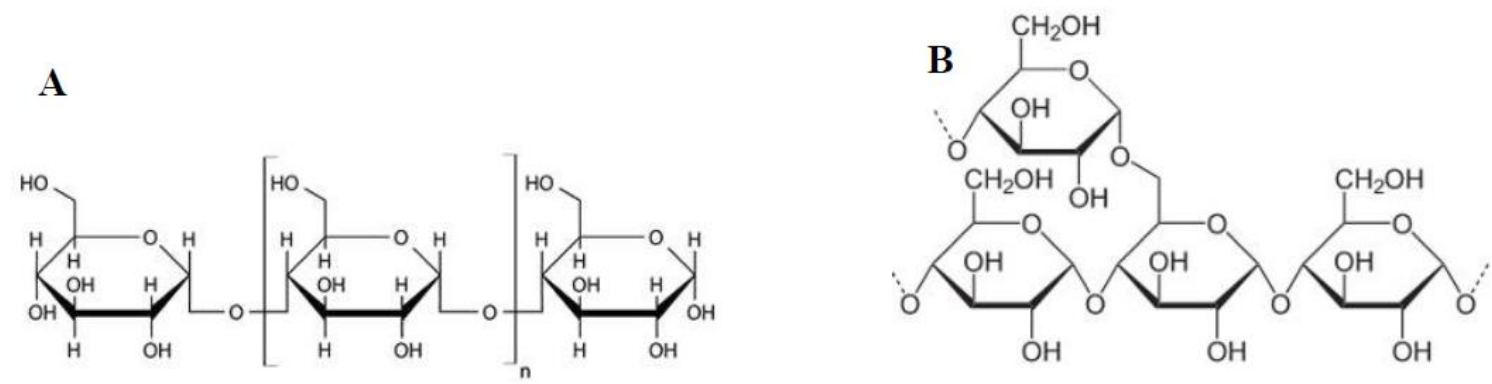

Fonte: elaborado pela autora. 


\subsection{Pré-tratamento enzimático}

Uma vez que a biomassa vegetal é composta por uma rede fibrosa composta pela celulose, hemicelulose e lignina, a hidrólise desses materiais em mono, di e oligossacarídeos é uma das etapas limitantes da DA. A cristalinidade e o grau de polimerização da celulose, assim como a área de superfície acessível às holoceluloses (celulose e hemiceluloses) são os principais fatores que afetam o rendimento de hidrólise durante o processo de digestão (JIN et al., 2009).

Muitas metodologias têm se voltado para acelerar e facilitar a degradação microbiológica de substratos ricos em lignocelulose (subprodutos florestais, palha, cascas, resíduos industriais e agrícolas) e aumentar a sacarificação de produtos ricos em amido (milho) (AMIN et al., 2017; PATINVOH et al., 2017; WAGNER et al., 2018).

Os pré-tratamentos da biomassa visam o rompimento das estruturas, incluindo a rede fibrosa formada pela lignina e hemicelulose, mudanças na porosidade e redução do tamanho das partículas. As estratégias comuns incluem pré-tratamentos biológicos (adição de fungos/ bactérias/ enzimas) (LIMA et al., 2016; MICHELIN et al., 2012; MICHELIN et al., 2015; MICHELIN et al., 2016; PASIN et al., 2020; POLIZELI, M. D. L. T. D. M. et al., 2017) físico (calor e pressão ao mesmo tempo, irradiação, ultrassom) e químico (uso de ácidos e/ou bases, ozonização, oxidação) (AMIN et al., 2017; WAGNER et al., 2018; WESTERHOLM; SCHNÜRER, 2019). Cada um desses pré-tratamentos tem uma peculiaridade diferente. As enzimas já são utilizadas em vários procedimentos nas indústrias de alimentos, oleoquímica, detergente, farmacêutica (SHARMA; VIVEKANAND; SINGH, 2008) e no tratamento de efluentes (CAMMAROTA et al., 2013; SOARES et al., 2019). O uso de enzimas hidrolíticas como aliadas ao processo de DA vem despertando um crescente interesse dentre as outras alternativas propostas para melhoria da fermentação. A aplicação de uma tecnologia híbrida (pré-tratamento enzimático associado à digestão) é um recurso importante para a otimização daDA (MENDES et al., 2010; SOARES et al., 2019; VALLADÃO et al., 2011). A etapa de pré-tratamento enzimático hidrolisa os substratos, permitindo um melhor desempenho da população microbiana em uma etapa posterior da DA.

\subsubsection{Enzimas degradantes da holocelulose e amido}

A degradação da celulose ocorre por meio de um complexo de enzimas hidrolíticas formado por endoglucanase (EG), exoglucanase ou celobiohidrolase ( $\mathrm{CBH}$ ), e $\beta$-glucosidase (BG) (HARRIS; DEBOLT, 2010; PAYNE et al., 2015) (Figura 5). As celulases operam mediante a adsorção à superfície celulósica. Comumente apresentam estrutura bimodular, formada por um domínio catalítico $(\mathrm{CCD})$ e por um domínio de ligação à celulose (CBM). Este 
último domínio está presente na maioria das endo e exoglucanases, e tem a propriedade de ligar a enzima a superfície celulósica (PRATES, 2013).

As EG (EC 3.2.1.4) clivam ligações $\beta$-1,4-glicosídicas internas, e sua atividade é usualmente determinada sob uma cadeia celulósica com alto grau de polimerização, como carboximetilcelulose (CMC). Os produtos dessas enzimas incluem a glucose, celobiose e celodextrinas (VLASENKO et al., 2010). As exoglucanases ou CBH clivam as extremidades acessíveis das moléculas de celulose liberando glucose e celobiose. São divididas em EC 3.2.1.91, as quais atuam nas extremidades não redutoras, e EC 3.2.1.176 que operam nas extremidades redutoras (OBENG et al., 2017; WILSON; KOSTYLEV, 2012). As $\beta$ glucosidases (EC 3.2.1.21) por sua vez, hidrolisam celobiose e outras celodextrinas, liberando glucose (PANDEY; SOCCOL, 2000).

Além dessas celulases canônicas, existem outras enzimas e proteínas que atuam na degradação da celulose, como as mono-oxigenases líticas de polissacarídeos dependentes de cobre (do inglês "copper dependent lytic polysaccharide monooxygenases - LPMOs) e as swoleninas (SWO) (Figura 5). As LPMOs clivam o polímero de celulose por oxidação dos C1, C-4 e C-6 (WU et al., 2014), sendo a Enzima de Atividade Auxiliar (AA9) a mais comum LPMO adicionada aos coquetéis enzimáticos comerciais (PASIN et al., 2020). As SWOs por sua vez, são proteínas não enzimáticas com alta homologia com as expansinas vegetais. Esta classe de moléculas quebra as ligações de hidrogênio entre as cadeias de celulose, afrouxando a estrutura e possibilitando maior acessibilidade às outras enzimas (PASIN et al., 2020; SANTOS et al., 2017).

Figura 5. Ação das celulases na estrutura cristalina e amorfa da celulose

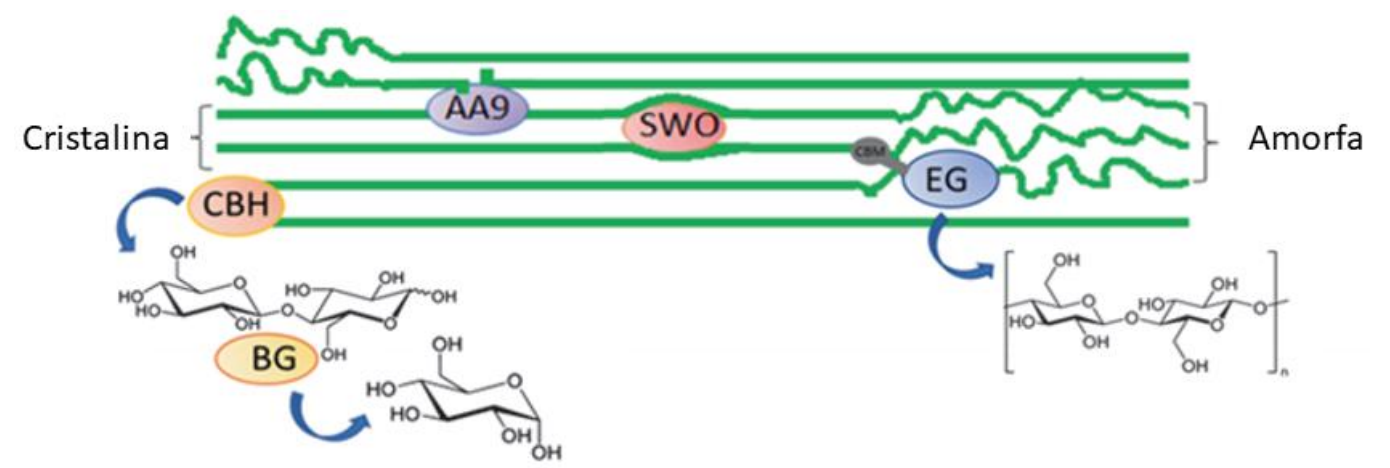

Em azul na região amorfa está representada a endoglucanase (EG) com um CBM ligado à região cristalina. Em laranja estão representadas as celobiohidrolases $(\mathrm{CBH})$ que atuam na liberação de celobiose na região terminal cristalina. Em amarelo está representada a $\beta$-glucosidase (BG) clivando a celobiose, em roxo a enzima de atividade auxiliar (AA9), e em rosa a swolenina (SWO), ambas atuando na desconstrução da cristalinidade celulolítica.

Fonte: PASIN et al. (2020) 
A hidrólise da hemicelulose ocorre por meio da ação de várias enzimas que trabalham em cooperação e sinergismo (Figura 6). A xilana, polímero formado por ligações $\beta-1,4$ entre as moléculas de xilose, é a principal e mais abundante classe deste polímero. As enzimas mais importantes na degradação da xilana são as endo- $\beta$-1,4-xilanase (EC 3.2.1.8) e $\beta$-1,4-xilosidase

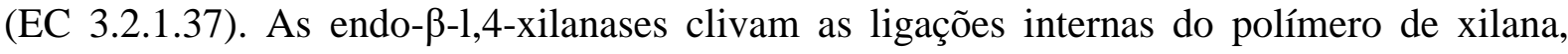
liberando xilose e xilo-oligossacarídeos e diminuindo assim o grau de polimerização (GALLARDO et al., 2010; POLIZELI et al., 2016). As $\beta$-1,4-xilosidases atuam nas extremidades não redutoras da xilana e também sob os xilo-oligossacarídeos incluindo a xilobiose, liberando monômeros de xilose (HEINEN et al., 2017; POLIZELI et al., 2016).

A remoção das ramificações ligadas à cadeia de xilana é promovida por um complexo de enzimas, dentre elas a $\alpha$-L-arabinofuranosidase, $\alpha$-glucuronidase, acetil xilana esterase e feruloil esterase (Figura 6). $\alpha$-L-arabinofuranosidases (EC 3.2.1.55) são exo enzimas que hidrolisam ligações $\alpha-1,5$ de glicosídeos terminais de arabinofuranosídeos em arabinanas, liberando resíduos de arabinofuranosil. Tão bem como atuam sobre ligações $\alpha-1,2$ e/ou $\alpha-1,3$ de arabinofuronosídeos da arabinana, arabinoxilanas e arabinogalactanos (JUTURU; WU, 2013; THAKUR; SHARMA; GOYAL, 2019). $\alpha$-Glucuronidases (EC 3.2.1.139) hidrolisam a ligação 1-2-glicosídica entre a xilana e a cadeia lateral do ácido 4- $O$-metil-D-glucurônico, liberando assim o ácido glucurônico (PASIN et al., 2020; SHALLOM; SHOHAM, 2003). Acetil xilana esterases (EC 3.1.1.72) removem os substituintes $O$-acetil na posição C2 e/ou C3 dos resíduos de xilose na acetil xilana (BLUM et al., 1999; CAUFRIER et al., 2003). Feruloil esterases (EC 3.1.1.73) clivam as ligações das cadeias laterais de arabinose ao ácido ferúlico (CREPIN; FAULDS; CONNERTON, 2004).

O xiloglucano, hemicelulose composta por glucose e xilose, é clivado por endo- $\beta-1,4-$ glucanases (EC 3.2.1.151). E a manana, um polissacarídeo linear composto por D-manose ou glucose e combinações de manose com grupos laterais de grupos galactosil é hidrolisada pela ação da endo-1,4- $\beta$-manosidase ou $\beta$-mananase (EC 3.2.1.78) e $\beta$-manosidases (EC 3.2.1.25) (DE VRIES; VISSER, 2001; POLIZELI et al., 2016). 
Figura 6. Representação simplificada da xilana com ramificações e os locais de hidrólise das enzimas

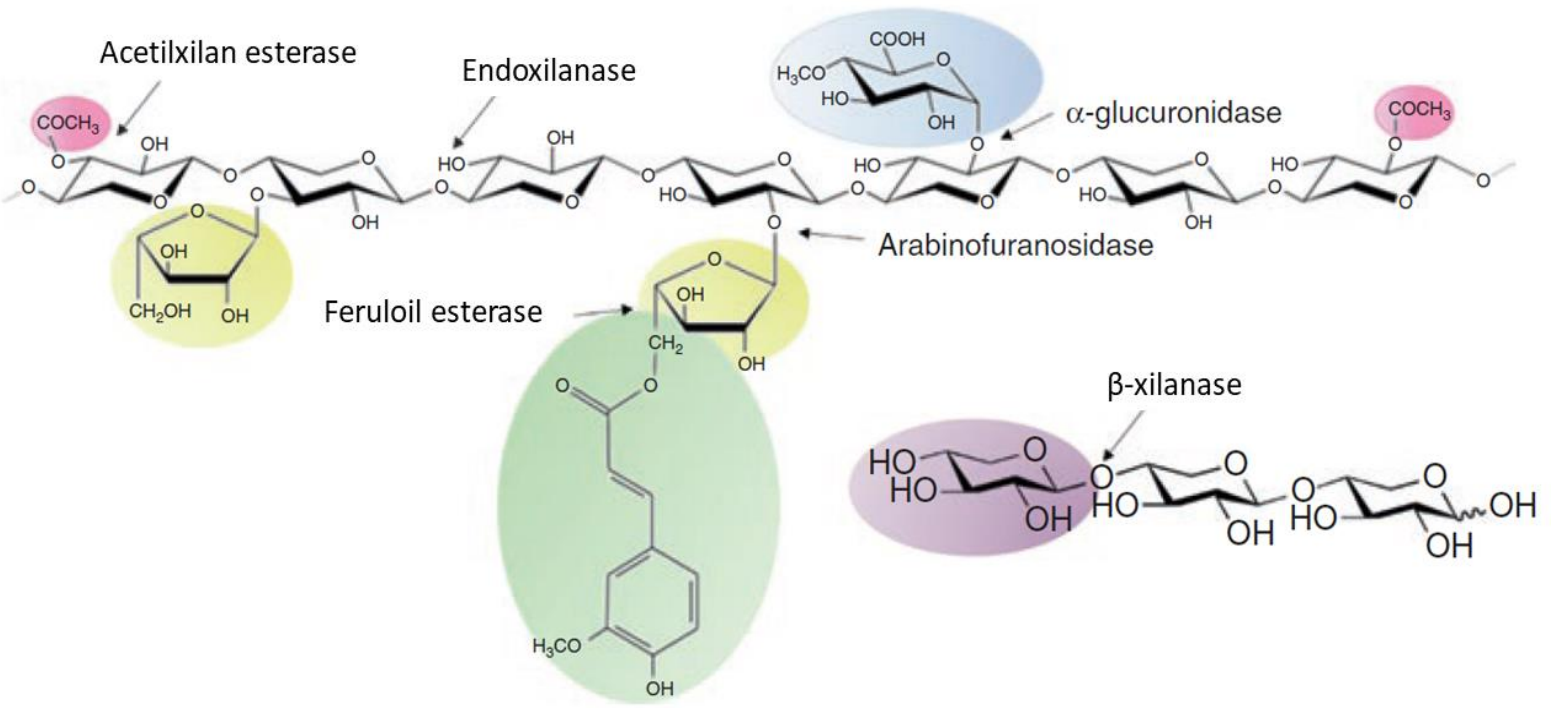

Em rosa estão representados os locais de substituições de acetil clivadas pela acetil xilana esterase. Em amarelo está destacada a remoção da arabinose da cadeia de xilana pela arabinofuranosidase. Em verde está a representação da separação do ácido ferúlico da arabinose pela feruloil esterase. O ácido 4-Ometil-D-glucurônico removido pela $\alpha$-glucuronidase é mostrado em azul. Em roxo está a extremidade não redutora de um oligossacarídeo clivado por $\beta$-xilanase resultando na liberação de monômeros de xilose. A região não destacada na região interior do esqueleto de xilana é hidrolisada por endoxilanases e ocasiona a liberação de xilooligossacarídeos.

Fonte: PASIN et al. (2020).

O amido, por sua vez, é degradado pelas enzimas $\alpha$-amilase (EC 3.2.1.1), $\beta$-amilase (EC 3.2.1.2), glucoamilase (EC 3.2.1.3), isoamilase (EC 3.2.1.68) e pululanase (EC 3.2.1.41)

(Figura 7). A $\alpha$-amilase age exclusivamente nas ligações $\alpha-1,4$ no interior da amilose e amilopectina liberando malto-oligossacarídeos. A $\beta$-amilase, presente principalmente em plantas, atua nas ligações $\alpha-1,4$ das extremidades não redutoras do amido resultando na liberação de unidades de maltose. A glucoamilase atua nas ligações $\alpha-1,4$ e em menor velocidade nas ligações $\alpha-1,6$ das extremidades não redutoras do amido de forma a liberar monômeros de glucose. A isoamilase hidrolisa ligações $\alpha-1,6$ presentes em ramificações com no máximo três unidades de glucose. A pululanase, amilase desramificante, age nas ligações $\alpha$ 1,6 do pululano, um polissacarídeo linear composto por maltotrioses unidas por ligações $\alpha-1,6$; sua atividade ocasiona a liberação de maltotrioses (PANDEY et al., 2000). 
Figura 7. Representação esquemática do sistema enzimático envolvido na degradação do amido

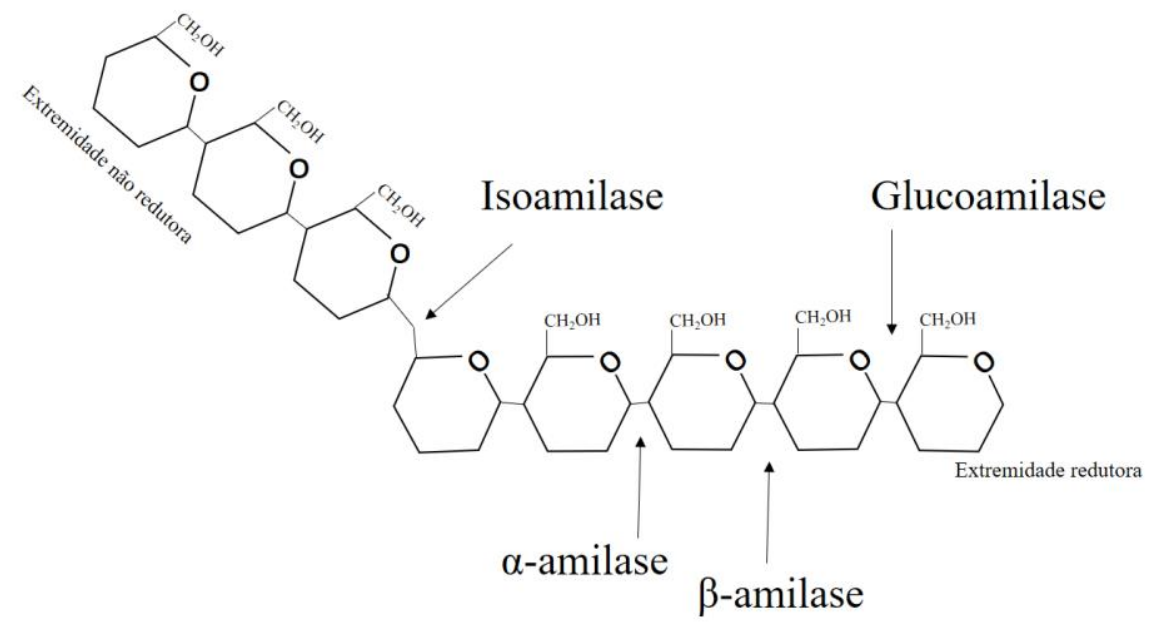

Fonte: elaborada pela autora.

A Tabela 1 traz um resumo das principais enzimas atuantes na degradação dos polímeros celulose e hemicelulose, assim como as enzimas atuantes na hidrólise do amido, a principal molécula de reserva energética presente nas células vegetais. Os alvos das enzimas e seus respectivos produtos também estão expostos na tabela. 
Tabela 1. Resumo das principais enzimas responsáveis pela bioconversão da biomassa vegetal, com destaque para seus respectivos alvos e produtos

\begin{tabular}{|c|c|c|c|}
\hline Substrato & Enzima & Alvo & Produto \\
\hline \multirow{3}{*}{ Celulose } & $\begin{array}{c}\text { Celobiohidrolases } \\
\text { (EC 3.2.1.9 } \\
\text { EC 3.2.1.176) }\end{array}$ & $\begin{array}{l}\text { Ligações glicosídicas } \beta-1,4 \text { nas } \\
\text { extremidades redutoras e não } \\
\text { redutoras }\end{array}$ & $\begin{array}{l}\text { Glucose e } \\
\text { celobiose }\end{array}$ \\
\hline & $\begin{array}{l}\text { Endoglucanase } \\
\text { (EC 3.2.1.4) }\end{array}$ & $\begin{array}{c}\text { Ligações glicosídicas } \beta-1,4 \\
\text { intramoleculares }\end{array}$ & Oligossacarídeos \\
\hline & $\begin{array}{l}\beta \text {-glucosidase } \\
(\text { EC 3.2.1.21) }\end{array}$ & Celobiose e celodextrinas & Glucose \\
\hline \multirow{6}{*}{ Hemicelulose } & $\begin{array}{l}\text { Endo- } \beta \text {-1,4-xilanase } \\
\quad \text { (EC 3.2.1.8) }\end{array}$ & Ligações $\beta-1,4$ no interior da xilana & $\begin{array}{c}\text { Xilose, xilo- } \\
\text { oligossacarídeos }\end{array}$ \\
\hline & $\begin{array}{l}\beta-1,4-\text { Xilosidase } \\
\text { (EC 3.2.1.37) }\end{array}$ & $\begin{array}{l}\text { Extremidades não redutoras da } \\
\text { xilana e xilo-oligossacarídeos } \\
\text { incluindo a xilobiose }\end{array}$ & Xilose \\
\hline & $\begin{array}{l}\text { Arabinofuranosidase } \\
\quad \text { (EC 3.2.1.55) }\end{array}$ & $\begin{array}{l}\alpha \text {-L-arabinofuranosídeos, arabinose } \\
\text { em ligações } \alpha-(1,3),(1,2) \text { e }(1,5)\end{array}$ & $\begin{array}{c}\text { Resíduos } \\
\text { de } \\
\text { arabinofuranosil e }\end{array}$ \\
\hline & $\begin{array}{l}\alpha \text {-Glucuronidase } \\
\text { (EC 3.2.1.139) }\end{array}$ & Ligação 1-2-glicosídica & $\begin{array}{c}\text { Ácido } \\
\text { galacturônico }\end{array}$ \\
\hline & $\begin{array}{c}\text { Endo- } \\
\text { 1,4- } \beta \text {-manosidase } \\
\text { (EC 3.2.1.78) }\end{array}$ & $\begin{array}{l}\text { Ligações 1,4- } \beta \text { da manana, } \\
\text { glucomanana e galactomanana }\end{array}$ & Manose \\
\hline & $\begin{array}{l}\beta \text {-manosidase } \\
\text { (EC 3.2.1.25) }\end{array}$ & $\begin{array}{l}\text { Extremidades não redutoras da } \\
\text { manana }\end{array}$ & Manose \\
\hline \multirow{4}{*}{ Amido } & $\begin{array}{c}\alpha \text {-amilase } \\
(\text { EC 3.2.1.1) }\end{array}$ & Ligações $\alpha-1,4$ internas & $\begin{array}{c}\text { Malto- } \\
\text { oligossacarídeos }\end{array}$ \\
\hline & $\begin{array}{c}\beta \text {-amilase } \\
(\text { EC 3.2.1.2) }\end{array}$ & $\begin{array}{c}\text { Ligações } \alpha-1,4 \text { nas extremidades } \\
\text { não redutoras }\end{array}$ & Maltose \\
\hline & $\begin{array}{c}\text { Isoamilase } \\
\text { (EC 3.2.1.68) }\end{array}$ & Ligações $\alpha-1,6$ & Glucose, maltose \\
\hline & $\begin{array}{l}\text { Glucoamilase } \\
\text { (EC 3.2.1.3) }\end{array}$ & $\begin{array}{l}\text { Ligações } \alpha-1,4 \text { e } \alpha-1,6 \text { nas } \\
\text { extremidades não redutoras }\end{array}$ & $\beta$-D-glucose \\
\hline
\end{tabular}

Fonte: PINHEIRO; POLIZELI (2021).

\subsection{Otimização de processos por meio da metodologia de superfície de resposta:} variáveis de processo e de mistura

O termo otimização tem sido empregado para designar um conjunto de experimentos que visa melhorar as características de um procedimento ou de um método, de forma a torná-lo mais eficiente, sensível e funcional (ARAUJO; BRERETON, 1996; BEZERRA et al., 2008).

As análises multivariadas vem sendo cada vez mais empregadas na otimização de 
métodos analíticos. Estas ferramentas baseiam-se no desenvolvimento de modelos matemáticos que permitem estabelecer a relevância e significância estatística dos efeitos dos fatores estudados, assim como estimar os efeitos de interação entre eles. Análises multivariadas são mais econômicas e efetivas devido ao menor tempo de execução e economia de reagentes, além disso, permitem que as variáveis estudadas sejam otimizadas concomitantemente (BRUNS; SCARMINIO; DE BARROS NETO, 2006; TAULER; WALCZAK, 2009).

Dentre as diversas técnicas multivariadas de otimização, há a Metodologia de Superfícies de Respostas (MSR), a qual apresenta uma alta eficiência e tem alto poder de modelagem. A MSR é a combinação de planejamento de experimentos, análise de regressão e métodos estatísticos. Tem como base o ajuste de modelos matemáticos empíricos aos dados experimentais obtidos de acordo com uma matriz experimental, e cujo objetivo é descrever o comportamento dos dados e obter previsões estatisticamente válidas (HANRAHAN; LU, 2006; NOVAES et al., 2017).

Os fatores (variáveis) que influenciam o desempenho de um experimento podem ser classificados em variáveis de processo ou variáveis de mistura. Matrizes experimentais aplicadas na otimização de variáveis de processo permitem a combinação independente de seus níveis, sem restrições relativas à proporção. As matrizes para otimização de variáveis de misturas por sua vez, dependem das proporções de seus componentes. Os planejamentos de misturas são aplicados no estudo de combinações entre os níveis das proporções das variáveis, e a resposta obtida a partir de planejamentos para otimização de misturas é em função das proporções de cada componente testado (MASSART et al., 1997; NOVAES et al., 2017).

\subsection{Digestão anaeróbia}

Evidências históricas indicam que o processo de DA é uma das tecnologias mais antigas utilizadas pelas comunidades humanas, uma vez que desde meados de 900 a.C., o gás natural proveniente da lama era usado para aquecer banhos de água na Assíria. Jan Baptita Van Helmont determinou pela primeira vez no século 17 que a matéria orgânica em decomposição poderia produzir gases inflamáveis, no entanto, foi somente em 1859 que se iniciou, em Bombaim (Índia), a industrialização da DA com o desenvolvimento da primeira planta de digestão. Desde então, à medida que o entendimento deste processo melhorou, mais técnicas e aplicações operacionais surgiram (ABBASI; TAUSEEF; ABBASI, 2012). Hoje em dia, devido à ampla gama de aplicações da DA nas indústrias de energia, biotecnologia, farmacêutica e de tratamento de lodo residual, há uma extensa quantidade de pesquisa sendo gerada na área. 
Para otimizar o processo de DA, é vital conhecer e compreender parâmetros operacionais e bioquímicos que influenciam diretamente na adaptação, organização e metabolismo dos micro-organismos característicos desse processo (LI, YEQING et al., 2020; WESTERHOLM; SCHNÜRER, 2019), uma vez que a comunidade microbiana é um sistema complexo no qual as espécies estão incessantemente reestruturando suas propriedades ecológicas e interações em resposta aos parâmetros de digestão aplicados (ALLISON; MARTINY, 2008).

\subsubsection{Bioquímica da DA}

A DA de compostos orgânicos é um processo que ocorre naturalmente. Os sistemas de tratamento biológico da biomassa são um tipo de aplicação tecnológica deste procedimento. Baseia-se na atividade de micro-organismos, em condições anaeróbias e de operação controlada, objetivando a conversão biológica de matéria orgânica complexa em compostos químicos mais simples, principalmente o metano. Gás este que foi descoberto em 1776 por Alessandro Volta, por meio da observação de bolhas vindas da lama como resultado da decomposição dos restos da planta (ZEHNDER; MITCHELL, 1978). A bioquímica da decomposição anaeróbia é sinergicamente realizada por grupos de micro-organismos distribuídos em quatro estágios principais: hidrólise, acidogênese, acetogênese e metanogênese (Figura 8) (LI, YEQING et al., 2020; ROBLES et al., 2018; WANG et al., 2018). 
Figura 8. Principais etapas e percursos do processo de DA

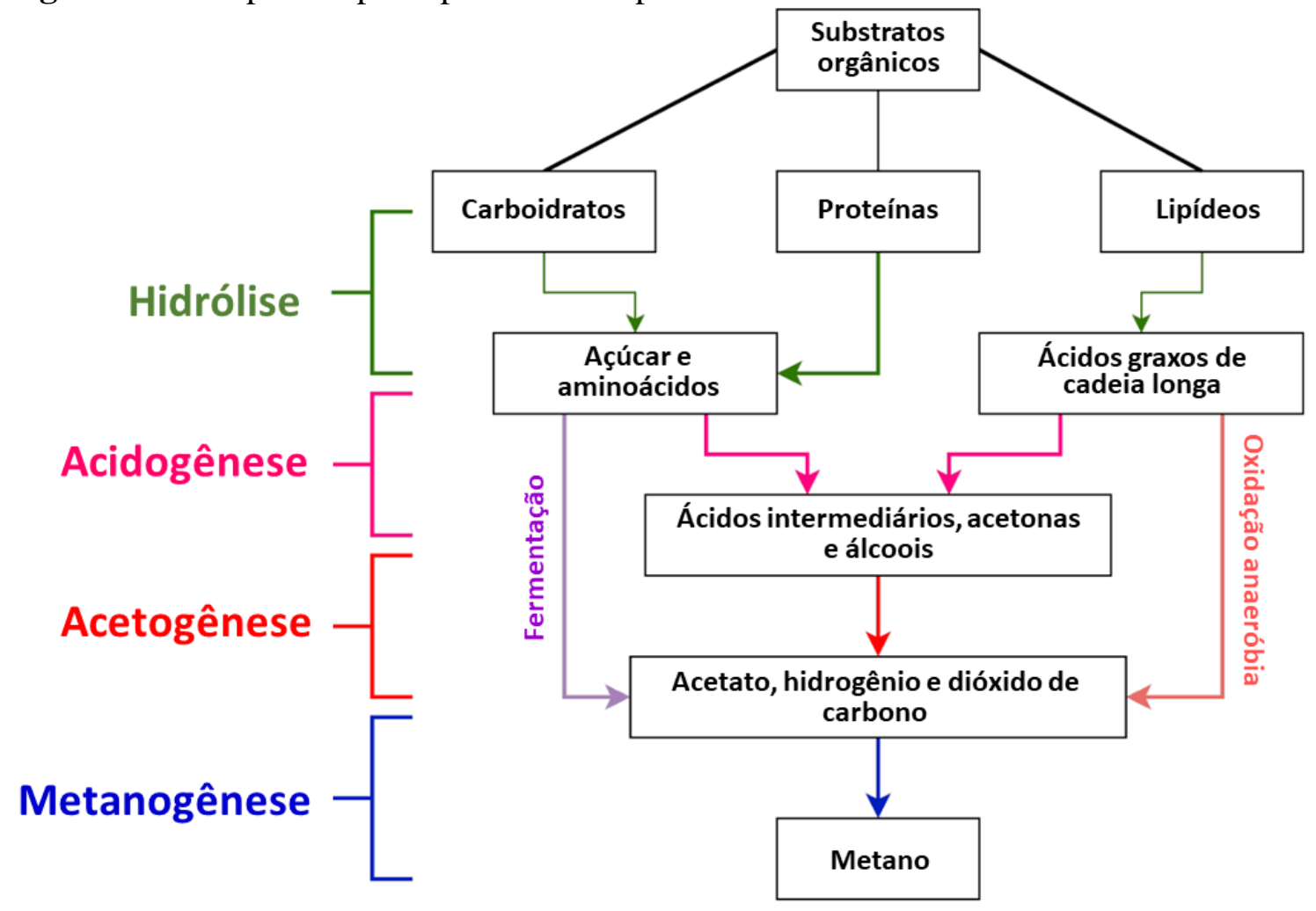

Fonte: elaborada pela autora.

A hidrólise é a primeira etapa, na qual a biomassa complexa, que não pode ser utilizada diretamente por micro-organismos, é decomposta em produtos mais simples (LI, YEQING et al., 2020). As bactérias hidrolíticas são caracterizadas por produzir celulossoma, o complexo multienzimático especial capaz de secretar diferentes hidrolases, como glucanases, hemicelulases, quitinases e outras (LAMED; SETTER; BAYER, 1983). Deste modo, a presença dessas e de outras enzimas extracelulares (proteases, lipases, amilases, pectinases, etc.) produzidas por bactérias especializadas, fungos filamentosos e leveduras permite a conversão parcial ou completa de polímeros no processo de hidrólise. Polissacarídeos, lipídios e proteínas são convertidos em moléculas mais curtas solúveis, ou seja, ácidos graxos de cadeia longa (AGCL) produzem glicerol e ácidos graxos de cadeia curta. Proteínas hidrolisadas produzem aminoácidos e oligopeptídeos e açúcares complexos resultam em mono-, di- e oligossacarídeos (ALI SHAH et al., 2014; BRYANT, 1979).

Os monômeros solúveis resultantes da hidrólise endógena ao sistema, quando dentro das células de bactérias acidogênicas, são convertidos em compostos com um a cinco unidades de carbono. Os produtos típicos da acidogênese são ácidos graxos voláteis de cadeia curta (AGV), como o ácido propiônico, butírico e valérico, no entanto outros produtos, como álcoois (etanol, metanol, butanol, propanol, etc), dióxido de carbono, amônia e hidrogênio também 
podem ser gerados dependendo do substrato. A formação dos produtos na acidogênese é limitada pela pressão parcial do hidrogênio. A via favorável das bactérias fermentativas é a produção de acetato via piruvato (com produção de hidrogênio). No entanto, se as condições ambientais não forem desejáveis, a pressão parcial de hidrogênio pode se tornar alta, e mais intermediários, como outros AGVs e álcoois, são produzidos (NGUYEN; NGUYEN; NGHIEM, 2019; ROBLES et al., 2018; SCHINK, 1997). A acidogênese geralmente ocorre em um ritmo mais rápido do que todos os outros estágios da DA (DEUBLEIN; STEINHAUSER, 2011). Com sua rapidez, a acidificação ocasionada pelos AGVs é amplamente relatada como uma causa de falha do digestor (AKUZAWA et al., 2011).

A próxima etapa é a acetogênese. Bactérias produtoras de hidrogênio obrigatórias convertem AGVs, etanol e até mesmo produtos da hidrólise (açúcares e aminoácidos) em acetato, hidrogênio e dióxido de carbono (BRYANT, 1979; DRAKE; G ÖßNER; DANIEL, 2008; SCHINK, 1997; WORM et al., 2010). O H $\mathrm{H}_{2}$ liberado nessas reações exibe efeito tóxico sobre os próprios micro-organismos que realizam o processo de acetogênese. Isso torna essencial a associação sintrófica entre as bactérias produtoras de hidrogênio e as arqueias produtoras de metano. Desta forma, metanogênicas hidrogenotróficas podem consumir rapidamente o hidrogênio produzido pelos micro-organismos acetogênicos e, como consequência, a pressão parcial do hidrogênio é mantida em um nível favorável para a acetogênese, devido ao não acúmulo de produtos acidogênicos, e o sistema não é interrompido (LI, YEQING et al., 2020; ROBLES et al., 2018; WANG et al., 2018).

A metanogênese caracteriza o estágio final da DA. Os intermediários, acetato, $\mathrm{CO}_{2} \mathrm{e}$ compostos metilados, são consumidos por arqueias metanogênicas e resultam na produção de metano (FERRY, 2010). As metanogênicas acetoclásticas transformam o acetato em grupos metila e $\mathrm{CO}_{2}$. Os grupos de metila são reduzidos a metano utilizando um elétron fornecido pelo grupo carboxila. $\mathrm{O} \mathrm{CO}_{2}$, por sua vez, é reduzido a metano por metanogênicas hidrogenotróficas, as quais utilizam $\mathrm{H}_{2}$ ou formato como doadores de elétrons. Compostos metilados têm o grupo metil reduzido a metano por metanogênicas metilotróficas (COSTA; LEIGH, 2014; LIU et al., 2018).

\subsubsection{Reações básicas envolvidas no processo de DA}

THEMELIS e KIM (2002) mostraram que a mistura de resíduos orgânicos pode ser aproximada pela fórmula química $\mathrm{C}_{6} \mathrm{H}_{10} \mathrm{O}_{4}$, excluindo nitrogênio e enxofre, cujas proporções são relativamente menores e ocorrem principalmente em resíduos de alimentos mistos. A reação de hidrólise pode ser escrita como mostrado na Equação 1. 
$\mathrm{C}_{6} \mathrm{H}_{10} \mathrm{O}_{4}+2 \mathrm{H}_{2} \mathrm{O} \rightarrow \mathrm{C}_{6} \mathrm{H}_{12} \mathrm{O}_{6}+\mathrm{H}_{2}$

Os compostos orgânicos hidrolisados (açúcares e aminoácidos) são convertidos em álcoois e ácidos orgânicos por bactérias fermentativas, conforme escrito nas Equações 2 e 3 (MADIGAN et al., 2016).

$\mathrm{C}_{6} \mathrm{H}_{12} \mathrm{O}_{6} \rightarrow 2 \mathrm{CH}_{3} \mathrm{CH}_{2} \mathrm{OH}+\mathrm{CO}_{2}$

$\mathrm{C}_{6} \mathrm{H}_{12} \mathrm{O}_{6}+2 \mathrm{H}_{2} \rightarrow 2 \mathrm{CH}_{3} \mathrm{CH}_{2} \mathrm{COOH}+2 \mathrm{H}_{2} \mathrm{O}$

Os ácidos orgânicos, exceto os ácidos acéticos (KOTHARI et al., 2014), são consumidos pelas bactérias acetogênicas e posteriormente convertido em ácido acético e hidrogênio, como escrito na Equação 4 (MADIGAN et al., 2016).

$\mathrm{CH}_{3} \mathrm{CH}_{2} \mathrm{COOH}+2 \mathrm{H}_{2} \mathrm{O} \rightarrow \mathrm{CH}_{3} \mathrm{COOH}+\mathrm{CO}_{2}+3 \mathrm{H}_{2}$

A última etapa envolve a formação de metano, em que os organismos metanogênicos consomem ácido acético, hidrogênio e dióxido de carbono e produzem metano. Como já mencionado, alguns metanógenos podem consumir metanol e vários outros substratos, incluindo compostos metilados (FERRY, 2012). As reações básicas envolvidas na formação de metano estão escritas nas Equações 5, 6, 7 e 8 (MADIGAN et al., 2016).

$\mathrm{CO}_{2}+4 \mathrm{H}_{2} \rightarrow \mathrm{CH}_{4}+2 \mathrm{H}_{2} \mathrm{O}$

$\mathrm{CH}_{3} \mathrm{COOH}+\mathrm{CO}_{2} \rightarrow \mathrm{CH}_{4}+2 \mathrm{CO}_{2}$

$\mathrm{CH}_{3} \mathrm{OH}+\mathrm{H}_{2} \rightarrow \mathrm{CH}_{4}+2 \mathrm{H}_{2} \mathrm{O}$

$2 \mathrm{CH}_{3} \mathrm{CH}_{2} \mathrm{OH}+\mathrm{CO}_{2} \rightarrow \mathrm{CH}_{3} \mathrm{COOH}+\mathrm{CH}_{4}$

\subsubsection{Parâmetros ambientais e operacionais}

A DA pode ser afetada por diversos fatores, que estão relacionados ao substrato, às características do biodigestor e às condições de operação. Fatores como tipo de biomassa aplicada, composição do inóculo, pH, temperatura, carga orgânica (CO), bioaumentação, etc., 
podem causar mudanças na diversidade da comunidade microbiana, alterando a bioquímica do processo e afetando assim toda a digestão e seus produtos finais (PINHEIRO; POLIZELI, 2021).

\subsubsection{Inóculo}

A diversidade microbiana no inóculo usado para iniciar um processo de DA foi relatada como um forte influenciador na taxa de degradação, tolerância ao estresse dos microorganismos e produção específica de metano (DE VRIEZE; VERSTRAETE, 2016; HAN et al., 2016; SATPATHY et al., 2016). Um inóculo com alta diversidade de micro-organismos pode ser favorável para DA porque espécies sensíveis podem ser substituídas por outras com funções semelhantes de forma a manter o rendimento dos produtos esperados (ROSENFELD, 2002).

O lodo proveniente de plantas de biogás já estabelecidas e funcionais é um recurso que pode ser utilizado para se iniciar uma nova planta de bioenergia baseada em DA. Esse lodo geralmente é composto por uma suspensão aquosa rica em compostos biodegradados, parcialmente biodegradados e sólidos essencialmente não biodegradáveis com matéria absorvida e dissolvida associada (HAMER; MASON, 1987), além do que contém a comunidade microbiana já pré-estabelecida oriunda de uma operação estável a longo prazo.

\subsubsection{Temperatura}

A temperatura aplicada a DA é um dos mais importantes fatores na seleção das espécies no processo, uma vez que os micro-organismos não possuem meios para controlar sua temperatura interna, que é então determinada pela temperatura ambiente externa. Diferentes condições de temperatura podem ser aplicadas aos processos biológicos, como por exemplo, psicrofílica $\left(0-20^{\circ} \mathrm{C}\right)$, mesofílica $\left(20-40{ }^{\circ} \mathrm{C}\right)$ ou termofílica $\left(45-60{ }^{\circ} \mathrm{C}\right)(\mathrm{CAO}$ et al., $2020 ; \mathrm{LV}$ et al., 2020).

A temperatura influencia expressivamente a estrutura e riqueza da comunidade microbiana, assim como a atividade enzimática, as taxas de reações e a produção de $\mathrm{CH}_{4}(\mathrm{CAO}$ et al., 2020; LV et al., 2020). Portanto, a regulação da temperatura é uma das principais estratégias nesse processo (LV et al., 2020; WANG et al., 2018). Como quase $80 \%$ do conteúdo do corpo celular de um micro-organismo é água, a maioria deles não consegue crescer em condições psicrofílicas, devido à perda de temperatura para o ambiente e, consequentemente, à redução da velocidade das reações intracelulares. A operação em temperatura termofílica fornece um nível mais alto de Firmicutes em comparação para Bacteroidetes / Proteobacteria (CHAPLEUR et al., 2016; LIU et al., 2018; THEUERL et al., 2018; WESTERHOLM; 
SCHNÜRER, 2019). Uma proporção mais baixa de Bacteroidetes diminui a taxa de hidrólise devido à redução da riqueza de enzimas lignocelulolíticas (GÜLLERT et al., 2016). Da mesma forma, a maior dominância do filo Thermotogae foi relatada em condições termofílicas (CHAPLEUR et al., 2016; LV et al., 2020; THEUERL et al., 2018). O filo Thermotogae é responsável por degradar polissacarídeos em etanol, acetato, $\mathrm{CO}_{2}$ e $\mathrm{H}_{2}$, e álcoois em $\mathrm{CO}_{2}$ e $\mathrm{H}_{2}$ quando em associação com anaeróbios consumidores de hidrogênio (STOLZE et al., 2018). Além disso, LV et al. (2020) também descobriu por meio de evidências estatísticas que as vias dominadas por Clostridiaceae estavam intimamente ligadas à metanogênese em digestores termofílicos.

As correlações microbianas, entre o aumento do nível de amônia e as altas temperaturas, foram revisadas por WESTERHOLM e SCHNÜRER (2019). Em temperaturas mais altas, a inibição por amônia é mais rápida por causa das mudanças de equilíbrio na direção da formação deste produto. Portanto, uma abundância relativa aumentada de Methanobacteriales e/ou Methanomicrobiales foi observada quando houve aumento de temperatura e acúmulo de amônia. A inibição por amônia é uma das causas mais comuns de falhas em digestores de DA em temperatura termofílica (CAO et al., 2020).

\subsubsection{Bioaumentação}

Bioaumentação é a adição de comunidade microbiana especializada ou mista a um sistema com o objetivo de melhorar funções do processo (DE VRIEZE; VERSTRAETE, 2016), como por exemplo, a degradação de contaminantes, redução da carga orgânica $(\mathrm{CO})$, adaptação microbiana e melhoria da produção de metano (DE VRIEZE; VERSTRAETE, 2016; HERRERO; STUCKEY, 2015).

A bioaumentação pode ser realizada com a adição no sistema de (1) uma cepa microbiana pura pré-adaptada ou comunidade, (2) bactérias geneticamente modificadas, ou (3) um vetor com genes relevantes, que serão transferidos por conjugação em micro-organismos presentes nos biossistemas (EL FANTROUSSI; AGATHOS, 2005).

\subsubsection{4. $\mathrm{pH}$}

$\mathrm{O} \mathrm{pH}$ é um fator ambiental central que influencia a DA. Mudanças no $\mathrm{pH}$ afetam significativamente os micro-organismos envolvidos no processo de digestão, uma vez que pode ocasionar a modificação de estruturas, aumentar ou diminuir a toxicidade do sistema e alterar taxas metabólicas. Os anaeróbios requerem uma faixa específica de $\mathrm{pH}$ para completar melhor as atividades fisiológicas normais e são muito sensíveis às flutuações dessa variável. Bactérias 
acidogênicas preferem um intervalo de $\mathrm{pH}$ de 5,5-8,5, enquanto para metanogênicas o intervalo é de 6,6-7,5. Portanto, a faixa de pH ideal para o sistema DA é entre 6,5 e 7,8 (LACKNER et al., 2020; LI, YEQING et al., 2020).

Dentro das etapas da DA, a acidogênese é geralmente a mais rápida. Uma utilização lenta ou inibida dos ácidos gerados devido à sobrecarga orgânica, substâncias tóxicas ou mudança rápida de temperatura podem levar ao acúmulo de $\mathrm{AGV}$. Altas quantidades de $\mathrm{AGV}$ no sistema têm um impacto direto no $\mathrm{pH}$, que afeta o crescimento dos micro-organismos. Adicionalmente, flutuações no $\mathrm{pH}$ podem influenciar a proporção das formas não-dissociadas e dissociadas dos AGV, e a primeira é muito mais tóxica para a comunidade microbiana, uma vez que pode se difundir através da membrana celular e causar uma diminuição do pH intracelular (KADAM; BOONE, 1996; VENKITESHWARAN et al., 2015).

\subsubsection{Carga orgânica}

A Carga Orgânica (CO) se refere a massa de sólidos voláteis carregados no digestor em uma unidade de tempo. A CO está intimamente relacionada ao Tempo de Retenção Hidráulica (TRH) no sistema, uma vez que deve haver um equilíbrio entre eles para o bom funcionamento da digestão. DAs com maiores CO devem envolver TRHs longos de modo a fornecer tempo suficiente para os anaeróbios degradarem os substratos (DEMIRER; CHEN, 2005; ROBLES et al., 2018).

\subsubsection{Co-digestão anaeróbia}

A co-digestão anaeróbia (CoDA), que envolve a digestão simultânea de duas ou mais matérias-primas, tem se mostrado benéfica para a viabilidade econômica, aumento da produção de metano e melhoria de alguns problemas emergentes da mono-digestão. Dentre as vantagens da CoDA estão o maior equilíbrio nutricional, diluição de substâncias toxicas, efeito sinérgico sobre os micro-organismos e diminuição da quantidade de compostos recalcitrantes na matériaprima (KANGLE et al., 2012; RABII et al., 2019).

A CoDA de diferentes matérias-primas com o dejeto animal pode aumentar a produção de biogás de $25 \%$ a $400 \%$ em comparação com a mono-digestão dos mesmos substratos. Na CoDA de dejeto suíno com glicerol em uma proporção de mistura de esterco/glicerol de 24/1 sob condições mesofílicas, houve um aumento de $400 \%$ na produção de biogás quando comparado a mono-digestão convencional do dejeto (HANZL, 2018; SHAH et al., 2015).

Matérias-primas caracterizadas por razões $\mathrm{C} / \mathrm{N}$ mais altas (> 50), como palha de arroz, trigo, talos de milho, algas marinhas, podem ser co-digeridas com matérias-primas de razões 
$\mathrm{C} / \mathrm{N}$ mais baixas, por exemplo dejeto de porcos, gado e aves, e resíduos de alimentos, de modo a atingir o equilíbrio de nutrientes e evitar a inibição que leva à instabilidade do sistema e redução da produção de metano (ALQARALLEH et al., 2018; HAGOS et al., 2017; PANPONG et al., 2014).

\subsubsection{Dejeto bovino}

Os dejetos de animais têm sido utilizados na biodigestão, tanto como fonte de matéria orgânica a ser degradada, como de micro-organismos anaeróbios, produtores de biogás (NESHAT et al., 2017). Os dejetos bovinos, por exemplo, são provenientes da atividade agropecuária que mais degrada o meio ambiente, devido ao grande número de animais e ao volume de resíduos gerados (10-20 kg por animal/dia). Os dejetos bovinos apresentam um alto potencial poluente, mas também energético, que pode ser aproveitado, utilizando sistemas controlados, como os biodigestores, pois a partir da fermentação das fezes há a emissão de metano $\left(\mathrm{CH}_{4}\right)$ e óxido nitroso $\left(\mathrm{N}_{2} \mathrm{O}\right)$ (COLATTO; LANGER, 2011; DOS SANTOS; NOGUEIRA, 2012).

O potencial de geração de biogás a partir do esterco bovino brasileiro está em média em 62,9 bilhões de $\mathrm{m}^{3}$ por ano, o que equivale a geração de 117,08 TWh de energia elétrica por ano. Adicionalmente, um manejo adequado do esterco evita emissões de gases de efeito estufa equivalente à mitigação de $564.122 \mathrm{Gg}$ de $\mathrm{CO}_{2}$ por ano (DOS SANTOS; NOGUEIRA, 2012).

\subsubsection{Biogás}

O biogás é um setor extremamente importante para toda a indústria de bioenergia. Ele é produzido via DA a partir de diferentes matérias orgânicas e é composto principalmente de metano $\left(\mathrm{CH}_{4}\right)$ e dióxido de carbono $\left(\mathrm{CO}_{2}\right)$. Os principais substratos utilizados para a produção de biogás são os dejetos de animais, lodo proveniente do tratamento de esgoto, resíduos da produção agrícola, fração orgânica dos resíduos domésticos e industriais, e culturas energéticas, incluindo milho e silagem de grama. O biogás é fornecido para uma variedade de usos e mercados, incluindo eletricidade, aquecimento e transporte. Em 2018, 59,3 bilhões de $\mathrm{m}^{3}$ de biogás foram produzidos globalmente com um conteúdo de energia equivalente a 1,36 EJ. Durante 2000-2018, o setor experimentou uma taxa de crescimento anual de 9\% (WBA, 2020).

A Europa é líder mundial na produção de biogás, sendo que em 2018 esta produziu 30,9 bilhões de $\mathrm{m}^{3}$ do gás em questão, o que equivale por mais da metade da produção global. A Ásia é a segunda maior produtora, com uma participação de 32\% (WBA, 2020).

O setor de transporte é responsável pelo consumo de cerca de $27 \%$ de toda a energia 
produzida globalmente. O petróleo bruto e seus derivados contribuem com $92 \%$ das necessidades de energia desse setor, enquanto os biocombustíveis (líquidos e biogás) têm uma participação de aproximadamente 3\% (WBA, 2020).

\subsubsection{Perfil da produção de biogás no Brasil}

No Brasil, já existem diversos projetos que visam a expansão da produção de biogás, visto que o país tem um dos maiores potenciais bioenergéticos do mundo devido ao alto volume de resíduos orgânicos disponíveis. A partir dos incentivos trazidos pelo RenovaBio, Nova Política Nacional dos Biocombustíveis, o biogás vem ganhando, desde 2018, valor agregado à matriz renovável de baixa emissão (junto com etanol e biodiesel) (MINISTÉRIO, 2018).

De acordo com a Cibiogás - Centro Internacional De Energias Renováveis - Biogás (CIBIOGÁS, 2020), o Brasil tem 521 usinas de geração de biogás em operação, que produziram juntas 1,3 bilhão de $\mathrm{m}^{3}$ em 2019. Setenta e oito por cento destas unidades em operação são de pequeno porte, com produção de até 1 milhão de $\mathrm{m}^{3}$ de biogás por ano, sendo que destas, $86 \%$ atuam com atividades agropecuárias (suinocultura, bovinocultura, agrícolas, resíduo sucroalcooleiro). As unidades de grande porte (a partir de 5 milhões de mªno) representam apenas $6 \%$ das usinas, no entanto, estas são responsáveis por $77 \%$ do biogás gerado e são principalmente em aterros sanitários e estações de tratamento de esgoto. São Paulo é o principal estado produtor de biogás, com 44 plantas que respondem por 35,3\% da geração nacional, a qual é proveniente de unidades em aterros, estações de tratamento de esgoto e usinas sucroenergéticas.

Quanto a aplicação energética, 84\% das usinas (439 unidades) geram eletricidade a partir do uso de 1,1 bilhão de $\mathrm{m}^{3}$ de biogás/ano; 70 delas geram energia térmica (utilizando 132 milhões de $\mathrm{m}^{3}$ de biogás por ano); e apenas 6 produzem biometano veicular a partir da purificação de 37,7 milhões de $\mathrm{m}^{3}$ de biogás por ano (CIBIOGÁS, 2020).

\subsection{5. Ácidos graxos voláteis}

Semelhante à refinaria de petróleo, a biorrefinaria com base na DA da biomassa, tem como objetivo fornecer uma gama de produtos bio-derivados valiosos comercialmente (LIN et al., 2013). Os ácidos graxos voláteis (AGVs) são formados como produtos intermediários do processo de DA e podem ser aplicados como precursores de diversos biomateriais essenciais (Tabela 2). Os AGVs são compostos monocarboxilatos alifáticos de cadeia curta contendo entre dois e seis átomos de carbono. Exemplos de AGVs são ácido acético, propiônico, isobutírico, butírico, isovalérico, valérico e capróico (BHATIA; YANG, 2017). 
Os estágios intermediários dentro da DA, acidogênese e acetogênese, podem ser potencializados para aumentar a produção de AGVs. Com base na robustez dos microorganismos envolvidos nessas etapas e na capacidade de manter sua atividade na ausência dos metanogênicos, as condições que funcionam a favor da produção ácida podem ser aumentadas no que é conhecido como digestão acidogênica. A eficiência de formação do substrato para AGVs pode ser quantificada em termos do grau de acidificação (fração da $\mathrm{CO}$ alimentada que é convertida em AGVs) e o rendimento do produto (total de AGVs produzidos por SV adicionado) (AHRING, 2003; KONDUSAMY; KALAMDHAD, 2014; WAINAINA, 2020).

Uma das aplicações diretas dos AGVs, em demonstrações piloto e em escala real, é a remoção biológica de nitrogênio e fósforo durante o tratamento de águas residuais (CHAE et al., 2004; OEHMEN et al., 2007). Os AGVs são usualmente adicionados no tratamento residual para aumentar a quantidade de fonte de carbono no processo de remoção de nutrientes, atuando assim como uma alternativa sustentável que pode melhorar a economia no procedimento, enquanto reduz a pegada de carbono (BLACKALL et al., 2002; MORSE et al., 1998).

Com o objetivo de reduzir o custo das matérias-primas e aumentar o valor ecológico, os AGVs podem ser empregados na síntese de polímeros ou plásticos biodegradáveis, como os polihidroxialcanoatos (PHAs), os quais têm características comparáveis aos materiais à base de petróleo, como o polipropileno (NIELSEN et al., 2017; STRAZZERA et al., 2018).

Os AGVs também podem ser usados para cultivar micro-organismos úteis na produção de biocombustíveis, como Cryptococcus curvatus e Yarrowia lipolytica para a produção de biodiesel (GAO et al., 2017; LEE et al., 2014; MA et al., 2013). Além disso, a mistura de AGVs pode ser reduzida, tanto biologicamente quanto quimicamente, a álcoois mistos que podem ser utilizados como combustíveis de transporte (VASQUEZ et al., 2014). A Tabela 2 traz exemplos de aplicações dos diferentes AGVs. 
Tabela 2. Potencial de aplicação dos AGVs

\begin{tabular}{cc}
\hline AGV & Área de aplicação \\
\hline Acético & Aditivos alimentares, plastificantes, corantes \\
Propiônico & Resinas, produtos farmacêuticos, tintas \\
Isobutírico & Pesticidas, aditivos alimentares, tintas \\
Butírico & Perfumes, têxteis, plásticos \\
Isovalérico & Produtos farmacêuticos, perfumes, fungicidas \\
Valérico & Plastificantes, lubrificantes \\
Capróico & Sabor de tabaco, borracha, graxa \\
\hline
\end{tabular}

Fonte: CALT (2015); WAINAINA et al. (2019).

\subsection{Fermentação alcoólica}

O etanol, ou álcool etílico, é um líquido volátil, inflamável e incolor. A produção alcoólica a partir de insumos renováveis (bioetanol) visa a substituição da gasolina no setor de transportes, além de ser útil nos mais variados setores industrias, como químico, cosmético, farmacêutico, médico, automotivo e de bebidas (VIERHOUT, 2014).

Dentre os biocombustíveis considerados para substituir os combustíveis fósseis utilizados no transporte, o bioetanol é a alternativa mais econômica e disponível até o momento. A produção de etanol atingiu um novo patamar em 2017 e é hoje o principal biocombustível do mundo. O US Energy Information Administration (EIA) indicou que, no primeiro semestre de 2017, a produção semanal de etanol foi em média 1,02 milhões de barris por dia, aumentando $5 \%$ em relação ao mesmo período de 2016, e sendo este valor $13 \%$ superior à produção média dos últimos cinco anos (HERNANDEZ et al., 2020).

Os substratos para a produção de bioetanol de $1^{\text {a }}$ geração incluem safras à base de amido, como trigo, milho, cevada, e centeio ou safras ricas em açúcar, como beterraba ou cana-deaçúcar (ADIB et al., 2015; VIERHOUT, 2014). Os EUA e o Brasil são os maiores produtores de bioetanol no cenário global, respondendo respectivamente por $58 \%$ e $27 \%$ da produção total no mundo. Nos Estados Unidos, o etanol é produzido principalmente a partir do milho, enquanto a cana-de-açúcar é a principal matéria-prima do mercado brasileiro (HERNANDEZ et al., 2020).

As fábricas modernas de etanol podem converter o grão de milho em etanol numa proporção de 2,7 - 2,8 galões por alqueire de plantação (MOSIER, 2020). O processo de moagem do milho a seco, tem como resultantes finais o etanol e produtos para ração animal (grãos moídos secos). Durante o processo de moagem a seco, o grão de milho é moído em moinhos de martelo até virar um farelo de $1 \mathrm{~mm}^{2}$ (RAUSCH et al., 2005). Este pó é misturado 
com água, de modo a formar uma massa pastosa, que é cozida e adicionada de enzimas, as quais irão hidrolisar o amido em monômeros de açúcar. Posteriormente, leveduras Saccharomyces cerevisiae serão adicionadas ao processo e serão responsáveis pela fermentação, ou seja, conversão dos monômeros de glucose em etanol (LENNARTSSON; ERLANDSSON; TAHERZADEH, 2014; TAHERZADEH et al., 2013). A etapa de pré-hidrólise pode ser eliminada por adição concomitante de enzimas sacarificantes e leveduras ao tanque de fermentação (DE JONG; JUNGMEIER, 2015). Após a conclusão da fermentação e consequente sequestro de $\mathrm{CO}_{2}$, a pasta aquosa restante (composta por células de levedura e resíduos dos grãos moídos) vai para a coluna de destilação (BOTHAST; SCHLICHER, 2005). O etanol é então separado, purificado e desidratado para concentrações acima de 99,7\% para aplicações de combustível. Os grãos restantes no destilador são secos e utilizados como uma fonte de proteína para alimentação animal (DE JONG; JUNGMEIER, 2015; MCALOON et al., 2000). 
Este trabalho buscou investigar a influência da hidrólise enzimática no aumento da biodegradabilidade da biomassa útil para produção bioenergética.

A Parte 1 deste trabalho traz resultados obtidos nos laboratórios de Microbiologia e Biologia Celular (Departamento de Biologia) e Laboratório de Biotecnologia Ambiental e Energias Renováveis - LABIORE (Departamento de Química), ambos pertencentes a FFCLRP/USP, Brasil. Esta primeira parte teve como objetivo geral selecionar e avaliar a hidrólise de 22 diferentes tipos de biomassas a partir da aplicação de 3 extratos enzimáticos, sendo dois deles produzidos por fungos selvagens e um de natureza comercial. A partir da seleção e otimização de um processo hidrolítico para a biomassa selecionada, o objetivo final foi o estudo da aplicação deste hidrolisado para a produção de metano.

Os objetivos específicos da Parte 1 foram:

- Seleção entre 22 biomassas aquelas mais hidrolisáveis pelos 3 diferentes extratos enzimáticos aplicados;

- Avaliação da hidrólise a partir de designs de misturas entre, ora os 3 extratos enzimáticos, ora entre as 3 biomassas previamente selecionadas (farelo de milho, casca de banana e farelo de grão de sorgo);

- Seleção de uma biomassa (farelo de milho) e otimização de sua hidrólise: concentração; tempo; $\mathrm{pH}$ e temperatura;

- Caracterização do extrato enzimático produzido por A. brasiliensis aplicado na hidrólise do farelo de milho: perfil enzimático, análise por PAGE e zimograma, temperatura e pH ótimo de dosagem da amilase presente no extrato;

- Comparação da produção de metano a partir do farelo de milho e hidrolisado de milho.

A Parte 2 do trabalho contempla os experimentos desenvolvidos durante o doutorado sanduíche realizado na Universidade de Borås, Suécia, no Laboratório de Biogás do departamento de Recuperação de Recursos. A partir do estudo preliminar de hidrólise da biomassa, essa segunda parte do trabalho objetivou avaliar e comparar a DA do farelo de milho em batelada e semi-contínua quando (i) sob influência do extrato bruto enzimático otimizado para produção de amilase, e (ii) em co-digestão com dejeto bovino. Adicionalmente, também se objetivou a avaliação da fermentação alcoólica do farelo de milho quando (i) pré-sacarificado pelo extrato bruto enzimático produzido por A. brasiliensis, e quando (ii) sacarificado ao mesmo tempo que fermentado.

Os objetivos específicos da Parte 2 foram: 
- DA em batelada para seleção de inóculo: dejeto bovino ou lodo termofílico;

- Mono e co-digestão em batelada para avaliação e seleção de substrato;

- DA semi-contínua do farelo de milho sob a influência da aplicação do extrato enzimático otimizado para produção de amilase e em co-digestão com dejeto bovino;

- Fermentação alcoólica do farelo de milho pré-sacarificado e sob concomitante sacarificação e fermentação. 


\section{Parte 1}

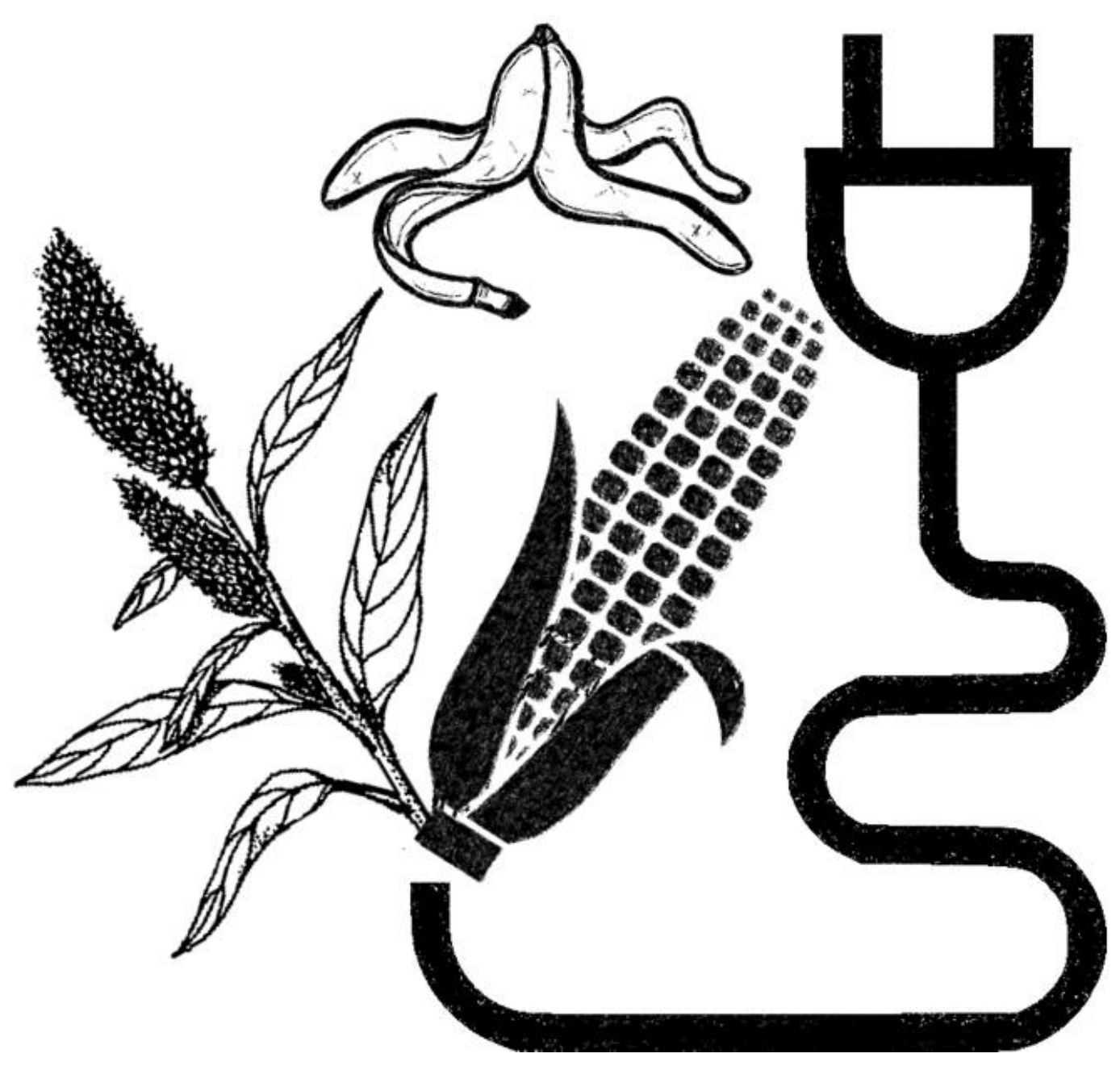

\section{Screening, hidrólise \& aplicação da biomassa}

Parte deste trabalho foi publicado na Biofuels, Bioproducts \& Biorefining em 2021 Apêndice 2, e parte está submetido para publicação na Biomass Conversion and Biorefinery (05/2021) - Apêndice 3. 


\subsection{Micro-organismos}

Os fungos Aspergillus brasiliensis e Aspergillus tamarii Kita foram provenientes da Coleção de Micologia do Laboratório de Microbiologia e Biologia Celular do Departamento de Biologia da Faculdade de Filosofia, Ciências e Letras de Ribeirão Preto - USP (SP/Brasil), onde estavam preservados em tubos com Potato Dextrose Ágar (PDA Himedia, Brasil) a $4^{\circ} \mathrm{C}$.

Aspergillus brasiliensis foi isolado da Mata Atlântica brasileira em Peruíbe - SP (ALMEIDA et al., 2018). Esta cepa está preservada sob o número de registro CFF124.

Aspergillus tamarii Kita foi isolado de uma amostra de solo da Mata Atlântica do refúgio biológico Bela Vista, Foz do Iguaçu - Brasil. A sequência parcial da região ITS1-5,8S-ITS2 do A. tamarii Kita está depositada no National Center for Biotechnology Information (NCBI) e tem o número de acesso KJ995575.1 (HEINEN et al., 2017).

\subsection{Biomassa}

Diferentes tipos de biomassa foram utilizados no screening: resíduo de malte (Hordeum vulgare) pós processo de maturação, gentilmente fornecido pela cervejaria "Colorado" de Ribeirão Preto/SP/Brasil; bagaço de cana-de-açúcar (Saccharum officinarum) moído e lavado, fornecido pela Usina Guarani (São Paulo/Brasil); capim-elefante (Pennisetum purpureum), obtido após 120 dias de plantio das sementes em solo úmido na cidade de Leme/SP/ Brasil e posteriormente seco em estufa a $50{ }^{\circ} \mathrm{C}$ por 24 horas e moído em moinho de facas $\left(1 \mathrm{~mm}^{2}\right)$. Tortas de laranja com pedaços grossos $\left(10 \mathrm{~mm}^{2}\right)$ e médios $\left(5 \mathrm{~mm}^{2}\right)$ foram resíduos de bagaço de laranja obtidos da indústria de suco de laranja (Citrosuco) próximo a cidade de São José do Rio Preto SP/Brasil. A casca de laranja (Citrus sinensis var. Bahia) e de banana (Musa spp. var. Prata) foram obtidas após o consumo das frutas, e então secas em estufa a $50{ }^{\circ} \mathrm{C}$ por 24 horas e moídas em moinho de facas até o tamanho de partícula de $1 \mathrm{~mm}^{2}$. O farelo de trigo (Triticum $s p$.) foi obtido comercialmente (Macrozen ${ }^{\circledR}$ - alimentos integrais), e a borra de café (Coffea $s p$.) foi coletada após o preparo da bebida por filtração do pó comercial 3 Corações®. O lodo branco foi fornecido pela Indústria Internacional Paper localizada na cidade de Luiz Antônio/SP/Brasil. Essa amostra de lodo foi autoclavada para evitar a proliferação de microorganismos e armazenada em sacos de polietileno em câmara fria $\left(4^{\circ} \mathrm{C}\right)$. A vinhaça utilizada foi fornecida pela Biosev - Leme/SP/Brasil. A palha do milho (Zea mays), caule e grão de sorgo (Sorghum bicolor), e caule de algodão (Gossypium hirsutum L.) foram obtidos de plantios na região de Leme/SP/Brasil, enquanto a casca e raiz de mandioca (Manihot esculenta) foram obtidas de um supermercado na cidade de Ribeirão Preto/SP/Brasil. Estas biomassas (palha do milho, caule e grãos de sorgo, caule de algodão, e casca e raiz de mandioca), foram secas em 
estufa a $50{ }^{\circ} \mathrm{C}$ por 24 horas e separadamente moídas em partículas de $1 \mathrm{~mm}^{2}$ em moinho de facas, de modo a originar os farelos secos dos respectivos substratos. Os Grãos de Destilaria Úmidos (Wet distillers grains - WDG), coprodutos da produção de etanol a partir da fermentação do milho, foram doados pela SJC Bioenergia. O farelo e a palha de soja (Glycine max), provenientes da Fazenda Três Pinheiros localizada em Planaltina/DF/Brasil, foram autoclavados a $121{ }^{\circ} \mathrm{C}$ por 2 horas, lavados e secos em estufa a $60{ }^{\circ} \mathrm{C}$ por 48 horas, e moídos em moinho de faca $\left(1 \mathrm{~mm}^{2}\right.$ para farelo de soja e $5 \mathrm{~mm}^{2}$ para palha de soja). O farelo de milho Fubá Mimoso Yoki® foi adquirido no supermercado.

\subsection{Produção de enzimas}

O extrato bruto otimizado para produção de amilase, denominado como AMI neste trabalho, foi preparado de acordo com ALMEIDA et al. (2018) com modificações. Culturas de A. brasiliensis foram obtidas mediante inóculo de $1,0 \mathrm{~mL}$ de uma solução de conídios $\left(10^{6}\right)$ em frascos Erlenmeyer de $125 \mathrm{~mL}$ contendo $25 \mathrm{~mL}$ de meio Segato Rizzatti (SR) (RIZZATTI et al., 2001) e $1 \%(\mathrm{~m} / \mathrm{v})$ de farelo de milho, previamente esterilizados em autoclave a $127{ }^{\circ} \mathrm{C}, 1,5$ atm por 15 minutos. Os meios foram ajustados em pH 6,0 e incubados a $30{ }^{\circ} \mathrm{C}$ por $120 \mathrm{~h} \mathrm{em}$ condição estática. O meio SR é composto por $5 \mathrm{~mL}$ de solução de sais SR [20x] $\left(\mathrm{MgSO}_{4} .7 \mathrm{H}_{2} \mathrm{O}\right.$ 0,24 g; $\mathrm{KH}_{2} \mathrm{PO}_{4} 0,3 \mathrm{~g} ; \mathrm{NH}_{4} \mathrm{H}_{2} \mathrm{PO}_{4} 1 \mathrm{~g}$ e água deionizada $100 \mathrm{~mL}$ ), extrato de levedura 0,45 g; peptona $0,02 \mathrm{~g}$; água deionizada q.s.p $100 \mathrm{~mL}$.

O extrato bruto otimizado para produção de xilanase por A. tamarii Kita, nomeado como XIL neste trabalho, foi produzido de acordo com HEINEN et al. (2017). Culturas de A. tamarii Kita foram obtidas mediante inóculo de $1,0 \mathrm{~mL}$ de solução de conídios $\left(10^{6}\right)$ em frascos Erlenmeyer de $125 \mathrm{~mL}$ contendo $3 \%$ de resíduo de malte $(\mathrm{m} / \mathrm{v})$ e $25 \mathrm{~mL}$ de água e solução de sais Adams (ADAMS, 1990) (1:3 v/v), previamente esterilizados em autoclave a $127^{\circ} \mathrm{C}, 1,5$ atm por 15 minutos. Os meios, com pH 6,0, foram incubados por 129 horas a $30^{\circ} \mathrm{C}$ em condição estática. A solução de sais Adams é composta por peptona $0,2 \mathrm{~g} ; \mathrm{KH}_{2} \mathrm{PO}_{4} 0,1 \mathrm{~g} ; \mathrm{MgSO}_{4} .7 \mathrm{H}_{2} \mathrm{O}$ $0,05 \mathrm{~g}$; água deionizada q.s.p. $100 \mathrm{~mL}$.

Após o tempo de cultivo, as culturas em ambos os casos foram filtradas a vácuo em papel filtro Whatman $n^{\circ} 1$ e as atividades enzimáticas foram determinadas a partir dos filtrados (extratos extracelulares brutos).

Celluclast $^{\mathrm{TM}}$ (Novozymes ${ }^{\circledR}$ ) contento celulases produzidas por Trichoderma reesei foi o consórcio enzimático testado neste projeto para a hidrólise celulolítica. O extrato comercial foi diluído dez vezes e, denominado CEL. 


\subsection{Dosagem das atividades enzimáticas}

As atividades de degradação de polissacarídeos por amilases, xilanases, pectinases, carboximetilcelulases (CMCases) e arabinanases foram analisadas com base na quantidade de açúcar redutor (AR) liberada segundo método de Miller com ácido 3,5-dinitrosalicílico (DNS) (MILLER, 1959).

As atividades de amilases, CMCases, xilanases, pectinases e arabinanases foram determinadas a partir de seus substratos naturais, isto é, amido de batata solúvel, carboximetilcelulose de média viscosidade, xilana de madeira de faia, pectato de sódio e arabinano linear, respectivamente. As misturas de $50 \mu \mathrm{L}$ de substrato (1\%) em tampão acetato de sódio $(100 \mathrm{mM}, \mathrm{pH} 5,0)$ e $50 \mu \mathrm{L}$ de extrato enzimático foram mantidas em banho-maria a 45,50 ou $70{ }^{\circ} \mathrm{C}$ (dependendo do experimento em questão) por 10 minutos no caso da dosagem das amilases, xilanases, pectinases e arabinanases, e por 60 minutos no caso de CMCases. Todas as amostras foram então fervidas a $100{ }^{\circ} \mathrm{C}$ por 5 minutos e, finalmente, $1 \mathrm{~mL}$ de água destilada foi adicionado a cada mistura. A concentração de AR foi determinada medindo as intensidades de cor em espectrofotômetro a $540 \mathrm{~nm}$. A unidade de atividade enzimática foi definida como a quantidade de enzima capaz de liberar $1 \mu \mathrm{mol}$ de RS por minuto. Foram utilizadas curvas padrões de glucose $(1 \mathrm{mg} / \mathrm{mL})$ para as celulases e amilases; xilose $(1 \mathrm{mg} / \mathrm{mL})$ para as xilanases; arabinose $(1 \mathrm{mg} / \mathrm{mL})$ para arabinanases; e ácido monogalacturônico $(1 \mathrm{mg} / \mathrm{mL})$ para pectinases.

A atividade de $\beta$-glucosidase foi determinada por hidrólise de $p$-nitrofenil- $\beta$-Dglucopiranosídeo (pNPG). O ensaio foi iniciado com $15 \mu \mathrm{L}$ do extrato bruto adicionado a 10 $\mu \mathrm{L}$ de tampão McIlvaine pH 6,0 e $25 \mu \mathrm{L}$ de pNPG (4 mM em $\mathrm{H}_{2} \mathrm{O}$ ) e incubado por 5 minutos a $50{ }^{\circ} \mathrm{C}$. A reação foi interrompida pela adição de $50 \mu \mathrm{L}$ de solução de $\mathrm{Na}_{2} \mathrm{CO}_{3} 0,2 \mathrm{M}$. A determinação foi realizada em espectrofotômetro a $405 \mathrm{~nm}$. A unidade enzimática (U) foi definida como a quantidade de enzima necessária para hidrolisar um $\mu$ mol do substrato por minuto.

\subsection{Determinação de Proteínas}

A quantificação de proteínas presentes nos extratos enzimáticos brutos decorreu por meio de Coomassie Brilliant Blue G-250 de acordo com a técnica de Bradford (BRADFORD, 1976), utilizando-se albumina de soro bovino como padrão. A leitura foi realizada em espectrofotômetro a $\lambda 595 \mathrm{~nm}$, e a unidade proteica foi definida como $\mathrm{mg}$ de proteína por $\mathrm{mL}$ $(\mathrm{mg} / \mathrm{mL})$. 


\subsection{Hidrólise da biomassa}

Para análise do efeito do pré-tratamento enzimático sobre os resíduos foi utilizada a metodologia de dosagem de AR, descrita por (MILLER, 1959), a qual possibilita quantificar os açúcares simples formados.

\subsubsection{Screening}

O screening para seleção dos substratos melhor hidrolisados pelos extratos enzimáticos foi realizado aplicando-se isoladamente cada extrato, XIL, AMI ou CEL, sobre os 22 diferentes tipos de biomassa (item 3.2.). Em cada caso, $50 \mathrm{mg}$ de biomassa e $1 \mathrm{~mL}$ de extrato $(1: 20 \mathrm{~m} / \mathrm{v})$ foram adicionados a tubos Eppendorf de $2 \mathrm{~mL}$, os quais foram mantidos a $50^{\circ} \mathrm{C}$ por 24 horas em banho de agitação a seco $(50 \mathrm{rpm})$ para que a hidrólise ocorresse. As concentrações de AR $(\mu \mathrm{mol} / \mathrm{mL})$ nos hidrolisados foram determinadas conforme item 3.6.

\subsubsection{Planejamento de misturas e análises estatísticas}

Seis planejamentos experimentais foram realizados. Todos eles compreendem simplexcentroide designs para 3 componentes, consistindo em frações puras e misturas de dois e três componentes.

Os três primeiros designs buscaram definir uma formulação de mistura enzimática ótima para a hidrólise dos substratos investigados, isto é, farelo de milho, casca de banana ou farelo de grão de sorgo. Assim, três extratos de enzimas, AMI (A), XIL (B) e CEL (C) foram as variáveis independentes testadas para hidrólise de cada biomassa.

Os três designs de misturas seguintes concentraram-se em testar como as três biomassas, em frações puras ou em misturas, podem ser hidrolisadas por cada um dos extratos enzimáticos testados, XIL, AMI e CEL. Assim, farelo de milho, casca de banana e farelo de sorgo foram as variáveis independentes nesses experimentos.

A produção de $\mathrm{AR}(\mu \mathrm{mol} / \mathrm{mL})$ obtida ao final dos experimentos foi utilizada como variável de resposta em todos esses ensaios.

As reações de mistura foram realizadas em tubos Eppendorf de $2 \mathrm{~mL}$ contendo $50 \mathrm{mg}$ de biomassa, $1 \mathrm{~mL}$ de extrato enzimático tamponado em acetato de sódio (100 mM, pH 5,0) e azida de sódio $15 \mathrm{mM}$ para evitar contaminação bacteriana. A hidrólise enzimática foi então realizada a $50^{\circ} \mathrm{C}$ e $50 \mathrm{rpm}$ em um banho de agitação seco. Após 24 horas de hidrólise, alíquotas de $10 \mu \mathrm{L}$ foram retiradas de cada tubo e imediatamente fervidas por 5 minutos para inativar as enzimas, e os AR foram então quantificados ( $\mu \mathrm{mol} / \mathrm{mL})$. 
O efeito de composições de mistura terciária de (i) biomassa, ou seja, farelo de milho, casca de banana e farelo de grão de sorgo, e também (ii) extratos de enzima, XIL, AMI e CEL foram investigados por meio de simplex centróide designs. Este tipo de projeto possui $2^{\mathrm{q}-1}$ pontos, onde $\mathrm{q}=3$ representa o número de componentes em cada sistema e $\mathrm{x} i$ representa a proporção do $i$-ésimo constituinte na mistura. A proporção dos componentes em cada planejamento variou entre 0 e 1 de acordo com a Equação 9.

$\sum_{i=1}^{3} x i=x_{1}+x_{2}+x_{3}=1 ; \quad 0 \leq x i \geq 1$

Para predizer a resposta variável $\mathbf{Y}$ em função dos três componentes, modelos polinomiais foram empregados para vincular a resposta com a composição das misturas. Os coeficientes de primeira ordem (Equação 10) medem o efeito relativo de substratos puros e os termos quadrático (Equação 11) e cúbico especial (Equação 12) medem as interações sinérgicas ou antagônicas entre as frações.

Modelo linear

$Y=\beta_{1} x_{1}+\beta_{2} x_{2}+\beta_{3} x_{3}$

Modelo quadrático

$Y=\beta_{1} x_{1}+\beta_{2} x_{2}+\beta_{3} x_{3}+\beta_{12} x_{1} x_{2}+\beta_{13} x_{1} x_{3}+\beta_{23} x_{2} x_{3}$

Modelo cúbico especial

$Y=\beta_{1} x_{1}+\beta_{2} x_{2}+\beta_{3} x_{3}+\beta_{12} x_{1} x_{2}+\beta_{13} x_{1} x_{3}+\beta_{23} x_{2} x_{3}+\beta_{123} x_{1} x_{2} x_{3}$

onde $Y$ é a variável dependente (produção de $\mathrm{AR}(\mu \mathrm{mol} / \mathrm{mL}), \beta i$ são os coeficientes de regressão (calculados a partir de dados experimentais) e Xi são as variáveis independentes (componentes) (CORNELL, 2011; GIESE et al., 2011; NETO; SCARMINIO; BRUNS, 2010).

Todos os modelos foram ajustados para cada variável de resposta por meio de métodos de regressão e analisados com ANOVA. A significância dos modelos de regressão foi avaliada ao nível de significância de 5 ou $10 \%$ ( $p$-valor $\leq 0,05$ ou $\leq 0,1)$ dependendo do experimento. A hipótese de que o modelo selecionado era adequado para descrever cada dado experimental foi verificada pela falta de ajuste. O software Statistica v.13.0 (STATSOFT, EUA) foi utilizado para as análises. 


\subsection{Caracterização do extrato enzimático produzido por $A$. brasiliensis}

\subsubsection{Gel de eletroforese em condições não desnaturantes (PAGE) e zimograma}

A eletroforese em condições não desnaturante foi realizada conforme o protocolo de (DAVIS, 1964). O gel de acrilamida foi utilizado na concentração de $10 \%$ e polimerizado em placas de vidro $(7,2 \times 10,2 \mathrm{~cm})$ com espessura de $1 \mathrm{~mm}$. O extrato bruto AMI (amostra em análise) foi ressuspenso em tampão de amostra, sendo glicerol 5\%, $5 \mu \mathrm{L}$ azul de bromofenol e $10 \mu \mathrm{L}$ da amostra. A eletroforese foi realizada em tampão Tris-glicina no pH 8,3 (Tris-HCl 25 $\mathrm{mmol} / \mathrm{L}$ e glicina $192 \mathrm{mmol} / \mathrm{L}$ ) durante 1-2 horas a $140 \mathrm{~V}$ e corrente elétrica de $40 \mathrm{~mA}$.

Foi utilizado marcador molecular de 10 a 250 kDa Precision Plus PorteinTM Standards da Bio-Rad. Após a corrida da eletroforese, o gel foi dividido em duas partes: uma metade do gel foi corado com Coomassie Blue segundo a metodologia descrita por LAWRENCE; BESIR (2009) para determinação do perfil proteico, enquanto a segunda metade foi submetida a técnica de zimograma. Para determinar a atividade amilolítica das proteínas presentes no gel, este foi

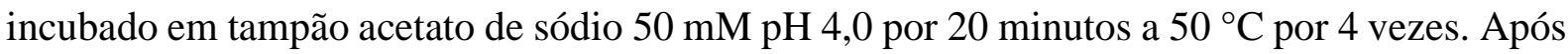
lavagem, o gel foi mantido em solução de amido solúvel $1 \%$ em tampão acetato de sódio 50 $\mathrm{mM}$ pH 4,0 a $70^{\circ} \mathrm{C}$ por 1 hora. Após este período as bandas foram reveladas em solução de iodo ( $\mathrm{I}_{2} 1 \%$; KI $\left.1,5 \%\right)$.

Os géis foi foto-documentados por meio de transiluminador.

\subsubsection{Caracterização quanto a temperatura e pH ótimos da amilase presente em AMI}

O efeito da temperatura sobre a atividade da amilase presente no extrato bruto produzido por A. brasiliensis decorreu mediante incubação do extrato com seu respectivo substrato (amido solúvel) nas temperaturas de 33, 35, 40, 45, 47, 50, 60, 70 e $80^{\circ} \mathrm{C}$. Decorrido o tempo de incubação (10 minutos), as amostras foram submetidas ao ensaio enzimático (item 3.4.).

A influência do $\mathrm{pH}$ sobre a atividade da amilase bruta foi verificada, variando-se o $\mathrm{pH}$ da reação entre 3,$75 ; 4,0 ; 4,6 ; 5,2$ e 5,45. O tampão utilizado foi: acetato de sódio $100 \mathrm{mM}$. Decorrido o tempo de incubação, as amostras foram submetidas ao ensaio enzimático (item 3.4.).

\subsection{Otimização da hidrólise do farelo de milho por AMI}

\subsubsection{Concentração do substrato e tempo de hidrólise}

A melhor concentração de farelo de milho para hidrólise foi testada em tubos Eppendorf de $2 \mathrm{~mL}$ dispostos em banho seco a $50{ }^{\circ} \mathrm{C}$ com agitação de $50 \mathrm{rpm}$ por 24 horas com $1 \mathrm{~mL}$ de AMI. A concentração final do substrato variou de 1, 2, 3, 4, 5, 6 e 7\%. 
Para análise do melhor tempo de hidrólise, foram realizados testes com o farelo de milho a uma concentração de $5 \%$. Tubos Eppendorf de $2 \mathrm{~mL}$ foram dispostos em banho seco a $50{ }^{\circ} \mathrm{C}$ com agitação de 50 rpm por 24, 48 e 72 horas. Após o tempo de hidrólise de cada experimento, a quantidade de AR foi medida pelo método de Miller.

\subsubsection{Estudo da temperatura e pH de hidrólise por planejamento experimental e análises estatísticas}

Um Delineamento Composto Central Rotacional (DCCR) e análise de superfície de resposta foram realizados a fim de se estudar o efeito da temperatura e $\mathrm{pH}$ na hidrólise do farelo de milho por AMI.

As variáveis independentes foram estudadas em cinco níveis $(-1,41 ;-1 ; 0 ;+1 ;+1,41)$ definidos de acordo com um planejamento fatorial $2^{2}$ com pontos axiais. O intervalo de estudo da temperatura variou de 33 a $47^{\circ} \mathrm{C}$ e o intervalo do $\mathrm{pH}$ estabelecido foi 3,75 a 5,45 (Tabela 3).

Tabela 3. Valores utilizados no DCCR para a hidrólise do farelo de milho por AMI

\begin{tabular}{ccccccc}
\hline Variável & Código & $\mathbf{- 1 , 4 1}$ & $\mathbf{- 1}$ & $\mathbf{0}$ & $\mathbf{1}$ & $\mathbf{1 , 4 1}$ \\
\hline Temperatura & $\mathrm{X}_{1}$ & 33 & 35 & 40 & 45 & 47 \\
$\mathrm{pH}$ & $\mathrm{X}_{2}$ & 3,75 & 4,0 & 4,6 & 5,2 & 5,45
\end{tabular}

Fonte: dados da autora.

Foi realizado um conjunto de 11 experimentos, três dos quais foram repetições dos pontos centrais. A resposta para as variáveis, onde $Y$ é a produção de $\mathrm{AR}(\mu \mathrm{mol} / \mathrm{mL})$, pode ser aproximada pela equação polinomial descrita na Equação 13.

$$
Y=\beta_{0}+\beta_{1} X_{1}+\beta_{2} X_{2}+\beta_{11} X_{1}^{2}+\beta_{22} X_{2}^{2}+\beta_{12} X_{1} X_{2}
$$

Onde $\beta_{0}$ é a intersecção, $\beta_{1}$ e $\beta_{2}$ são os coeficientes de primeira ordem do modelo (linear), $\beta_{11}$ e $\beta_{22}$ são os coeficientes de segunda ordem (quadráticos), $\beta_{12}$ é o coeficiente entre produtos, $\mathrm{X}_{1}$ e $\mathrm{X}_{2}$ são as variáveis independentes. Neste caso, $\mathrm{X}_{1}$ é a variável temperatura e $\mathrm{X}_{2}$ é o $\mathrm{pH}$.

A significância do modelo polinomial foi considerada adequada e significativa com base nos resultados da ANOVA, ou seja, falta de ajuste, percentual de variação $\left(\mathrm{R}^{2}\right)$ e o valor calculado do teste F. O software Statistica v.13.0 (STATSOFT, EUA) foi usado para analisar 
os dados de regressão experimental e análise gráfica. A análise de variância foi realizada no nível de significância de $10 \%$ ( $p$-valor $\leq 0,1$ ).

Os tratamentos ocorreram em Eppendorf de $2 \mathrm{~mL}$, por 48 horas sob agitação de $50 \mathrm{rpm}$ em banho seco. Para cada $50 \mathrm{mg}$ de farelo de milho, adicionou-se $1 \mathrm{~mL}$ de extrato bruto enzimático, $10 \mu \mathrm{l}$ de azida sódica $15 \mathrm{mM}$ e $50 \mu \mathrm{L}$ de tampão acetato de sódio $1 \mathrm{M}$.

\subsection{Efeito da temperatura sobre a hidrólise do farelo de milho}

Foram realizados testes de hidrólise do farelo de milho na ausência de extrato enzimático e variando-se as temperaturas de reação. Os experimentos foram realizados sob as mesmas temperaturas do planejamento experimental $\left(33,35,40,45\right.$ e $\left.47^{\circ} \mathrm{C}\right)$, no entanto, ao invés de extrato enzimático, foi adicionado $1 \mathrm{~mL}$ de água destilada e $30 \mu \mathrm{l}$ de azida sódica 15 $\mathrm{mM}$ para cada $50 \mathrm{mg}$ de farelo de milho. Os testes ocorreram em Eppendorfs de $2 \mathrm{~mL}$ em banho seco com agitação de $50 \mathrm{rpm}$ por 48 horas. Após o tempo de hidrólise, utilizou-se da metodologia de Miller (MILLER, 1959) para quantificação do AR liberado.

\subsection{Hidrólise do farelo de milho acrescido do micélio de $A$. brasiliensis}

Testes de hidrólise foram realizados com o produto da fermentação em estado sólido do farelo de milho com A. brasiliensis. Em frascos Erlenmeyer de $125 \mathrm{~mL}$ foram adicionados $2 \mathrm{~g}$ de farelo de milho, $3 \mathrm{~mL}$ de solução de sais SR e $1 \mathrm{~mL}$ de uma solução de esporos $\left(10^{6}\right)$ do fungo A. brasiliensis. Os meios de cultivo foram incubados por 120 horas a $30^{\circ} \mathrm{C}$ sem agitação. Após o tempo de crescimento do micro-organismo, as culturas foram maceradas em grau de porcelana e secas em estufa a $50^{\circ} \mathrm{C}$ por 12 horas. $\mathrm{O}$ farelo de milho acrescido do micélio de $A$. brasiliensis foi então hidrolisado por AMI. A hidrólise ocorreu em Eppendorfs de $2 \mathrm{~mL}$, onde $50 \mathrm{mg}$ de farelo de milho acrescido de micélio (produto da FES seco) foi posto em contato com $1 \mathrm{~mL}$ de extrato enzimático produzido AMI e $30 \mu \mathrm{L}$ de azida sódica $15 \mathrm{mM}$ por 48 horas a $45^{\circ} \mathrm{C}$ em banho seco sob agitação de $50 \mathrm{rpm}$. Após o tempo de hidrólise foi analisada a formação de AR pela metodologia de Miller (MILLER, 1959).

\subsection{Ensaios do potencial de produção de metano em modo descontínuo}

Estes ensaios foram realizados empregando-se o método do frasco invertido no Laboratório de Biotecnologia Ambiental e Energias Renováveis - LABIORE/FFCLRP/USP em colaboração com a Professora Dra.Valeria Reginatto Spiller. 


\subsubsection{Materiais}

Foram utilizados como substratos o farelo de milho Yoki® e o hidrolisado de farelo de milho (enzimaticamente tratado conforme as condições otimizadas neste trabalho).

Como inóculo (fonte de microbiota anaeróbia) foi utilizado o dejeto bovino coletado na Universidade Estadual Paulista, Campus de Jaboticabal, Faculdade de Ciências Agrárias e Veterinárias.

\subsubsection{Sólidos Totais e Sólidos Voláteis}

Tanto o inóculo (dejeto bovino), quanto os substratos (hidrolisado de farelo de milho e farelo não tratado) foram caracterizados quanto a concentração de Sólidos Totais (ST) e Sólidos Voláteis (SV), conforme metodologia sugerida por (SLUITER et al., 2005) que compreende secagem a $105{ }^{\circ} \mathrm{C}$ durante a noite, seguido pela combustão dos resíduos secos a $550{ }^{\circ} \mathrm{C}$ por 3 horas em mufla (SLUITER et al., 2008).

\subsubsection{Configuração experimental}

Os biodigestores e o sistema de coleta de gases para os testes de produção de metano foram construídos segundo a metodologia de frascos invertidos descrita por (AQUINO et al., 2007) (Figura 9).

Figura 9. Esquema do modelo de aparato experimental para medição do volume de metano produzido

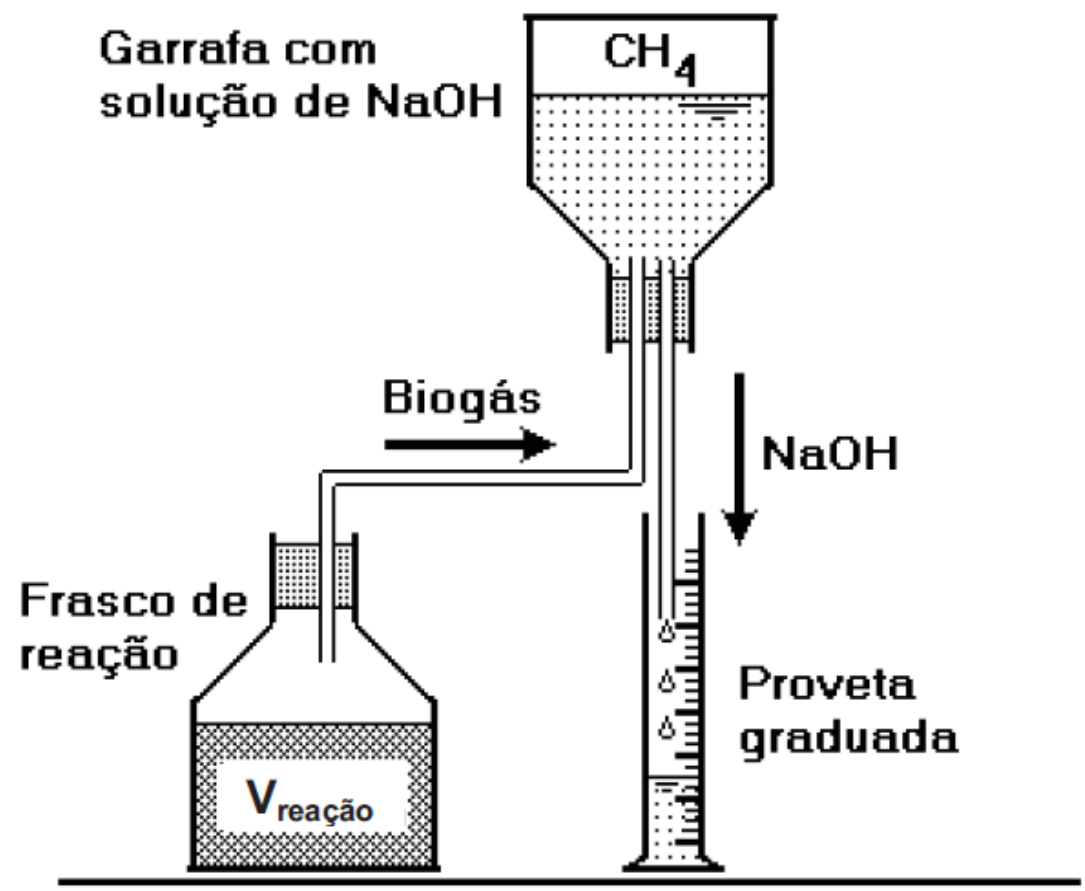

Fonte: AQUINO et al. (2007). 
Os experimentos foram realizados usando dejeto bovino como inóculo e farelo de milho previamente hidrolisado ou não (controle) como substratos. O hidrolisado de farelo de milho adicionado ao biodigestor, foi o produto bruto contendo extrato enzimático bruto, AR obtido durante a hidrólise, assim como o farelo remanescente não degradado.

A Figura 9 mostra uma visão geral esquemática da configuração experimental. Frascos tipo Duran ${ }^{(\mathrm{R})}$ de $250 \mathrm{~mL}$ foram usados como biorreatores. Para a configuração experimental; 4,3 g de SV de substratos foram adicionados a cada digestor, e o inóculo foi acrescentado mantendo-se uma relação S/I (substrato/inóculo) de 1:2 com base nas concentrações de SV do substrato e do inóculo. Solução de micro-nutrientes (nitrofosfatada) foi adicionada em cada biorreator na proporção de $1 \mathrm{~mL} / \mathrm{L}$, assim como a água de torneira, que foi acrescentada de modo a completar o volume de $200 \mathrm{~mL}$.

Os experimentos foram realizados sem qualquer ajuste de $\mathrm{pH}$, uma vez que o inóculo apresentava um $\mathrm{pH}$ de 8,0 \pm 0,5. Reatores contendo inóculo e água de torneira foram utilizados como branco, de modo a revelar qualquer produção de metano pelo próprio inóculo. Como controle positivo foram realizados experimentos cujos reatores continham $100 \mathrm{~mL}$ de uma solução de glucose (Sigma Aldrich) na concentração de $35 \mathrm{~g} / \mathrm{L}$ acrescidos de dejeto bovino, mantendo-se uma relação S/I (substrato/inóculo) de 1:2 com base em SV.

$\mathrm{O}$ conteúdo dos biorreatores foi borbulhado com $\mathrm{N}_{2}$ por 2 minutos, para atingir mais rapidamente as condições anaeróbias. Em seguida os biorreatores foram selados com um septo de borracha e acoplados ao sistema de frasco invertido, demonstrado na Figura 9.

Os reatores foram agitados manualmente uma vez ao dia e todos os experimentos foram feitos em triplicata. A temperatura dos frascos foi mantida a $37 \pm 2{ }^{\circ} \mathrm{C}$, com auxílio de um banho termostatizado.

A tubulação de saída de gás estava acoplada a um sistema de medida de gás, no qual o gás produzido era recolhido em um frasco tipo Mariotte invertido contendo $\mathrm{NaOH} 5 \%(\mathrm{~m} / \mathrm{v})$. $\mathrm{O}$ volume de $\mathrm{NaOH}$ deslocado era captado em uma proveta e representava o volume de gás total gerado, exceto o $\mathrm{CO}_{2}$ pois este ficava retido no $\mathrm{NaOH}$. Os ensaios foram finalizados quando não se observou por dias seguidos nenhuma produção de gás, o que ocorreu em torno de 13 dias.

\subsubsection{Avaliação cinética da produção de metano}

O modelo de Gompertz modificado (Equação 14) (LAY; LI; NOIKE, 1996) foi ajustado aos dados experimentais de volume de metano em função do tempo. Este modelo 
descreve a produção acumulativa de metano e a duração da fase lag também é incluída no modelo.

$G(t)=G \max \cdot \exp \left\{-\exp \left[\frac{R m \cdot e}{G \max }(\lambda-t)+1\right]\right\}$

Onde $\mathrm{G}(\mathrm{t})$ é a produção de metano $\left(\mathrm{NmL} \mathrm{CH}_{4} / \mathrm{g} \mathrm{SV}\right)$ durante o tempo de digestão $(\mathrm{t})$, Gmax é a produção máxima de metano $\left(\mathrm{NmL} \mathrm{CH}_{4} / \mathrm{g} \mathrm{SV}\right)$ no tempo infinito, $\mathrm{Rm}$ é a taxa máxima de produção de metano $\left(\mathrm{NmL} \mathrm{CH}_{4} / \mathrm{g} \mathrm{SV} /\right.$ dia $), e$ é a constante de Euler $=2,718$, $\lambda$ é a duração da fase de latência (lag) e t é o tempo de ensaio (dia).

\subsection{Análises estatísticas}

Os experimentos de hidrólise foram concebidos em triplicata e os desvios padrão foram analisados para o conjunto de execuções experimentais. Análise de variância (ANOVA) usando o software Statistica 13 foi executado para comparar a confiança intervalos e significância entre os dados experimentais dos planejamentos de mistura, DCCR e tratamentos de produção de metano. Os fatores foram considerados significativos quando a probabilidade (valor $P$ ) foi inferior a 0,05 .

O software Origin 2019 foi usado para modelagem de Gompertz modificado. 


\section{Resultados \& Discussão - Parte 1}




\subsection{Produção dos extratos enzimáticos}

A produção e utilização de enzimas nos processos industriais devem ser economicamente viáveis, de forma a não gerar aumentos significativos de custos processuais. Diante desse fato, a produção de enzimas por sistemas comuns e convencionais, como por exemplo a fermentação submersa a partir de resíduos agroindustriais como substratos e fungos selvagens como organismos produtores, proporcionam custos de produção reduzidos e tornam o processo sustentável e econômico (DOS SANTOS FERREIRA et al., 2020; DUARTE et al., 2015; GUTARRA et al., 2007).

Os resultados da produção e determinação das atividades enzimáticas mostraram que as xilanases foram as principais enzimas presentes no extrato XIL a $50{ }^{\circ} \mathrm{C}(23,75 \pm 0,63 \mathrm{U} / \mathrm{mL})$ e as amilases no extrato $\mathrm{AMI}\left(6,0 \pm 0,5 \mathrm{U} / \mathrm{mL}\right.$ quando dosada a $\left.70{ }^{\circ} \mathrm{C}\right)$.

Uma vez que os dois extratos enzimáticos produzidos eram brutos, várias outras enzimas puderam ser encontradas em sua composição (Tabela 4).

Tabela 4. Atividades enzimáticas presentes em cada extrato bruto

\begin{tabular}{cccc}
\hline $\begin{array}{c}\text { Extrato } \\
\text { enzimático }\end{array}$ & Enzima & Atividade $(\mathbf{U} / \mathbf{m L})$ & Referência \\
\hline & Amilase & $6,00 \pm 0,10$ & \\
Pectinase & $0,89 \pm 0,05$ & \\
AMI & Xilanase & $1,00 \pm 0,18$ & Este trabalho \\
& Arabinanase & $0,80 \pm 0,29$ & \\
CMCase & $0,68 \pm 0,14$ & \\
$\beta$-glucosidase & $0,02 \pm 0,01$ & \\
XIL & Xilanase & $23,75 \pm 0,63$ & HEINEN et al. \\
& Pectinase & $0,19 \pm 0,01$ & \\
& Amilase & $6,50 \pm 0,15$ & \\
& Endo-1,4- $\beta$-glucanase & $0,15 \pm 0,01$ & \\
\hline
\end{tabular}

AMI: extrato produto produzido por A. brasiliensis, XIL: extrato bruto produzido por A tamarii Kita. Fonte: dados da autora e HEINEN et al. (2017).

Além disso, SUWANNARANGSEE et al. (2012) e ABDULLAH et al. (2015) relataram o perfil de atividade de Celluclast ${ }^{\mathrm{TM}}$ usando análise proteômica com LC/MS/MS. Eles descobriram que entre as 20 enzimas presentes no Celluclast ${ }^{\mathrm{TM}}, 35 \%$ são celulases: 2 celobiohidrolases (CBH I e CBH II) e 5 endoglucanases, e 40\% são hemicelulases: 2 xilanases, $2 \beta$-xilosidases, 1 xiloglucanase, 1 swolenina, 1 Cip1 (cellulose induced protein) e 1 Cip2. Nenhuma $\beta$-glucosidase foi reportada. 
No presente estudo, as CMCases do Celluclast ${ }^{\mathrm{TM}}$ concentrado foram quantificadas em $78,66 \pm 2,30 \mathrm{U} / \mathrm{mL}$. Para os testes de hidrólise, o extrato comercial foi diluído em 10 vezes, apresentando desta forma uma atividade de 7,8 CMCase U/mL.

\subsection{Seleção dos resíduos hidrolisáveis}

A seleção de um pré-tratamento adequado tem um efeito significativo na viabilidade econômica da produção de biocombustíveis. Portanto, é importante selecionar métodos de prétratamento e substratos adequados, que resultem em concentrações mais altas de açúcares liberados, os quais podem ser mais rapidamente e facilmente utilizados nas etapas seguintes de produção de biocombustível (JAFARI; AMIRI; KARIMI, 2016; SHAFIEI; KARIMI; TAHERZADEH, 2011).

No screening realizado neste trabalho, extratos enzimáticos brutos, XIL, AMI e CEL, foram aplicados individualmente para a hidrólise de 22 amostras de biomassa, e os resultados da quantidade de $\mathrm{AR}(\mu \mathrm{mol} / \mathrm{mL})$ liberada após 24 horas de hidrólise a $50{ }^{\circ} \mathrm{C}$ são mostrados na Figura 10. 
Figura 10. Seleção de biomassa. Produção de AR ( $\mu \mathrm{mol} / \mathrm{mL})$ após 24 horas de hidrólise a 50 ${ }^{\circ} \mathrm{C}$, pH 5,0 com os extratos enzimáticos AMI (A), XIL (B) e CEL (C)
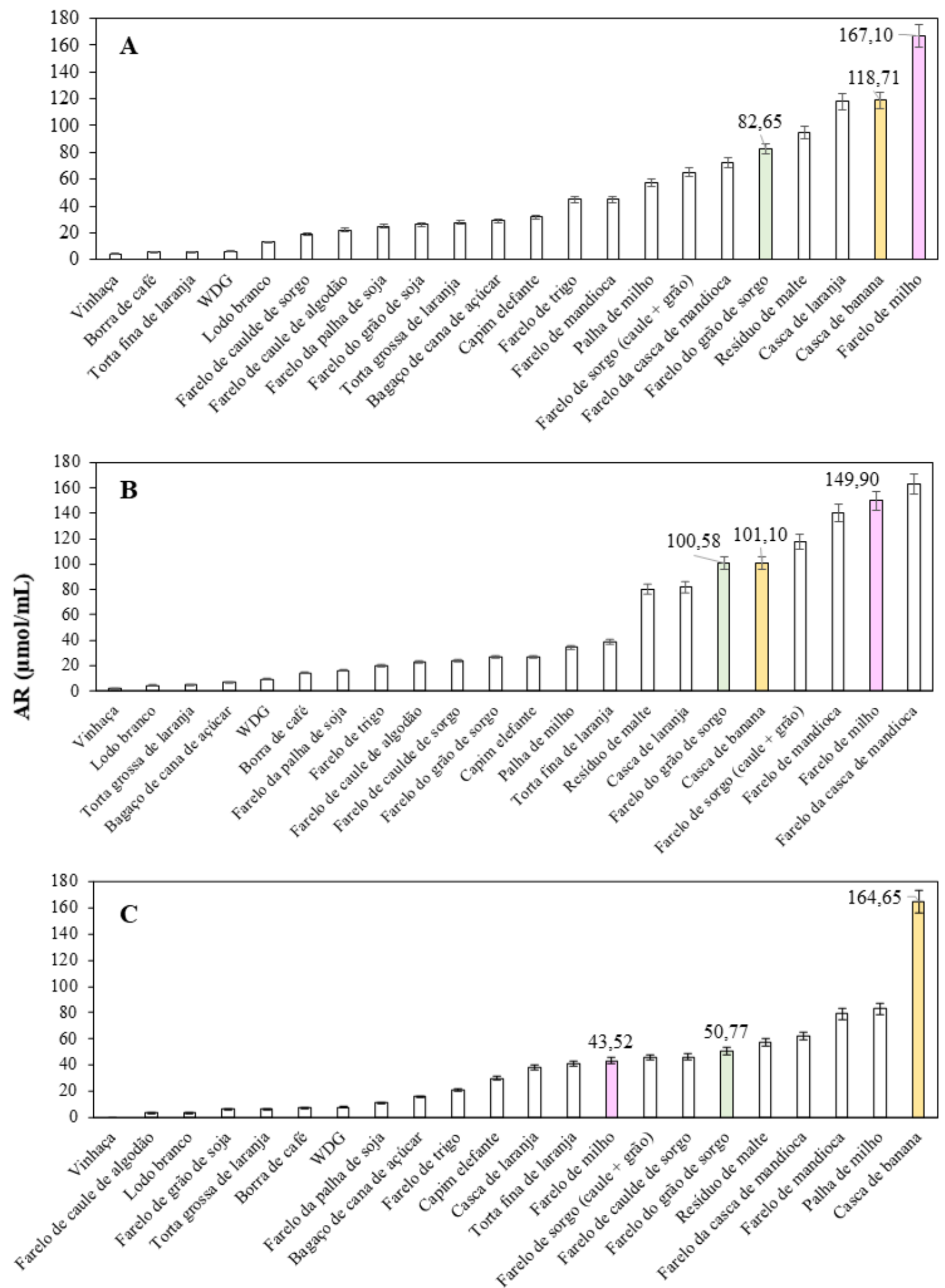

Biomassa

Fonte: dados da autora. 
Farelo de milho, casca de banana, casca de laranja, resíduo de malte, farelo de semente de sorgo e farelo de casca de mandioca apresentaram produções relativamente altas de AR quando hidrolisados com AMI, sendo 167,1 $\pm 5,01 ; 118,71 \pm 3,5 ; 118,0 \pm 3,5 ; 94,38 \pm 2,8$; $82,65 \pm 2,4$ e $72,45 \pm 2,17 \mu \mathrm{mol} / \mathrm{mL}$ os valores respectivamente encontrados após 24 horas de hidrólise (Figura 10A).

O tratamento com XIL resultou em uma hidrólise relativamente alta do farelo de casca de mandioca, farelo de milho, farelo de mandioca, farelo de sorgo total, casca de banana e farelo de semente de sorgo com produções de AR correspondentes a 162,97 \pm 4,98; 149,9 \pm 4,5; $140,71 \pm 4,22 ; 117,76 \pm 3,53 ; 101,1 \pm 3,0$ e $100,58 \pm 3,0 \mu \mathrm{mol} / \mathrm{mL}$, respectivamente (Figura 10B).

Considerando as seis primeiras biomassas com os maiores valores de AR liberado após o processo de hidrólise por AMI ou XIL (mínimo de $80 \mu \mathrm{mol} / \mathrm{mL}$ ), os três substratos que se destacaram e mostraram concomitantemente maior capacidade hidrolítica sob as condições aplicadas, foram respectivamente, farelo de milho, casca de banana e farelo de semente de sorgo.

O farelo de milho (Yoki®) é uma biomassa rica em carboidratos $82 \%$, com 7,4\% de proteína e $2 \%$ de lipídios. Da mesma forma, os grãos de semente de sorgo têm uma composição semelhante, embora com teor proteico de 13-15\% (WALL; BLESSIN, 1970). A razão entre os componentes fermentáveis/não fermentáveis do farelo de milho e grão de semente de sorgo podem ter contribuído para seu alto potencial de liberação de AR durante a hidrólise por AMI e XIL, uma vez que ambos extratos brutos são ricos em amilases. Além disso, foi relatado que a casca de banana contém lignina, hemicelulose e celulose, as quais correspondem respectivamente a 9,82\%, 25,52\% e 11,45\% da biomassa (OROZCO et al., 2014). Ambos os extratos enzimáticos brutos de AMI e XIL contêm uma quantidade significativa de hemicelulases (especialmente XIL), o que pode ter contribuído significativamente para a liberação de AR quando os substratos foram submetidos a hidrólise.

Adicionalmente, ao aplicar o CEL (Figura 10C), a maior liberação de AR foi observada para a casca de banana com rendimento de 164,65 \pm 4,9 $\mu \mathrm{mol} \mathrm{AR} / \mathrm{mL}$, o que corresponde a uma produção de AR $50 \%$ maior do que aquela obtida com as duas seguintes melhores biomassas hidrolisadas pelo mesmo extrato enzimático, palha de milho e farelo de mandioca. CEL é um extrato rico em celulase com quantidades significativas de hemicelulases, incluindo swolenina, Cip1 e Cip2 (SUWANNARANGSEE et al., 2012). A atividade sinérgica entre estas diferentes enzimas presentes no extrato CEL podem ter contribuído com a degradação da biomassa. Cip1 e Cip2 apresentam sítios de ligação aos carboidratos e são co-reguladas com 
outras celulases conhecidas. A Cip1 tem função pouco conhecida apesar de alguns estudos indicarem baixa atividade sobre $p$-nitrofenil- $\beta$ D-celobiósido e sinergismo com LPMOs e swolenina (MENDOZA, 2013). Adicionalmente, o produto do gene cip2 demonstrou exibir atividade de glucuronoil esterase, a qual pode estar relacionada à quebra de ligações éster entre a hemicelulose e a lignina (GUTARRA et al., 2007). Desta forma, esta atividade pode ter contribuído com a hidrólise da casca de banana, que é um resíduo lignocelulolítico.

Considerando as produções de AR obtidas durante a triagem, juntamente com os produtos de valor agregado para biorrefinarias; farelo de milho, casca de banana e farelo de semente de sorgo foram selecionados para investigações adicionais usando testes de planejamento experimental do tipo simplex-centroide com três fatores. A banana é amplamente cultivada em mais de 130 países em todo o mundo, tornando-se a segunda maior fruta tropical produzida no mundo (JITJAMNONG et al., 2020; PISUTPAISAL; BOONYAWANICH; SAOWALUCK, 2014). Em geral, a casca de banana (30-40\% do peso total da fruta) é descartada como resíduo sólido; no entanto, quando a casca é decomposta, ela produz gases nocivos, por exemplo, sulfeto de hidrogênio e amônia (PISUTPAISAL; BOONYAWANICH; SAOWALUCK, 2014). Assim, a gestão sustentável desses resíduos altamente orgânicos pode envolver sua aplicação como bioabsorventes, e também como substrato para bioetanol (BETIKU; AJALA, 2014; BETIKU; AKINTUNDE; OJUMU, 2016; GOHAIN; DEVI; DEKA, 2017), biodiesel (JITJAMNONG et al., 2020) e biogás (ACHINAS; KROONEMAN; EUVERINK, 2019; CLARKE et al., 2008; PISUTPAISAL; BOONYAWANICH; SAOWALUCK, 2014).

O sorgo é a quinta cultura de cereal mais importante do mundo. É uma cultura de segurança alimentar em vários países, principalmente na África e na Ásia. No entanto, a área de produção nesses países está diminuindo devido à falta de mercados estabelecidos, pressões sociais e preferências do consumidor. Uma forma de aumentar as oportunidades de mercado do sorgo é promover seu uso múltiplo, por exemplo, para alimentos, ração para gado e biocombustíveis. O dilema das safras de grãos alimentícios sendo usadas para a produção de biocombustíveis é crítico. No entanto, certos tipos de espécies ou genótipos de sorgo, especificamente adequados para a produção de bioenergia, podem gerar uma grande quantidade de biomassa com benefícios econômicos, ou seja, menor necessidade de nutrientes, fertilizantes e água (ALMODARES; HATAMIPOUR, 2011; BRIAND; GELETA; KRATOCHVIL, 2018; SIPOS et al., 2009). Vários estudos consideram o grão de sorgo como uma cultura energética viável para a produção de biogás e bioetanol (ALMODARES; HADI, 2009; MATSAKAS; 


\section{CHRISTAKOPOULOS, 2013; OSTOVAREH; KARIMI; ZAMANI, 2015; STAMENKOVIĆ} et al., 2020).

Por último, mas não menos importante, o milho é outra cultura de grãos amplamente cultivada e importante no mundo todo. O etanol, refinado do milho, é o principal biocombustível nos Estados Unidos (EUA) (GILBERT; MUGERA, 2020). A produção de milho nos EUA foi estimada em um volume de 366,3 milhões de toneladas métricas em 2018/19 (SHAHBANDEH, M. , 2020). As áreas de terras destinadas ao cultivo do milho aumentaram expressivamente nos últimos anos, e agora há uma produção norte americana exacerbada (IRMAK; TIRYAKI, 2020). Adicionalmente, na última década, o Brasil se tornou o terceiro maior produtor global de milho e o segundo maior exportador deste grão (ALLEN; VALDES, 2016). A Companhia Nacional de Abastecimento (CONAB) estimou que o Brasil produzirá 112,9 milhões de toneladas métricas de milho no ano de comercialização de 2020/21, e a área cultivada é estimada em 19,776 milhões de hectares (CONAB, 2021). O milho é um grão com forte demanda doméstica, principalmente de produtores de ração animal e usinas de bioetanol à base de milho (GOMES, 2020). Devido à composição rica em carboidratos, a produção exacerbada de farelo de milho (milho seco moído) também pode ser utilizada como substrato para a produção de outros produtos de valor agregado, como o biogás (SEPPÄLÄ et al., 2013).

\subsection{Variáveis de resposta, ajuste de modelo e análises de regressão}

As misturas de extratos enzimáticos foram estudadas através de planejamento de mistura do tipo simplex-centroide. Seis planejamentos diferentes foram realizados após a seleção de biomassa na triagem anterior. Primeiramente, foram investigados os efeitos do uso de três diferentes extratos enzimáticos (XIL, AMI e CEL) e suas misturas na hidrólise de amostras de biomassa. Em segundo lugar, por meio da aplicação de extratos brutos individuais (XIL, AMI e CEL) foi estudada a hidrólise de misturas da biomassa, farelo de milho, casca de banana e farelo de grão de sorgo. Para todos os experimentos, a produção de AR ( $\mu \mathrm{mol} / \mathrm{mL})$ foi a variável de resposta após 24 horas de hidrólise.

\subsubsection{Planejamento de mistura com extratos enzimáticos}

As misturas entre os extratos enzimáticos brutos, isto é, XIL, AMI e CEL foram (como descrito acima) aplicadas à hidrólise de biomassa. As configurações experimentais e os dados de resposta para a variável dependente (AR liberado) estão presentes na Tabela 5. 
Tabela 5. Design de mistura: hidrólise da biomassa durante 24 horas utilizando extratos das enzimas XIL, AMI e CEL e suas diferentes misturas. A variável de resposta utilizada foi a concentração de $\mathrm{AR}(\mu \mathrm{mol} / \mathrm{mL})$ liberado

\begin{tabular}{ccccccc}
\hline & \multicolumn{3}{c}{ Variável (mL) } & \multicolumn{3}{c}{ AR ( $\mathbf{\mu m o l} / \mathbf{m L})$ liberado } \\
\cline { 2 - 7 } & $\boldsymbol{X I L}$ & $\boldsymbol{A M I}$ & $\boldsymbol{C E L}$ & $\begin{array}{c}\text { Farelo de } \\
\text { milho }\end{array}$ & $\begin{array}{c}\text { Casca de } \\
\text { banana }\end{array}$ & $\begin{array}{c}\text { Farelo de } \\
\text { grão de sorgo }\end{array}$ \\
\cline { 2 - 7 } $\mathbf{1}$ & $1(1)$ & $0(0)$ & $0(0)$ & 169,03 & 93,22 & 70,16 \\
$\mathbf{2}$ & $0(0)$ & $1(1)$ & $0(0)$ & 174,19 & 131,45 & 97,09 \\
$\mathbf{3}$ & $0(0)$ & $0(0)$ & $1(1)$ & 78,54 & 143,54 & 61,29 \\
$\mathbf{4}$ & $0,5(0,5)$ & $0,5(0,5)$ & $0(0)$ & 153,38 & 144,67 & 155,64 \\
$\mathbf{5}$ & $0,5(0,5)$ & $0(0)$ & $0,5(0,5)$ & 113,87 & 153,22 & 68,06 \\
$\mathbf{6}$ & $0(0)$ & $0,5(0,5)$ & $0,5(0,5)$ & 140,48 & 97,58 & 142,09 \\
$\mathbf{7}^{\mathbf{a}}$ & $0,33(0,33)$ & $0,33(0,33)$ & $0,33(0,33)$ & 105,80 & 139,51 & 190,16 \\
$\mathbf{8}^{\mathbf{a}}$ & $0,33(0,33)$ & $0,33(0,33)$ & $0,33(0,33)$ & 136,77 & 155 & 166,12 \\
$\mathbf{9}^{\mathbf{a}}$ & $0,33(0,33)$ & $0,33(0,33)$ & $0,33(0,33)$ & 138,38 & 157,09 & 160,64 \\
\hline
\end{tabular}

A soma de todos os componentes nos ensaios foi sempre $100 \%(100 \%$ ou $1=1 \mathrm{~mL}$ de extrato enzimático). ${ }^{a}$ Réplica do ensaio número 7 ou ponto central. A hidrólise foi realizada a $50^{\circ} \mathrm{C}$ e $50 \mathrm{rpm}$, por 24 horas.

Fonte: dados da autora.

Os dados de resposta foram analisados sequencialmente usando uma análise de regressão múltipla de modo a encontrar o modelo ajustado. O modelo linear demonstrou ser o mais adequado para hidrólise do farelo de milho $\left(\mathrm{R}^{2}=81,3 \%, p_{\text {model }}=0,0065\right)$, enquanto para casca de banana e farelo de grão de sorgo o modelo quadrático foi o mais adequado, $\mathrm{R}^{2}=90,3 \%$, $p_{\text {model }}=0,09, \mathrm{e}^{2}=87,2 \%, p_{\text {model }}=0,04$, respectivamente. Os valores de $p$ foram maiores que 0,05 no teste de falta de ajuste para os três modelos selecionados (Tabela 6). 
Tabela 6. Análise de variância (ANOVA) referente ao design de mistura envolvendo a produção de AR $(\mu \mathrm{mol} / \mathrm{mL})$ obtida pela hidrólise enzimática ocasionada por misturas entre os extratos AMI, XIL e CEL

\begin{tabular}{|c|c|c|c|c|c|c|c|c|}
\hline \multirow[b]{2}{*}{ Biomassa } & \multirow[b]{2}{*}{ Modelo } & \multirow{2}{*}{$\begin{array}{l}\text { Fonte de } \\
\text { variaçãao }\end{array}$} & \multirow{2}{*}{$\begin{array}{l}\text { Soma dos } \\
\text { Quadrados } \\
\text { (SQ) }\end{array}$} & \multirow{2}{*}{$\begin{array}{c}\text { Graus de } \\
\text { Liberdade } \\
\text { (GL) }\end{array}$} & \multirow{2}{*}{$\begin{array}{c}\text { Quadrado } \\
\text { Médio } \\
\text { (QM) }\end{array}$} & \multicolumn{2}{|c|}{ Teste F } & \multirow[b]{2}{*}{$\mathbf{p}$} \\
\hline & & & & & & $F_{\text {calc }}$ & $F_{\text {tab }}$ & \\
\hline \multirow{5}{*}{$\begin{array}{l}\text { Farelo de } \\
\text { milho }\end{array}$} & \multirow{5}{*}{ Linear } & Modelo & 6148,44 & 2 & 3074,22 & $\begin{array}{c}13,0 \\
6\end{array}$ & $5,14^{\mathrm{a}}$ & 0,006 \\
\hline & & Erro total & 1412,41 & 6 & 235,40 & & & \\
\hline & & Falta de ajuste & 738,02 & 4 & 184,50 & 0,55 & $19,25^{\mathrm{b}}$ & 0,72 \\
\hline & & Erro puro & 674,40 & 2 & 337,20 & & & \\
\hline & & Total & 7560,85 & 8 & 945,11 & & $\alpha=0,05$ & \\
\hline \multirow{5}{*}{$\begin{array}{c}\text { Casca de } \\
\text { banana }\end{array}$} & \multirow{5}{*}{ Quadrático } & Modelo & 4125,33 & 5 & 825,07 & 5,63 & $5,3^{\mathrm{a}}$ & 0,09 \\
\hline & & Erro total & 439,81 & 3 & 146,60 & & & \\
\hline & & Falta de ajuste & 255,35 & 1 & 255,35 & 2,77 & $8,52^{\mathrm{b}}$ & 0,23 \\
\hline & & Erro puro & 184,45 & 2 & 92,23 & & & \\
\hline & & Total & 4565,14 & 8 & 570,64 & & $\alpha=0,1$ & \\
\hline \multirow{5}{*}{$\begin{array}{l}\text { Farelo de grão } \\
\text { de sorgo }\end{array}$} & \multirow{5}{*}{ Quadrático } & Modelo & 14467,26 & 4 & 3616,82 & 6,87 & $4,10^{\mathrm{a}}$ & 0,04 \\
\hline & & Erro total & 2106,08 & 4 & 526,52 & & & \\
\hline & & Falta de ajuste & 1612,96 & 2 & 806,48 & 3,27 & $9^{b}$ & 0,23 \\
\hline & & Erro puro & 493,13 & 2 & 246,56 & & & \\
\hline & & Total & 16573,35 & 8 & 2071,67 & & $\alpha=0,1$ & \\
\hline
\end{tabular}

1. $R^{2}=0.81 ;{ }^{\mathrm{a}} \mathrm{F} 95 \% .2,6 ;{ }^{\mathrm{b}} \mathrm{F} 95 \% .4,2$

2. $R^{2}=0,9 ;{ }^{\mathrm{a}} \mathrm{F} 90 \% \cdot 5,3 ;{ }^{\mathrm{b}} \mathrm{F} 90 \% .1,2$

3. $R^{2}=0,87$; $\mathrm{a}$ 90\%. 4,$4 ;{ }^{\text {bF }} 90 \% \cdot 2,2$

Fonte: dados da autora.

Cada modelo ajustado para a variável de resposta, produção de AR $(\mu \mathrm{mol} / \mathrm{mL})$, foi expresso pelas Equações 15 (farelo de milho), 16 (casca de banana) e 17 (farelo de grão de sorgo).

$A R(\mu \mathrm{mol} / \mathrm{mL})=155.42(A)+170.19(B)+77.86(C)$

$A R(\mu \mathrm{mol} / \mathrm{mL})=91.41(A)+129.64(B)+141.73(C)+165.52(A B)+175.54(A C)$

$A R(\mu \mathrm{mol} / \mathrm{mL})=69.24(A)+92.13(B)+90.37(C)+379.09(A B)+282.63(B C)$

onde A, B e C correspondem a valores codificados para XIL, AMI e CEL, respectivamente. 
Os modelos matemáticos foram avaliados por meio de análise de variância (ANOVA) (Tabela 6) e teste F. Para modelos estatisticamente significativos, o valor F calculado deve ser maior do que o valor F crítico (tabelado).

Ao obter a equação reduzida para cada modelo, as respostas da produção de AR em relação às combinações dos componentes foram representadas graficamente por contorno ternário (Figuras 11 A, B e C). 
Figura 11. Superfície de resposta obtida pelo design de misturas entre extratos brutos aplicados no farelo de milho (A), casca de banana (B) e farelo de grão de sorgo (C)

A

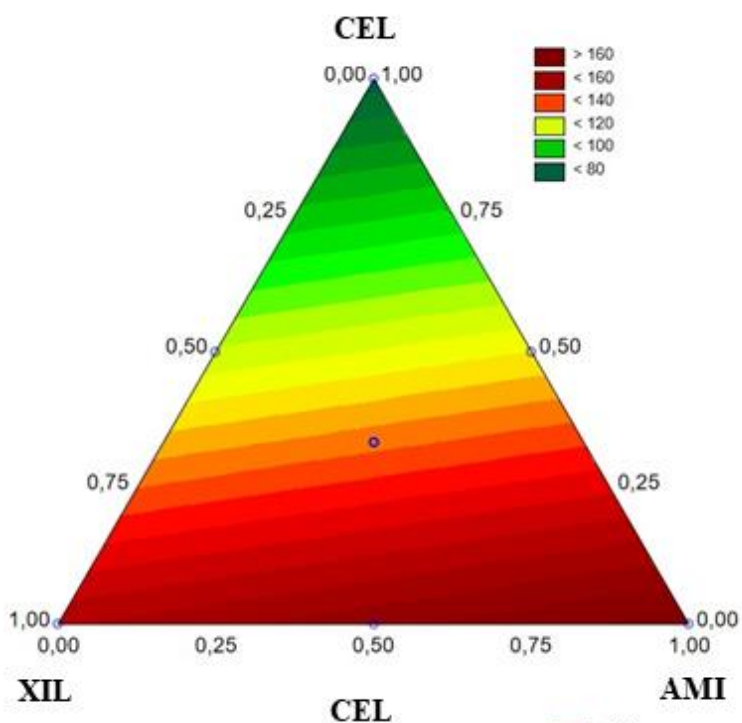

B

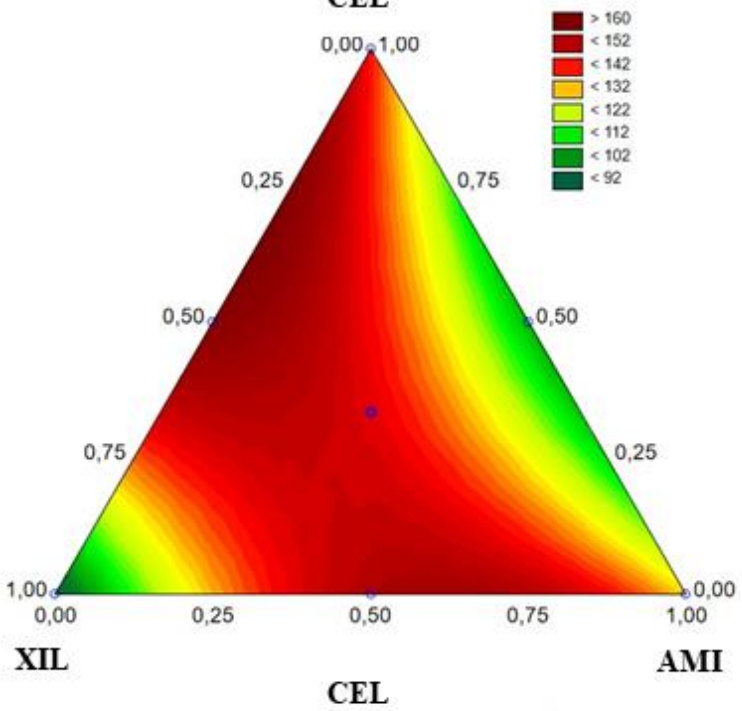

C

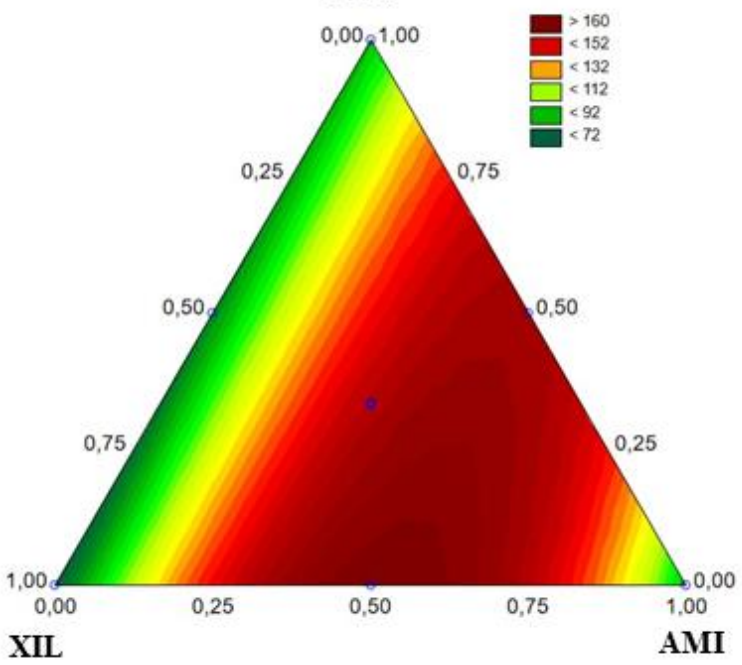

As variáveis independentes foram os extratos: AMI, XIL e CEL. Variável dependente: AR $(\mu \mathrm{mol} / \mathrm{mL})$. Após 24 horas de hidrólise a $50 \mathrm{rpm}$, as alíquotas foram analisadas quanto ao conteúdo de AR $(\mu \mathrm{mol} / \mathrm{mL})$.

Fonte: dados da autora. 
A partir dos modelos ajustados e da Tabela 5 (colunas 5-7) foi possível deduzir o desempenho individual dos extratos puros e suas misturas. Para a hidrólise do farelo de milho, o desempenho individual de AMI e XIL mostrou melhores efeitos de hidrólise, ou seja, produções de AR de 174,19 e 169,03 $\mu \mathrm{mol} / \mathrm{mL}$, respectivamente. De acordo com o modelo ajustado, o coeficiente beta ou terciário não foi significativo, o que também é exibido no gráfico de contorno (Figura 11A). Ambos os extratos (AMI e XIL) são ricos em amilase $(6,0 \pm 0,5$ $\mathrm{U} / \mathrm{mL}$ e $6,5 \pm 0,158 \mathrm{U} / \mathrm{mL}$, respectivamente) e podem ter sido suficientes para proporcionar a hidrólise do amido, principal carboidrato componente do farelo de milho (82\%).

Quando foi estudada a hidrólise da casca de banana, as duas misturas binárias, ou seja, XIL com CEL e XIL com AMI, exibiram efeitos sinérgicos significativos ( $p$-valor $=0,04 \mathrm{e}$ 0,05, respectivamente). Conforme mostrado na $6^{\mathrm{a}}$ coluna da Tabela 5, a liberação de AR nas combinações binárias foi de $153,22 \mu \mathrm{mol} / \mathrm{mL}$ e $144,67 \mu \mathrm{mol} / \mathrm{mL}$, respectivamente. Esses resultados estão de acordo com os efeitos sinérgicos exibidos na Figura 11B. Foi relatado que a casca da banana mostra $25 \%$ de hemicelulose e $11,45 \%$ de celulose em sua composição (OROZCO et al., 2014). Assim, a atividade da xilanase foi elevada em XIL (23 U/mL), podendo ter proporcionado a acessibilidade à celulose presente no resíduo, o que provavelmente explica porque as duas combinações binárias envolvidas neste extrato se destacaram.

A hidrólise do farelo de grão de sorgo mostrou que as duas misturas binárias, ou seja, XIL com AMI e AMI com CEL, exibiram efeitos sinérgicos significativos ( $p$-valor $=0,01 \mathrm{e}$ 0,04, respectivamente). Conforme mostrado na $7^{\text {a }}$ coluna da Tabela 5, a liberação de AR nas combinações binárias foi de $153,22 \mu \mathrm{mol} / \mathrm{mL}$ e $142,09 \mu \mathrm{mol} / \mathrm{mL}$, respectivamente. Esses resultados estão de acordo com o tamanho dos efeitos sinérgicos exibidos na Figura 11C. Os grãos de sorgo apresentam composição semelhante ao milho, contendo 70\% de amido (WALL; BLESSIN, 1970). XIL e AMI são extratos ricos em amilase $(6,0 \pm 0,5 \mathrm{U} / \mathrm{mL})$, o que poderia ter proporcionado a maior sacarificação do amido quando ambos foram aplicados no planejamento de mistura.

\subsubsection{Planejamento de misturas com a biomassa}

O design de mistura entre a biomassa, farelo de milho, casca de banana e farelo de grão de sorgo foi (conforme descrito acima) submetido a hidrólise pelos extratos enzimáticos, AMI, XIL e CEL. As configurações experimentais, bem como a variável de resposta (dados experimentais) avaliadas durante os experimentos estão presentes na Tabela 7. 
Tabela 7. Design de mistura: hidrólise da biomassa (farelo de milho, casca de banana, farelo do grão de sorgo) aplicando-se extratos enzimáticos XIL, AMI e CEL e suas diferentes misturas. A variável de resposta utilizada foi a concentração de AR $(\mu \mathrm{mol} / \mathrm{mL})$ liberado

Variável (g)

AR ( $\mu \mathrm{mol} / \mathrm{mL})$ liberado

\begin{tabular}{ccccccc} 
Ensaio & $\begin{array}{c}\text { Farelo de } \\
\text { milho }\end{array}$ & $\begin{array}{c}\text { Casca de } \\
\text { banana }\end{array}$ & $\begin{array}{c}\text { Farelo de grão de } \\
\text { sorgo }\end{array}$ & AMI & XIL & CEL \\
\hline 1 & $50(1)$ & $0(0)$ & $0(0)$ & 170,00 & 135,96 & 88,06 \\
2 & $0(0)$ & $50(1)$ & $0(0)$ & 155,64 & 117,90 & 175,32 \\
3 & $0(0)$ & $0(0)$ & $50(1)$ & 126,77 & 72,74 & 101,61 \\
4 & $25(0,5)$ & $25(0,5)$ & $0(0)$ & 159,67 & 72,41 & 129,83 \\
5 & $25(0,5)$ & $0(0)$ & $25(0,5)$ & 158,54 & 70,80 & 93,22 \\
6 & $0(0)$ & $25(0,5)$ & $25(0,5)$ & 159,03 & 111,77 & 142,41 \\
$7^{\text {a }}$ & $0,167(0,33)$ & $0,167(0,33)$ & $0,167(0,33)$ & 155,80 & 110,32 & 118,22 \\
$8^{\text {a }}$ & $0,167(0,33)$ & $0,167(0,33)$ & $0,167(0,33)$ & 155,80 & 108,54 & 136,45 \\
$9^{a}$ & $0,167(0,33)$ & $0,167(0,33)$ & $0,167(0,33)$ & 157,74 & 109,67 & 122,09
\end{tabular}

A soma de todos os componentes nos ensaios foi sempre $100 \%(100 \%$ ou $1=1 \mathrm{~mL}$ de extrato enzimático). ${ }^{a}$ Réplica do ensaio número 7 ou ponto central. A hidrólise foi realizada a $50^{\circ} \mathrm{C}$ e $50 \mathrm{rpm}$, por 24 horas.

Fonte: dados da autora.

Modelos lineares, quadráticos e cúbicos especiais foram usados para descrever a variável de resposta, e a Tabela 8 mostra os resultados da análise de variância (ANOVA) correspondente aos melhores modelos ajustados. 
Tabela 8. Análise de variância (ANOVA) referente ao design de mistura envolvendo a produção de AR $(\mu \mathrm{mol} / \mathrm{mL})$ obtida pela aplicação dos extratos brutos nas misturas das biomassas farelo de milho, casca de banana e farelo de grão de sorgo

\begin{tabular}{|c|c|c|c|c|c|c|c|c|}
\hline \multirow{2}{*}{$\begin{array}{c}\text { Extrato } \\
\text { enzimático }\end{array}$} & \multirow{2}{*}{ Modelo } & \multirow{2}{*}{$\begin{array}{l}\text { Fonte de } \\
\text { variaçãao }\end{array}$} & \multirow{2}{*}{ SQ } & \multirow{2}{*}{ GL } & \multirow{2}{*}{ QM } & \multicolumn{2}{|c|}{ Teste F } & \multirow{2}{*}{$p$} \\
\hline & & & & & & $F_{\text {calc }}$ & $F_{\text {tab }}$ & \\
\hline \multirow{5}{*}{ AMI } & \multirow{5}{*}{$\begin{array}{l}\text { Cúbico } \\
\text { especial }\end{array}$} & Modelo & 1070,81 & 5 & 214,16 & 70,41 & $9,01^{\mathrm{a}}$ & 0,002 \\
\hline & & Erro total & 9,12 & 3 & 3,04 & & & \\
\hline & & Falta de ajuste & 6,61 & 1 & 6,61 & 5,27 & $18,5^{\mathrm{b}}$ & 0,140 \\
\hline & & Erro puro & 2,50 & 2 & 1,25 & & & \\
\hline & & Total & 1079,94 & 8 & 134,99 & & $\alpha=0,05$ & \\
\hline \multirow{5}{*}{ XIL } & \multirow{5}{*}{$\begin{array}{l}\text { Cúbico } \\
\text { especial }\end{array}$} & Modelo & 4369,98 & 6 & 728,16 & 897,52 & $19,32^{\mathrm{a}}$ & 0,001 \\
\hline & & Erro total & 1,623 & 2 & 0,81 & & & \\
\hline & & Falta de ajuste & 0 & 0 & 0 & 0 & 0 & 0 \\
\hline & & Erro puro & 1,62 & 2 & 0,81 & & & \\
\hline & & Total & 4370,60 & 8 & 542,32 & & $\alpha=0,05$ & \\
\hline \multirow{5}{*}{ CEL } & \multirow{5}{*}{ Linear } & Modelo & 5699,18 & 2 & 2849,59 & 73,90 & $5,14^{\mathrm{a}}$ & 0,000 \\
\hline & & Erro total & 231,35 & 6 & 38,56 & & & \\
\hline & & Falta de ajuste & 46,85 & 4 & 11,71 & 0,12 & $19,2^{\mathrm{b}}$ & 0,950 \\
\hline & & Erro puro & 184,50 & 2 & 92,25 & & & \\
\hline & & Total & 5930,53 & 8 & 741,31 & & $\alpha=0,05$ & \\
\hline
\end{tabular}

1. $R^{2}=0,99 ;{ }^{\mathrm{a}} \mathrm{F} 95 \% .5,3 ;{ }^{\mathrm{b}} \mathrm{F} 95 \% \cdot 1,2$

2. $R^{2}=0,77 ;{ }^{\mathrm{a}} \mathrm{F} 95 \% .3,5 ;{ }^{\mathrm{b}} \mathrm{F} 95 \% .3,2$

3. $R^{2}=0,96 ;$ a $95 \% .2,6 ;{ }^{\mathrm{b}} \mathrm{F} 95 \% .4,2$

Fonte: dados da autora.

O modelo cúbico especial demonstrou ser o mais adequado para descrever a hidrólise das misturas de biomassa por AMI $\left(\mathrm{R}^{2}=99,1 \%\right.$, $\left.p_{\text {model }}=0,002\right)$ e XIL $\left(\mathrm{R}^{2}=99,9 \%, p_{\text {model }}=\right.$ 0,001). Para os resultados cuja hidrólise decorreu com a aplicação de CEL, o modelo linear foi o mais adequado $\left(\mathrm{R}^{2}=96 \%\right.$, pmodel $\left.=0,00005\right)$. Os coeficientes de regressão estimados e os erros padrão para cada modelo estão descritos na Tabela 8.

Os modelos ajustados para a variável de resposta (produção de $\mathrm{AR}(\mu \mathrm{mol} / \mathrm{mL})$ ) estão expressos nas Equações 18 (AMI), 19 (XIL) e 20 (CEL):

$$
\begin{aligned}
& A R=168.95(A)+154.59(B)+126.77(C)+42.72(A C)+73.4(B C)-177.0(A B C) \\
& A R=135.96(A)+117.9(B)+72.74(C)-218.08(A B)-134.2(A C)+65.8(B C)+ \\
& 876.81(A B C)
\end{aligned}
$$


$A R 87.90(\mathrm{~A})+177.38(\mathrm{~B})+103.77(\mathrm{C})$

onde A, B e C correspondem aos valores codificados para farelo de milho, casca de banana e farelo de grão de sorgo, respectivamente.

A resposta variável, produção de $\mathrm{AR}$, para cada planejamento de mistura foi representada graficamente por meio de gráficos de contorno ternário (Figuras 12 A, B e C). 
Figura 12. Superfície de resposta obtida pelo design de misturas entre biomassas quando aplicado AMI (A), XIL (B) e CEL (C)

A

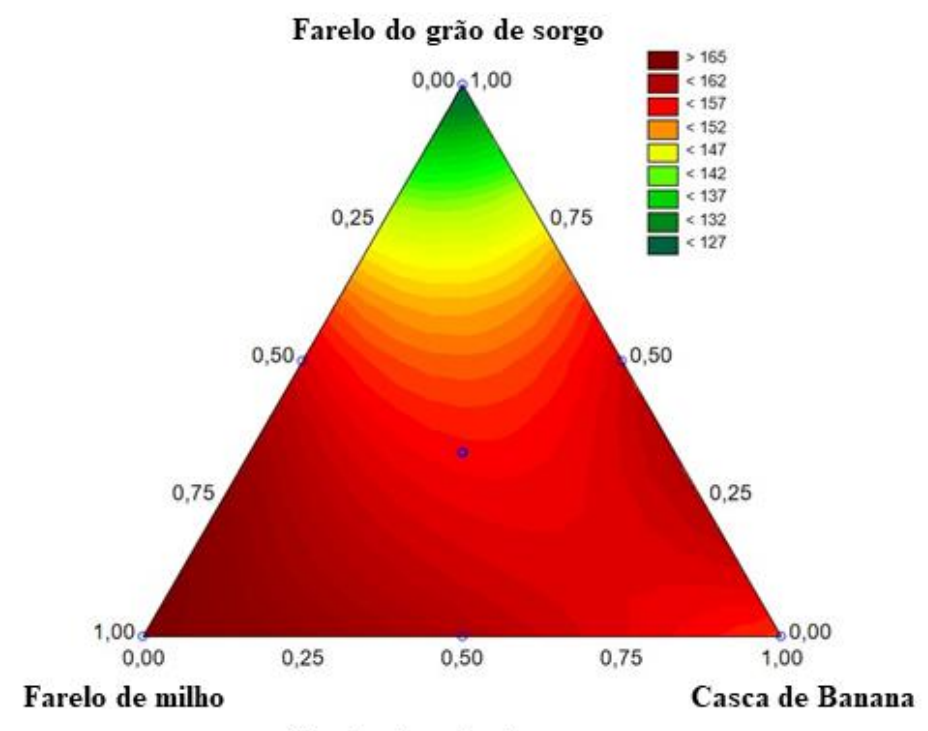

B

Farelo do grão de sorgo

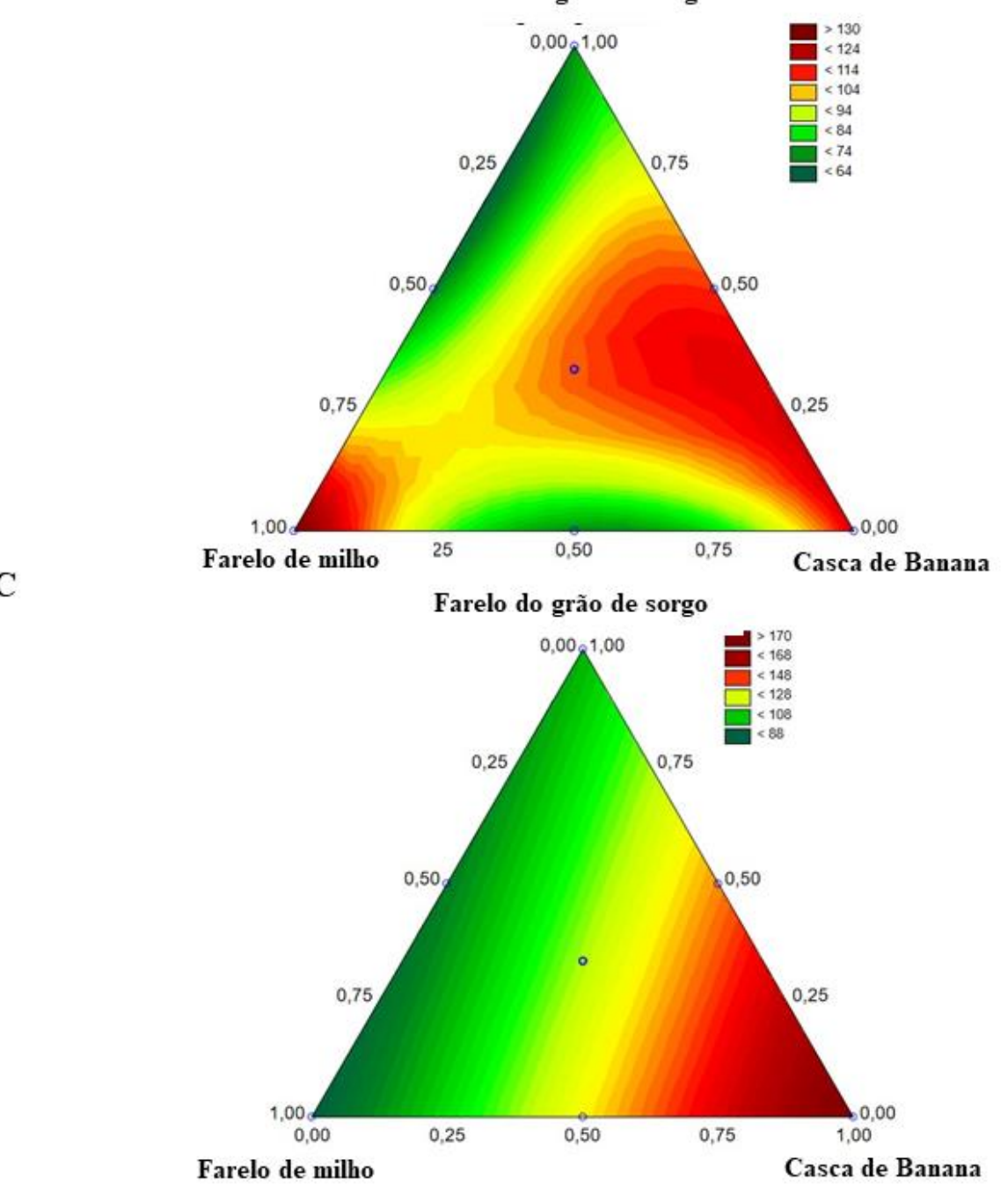

C

As variáveis independentes foram as biomassas: farelo de milho, casca de banana e farelo de grão de sorgo. Variável dependente: AR $(\mu \mathrm{mol} / \mathrm{mL})$. Após 24 horas de hidrólise a $50 \mathrm{rpm}$, as alíquotas foram analisadas quanto ao conteúdo de $\mathrm{AR}(\mu \mathrm{mol} / \mathrm{mL})$.

Fonte: dados da autora. 
Ao analisar os resultados do planejamento de mistura das biomassas com a aplicação de AMI, o desempenho individual do farelo de milho demonstrou o maior coeficiente de produção de AR (170 $\mu \mathrm{mol} / \mathrm{mL})$ ( $p$-valor 0,000002), seguido pelo desempenho de casca de banana pura (p-valor 0,000002). Por outro lado, a mistura ternária entre as biomassas, exibiu efeito antagônico significativo no rendimento de AR ( $p$-valor 0,02$)$. Estes resultados estão de acordo com os efeitos sinérgicos e antagônicos exibidos na Figura 12A.

Quando foi estudada a hidrólise da biomassa por XIL, a mistura ternária entre as biomassas exibiu efeito sinérgico significativo ( $p$-valor 0,0007 ). Este resultado pode ser visto na Figura 12B, a qual também apresenta o bom desempenho de XIL na hidrólise do farelo de milho ( $p$-valor $=0,00004)$. O extrato bruto XIL é otimizado para a produção de xilanases $(23,75$ $\pm 0,63 \mathrm{U} / \mathrm{mL})$, com a ocorrência de outras enzimas, como as amilases $(6,5 \pm 0,158 \mathrm{U} / \mathrm{mL})$. O farelo de milho, a casca de banana e o farelo de grão de sorgo são biomassas cuja composição centesimal, como já citado acima, é variável. O sinergismo entre as enzimas presentes no extrato bruto pode ter aumentado a acessibilidade à celulose presente no sortimento de biomassa, e também influenciado na sacarificação do amido de todos os três componentes.

Os efeitos da aplicação de CEL no planejamento de misturas foram melhor ajustados pelo modelo linear (Tabela 8 e Figura 12C). A casca de banana pura resultou nos melhores efeitos de hidrólise ( $p$-valor $\leq 0,000)$, com uma produção de AR correspondente a 175,32 $\mu \mathrm{mol} / \mathrm{mL}$. De acordo com o modelo ajustado, os coeficientes beta ou terciário não foram significativos.

A especificidade de uma mistura ternária para hidrólise de substrato pode ser devido às diferenças em suas estruturas e composições (BERLIN et al., 2007) e também ao sinergismo enzimático. Um grande número de estudos tem descrito o sinergismo entre as diversas celulases, hemicelulases e entre ambos os grupos (MALGAS et al., 2020). BANERJEE et al. (2010) descreveram um sinergismo entre $\mathrm{CBHs}$ (CBH1 e CBH2 de T. reesei), EG (EG1), $\beta$ glucosidase, GH10 endo $\beta$-1,4-xilanase e $\beta$-xilosidase. Portanto, o desenvolvimento e o conhecimento no campo do sinergismo enzimático residem no estabelecimento de combinações enzimáticas ideais para o pré-tratamento específico de cada biomassa em particular. Essas seleções não são simples e nem diretas. Desta forma, a opção é utilizar uma combinação de ensaios que permita um processo de bioconversão eficaz e econômico.

Os designs de mistura utilizando ora três diferentes extratos enzimáticos, ora três biomassas, mostraram duas zonas principais de alta produção de AR. Ambas zonas estavam localizados em um dos lados dos triângulos, $(i)$ farelo de milho hidrolisado por AMI e (ii) casca de banana hidrolisada por CEL. No entanto, para a continuação deste trabalho o farelo de milho 
hidrolisado por AMI foi selecionado e testado nos experimentos seguintes. As plantas de bioetanol que usam o amido de safras agrícolas, representam uma tecnologia bem estabelecida em escala industrial. Atualmente, elas são uma de fonte de bioenergia crucial. No entanto, existem algumas restrições relacionadas à essas usinas de bioetanol de $1^{\mathrm{a}}$ geração, incluindo o caráter intensivo de energia necessária ao processo. Deste modo, esta tese investigou estratégias úteis para o estabelecimento de biorefinarias no ramo industrial do milho.

O biorefinamento é o processamento sustentável de biomassa em um espectro de produtos comercializáveis e energia. Uma biorrefinaria a base de milho poderá processar esta biomassa para diversos fins, como os biocombustíveis (etanol e biogás), energia (biogás) e produtos químicos de base biológica, por exemplo os ácidos graxos voláteis.

\subsection{Caracterização do extrato enzimático produzido por $A$. brasiliensis \\ 4.4.1. Gel de eletroforese em condições não desnaturantes (PAGE) e zimograma}

AMI foi produzido por A. brasiliensis utilizando farelo de milho como fonte de carbono. Como citado no item 3.4., várias enzimas cuja atividade foi testada nas condições otimizadas de hidrólise $\left(45^{\circ} \mathrm{Ce} \mathrm{pH} 4,5\right)$ se fazem presentes no extrato.

O gel PAGE a seguir (Figura 13) também comprova a existência de diversas proteínas presentes no extrato, uma vez que cada banda representa uma dessas moléculas em questão. AMI foi otimizado para produção de amilase, desta forma o gel de atividade (zimograma) como mostra a Figura 13, comprova a existência de uma forte e expressiva banda referente a presença desta enzima no extrato. 
Figura 13. Eletroforese (azul) e zimograma (marrom) em gel de poliacrilamida em condições não - desnaturantes (PAGE 10\%) do consórcio enzimático produzido por A. brasiliensis

M

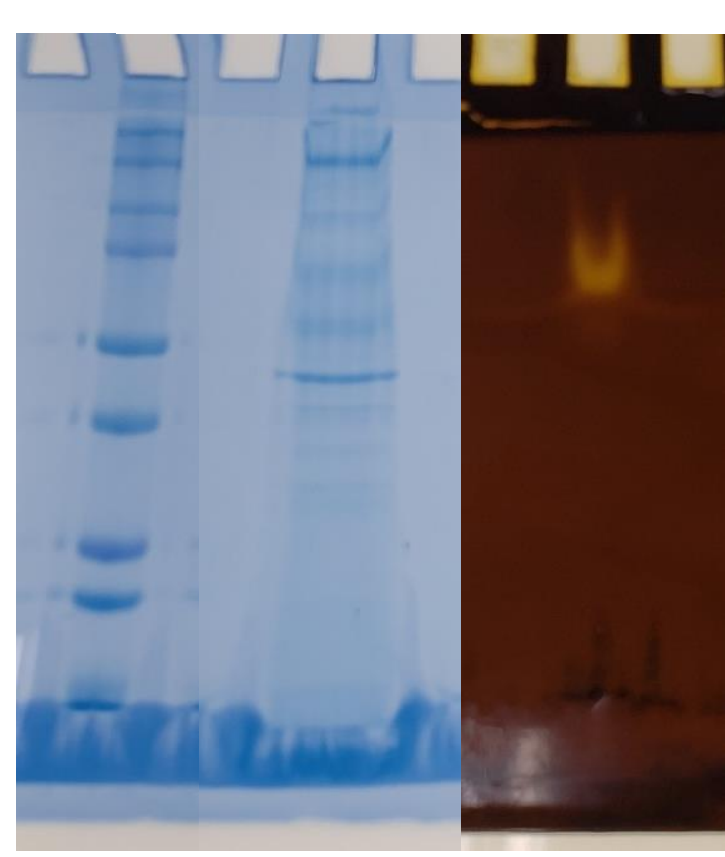

(M) marcador molecular, (A) extrato enzimático e (Z) zimograma. Fonte: dados da autora.

\subsubsection{Caracterização quanto a temperatura e pH ótimos da amilase presente em AMI}

Uma vez que AMI foi otimizado para produção de amilases utilizando a biomassa, farelo de milho, como fonte de carbono, testes foram realizados para se conhecer a temperatura e $\mathrm{pH}$ ótimos de dosagem desta enzima.

Foram testadas as temperaturas empregadas nos testes de DCCR durante a otimização da hidrólise e também algumas mais elevadas. A Figura 14 mostra a temperatura ótima de dosagem da amilase quando em extrato bruto. Nota-se que a máxima atividade foi encontrada na faixa de $60-70{ }^{\circ} \mathrm{C}(6,0 \pm 0,5 \mathrm{U} / \mathrm{mL})$, sendo esta $55 \%$ maior do que quando a dosagem ocorreu a $50{ }^{\circ} \mathrm{C}(2,75 \pm 0,5 \mathrm{U} / \mathrm{mL})$. E a $80{ }^{\circ} \mathrm{C}$ nota-se um decaimento da atividade em $68 \%$.

ALMEIDA et al. (2018) ao caracterizar amilases de A. brasiliensis produzidas a partir da maltose como fonte de carbono, também constatou que a temperatura de reação ideal está entre 60 e $75^{\circ} \mathrm{C}$. 
Figura 14. Temperatura ótima de dosagem da amilase bruta no consórcio enzimático AMI

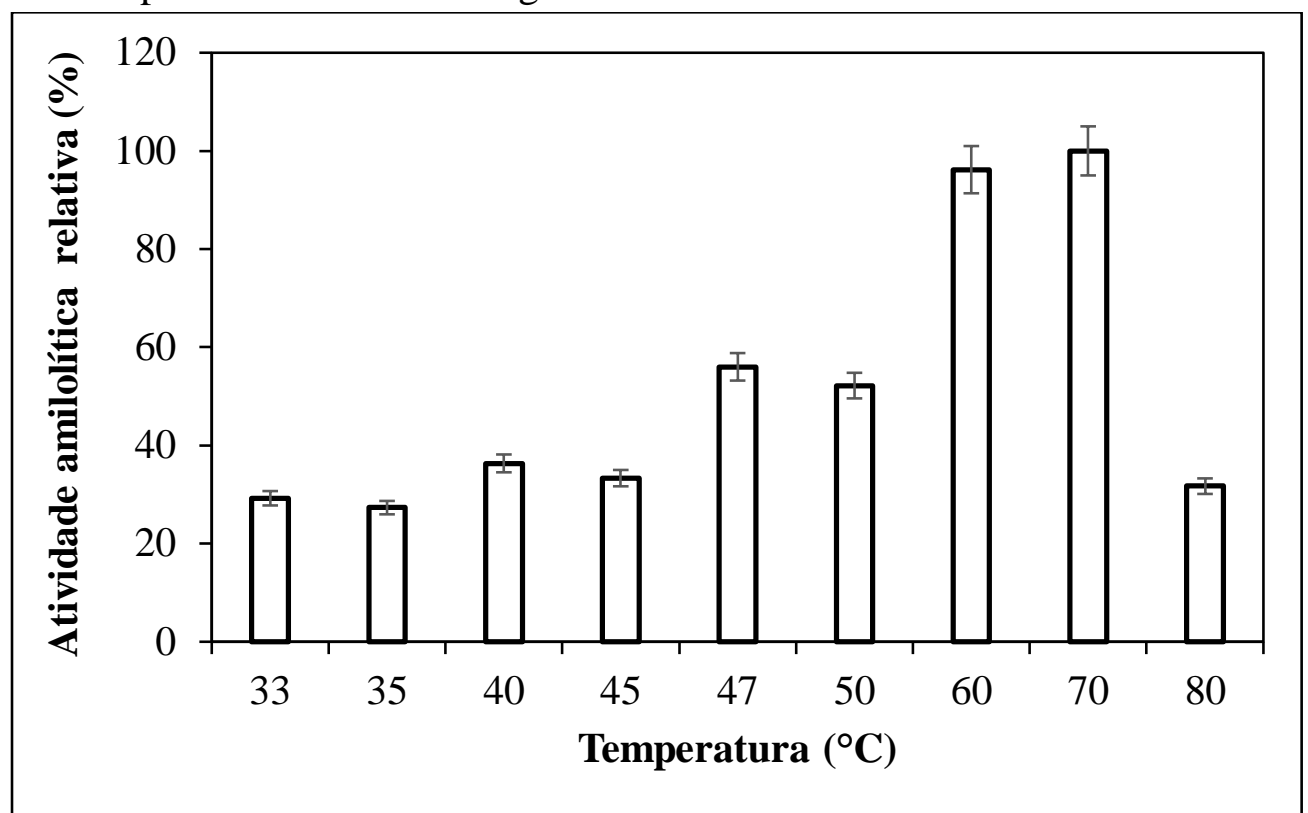

$\mathrm{O}$ consórcio foi produzido com A. brasiliensis cultivado a $30^{\circ} \mathrm{C}$ em meio SR, sem agitação, suplementado com farelo de milho (1\%) como fonte de carbono, por 120 horas. Fonte: dados da autora.

A temperatura ótima de dosagem $\left(70^{\circ} \mathrm{C}\right)$ não é a mesma que foi selecionada nos testes de otimização para maior hidrólise do resíduo farelo de milho $\left(45^{\circ} \mathrm{C}\right)$, que será descrito no item 4.5.3. Isso leva a inferência de que a presença de várias enzimas atuando de forma conjunta e possivelmente sinérgica possibilita a máxima hidrólise de açúcares complexos presentes nos resíduos. Além disso, a estrutura da enzima e consequentemente sua atividade catalítica pode ser influenciada quando na presença ou ausência do substrato, que é o que podemos ver neste caso.

Os testes de $\mathrm{pH}$ ótimo de dosagem da amilase procederam-se variando os valores de pHs que foram utilizados no DCCR de otimização da hidrólise (Figura 15). 
Figura 15. pH ótimo de dosagem da amilase bruta no consórcio enzimático AMI

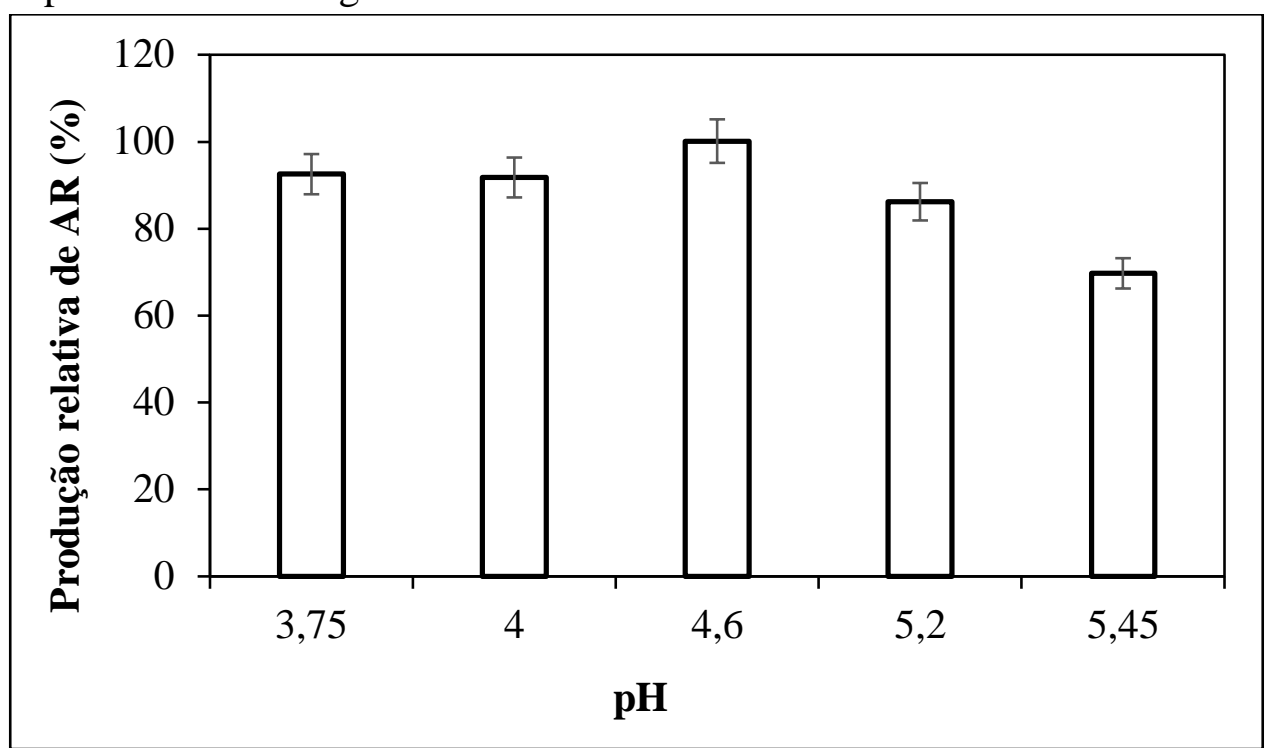

$\mathrm{O}$ consórcio foi produzido com A. brasiliensis cultivado a $30^{\circ} \mathrm{C}$ em meio $\mathrm{SR}$, sem agitação, suplementado com farelo de milho (1\%) como fonte de carbono, por 120 horas.

Fonte: dados da autora.

A faixa de $\mathrm{pH}$ ótimo de dosagem da amilase ficou entre 3,75 e 4,6. Nesta faixa, a atividade amilolítica variou entre 5,8 $\pm 1 \mathrm{U} / \mathrm{mL}$ e decaiu 15 e $30 \%$ de sua atividade nos pHs 5,2 e 5,45, respectivamente.

ALMEIDA et al. (2018) ao estudar amilases de A. brasiliensis produzidas a partir da maltose, constatou que o pH de reação ideal estava entre 3,5 e 5,0.

\subsection{Otimização da hidrólise do farelo de milho por AMI}

\subsubsection{Concentração do farelo de milho}

Testes foram feitos para analisar qual a melhor concentração da biomassa para a hidrólise. Diferentes concentrações do farelo de milho (1, 2, 3, 4, 5, 6 e 7\%) foram submetidos a hidrólise com $1 \mathrm{~mL}$ de extrato AMI em tubos Eppendorf de $2 \mathrm{~mL}$. A Figura 16 traz os resultados encontrados. Nota-se que as concentrações de 5, 6 e 7\% foram aquelas que se mostraram promissoras para a formação de açúcares simples. Uma vez que se observou uma máxima liberação de AR a uma concentração de biomassa de 5\% (174 $\mu \mathrm{mol} \mathrm{AR} / \mathrm{ml})$, os testes seguintes foram realizados com essa porcentagem. 
Figura 16. Hidrólises relativas (\%) referentes a produção de AR variando-se a concentração do farelo de milho

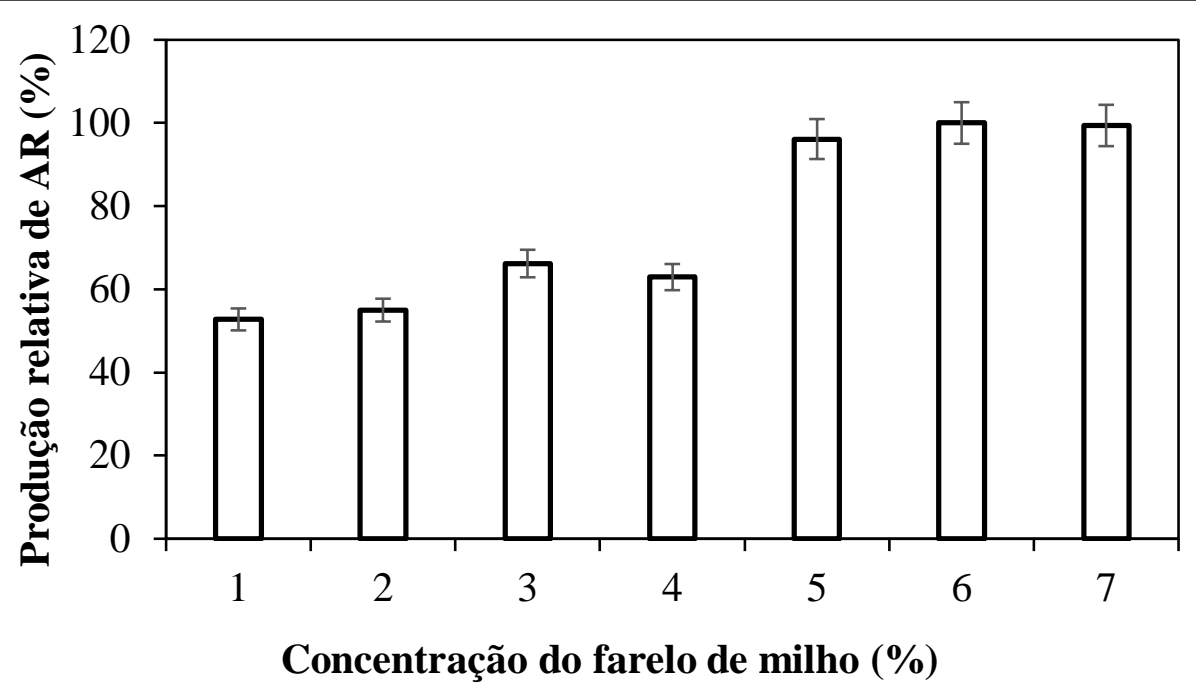

Hidrólises ocorreram a $50^{\circ} \mathrm{C}$, por 24 horas, sob agitação de $50 \mathrm{rpm}$.

Fonte: dados da autora.

\subsubsection{Tempo de hidrólise}

O melhor tempo de hidrólise do farelo de milho por AMI também foi estudado. Testes de hidrólise a $50^{\circ} \mathrm{C}$ com farelo de milho a $5 \%$ foram procedidos por 24 , 48 e 72 horas. Os resultados encontrados após o tempo de hidrólise encontram-se na Figura 17, sendo o eixo Y correspondente a porcentagem de hidrólise do amido (principal carboidrato de reserva energética) presente no farelo de milho, ou seja, $100 \%$ sinalizaria a hidrólise total dos carboidratos presente na biomassa $(0,82: 1 \mathrm{~m} / \mathrm{m})$. O tempo de 48 horas foi aquele no qual houve a maior porcentagem de conversão do amido em AR. O tempo de 24 horas não foi suficiente para que todo o farelo fosse quebrado a açúcares mais simples, e no tempo de 72 horas não houve um significativo aumento na liberação de AR quando comparado ao valor encontrado com 48 horas de tratamento. 
Figura 17. Hidrólise (\%) do farelo de milho variando-se o tempo de tratamento

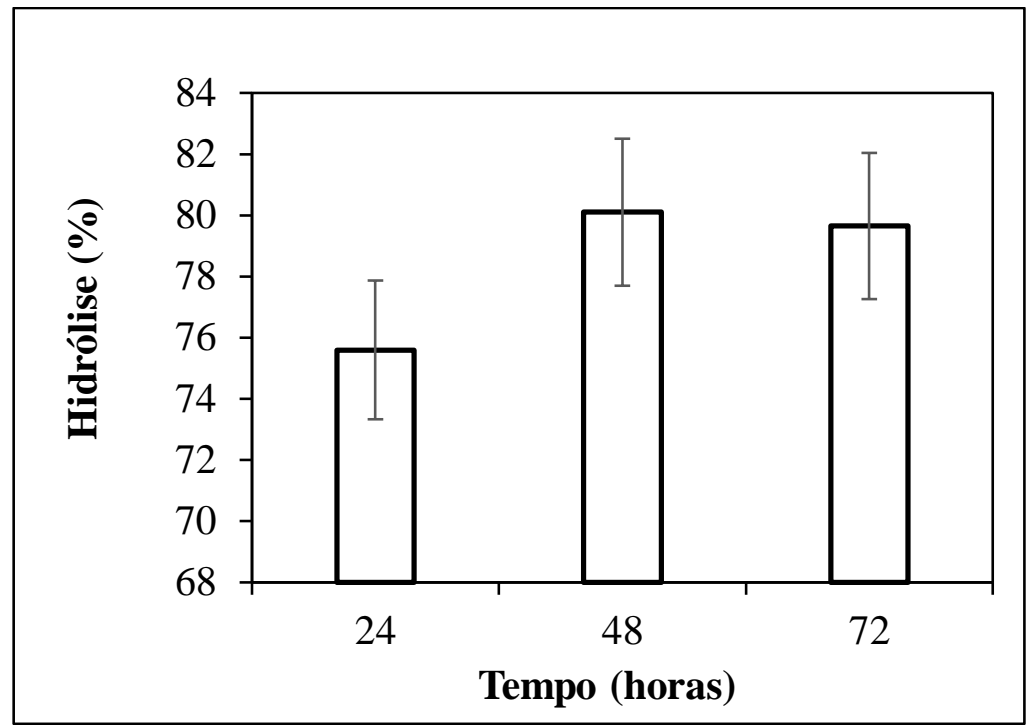

Testes ocorreram a $50^{\circ} \mathrm{C}$, farelo de milho $5 \%$ com AMI sob agitação de $50 \mathrm{rpm}$. As porcentagens correspondem a hidrólise dos carboidratos que compõe o farelo de milho $(0,82: 1 \mathrm{~m} / \mathrm{m})$. Fonte: dados da autora.

\subsubsection{Otimização da temperatura e pH por planejamento experimental e análise de superfície de resposta}

Juntamente com a concentração de enzima e tempo de reação, a eficiência da hidrólise enzimática depende fortemente do $\mathrm{pH}$ e da temperatura. Deste modo, estudou-se a melhor faixa de $\mathrm{pH}$ e temperatura em que o extrato bruto AMI atua sobre o farelo de milho e consequentemente ocasiona a liberação de AR. O intervalo de estudo da temperatura variou de 33 a $47^{\circ} \mathrm{C}$ e o intervalo do $\mathrm{pH}$ estabelecido foi 3,75 a 5,45 .

A matriz do DCCR e os valores experimentais obtidos em termos de AR liberado $(\mu \mathrm{mol} / \mathrm{mL})$ quando o $\mathrm{pH}$ e a temperatura foram testados simultaneamente e são apresentados na Tabela 9. 
Tabela 9. Matriz do DCCR e os valores experimentais avaliados no efeito da temperatura e $\mathrm{pH}$ sobre a hidrólise do farelo de milho pelo consórcio enzimático AMI

\begin{tabular}{cccc}
\hline \multirow{2}{*}{ Experimento } & \multicolumn{2}{c}{ Variáveis } & \multirow{2}{*}{ AR liberado $(\boldsymbol{\mu m o l} / \mathbf{m L})$} \\
\cline { 2 - 3 } & Temperatura & $4,0(-1)$ & 135,96 \\
\hline 1 & $35(-1)$ & $4,0(-1)$ & 210,00 \\
3 & $45(1)$ & $5,2(1)$ & 114,51 \\
4 & $35(-1)$ & $5,2(1)$ & 144,83 \\
5 & $45(1)$ & $4,6(0)$ & 90,32 \\
6 & $33(-1,41)$ & $4,6(0)$ & 143,54 \\
7 & $47(1,41)$ & $3,75(-1,41)$ & 175,80 \\
8 & $40(0)$ & $5,45(1,41)$ & 112,90 \\
9 & $40(0)$ & $4,6(0)$ & 190,80 \\
$10^{\text {a }}$ & $40(0)$ & $4,6(0)$ & 181,29 \\
$11^{\text {a }}$ & $40(0)$ & $4,6(0)$ & 182,74
\end{tabular}

Os valores codificados das variáveis estão entre parênteses. ${ }^{\text {a }}$ Réplica do ensaio número 9 ou ponto central. Análises ocorreram através da quantificação de AR liberado $(\mu \mathrm{mol} / \mathrm{mL})$. Hidrólises ocorreram com farelo de milho (5\%) por 48 horas sob agitação de $50 \mathrm{rpm}$ em banho seco.

Fonte: dados da autora.

Com a realização do delineamento, foi possível fazer uma análise das variáveis por meio dos efeitos e coeficientes de regressão. Analisando os dados presentes na Tabela 10 e o modelo equacional apresentado na Equação 21, pôde-se obter um modelo com as variáveis pH e temperatura em função da variável dependente (liberação de AR).

$A R=184.86+22.49(T)-28.88(T)^{2}-21.97(p H)-15.09(p H)^{2}$

onde, $\mathrm{T}$ e $\mathrm{pH}$ correspondem à temperatura e $\mathrm{pH}$, respectivamente. 
Tabela 10. Efeitos e interações calculados para as variáveis estudadas na hidrólise do farelo de milho por AMI

\begin{tabular}{ccccc}
\hline Fatores & Efeitos & Erro padrão & $\mathbf{t}(\mathbf{6})^{\mathbf{a}}$ & $\boldsymbol{p}_{\text {-valor }}$ \\
\hline Média & 184,86 & 9,16 & 20,16 & $<0,001$ \\
Temperatura (T1) & 44,98 & 11,24 & 4,00 & 0,007 \\
Temperatura $\left(\mathrm{T}^{2}\right)$ & $-57,76$ & 13,41 & $-4,30$ & 0,005 \\
pH (X2) & $-43,95$ & 11,24 & $-3,90$ & 0,007 \\
pH (X2 $\left.{ }^{2}\right)$ & $-30,18$ & 13,41 & 2,24 & 0,065 \\
\hline
\end{tabular}

${ }^{a}$ valor de influência no processo (estatística do teste).

${ }^{\mathrm{b}}$ probabilidade de significância do teste $\mathrm{t}$, a 6 graus de liberdade.

Fonte: dados da autora.

O resultado experimental mostrou um bom ajuste dos dados ao modelo polinomial de segunda ordem. Pela análise, os efeitos lineares e quadráticos de $\mathrm{pH}$ e temperatura demonstraram ser significativos para a resposta ao tratamento, uma vez que a distribuição $t$ de Student e o $p$-valor apresentados na Tabela 10 colocam os resultados dentro do nível de significância $(10 \%)$ esperado ( $\mathrm{p}_{\text {temperatura }}=0,007, \mathrm{p}_{\text {temperatura }}{ }^{2}=0,005, \mathrm{p}_{\mathrm{pH}}=0,007, \mathrm{p}_{\mathrm{pH}}{ }^{2}=0,065$ ).

Adicionalmente, a Equação 21 revela como as variáveis individuais afetaram a produção de AR. O sinal positivo para o termo linear da temperatura indica que, a princípio, essa variável independente intensifica a hidrólise da biomassa em estudo. No entanto, a presença de um termo quadrático no modelo significa que o efeito dessa variável muda quando é aumentada. Assim, o sinal negativo para o termo quadrático de temperatura, indica uma curva côncava no modelo, ou seja, espera-se que esse parâmetro comece a afetar negativamente a variável dependente. Além disso, o valor do coeficiente negativo para o termo linear do $\mathrm{pH}$ significa que o aumento desse fator reduz o desempenho do tratamento, do mesmo modo que o valor negativo para o termo quadrático indica uma curva côncava no modelo.

Os termos do modelo significativo foram então avaliados por análise de variância (ANOVA) e teste F (Tabela 11) ( $p$-valor $\leq 0,1)$. Segundo o modelo de segunda ordem ajustado, o coeficiente de correlação $\left(\mathrm{R}^{2}\right)$ foi de 0,89 , o que infere que $89 \%$ da variação da amostra para a produção de AR seja atribuída as variáveis independentes, e somente $11 \%$ dessa variação total pode não ser explicada pelo modelo. Adicionalmente, segundo BOX; HUNTER; HUNTER (1986) para que uma regressão seja não apenas significativa, mas também útil para fins preditivos, a relação de $\mathrm{F}_{\text {calculado }} / \mathrm{F}_{\text {tabelado }}$ deve ser superior a três. No caso deste estudo $\mathrm{F}_{\text {cal }}$ foi cerca de 4 vezes maior que o $\mathrm{F}_{\text {tab }}$, o que significa que o modelo é preditivo e estatisticamente significativo ao nível de confiança de $90 \%$. 
Tabela 11. Análise de variância (ANOVA) do DCCR para estudo das variáveis independentes temperatura e $\mathrm{pH}$ durante a hidrólise do farelo de milho por AMI

\begin{tabular}{ccccccc}
\hline Modelo & Efeito & SQ & GL & QM & $\mathbf{F}_{\text {cal }}$ & $\mathbf{F}_{\text {tab }}$ \\
\hline & Temperatura (T1) & 4035,06 & 1 & 4035,058 & & \\
& Temperatura (T12) & 4673,66 & 1 & 4673,664 & & \\
Quadrático & $\mathrm{pH}(\mathrm{X} 2)$ & 3853,12 & 1 & 3853,119 & & \\
(segunda ordem) & $\mathrm{pH}\left(\mathrm{X} 2^{2}\right)$ & 1275,99 & 1 & 1275,994 & & \\
\cline { 2 - 7 } & Regressão (R) & 12834,7 & 4 & 3208,67 & 12,72 & $3,18^{\mathrm{a}}$ \\
& Resíduo (r) & 1512,64 & 6 & 252,10 & & \\
& Total (T) & 14347,34 & 10 & & & $\alpha=0,1$ \\
\hline
\end{tabular}

$\mathrm{R}^{2}=0,89,{ }^{\mathrm{a}} \mathrm{F}_{4 ; 6 ; 0,1}$

Fonte: dados da autora.

Verificou-se pela Tabela 11 de análise de variância que o modelo é adequado para descrever os dados e construir uma superfície de resposta. O gráfico gerado (Figura 18) apresenta a influência de ambas as variáveis no tratamento enzimático do farelo de milho. A faixa de temperatura de $40-45^{\circ} \mathrm{C}$ e $\mathrm{pH}$ 4,0-4,5 são parâmetros vantajosos para a hidrólise do milho por AMI, alcançando uma produção de AR de 180-210 $\mu \mathrm{mol} / \mathrm{mL}(32,4-37,8 \mathrm{~g} / \mathrm{L})$, o que corresponde a hidrólise de $79-92 \%$ dos carboidratos presentes no farelo, uma vez que $82 \%$ desta biomassa é correspondente a esse macronutriente. 
Figura 18. Superfície de resposta obtida a partir do modelo de segunda ordem

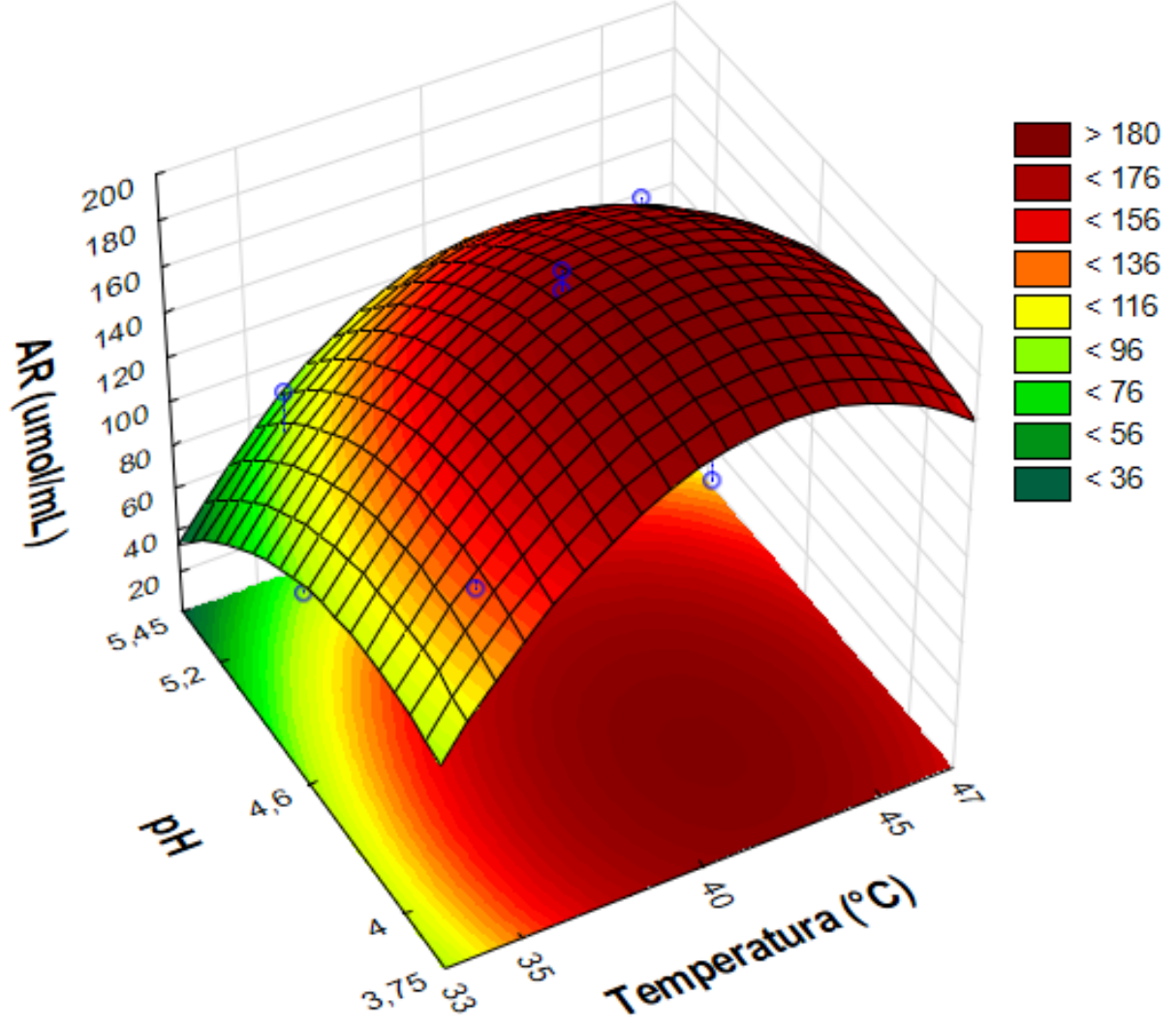

Variáveis independentes: temperatura e pH. Após 48 horas de hidrólise do farelo de milho por AMI a $50 \mathrm{rpm}$, as alíquotas foram analisadas quanto ao teor de AR liberado $(\mu \mathrm{mol} / \mathrm{mL})$ pelo método de Miller. Fonte: dados da autora.

\subsubsection{Efeito da temperatura sobre a hidrólise do farelo de milho}

A hidrólise do farelo de milho também foi estudada variando-se apenas a temperatura de reação (ausência de AMI). O resultado de AR encontrado após o tempo de hidrólise pode ser visto na Figura 19. Independente das temperaturas empregas, a formação de AR na presença de água destilada é muito menor do que quando há a aplicação do consórcio enzimático nas condições otimizadas de temperatura, pH, concentração e tempo (formação de 180-210 $\mu$ mol de $\mathrm{AR} / \mathrm{mL}$ (Figura 18). A atuação das enzimas (a uma baixa temperatura que não ocasione o uso de energia de forma dispendiosa nas industrias) foi imprescindível para a quebra dos açúcares complexos do farelo de milho. 
Figura 19. AR produzido na hidrólise do farelo de milho sob influência somente da temperatura

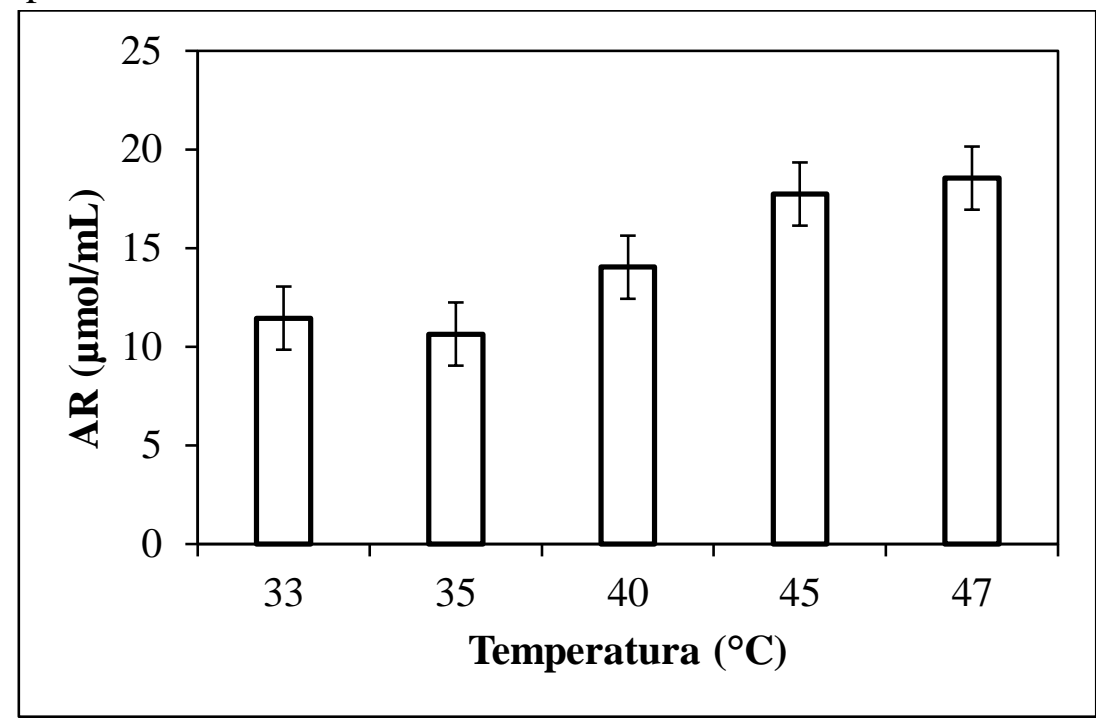

Testes ocorreram com farelo de milho 5\% com água destilada sob agitação de 50 rpm. Fonte: dados da autora.

\subsection{Hidrólise do farelo de milho acrescido do micélio de $A$. brasiliensis}

A Figura 20 traz a produção relativa de AR (\%) encontrada após 48 horas de hidrólise das biomassas farelo de milho e farelo de milho acrescido de A. brasiliensis por AMI.

A produção de AR foi $60 \%$ maior quando o farelo de milho não continha o microorganismo crescido sobre si. O fungo A. brasiliensis pode ter consumido grande parte dos açúcares do farelo para seu metabolismo e crescimento, de modo que quando na presença do consórcio enzimático uma menor quantidade de açúcar estaria disponível para hidrólise. Adicionalmente, também pode-se inferir que na condição de aplicação do farelo de milho adicionado de micélio havia uma menor quantidade de farelo como substrato. A parede celular fúngica é composta principalmente por quitina (RUIZ-HERRERA, 1991), desta forma havia uma menor quantidade de matéria útil para hidrólise pelo extrato enzimático otimizado para produção de amilase quando o experimento decorreu com farelo e micélio.

Uma vez que a produção de AR foi cerca de $60 \%$ maior com o farelo de milho não acrescido de micélio (oriundo de FES com A. brasiliensis), descartou-se a opção de dar continuidade aos experimentos com o farelo de milho adicionado de células fúngicas. 
Figura 20. Produção relativa de AR (\%). (1) farelo de milho puro e (2) é o farelo de milho acrescido de A. brasiliensis

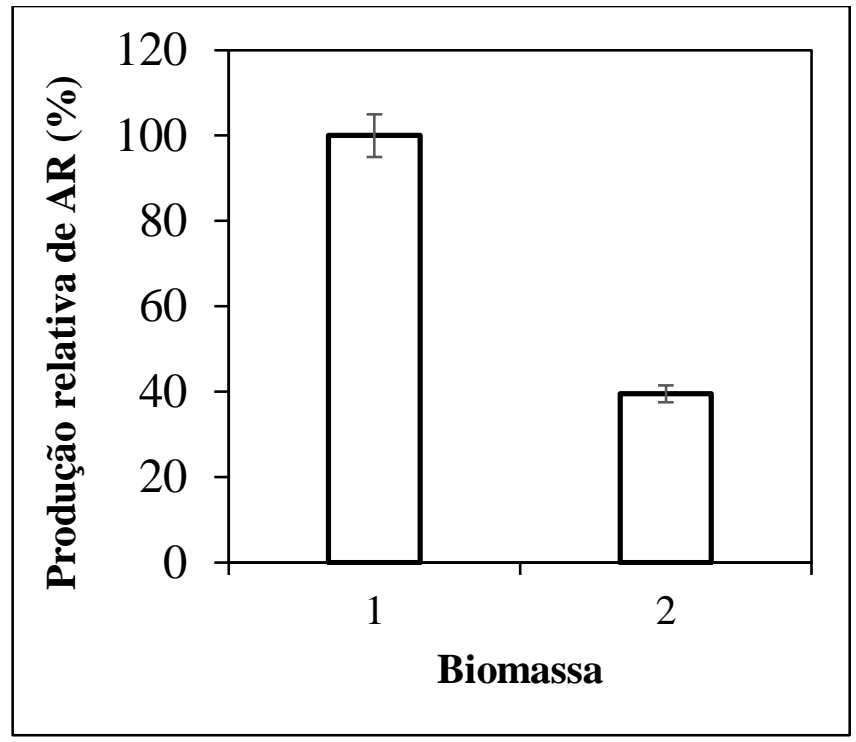

Hidrólise ocorreu por 48 horas com aplicação de AMI sob agitação de 50 rpm. Fonte: dados da autora.

\subsection{Potencial do farelo de milho para a produção de metano}

Após os experimentos de otimização da hidrólise do farelo de milho, foi investigado e comparado o potencial de produção de metano a partir desta biomassa previamente hidrolisada ou não por AMI.

Os efeitos do pré-tratamento enzimático no farelo de milho foram avaliados comparando as produções específicas de metano (NmL/g SV) no processo de DA em modo descontínuo utilizando dejeto bovino como inóculo. Foi comparada a produção de metano a partir de dois substratos derivados do farelo de milho: (i) farelo de milho não tratado, e (ii) hidrolisado de farelo de milho (composto pelo extrato enzimático bruto, açúcares redutores obtidos durante a hidrólise, e farelo remanescente não degradado).

\subsubsection{Caracterização dos substratos e inóculo}

De acordo com a literatura, a razão substrato/inóculo (S/I), também conhecida como razão alimento/ micro-organismo, do inglês food/microrganism (F/M) é um fator altamente importante na DA (BROWN; SHI; LI, 2012; CUI; SHI; LI, 2011). Por este motivo, as concentrações de ST e SV serviram para caracterizar o substrato e o inóculo, além de auxiliar na padronização dos ensaios de potencial de produção de metano, nos quais, a S/I foi mantida em 1:2. 
O teor de ST e SV do inóculo e dos substratos, hidrolisado de farelo de milho e farelo não tratado, estão descritos na Tabela 12. A análise de ST definiu a quantidade de matéria orgânica presente em cada material de estudo. Os ST, também denominados de resíduos totais, consistiram na matéria orgânica que restou após o processo de secagem dos substratos em estufa a $103-105^{\circ} \mathrm{C}$. Os $\mathrm{SV}$, também denominados de resíduos voláteis, correspondem a porção dos sólidos (sólidos totais, suspensos ou dissolvidos) que se perdeu após a calcinação da amostra a $550-600^{\circ} \mathrm{C}$ em forno mufla. Ao final do processo de calcinação, resultaram apenas cinzas (matéria mineral inorgânica), correspondendo à fração de Sólidos Fixos (SF). Desta forma, a diferença entre a massa de matéria seca (ST) e a massa de matéria inorgânica (SF) correspondeu ao valor de sólidos voláteis presente em cada substrato. A fração volátil do substrato representa a quantidade de matéria orgânica disponível para ser biodigerida.

Como pode ser visto na Tabela 12, o conteúdo de SV do farelo de milho tratado e não tratado correspondem a 100\% do conteúdo de ST. O dejeto bovino utilizado apresentou SV de $66 \pm 2 \%$ em relação ao teor de ST.

A composição do dejeto bovino não é fixa, uma vez que varia em função de diversos fatores, como a espécie animal, a raça, a idade, a alimentação, o material utilizado como cama, o manejo do esterco, etc. A alimentação do animal é o fator que mais influencia os teores de carboidratos de rápida degradação e frações fibrosas presentes no esterco (DOS SANTOS; NOGUEIRA, 2012). Desta forma, visto a origem biológica deste material, sua composição de SV e ST é diferente daquela encontrada com farelo de milho, pois ao contrário desta biomassa, a qual tem em sua composição $82 \%$ de carboidratos, $5,4 \%$ de fibras e $7,4 \%$ de proteínas, o dejeto é um excremento biológico cuja composição (água, material não digerido e bactérias) é muito variável.

Tabela 12. Conteúdo de ST e SV dos substratos e inóculo utilizados nos ensaios de produção de metano

\begin{tabular}{cccc}
\hline Material & ST $(\mathbf{g} / \mathbf{K g})$ & SV $(\mathbf{g} / \mathbf{K g})$ & SV $(\%)$ entre ST \\
\hline Farelo de milho não tratado & $862,76 \pm 4,00$ & $861,69 \pm 2,48$ & 99 \\
Hidrolisado de farelo de milho & $889,80 \pm 3,00$ & $889,98 \pm 2,00$ & 100 \\
Dejeto bovino (inóculo) & $33,98 \pm 3,00$ & $22,94 \pm 1,00$ & 66
\end{tabular}

ST: sólidos totais.

SV: sólidos voláteis.

Fonte: dados da autora. 


\subsubsection{Rendimento e cinética da produção de metano}

Os experimentos do potencial de produção de metano em modo descontínuo foram realizados durante 13 dias, a produção acumulativa de metano está representada na Figura 21. O desempenho da DA descreve a produção de metano em função do tempo.

$\mathrm{O}$ pH nos biorreatores não foi ajustado durante a fermentação, sendo que o pH inicial era de $8,0 \pm 0,5$, e o final em 6,5 $\pm 0,5$, indicando condições de DA adequadas ao longo do processo.

A Figura 21 nos mostra que após 8 dias de incubação, o metano produzido a partir do hidrolisado de farelo de milho foi de $23,05 \mathrm{NmL} / \mathrm{g} \mathrm{SV}$, sendo que no mesmo período, o farelo de milho não tratado acumulou apenas $10 \pm 1 \mathrm{NmL} / \mathrm{g}$ SV. O tratamento enzimático apresentou efeitos positivos nítidos com relação a produção de metano, uma vez que os valores encontrados também estão próximos aqueles gerados pelo controle positivo, constituído apenas por glucose $\left(25 \pm 2 \mathrm{NmL} / \mathrm{g} \mathrm{SV}\right.$ no $8^{\circ}$ dia de fermentação).

Alguns modelos matemáticos, como Gompertz modificado, são empregados para estimar algumas variáveis cinéticas. O modelo de Gompertz prevê o acúmulo máximo de metano $\left(\mathbf{H}_{\mathbf{m a x}}\right)$, a velocidade máxima de produção $(\mathbf{R m})$ e a fase de latência $(\boldsymbol{\lambda})$ do processo descontínuo (DE GIOANNIS et al., 2013; PEIXOTO et al., 2012; QUÉMÉNEUR et al., 2012). A Figura 21 e Tabela 13 trazem dados correspondentes aos parâmetros cinéticos preditos pelo modelo de Gompertz modificado aplicado aos dados obtidos da biodigestão. 
Figura 21. Produção acumulativa de metano, onde — é o controle positivo (glucose), • farelo de milho não tratado, $\boldsymbol{\Delta}$ hidrolisado de farelo de milho (pré-tratado com AMI)

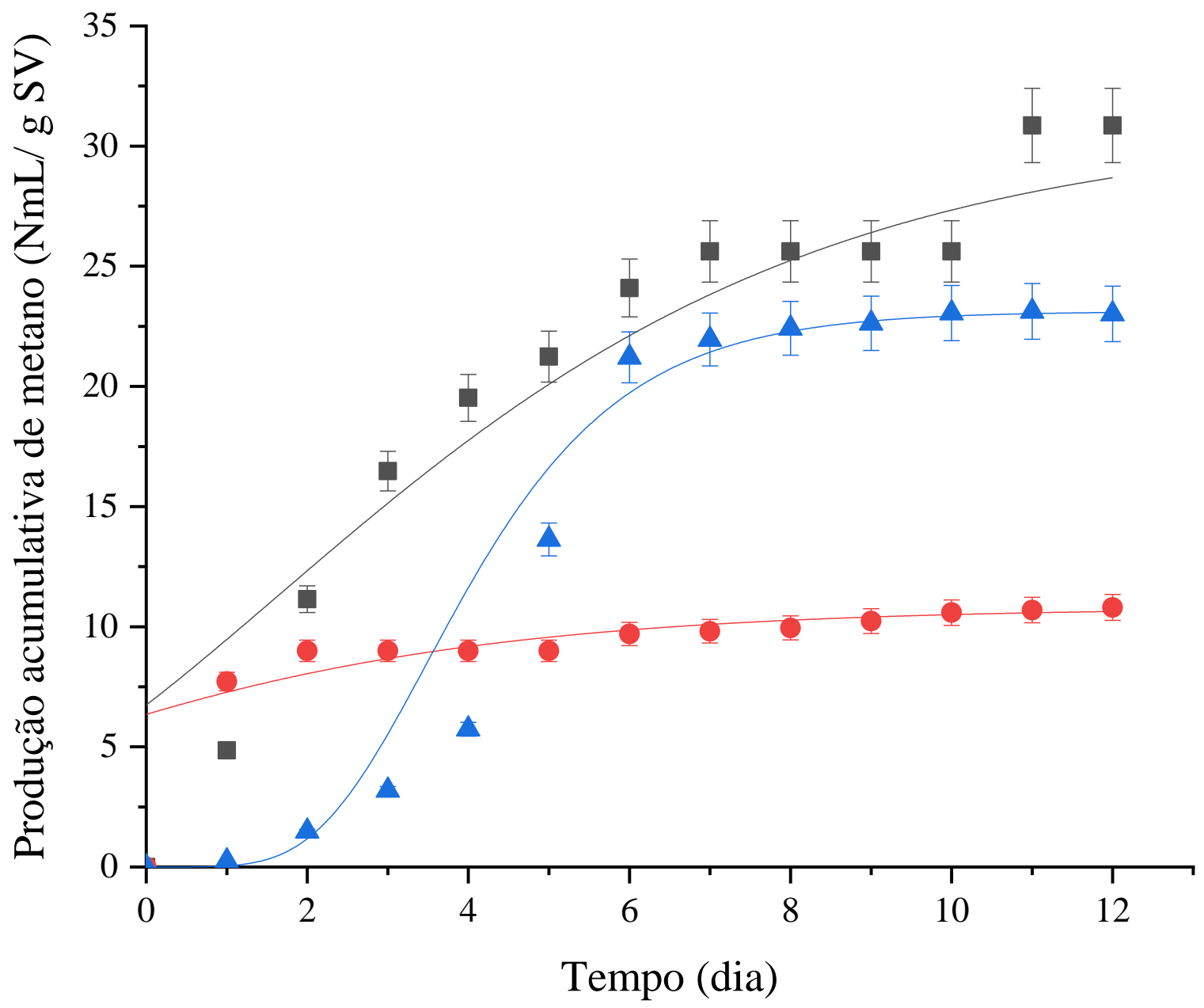

As linhas de tendência foram obtidas pelo ajuste do modelo de Gompertz modificado.

O metano produzido apenas pelo inóculo (branco) foi subtraído de cada ensaio.

Fonte: dados da autora.

Tabela 13. Dados cinéticos obtidos pelo modelo de Gompertz modificado para produção de metano a partir do farelo de milho tratado e não tratado

\begin{tabular}{|c|c|c|c|c|}
\hline Substrato & $\begin{array}{c}\text { Hmax }^{\mathbf{a}} \\
(\mathrm{NmL} / \mathbf{g ~ S V})\end{array}$ & $\begin{array}{c}\mathbf{R m}^{\mathrm{b}} \\
(\mathrm{NmL} / \mathrm{g} \mathrm{SV} / \mathrm{dia})\end{array}$ & $\lambda^{\mathrm{c}}(\mathrm{dia})$ & $\mathbf{R}^{2}$ \\
\hline Glucose & $28,46 \pm 1,05$ & 0,044 & $3,058 \pm 0,21$ & 0,963 \\
\hline Farelo de milho não tratado & $9,82 \pm 0,21$ & 0,75 & $1,50 \pm 0,19$ & 0,936 \\
\hline Hidrolisado de farelo de milho & $23,23 \pm 0,54$ & 0,113 & $5,23 \pm 0,10$ & 0,987 \\
\hline
\end{tabular}

a Potencial máximo de produção de metano (NmL/g SV).

b Velocidade máxima de produção de metano ( $\mathrm{NmL} / \mathrm{g} \mathrm{SV/dia).}$

${ }^{c}$ Fase Lag - tempo para iniciar a produção de metano (dias).

Fonte: dados da autora.

De acordo com o ajuste do modelo de Gompertz aos dados experimentais, o volume de metano acumulado chega a ser $57 \%$ maior quando o substrato é o hidrolisado de farelo de milho. 
A maior produção acumulativa de metano pode ser alcançada devido à presença de açúcares liberados no hidrolisado imediatamente disponível para os micro-organismos. A produção de metano em relação à concentração de sólidos do hidrolisado de farelo de milho foi similar ao obtido apenas com glucose (controle). Isto revela a importância do tratamento enzimático, para o aumento da biodisponibilidade dos carboidratos do farelo tornando-o um substrato comparável à glucose para a produção de metano.

Com relação a fase de latência, esta foi menor no caso da digestão com farelo não tratado, sendo que o acúmulo de metano ocorreu apenas durante os 3 primeiros dias. Esse acúmulo inicial de metano pode ter sido resultado da utilização direta de açúcares simples presentes inicialmente no substrato e solubilizados no líquido. Além disso, pode se inferir que houve uma menor produção de metano quando não houve o pré-tratamento do substrato devido a um potencial celulolítico do dejeto, o qual não favoreceu o consumo do amido (polímero complexo) principal componente do farelo de milho. A microbiota presente no dejeto varia em função de diversos fatores, sendo a alimentação um dos aspectos que mais influência na composição dos micro-organismos presentes (OZBAYRAM et al., 2018), o que por consequência dita o potencial de digestão de cada amostra.

Dentre os diferentes pré-tratamentos (biológicos e químicos) recomendados para melhorar a fase de hidrólise nas digestões anaeróbias, a hidrólise enzimática é uma ótima alternativa de tecnologia sustentável (DOS SANTOS FERREIRA et al., 2020). VALLADAO et al. (2009), mostrou que lipases de Penicillium sp. quando aplicadas no tratamento anaeróbio de efluentes de um abatedouro de aves, com alto teor de gordura, possibilitaram uma produção de metano $50 \%$ maior do que aquela apresentada pelo controle (sem pré-tratamento enzimático). Em outro estudo, foi avaliada a aplicação do extrato enzimático produzido por fermentação em estado sólido usando Aspergillus níger em meio de cultura com a fração orgânica de resíduo sólido e farelo de trigo como substratos. A aplicação deste extrato enzimático como um pré-tratamento na DA ora do farelo de trigo, ora da fração orgânica de resíduo sólido resultou em uma maior produção específica de metano, $75 \%$ e 78\% respectivamente, quando comparadas ao controle (sem o pré-tratamento enzimático) (MLAIK et al., 2019).

O pré-tratamento biológico, com ênfase em processos enzimáticos, permanece pouco explorado nos processos de DA, portanto, mais estudos sobre tecnologias híbridas, tratamento enzimático antes ou durante a DA, são necessários para propiciar: $(i)$ maior rendimento da digestão, (ii) direcionar a produção de produtos químicos de base biológica, por 
exemplo os ácidos graxos voláteis, e (iii) aumentar as concentrações de metano como produto final do processo, alcançando assim uma maior viabilidade econômica em escala industrial. 


\section{Conclusões \& Perspectivas - Parte 1}


Esta parte do trabalho relatou o screening de biomassas a serem utilizadas em ensaios de design de misturas visando a otimização de coquetéis para sacarificação de biomassa como pré-tratamento biológico para produção de biocombustíveis. O farelo de milho pode ser hidrolisado com sucesso pelo extrato enzimático rico em amilase produzida por A. brasiliensis, liberando uma quantidade de $173 \mu \mathrm{mol} / \mathrm{mL}$. Além disso, a casca de banana mostrou-se efetivamente hidrolisada pelo extrato enzimático Celluclast ${ }^{\mathrm{TM}}$, liberando a quantidade de 175 $\mu \mathrm{mol} / \mathrm{mL}$. Assim, a abordagem de identificação de misturas entre biomassas ou extratos enzimáticos brutos para otimizar o desenvolvimento de coquetéis para sacarificação de diferentes substratos exibiu vários graus de sinergismo enzimático, dependendo de cada tipo de biomassa. Uma combinação enzimática específica e ação sinérgica para hidrólise de biomassa podem agregar valor ao negócio de biocombustíveis, tornando o processo ainda mais sustentável e produtivo.

Adicionalmente, nesta primeira parte foi otimizada a hidrólise do farelo de milho pelo consórcio enzimático AMI, o qual foi produzido a partir do próprio farelo de milho como fonte de carbono. Esse consórcio enzimático rico em amilase, 166,66 U de amilase/mg de proteína, apresentou $\mathrm{pH} 4,0$ e temperatura de $70{ }^{\circ} \mathrm{C}$ como as melhores condições para a atividade amilolítica bruta. A otimização da hidrólise do farelo de milho, por sua vez, mostrou que 5\% de substrato e 48 horas foram parâmetros essenciais para maior liberação de AR ( $\mu \mathrm{mol} / \mathrm{mL})$. A partir dos resultados do DCCR, viu-se que as faixas de $\mathrm{pH} 4,0-4,5$ e de temperatura $40-45^{\circ} \mathrm{C}$ foram ótimos para a hidrólise desta biomassa. A hidrólise em $\mathrm{pH}$ ácido e a temperaturas não elevadas torna o processo adequado para a produção industrial, por exemplo, nas etapas de hidrólise na produção de combustível e ração.

Resultados promissores na produção de biogás/metano foram encontrados por meio da tecnologia biológica do tratamento enzimático aplicada previamente a DA. Verificou-se que quando houve um tratamento enzimático do farelo de milho com extrato bruto rico em amilase, o potencial máximo de produção de metano (NmL/g SV) em DA descontínua foi $42 \%$ maior do que quando o farelo de milho não foi pré-hidrolisado. Desta forma, a associação de prétratamento enzimático pode ser uma ferramenta importante para melhorar a utilização de biomassa/produtos agrícolas associados a dejetos bovinos (inoculantes) para a produção de biogás e bioenergia. 

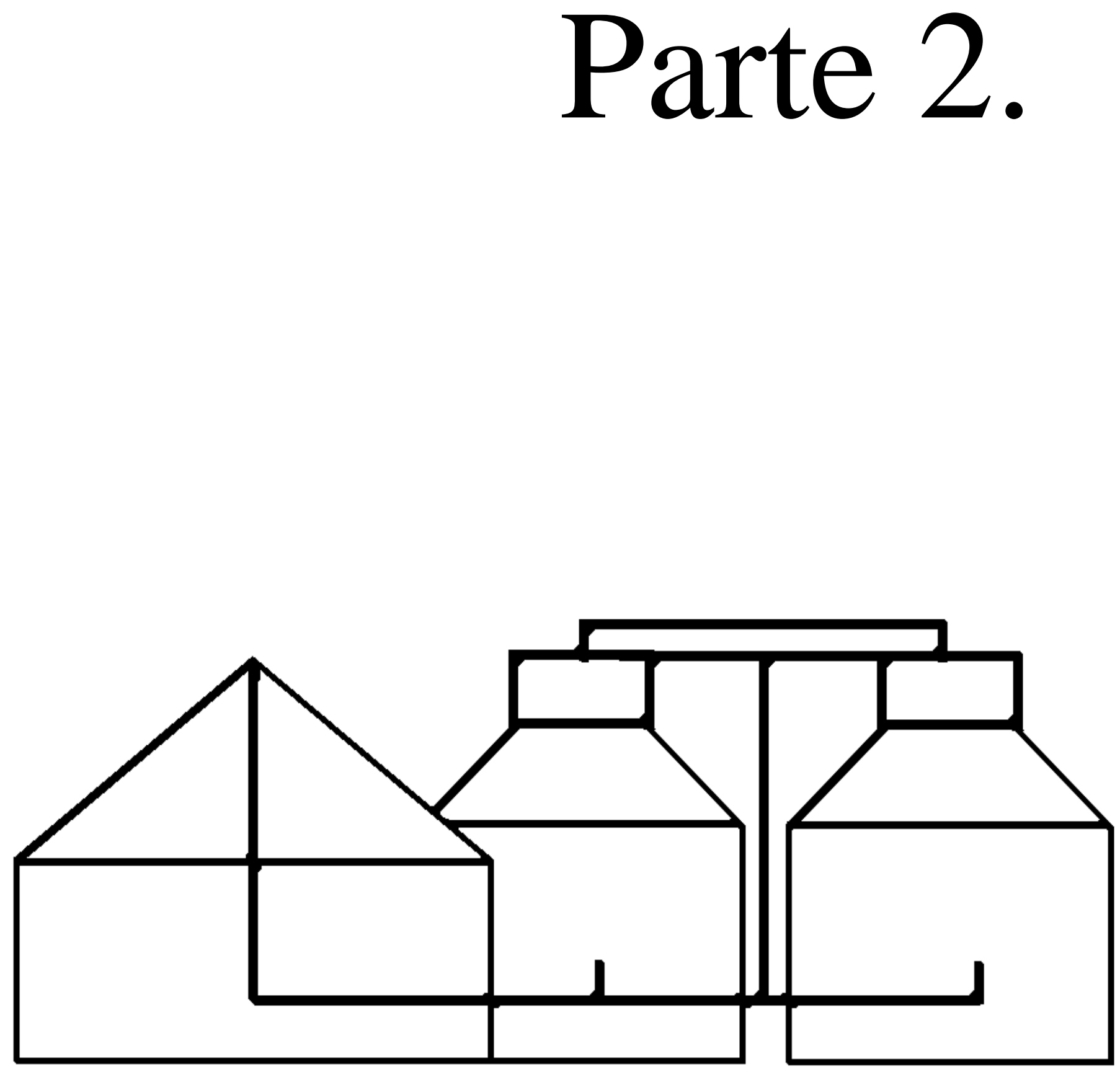

\section{Digestão anaeróbia \& fermentação alcoólica}

Parte deste trabalho está submetido para publicação na Biofuels, Bioproducts \& Biorefining (06/2021) - Apêndice 4. 
Os resultados apresentados da Parte 2 desta tese de doutorado foram realizados no Laboratório de Biogás, do Departamento de Resource Recovery da University of Borås, Borås/ Suécia. Os experimentos foram realizados durante o período de doutorado sanduíche concedido pela CAPES/PRINT - Edital nº 41/2017 (Número de Processo: 88887.368240/2019-00).
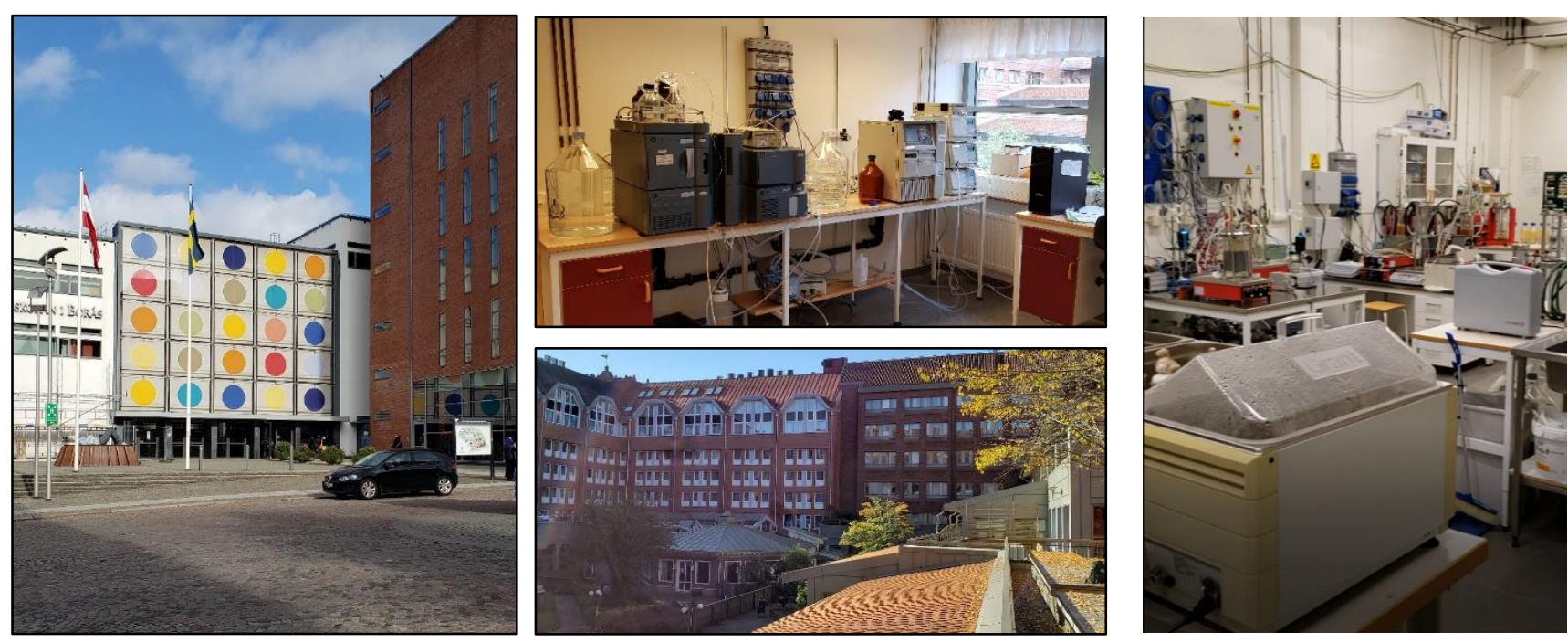


\section{Material \& Métodos - Parte 2}




\subsection{Substrato e inóculo para DA}

O farelo de milho Risenta® foi adquirido no supermercado ICA da rede sueca. O dejeto bovino foi coletado em uma fazenda de gado - Hushållningssällskapet Sjuhärad (Rådde Gård 1, 51452 Länghem - Suécia). O dejeto foi filtrado em uma peneira de porosidade de $2 \mathrm{~mm}$ para remover a grama e armazenado em recipientes plásticos a $-20{ }^{\circ} \mathrm{C}$ para evitar a biodegradação. O lodo usado como inóculo foi obtido de uma usina de biogás em escala real que trabalha com CoDA termofílica $\left(55 \pm 1^{\circ} \mathrm{C}\right.$ ) de resíduos domésticos (Borås Energy and Environment $\mathrm{AB}$, Borås, Suécia). O lodo foi filtrado em uma peneira de porosidade de $2 \mathrm{~mm}$ para remoção de areia, plástico e outras partículas indesejadas. Previamente ao uso, foi realizada aclimatação por cinco dias em uma incubadora a $55^{\circ} \mathrm{C}$.

\subsection{Produção do extrato enzimático AMI e dosagem da atividade amilolítica}

Foi utilizado como organismo produtor do extrato enzimático AMI o A. brasiliensis cedido pela Coleção de Micologia do Laboratório de Microbiologia e Biologia Celular do Departamento de Biologia da Faculdade de Filosofia, Ciências e Letras de Ribeirão Preto Universidade de São Paulo (SP, Brasil). O fungo foi mantido em laboratório a $4{ }^{\circ} \mathrm{C}$ em cepas de BDA (ágar batata dextrose) compostos por (em g/L): glucose 20, ágar 15 e extrato de batata 4. Novas cepas de A. brasiliensis eram preparadas via transferência de esporos, usando um bastão de metal esterilizado, de cepas pré-crescidas e então incubados por 5 dias a $30{ }^{\circ} \mathrm{C}$.

O extrato bruto otimizado para produção de amilase, AMI, foi preparado como já descrito na Parte 1. Culturas de A. brasiliensis foram obtidas a partir do inóculo de $1,0 \mathrm{~mL}$ de uma solução de conídios $\left(10^{6}\right)$ em frascos Erlenmeyer de $125 \mathrm{~mL}$ contendo $25 \mathrm{~mL}$ de meio SR (RIZZATTI et al., 2001) e 1\% (m/v) de farelo de milho. Os meios foram ajustados em pH 6,0 e incubados a $30^{\circ} \mathrm{C}$ por $120 \mathrm{~h}$ em condição estática.

A dosagem da amilase presente no extrato AMI também decorreu seguindo a metodologia de Miller, como previamente apresentado na Parte 1. A atividade amilolítica foi determinada a partir do substrato amido de batata solúvel. Misturas de $50 \mu \mathrm{L}$ de substrato (1\%) em tampão acetato de sódio $(100 \mathrm{mM}, \mathrm{pH} 4,0)$ e $50 \mu \mathrm{L}$ de extrato enzimático foram mantidas em banho úmido a $70{ }^{\circ} \mathrm{C}$ por 10 minutos. As amostras foram então fervidas a $100{ }^{\circ} \mathrm{C}$ por 5 minutos e $1 \mathrm{~mL}$ de água destilada foi adicionado. A concentração de AR foi determinada em espectrofotômetro a $540 \mathrm{~nm}$. A unidade de atividade enzimática foi definida como a quantidade de enzima capaz de liberar $1 \mu \mathrm{mol}$ de RS por minuto. 


\subsection{Otimização da hidrólise}

\subsubsection{Proporção entre substrato e AMI}

O pré-tratamento do farelo de milho por AMI foi testado em diferentes proporções de substrato e extrato enzimático, com uma carga de sólidos de 10\%. Os testes decorreram em tubos Falcon de $15 \mathrm{~mL}$ aquecidos em banho termostatizado a $45^{\circ} \mathrm{C}$ sob agitação de $100 \mathrm{rpm}$ por 48 horas. $\mathrm{O}$ volume final no sistema foi mantido em $11 \mathrm{~mL}$, de forma que a proporção entre a biomassa e extrato enzimático variou conforme descrito na Tabela 14. Alíquotas foram usadas para quantificar o AR seguindo o método de Miller (MILLER, 1959), de modo que o desempenho da hidrólise foi acompanhado pela determinação da concentração (g/L) de AR liberados ao final do período de incubação.

Tabela 14. Proporções entre o farelo de milho e AMI testadas para maximização da hidrólise

\begin{tabular}{ccccc}
\hline $\begin{array}{c}\text { Proporção substrato/AMI } \\
(\mathbf{m} / \mathbf{v})\end{array}$ & $\begin{array}{c}\text { Farelo de } \\
\text { milho }(\mathbf{g})\end{array}$ & AMI $(\mathbf{m L})$ & $\begin{array}{c}\text { Água destilada } \\
(\mathbf{m L})\end{array}$ & $\begin{array}{c}\text { Unidade de amilase } \\
\text { bruta/ g de } \\
\text { substrato }\end{array}$ \\
\hline $1: 10$ & 1 & 10,00 & 0 & 34,00 \\
$1: 8$ & 1 & 8,00 & 2,00 & 27,20 \\
$1: 6$ & 1 & 6,00 & 4,00 & 20,40 \\
$1: 4$ & 1 & 4,00 & 6,00 & 13,60 \\
$1: 2$ & 1 & 2,00 & 8,00 & 6,80 \\
$1: 1$ & 1 & 1,00 & 9,00 & 3,40 \\
$1: 0,5$ & 1 & 0,50 & 9,50 & 1,70 \\
$1: 0,25$ & 1 & 0,25 & 9,75 & 0,85 \\
Água destilada & 1 & 0 & 10 & 0 \\
\hline
\end{tabular}

Fonte: dados da autora.

\subsubsection{Tempo de ensaio}

Foi analisado a produção de AR conforme o tempo de hidrólise seguindo as proporções de farelo/AMI pré-selecionadas. Foram realizados ensaios em tubos Falcon de $15 \mathrm{~mL}$ dispostos em banho termostatizado a $45^{\circ} \mathrm{C}$ sob agitação de $100 \mathrm{rpm}$ durante $24,48,72,96,120$ e 144 horas. Após o tempo de hidrólise de cada experimento, alíquotas foram utilizadas para quantificação do AR ( $\mu \mathrm{mol} / \mathrm{mL})$ pelo método descrito por Miller (MILLER, 1959).

\subsection{Configuração experimental em batelada}

\subsubsection{Seleção de inóculo}

Dejeto bovino e lodo termofílico foram testados como inóculos da DA. Foram utilizados diferentes substratos, como (i) farelo de milho, (ii) farelo de milho hidrolisado enzimaticamente por 48 e (iii) 96 horas, (iv) AMI e (v) farelo de milho + AMI. 
Os experimentos de digestão foram realizados sem qualquer ajuste de $\mathrm{pH}$, uma vez que os inóculos, tanto o dejeto quanto o lodo, apresentavam um $\mathrm{pH}$ elevado de 7,6 e 8,4, respectivamente.

Com relação ao branco do experimento, apenas o respectivo inóculo e água de torneira foram usados para revelar qualquer produção de metano pelo próprio inóculo. Adicionalmente, como controle positivo foi utilizado a celulose microcristalina de tamanho de partícula de 50 $\mu \mathrm{m}$ (Sigma Aldrich, Darmstadt, Alemanha). A Figura 22 ilustra um esquema geral da configuração experimental.

Figura 22. Configuração experimental dos testes de DA em batelada, que ocorreram em frascos de vidro de $118 \mathrm{~mL}$, sem ajuste inicial do $\mathrm{pH}$ do meio

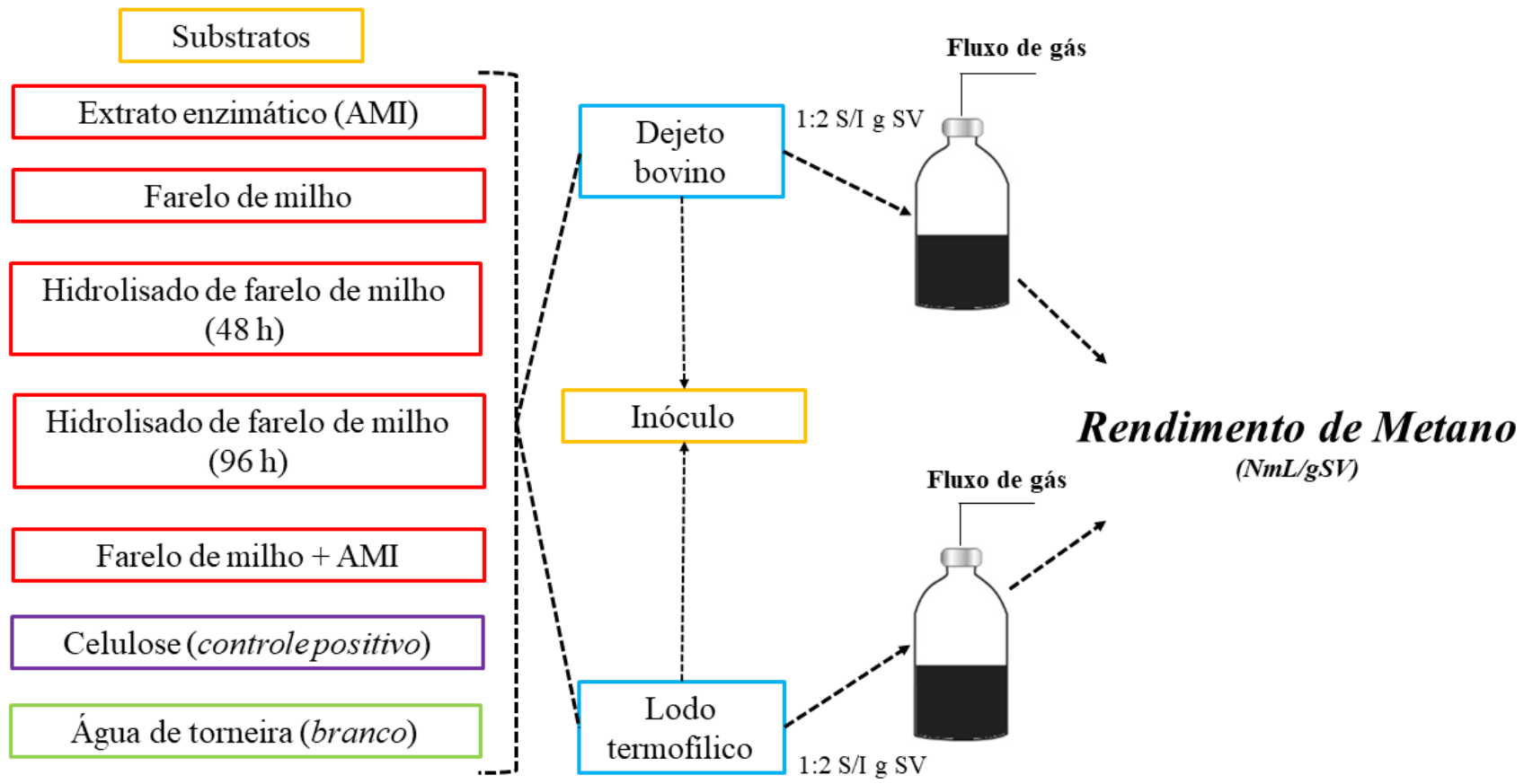

Fonte: elaborado pela autora.

Os ensaios com dejeto bovino como inóculo foram realizados em condições mesofílicas $\left(37 \pm 2{ }^{\circ} \mathrm{C}\right)$, e os com lodo do biodigestor foram realizados em condições termofílicas $(55 \pm 2$ $\left.{ }^{\circ} \mathrm{C}\right)$. Frascos de vidro de $118 \mathrm{~mL}$ foram usados como reatores.

Para esta configuração experimental, substratos com carga de $0,4 \mathrm{~g}$ de sólidos voláteis (SV) foram usados e, em seguida, o inóculo foi adicionado mantendo uma proporção de 1:2 de S/I (Substrato/Inóculo na base de SV).

\subsubsection{Seleção de substrato e CoDA em batelada}

Para seleção do substrato (em mono ou co-digestão), cuja maior produção acumulativa de metano em batelada se destacasse, foi utilizado o lodo termofílico como inóculo na 
proporção 1:2 (S/I na base de SV). Os substratos testados foram (i) AMI, (ii) farelo de milho, (iii) hidrolisado de farelo de milho (48 h), (iv) hidrolisado de farelo de milho (96 h), (v) farelo de milho + AMI e (vi) dejeto bovino. Como controle positivo foi utilizado a celulose microcristalina de tamanho de partícula de $50 \mu \mathrm{m}$ (Sigma Aldrich, Darmstadt, Alemanha), e o metano produzido apenas pelo inóculo (branco) foi subtraído de cada ensaio.

Nestes testes de seleção de substratos, cada um dos substratos acima mencionados além de testados em mono-digestão, também foram testados quando em co-digestão com dejeto bovino. Ou seja, nestes experimentos, o dejeto foi aplicado como co-substrato para a CoDA.

A Figura 23 mostra uma visão geral esquemática da configuração experimental e a Tabela 15 traz a disposição dos ensaios.

Figura 23. Diagrama esquemático da configuração experimental dos ensaios em batelada para seleção de substrato e CoDA na razão substrato para inóculo (S/I) de 1:2 na base de SV

Substratos da mono-digestão
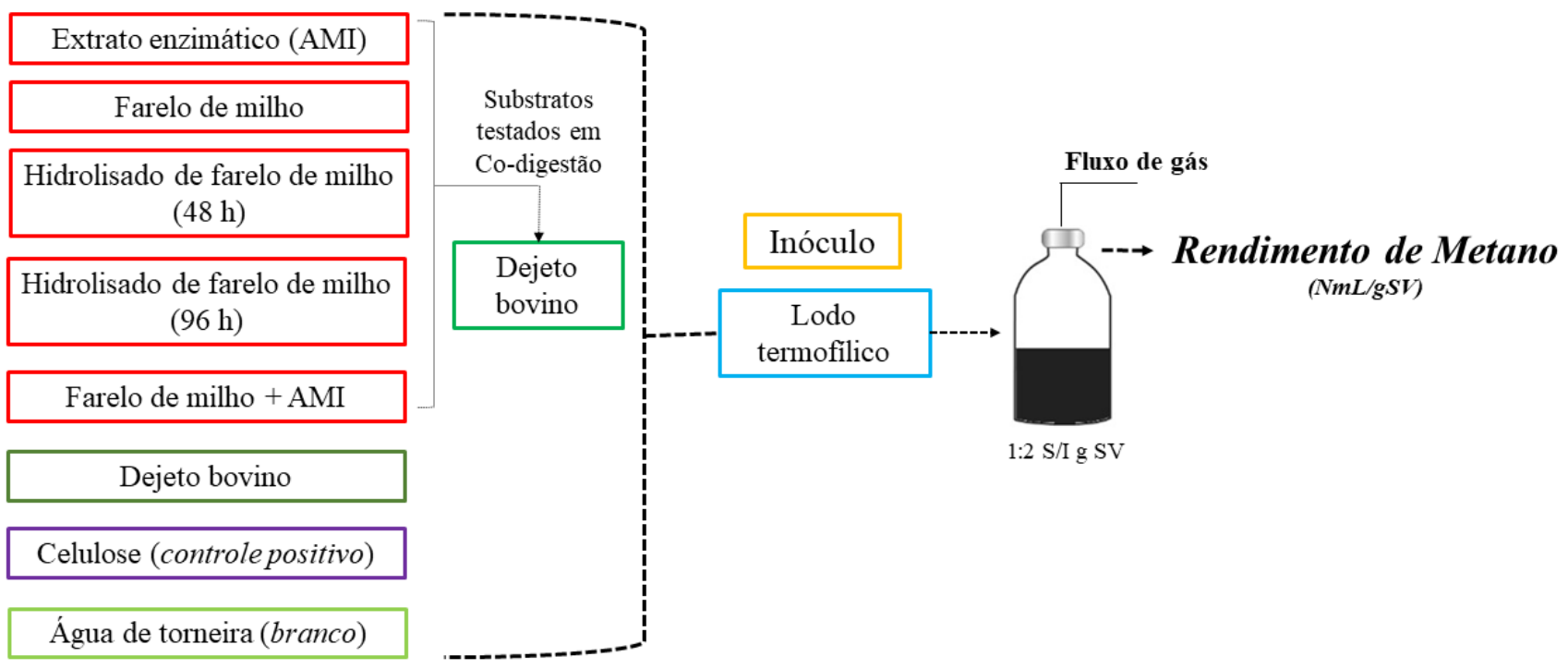

Fonte: elaborado pela autora. 
Tabela 15. Configuração experimental da CoDA em batelada para seleção de substrato

\begin{tabular}{|c|c|c|c|c|}
\hline \multirow{2}{*}{ Ensaio } & \multicolumn{4}{|c|}{ Substratos } \\
\hline & AMI & Farelo de milho & Farelo hidrolisado ${ }^{a}$ & Dejeto bovino \\
\hline 1 & + & - & - & - \\
\hline 2 & - & + & - & - \\
\hline 3 & - & - & + & - \\
\hline 4 & + & + & - & - \\
\hline 5 & - & - & - & + \\
\hline 6 & - & + & - & + \\
\hline 7 & - & - & + & + \\
\hline 8 & + & + & - & + \\
\hline
\end{tabular}

O inóculo utilizado foi o lodo termofílico proveniente da Borås Energi och Miljö AB. Os símbolos (+) significam a presença do substrato no ensaio e (-) a ausência. A celulose foi usada como controle positivo.

${ }^{\text {a }}$ Foram testados ambos os hidrolisados de farelos de milho tratados por 48 e 96 horas.

Fonte: dados da autora.

Os ensaios foram realizados em condições termofílicas $\left(55 \pm 2{ }^{\circ} \mathrm{C}\right)$. Frascos de vidro de $118 \mathrm{~mL}$ foram usados como reatores. Para a configuração experimental; substratos com carga de $0,4 \mathrm{~g}$ de SV foram usados e, em seguida, o inóculo foi adicionado mantendo uma proporção de S/I (substrato/inóculo) de 1:2 na base de SV. Na CoDA, o substrato foi uma mistura 1:1 entre dejeto bovino e farelo de milho, ou hidrolisado de milho, mantendo-se a mesma carga de $0,4 \mathrm{~g}$ SV.

Os experimentos foram realizados sem ajuste de $\mathrm{pH}$, uma vez que lodo termofílico como inóculo definia um pH inicial de 8,4 para a digestão.

\subsubsection{Mensuração do gás nos experimentos em batelada}

Nos experimentos de DA em batelada, cada um dos reatores foi selado com um septo de borracha e tampa de alumínio. O headspace (espaço não preenchido deixado acima do conteúdo do recipiente) foi preenchido com $\mathrm{N}_{2}$ por $2 \mathrm{~min}$, de modo a atingir condições anaeróbias. Os reatores foram agitados manualmente uma vez ao dia. Todas as configurações experimentais foram feitas em triplicata.

As amostras de gás foram coletadas regularmente do headspace a fim de se evitar uma sobrepressão dentro dos frascos. O gás era liberado após cada ocasião de medição usando uma agulha (Sterican® $\varnothing 0,4 \times 20 \mathrm{~mm}$ B. Braun, Alemanha), e então a composição do gás no headspace era medida novamente. A produção acumulativa de metano foi calculada a partir dos dados obtidos por cromatografia gasosa (CG), usando a lei dos gases ideais e assumindo misturas de gases ideais conforme descrito por HANSEN et al. (2004) e TEGHAMMAR et al. (2010). 
Todos os volumes de metano $(\mathrm{NmL})$ foram relatados em condições normais $\left(0^{\circ} \mathrm{C}\right.$; $101,3 \mathrm{kPa}$ ) de acordo com a ISO 10780 (1994).

\subsubsection{Cinética}

O modelo de Gompertz modificado (Equação 14) (DE GIOANNIS et al., 2013; PEIXOTO et al., 2012; QUÉMÉNEUR et al., 2012) foi ajustado aos dados experimentais.

\subsection{Configuração experimental dos ensaios em modo semi-contínuo}

Os testes operados em modo contínuo foram realizados para simular a operação semicontínua de biorreatores metanogênicos em escala real. Para tal, foram utilizados seis reatores de tanque agitado contínuo ou, do inglês, Continuous Stirring Tank Reactor, CSTRs com um volume total de 2,2 L cada, sendo o volume de trabalho de $2 \mathrm{~L}$. Cada reator foi equipado com um agitador mecânico, que funcionou em modo contínuo (10 rpm) para evitar limitações na transferência de massa. A Tabela 16 mostra em resumo os parâmetros utilizados para a DA semi-contínua.

$\mathrm{O} \mathrm{N}_{2}$ foi usado por dois minutos para preencher o headspace de cada frasco, de modo a se criar condições anaeróbias. Todos os reatores foram incubados em banho-maria termostático a $55{ }^{\circ} \mathrm{C}$. $\mathrm{O} \mathrm{pH}$ do líquido da digestão (digestato) foi verificado diariamente, enquanto a determinação dos ST, SV, alcalinidade total (AT) e ácidos graxos voláteis (AGV) foram registrados semanalmente de modo a se acompanhar a estabilidade do processo. As análises foram realizadas a partir das amostras de lodo digerido, retiradas de acordo com o procedimento de alimentação. A produção de metano de cada reator foi monitorada continuamente com instrumento $\mu$-flow on-line (Bioprocess control AB, Suécia) (Figura 24). 
Figura 24. Aparato experimental da DA semi-contínua. (A) Reator de vidro 2,2 L, (B) reatores em banho termostatizado, $(\mathbf{C})$ reatores conectados ao instrumento $\mu$-flow on-line (Bioprocess control $\mathrm{AB}$ ) para coleta de dados da produção de metano

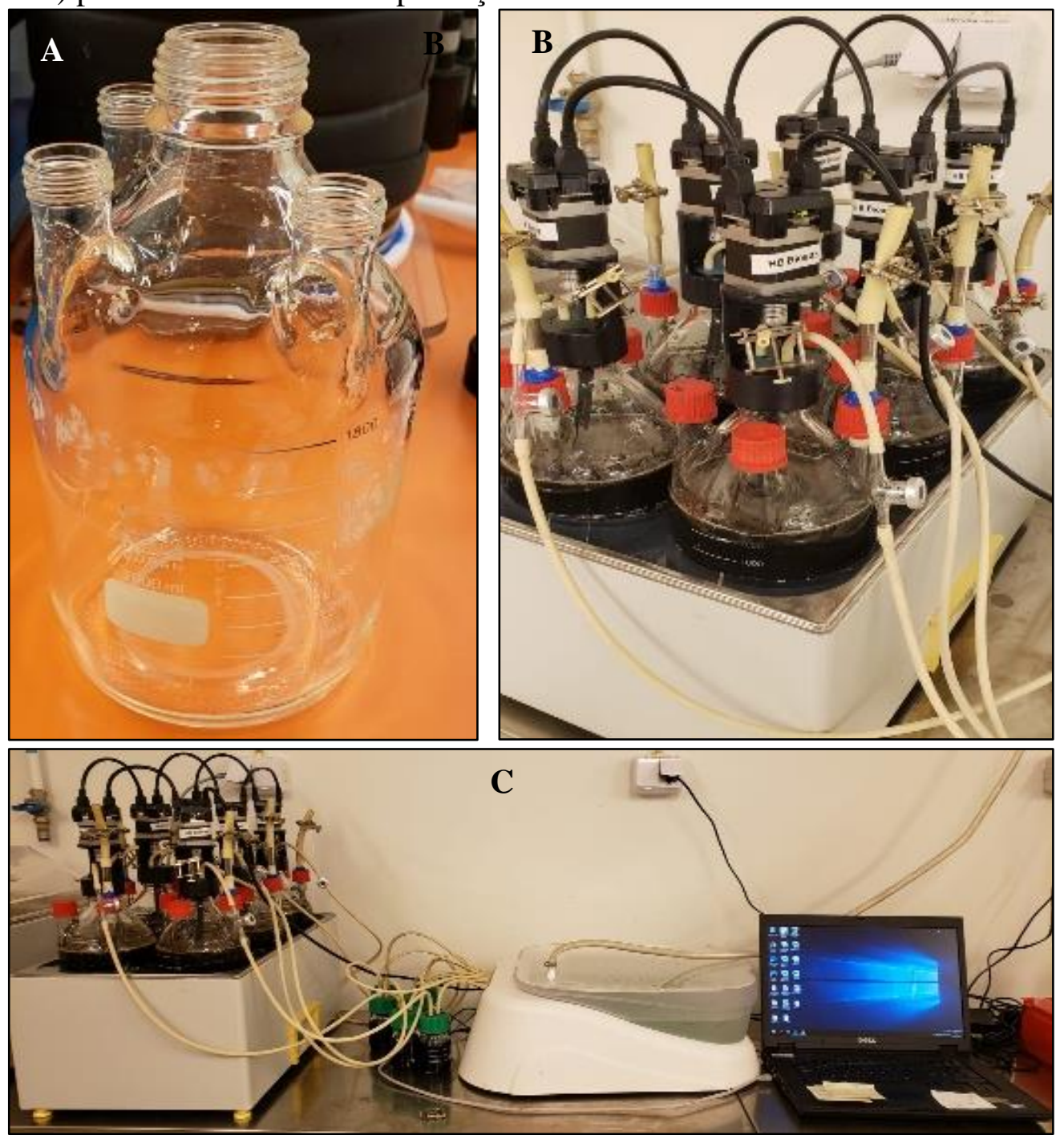

Fonte: dados da autora.

Tabela 16. Descrição dos parâmetros aplicados na DA semi-contínua

\section{Parâmetros}

Inóculo (lodo termofílico)

Farelo de milho

Extrato enzimático

Dejeto bovino

Celulose (controle positivo)

Razão substrato/inóculo

Tempo de retenção hidráulica (TRH)

Carga orgânica (CO)

Volume do reator

Volume de trabalho

Temperatura

Tempo de incubação

\section{Descrição}

Sobacken, Borås

Risenta ${ }^{\circledR}$

AMI (3,4 U de amilase/mL)

Farmland, Hushållningssällskapet Sjuhärad

Partícula de $50 \mu \mathrm{m}^{2}$ (Sigma Aldrich, Darmstadt, Germany)

$1: 2$ (g SV)

20 dias

Inicial $\rightarrow$ alvo: $0.5 ; 1 ; 2$ e 3 (g SV/L/d)

$2200 \mathrm{~mL}$

$2000 \mathrm{~mL}$

$55 \pm 2{ }^{\circ} \mathrm{C}$

140 dias

Fonte: dados da autora. 


\subsubsection{Ensaios em modo semi-contínuo}

Foram empregados dois reatores (M1 e M2) de 2,2 L para digerir apenas farelo de milho (mono-digestão). Outro par de reatores (MEx1 e MEx2) foi usado para digerir farelo de milho na presença do extrato enzimático AMI $(10 \% \mathrm{~m} / \mathrm{v}$, sendo o extrato adicionado ao reator uma vez na semana), e o terceiro par de reatores (MDe1 e MDe2) foi usado para o teste de CoDA do farelo de milho e dejeto bovino na proporção de mistura de 1:1 (base SV).

Os reatores tiveram um tempo de retenção hidráulica (TRH) de 20 dias. Os reatores foram preenchidos com $2 \mathrm{~L}$ de inóculo (lodo termofílico) e inicialmente a alimentação foi realizada com uma Carga Orgânica $(\mathrm{CO})$ de 0,5 g/L/d. Posteriormente, a CO foi aumentada para 1,0, 2,0 e 3,0 g/L/d.

A Tabela 17 traz em detalhes as condições aplicadas a cada reator ao longo do experimento de digestão semi-contínua. 
Tabela 17. Configuração experimental da digestão semi-contínua

\begin{tabular}{|c|c|c|c|}
\hline Semana & Reator & $\begin{array}{c}\text { CO } \\
(\mathrm{g} \mathrm{SV} / \mathrm{L} / \mathrm{d})\end{array}$ & Substrato \\
\hline \multirow{3}{*}{1} & M1 e M2 & & farelo de milho \\
\hline & MEx1 e MEx2 & 0,5 & farelo de milho + AMI $^{\mathrm{a}}$ \\
\hline & MDe1 e MDe2 & & farelo de milho + dejeto bovino ${ }^{\mathrm{b}}$ \\
\hline \multirow{3}{*}{2 e 3} & M1 e M2 & & farelo de milho \\
\hline & MEx1 e MEx2 & 1,0 & farelo de milho $+\mathrm{AMI}^{\mathrm{a}}$ \\
\hline & MDe1 e MDe2 & & farelo de milho + dejeto bovino ${ }^{\mathrm{b}}$ \\
\hline \multirow{3}{*}{4} & M1 e M2 & & farelo de milho \\
\hline & MEx1 e MEx2 & 2,0 & farelo de milho $+\mathrm{AMI}^{\mathrm{a}}$ \\
\hline & MDe1 e MDe2 & & farelo de milho + dejeto bovino ${ }^{b}$ \\
\hline \multirow{3}{*}{5} & M1 e M2 & 1,0 & farelo de milho \\
\hline & MEx1 e MEx2 & 1,0 & farelo de milho $+\mathrm{AMI}^{\mathrm{a}}$ \\
\hline & MDe1 e MDe2 & 2,0 & farelo de milho + dejeto bovino ${ }^{\mathrm{b}}$ \\
\hline \multirow{3}{*}{6} & M1 e M2 & 0,5 & farelo de milho \\
\hline & MEx1 e MEx2 & 0,5 & farelo de milho $+\mathrm{AMI}^{\mathrm{a}}$ \\
\hline & MDe1 e MDe2 & 2,0 & farelo de milho + dejeto bovino ${ }^{b}$ \\
\hline \multirow{3}{*}{7 e 8} & M1 e M2 & 1,0 & farelo de milho \\
\hline & MEx1 e MEx2 & 1,0 & farelo de milho $+\mathrm{AMI}^{\mathrm{a}}$ \\
\hline & MDe1 e MDe2 & 2,0 & farelo de milho + dejeto bovino ${ }^{b}$ \\
\hline \multirow{3}{*}{9 e 10} & M1 e M2 & 1,0 & farelo de milho + dejeto bovino ${ }^{b}$ \\
\hline & MEx1 e MEx2 & 1,0 & farelo de milho + AMI $^{\mathrm{a}}$ \\
\hline & MDe1 e MDe2 & 3,0 & farelo de milho + dejeto bovino ${ }^{b}$ \\
\hline \multirow{3}{*}{11} & M1 e M2 & 1,0 & farelo de milho + dejeto bovino ${ }^{b}$ \\
\hline & MEx1 e MEx2 & 1,0 & farelo de milho $+\mathrm{AMI}^{\mathrm{ac}}$ \\
\hline & MDe1 e MDe2 & 3,0 & farelo de milho + dejeto bovino ${ }^{\mathrm{b}}$ \\
\hline \multirow{3}{*}{12} & M1 e M2 & 1,0 & farelo de milho + dejeto bovino ${ }^{b}$ \\
\hline & MEx1 e MEx2 & 1,0 & farelo de milho $+\mathrm{AMI}^{\mathrm{a}}$ \\
\hline & MDe1 e MDe2 & 3,0 & farelo de milho + dejeto bovino ${ }^{b}$ \\
\hline 13,14 & M1 e M2 & 1,0 & farelo de milho + dejeto bovino ${ }^{b}$ \\
\hline 15,16 & MDe1 e MDe2 & 3,0 & farelo de milho + dejeto bovino ${ }^{\mathrm{b}}$ \\
\hline 17,18, & M1 e M2 & 1,0 & farelo de milho + dejeto bovino ${ }^{\mathrm{ab}}$ \\
\hline 19,20 & MDe1 e MDe2 & 3,0 & farelo de milho + dejeto bovino ${ }^{\mathrm{ab}}$ \\
\hline
\end{tabular}

${ }^{a}$ Extrato enzimático adicionado uma vez por semana em cada reator seguindo $10 \%$ da carga de sólidos diária.

${ }^{\mathrm{b}}$ Proporção de 1:1 (g de SV) entre os substratos.

c Substituição de cultura por novo inóculo (1L).

Fonte: dados da autora.

\subsection{Taxa de degradação do substrato na DA}

A taxa de degradação (TD) com base nos dados de SV e ST foi determinada utilizando um cálculo simplificado usualmente aplicado nas instalações em larga escala na Suécia (Equação 22). O volume de substrato e digestato são assumidos como iguais, ST é expresso em $\%$ de peso seco e SV em \% de ST. 
$T D=\frac{(\text { ST substrato } \times \text { SV substrato })-(\text { STdigestato } x \text { SV digestato })}{(\text { ST substrato } x \text { SV substrato })} \times 100$

\subsection{Métodos analíticos usados nos testes de DA}

\subsubsection{ST e SV}

Assim como já descrito o item 3.9.2. da Parte 1, a análise dos ST e SV decorreu seguindo a mesma metodologia previamente citada.

\subsubsection{Cromatografia gasosa}

O gás metano produzido nas DAs em batelada foi determinado usando cromatografia gasosa ou CG (PerkinElmer Clarus 590, PerkinElmer Inc., Waltham, MA, EUA) equipado com uma coluna empacotada $(60 \times 1,8$ DO, 80/100, Mesh, PerkinElmer Inc., Waltham, MA, EUA), e um detector de condutividade térmica (PerkinElmer Inc., Waltham, MA, EUA), com temperatura de injeção de $150{ }^{\circ} \mathrm{C}$. O gás de arraste foi o nitrogênio operado com uma taxa de fluxo de $20 \mathrm{~mL} / \mathrm{min}$ a $60^{\circ} \mathrm{C}$. As amostras de gás foram retiradas dos digestores e injetadas no GC usando uma seringa de gás de pressão de $250 \mu \mathrm{L}$ (VICI, Precision Sampling Inc., Baton Rouge, LA, EUA).

\subsubsection{Sistema Automático de Teste de Potencial de Metano}

A produção diária de metano em cada reator durante o processo contínuo foi monitorada continuamente com o instrumento $\mu$-flow on-line - Sistema de Teste de Potencial de Metano Automático, do inglês Automatic Methane Potential Test System, AMPTS® (Bioprocess control AB, Lund, Suécia) (Figura 25). O biogás gerado foi forçado a passar por um frasco separado preenchido com uma solução de $\mathrm{NaOH} 3 \mathrm{M}$ de forma a reter o $\mathrm{CO}_{2}$ e $\mathrm{H}_{2} \mathrm{~S}$ antes que o gás atingisse a unidade de detecção da produção. O instrumento $\mu$-flow on-line tem uma faixa de medição linear entre 20 e $4000 \mathrm{NmL} / \mathrm{h}$ e funciona por deslocamento de líquido e princípio de flutuabilidade, permitindo monitorar a produção de gás ultrabaixas. Inclui compensação de temperatura e pressão em tempo real para a normalização da produção de gás e volume para condições normais $\left(0^{\circ} \mathrm{C}\right.$ e $\left.1 \mathrm{~atm}\right)$. 
Figura 25. Ilustração esquemática do AMPTS II. (A) reator de garrafa de vidro de $2200 \mathrm{~mL}$, (B) frasco de vidro com $\mathrm{NaOH}$, (C) dispositivo de medição da produção de metano, (D) processamento de dados

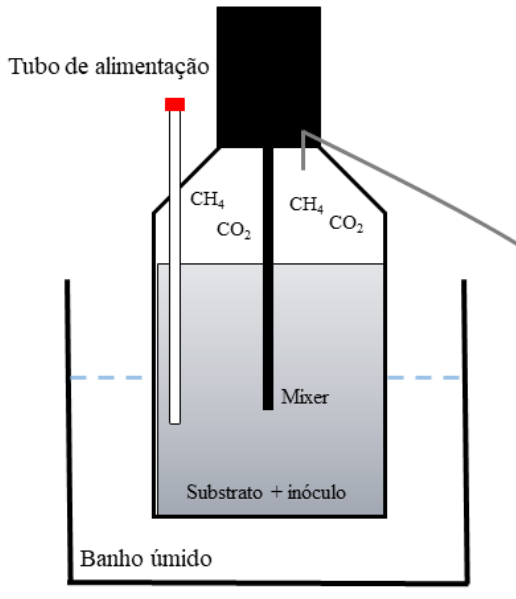

A

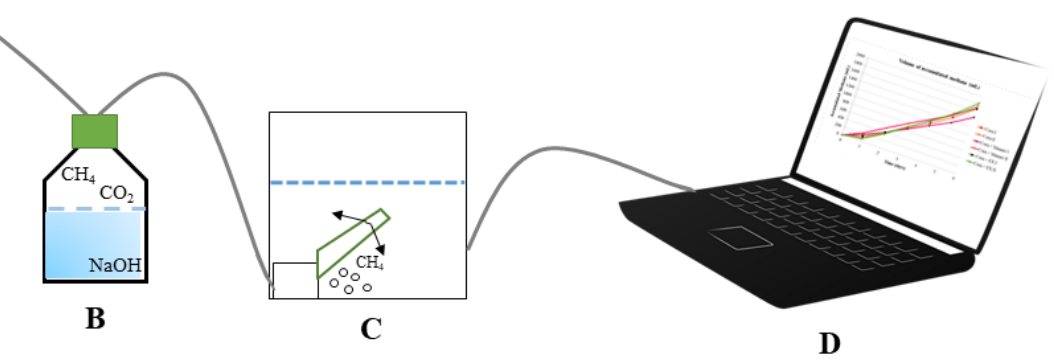

Fonte: elaborado pela autora.

\subsubsection{Alcalinidade}

A alcalinidade foi definida como carbonato inorgânico total e determinada pelo método de titulação Nordmann como descrito em HACH-COMPANY (2015). As amostras das digestões foram centrifugadas a $5000 \mathrm{~g}$ por $10 \mathrm{~min}$ e, em seguida, $5 \mathrm{~mL}$ do sobrenadante foram titulados com ácido sulfúrico 0,05 M até pH 5. A titulação foi então continuada até pH 4,4 a fim de determinar a concentração de ácidos graxos voláteis (AGV), os quais foram medidos como equivalente de ácido acético.

\subsection{Fermentação alcoólica}

A fermentação etanólica do farelo de milho e de seu hidrolisado (farelo enzimaticamente tratado por AMI) foi testada com uma carga de sólidos de $10 \%(\mathrm{~m} / \mathrm{v})$. O coquetel enzimático bruto AMI, com atividade de 3,4 unidades de amilase $(\mathrm{U}) / \mathrm{mL}$, foi aplicado na (i) hidrólise prévia do farelo de milho (pré-sacarificação) e também (ii) concomitante à fermentação etanólica (sacarificação e fermentação simultâneas).

Os experimentos de pré-sacarificação foram realizados em tubos Falcon estéreis de 45 $\mathrm{mL}$ contendo $10 \mathrm{~mL}$ de AMI e $1 \mathrm{~g}$ de farelo de milho. Os frascos foram incubados a $45^{\circ} \mathrm{C}$ por $48 \mathrm{~h}$ em banho termostatizado com agitação de 100 rpm.

Os testes de fermentação alcoólica por sua vez, decorreram em tubos Falcon estéreis de $45 \mathrm{~mL}$ contendo ( $i$ ) hidrolisado proveniente da pré-sacarificação do farelo de milho e (ii) farelo de milho + AMI (para sacarificação ao mesmo tempo da fermentação). Os frascos foram 
suplementados com $2 \mathrm{~g} / \mathrm{L}$ de levedura (Saccharomyces cerevisiae) (Leaf Technologies, França). As amostras tiveram o $\mathrm{pH}$ ajustado para 5,0 e foram incubadas a $35{ }^{\circ} \mathrm{C}$ por $48 \mathrm{~h}$ em banho termostatizado com agitação de $100 \mathrm{rpm}$. Ao final da fermentação, os fermentados foram centrifugados a $10000 \mathrm{~g}$ por $10 \mathrm{~min}$. Os sobrenadantes foram analisados quanto ao teor de glucose e etanol por Cromatografia Líquida de Alta Eficiência (CLAE) e quanto a produção de AR $(\mu \mathrm{mol} / \mathrm{mL})$ pela metodologia de Miller. Os controles foram feitos aplicando-se água destilada em vez de extrato enzimático. Todos os experimentos foram realizados com duas repetições.

\subsubsection{Rendimento teórico (Gay-Lussac)}

Através da equação de Gay-Lussac (SCHLENK, 1985) (Equação 23), foi calculado o rendimento teórico da fermentação etanólica a partir da quantidade de glucose presente nas amostras.

$1 \mathrm{C}_{6} \mathrm{H}_{12} \mathrm{O}_{6} \rightarrow 2 \mathrm{C}_{2} \mathrm{H}_{5} \mathrm{OH}+2 \mathrm{CO}_{2}$

Onde:

$180 \mathrm{~g}$ de glucose $\rightarrow 92 \mathrm{~g}$ de etanol

$100 \mathrm{~g}$ de glucose $\rightarrow \mathrm{X}$ g de etanol

$\mathrm{X}=51,11 \mathrm{~g}$ de etanol/ $100 \mathrm{~g}$ de glucose

O farelo de milho aplicado continha $73 \%$ de carboidrato, desta forma o rendimento etanólico teórico considerado foi de 37,31 g de etanol para cada $100 \mathrm{~g}$ de farelo (contendo $73 \mathrm{~g}$ de carboidratos).

\subsubsection{Cromatografia Líquida de Alta Eficiência}

CLAE foi usado para a análise de glucose e etanol obtidos durante a hidrólise e DA do farelo de milho. A glucose foi derivada da hidrólise enzimática dos carboidratos do farelo de milho com o extrato enzimático bruto AMI e o etanol derivado da fermentação por S. cerevisiae. O sistema de cromatografia (Waters 2695, Milford, MA, EUA) era composto por um detector de índice de refração (Waters 2414, Milford, MA, EUA), e a determinação de etanol e glucose foi realizada em coluna de troca iônica à base de íon hidrogênio (Aminex HPX-87H, Bio-Rad, Hercules, CA, EUA) a $60{ }^{\circ} \mathrm{C}$ com $0,6 \mathrm{~mL} / \mathrm{min}$ de $\mathrm{H}_{2} \mathrm{SO}_{4} 5 \mathrm{mM}$ como o eluente. 


\subsection{Análise Estatística}

Os dados experimentais foram analisados usando análise de modelo linear geral de variância (ANOVA) com a produção de metano como a variável de resposta. Os experimentos de DA em batelada foram projetados em triplicata e as digestões semi-contínuas em duplicata. As análises estatísticas foram realizadas no Statistica 13. ANOVA e teste de comparação múltipla de Tukey foram realizados para verificar a significância estatística nos conjuntos de dados em um intervalo de confiança de $95 \%$.

O software Origin 2019 foi usado para modelagem de Gompertz modificado. 


\section{Resultados \& Discussão-Parte 2}




\subsection{Produção do extrato enzimático}

O extrato bruto otimizado para produção de amilase (AMI), quando produzido na Suécia apresentou atividade amilolítica de 3,4 \pm 0,5 U/mL. A menor atividade amilolítica encontrada no extrato produzido durante o doutorado sanduíche, pode ser devido a mudança no farelo de milho utilizado como fonte de carbono (marcas diferentes, com porcentagens de carboidratos diferentes), ao mesmo tempo que trata-se de uma produção biológica, e o microorganismo produtor estava sob condições ambientais e laboratoriais diferentes.

\subsection{Otimização da hidrólise}

Estudos preliminares no Brasil mostraram que o $\mathrm{pH}$ 4,0-4,5 foi o melhor para hidrólise do farelo de milho por AMI, sendo o tampão acetato de sódio aquele utilizado nos experimentos. No entanto, uma vez que este trabalho analisa a produção de metano a partir de um substrato específico (farelo de milho e hidrolisado de farelo de milho), o uso de ácido acético foi evitado. Como o ácido acético é um dos substratos das bactérias acetogênicas e arqueas metanogênicas durante a DA, para garantir que todo o metano produzido neste trabalho fosse unicamente proveniente do substrato em estudo, optou-se pelo uso de água destilada como solução de diluição nos experimentos de hidrólise (sem ajuste de $\mathrm{pH}$ ).

\subsubsection{Proporção entre substrato e extrato enzimático}

O grau de hidrólise do amido natural do farelo de milho depende de fatores como a concentração e composição do substrato, a concentração da enzima e as condições do processo aplicado. Levando-se em consideração que o farelo de milho utilizado nos experimentos de hidrólise no Brasil e na Suécia foram de marcas diferentes, e com o objetivo de estudar melhor as proporções entre substrato e extrato enzimático para hidrólise, foram realizados novos experimentos variando-se inicialmente o volume de extrato bruto (e consequentemente a quantidade de unidades enzimáticas) para a hidrólise do farelo. $\mathrm{O}$ primeiro conjunto de experimentos foi conduzido com o objetivo de determinar a proporção de substrato e extrato enzimático para uma adequada hidrólise do farelo. O pré-tratamento foi testado em diferentes proporções de substrato e extrato enzimático, com uma carga de sólidos de 10\% (Tabela 18). 
Tabela 18. Proporção entre farelo de milho e extrato enzimático aplicada nos testes de hidrólise, com consequente liberação de AR no sistema

\begin{tabular}{ccc}
$\begin{array}{c}\text { Proporção substrato/AMI } \\
(\mathbf{m} / \mathbf{v})\end{array}$ & $\begin{array}{c}\text { Unidade de amilase bruta/ g } \\
\text { de substrato }\end{array}$ & $\begin{array}{c}\text { AR liberado no sistema } \\
(\boldsymbol{\mu ~ m o l} / \mathbf{1 1} \mathbf{m L})\end{array}$ \\
\hline $1: 10$ & 34,00 & 3217,57 \\
$1: 8$ & 27,20 & 3319,18 \\
$1: 6$ & 20,40 & 2592,51 \\
$1: 4$ & 13,60 & 1456,61 \\
$1: 2$ & 6,80 & 490,30 \\
$1: 1$ & 3,40 & 486,10 \\
$1: 0,5$ & 1,70 & 248,12 \\
$1: 0,25$ & 0,85 & 191,66 \\
Água destilada & 0 & 133,24 \\
\hline
\end{tabular}

Testes decorreram em tubos Falcon de $15 \mathrm{~mL}$, a $45^{\circ} \mathrm{C}$ sob agitação de $100 \mathrm{rpm}$ por 48 horas com uma carga de sólidos de $10 \%$.

Fonte: dados da autora.

A Figura 26, por sua vez, expressa os dados de AR obtidos ao final do teste de hidrólise em $\mathrm{g} / \mathrm{L}$.

Figura 26. AR (g/L) liberado seguindo as respectivas proporções entre farelo de milho $(\mathrm{g})$ e AMI $(\mathrm{mL})$

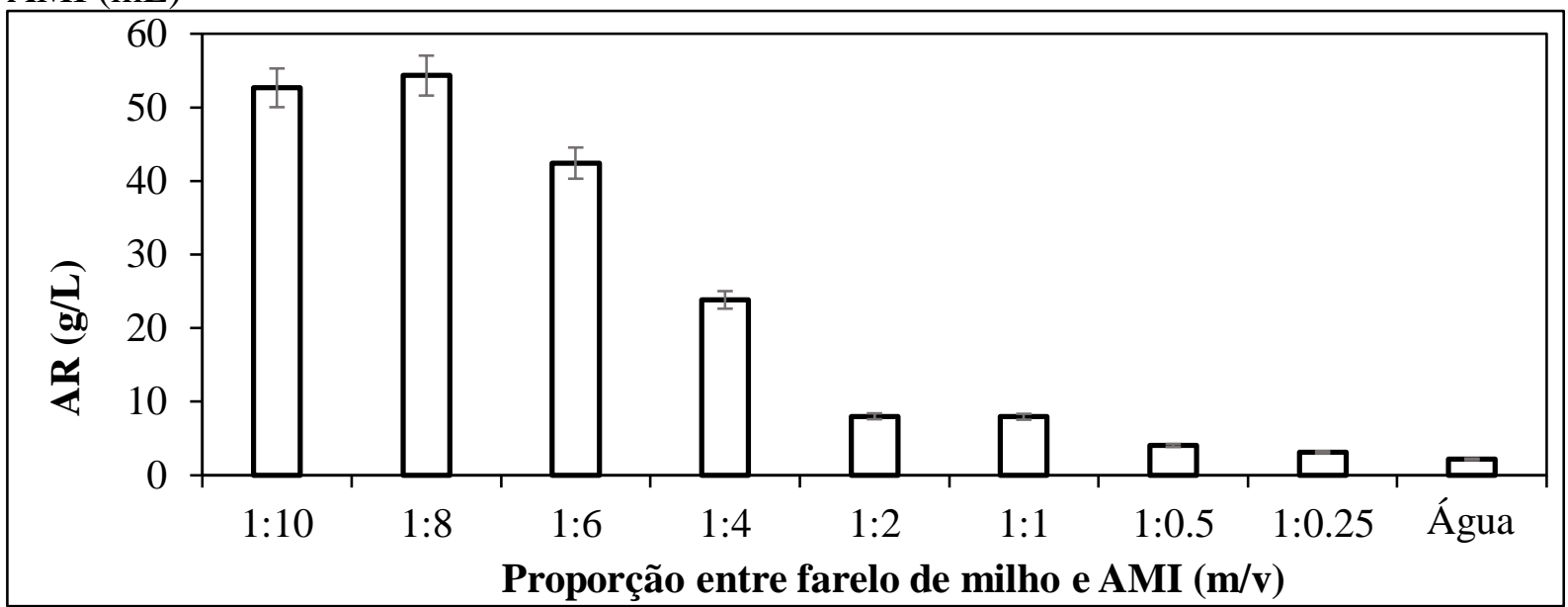

A carga de sólidos utilizada foi de $10 \%$.

Fonte: dados da autora.

As proporções 1:10 e 1:8 (p/v de substrato e extrato enzimático) apresentaram a maior quantidade de RS liberado no sistema. Considerando o desvio padrão de 5\%, não há diferença significativa entre esses experimentos. A proporção 1:10 (m/v), correspondente a uma aplicação amilolítica de $34 \mathrm{U}$ por grama de farelo de milho, resultou na formação de 52,65 g/L de AR, o que corresponde a uma hidrólise de $79 \pm 5 \%$ dos carboidratos do substrato, os quais representam $73 \%$ da composição desta biomassa (composta em g/100g: gordura 1,20; carboidrato 73; fibra 
4,10 e proteína 8). Por outro lado, a proporção 1:8, contendo 27,2 U de amilase por grama de farelo, liberou 54,31 g de AR/L (correspondendo a uma porcentagem de hidrólise dos carboidratos de $81 \pm 5 \%$ ). No entanto, considerando o desvio padrão de $5 \%$, não há diferença significativa entre estes resultados.

AMI é um extrato bruto que além da atividade amilolítica também possui atividades de xilanase $(1,00 \pm 0,18 \mathrm{U} / \mathrm{mL})$, pectinase $(0,89 \pm 0,05 \mathrm{U} / \mathrm{mL})$, CMCase $(0,68 \mathrm{U} / \mathrm{mL} \pm 0,14)$, arabinanase $(0,80 \pm 0,29 \mathrm{U} / \mathrm{mL})$ e $\beta$-glucosidase $(0,02 \pm 0,003 \mathrm{U} / \mathrm{mL})$ (Tabela 4). Um maior número de enzimas no sistema possibilita maior produção de açúcares simples. A hidrólise do amido de milho consiste na conversão de amilose e amilopectina em glucose, e os resultados obtidos neste trabalho são comparáveis ao de outros pesquisadores. ARASARATNAM e BALASUBRAMANIAM (1993) relataram uma hidrólise de $76 \%$ do amido de milho por meio de uma combinação de $\alpha$-amilase e glucoamilase. Rendimento semelhante, inferior a $80 \%$, também foi obtido quando os grânulos de amido foram hidrolisados por glucoamilase (KIMURA; ROBYT, 1995).

Os ensaios seguintes de hidrólise foram realizados aplicando-se as condições operacionais obtidas com uma carga sólida de 10\% na proporção de 1:10 e 1:8 (g de farelo de milho/mL de AMI).

\subsubsection{Tempo de hidrólise}

Como as proporções 1:10 e 1:8 (m/v) entre farelo de milho e AMI foram as selecionadas para maximização da hidrólise numa carga de sólido de 10\%, ambas proporções foram testadas nos experimentos de seleção do tempo de hidrólise. Alíquotas foram retiradas das amostras experimentais a cada 24 horas durante 6 dias. Os valores de AR ( $\mu \mathrm{mol} / \mathrm{mL})$ liberados no sistema estão apresentados na Figura 27. 
Figura 27. AR total $(\mu \mathrm{mol} / 11 \mathrm{~mL})$ liberado no sistema a cada 24 horas durante a hidrólise do farelo de milho (na carga de sólidos de 10\%) de acordo com as proporções: $\square$ 1:10 e $\square$ 1: 8 (g de farelo: $\mathrm{mL}$ de AMI)

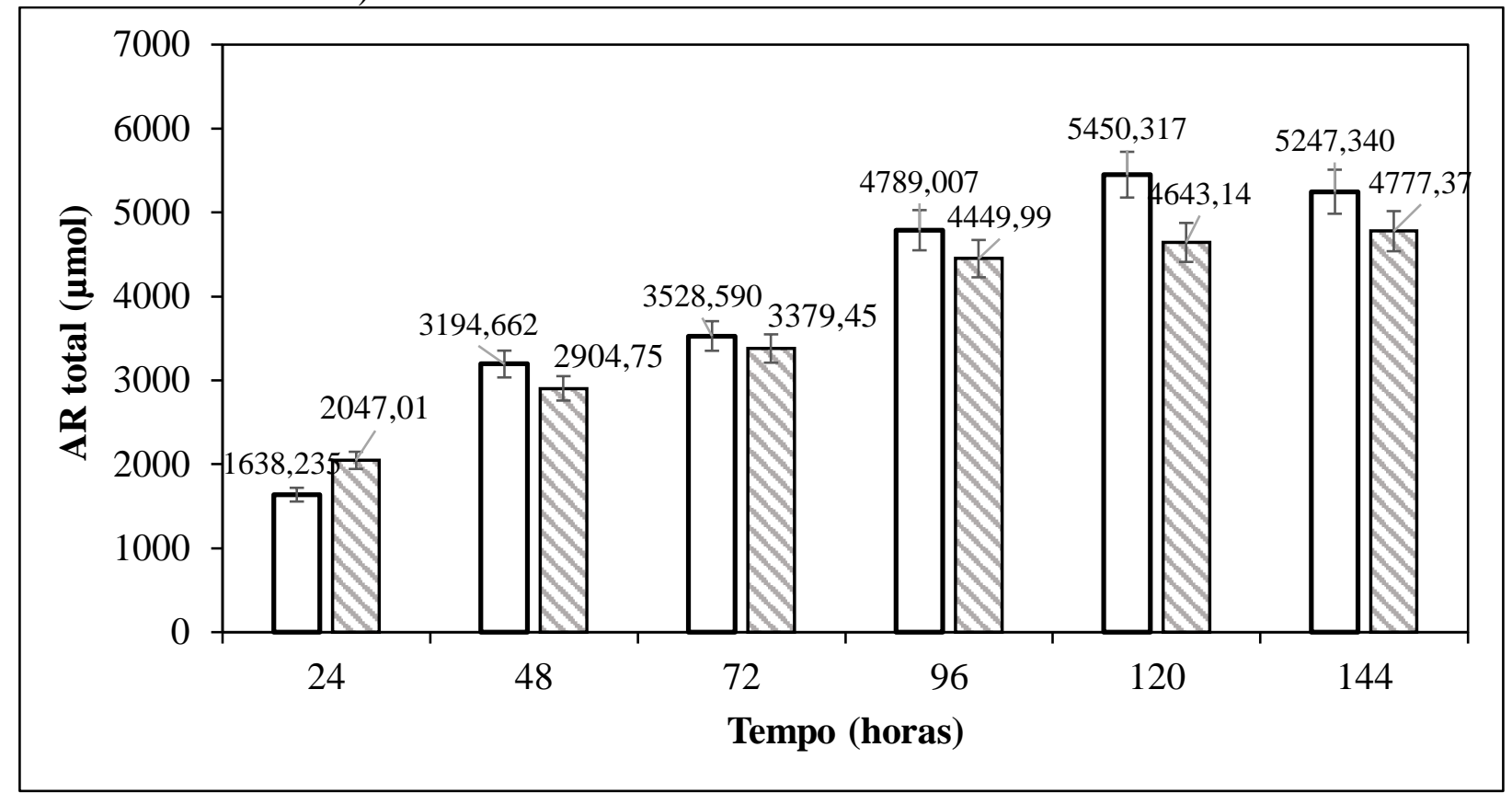

Hidrólises ocorreram em banho termostatizado a $45^{\circ} \mathrm{C}$, sob agitação de $100 \mathrm{rpm}$.

Fonte: dados da autora.

O farelo de milho aplicado era composto por $73 \mathrm{~g}$ de carboidratos/100 g, desta forma, nos experimentos em que foi aplicado $1 \mathrm{~g}$ de farelo a cada tubo Falcon, 0,73g correspondiam a carboidratos. Segundo CORTEZ e WILD-ALTAMIRANO (1972), o principal componente químico do grão de milho é o amido, que fornece de 72 a $73 \%$ do peso do grão, outros açucares simples também estão presentes como glucose, sacarose e frutose, mas em quantidades que variam de 1 a $3 \%$ do peso do grão. Desta forma, considerando o amido o principal carboidrato de serva do milho, a quebra de $0,73 \mathrm{~g}$ de carboidratos representa a liberação de 4055,5 $\mu$ mol de AR no sistema. Como pode ser visto nos dados da Figura 27, com 96 horas de tratamento em ambas as proporções mais de $4500 \mu \mathrm{mol}$ de AR já estavam disponíveis no sistema, indicando ótimos resultados de hidrólise ( $100 \%$ do amido disposto no farelo de milho foi hidrolisado).

No entanto, dois dos principais objetivos do processo hidrolítico são: grau de hidrólise alvo e alta eficiência de custo. Para se obter um processo hidrolítico produtivo competitivo, é importante que a condição escolhida tenha uma alta atividade hidrolítica e uma alta relação atividade/custo. Desta forma, os tempos de 48 e 96 horas foram selecionados para hidrólise do farelo de milho por AMI, uma vez que foi atingido um alto percentual de hidrólise. Se considerado 4055,5 $\mu \mathrm{mol}$ de AR como resultante da hidrólise total de carboidratos presente no farelo de milho, nos tempos de 48 e 96 horas, respectivamente, foi atingida uma hidrólise de 83 e $100 \%$ destes componentes. 


\subsection{Caracterização dos substratos e inóculos utilizados na DA}

O lodo termofílilco fornecido pela Borås Energy and Environment AB, Borås, Suécia foi previamente caracterizado pelo fornecedor e apresentava $\mathrm{pH}$ de 8,4, $1500 \mathrm{mg} / \mathrm{L}$ de ácidos graxos voláteis, $2700 \mathrm{mg} / \mathrm{L}$ de $\mathrm{NH}_{4}, 7800 \mathrm{mg} / \mathrm{L}$ de alcalinidade do bicarbonato e $9500 \mathrm{mg} / \mathrm{L}$ alcalinidade total.

Análises de ST e SV foram realizados com o objetivo de caracterizar os substratos e os inóculos testados nos experimentos de DA. O conteúdo de ST e SV do farelo de milho e do hidrolisado de farelo de milho, assim como do dejeto bovino e lodo termofílico estão descritos na Tabela 19. Farelo de milho não tratado e o hidrolisado de farelo de milho, apresentaram uma taxa de SV $100 \%$ do conteúdo de ST. A porcentagem de SV do dejeto bovino foi de $77 \%$ do ST, enquanto o lodo termofílico apresentou um conteúdo de SV de $65 \%$ entre o conteúdo de ST. Um alto teor de SV no substrato significa grande biodisponibilidade de matéria orgânica (WANG et al., 2020).

Tabela 19. Conteúdo de ST e SV dos substratos e inóculo utilizados na DA em batelada e semicontínua

\begin{tabular}{cccc}
\hline Material & ST $(\mathbf{g} / \mathbf{K g})$ & $\mathbf{S V}(\mathbf{g} / \mathbf{K g})$ & $\mathbf{S V}(\boldsymbol{\%})$ entre ST \\
\hline Farelo de milho não tratado & $862,76 \pm 4,00$ & $861,69 \pm 4,00$ & 99,88 \\
Hidrolisado de farelo de milho & $889,8 \pm 3,50$ & $889,8 \pm 3,50$ & 100 \\
Dejeto bovino & $67,35 \pm 2,00$ & $51,51 \pm 2,00$ & 77 \\
Lodo termofílico & $37,85 \pm 2,00$ & $24,9 \pm 2,00$ & 65 \\
\hline
\end{tabular}

Fonte: dados da autora.

Adicionalmente, o lodo termofílico utilizado apresentava $\mathrm{pH} 8,4$, ácidos graxos voláteis: $1500 \mathrm{mg} / \mathrm{L}, \mathrm{NH}_{4}: 2700 \mathrm{mg} / \mathrm{L}$, alcalinidade do bicarbonato: $7800 \mathrm{mg} / \mathrm{L}$ e alcalinidade total: 9 $500 \mathrm{mg} / \mathrm{L}$.

\subsection{DA em batelada}

\subsubsection{Seleção de inóculo}

O efeito do pré-tratamento enzimático do farelo de milho foi testado para a produção de metano e comparado aquela gerada pela biomassa não tratada. Inicialmente foram verificados dois potenciais inóculos para a DA, o dejeto bovino e o lodo termofílico proveniente de uma planta de biogás em escala real.

Ambas as amostras, farelo de milho não tratado e hidrolisado de milho, foram submetidas à DA em batelada. Na proporção de 1:2 S/I na base de SV, foram realizados experimentos em frascos de vidro de $118 \mathrm{~mL}$ sob condições termofílicas $\left(55 \pm 2{ }^{\circ} \mathrm{C}\right)$ quando o lodo foi aplicado como inóculo e condições mesofílicas $\left(37 \pm 2{ }^{\circ} \mathrm{C}\right)$ quando o dejeto foi utilizado 
como fonte inicial da microbiota.

A Figura 28 descreve a produção acumulada de metano $(\mathrm{NmL})$ por grama de $\mathrm{SV}$ presente em cada sistema quando o lodo termofílico foi utilizado como inoculante.

Figura 28. Produção acumulativa de metano utilizando o lodo termofílico como inóculo na proporção S/I de 0,5

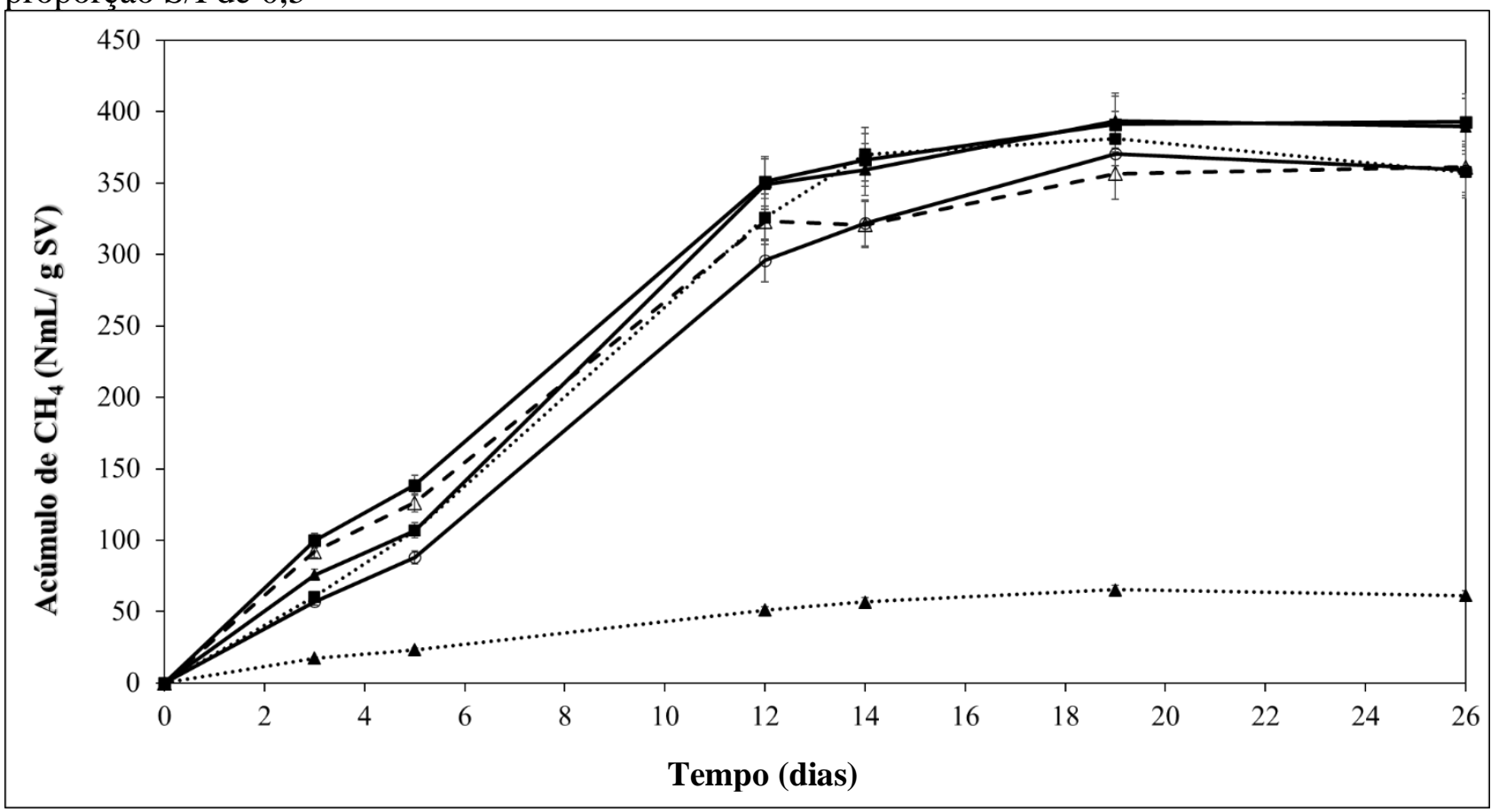

Os substratos foram: $\cdots \cdot \boldsymbol{*}$ AMI, $\cdots \cdot$ farelo de milho, $\rightarrow$ hidrolisado de farelo de milho (48 horas), $\triangle \checkmark$ hidrolisado de farelo de milho (96 horas), $\neg$ farelo de milho + AMI e $\_$celulose (controle). O metano produzido apenas pelo inóculo (branco) foi subtraído de cada ensaio.

Fonte: dados da autora.

O curso de tempo para a produção de metano nos testes em batelada (Figura 28) descreve o comportamento microbiano durante a degradação do substrato, onde podem ser observados os períodos de adaptação, crescimento e fase estacionária. No terceiro e quinto dia de DA, o hidrolisado de milho tratado por 48 horas apresentou um acúmulo de metano de 100 \pm 2 e $138 \pm 2 \mathrm{NmL} / \mathrm{g} \mathrm{SV}$, respectivamente. Esta produção foi $43 \%$ e $23 \%$ maior do que aquela ocasionada pelo farelo de milho não tratado no mesmo período. Quando o platô de acúmulo foi atingido com 12 dias de incubação, o metano acumulado foi de $360 \mathrm{NmL} / \mathrm{g} \mathrm{SV}$ quando utilizado o hidrolisado de milho tratado por 48 horas, enquanto que com o substrato não tratado houve o acúmulo de $323 \mathrm{NmL} / \mathrm{g} \mathrm{SV}$. A produção de metano a partir dos substratos testados apresentou efeitos positivos, uma vez que os valores de produção acumulada de gás foram próximos daqueles gerados pelo controle positivo (296 NmL/g SV). 
O segundo inóculo testado para produção de metano durante a DA foi o dejeto bovino. A Figura 29 traz os dados de acúmulo de $\mathrm{CH}_{4}(\mathrm{NmL} / \mathrm{g} \mathrm{SV})$ após a primeira e segunda alimentação dos reatores com os respectivos substratos.

Figura 29. Produção acumulativa de metano (NmL/g SV) utilizando o dejeto bovino como inóculo na proporção $\mathrm{S} / \mathrm{I}$ de 0,5 , após a primeira e a segunda alimentação

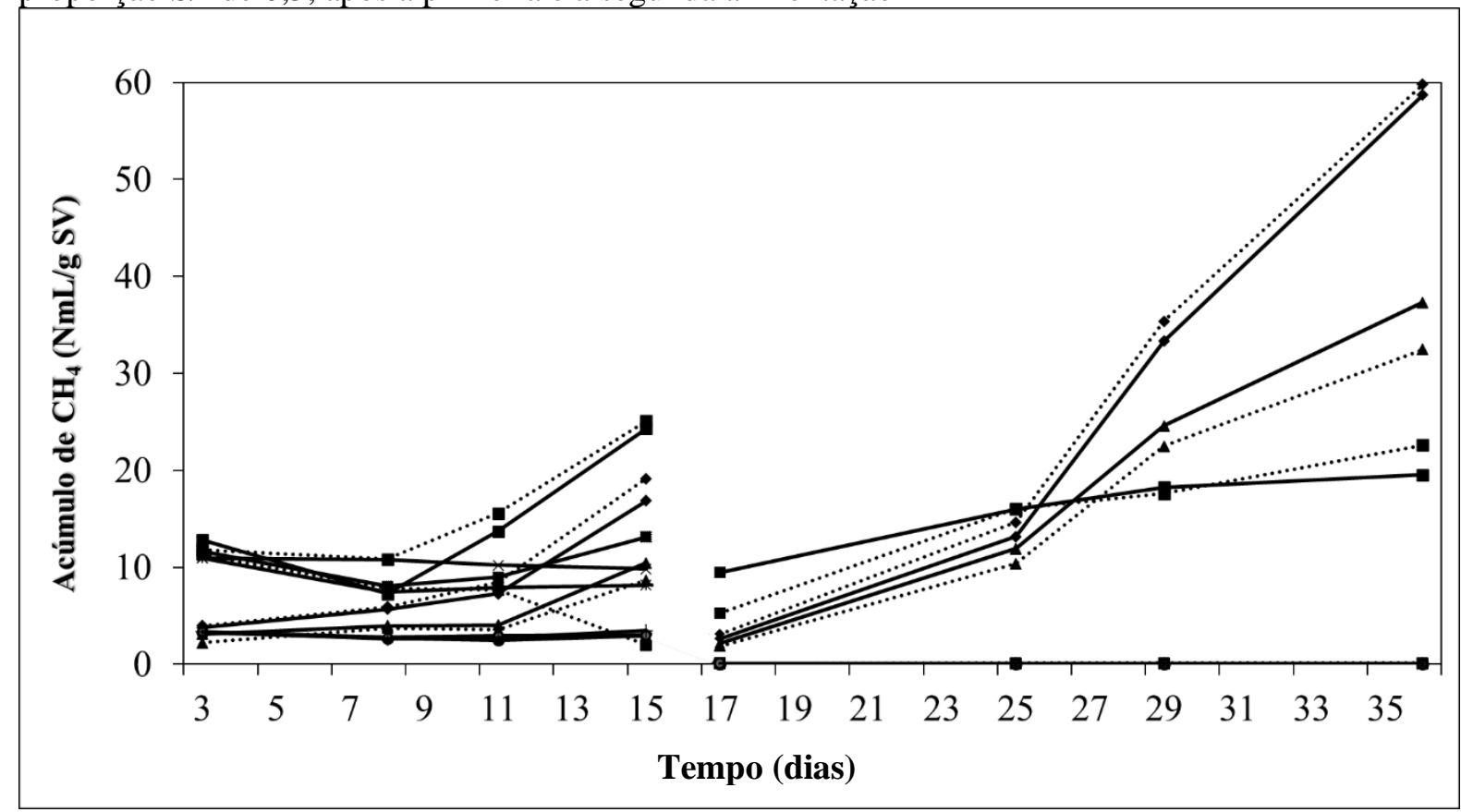

As linhas indicam duplicatas dos substratos: $\rightarrow-, \cdot . \bullet \cdot . \cdot$ celulose; $\rightarrow,, \cdots \bullet \cdot \cdot$ extrato enzimático AMI; $-\times-$ ,$\cdots \times \cdot \cdot$ farelo de milho; $\rightarrow, \cdots \odot \cdot$ hidrolisado de farelo de milho $(48 \mathrm{~h}) ;+, \rightarrow$ hidrolisado de farelo de milho $(96 \mathrm{~h}$ ), e $*$, $\rightarrow$ farelo de milho + AMI.

$\mathrm{O}$ metano produzido apenas pelo inóculo (branco $\rightarrow$ e $\cdots \cdot \cdot \cdot$ ) não foi subtraído de cada ensaio. Fonte: dados da autora.

Os reatores foram alimentados com uma relação $\mathrm{S} / \mathrm{I}$ de 0,5 , e como pode ser visto na Figura 29 quando o farelo de milho ou hidrolisado de farelo de milho (48 ou 96 h) estavam presentem no reator, o sistema não revelou um volume acumulativo significativo de metano, sendo que no $11^{\circ}$ dia de DA os valores acumulativos foram para farelo de milho 8,3 \pm 0,5; hidrolisados 2,4 $\pm 0,4 \mathrm{NmL} / \mathrm{g} \mathrm{SV}$. Apenas os reatores contendo celulose, água, extrato enzimático AMI ou para farelo de milho + AMI que mostram um acúmulo de gás um pouco mais relevante, os quais foram respectivamente de $14,63 \pm 0,5 ; 3,7 \pm 0,5 ; 7,83 \pm 0,5$ e $9,07 \pm$ 0,5 NmL/g SV. Após 15 dias de DA, o sistema foi alimentado pela segunda vez com cada respectivo substrato na relação $\mathrm{S} / \mathrm{I}$ de 0,5 . Mesmo após a segunda alimentação, não houve aumento no volume significativo de metano produzido quando farelo de milho (pré-hidrolisado ou não) estava presente no sistema, apenas os reatores contendo água, AMI e celulose apresentaram um aumento no acúmulo de $\mathrm{CH}_{4}$, com valores que chegaram a 34,8 $\pm 0,5 ; 59,2 \pm$ 
0,5 e $21,0 \pm 0,5 \mathrm{NmL} / \mathrm{g} \mathrm{SV}$ no $35^{\circ}$ dia de DA.

Ao final do teste de digestão, o pH nos reatores contendo farelo de milho e hidrolisados de milho (por 48 e 96 horas) estava na faixa de 4,5 \pm 0,5 (no $35^{\circ}$ dia de DA), o que significa que os sistemas não funcionaram adequadamente. A baixa produção de metano nestes ensaios pode ser devido à alta $\mathrm{CO}$ que sobrecarregou o sistema inoculado com micro-organismos provenientes do dejeto. A alta $\mathrm{CO}$ é um dos fatores apontados por alguns autores que pode favorecer determinados grupos de bactérias, que por sua vez resultam na exacerbada produção de, por exemplo, ácidos graxos voláteis, ocasionando o decaimento do $\mathrm{pH}$ no sistema e consequente inibição do metabolismo dos micro-organismos sensíveis a pHs mais baixos (archaea metanogênicas) (DEMIRER; CHEN, 2005; ROBLES et al., 2018).

Levando-se em consideração a quantidade de metano acumulado (NmL/g SV) quando foi aplicado, ora o lodo termofílico ora o dejeto bovino como inoculantes, concluiu-se que o acúmulo de $\mathrm{CH}_{4}$ quando o dejeto é empregado como inóculo é muito menor que a digestão com lodo termofílico. O inóculo proveniente de uma planta de biogás em escala real tende a estar mais equilibrado com relação aos grupos microbianos, a quantidade de micro-organismos pode ser maior devido a estabilidade do sistema, assim como a rede dos organismos que trabalham em anaerobiose tende a estar melhor estabelecida para servir como iniciadora de uma nova planta de biodigestão. A diversidade microbiana do inóculo é um forte influenciador na taxa de degradação do substrato, tolerância ao estresse e rendimento específico dos gases (DE VRIEZE et al., 2015; HAN et al., 2016; SATPATHY et al., 2016). Um inóculo com alta diversidade de micro-organismos pode ser favorável para DA uma vez que espécies sensíveis podem ser substituídas por outras com funções semelhantes (ROSENFELD, 2002).

À essa discussão decorrente da seleção de inóculo, pode-se mencionar os resultados da produção anaeróbia realizada no Laboratório de Biotecnologia Ambiental e Energias Renováveis- FFCLRP/USP, Brasil (Parte 1). Os valores de metano acumulado utilizando dejeto bovino foram similares aos testes realizados no Brasil e na Suécia. Portanto, esta diferença não pode ser atribuída a diferentes metodologias, mas especialmente a aclimatação dos microorganismos às condições de metanogênese.

Muitos autores vêm descrevendo resultados distintos com relação ao tipo de inoculante utilizado. LIU et al. (2017) observaram diferenças na produção de metano ao comparar o uso de três inoculantes (lodo municipal, vinhaça e esterco), assim como GU et al. (2014) que relataram diferentes produções de biogás na digestão da palha de arroz utilizando os inóculos, esterco de gado leiteiro, lodo municipal, lodo granular anaeróbio, esterco de suínos e esterco de aves. DE VRIEZE et al. (2015) observaram que a abundância da comunidade metanogênica no 
início de um processo de biogás resultou em diferentes potenciais de biometano. Adicionalmente, LI, YEQING et al. (2020) relataram que o método de aclimatação contínua do inóculo pode melhorar a estabilidade do sistema e desta forma incrementar a produção de metano devido ao domínio das espécies Methanobacterium e Methanosarcina e extinção de outras espécies.

Desta forma, tendo em consideração os valores de produção acumulada de metano, o lodo termofílico mostrou-se promissor para iniciar uma DA, e foi selecionado para a continuação dos próximos testes de DA.

\subsubsection{Seleção de substrato e CoDA em batelada}

A produção de metano a partir do farelo de milho foi avaliada em batelada com ou sem o pré-tratamento enzimático e também em CoDA com o dejeto bovino. Uma vez que o dejeto não se mostrou promissor como inóculo para DA nos testes realizados, este foi testado como um co-substrato do farelo de milho na DA. Desta forma, utilizando como inóculo o lodo termofílico proveniente de uma planta de biogás em escala real, experimentos foram realizados em reatores descontínuos de $118 \mathrm{~mL}$ durante 26 dias sob condições termofílicas $\left(55 \pm 2{ }^{\circ} \mathrm{C}\right)$. A

Figura 30 mostra o acúmulo de metano por grama de SV adicionado ao sistema. 
Figura 30. Produção acumulativa de metano (NmL/g SV) nos testes de CoDA sob a proporção S/I de 0,5 utilizando como inóculo o lodo termofílico

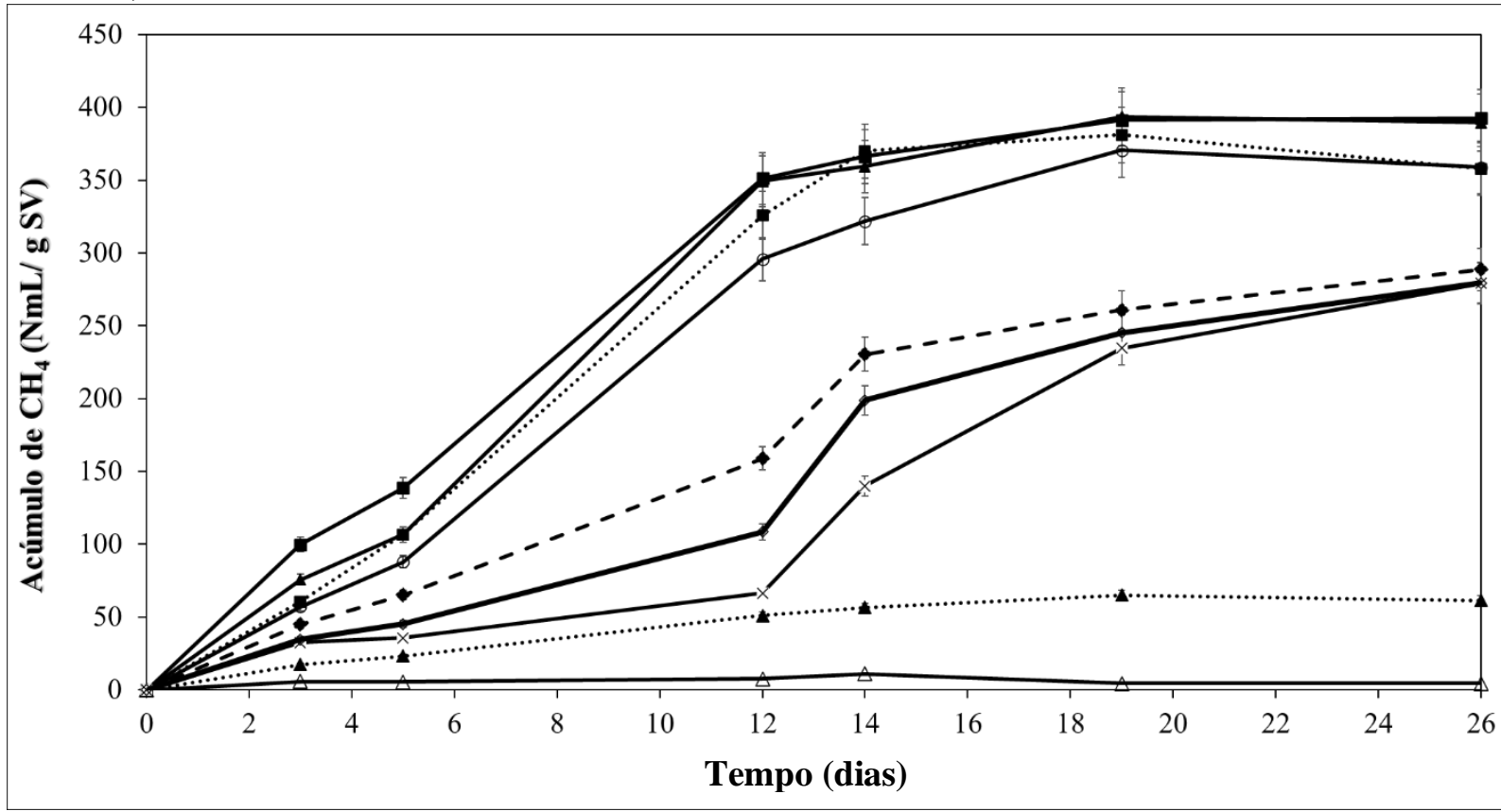

Os substratos foram: $\cdots \cdot \cdot$ AMI, $\cdots \cdot \cdot$ farelo de milho, $\rightarrow \boldsymbol{-}$ hidrolisado de farelo de milho por 48 horas, $\triangle$ farelo de milho + AMI, $\triangle$ dejeto bovino, $\rightarrow-$ farelo de milho + dejeto bovino,,$-\times-$ hidrolisado de milho por 48 horas + dejeto bovino, $\sim$ farelo de milho + AMI + dejeto bovino, 2 celulose (controle).

O metano produzido apenas pelo inóculo (branco) foi subtraído de cada ensaio.

Fonte: dados da autora.

Observa-se que no terceiro e quinto dia de digestão, o hidrolisado de farelo de milho apresentou respectivamente um acúmulo de metano de $100 \pm 5$ e $138 \pm 6,5 \mathrm{NmL} / \mathrm{g}$ VS. Valores estes que correspondem a produções $43 \%$ e $23 \%$ maiores do que o farelo não tratado nos mesmos períodos.

Quando o platô de produção de metano foi atingido com 12 dias de incubação, o acúmulo deste gás em questão a partir do uso dos diferentes substratos apresentou efeitos positivos, uma vez que estes valores foram próximos ao produzido pelo controle positivo (296 $\pm 15 \mathrm{NmL} / \mathrm{g} \mathrm{SV}$ ). Ainda no mesmo período observado, a produção de metano em batelada a partir das amostras de hidrolisado de milho foi $11 \%$ maior do que aquela observada pelo farelo não tratado (323 $\pm 15 \mathrm{NmL} \mathrm{CH}_{4} / \mathrm{g} \mathrm{SV}$ ). Adicionalmente, o acúmulo de metano a partir do farelo de milho no $26^{\circ}$ dia da DA foi de $358 \mathrm{NmL} \mathrm{CH}_{4} / \mathrm{g} \mathrm{SV}$, o que está de acordo com outros autores. KOLBL et al. (2014) relataram a produção de $\mathrm{CH}_{4}$ na ordem de $319 \pm 33,9 \mathrm{NmL} \mathrm{CH}_{4} / \mathrm{g} \mathrm{SV}$ quando aplicado farelo de milho como substrato em ensaios em batelada.

Quanto a digestão do dejeto bovino, o uso do dejeto como única fonte de substrato resultou no menor acúmulo de metano durante o período de digestão estudado. $\mathrm{O}$ rendimento de metano não foi superior a $11 \pm 0,5 \mathrm{NmL} / \mathrm{g}$ VS quando o dejeto foi aplicado como mono- 
substrato. No entanto, comparando os dados observados e calculados de acúmulo de $\mathrm{CH}_{4}$ a partir de cada substrato individualmente (farelo de milho, hidrolisado de farelo de milho, AMI, dejeto bovino) pôde-se observar efeitos sinérgicos ao se misturar esses substratos para codigestão. O metano acumulado a partir da farinha de milho foi de $390 \mathrm{NmL} / \mathrm{g} \mathrm{SV}$, enquanto para o dejeto bovino o acúmulo de $\mathrm{CH}_{4}$ chegou a aproximadamente $65 \mathrm{NmL} / \mathrm{g} \mathrm{SV}$ após 26 dias de digestão nos ensaios em batelada. Levando - se em conta uma proporção de mistura de 1:1 com base em VS na CoDA, isso resultaria em um valor calculado de acúmulo de metano de 200,5 NmL / g SV, que pode ser comparado ao valor experimental de $280 \mathrm{~mL}$ / g SV (Figura 30). Ou seja, o acúmulo de metano experimental chegou a ser $30 \%$ maior do que o valor calculado com base na soma do acúmulo de metano observados para os substratos individuais, o que leva a inferência de efeitos sinérgicos a partir das misturas na CoDA.

A co-digestão compreende a mistura de dois ou mais substratos em uma proporção adequada para se obter características complementares para a digestão. A CoDA pode ter vantagens distintas, incluindo diluição de resíduos inibitórios, suplementação, diversificação e balanceamento de nutrientes, sinergismo positivo, aumento da produção de biogás e melhoria da economia do sistema (ARNELL et al., 2016; BORA et al., 2014; JUTURU; WU, 2013; KIM; HAN; SHIN, 2004; PAVAN et al., 2007; STROOT et al., 2001; ZAHER et al., 2009). SONG e ZHANG (2015) mostraram que o rendimento de metano foi maior com a co-digestão da palha de trigo e dejeto bovino do que houve a mono-digestão de cada substrato. Adicionalmente, outras pesquisas também mostram que melhoraram o desempenho da DA por meio do uso concomitante de diferentes resíduos orgânicos. TASNIM; IQBAL e CHOWDHURY (2017) relataram a co-digestão de dejeto bovino e resíduos de cozinha, KHAYUM; ANBARASU e MURUGAN (2018) descreveram a DA de dejeto bovino e resíduos de chá, ABOUDI; ÁLVAREZ-GALLEGO e ROMERO-GARCÍA (2016) pesquisaram a DA a partir do dejeto bovino com subproduto de beterraba, HASSAN et al. (2017) por sua vez, descreveram o co-digestão de dejeto de ganso com palha de trigo, LI et al. (2016) testaram a CoDA do dejeto bovino com palha de milho e resíduos de tomate, LI, K. et al. (2018) descreveram a co-digestão de dejeto de aves e suínos com polpa de maçã e palha de milho, AKYOL et al. (2016) o dejeto bovino com cevada e LI, W. et al. (2018) descreveram a digestão concomitante de dejeto de ovelha com resíduos de papel.

O maior acúmulo de metano foi obtido nos ensaios em batelada com hidrolisado de farelo de milho e farelo de milho adicionado de AMI no $26^{\circ}$ dia de digestão. Ambos substratos ocasionaram o acúmulo de $390 \pm 10 \mathrm{NmL} \mathrm{CH}_{4} / \mathrm{g} \mathrm{SV}$, o que corresponde a uma produção $8 \%$ e $28 \%$ maior do que aquela encontrada com os substratos puros e co-digeridos, respectivamente, 
no mesmo período. O extrato bruto AMI é rico em amilases $(3,4 \mathrm{U} / \mathrm{mL})$, portanto, contém enzimas que catalisam a hidrólise de ligações $\alpha$-D-(1-4)-glicosídicas internas no amido e também glucoamilases que catalisam a hidrólise de $\alpha$-D-(1-4) e ligações $\alpha$-D-(1-6)glicosídicas do amido das extremidades não redutoras (KOLBL et al., 2014). O uso de hidrolisado de farelo de milho ou mesmo o farelo adicionado de AMI como substrato da digestão em batelada permitiu uma maior formação de açúcares fermentáveis, o que favoreceu a produção de gás durante a DA.

Testes em batelada aplicando-se enzimas diretamente nos digestores foram descritos por vários autores a partir de diferentes culturas energéticas como substratos, no entanto os resultados mostram diferentes efeitos no aumento da produção de biogás. KAISER (2004), por exemplo, relatou melhorias significativas na produção de biogás usando silagem de milho e enzimas. No entanto, nenhum aumento na produção de biogás foi observado por OLIVAMERENCIO et al. (2015), o qual adicionou enzimas diretamente na DA da silagem de milho. Portanto, a real conveniência no uso de enzimas deve ser investigada caso a caso.

Os ensaios em batelada são comumente usados para identificar substratos adequados para uma digestão (CALLAGHAN et al., 2002; MURTO; BJÖRNSSON; MATTIASSON, 2004; PATINVOH et al., 2020). Consequentemente, os indicadores de estabilidade para digestores anaeróbios devem ser melhor avaliados por meio de experimentação contínua e a longo prazo (COOK et al., 2017; FERRER; VÁZQUEZ; FONT, 2010). Produção de metano, pH e a razão AGV/AT são alguns dos indicadores de estabilidade que especificam o poder metabólico do digestor (COOK et al., 2017; LUKITAWESA et al., 2020; SCHOEN et al., 2009). Esses parâmetros foram então estudados nos seguintes experimentos de DA semicontínua.

\subsubsection{Análise estatística e cinética dos testes em batelada}

A análise estatística do acúmulo de $\mathrm{CH}_{4}$ quando a platô de produção foi atingido a partir do $12^{\circ}$ dia de DA mostrou que houve uma diferença entre os substratos aplicados na digestão em batelada (p-valor $(\leq 0,000)<\alpha(0,05) ; \mathrm{F}(865,47)>\mathrm{f}(31,64)$ ). Os resultados dos testes simultâneos de Tukey indicaram que o acúmulo de $\mathrm{CH}_{4}$ a partir do $12^{\circ}$ dia de digestão com o farelo de milho, hidrolisado de farelo de milho e farelo de milho adicionado de AMI foram estatisticamente diferentes dos acúmulos de gás envolvendo a CoDA com dejeto bovino ( $p$ valor $<0,02 ;<0,007 \mathrm{e}<0,001$, respectivamente). No entanto, não há diferença estatística no acúmulo de metano a partir do platô atingido no dia 12 das digestões quando envolvida a monodigestão do farelo de milho (farelo hidrolisado, farelo de milho e farelo adicionado de AMI). 
A modelagem de Gompertz modificado, capaz de prever alguns parâmetros cinéticos, foi utilizado para prever o acúmulo máximo de metano, a velocidade máxima de produção e a fase de latência nos processos empregados. A Tabela 20 traz os dados correspondentes a parâmetros cinéticos preditos pelo modelo de Gompertz modificado aplicado aos dados obtidos da DA em batelada com os diversos substratos testados.

Tabela 20. Variáveis cinéticas obtidas pelo modelo de Gompertz modificado para o acúmulo de metano a partir dos substratos testados na mono e co-digestão

\begin{tabular}{ccccc}
\hline Substrato & $\begin{array}{c}\mathbf{H}_{\mathbf{m a x}}{ }^{\mathbf{a}} \\
(\mathbf{N m L /} \mathbf{g} \mathbf{~ S V})\end{array}$ & $\begin{array}{c}\mathbf{R}_{\mathbf{m}}{ }^{\mathbf{b}} \\
(\mathbf{N m L} \mathbf{g} \mathbf{S V} / \mathbf{d i a})\end{array}$ & $\boldsymbol{\lambda}^{\mathbf{c}}(\mathbf{d i a})$ & $\mathbf{R}^{\mathbf{2}}$ \\
\hline AMI & 64,19 & 5,37 & 4,82 & 0,98 \\
Farelo de milho & 377,64 & 43,16 & 5,44 & 0,98 \\
Hidrolisado de farelo de milho (48h) & 399,10 & 38,94 & 4,78 & 0,99 \\
Farelo de milho + AMI & 399,34 & 40,39 & 5,51 & 0,99 \\
Celulose & 373,03 & 33,88 & 6,14 & 0,99 \\
Dejeto bovino & 6,76 & 2,27 & 1,36 & 0,93 \\
Farelo de milho + dejeto & 310,23 & 17,75 & 7,95 & 0,97 \\
Hidrolisado de farelo de milho + dejeto & 383,66 & 15,55 & 14,47 & 0,94 \\
Farelo de milho + AMI + dejeto & 326,26 & 15,84 & 10,48 & 0,95 \\
\hline
\end{tabular}

${ }^{a}$ Potencial máximo de produção de metano (NmL/g SV).

${ }^{b}$ Velocidade máxima de produção de metano (NmL/g SV/dia).

${ }^{c}$ Fase Lag - tempo para iniciar a produção de metano (dias).

Fonte: dados da autora.

De acordo com o ajuste do modelo de Gompertz modificado aos dados experimentais, o acúmulo máximo de metano no tempo testado chega a $399 \mathrm{NmL}$ g SV quando o substrato é o hidrolisado de farelo de milho ou o farelo adicionado de AMI. Com relação a fase de latência, esta foi menor no caso da mono-digestão, sendo que o início da produção de metano ocorreu já nos primeiros 4-5 dias. Para as digestões em batelada, o estágio de pré-tratamento enzimático ou ainda a adição concomitante de extrato AMI na DA do farelo de milho possibilitou a hidrólise da biomassa em moléculas mais simples, reduzindo o diâmetro das partículas, facilitando assim o contato entre a biomassa e os micro-organismos. Isto permitiu um melhor desempenho da população microbiana nas fases iniciais da DA. A CoDA, por sua vez, por conter o dejeto bovino com matéria recalcitrante em sua composição ocasionou uma fase de latência mais longa (15-17 dias). 


\subsection{DA semi-contínua}

Os ensaios semi-contínuos foram realizados com a utilização de CSTRs, com volume ativo de 2 litros cada, incubados em banho termostático a $55 \pm 2{ }^{\circ} \mathrm{C}$. Três ensaios diferentes foram realizados; um par de reatores digeriu apenas farelo de milho (reatores M1 e M2), um segundo par de reatores digeriu farelo de milho na presença do extrato enzimático AMI (adicionado uma vez na semana na proporção de 1:10 (g SV adicionado no dia/mL de extrato)) (reatores MExe1 e MEx2), e um terceiro par de reatores assimilou farelo de milho e dejeto bovino (base 1:1 SV) (reatores MDe1 e MDe2).

\subsubsection{Estabilidade do processo e produção de metano no início do processo}

O AMPTS II é o sistema de teste automático projetado especialmente para análise do potencial de Biometano (PBM). O AMPTS II foi desenvolvido com extensa avaliação de grupos de pesquisa e tem sido citado por um número crescente de publicações nos últimos anos (BADSHAH et al., 2012; SHEN et al., 2014).

A DA semi-contínua foi realizada por um período de 140 dias, totalizando 20 semanas. A estabilidade dos reatores foi controlada pela determinação da razão entre a quantidade de Ácidos Graxos Totais e a Alcalinidade Total (AGV/AT). A razão AGV/AT encontrada ao longo da DA semi-contínua pode ser vista nas Figura 31A, B e C. Há uma relação direta entre as variações de alcalinidade e o acúmulo de AGV. Manter uma relação AGV/AT em torno de 0,08 é recomendado para garantir um processo estável, ao tempo em que um aumento nesta razão, acima de 0,35, indica início de falha processo (GERARDI, 2003; SWITZENBAUM; GIRALDO-GOMEZ; HICKEY, 1990). 
Figura 31. Resultados semanais da digestão semi-contínua. pH, razão AGV/AT e média diária da produção de metano $\left(\mathrm{NmL} \mathrm{CH}_{4} /\right.$ dia) dos reatores $(\mathbf{A}) \rightarrow \mathrm{M} 1$ e $\cdots \cdot \cdot \mathrm{M} 2,(\mathbf{B}) \rightarrow \mathrm{MEx} 1$,

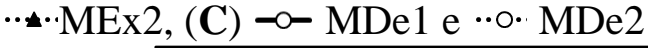
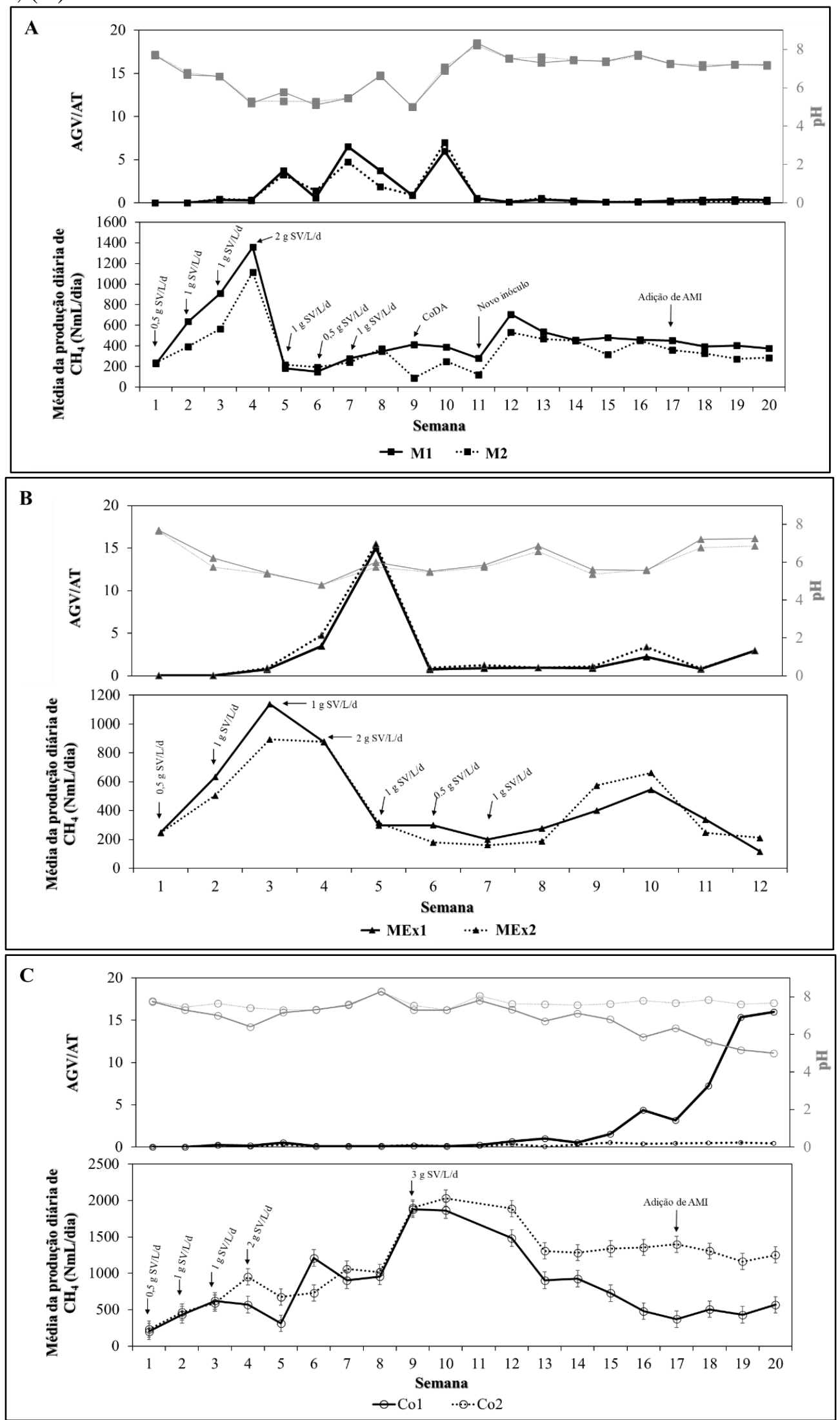

Fonte: dados da autora. 
No início do processo, todos os reatores apresentaram uma relação AGV/AT de 0,012. Durante a primeira semana, a CO em todos os seis reatores foi de $0,5 \mathrm{~g} \mathrm{SV} / \mathrm{L} / \mathrm{dia}$. Como mostra a Figura 31, ao final da primeira semana a razão AGV/AT estava entre 0,016 - 0,019 em todos os seis reatores. Na segunda semana de DA, a CO foi aumentada para $1 \mathrm{~g} \mathrm{SV/L/dia} \mathrm{e} \mathrm{mantida}$ por 2 semanas. Ao final da terceira semana, a AGV/AT foi de 0,35;0,45;0,25;0,25;0,75 e 0,92 nos reatores de M1, M2, MEx1 e MEx2, MDe1, MDe2, respectivamente. Na quarta semana, a CO foi aumentada para $2 \mathrm{~g} \mathrm{SV/L/dia.} \mathrm{No} \mathrm{entanto,} \mathrm{os} \mathrm{reatores} \mathrm{M1} \mathrm{e} \mathrm{M2} \mathrm{com} \mathrm{farelo}$ de milho como substratos (Figura 31A) e os reatores MEx1 e MEx2 (Figura 31B) com farelo de milho + AMI como substratos apresentaram instabilidade nesta taxa de alimentação, visto que houve uma alta relação nos valores de AGV/AT e uma grande diminuição na média diária da produção de metano. Pesquisas anteriores mostraram que para a produção estável de biogás em pequenos reatores, baixas $\mathrm{CO}$ variando de 0,7-1,4 g SV/L/d são recomendados durante a DA de resíduos alimentares ricos em carboidratos, lipídeos e proteínas (ZHANG et al., 2014).

$\mathrm{O}$ aumento do AGV/AT pode ser explicado pela natureza das reações cinéticas no processo de DA. É importante observar que o farelo de milho aqui aplicado é caracterizado por ser um material de grande área superficial. Esta característica, pode ter promovido uma alta taxa de hidrólise catalisada pelas enzimas presentes no inóculo (endógenas). Por consequência, a conversão dos produtos da hidrólise em AGV ocorreu rapidamente pela atividade das bactérias acidogênicas, as quais são caracterizadas por taxas de crescimento rápido (WAINAINA et al., 2019). No entanto, as metanogênicas que consomem AGV requerem um tempo duplicado em comparação às acidogênicas para o consumo e metabolização destes substratos. Portanto, nas condições prevalecentes do experimento, o acúmulo de AGV pode ter decorrido em um ritmo mais rápido do que o seu consumo, situação que pode ter levado o processo à falha quanto a produção de gás. Os resultados obtidos no presente trabalho estão de acordo com pesquisas anteriores nas quais o tamanho das partículas dos resíduos alimentares estimulou a alta produção de AGV em detrimento do metano (IZUMI et al., 2010). A alta produção de $\mathrm{AGV}$ na DA pode, no entanto, ser transformada em uma oportunidade. Isso ocorre porque as próprias moléculas de AGV têm um alto valor de mercado e podem ser aplicadas em várias indústrias químicas, como por exemplo na fabricação de blocos de construção. Além disso, os AGV podem ser utilizados para sintetizar bioplásticos, biomassa fúngica rica em proteínas ou mesmo biocombustíveis líquidos (WAINAINA et al., 2020). 


\subsubsection{Estratégias para restaurar o processo de mono-digestão do farelo de milho}

Levando em consideração a instabilidade de produção de metano nos reatores M1, M2, MEx1 e MEx2, durante as 4 primeiras semanas de DA, foram realizadas tentativas para auxiliar estes reatores instáveis. $\mathrm{Na} 5^{\mathrm{a}}$ semana de DA, esses 4 reatores retornaram a uma $\mathrm{CO}$ de $1 \mathrm{~g}$ $\mathrm{SV} / \mathrm{L} /$ dia, na $6^{\mathrm{a}}$ semana a uma CO de $0,5 \mathrm{~g} \mathrm{SV/L/dia} \mathrm{e} \mathrm{a} \mathrm{partir} \mathrm{da} 7^{\mathrm{a}}$ semana foi mantida uma $\mathrm{CO}$ de $1 \mathrm{~g} \mathrm{SV/L/dia} \mathrm{(Figura} \mathrm{31A} \mathrm{e} \mathrm{31B).}$

Analisando os reatores de número M1 e M2, cuja alimentação foi feita com farelo de milho, foi observada novamente uma baixa produção diária de metano e uma relação AGV/AT muito alta nas semanas 5-8 nas quais a $\mathrm{CO}$ foi de $1 \mathrm{~g}$ SV/L/dia. A primeira tentativa de melhorar a produção de metano teve início no início na $9^{\mathrm{a}}$ semana, na qual os dois reatores foram alimentados com a CoDA de farelo de milho e dejeto bovino na proporção de 1:1 e CO de $1 \mathrm{~g}$ SV/L/dia. Esta CoDA diminuiu a razão AGV/AT (Figura 31A), mas a média da produção diária de metano ainda estava baixo. Em uma segunda tentativa de salvar os reatores M1 e M2, na $11^{\mathrm{a}}$ semana, 1 litro de novo inóculo (lodo termofílico) substituiu a mesma quantidade de volume do meio da cultura presente no sistema. Com um novo inóculo e trabalhando em CoDA (farelo de milho e dejeto bovino), ambos os reatores apresentaram uma média de produção diária de metano estável $(405,62 \pm 76 \mathrm{NmL} \mathrm{CH}$ /dia) e ótima relação $\operatorname{AGV/AT~}(0,2)$ nas semanas que se seguiram (semanas 12-17).

Vários pesquisadores investigaram a prática de adicionar cultura exógena à DA (bioaumentação). BOCHER et al. (2015) relataram uma melhora funcional da degradação do propionato após o aumento com a comunidade metanogênica. Da mesma forma, LINS; REITSCHULER e ILLMER (2014) observaram o aumento da estabilidade e atividade do grupo metanogênico após bioaumentação com Methanosarcina sp. A adição desta espécie melhorou a digestão devido ao seu domínio ou mudança de domínio com Methanosaeta sp. após estabilizar as condições que inicialmente causaram a cessação da metanogênese (CONKLIN; STENSEL; FERGUSON, 2006). FERRARO et al. (2019) bioaumentou a DA da palha de trigo com um inóculo misto de fungos ruminais anaeróbios e bactérias fermentadoras produtoras de hidrogênio. A adição levou a uma maior produção de $\mathrm{CH}_{4}$ e maiores frações de Archaea, especialmente Methanosarcina, o que garantiu uma maior diversificação das vias metabólicas e melhor desempenho e resistência do sistema.

Portanto, a alteração do processo de digestão através da adição de novo inóculo neste presente trabalho de doutorado trouxe uma nova microbiota metabolicamente ativa para o reator, desencadeando um melhor consumo de substratos e consequente restabelecimento da produção de metano. 


\subsubsection{Influência do extrato enzimático na DA semi-contínua do farelo de milho}

Levando em consideração a instabilidade da produção de metano nos reatores MEx1 e MEx2 durante as 4 primeiras semanas de DA, na $5^{\mathrm{a}}$ semana de digestão iniciou-se a alimentação dos digestores com uma $\mathrm{CO}$ de $1 \mathrm{gVS} / \mathrm{L} /$ dia. Posteriormente, a $\mathrm{CO}$ foi ainda mais reduzida, retornando a uma alimentação de $0,5 \mathrm{gVS} / \mathrm{L} /$ dia na $6^{\mathrm{a}}$ semana, e somente a partir da $7^{\mathrm{a}}$ semana retornou para uma $\mathrm{CO}$ de $1 \mathrm{gVS} / \mathrm{L} / \mathrm{dia}$.

Os reatores MEx1 e MEx2 mantiveram uma produção diária de metano constante $\left(239,16 \pm 63 \mathrm{NmL} \mathrm{CH}_{4} /\right.$ dia $)$ ao longo das semanas 5 a 8 e também tiveram uma melhora na média de produção diária $\left(545,07 \pm 109,2 \mathrm{NmL} \mathrm{CH}_{4} /\right.$ dia $)$ na $9^{\mathrm{a}}$ e $10^{\mathrm{a}}$ semanas (Figura 31B), porém após isso, ambos os reatores com farelo de milho + AMI mostraram uma diminuição na média de produção diária de metano, ao mesmo tempo que a razão AGV/AT aumentou (Figura 31B) e então a produção de metano cessou. Algumas estratégias empregadas para se evitar a perda de reatores e propiciar a metanogênese incluem a redução drástica da $\mathrm{CO}$ e adição de reagentes alcalinos, como $\mathrm{NaHCO}_{3}$ e CaO (BEYER et al., 2019; LI, L. et al., 2018). Nessas 5 semanas de DA, o pH desses reatores MEx1 e MEx2 foi mantido em torno de 7,0 (Figura 31B), por meio da adição diária de bicarbonato de sódio nas proporções necessárias para manter um pH 7,0, no entanto, a falha do sistema foi inevitável devido à alta carga orgânica de um substrato altamente degradável.

A adição de enzimas exógenas a DA auxiliou na etapa de hidrólise e facilitou ainda mais o acesso dos micro-organismos responsáveis pelo processo anaeróbio aos substratos, no entanto, como foi observado, o uso de enzimas em processos anaeróbios está sujeito a certos critérios, como a toxicidade dos produtos gerados (DOS SANTOS FERREIRA et al., 2020; PANIGRAHI; DUBEY, 2019). As arqueias metanogênicas envolvidas na etapa final da DA são as mais sensíveis entre todos os grupos de micro-organismos envolvidos no processo e requerem controles de processamento específicos para que a estabilidade seja garantida (GOUX et al., 2016). De fato, para materiais orgânicos altamente degradáveis, como farelo de milho adicionado de enzimas exógenas, a metanogênese atuou como a etapa limitadora da taxa de DA (MA et al., 2013). Os micro-organismos metanogênicos que não estavam em equilíbrio com as reações promovidas nas fases intermediárias da DA, que propiciaram a formação excessiva de AGVs, serviram como etapa limitante e não funcional nos experimentos cujo substrato era o farelo de milho adicionado de extrato enzimático (altamente degradável). O acúmulo de AGVs ocasionou queda do $\mathrm{pH}$, o que inibiu a metanogênese e levou a falha do processo que visava o acúmulo de metano (KUMAR; SAMADDER, 2020).

Com relação ao farelo de milho aplicado na DA, os resultados alcançados neste trabalho 
a partir de ensaios em batelada mostraram que o hidrolisado de farelo de milho e o farelo adicionado de extrato enzimático (farelo de milho + AMI) propiciaram maior acúmulo de metano, o que leva a inferência de que este resultado seja devido ao consumo facilitado destes substratos pelos micro-organismos endógenos do inóculo no tempo determinado, uma vez que a biomassa encontrava-se hidrolisada por enzimas exógenas previamente a digestão ou durante o processo de DA. Porém, nos ensaios semi-contínuos de DA, os quais se aproximam mais da mimetização de processos em escala real, a adição do extrato enzimático nos reatores não foi favorável ao processo. A adição de enzimas exógenas ao sistema não acarretou aumento na produção de metano, pelo contrário, o processo falhou quanto a geração de gás. Em ensaio semi-contínuo, a alta degradabilidade intrínseca do farelo de milho foi potencializada pela atividade enzimática, o que levou a uma acelerada fase acidogênica e por consequente acúmulo de AGV.

\subsubsection{Influência da co-digestão}

Os reatores MDe1 e MDe2, conforme mencionado anteriormente, foram aqueles em que a digestão do farelo de milho foi testada na presença de um co-substrato, dejeto bovino. Como mostra a Figuras 31C, esses reatores foram aqueles com maior média de produção diária de metano e foi possível atingir um $\mathrm{CO}$ de $3 \mathrm{~g} \mathrm{SV/L/dia.} \mathrm{Como} \mathrm{mencionado} \mathrm{acima,} \mathrm{na} \mathrm{quarta}$ semana de DA o CO foi aumentado para 2 g SV/L/dia e os reatores MDe1 e MDe2 mostraram manter uma alta e estável média diária da produção de metano com baixas razões AGV/AT. Desta forma, na $9^{\mathrm{a}}$ semana a CO foi aumentada para $3 \mathrm{~g} \mathrm{SV/L/dia} \mathrm{e} \mathrm{mantida} \mathrm{até} \mathrm{o} \mathrm{final} \mathrm{do}$ experimento (Figura 31C). Após a semana de número 15, um desses reatores (MDe1) começou a mostrar instabilidade, com taxas decrescentes de produção de metano seguido por um aumento acentuado na razão AGV/AT e decaimento no $\mathrm{pH}$, durante as últimas semanas de digestão (17-20) (Figura 31C).

O dejeto bovino, resíduo orgânico que vem sendo amplamente estudado no processo de DA, caracteriza-se pelo fácil acesso, alta densidade energética e elevado teor de nutrientes (ZHOU et al., 2021). Desta forma, o uso deste esterco como co-substrato na DA oferece capacidade tamponante e atua como uma segunda fonte de micro-organismos de modo a incrementar a capacidade enzimática adicional ao processo anaeróbio (DAI et al., 2016; LI, YU et al., 2020).

O dejeto bovino é um dos resíduos mais interessantes, utilizado como co-substrato na CoDA de biomassa (XING et al., 2020; XU et al., 2020). A Pesquisa da Pecuária Municipal de 2019, divulgada pelo IBGE (Instituto Brasileiro de Geografia e Estatística) (IBGE, 2019), 
mostrou que o rebanho de bovinos brasileiro conta com 214,7 milhões de cabeças de gado, portanto, o uso dos dejetos em processos de CoDA ajuda a mitigar os efeitos negativos sobre as mudanças climáticas devido às emissões de gases de efeito estufa durante o armazenamento e processamento (LI, YU et al., 2020). LI et al. (2015) investigaram a CoDA da palha de arroz com dejeto bovino (S/I 1:1 g SV) e obtiveram uma melhoria de 9,6\% na produção de metano em relação à DA da palha de arroz individualmente. Do mesmo modo, AKYOL et al. (2016) relataram que o processo de CoDA de esterco bovino e cevada foi mais eficiente em todas as relações de mistura estudadas (1:1, 2:1 e 1:2) em comparação com a mono-digestão. Em outro estudo de CoDA a partir de resíduos de tomate e milho com dejeto de bovinos, foi visto que as misturas contendo $13 \%, 33 \%$ e $54 \%$ de esterco de vaca têm produções 10,2; 0,9 e 0,5 vezes maiores do que a digestão de substratos individuais, respectivamente (LI et al., 2016). MONTORO et al. (2019) também relataram que a concomitante digestão de esterco bovino e batata doce teve efeitos sinérgicos positivos, com aumento da capacidade tampão e do balanço de nutrientes no sistema, o que levou a uma melhoria na biodegradação dos substratos.

Em comparação com a mono-digestão do farelo de milho, a CoDA deste substrato com dejeto bovino mostrou oferecer um $\mathrm{pH}$ adequado aos digestores, de modo a se evitar a acidificação do sistema, melhor balanço de nutrientes para o crescimento de micro-organismos anaeróbios e alta capacidade tamponante. Por esses motivos, infere-se que a co-digestão potencializou a biodiversidade nos digestores e produziu efeitos sinérgicos, que resultaram na obtenção de um rendimento de metano maior e mais estável do que a mono-digestão do farelo de milho ou adicionado de enzimas.

\subsubsection{Adição de extrato enzimático nos reatores estáveis trabalhando em co-digestão}

Com o objetivo de estudar a influência de enzimas na produção de metano a partir da co-digestão do farelo de milho e dejeto bovino, o extrato bruto AMI foi adicionado uma vez por semana aos reatores M1, M2, MDe1 e MDe2 (semanas 17 a 20 durante o semi- experimento contínuo). Como mencionado acima, nesta fase, mesmo os reatores M1 e M2 funcionavam como reatores de co-digestão. O extrato enzimático foi adicionado em cada digestor com base em uma carga de SV diária de 10\%. Os reatores M1 e M2 que operavam com uma CO de 1 g $\mathrm{SV} / \mathrm{L} /$ dia, receberam em um dia da semana $117 \mathrm{U}$ de amilase $(34,4 \mathrm{~mL}$ de AMI), enquanto os reatores MDe1 e MDe2 que operavam com uma CO de $3 \mathrm{~g} \mathrm{SV/L/dia,} \mathrm{foram} \mathrm{adicionados} \mathrm{de}$ 175,4 U de amilase (51,6 mL de AMI) uma vez por semana. Três desses quatro reatores mostraram uma operação estável, com uma persistente produção diária de metano de 358,94 \pm 60,61 $\mathrm{NmL} \mathrm{CH}_{4} /$ dia nos reatores M1, M2 (Figura 31A), e 1280,12 \pm 99,4 $\mathrm{NmL} \mathrm{CH}_{4} / \mathrm{dia}_{\text {no }}$ 
reator MDe2 (Figura 31C). Em contrapartida, o processo que já vinha instável no reator MDe1, com uma diminuição na produção de metano desde a semana 15, continuou com um rendimento diário de 369,66 $\mathrm{NmL} \mathrm{CH}_{4} /$ dia desde a $17^{\mathrm{a}}$ semana (Figura 31C).

Conforme mostrado na Figura 31A e C, a adição de enzimas exógenas uma vez por semana nos reatores, não causou um aumento significativo no rendimento de metano. Esse resultado está de acordo com os encontrados em ensaios em batelada (Figura 28 e 30), que mostraram que o próprio extrato bruto da enzima como único substrato não resultará em uma produção marcável de metano, principalmente se comparada ao do farelo de milho. No experimento semi-contínuo, a adição do extrato enzimático também não levou a nenhum aumento marcante na produção de metano (Figuras 31A e C). O sistema nos três reatores (M1, M2 e MDe2) apresentou performance estável e bem ajustado, e a adição da enzima não afetou o desempenho. O grau de degradação do substrato nas últimas semanas de experimento ficou em torno de $99 \pm 0,5 \%$ nos reatores M1, M2 e 72,08 \pm 4,4\% no reator MDe2 (Figura 32), consequentemente a maioria dos substratos disponíveis já estavam degradados. Uma vez que os sistemas estavam equilibrados, os substratos adicionados foram rapidamente consumidos pelos micro-organismos.

Além disso, há pesquisadores conjeturando que enzimas são metabolizadas como substrato quando aplicadas diretamente em digestores, inferindo que a aplicação direta de enzimas é um método de processo inviável em instalações reais (processos contínuos). BRULÉ et al. (2007) sugeriu que a degradação de enzimas exógenas pode ser realizada por bactérias endógenas presentes no inóculo quando diferentes substratos são tratados. BINNER et al. (2011) observaram uma degradação parcial ou completa de cinco diferentes misturas de enzimas comerciais dentro da primeira hora após a suplementação enzimática direta na DA da silagem de milho.

\subsubsection{Mono-digestão do farelo de milho como alternativa para produção de AGVs}

O propósito inicial da DA neste projeto envolvia o estudo da produção de metano a partir de farelo de milho adicionado de extrato enzimático produzido por fungo selvagem, porém outras possibilidades foram favorecidas pela aplicação deste substrato altamente degradável. Como visto na Figura 31A e B, os níveis de AGVs/AT durante o processo de digestão indicaram um elevado acúmulo desses ácidos ao longo do tempo.

Quando o produto final almejado a partir da DA não é o biogás, diversas estratégias podem ser utilizadas propositalmente para aumentar o acúmulo de produtos intermediários e inibir as arqueias metanogênicas. Dentre essas estratégias pode-se citar o uso de agentes 
químicos, choque térmico da microflora inoculante e operação em níveis de pH severos (DO CARMO LAMAISON et al., 2015; FONSECA; GUAZZARONI; REGINATTO, 2016). Uma vez que as arqueias formadoras de metano são ativas na faixa de $\mathrm{pH}$ neutro, a aplicação de faixas de $\mathrm{pH}$ ácidas e alcalinas pode ser potencialmente benéfica para o acúmulo de AGVs. Por outro lado, as bactérias acidogênicas fermentativas podem permanecer ativas em níveis muito baixos de $\mathrm{pH}$, como $\mathrm{pH}$ 3, ou mesmo em níveis muito altos, como $\mathrm{pH} 12$ (LIU et al., 2012).

A aplicação de farelo de milho na DA é uma alternativa viável quando se almeja a produção de AGVs, uma vez que este substrato se mostrou facilmente degradável, e tem esse nível de degradação ainda mais elevado quando adicionado de enzimas exógenas. Os AGVs podem ser aplicados como precursores de diversos biomateriais essenciais, como por exemplo os polímeros ou plásticos biodegradáveis (olihidroxialcanoatos), podem atuar na remoção biológica de nitrogênio e fósforo durante o tratamento de águas residuais (NIELSEN et al., 2017; STRAZZERA et al., 2018), e também podem ser usados para cultivar micro-organismos para produção de biocombustíveis (GAO et al., 2017; LEE et al., 2014; LIANG; JIANG, 2013).

Adicionalmente, a taxa de degradação (Figura 32) mostra como os substratos foram degradados durante a DA nos respectivos reatores. Como pode-se verificar, quando o farelo era o único substrato na DA, reatores M1 e M2, o grau de degradação foi maior (quase 100\%). Esse resultado pode indicar o motivo pelo qual a mono-digestão do milho não foi a melhor alternativa para a produção de metano. Por ser uma biomassa facilmente degradável pelos microorganismos anaeróbios, sua rápida degradação causou uma alta produção de AGVs (como pode ser visto através da razão AGV/AT na Figura 31A), resultando em uma rápida diminuição de $\mathrm{pH}$. O dejeto bovino quando presente no sistema ocasionou uma menor taxa de degradação que foi essencial para a estabilidade da DA. 
Figura 32. Taxa de degradação dos substratos (\%) durante a DA semi-contínua dos reatores

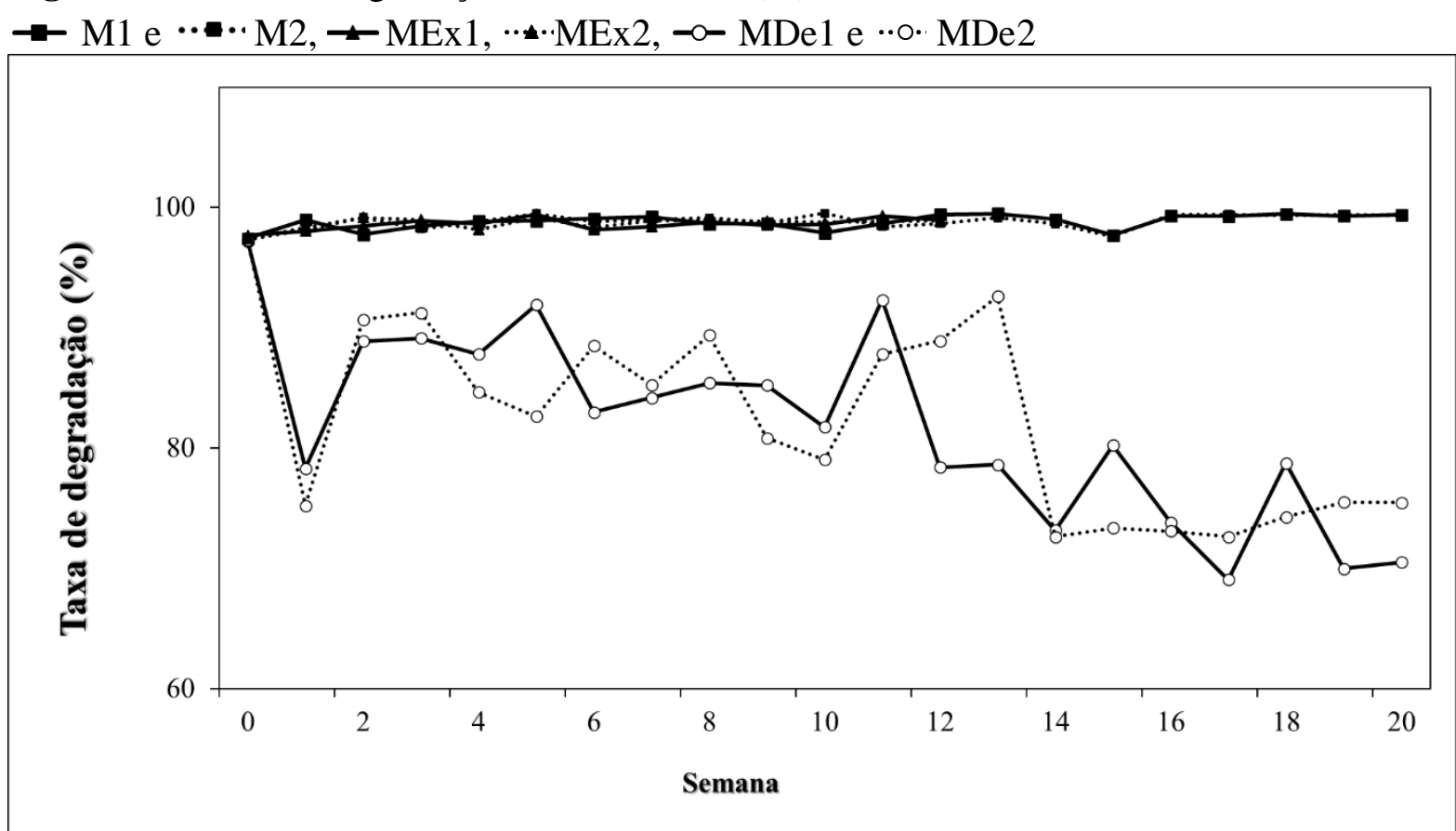

Fonte: dados da autora.

\subsection{Fermentação alcoólica}

A fermentação alcoólica ao nível industrial consiste na transformação de açúcares simples em etanol por meio da ação catalítica de leveduras. Entretanto, para a obtenção de etanol a partir de biomassas, normalmente é necessário incluir uma etapa de pré-tratamento a fim de disponibilizar os açúcares fermentáveis.

A fim de se estudar a importância da hidrólise enzimática para o processo fermentativo do farelo de milho, quatro diferentes situações foram estudadas, $(i)$ hidrólise (por AMI) e fermentação separadas (HFSep), (ii) hidrólise (em água destilada) e fermentação separadas (controle HFSep), (iii) hidrólise (por AMI) e fermentação simultâneas (HFSim), e (iv) hidrólise (em água destilada) e fermentação simultâneas (controle HFSim). Em todos os casos a determinação de etanol presente nos meios reacionais inicial e final ocorreu por Cromatografia Líquida de Alta Eficiência (CLAE) (Tabela 21), e nos quatro processos a fermentação decorreu a partir da S. cerevisiae (Leaf Technologies, França) a $35^{\circ} \mathrm{C}$ por 48 horas. 
Tabela 21. Concentração de etanol e rendimento etanólico resultante dos processos fermentativos com farelo de milho

\begin{tabular}{lcc}
\hline Condição & Concentração de etanol (g/L) & $\begin{array}{c}\text { Rendimento etanólico (\%) com base } \\
\text { no valor teórico }\end{array}$ \\
\hline FHSep & $36,00 \pm 1,00$ & $99,00 \pm 1,00$ \\
FHSep (controle) & $0,07 \pm 0,01$ & $0,18 \pm 0,02$ \\
FHSim & $23,00 \pm 1,00$ & $63,50 \pm 3,00$ \\
FHSim (controle) & $2,00 \pm 0,50$ & $5,65 \pm 0,50$ \\
\hline a Potencial teórico de $37,31 \mathrm{~g} / \mathrm{L}$, considerando $73 \mathrm{~g}$ de carboidratos por $100 \mathrm{~g}$ de farelo de milho. \\
Fonte: dados da autora.
\end{tabular}

Para a HFSep, o farelo de milho foi primeiramente hidrolisado por AMI nas condições otimizadas ao longo deste trabalho $\left(48 \mathrm{~h}\right.$ a $45^{\circ} \mathrm{C}, \mathrm{pH} 4,5$, proporção 1:10 (massa de farelo de milho: volume de AMI)). A partir dos resultados de CLAE constatou-se que este pré-tratamento enzimático do farelo de milho resultou na liberação de $52 \pm 3 \mathrm{~g}$ de glucose/ L, o que corresponde a um percentual de hidrólise de 71,5 $\pm 3 \%$ dos carboidratos presentes nesta biomassa $(73 \mathrm{~g}$ de carboidrato para cada $100 \mathrm{~g}$ de farelo). Após a hidrólise, decorreu-se a fermentação, e a partir desta houve a produção de $36 \pm 1 \mathrm{~g}$ de etanol/ L, correspondendo a um rendimento percentual etanólico de $99 \pm 1 \%$ com relação ao potencial teórico, já que a produção teórica foi de 37,31 $\mathrm{g} / \mathrm{L}$ considerando $73 \mathrm{~g}$ de carboidratos por $100 \mathrm{~g}$ de farelo de milho.

O processo de HFSep por sua vez, resultou na produção de $23 \pm 1 \mathrm{~g}$ de etanol/ L. Esse valor corresponde a um rendimento percentual etanólico de 63,5 3 \% com relação ao potencial teórico (Tabela 21).

A fim de se comparar e destacar a importância das enzimas para o processo fermentativo do farelo de milho, fermentações contendo água destilada como meio reacional ao invés de extrato enzimático foram testadas quanto a produção de etanol (Tabela 21). Quando o farelo de milho foi pré-tratado com água destilada (controle correspondente a HFSep), houve uma produção de etanol de $0,07 \pm 0,01 \mathrm{~g} / \mathrm{L}$, o que corresponde a um rendimento percentual etanólico de $0,18 \pm 0,02 \%$. Adicionalmente, o controle correspondente à HFSim (onde o soluto foi água destilada ao invés de AMI) mostrou uma produção de etanol de $2 \pm 0,5 \mathrm{~g} / \mathrm{L}$, o que é equivalente a um rendimento percentual etanólico de 5,65 $\pm 0,5 \%$.

Esses resultados mostram que o pré-tratamento (pré-sacarificação) do farelo de milho com um extrato enzimático bruto rico em amilase e produzido por um fungo selvagem $(A$. brasiliensis) é uma ótima opção para o incremento da produção de etanol. A hidrólise enzimática do farelo de milho liberou moléculas de glucose. A presença de açúcar simples e acessível ao micro-organismo fermentativo resultou em uma maior produção de etanol com 
total conversão do substrato no tempo testado. Quando o milho foi tratado previamente à fermentação alcoólica, houve um rendimento percentual de quase 100\% (com base no rendimento teórico), que foi $46 \%$ superior ao rendimento obtido quando a sacarificação foi realizada no mesmo momento da fermentação. A disponibilidade de açúcares mais complexos como substratos para os ensaios de HFSim podem ter retardado o tempo de conversão dos substratos em produtos, desta forma a quantidade de etanol produzida no tempo testado foi inferior àquela encontrada nos testes de HFSep.

HFSep tem a vantagem de que cada uma das duas etapas pode ser otimizada separadamente em relação à temperatura e ao $\mathrm{pH}$, e também em relação aos equipamentos, como por exemplo o que envolve a agitação. Adicionalmente, a fermentação pode ser realizada com um caldo líquido, em vez de lodo contendo material sólido como é o caso do HFSim, o que facilita a transferência de massa e possibilita a reciclagem da levedura após a fermentação por filtração ou centrifugação (GALBE; WALLBERG; ZACCHI, 2011).

Os esforços de integração de processos (sacarificação + fermentação) ainda são limitados por obstáculos (RAMOS et al., 2015). Neste sentido, estudos de padronização das condições ideais para a integração dos processos vêm sendo elaborados, a exemplo do processo de hidrólise híbrida $(\mathrm{HH})$, onde a hidrólise é realizada em condições que são ideais para o desempenho da enzima, e as condições ótimas de fermentação são aplicadas antes que o nível de conversão do substrato alcance taxas de inibição do produto (TETER; SUTTON; EMME, 2014). 


\section{Observacões finais \& Perspectivas - Parte 2}


O desenvolvimento do presente estudo possibilitou uma análise de como o uso de diferentes biomassas, mais especificamente a biomassa proveniente do milho pode contribuir para a produção sustentável de energia e alternativas de biorefinarias.

Um dos objetivos do conceito de economia circular passa pela utilização da biomassa como recurso energético, minimizando os seus impactos negativos no ambiente. Instalações de fermentação alcoólica, que são convencionalmente usadas para produzir etanol, podem servir potencialmente para obter economias circulares por conversão em biorefinarias, pelo emprego da digestão anaeróbia para produção diversificada de produtos como biogás e AGVs.

As usinas sucroalcooleiras além de muito interessadas pela utilização da biomassa, buscam inovar-se tecnologicamente devido a demanda energética ser cada vez mais crescente, e também pela sustentabilidade ser uma demanda crucial. Deste modo, dada à importância da pesquisa, a segunda parte do projeto visou o estudo do farelo de milho hidrolisado por um extrato enzimático bruto como substrato para o processo de digestão anaeróbia e fermentação alcoólica.

De acordo com os resultados experimentais encontrados nesta Parte 2, as seguintes conclusões podem ser tiradas:

1) As proporções 1:10 e 1:8 (m/v) de farelo de milho e extrato enzimático AMI foram as melhores para hidrolisar o substrato (farelo de milho). As maiores concentrações de AR liberadas no sistema foram respectivamente 52,65 e 54,31 g de AR/L (correspondendo à hidrólise do amido de $79 \pm 5$ e $81 \pm 5 \%$, respectivamente).

2) A partir de testes em batelada:

(i) O lodo termofílico proveniente de uma planta de biogás em atividade, desencadeou os melhores resultados de digestão dos substratos em DA.

(ii) A DA do farelo de milho, do hidrolisado de farelo de milho ou mesmo do farelo de milho adicionado de AMI apresentaram os melhores resultados quanto ao acúmulo de metano no período estudado (390 NmL/ g SV).

(ii) Um importante efeito sinérgico foi encontrado na co-digestão dos substratos farelo de milho e dejeto bovino. O acúmulo de metano observado a partir da co-digestão ( $280 \mathrm{NmL} / \mathrm{g} \mathrm{SV}$ ) foi $30 \%$ superior aos dados calculados/esperados (200,5 NmL / g SV).

3) A partir de testes de digestão semi-contínua:

(i) A aplicação de enzimas brutas na DA de culturas energéticas com alta degradabilidade (como por exemplo o farelo de milho, que apresenta um teor de carboidratos estruturais de $73 \%$ ) não foi benéfica em termos de produção de metano. 
(ii) A co-digestão de farelo de milho e dejeto bovino (1:1 na base g de SV) foi estável ao longo de 140 dias, atingindo uma CO de $3 \mathrm{~g} \mathrm{SV/L/dia} \mathrm{e} \mathrm{uma} \mathrm{produção} \mathrm{diária} \mathrm{de} \mathrm{metano} \mathrm{de} \mathrm{1280,12}$ \pm 99,4 $\mathrm{NmL} \mathrm{CH}_{4} /$ dia.

(iii) A mono-digestão do farelo de milho levou à alta produção de $\mathrm{AGV}$ e à diminuição do $\mathrm{pH}$ durante a DA. A alta degradabilidade do farelo de milho pode agregar valor ao mercado de AGV por meio do processo de AD.

(iv) A fermentação alcoólica (FHSep) a partir do farelo de milho pré-sacarificado com extrato enzimático bruto produzido por fungo filamentoso selvagem, alcançou um rendimento etanólico de $100 \%$ com relação ao potencial teórico, o que mostra a potencialidade de enzimas brutas em processos industriais.

A partir dos resultados obtidos ao longo desta pesquisa, como perspectivas seguem as possíveis áreas para futuras investigações e melhorias:

- A extensão dos períodos de operação para a digestão anaeróbia em altas taxas de carregamento orgânico usando os biorreatores para determinar por quanto tempo o processo pode ocorrer sem falhas de fermentação;

- Investigações adicionais poderiam, ser realizadas para lançar mais luz sobre o potencial de possíveis estratégias de otimização, de modo a visar a produção e recuperação de AGV como o principal produto de um processo de DA alimentado com farelo de milho. 


\section{Referências Bibliográficas}


ABBASI, T.; TAUSEEF, S.; ABBASI, S. A brief history of anaerobic digestion and "biogas". In: Biogas Energy: Springer, p. 11-23, 2012.

ABDULLAH, R.; NISAR, K.; ASLAM, A.; IQTEDAR, M.; NAZ, S. Enhanced production of xylanase from locally isolated fungal strain using agro-industrial residues under solid-state fermentation. Natural Product Research, 29, n. 11, p. 1006-1011, 2015.

ABOUDI, K.; ÁLVAREZ-GALLEGO, C. J.; ROMERO-GARCÍA, L. I. Evaluation of methane generation and process stability from anaerobic co-digestion of sugar beet by-product and cow manure. Journal of Bioscience and Bioengineering, 121, n. 5, p. 566-572, 2016.

ACHINAS, S.; KROONEMAN, J.; EUVERINK, G. J. W. Enhanced biogas production from the anaerobic batch treatment of banana peels. Engineering, 5, n. 5, p. 970-978, 2019.

ADAMS, P. Mycelial amylase activities of thermophilic species of Rhizomucor, Humicola and Papulaspora. Mycopathologia, 112, n. 1, p. 35-37, 1990.

ADIB, R.; MURDOCK, H.; APPAVOU, F.; BROWN, A.; EPP, B.; LEIDREITER, A.; LINS, C.; MURDOCK, H.; MUSOLINO, E.; PETRICHENKO, K. Renewables 2015 global status report. REN21 Secretariat, Paris, France, 162, 2015.

AHRING, B. K. Perspectives for anaerobic digestion. In: Biomethanation I: Springer, p. 1-30, 2003.

AKUZAWA, M.; HORI, T.; HARUTA, S.; UENO, Y.; ISHII, M.; IGARASHI, Y. Distinctive responses of metabolically active microbiota to acidification in a thermophilic anaerobic digester. Microbial Ecology, 61, n. 3, p. 595-605, 2011.

AKYOL, Ç.; OZBAYRAM, E. G.; INCE, O.; KLEINSTEUBER, S.; INCE, B. Anaerobic codigestion of cow manure and barley: Effect of cow manure to barley ratio on methane production and digestion stability. Environmental Progress \& Sustainable Energy, 35, n. 2, p. 589-595, 2016.

ALI SHAH, F.; MAHMOOD, Q.; MAROOF SHAH, M.; PERVEZ, A.; AHMAD ASAD, S. Microbial ecology of anaerobic digesters: the key players of anaerobiosis. The Scientific World Journal, 2014, 2014.

ALLEN, E.; VALDES, C. Brazil's corn industry and the effect on the seasonal pattern of US corn exports. United States Department of Agriculture, Economic Research Service, 2016.

ALLISON, S. D.; MARTINY, J. B. Resistance, resilience, and redundancy in microbial communities. Proceedings of the National Academy of Sciences, 105, n. Supplement 1, p. 11512-11519, 2008.

ALMEIDA, P. Z.; MESSIAS, J. M.; PEREIRA, M. G.; PINHEIRO, V. E.; MONTEIRO, L. M. O.; HEINEN, P. R.; CARDOSO, G. C.; JORGE, J. A.; POLIZELI, M. L. T. M. Mixture design of starchy substrates hydrolysis by an immobilized glucoamylase from Aspergillus brasiliensis. Biocatalysis and Biotransformation, 36, n. 5, p. 389-395, 2018. 
ALMODARES, A.; HADI, M. R. Production of bioethanol from sweet sorghum: A review. African Journal of Agricultural Research, 4, n. 9, p. 772-780, 2009.

ALMODARES, A.; HATAMIPOUR, M. Planting sweet sorghum under hot and dry climatic condition for bioethanol production. Linköping University Electronic Press, p. 266-272, 2011.

ALQARALLEH, R. M. Z. Thermophilic and Hyper-thermophilic Anaerobic Co-digestion of Thickened Waste Activated Sludge and Fat, Oil, and Grease, 2014. Tese (Doutorado em Engenharia Ambiental) - Ottawa-Carleton Institute for Environmental Engineering, Department of Civil Engineering, University of Ottawa, CA, 2014.

ALVES, B. B. Biomassa na produção de energia limpa. 2019. Monografia (Bacharel em Engenharia de Produção) - UNICESUMAR - Centro Universitário de Maringá, PR, Brasil, 2014.

AMIN, F. R.; KHALID, H.; ZHANG, H.; U RAHMAN, S.; ZHANG, R.; LIU, G.; CHEN, C. Pretreatment methods of lignocellulosic biomass for anaerobic digestion. Amb Express, 7, n. 1, p. 72, 2017.

ANDERSON-COOK, C. M.; BORROR, C. M.; MONTGOMERY, D. C. Response surface design evaluation and comparison. Journal of Statistical Planning and Inference, 139, n. 2, p. 629641, 2009.

AQUINO, S. F.; CHERNICHARO, C. A.; FORESTI, E.; SANTOS, M. d. L. F. d.; MONTEGGIA, L. O. Metodologias para determinação da atividade metanogênica específica (AME) em lodos anaeróbios. Engenharia Sanitária e Ambiental, 12, n. 2, p. 192-201, 2007.

ARASARATNAM, V.; BALASUBRAMANIAM, K. Synergistic action of $\alpha$-amylase and glucoamylase on raw corn. Starch-Stärke, 45, n. 6, p. 231-233, 1993.

ARAUJO, P. W.; BRERETON, R. G. Experimental design III. Quantification. TrAC Trends in Analytical Chemistry, 15, n. 3, p. 156-163, 1996.

ARNELL, M.; ASTALS, S.; ÅMAND, L.; BATSTONE, D. J.; JENSEN, P. D.; JEPPSSON, U. Modelling anaerobic co-digestion in Benchmark Simulation Model No. 2: parameter estimation, substrate characterisation and plant-wide integration. Water Research, 98, p. 138146, 2016.

AURILIA, V.; MARTIN, J. C.; MCCRAE, S. I.; SCOTT, K. P.; RINCON, M. T.; FLINT, H. J. Three multidomain esterases from the cellulolytic rumen anaerobe Ruminococcus flavefaciens 17 that carry divergent dockerin sequences. Microbiology, 146, n. 6, p. 1391-1397, 2000.

BADSHAH, M.; LAM, D. M.; LIU, J.; MATTIASSON, B. Use of an automatic methane potential test system for evaluating the biomethane potential of sugarcane bagasse after different treatments. Bioresource Technology, 114, p. 262-269, 2012.

BAJPAI, P. Wood and Fiber Fundamentals. In: Biermann's Handbook of Pulp and Paper: Raw Material and Pulp Making, Third Edition, Elsevier, p. 19-74, 2018. 
BANERJEE, G.; CAR, S.; SCOTT-CRAIG, J. S.; BORRUSCH, M. S.; WALTON, J. D. Rapid optimization of enzyme mixtures for deconstruction of diverse pretreatment/biomass feedstock combinations. Biotechnology for Biofuels, 3, n. 1, p. 22, 2010.

BAUER, W. Biogas beats bioethanol. Asia Pacific Biotech News, 19, n. 8, p. 16-17, 2015.

BERLIN, A.; MAXIMENKO, V.; GILKES, N.; SADDLER, J. Optimization of enzyme complexes for lignocellulose hydrolysis. Biotechnology and Bioengineering, 97, n. 2, p. 287 296, 2007.

BETIKU, E.; AJALA, S. O. Modeling and optimization of Thevetia peruviana (yellow oleander) oil biodiesel synthesis via Musa paradisiacal (plantain) peels as heterogeneous base catalyst: A case of artificial neural network vs. response surface methodology. Industrial Crops And Products, 53, p. 314-322, 2014.

BETIKU, E.; AKINTUNDE, A. M.; OJUMU, T. V. Banana peels as a biobase catalyst for fatty acid methyl esters production using Napoleon's plume (Bauhinia monandra) seed oil: A process parameters optimization study. Energy, 103, p. 797-806, 2016.

BEYER, E.; NEUMANN, J.; AWE, D.; PFEIFFER, W.; TRÄNCKNER, J. Anaerobic treatment of residuals from tanks transporting food and fodder. Environmental Science and Pollution Research, 26, n. 32, p. 32698-32707, 2019.

BEZERRA, M. A.; SANTELLI, R. E.; OLIVEIRA, E. P.; VILLAR, L. S.; ESCALEIRA, L. A. Response surface methodology (RSM) as a tool for optimization in analytical chemistry. Talanta, 76, n. 5, p. 965-977, 2008.

BHATIA, S. K.; YANG, Y.-H. Microbial production of volatile fatty acids: current status and future perspectives. Reviews in Environmental Science and Bio/Technology, 16, n. 2, p. 327 $345,2017$.

BINNER, R.; MENATH, V.; HUBER, H.; THOMM, M.; BISCHOF, F.; SCHMACK, D.; REUTER, M. Comparative study of stability and half-life of enzymes and enzyme aggregates implemented in anaerobic biogas processes. Biomass conversion and Biorefinery, 1, n. 1, p. $1-8,2011$.

BLACKALL, L. L.; CROCETTI, G. R.; SAUNDERS, A. M.; BOND, P. L. A review and update of the microbiology of enhanced biological phosphorus removal in wastewater treatment plants. Antonie Van Leeuwenhoek, 81, n. 1-4, p. 681-691, 2002.

BLUM, D. L.; LI, X.-L.; CHEN, H.; LJUNGDAHL, L. G. Characterization of an acetyl xylan esterase from the anaerobic fungus Orpinomyces sp. strain PC-2. Applied and Environmental Microbiology, 65, n. 9, p. 3990-3995, 1999.

BOCHER, B. T.; CHERUKURI, K.; MAKI, J.; JOHNSON, M.; ZITOMER, D. Relating methanogen community structure and anaerobic digester function. Water Research, 70, p. 425-435, 2015. 
BON, E. P.; GÍRIO, F.; PEREIRA JUNIOR, N. Enzimas na produção de etanol. In: ELBA, P.S. Enzimas em biotecnologia: produção, aplicações e mercado. Rio de Janeiro: Interciência, p. 241-272, 2008.

BORA, B. J.; SAHA, U. K.; CHATTERJEE, S.; VEER, V. Effect of compression ratio on performance, combustion and emission characteristics of a dual fuel diesel engine run on raw biogas. Energy Conversion and Management, 87, p. 1000-1009, 2014.

BOTHAST, R.; SCHLICHER, M. Biotechnological processes for conversion of corn into ethanol. Applied Microbiology and Biotechnology, 67, n. 1, p. 19-25, 2005.

BOX, G. E. P.; HUNTER, W. G.; HUNTER, J. S. Statistics for experimenters, an introduction to design, data analysis, and model building, John Wiley and Sons, New York, NY. pp. 653, 1978.

BRADFORD, M. M. A rapid and sensitive method for the quantitation of microgram quantities of protein utilizing the principle of protein-dye binding. Analytical Biochemistry, 72, n. 1-2, p. 248-254, 1976.

BRIAND, C.; GELETA, S.; KRATOCHVIL, R. Sweet sorghum (Sorghum bicolor [L.] Moench) a potential biofuel feedstock: Analysis of cultivar performance in the Mid-Atlantic. Renewable Energy, 129, p. 328-333, 2018.

BROWN, D.; SHI, J.; LI, Y. Comparison of solid-state to liquid anaerobic digestion of lignocellulosic feedstocks for biogas production. Bioresource Technology, 124, p. 379-386, 2012.

BRULÉ, M.; OECHSNER, H.; FISCHER, L.; LEMMER, A.; JUNGBLUTH, T. Effect of enzymatic substrate preparation on the biogas yield of energy crops. Landtechnik, 62, n. 6, p. 414-415, 2007.

BRUNS, R. E.; SCARMINIO, I. S.; DE BARROS NETO, B. Statistical design-chemometrics. Elsevier, p. 1-412, 2005.

BRYANT, M. Microbial methane production - theoretical aspects. Journal of Animal Science, 48, n. 1, p. 193-201, 1979.

BUSSAMRA, B. C.; FREITAS, S.; DA COSTA, A. C. Improvement on sugar cane bagasse hydrolysis using enzymatic mixture designed cocktail. Bioresource Technology, 187, p. 173$181,2015$.

CALLAGHAN, F.; WASE, D.; THAYANITHY, K.; FORSTER, C. Continuous co-digestion of cattle slurry with fruit and vegetable wastes and chicken manure. Biomass and Bioenergy, 22, n. 1, p. 71-77, 2002.

CAMMAROTA, M. C.; ROSA, D. R.; DUARTE, I. C.; SAAVEDRA, N. K.; VARESCHE, M. B.; ZAIAT, M.; FREIRE, D. M. The effect of enzymatic pre-hydrolysis of dairy wastewater on the granular and immobilized microbial community in anaerobic bioreactors. Environmental Technology, 34, n. 4, p. 417-428, 2013. 
CAO, L.; KEENER, H.; HUANG, Z.; LIU, Y.; RUAN, R.; XU, F. Effects of temperature and inoculation ratio on methane production and nutrient solubility of swine manure anaerobic digestion. Bioresource Technology, v. 299, 122552, 2020.

CAUFRIER, F.; MARTINOU, A.; DUPONT, C.; BOURIOTIS, V. Carbohydrate esterase family 4 enzymes: substrate specificity. Carbohydrate Research, 338, n. 7, p. 687-692, 2003.

CHAE, S. R.; LEE, S. H.; KIM, J.; PAIK, B.; SONG, Y.; PARK, H.; SHIN, H.-S. Simultaneous removal of organic and strong nitrogen from sewage in a pilot-scale BNR process supplemented with food waste. Water Science and Technology, 49, n. 5-6, p. 257-264, 2004.

CHANTAWONGSA, N.; KONGKIATTIKAJORN, J. Pretreatment methods for banana peel as a substrate for the bioproduction of ethanol in SHF and SSF. International Journal of the Computer, the Internet and Management, 21, p. 15-19, 2013.

CHAPLEUR, O.; MAZEAS, L.; GODON, J.-J.; BOUCHEZ, T. Asymmetrical response of anaerobic digestion microbiota to temperature changes. Applied Microbiology And Biotechnology, 100, n. 3, p. 1445-1457, 2016.

CIBIOGÁS. Nota Técnica: N 002/2010. Panorama do Biogás no Brasil em 2019. 2020. Disponível em: https://biblioteca.cibiogas.org/biblioteca/notatecnica/pdf/panorama-do-biogasno-brasil-em-2019.pdf 2020. Acessado em maio de 2021.

CIOLACU, D. E. Biochemical modification of lignocellulosic biomass. In: POPA, V.; VOLF, I. Biomass as Renewable Raw Material to Obtain Bioproducts of High-Tech Value. Amsterdam: Elsevier, p. 315-350, 2018.

CLARKE, W. P.; RADNIDGE, P.; LAI, T.; JENSEN, P.; HARDIN, M. Digestion of waste bananas to generate energy in Australia. Waste Management, 28, n. 3, p. 527-533, 2008.

COLATTO, L.; LANGER, M. Biodigestor-resíduo sólido pecuário para produção de energia. Unoesc \& Ciência-ACET, 2, n. 2, p. 119-128, 2011.

CONAB, Companhia Nacional de Abastecimento. Perspectives for the Brazilian grain harvest 2020/21. 2021. Disponível em: www.conab.gov.br. Acessado em maio de 2021.

CONKLIN, A.; STENSEL, H. D.; FERGUSON, J. Growth kinetics and competition between Methanosarcina and Methanosaeta in mesophilic anaerobic digestion. Water Environment Research, 78, n. 5, p. 486-496, 2006.

COOK, S. M.; SKERLOS, S. J.; RASKIN, L.; LOVE, N. G. A stability assessment tool for anaerobic codigestion. Water Research, 112, p. 19-28, 2017.

CORNELL, J. A. Experiments with mixtures: designs, models, and the analysis of mixture data. John Wiley \& Sons, 2011. 111815049X.

CORREDOR, D.; BEAN, S.; WANG, D. Pretreatment and enzymatic hydrolysis of sorghum bran. Cereal Chemistry, 84, n. 1, p. 61-66, 2007. 
CORTEZ, A.; WILD-ALTAMIRANO, C. Contributions to the limetreated corn flour technology. In: BRESSANI, R.; BRAHAM, J. E.; BÉHAR, M. Nutritional improvement of maize. INCAP Pub, 4, p. 99-106, 1972.

COSTA, K. C.; LEIGH, J. A. Metabolic versatility in methanogens. Current Opinion In Biotechnology, 29, p. 70-75, 2014.

CREPIN, V. F.; FAULDS, C. B.; CONNERTON, I. Functional classification of the microbial feruloyl esterases. Applied Microbiology and Biotechnology, 63, n. 6, p. 647-652, 2004.

CUI, Z.; SHI, J.; LI, Y. Solid-state anaerobic digestion of spent wheat straw from horse stall. Bioresource Technology, 102, n. 20, p. 9432-9437, 2011.

DAI, X.; CHEN, Y.; ZHANG, D.; YI, J. High-solid anaerobic co-digestion of sewage sludge and cattle manure: the effects of volatile solid ratio and pH. Scientific Reports, 6, p. 35194, 2016.

DAVIS, B. J. Disc electrophoresis II. Method and application to human serum proteins. Annals of the New York Academy of Sciences, 121, n. 2, p. 404-427, 1964.

DE GIOANNIS, G.; MUNTONI, A.; POLETTINI, A.; POMI, R. A review of dark fermentative hydrogen production from biodegradable municipal waste fractions. Waste Management, 33, n. 6, p. 1345-1361, 2013.

DE JONG, E.; JUNGMEIER, G. Biorefinery concepts in comparison to petrochemical refineries. In: PANDEY, A.; HOFER, R. LARROCHE, C. Industrial Biorefineries \& White Biotechnology, Elsevier, p. 3-33, 2015.

DE VRIES, R. P.; VISSER, J. Aspergillus enzymes involved in degradation of plant cell wall polysaccharides. Microbiology and Molecular Biology Reviews, 65, n. 4, p. 497-522, 2001.

DE VRIEZE, J.; GILDEMYN, S.; VILCHEZ-VARGAS, R.; JÁUREGUI, R.; PIEPER, D. H.; VERSTRAETE, W.; BOON, N. Inoculum selection is crucial to ensure operational stability in anaerobic digestion. Applied Microbiology and Biotechnology, 99, n. 1, p. 189-199, 2015.

DE VRIEZE, J.; VERSTRAETE, W. Perspectives for microbial community composition in anaerobic digestion: from abundance and activity to connectivity. Environmental Microbiology, 18, n. 9, p. 2797-2809, 2016.

DEJAEGHER, B.; VANDER HEYDEN, Y. Experimental designs and their recent advances in set-up, data interpretation, and analytical applications. Journal of Pharmaceutical and Biomedical Analysis, 56, n. 2, p. 141-158, 2011.

DEMIRER, G.; CHEN, S. Two-phase anaerobic digestion of unscreened dairy manure. Process Biochemistry, 40, n. 11, p. 3542-3549, 2005.

DETTORI-CAMPUS, B.; PRIEST, F.; STARK, J. Hydrolysis of starch granules by the amylase from Bacillus stearothermophilus NCA 26. Process Biochemistry, 27, n. 1, p. 17-21, 1992.

DEUBLEIN, D.; STEINHAUSER, A. Biogas from waste and renewable resources: An introduction. John Wiley \& Sons, 2011. 
DO CARMO LAMAISON, F.; DE ANDRADE, P. A. M.; BIGATON, A. D.; ANDREOTE, F. D.; ANTÔNIO, R. V.; REGINATTO, V. Long-term effect of acid and heat pretreatment of sludge from a sugarcane vinasse treatment plant on the microbial community and on thermophilic biohydrogen production. International Journal of Hydrogen Energy, 40, n. 41, p. 14124-14133, 2015.

DOS SANTOS, A. C.; XIMENES, E.; KIM, Y.; LADISCH, M. R. Lignin-enzyme interactions in the hydrolysis of lignocellulosic biomass. Trends in Biotechnology, 37, n. 5, p. 518-531, 2019.

DOS SANTOS FERREIRA, J.; DE OLIVEIRA, D.; MALDONADO, R. R.; KAMIMURA, E. S.; FURIGO, A. Enzymatic pretreatment and anaerobic co-digestion as a new technology to highmethane production. Applied Microbiology and Biotechnology, p. 1-12, 2020.

DOS SANTOS, I. A.; NOGUEIRA, L. A. H. Estudo energético do esterco bovino: seu valor de substituição e impacto da biodigestão anaeróbia. Revista Agrogeoambiental, 4, n. 1, 2012.

DRAKE, H.; G ÖßNER, A.; DANIEL, S. Old acetogens, new light. Annals of the New York Academy of Sciences, 1125, n. 1, p. 100, 2008.

DUARTE, J.; SILVA, L.; FREIRE, D.; CAMMAROTA, M.; GUTARRA, M. Enzymatic hydrolysis and anaerobic biological treatment of fish industry effluent: Evaluation of the mesophilic and thermophilic conditions. Renewable Energy, 83, p. 455-462, 2015.

EL FANTROUSSI, S.; AGATHOS, S. N. Is bioaugmentation a feasible strategy for pollutant removal and site remediation? Current opinion in microbiology, 8, n. 3, p. 268-275, 2005.

FERRARO, A.; MASSINI, G.; MIRITANA, V. M.; SIGNORINI, A.; RACE, M.; FABBRICINO, M. A simplified model to simulate bioaugmented anaerobic digestion of lignocellulosic biomass: Biogas production efficiency related to microbiological data. Science of The Total Environment, 691, p. 885-895, 2019.

FERRER, I.; VÁZQUEZ, F.; FONT, X. Long term operation of a thermophilic anaerobic reactor: process stability and efficiency at decreasing sludge retention time. Bioresource Technology, 101, n. 9, p. 2972-2980, 2010.

FERRY, J. G. How to make a living by exhaling methane. Annual Review of Microbiology, 64, p. 453-473, 2010.

FERRY, J. G. Methanogenesis: ecology, physiology, biochemistry \& genetics. Springer Science \& Business Media, 2012.

FONSECA, B. C.; GUAZZARONI, M.-E.; REGINATTO, V. Fermentative production of $\mathrm{H}_{2}$ from different concentrations of galactose by the new isolate Clostridium beijerinckii $\mathrm{Br} 21$. International Journal of Hydrogen Energy, 41, n. 46, p. 21109-21120, 2016.

FREESE, M.; SCHMIDT, I.; FISCHER, K. Hemicellulose composition in the outer cell wall layers of paper grade and dissolving pulp. Wiley Online Library, p. 13-18, 2005. 
GALBE, M.; WALLBERG, O.; ZACCHI, G. Techno-economic aspects of ethanol production from lignocellulosic agricultural crops and residues. In: MOO-YOUNG, M. Comprehensive Biotechnology, Elsevier, p. 615-628, 2011.

GALLARDO, O.; FERNÁNDEZ-FERNÁNDEZ, M.; VALLS, C.; VALENZUELA, S. V.; RONCERO, M. B.; VIDAL, T.; DÍAZ, P.; PASTOR, F. J. Characterization of a family GH5 xylanase with activity on neutral oligosaccharides and evaluation as a pulp bleaching aid. Applied and Environmental Microbiology, 76, n. 18, p. 6290-6294, 2010.

GAO, D.; CHUNDAWAT, S. P. S.; KRISHNAN, C.; BALAN, V.; DALE, B. E. Mixture optimization of six core glycosyl hydrolases for maximizing saccharification of ammonia fiber expansion (AFEX) pretreated corn stover. Bioresource Technology, 101, n. 8, p. 2770-2781, 2010.

GAO, R.; LI, Z.; ZHOU, X.; CHENG, S.; ZHENG, L. Oleaginous yeast Yarrowia lipolytica culture with synthetic and food waste-derived volatile fatty acids for lipid production. Biotechnology for Biofuels, 10, n. 1, p. 247, 2017.

GARCIA, N. H.; BENEDETTI, M.; BOLZONELLA, D. Effects of enzymes addition on biogas production from anaerobic digestion of agricultural biomasses. Waste and Biomass Valorization, 10, n. 12, p. 3711-3722, 2019.

GERARDI, M. H. The microbiology of anaerobic digesters. John Wiley \& Sons, 2003.

GIESE, E. C.; DEKKER, R. F.; SCARMINIO, I. S.; BARBOSA, A. M.; DA SILVA, R. Comparison of $\beta-1,3$-glucanase production by Botryosphaeria rhodina MAMB-05 and Trichoderma harzianum Rifai and its optimization using a statistical mixture-design. Biochemical Engineering Journal, 53, n. 2, p. 239-243, 2011.

GILBERT, C. L.; MUGERA, H. K. Competitive storage, biofuels and the corn price. Journal of Agricultural Economics, 71, n. 2, p. 384-411, 2020.

GOHAIN, M.; DEVI, A.; DEKA, D. Musa balbisiana Colla peel as highly effective renewable heterogeneous base catalyst for biodiesel production. Industrial Crops and Products, 109, p. $8-18,2017$.

GOMES, J. R. Viewpoint: Brazil 2020-21 corn outlook uncertain - Argus Media, 2020. Disponível em: https://www.argusmedia.com/en/news/2172568-viewpoint-brazil-202021corn-outlook-uncertain. Acessado em maio de 2021.

GOUX, X.; CALUSINSKA, M.; FOSSÉPRÉ, M.; BENIZRI, E.; DELFOSSE, P. Start-up phase of an anaerobic full-scale farm reactor-Appearance of mesophilic anaerobic conditions and establishment of the methanogenic microbial community. Bioresource Technology, 212, p. 217-226, 2016.

GU, Y.; CHEN, X.; LIU, Z.; ZHOU, X.; ZHANG, Y. Effect of inoculum sources on the anaerobic digestion of rice straw. Bioresource Technology, 158, p. 149-155, 2014.

GÜlLERT, S.; FISCHER, M. A.; TURAEV, D.; NOEBAUER, B.; ILMBERGER, N.; WEMHEUER, B.; ALAWI, M.; RATTEI, T.; DANIEL, R.; SCHMITZ, R. A. Deep 
metagenome and metatranscriptome analyses of microbial communities affiliated with an industrial biogas fermenter, a cow rumen, and elephant feces reveal major differences in carbohydrate hydrolysis strategies. Biotechnology for Biofuels, 9, n. 1, p. 121, 2016.

GUPTA, V.; CARROTT, P.; SINGH, R.; CHAUDHARY, M.; KUSHWAHA, S. Cellulose: a review as natural, modified and activated carbon adsorbent. Bioresource Technology, 216, p. 1066-1076, 2016.

GUPTA, V. K. New and future developments in microbial biotechnology and bioengineering: Aspergillus system properties and applications, Elsevier, 2016.

GUTARRA, M. L.; GODOY, M. G.; CASTILHO, L. R.; FREIRE, D. M. Inoculum strategies for Penicillium simplicissimum lipase production by solid-state fermentation using a residue from the babassu oil industry. Journal of Chemical Technology \& Biotechnology, 82, n. 3, p. 313 318, 2007.

HACH-COMPANY. Determination of FOS/TAC Value in Biogas Reactors. Hach Lange GmbH. DOC316.52.93087. 2015. Disponível em: www.hach.com. Acessado em maio de 2021.

HAGOS, K.; ZONG, J.; LI, D.; LIU, C.; LU, X. Anaerobic co-digestion process for biogas production: progress, challenges and perspectives. Renewable and Sustainable Energy Reviews, 76, p. 1485-1496, 2017.

HAMER, G.; MASON, C. Fundamental aspects of waste sewage sludge treatment: microbial solids biodegradation in an aerobic thermophilic semi-continuous system. Bioprocess Engineering, 2, n. 2, p. 69-77, 1987.

HAN, S.; LIU, Y.; ZHANG, S.; LUO, G. Reactor performances and microbial communities of biogas reactors: effects of inoculum sources. Applied Microbiology and Biotechnology, 100, n. 2, p. 987-995, 2016.

HANRAHAN, G.; LU, K. Application of factorial and response surface methodology in modern experimental design and optimization. Critical Reviews in Analytical Chemistry, 36, n. 3-4, p. 141-151, 2006.

HANSEN, T. L.; SCHMIDT, J. E.; ANGELIDAKI, I.; MARCA, E.; LA COUR JANSEN, J.; MOSBÆK, H.; CHRISTENSEN, T. H. Method for determination of methane potentials of solid organic waste. Waste Management, 24, n. 4, p. 393-400, 2004.

HANZL, I. Effect of different compositions on anaerobic co-digestion of cattle manure and agroindustrial by-products. Agronomy Research, 16, n. 1, p. 176-187, 2018.

HARRIS, D.; DEBOLT, S. Synthesis, regulation and utilization of lignocellulosic biomass. Plant Biotechnology Journal, 8, n. 3, p. 244-262, 2010.

HASSAN, M.; DING, W.; UMAR, M.; RASOOL, G. Batch and semi-continuous anaerobic codigestion of goose manure with alkali solubilized wheat straw: a case of carbon to nitrogen ratio and organic loading rate regression optimization. Bioresource Technology, 230, p. 24-32, 2017. 
HEINEN, P.; PEREIRA, M.; RECHIA, C.; ALMEIDA, P.; MONTEIRO, L.; PASIN, T.; MESSIAS, J.; CEREIA, M.; KADOWAKI, M.; JORGE, J. Immobilized endo-xylanase of Aspergillus tamarii Kita: an interesting biological tool for production of xylooligosaccharides at high temperatures. Process Biochemistry, 53, p. 145-152, 2017.

HERNANDEZ, J. A.; UDDIN, G. S.; DUTTA, A.; AHMED, A.; KANG, S. H. Are ethanol markets globalized or regionalized? Physica A: Statistical Mechanics and its Applications, p. 124094, 2020.

HERRERO, M.; STUCKEY, D. Bioaugmentation and its application in wastewater treatment: a review. Chemosphere, 140, p. 119-128, 2015.

IBGE - Instituto Brasileiro de Geografia e Estatística, 2019. Produção da Pecuária Municipal 2019. Diretoria de Pesquisas, Coordenação de Agropecuária, Pesquisa da Pecuária Municipal 2019. Disponível em:

https://biblioteca.ibge.gov.br/visualizacao/periodicos/84/ppm_2019_v47_br_informativo.pdf. Acessado em maio de 2021.

IOELOVICH, M.; LEYKIN, A. Structural investigations of various cotton fibers and cotton celluloses. BioResources, 3, n. 1, p. 170-177, 2008.

IRMAK, S.; TIRYAKI, O. N. Is it economical and beneficial to produce hydrogen from excess corn kernels? Fuel, 272, p. 117747, 2020.

IZUMI, K.; OKISHIO, Y.-k.; NAGAO, N.; NIWA, C.; YAMAMOTO, S.; TODA, T. Effects of particle size on anaerobic digestion of food waste. International Biodeterioration \& Biodegradation, 64, n. 7, p. 601-608, 2010.

JAFARI, Y.; AMIRI, H.; KARIMI, K. Acetone pretreatment for improvement of acetone, butanol, and ethanol production from sweet sorghum bagasse. Applied Energy, 168, p. 216-225, 2016.

JIN, A.; REN, J.; PENG, F.; XU, F.; ZHOU, G.; SUN, R.; KENNEDY, J. Comparative characterization of degraded and non-degradative hemicelluloses from barley straw and maize stems: composition, structure, and thermal properties. Carbohydrate Polymers, 78, n. 3, p. 609-619, 2009.

JITJAMNONG， J.; THUNYARATCHATANON， C.; LUENGNARUEMITCHAI, A.; KONGRIT, N.; KASETSOMBOON, N.; SOPAJARN, A.; CHUAYKARN, N.; KHANTIKULANON, N. Response surface optimization of biodiesel synthesis over a novel biochar-based heterogeneous catalyst from cultivated (Musa sapientum) banana peels. Biomass Conversion and Biorefinery, p. 1-17, 2020.

JUTURU, V.; WU, J. C. Insight into microbial hemicellulases other than xylanases: a review. Journal of Chemical Technology \& Biotechnology, 88, n. 3, p. 353-363, 2013.

KADAM, P. C.; BOONE, D. R. Influence of $\mathrm{pH}$ on ammonia accumulation and toxicity in halophilic, methylotrophic methanogens. Applied and Environmental Microbiology, 62, n. 12, p. 4486-4492, 1996. 
KAISER, F. Untersuchungen der wirkung von MethaPlus S100 auf die vergärung von maissilage in laborfermentern. Report of Bayerische Landeanstalt für Landwirtschaft, 2004.

KANGLE, K.; KORE, S.; KORE, V.; KULKARNI, G. Recent trends in anaerobic codigestion: a review. Universal Journal of Environmental Research and Technology, 2, n. 4, p. 210-219, 2012.

KARAKATSANIS, A.; LIAKOPOULOU-KYRIAKIDES, M. Comparative study of hydrolysis of various starches by alpha-amylase and glucoamylase in PEG-dextran and PEG-substrate aqueous two phase systems. Starch-Stärke, 50, n. 8, p. 349-353, 1998.

KHAYUM, N.; ANBARASU, S.; MURUGAN, S. Biogas potential from spent tea waste: A laboratory scale investigation of co-digestion with cow manure. Energy, 165, p. 760-768, 2018.

KIM, S.-H.; HAN, S.-K.; SHIN, H.-S. Feasibility of biohydrogen production by anaerobic codigestion of food waste and sewage sludge. International Journal of Hydrogen Energy, 29, n. 15, p. 1607-1616, 2004.

KIMURA, A.; ROBYT, J. F. Reaction of enzymes with starch granules: kinetics and products of the reaction with glucoamylase. Carbohydrate Research, 277, n. 1, p. 87-107, 1995.

KOLBL, S.; PALOCZI, A.; PANJAN, J.; STRES, B. Addressing case specific biogas plant tasks: Industry oriented methane yields derived from 5 L Automatic Methane Potential Test Systems in batch or semi-continuous tests using realistic inocula, substrate particle sizes and organic loading. Bioresource Technology, 153, p. 180-188, 2014.

KONDUSAMY, D.; KALAMDHAD, A. S. Pre-treatment and anaerobic digestion of food waste for high rate methane production - A review. Journal of Environmental Chemical Engineering, 2, n. 3, p. 1821-1830, 2014.

KOTHARI, R.; PANDEY, A.; KUMAR, S.; TYAGI, V.; TYAGI, S. Different aspects of dry anaerobic digestion for bio-energy: An overview. Renewable and Sustainable Energy Reviews, 39, p. 174-195, 2014.

KUMAR, A.; SAMADDER, S. Performance evaluation of anaerobic digestion technology for energy recovery from organic fraction of municipal solid waste: A review. Energy, p. 117253, 2020.

LACKNER, N.; WAGNER, A. O.; MARKT, R.; ILLMER, P. pH and phosphate induced shifts in carbon flow and microbial community during thermophilic anaerobic digestion. Microorganisms, 8, n. 2, p. 286, 2020.

LAMED, R.; SETTER, E.; BAYER, E. A. Characterization of a cellulose-binding, cellulasecontaining complex in Clostridium thermocellum. Journal of Bacteriology, 156, n. 2, p. 828836, 1983.

LAWRENCE, A.-M.; BESIR, H. Staining of proteins in gels with Coomassie G-250 without organic solvent and acetic acid. Journal of Visualized Experiments, n. 30, p. e1350, 2009. 
LAY, J.-J.; LI, Y.-Y.; NOIKE, T. Effect of moisture content and chemical nature on methane fermentation characteristics of municipal solid wastes. Doboku Gakkai Ronbunshu, 1996, n. 552, p. 101-108, 1996.

LEACH, H.; SCHOCH, T. Structure of starch granule II. Action of various amylases on starches. Cereal Chemistry, 38, p. 318-327, 1963.

LEE, W. S.; CHUA, A. S. M.; YEOH, H. K.; NGOH, G. C. A review of the production and applications of waste-derived volatile fatty acids. Chemical Engineering Journal, 235, p. 8399, 2014.

LENNARTSSON, P. R.; ERLANDSSON, P.; TAHERZADEH, M. J. Integration of the first and second generation bioethanol processes and the importance of by-products. Bioresource Technology, 165, p. 3-8, 2014.

LI, D.; LIU, S.; MI, L.; LI, Z.; YUAN, Y.; YAN, Z.; LIU, X. Effects of feedstock ratio and organic loading rate on the anaerobic mesophilic co-digestion of rice straw and cow manure. Bioresource Technology, 189, p. 319-326, 2015.

LI, K.; LIU, R.; CUI, S.; YU, Q.; MA, R. Anaerobic co-digestion of animal manures with corn stover or apple pulp for enhanced biogas production. Renewable Energy, 118, p. 335-342, 2018.

LI, L.; PENG, X.; WANG, X.; WU, D. Anaerobic digestion of food waste: A review focusing on process stability. Bioresource Technology, 248, p. 20-28, 2018.

LI, W.; SIDDHU, M. A. H.; AMIN, F. R.; HE, Y.; ZHANG, R.; LIU, G.; CHEN, C. Methane production through anaerobic co-digestion of sheep dung and waste paper. Energy Conversion and Management, 156, p. 279-287, 2018.

LI, X.-L.; ŠPÁNIKOVÁ, S.; DE VRIES, R. P.; BIELY, P. Identification of genes encoding microbial glucuronoyl esterases. FEBS letters, 581, n. 21, p. 4029-4035, 2007.

LI, Y.; LI, Y.; ZHANG, D.; LI, G.; LU, J.; LI, S. Solid state anaerobic co-digestion of tomato residues with dairy manure and corn stover for biogas production. Bioresource Technology, 217, p. 50-55, 2016.

LI, Y.; WANG, Z.; LI, T.; JIANG, S.; SUN, Z.; JIANG, H.; QIAN, M.; ZHOU, H.; XU, Q. Changes in microbial community and methanogenesis during high-solid anaerobic digestion of ensiled corn stover. Journal of Cleaner Production, 242, p. 118479, 2020.

LI, Y.; ZHAO, J.; KROONEMAN, J.; EUVERINK, G. J. W. Strategies to boost anaerobic digestion performance of cow manure: Laboratory achievements and their full-scale application potential. Science of The Total Environment, p. 142940, 2020.

LIANG, M.-H.; JIANG, J.-G. Advancing oleaginous microorganisms to produce lipid via metabolic engineering technology. Progress in Lipid Research, 52, n. 4, p. 395-408, 2013.

LIMA, M. S.; DAMASIO, A. R. L.; CRNKOVIC, P. M.; PINTO, M. R.; DA SILVA, A. M.; DA SILVA, J. C.; SEGATO, F.; DE LUCAS, R. C.; JORGE, J. A.; POLIZELI, M. L. M. Co- 
cultivation of Aspergillus nidulans recombinant strains produces an enzymatic cocktail as alternative to alkaline sugarcane bagasse pretreatment. Frontiers in Microbiology, 7, p. 583, 2016.

LIN, C. S.; PFALTZGRAFF, L. A.; HERRERO-DAVILA, L.; MUBOFU, E. B.; SOLHY, A.; CLARK, J. H.; KOUTINAS, A. A.; KOPSAHELIS, N.; STAMATELATOU, K.; DICKSON, F. Food Waste as a Valuable Resource for the Production of Chemicals, Materials and Fuels. Current Situation and Perspective. Energy \& Environmental Science, 6, 2013.

LINS, P.; REITSCHULER, C.; ILLMER, P. Methanosarcina spp., the key to relieve the start-up of a thermophilic anaerobic digestion suffering from high acetic acid loads. Bioresource Technology, 152, p. 347-354, 2014.

LISPERGUER, J.; PEREZ, P.; URIZAR, S. Structure and thermal properties of lignins: characterization by infrared spectroscopy and differential scanning calorimetry. Journal of the Chilean Chemical Society, 54, n. 4, p. 460-463, 2009.

LIU, C.; WACHEMO, A. C.; TONG, H.; SHI, S.; ZHANG, L.; YUAN, H.; LI, X. Biogas production and microbial community properties during anaerobic digestion of corn stover at different temperatures. Bioresource Technology, 261, p. 93-103, 2018.

LIU, H.; WANG, J.; LIU, X.; FU, B.; CHEN, J.; YU, H.-Q. Acidogenic fermentation of proteinaceous sewage sludge: effect of pH. Water Research, 46, n. 3, p. 799-807, 2012.

LIU, T.; SUN, L.; MÜLLER, B.; SCHNÜRER, A. Importance of inoculum source and initial community structure for biogas production from agricultural substrates. Bioresource Technology, 245, p. 768-777, 2017.

LUKITAWESA; PATINVOH, R. J.; MILLATI, R.; SÁRVÁRI-HORVÁTH, I.; TAHERZADEH, M. J. Factors influencing volatile fatty acids production from food wastes via anaerobic digestion. Bioengineered, 11, n. 1, p. 39-52, 2020.

LV, Z.; WANG, J.; CHEN, Z.; CHEN, X.; ZHANG, L.; LI, C.; CHEN, Z.; ZHANG, J.; WU, X.; JIA, H. Temperature regulations impose positive influence on the biomethane potential versus digesting modes treating agricultural residues. Bioresource Technology, 301, p. 122747, 2020.

LYND, L. R.; LASER, M. S.; BRANSBY, D.; DALE, B. E.; DAVISON, B.; HAMILTON, R.; HIMMEL, M.; KELLER, M.; MCMILLAN, J. D.; SHEEHAN, J. How biotech can transform biofuels. Nature Biotechnology, 26, n. 2, 2008.

MA, J.; FREAR, C.; WANG, Z.-w.; YU, L.; ZHAO, Q.; LI, X.; CHEN, S. A simple methodology for rate-limiting step determination for anaerobic digestion of complex substrates and effect of microbial community ratio. Bioresource Technology, 134, p. 391-395, 2013.

MADiGAN, M. T.; MARTINKO, J. M.; BENDER, K. S.; BUCKLEY, D. H.; STAHL, D. A. Microbiologia de Brock-14ª Edição. Artmed Editora: Porto Alegre, 2016.

MALGAS, S.; MKABAYI, L.; MATHIBE, B. N.; THORESEN, M.; MAFA, M. S.; LE ROESHILL, M.; VAN ZYL, W. H. E.; PLETSCHKE, B. I. Enzymatic path to bioconversion of lignocellulosic biomass. In: Filho, E. X. F.; Moreira, L. R. S.; Ximenes, E. A.; Farinas, C. S. 
Recent advances in bioconversion of lignocellulose to biofuels and value added chemicals within the biorefinery concept, p. 5-32, 2020.

MANDER, L.; LIU, H.-W. Comprehensive natural products II: Chemistry and Biology. Elsevier, 2010. 0080453821.

MARTÍN, C.; GALBE, M.; NILVEBRANT, N.-O.; JÖNSSON, L. J. Comparison of the fermentability of enzymatic hydrolyzates of sugarcane bagasse pretreated by steam explosion using different impregnating agents. In: Biotechnology for Fuels and Chemicals: Springer, 2002. p. 699-716.

MARTÍNEZ-TRUJILLO, M. A.; BAUTISTA-RANGEL， K.; GARCÍA-RIVERO, M.; MARTÍNEZ-ESTRADA, A.; CRUZ-DÍAZ, M. R. Enzymatic saccharification of banana peel and sequential fermentation of the reducing sugars to produce lactic acid. Bioprocess and Biosystems Engineering, 43, n. 3, p. 413-427, 2020.

MASSART, D.; VANDEGINSTE, B.; BUYDENS, L.; DE JONG, S.; LEWI, P.; SMEYERSVERBEKE, J. Handbook of Chemometrics and Qualimetrics: Part A. Series: Data Handling in Science and Technology Volume 20A, Elsevier: Amsterdam, 1997.

MATSAKAS, L.; CHRISTAKOPOULOS, P. Fermentation of liquefacted hydrothermally pretreated sweet sorghum bagasse to ethanol at high-solids content. Bioresource Technology, 127, p. 202-208, 2013.

MCALOON, A.; TAYLOR, F.; YEE, W.; IBSEN, K.; WOOLEY, R. Determining the cost of producing ethanol from corn starch and lignocellulosic feedstocks. National Renewable Energy Lab., Golden, CO (US), 2000. Disponível em: https://www.nrel.gov/docs/fy01osti/28893.pdf. Acessado em maio de 2021.

MENDES, A. A.; PEREIRA, E. B.; FURIGO JR, A.; CASTRO, H. F. d. Anaerobic biodegradability of dairy wastewater pretreated with porcine pancreas lipase. Brazilian Archives of Biology and Technology, 53, n. 6, p. 1279-1284, 2010.

MENDOZA, D. Proteômica aplicada à caracterização do secretoma de Trichoderma harzianum. 2013. Tese (Doutorado). Universidade de Brasília. Brasília, DF. Miranda, JE, 2013.

MEYER, A. S.; ROSGAARD, L.; SØRENSEN, H. R. The minimal enzyme cocktail concept for biomass processing. Journal of Cereal Science, 50, n. 3, p. 337-344, 2009.

MICHELIN, M.; POLIZELI, M. L. T. M.; RUZENE, D. S.; SILVA, D. P.; VICENTE, A. A.; JORGE, J. A.; TERENZI, H. F.; TEIXEIRA, J. A. Xylanase and $\beta$-xylosidase production by Aspergillus ochraceus: new perspectives for the application of wheat straw autohydrolysis liquor. Applied Biochemistry and Biotechnology, 166, n. 2, p. 336-347, 2012.

MICHELIN, M.; RUÍZ, H. A.; SILVA, D. P. d.; RUZENE, D. S.; TEIXEIRA, J. A.; POLIZELI, M. L. T. M. Cellulose from lignocellulosic waste. In: RAMAWAT, K. G.; MÉRILLON, J-M. Polysaccharides, pp 475-511, 2015. 
MICHELIN, M.; XIMENES, E.; POLIZELI, M. L. T. M.; LADISCH, M. R. Effect of phenolic compounds from pretreated sugarcane bagasse on cellulolytic and hemicellulolytic activities. Bioresource Technology, 199, p. 275-278, 2016.

MILLER, G. L. Use of dinitrosalicylic acid reagent for determination of reducing sugar. Analytical Chemistry, 31, n. 3, p. 426-428, 1959.

MINISTÉRIO - Ministro de Minas e Energia, Assessoria de Comunicação Social. Brasil institui Política Nacional dos Biocombustíveis (RenovaBio), 2018. Disponóvel em: http://antigo.mme.gov.br/. Acessado em meio de 2021.

MLAIK, N.; KHOUFI, S.; HAMZA, M.; MASMOUDI, M. A.; SAYADI, S. Enzymatic prehydrolysis of organic fraction of municipal solid waste to enhance anaerobic digestion. Biomass and Bioenergy, 127, p. 105286, 2019.

MOJOVIĆ, L.; NIKOLIĆ, S.; RAKIN, M.; VUKASINOVIĆ, M. Production of bioethanol from corn meal hydrolyzates. Fuel, 85, n. 12-13, p. 1750-1755, 2006.

MONTEIRO, L. M. O. Estudo bioquímico de beta-glucosidases de Malbranchea pulchella e aplicações na hidrólise de resíduos agroindustriais e de antocianinas. 2016. Dissertação (Mestrado em Ciências) - Faculdade de Medicina de Ribeirão Preto - Universidade de São Paulo, departamento de Bioquímica, São Paulo, 2016.

MONTORO, S.; LUCAS JR, J.; SANTOS, D.; COSTA, M. Anaerobic co-digestion of sweet potato and dairy cattle manure: a technical and economic evaluation for energy and biofertilizer production. Journal of Cleaner Production, 226, p. 1082-1091, 2019.

MORSE, G.; BRETT, S.; GUY, J.; LESTER, J. Phosphorus removal and recovery technologies. Science of the Total Environment, 212, n. 1, p. 69-81, 1998.

MOSIER, N. S. Cellulosic ethanol - biofuel beyond corn. Elsevier. 217-221, 2020.

MURTO, M.; BJÖRNSSON, L.; MATTIASSON, B. Impact of food industrial waste on anaerobic co-digestion of sewage sludge and pig manure. Journal of Environmental Management, 70, n. 2, p. 101-107, 2004.

NEOFYTOU, H.; NIKAS, A.; DOUKAS, H. Sustainable energy transition readiness: A multicriteria assessment index. Renewable and Sustainable Energy Reviews, 131, p. 109988, 2020 .

NESHAT, S. A.; MOHAMMADI, M.; NAJAFPOUR, G. D.; LAHIJANI, P. Anaerobic codigestion of animal manures and lignocellulosic residues as a potent approach for sustainable biogas production. Renewable and Sustainable Energy Reviews, 79, p. 308-322, 2017.

NETO, B. B.; SCARMINIO, I. S.; BRUNS, R. E. Como fazer experimentos. Aplicações na ciência e na indústria. Bookman; Ciencias Biologicas e Naturais edition, Brasil, 2010.

NGUYEN, L. N.; NGUYEN, A. Q.; NGHIEM, L. D. Microbial community in anaerobic digestion system: Progression in microbial ecology. In: BUI, X-T.; CHIEMCHAISRI, C.; FUJIOKA, T.; VARJANI, S. Water and Wastewater Treatment Technologies. Springer, p. 331-355, 2019. 
NIELSEN, C.; RAHMAN, A.; REHMAN, A. U.; WALSH, M. K.; MILLER, C. D. Food waste conversion to microbial polyhydroxyalkanoates. Microbial Biotechnology, 10, n. 6, p. 1338$1352,2017$.

NOVAES, C.; YAMAKI, R.; DE PAULA, V.; DO NASCIMENTO JÚNIOR, B.; BARRETO, J.; VALASQUES, G.; BEZERRA, M. Otimização de métodos analíticos usando metodologia de superfícies de resposta-Parte I: variáveis de processo. Revista Virtual Quimica, 9, n. 3, p. 1284-1215, 2017.

NUNES, L.; CAUSER, T.; CIOLKOSZ, D. Biomass for energy: a review on supply chain management models. Renewable and Sustainable Energy Reviews, 120, p. 109658, 2020.

OBENG, E. M.; ADAM, S. N. N.; BUDIMAN, C.; ONGKUDON, C. M.; MAAS, R.; JOSE, J. Lignocellulases: a review of emerging and developing enzymes, systems, and practices. Bioresources and Bioprocessing, 4, n. 1, p. 16, 2017.

OBEROI, H. S.; VADLANI, P. V.; SAIDA, L.; BANSAL, S.; HUGHES, J. D. Ethanol production from banana peels using statistically optimized simultaneous saccharification and fermentation process. Waste Management, 31, n. 7, p. 1576-1584, 2011.

OEHMEN, A.; LEMOS, P. C.; CARVALHO, G.; YUAN, Z.; KELLER, J.; BLACKALL, L. L.; REIS, M. A. Advances in enhanced biological phosphorus removal: from micro to macro scale. Water Research, 41, n. 11, p. 2271-2300, 2007.

OLIVA-MERENCIO, D.; PEREDA-REYES, I.; SCHIMPF, U.; KOEHLER, S.; SILVA, A. J. d. Cellulase effect on anaerobic digestion of maize silage under discontinuous operation. Engenharia Agrícola, 35, n. 5, p. 951-958, 2015.

OROZCO, R. S.; HERNÁNDEZ, P. B.; MORALES, G. R.; NÚÑEZ, F. U.; VILLAFUERTE, J. O.; LUGO, V. L.; RAMÍREZ, N. F.; DÍAZ, C. E. B.; VÁZQUEZ, P. C. Characterization of lignocellulosic fruit waste as an alternative feedstock for bioethanol production. BioResources, 9, n. 2, p. 1873-1885, 2014.

OSTOVAREH, S.; KARIMI, K.; ZAMANI, A. Efficient conversion of sweet sorghum stalks to biogas and ethanol using organosolv pretreatment. Industrial Crops and Products, 66, p. 170$177,2015$.

OZBAYRAM, E. G.; INCE, O.; INCE, B.; HARMS, H.; KLEINSTEUBER, S. Comparison of rumen and manure microbiomes and implications for the inoculation of anaerobic digesters. Microorganisms, 6, n. 1, p. 15, 2018.

PANDEY, A.; SOCCOL, C. R. Economic utilization of crop residues for value addition: a futuristic approach. Journal of Scientific \& Industrial Research, 59, p. 12-22, 2000.

PANDEY, A.; SOCCOL, C. R.; NIGAM, P.; SOCCOL, V. T. Biotechnological potential of agroindustrial residues. I: sugarcane bagasse. Bioresource Technology, 74, n. 1, p. 69-80, 2000. 
PANIGRAHI, S.; DUBEY, B. K. A critical review on operating parameters and strategies to improve the biogas yield from anaerobic digestion of organic fraction of municipal solid waste. Renewable Energy, 143, p. 779-797, 2019.

PANPONG, K.; SRISUWAN, G.; SOMPONG, O.; KONGJAN, P. Anaerobic co-digestion of canned seafood wastewater with glycerol waste for enhanced biogas production. Energy Procedia, 52, p. 328-336, 2014.

PASIN, T. M.; DE ALMEIDA, P. Z.; SCARCELLA, A. S. A.; INFANTE, J. C. POLIZELI, M. L. T. M. Bioconversion of agro-industrial residues to second-generation bioethanol. In: SONIL, N.; VO, D-V. N.; SARANGI, P. K. Biorefinery of alternative resources: targeting green fuels and platform chemicals: Springer, p. 23-47, 2020.

PATINVOH, R. J.; LUNDIN, M.; TAHERZADEH, M. J.; HORVÁTH, I. S. Dry anaerobic codigestion of citrus wastes with keratin and lignocellulosic wastes: batch and continuous processes. Waste and Biomass Valorization, 11, n. 2, p. 423-434, 2020.

PATINVOH, R. J.; OSADOLOR, O. A.; CHANDOLIAS, K.; HORVÁTH, I. S.; TAHERZADEH, M. J. Innovative pretreatment strategies for biogas production. Bioresource Technology, 224, p. 13-24, 2017.

PAVAN, P.; BOLZONELLA, D.; BATTISTONI, E.; CECCHI, F. Anaerobic co-digestion of sludge with other organic wastes in small wastewater treatment plants: an economic considerations evaluation. Water Science and Technology, 56, n. 10, p. 45-53, 2007.

PAYNE, C. M.; KNOTT, B. C.; MAYES, H. B.; HANSSON, H.; HIMMEL, M. E.; SANDGREN, M.; STAHLBERG, J.; BECKHAM, G. T. Fungal cellulases. Chemical Reviews, 115, n. 3, p. 1308-1448, 2015.

PEIXOTO, G.; PANTOJA-FILHO, J. L. R.; AGNELLI, J. A. B.; BARBOZA, M.; ZAIAT, M. Hydrogen and methane production, energy recovery, and organic matter removal from effluents in a two-stage fermentative process. Applied Biochemistry and Biotechnology, 168, n. 3, p. 651-671, 2012.

PINHEIRO, V. E.; POLIZELI, M. L. T. M. Environmental parameters affecting the anaerobic microbial community. In: Wastewater Treatment Reactors: Elsevier, p. 219-252, 2021.

PISUTPAISAL, N.; BOONYAWANICH, S.; SAOWALUCK, H. Feasibility of biomethane production from banana peel. Energy Procedia, 50, p. 782-788, 2014.

POLIZELI, M. L. T. M.; RIZZATTI, A.; MONTI, R.; TERENZI, H.; JORGE, J. A.; AMORIM, D. Xylanases from fungi: properties and industrial applications. Applied Microbiology and Biotechnology, 67, n. 5, p. 577-591, 2005.

POLIZELI, M. L. T. M.; VICI, A.; SCARCELLA, A.; CEREIA, M.; PEREIRA, M. Enzyme system from Aspergillus in current industrial uses and future applications in the production of second-generation ethanol. In: GUPTA, V. New and Future Developments in Microbial Biotechnology and Bioengineering: Elsevier, p. 127-140, 2016. 
POLIZELI, M. L. T. M.; SOMERA, A. F.; DE LUCAS, R. C.; NOZAWA, M. S. F.; MICHELIN, M. Enzymes involved in the biodegradation of sugarcane biomass: challenges and perspectives. In: BUCKERIDGE, M. S.; DE SOUZA, A. P. Advances of basic science for second generation bioethanol from sugarcane: Springer, p. 55-79, 2017.

PRATES, E. T. Dinâmica molecular de hidrolases para sacarificação: de celulose e proteínas correlatas. 2013. Tese (Doutorado) - Universidade Estadual de Campinas, Instituto de Química, Campinas, SP, 2013.

QUÉMÉNEUR, M.; HAMELIN, J.; BARAKAT, A.; STEYER, J.-P.; CARRÈRE, H.; TRABLY, E. Inhibition of fermentative hydrogen production by lignocellulose-derived compounds in mixed cultures. International Journal of Hydrogen Energy, 37, n. 4, p. 3150-3159, 2012.

RABII, A.; ALDIN, S.; DAHMAN, Y.; ELBESHBISHY, E. A review on anaerobic co-digestion with a focus on the microbial populations and the effect of multi-stage digester configuration. Energies, 12, n. 6, p. 1106, 2019.

RAMOS, L. P.; DA SILVA, L.; BALlEM, A. C.; PITARELO, A. P.; CHIARELlO, L. M.; SILVEIRA, M. H. L. Enzymatic hydrolysis of steam-exploded sugarcane bagasse using high total solids and low enzyme loadings. Bioresource Technology, 175, p. 195-202, 2015.

RAUSCH, K. D.; BELYEA, R.; ELLERSIECK, M.; SINGH, V.; JOHNSTON, D.; TUMBLESON, M. E. Particle size distributions of ground corn and DDGS from dry grind processing. Transactions of the ASAE, 48, n. 1, p. 273-277, 2005.

RAVINDRAN, R.; JAISWAL, A. K. A comprehensive review on pre-treatment strategy for lignocellulosic food industry waste: challenges and opportunities. Bioresource Technology, 199, p. 92-102, 2016.

REDENBACH, M.; KIESER, H. M.; DENAPAITE, D.; EICHNER, A.; CULLUM, J.; KINASHI, H.; HOPWOOD, D. A set of ordered cosmids and a detailed genetic and physical map for the $8 \mathrm{Mb}$ Streptomyces coelicolor A3 (2) chromosome. Molecular Microbiology, 21, n. 1, p. 77 96, 1996.

REHMAN, S.; ASLAM, H.; AHMAD, A.; KHAN, S. A.; SOHAIL, M. Production of plant cell wall degrading enzymes by monoculture and co-culture of Aspergillus niger and Aspergillus terreus under SSF of banana peels. Brazilian Journal of Microbiology, 45, n. 4, p. 1485-1492, 2014.

RIZZATTI, A.; JORGE, J.; TERENZI, H.; RECHIA, C.; POLIZELI, M. Purification and properties of a thermostable extracellular $\beta$-D-xylosidase produced by a thermotolerant Aspergillus phoenicis. Journal of Industrial Microbiology and Biotechnology, 26, n. 3, p. 156-160, 2001.

ROBLES, G.; NAIR, R. B.; KLEINSTEUBER, S.; NIKOLAUSZ, M.; HORVÁTH, I. S. Biogas production: microbiological aspects. In: TABATABAEI, M.; GHANAVATI, H. Biogas: Springer, p. 163-198, 2018.

ROSENFELD, J. S. Functional redundancy in ecology and conservation. Oikos, 98, n. 1, p. 156$162,2002$. 
RUIZ-HERRERA, J. Fungal cell wall: structure, synthesis, and assembly. CRC press, 2 ed., pp. 203, 1991.

SANTOS, C. A.; FERREIRA-FILHO, J. A.; O’DONOVAN, A.; GUPTA, V. K.; TUOHY, M. G.; SOUZA, A. P. Production of a recombinant swollenin from Trichoderma harzianum in Escherichia coli and its potential synergistic role in biomass degradation. Microbial Cell Factories, 16, n. 1, p. 1-11, 2017.

SATPATHY, P.; STEINIGEWEG, S.; CYPIONKA, H.; ENGELEN, B. Different substrates and starter inocula govern microbial community structures in biogas reactors. Environmental Technology, 37, n. 11, p. 1441-1450, 2016.

SCHINK, B. Energetics of syntrophic cooperation in methanogenic degradation. Microbiology and Molecular Biology Reviews, 61, n. 2, p. 262-280, 1997.

SCHLENK, F. Early research on fermentation - a story of missed opportunities. Trends in Biochemical Sciences, 10, n. 6, p. 252-254, 1985.

SCHOEN, M. A.; SPERL, D.; GADERMAIER, M.; GOBERNA, M.; FRANKE-WHITTLE, I.; INSAM, H.; ABLINGER, J.; WETT, B. Population dynamics at digester overload conditions. Bioresource Technology, 100, n. 23, p. 5648-5655, 2009.

SCREMIN, L. B. Controle analítico das perdas ligno (hemi) celulósicas durante a derivatização química do bagaço de cana. 2014. Trabalho de Conclusão de Curso (Graduação) - Universidade Tecnológica Federal do Paraná, Curitiba, 2014.

SEPPÄLÄ, M.; PYYKKÖNEN, V.; VÄISÄNEN, A.; RINTALA, J. Biomethane production from maize and liquid cow manure - Effect of share of maize, post-methanation potential and digestate characteristics. Fuel, 107, p. 209-216, 2013.

SHAFIEI, M.; KARIMI, K.; TAHERZADEH, M. J. Techno-economical study of ethanol and biogas from spruce wood by NMMO-pretreatment and rapid fermentation and digestion. Bioresource Technology, 102, n. 17, p. 7879-7886, 2011.

SHAH, F. A.; MAHMOOD, Q.; RASHID, N.; PERVEZ, A.; RAJA, I. A.; SHAH, M. M. Codigestion, pretreatment and digester design for enhanced methanogenesis. Renewable and Sustainable Energy Reviews, 42, p. 627-642, 2015.

SHAHBANDEH, M. Corn production worldwide 2018/2019, by country. Statista, 2020. Disponível em: https://www.statista.com/statistics/254292/global-corn-production-bycountry/. Acessado em maio de 2021.

SHALlOM, D.; SHOHAM, Y. Microbial hemicellulases. Current Opinion in Microbiology, 6, n. 3, p. 219-228, 2003.

SHARMA, A.; VIVEKANAND, V.; SINGH, R. P. Solid-state fermentation for gluconic acid production from sugarcane molasses by Aspergillus niger ARNU-4 employing tea waste as the novel solid support. Bioresource Technology, 99, n. 9, p. 3444-3450, 2008. 
SHEN, S.; NGES, I. A.; YUN, J.; LIU, J. Pre-treatments for enhanced biochemical methane potential of bamboo waste. Chemical Engineering Journal, 240, p. 253-259, 2014.

SIPOS, B.; RÉCZEY, J.; SOMORAI, Z.; KÁDÁR, Z.; DIENES, D.; RÉCZEY, K. Sweet sorghum as feedstock for ethanol production: enzymatic hydrolysis of steam-pretreated bagasse. Applied Biochemistry and Biotechnology, 153, n. 1-3, p. 151-162, 2009.

SLUITER, A.; HAMES, B.; RUIZ, R.; SCARLATA, C.; SLUITER, J.; TEMPLETON, D.; CROCKER, D. Determination of structural carbohydrates and lignin in biomass. Laboratory Analytical Procedure, Technical Report NREL/TP-510-42618, 2008.

SLUITER, A.; RUIZ, R.; SCARLATA, C.; SLUITER, J.; TEMPLETON, D. Determination of extractives in biomass. Laboratory analytical procedure, Technical Report NREL/TP-51042619, 2005.

SOARES, J. L.; CAMMAROTA, M. C.; GUTARRA, M. L. E.; VOLSCHAN, I. Reduction of scum accumulation through the addition of low-cost enzymatic extract in the feeding of highrate anaerobic reactor. Water Science and Technology, 80, n. 1, p. 67-74, 2019.

SONG, Z.; ZHANG, C. Anaerobic codigestion of pretreated wheat straw with cattle manure and analysis of the microbial community. Bioresource Technology, 186, p. 128-135, 2015.

STAMENKOVIĆ, O. S.; SILIVERU, K.; VELJKOVIĆ, V. B.; BANKOVIĆ-ILIĆ, I. B.; TASIĆ, M. B.; CIAMPITTI, I. A.; ĐALOVIĆ, I. G.; MITROVIĆ, P. M.; SIKORA, V. Š.; PRASAD, P. V. Production of biofuels from sorghum. Renewable and Sustainable Energy Reviews, 124, p. 109769, 2020.

STOLZE, Y.; BREMGES, A.; MAUS, I.; PÜHLER, A.; SCZYRBA, A.; SCHLÜTER, A. Targeted in situ metatranscriptomics for selected taxa from mesophilic and thermophilic biogas plants. Microbial Biotechnology, 11, n. 4, p. 667-679, 2018.

STRAZZERA, G.; BATTISTA, F.; GARCIA, N. H.; FRISON, N.; BOLZONELLA, D. Volatile fatty acids production from food wastes for biorefinery platforms: a review. Journal of Environmental Management, 226, p. 278-288, 2018.

STROOT, P. G.; MCMAHON, K. D.; MACKIE, R. I.; RASKIN, L. Anaerobic codigestion of municipal solid waste and biosolids under various mixing conditions - I. Digester performance. Water Research, 35, n. 7, p. 1804-1816, 2001.

SUWANNARANGSEE, S.; BUNTERNGSOOK, B.; ARNTHONG, J.; PAEMANEE, A.; THAMCHAIPENET, A.; EURWILAICHITR, L.; LAOSIRIPOJANA, N.; CHAMPREDA, V. Optimisation of synergistic biomass-degrading enzyme systems for efficient rice straw hydrolysis using an experimental mixture design. Bioresource Technology, 119, p. 252-261, 2012.

SWITZENBAUM, M. S.; GIRALDO-GOMEZ, E.; HICKEY, R. F. Monitoring of the anaerobic methane fermentation process. Enzyme and Microbial Technology, 12, n. 10, p. 722-730, 1990. 
TAHERZADEH, M. J.; KARIMI, K. Pretreatment of lignocellulosic wastes to improve ethanol and biogas production: a review. International Journal of Molecular Sciences, 9, n. 9, p. 1621-1651, 2008.

TAHERZADEH, M. J.; LENNARTSSON, P. R.; TEICHERT, O.; NORDHOLM, H. Bioethanol production processes. Biofuels Production, p. 211-253, 2013.

TASNIM, F.; IQBAL, S. A.; CHOWDHURY, A. R. Biogas production from anaerobic codigestion of cow manure with kitchen waste and Water Hyacinth. Renewable Energy, 109, p. 434-439, 2017.

TAULER, R.; WALCZAK, B. Comprehensive chemometrics: chemical and biochemical data analysis. TAULER, R.; WALCZAK, R. (Editors): Elsevier, pp. 2896, 2009.

TEGHAMMAR, A.; YNGVESSON, J.; LUNDIN, M.; TAHERZADEH, M. J.; HORVÁTH, I. S. Pretreatment of paper tube residuals for improved biogas production. Bioresource Technology, 101, n. 4, p. 1206-1212, 2010.

TETER, S.; SUTTON, K. B.; EMME, B. Enzymatic processes and enzyme development in biorefining. In: WALDRON, K. W. Advances in biorefineries: Elsevier, p. 199-233, 2014.

THAKUR, A.; SHARMA, K.; GOYAL, A. $\alpha$-L-arabinofuranosidase: a potential enzyme for the food industry. In: PARAMESWARAN, B.; VARJANI, S.; RAVEENDRAN, S. Green bioprocesses: Springer, p. 229-244, 2019.

THEMELIS, N. J.; KIM, Y. H. Material and energy balances in a large-scale aerobic bioconversion cell. Waste Management \& Research, 20, n. 3, p. 234-242, 2002.

THEUERL, S.; KLANG, J.; HEIERMANN, M.; DE VRIEZE, J. Marker microbiome clusters are determined by operational parameters and specific key taxa combinations in anaerobic digestion. Bioresource Technology, 263, p. 128-135, 2018.

TIRYAKI, O. N.; IRMAK, S.; RAMCHANDRAN, D.; SUBBIAH, J.; MORTON, M. Utilization of excess corn kernels for hydrogen gas biofuel production. International Journal of Hydrogen Energy, 44, n. 57, p. 29956-29963, 2019.

VALLADAO, A.; SARTORE, P.; FREIRE, D.; CAMMAROTA, M. Evaluation of different prehydrolysis times and enzyme pool concentrations on the biodegradability of poultry slaughterhouse wastewater with a high fat content. Water Science and Technology, 60, n. 1, p. 243-249, 2009.

VALLADÃO, A.; TORRES, A.; FREIRE, D.; CAMMAROTA, M. Profiles of fatty acids and triacylglycerols and their influence on the anaerobic biodegradability of effluents from poultry slaughterhouse. Bioresource Technology, 102, n. 14, p. 7043-7050, 2011.

VASQUEZ, S. T.; DUNKLEMAN, J.; CHAUDHURI, S. K.; BOND, A.; HOLTZAPPLE, M. T. Biomass conversion to hydrocarbon fuels using the MixAlco ${ }^{\mathrm{TM}}$ process at a pilot-plant scale. Biomass and Bioenergy, 62, p. 138-148, 2014. 
VENKITESHWARAN, K.; BOCHER, B.; MAKI, J.; ZITOMER, D. Relating anaerobic digestion microbial community and process function: supplementary issue: water microbiology. Microbiology Insights, 8, p. MBI. S33593, 2015.

VIERHOUT, R. Renewable ethanol: driving jobs, growth and innovation throughout Europe. State of the Industry Report. ePure European Renewable Ethanol Association, 2014. Disponível em: https://www.liquid-energy.ch/wp/wp-content/uploads/2014-06-14-Ethanol-State-of-theIndustry-Report-2014.pdf. Acessado em maio de 2021.

VLASENKO, E.; SCHÜLEIN, M.; CHERRY, J.; XU, F. Substrate specificity of family 5, 6, 7, 9, 12, and 45 endoglucanases. Bioresource Technology, 101, n. 7, p. 2405-2411, 2010.

WAGNER, A. O.; LACKNER, N.; MUTSCHLECHNER, M.; PREM, E. M.; MARKT, R.; ILLMER, P. Biological pretreatment strategies for second-generation lignocellulosic resources to enhance biogas production. Energies, 11, n. 7, p. 1797, 2018.

WAINAINA, S. Developing a food waste-based volatile fatty acids platform using an immersed membrane bioreactor. 2020. Tese (Doutorado) - Swedish Centre for Resource Recovery, University of Borås, Sweden, 2020.

WAINAINA, S.; KISWORINI, A. D.; FANANI, M.; WIKANDARI, R.; MILLATI, R.; NIKLASSON, C.; TAHERZADEH, M. J. Utilization of food waste-derived volatile fatty acids for production of edible Rhizopus oligosporus fungal biomass. Bioresource Technology, 310 , p. $123444,2020$.

WAINAINA, S.; LUKITAWESA; KUMAR AWASTHI, M.; TAHERZADEH, M. J. Bioengineering of anaerobic digestion for volatile fatty acids, hydrogen or methane production: a critical review. Bioengineered, 10, n. 1, p. 437-458, 2019.

WALL, J. S.; BLESSIN, C. W. Composition of sorghum plant and grain. Sorghum Production and Utilization, p. 118-166, 1970.

WANG, P.; WANG, H.; QIU, Y.; REN, L.; JIANG, B. Microbial characteristics in anaerobic digestion process of food waste for methane production - a review. Bioresource Technology, 248, p. 29-36, 2018.

WANG, Z.; JIANG, Y.; WANG, S.; ZHANG, Y.; HU, Y.; HU, Z.-h.; WU, G.; ZHAN, X. Impact of total solids content on anaerobic co-digestion of pig manure and food waste: insights into shifting of the methanogenic pathway. Waste Management, 114, p. 96-106, 2020.

WBA, World Bioenergy Association. WBA Global Bioenergy Statistics 2020, 2020. Disponível em: http://www.worldbioenergy.org/global-bioenergy-statistics/. Acessado em maio de 2021.

WESTERHOLM, M.; SCHNÜRER, A. Microbial responses to different operating practices for biogas production systems. Anaerobic Digestion, p. 1-36, 2019.

WILSON, D. B.; KOSTYLEV, M. Cellulase processivity. In: BASKAR, C.; BASKAR, S.; DHILLON, R. Biomass Conversion: Springer, p. 93-99, 2012. 
WORM, P.; MÜLlER, N.; PlUGGE, C. M.; STAMS, A. J.; SCHINK, B. Syntrophy in methanogenic degradation. In: HACKSTEIN, J. H. P. (Endo) symbiotic methanogenic archaea: Springer, p. 143-173, 2010.

XING, B.-S.; CAO, S.; HAN, Y.; WEN, J.; ZHANG, K.; WANG, X. C. Stable and high-rate anaerobic co-digestion of food waste and cow manure: optimisation of start-up conditions. Bioresource Technology, p. 123195, 2020.

XU, H.; YUN, S.; WANG, C.; WANG, Z.; HAN, F.; JIA, B.; CHEN, J.; LI, B. Improving performance and phosphorus content of anaerobic co-digestion of dairy manure with aloe peel waste using vermiculite. Bioresource Technology, 301, p. 122753, 2020.

ZAHER, U.; LI, R.; JEPPSSON, U.; STEYER, J.-P.; CHEN, S. GISCOD: general integrated solid waste co-digestion model. Water Research, 43, n. 10, p. 2717-2727, 2009.

ZEHNDER, A. J.; MITCHELL, R. Ecology of methane formation. Water Pollution Microbiology, 2, p. 349-376, 1978.

ZHANG, C.; SU, H.; BAEYENS, J.; TAN, T. Reviewing the anaerobic digestion of food waste for biogas production. Renewable and Sustainable Energy Reviews, 38, p. 383-392, 2014.

ZHOU, J.; ZHANG, Y.; KHOSHNEVISAN, B.; DUAN, N. Meta-analysis of anaerobic codigestion of livestock manure in last decade: Identification of synergistic effect and optimization synergy range. Applied Energy, 282, p. 116128, 2021. 


\section{$\underline{\text { Apêndices }}$}




\title{
Apêndice 1
}

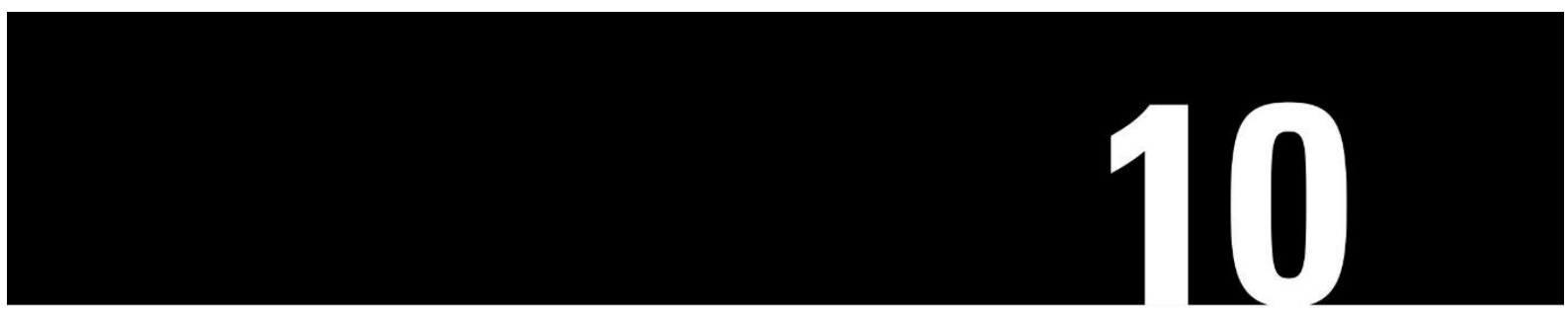

\section{Environmental parameters affecting the anaerobic microbial community}

\author{
Vanessa Elisa Pinheiro ${ }^{1,2}$ and Maria de Lourdes Teixeira \\ de Moraes Polizeli ${ }^{1,3}$ \\ ${ }^{1}$ Department of Biochemistry and Immunology, Ribeirão Preto Medical \\ School, University of São Paulo, São Paulo, Brazil ${ }^{2}$ Swedish Centre for \\ Resource Recovery, University of Borås, Borås, Sweden ${ }^{3}$ Department of \\ Biology, Faculty of Philosophy, Science and Letters of Ribeirão Preto, \\ University of São Paulo, São Paulo, Brazil
}

\subsection{Introduction}

As the world's population continues to grow, it is necessary to find ways to develop practical wastewater treatment methods while reducing the dependence on fossil fuels (Westerholm and Schnürer, 2019). Anaerobic digestion (AD) is an extensive industrial fermentation technology based on biological, natural, and sustainable processes which can remove organic pollutants from waste and wastewater and generate energy (Maroun and El Fadel, 2007; Appels et al., 2008; Tian et al., 2015; Robles et al., 2018; Feng et al., 2019; Li et al., 2019).

In fact, historical evidence indicates that the $\mathrm{AD}$ process is one of the oldest technologies that communities have taken advantage of the benefits, since mid-900 BCE, when the natural gas coming from mud was used to heat water baths in Assyria. It was Jan Baptita Van Helmont, who in the 17th century first determined decaying organic matter could produce flammable gases. Nevertheless, the industrialization of $\mathrm{AD}$ began in 1859 in Bombay (India), with the development of the first digestion plant. Since then, as the understanding of $\mathrm{AD}$ process improved, more operational techniques and applications emerged (Abbasi et al., 2012).

Nowadays, due to AD's wide range of applications in energy, biotechnological, pharmaceutical, and waste sludge treatment industries (Fig. 10.1), there is an extensive amount of research 
Figure 10.1 Anaerobic digestion (AD) is being applied in a wide range of industrial sectors.

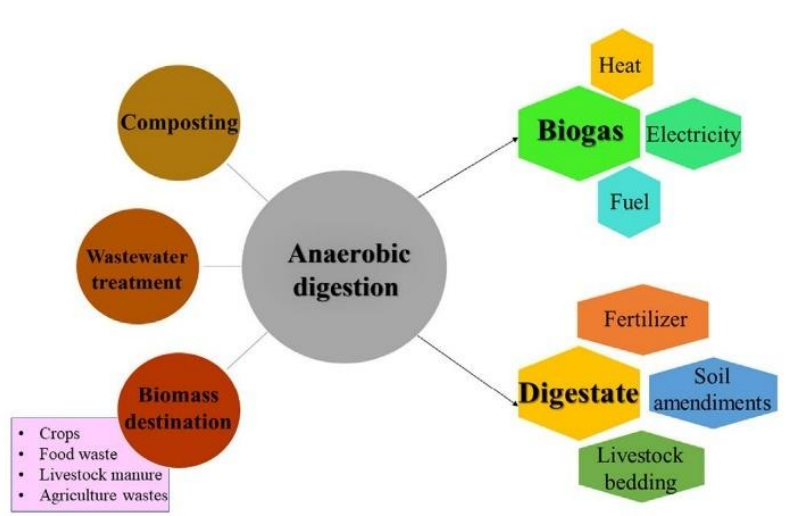

being generated in the $\mathrm{AD}$ field. However, the microbiological shifts of this system are still only partially known.

In order to optimize the $\mathrm{AD}$ process, it is vital to know and understand how the microorganisms adapt to operating fluctuations (Westerholm and Schnürer, 2019; Li et al., 2019) since the microbial community is a complex system in which species are incessantly restructuring their ecological properties and interactions in response to these disturbances (Allison and Martiny, 2008). As the dynamic effect of resistance and resilience of microorganisms in $\mathrm{AD}$ are obscure, this limits the applicability of targeted methods for enhancing the system in industries (Kovalovszki et al., 2020). This chapter was, therefore, prepared to summarize the current research and knowledge focusing on the conceptual impacts of different operating strategies on the microbial community in $\mathrm{AD}$, aiming to draw a scenario around the key drivers of this system.

\subsection{Biochemistry of AD}

$\mathrm{AD}$ of organic compounds is a naturally occurring process. The biological waste treatment systems are the technological application of this procedure. It is based on the activity of microorganisms, under anaerobic and controlled operating conditions, aiming at the biological conversion of complex organic matter into simpler chemical compounds, mainly methane, which was discovered in 1776 by Alessandro Volta, through the observation of bubbles coming from mud as a result of plant remains decomposition (Zehnder, 1978). 
The biochemistry of anaerobic decomposition is synergistically performed by groups of microorganisms distributed into four main stages: hydrolysis, acidogenesis, acetogenesis, and methanogenesis (Fig. 10.2) (Robles et al., 2018; Wang et al., 2018a; Li et al., 2019).

Hydrolysis is the first step, in which complex organic biomass that cannot be directly utilized by microorganisms is decomposed into soluble shorter compost (Meegoda et al., 2018; Li et al., 2019).

Hydrolytic bacteria are characterized to produce cellulosome, a special multienzyme complex able to secret different hydrolases, such as glucanases, hemicellulases, chitinases, and others (Lamed et al., 1983). Thus the presence of these and other different extracellular enzymes (proteases, lipases, amylases, pectinases, etc.) produced by specialized bacteria and also by filamentous fungi and yeasts allows the partial or complete conversion of polymers by the hydrolysis process. So, polymers, such as polysaccharides, lipids, and proteins are converted into soluble shorter molecules, that is, long-chain fatty acids (LCFA) produce glycerol and short-chain fatty acid, hydrolyzed proteins produce amino acids and oligopeptides, and hydrolyzed sugars produce mono-, di-, and oligosaccharides

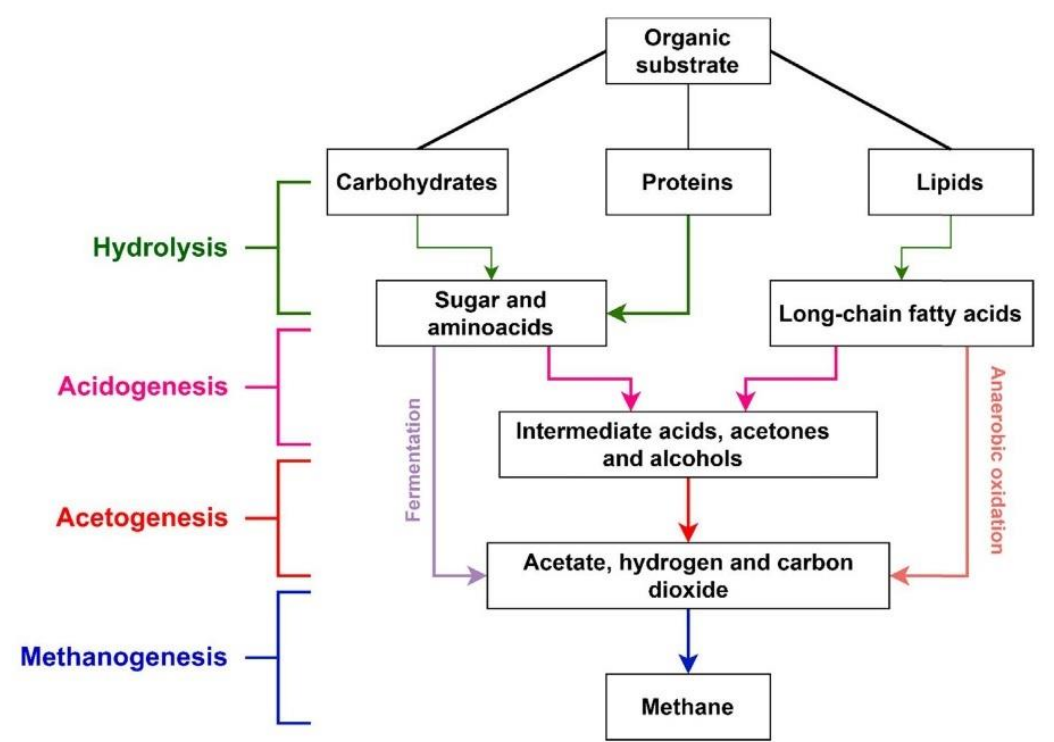

Figure 10.2 Main steps and pathways of the AD process. Source: Vanessa Elisa Pinheiro. 
Table 10.1 Important groups of hydrolytic enzymes and their substrates and products.

\begin{tabular}{|c|c|c|c|}
\hline Enzyme & Target & Breakdown products & References \\
\hline Endopeptidase (EC 3.4.21.-) & $\begin{array}{l}\text { Intramolecular polypeptide } \\
\text { bonds }\end{array}$ & Amino acids & $\begin{array}{l}\text { Vermelho et al. (2008); } \\
\text { Polizeli et al. (2012) }\end{array}$ \\
\hline Exopeptidase (EC 3.4.11.-) & Ending bonds & & \\
\hline Cellobiohydrolase (EC 3.2.1.91) & $\begin{array}{l}\beta-1,4 \text {-glycoside bonds in } \\
\text { nonreducing and reducing ends }\end{array}$ & Cellobiose & $\begin{array}{l}\text { Michelin et al. (2013); } \\
\text { Polizeli et al. (2017); }\end{array}$ \\
\hline Endoglucanase (EC 3.2.1.4) & $\begin{array}{l}\text { Intramolecular 3-1,4-glycoside } \\
\text { bonds }\end{array}$ & Cellobiose & Monteiro et al. (2019) \\
\hline$\beta$-glucosidase (EC 3.2.1.21) & Cellobiose and cellodextrins & Glucose & \\
\hline Endo-3-1.4-xylanase (EC 3.2.1.8) & $\begin{array}{l}\text { Intramolecular } 3-1,4 \text { xylan } \\
\text { bonds }\end{array}$ & Xylose, xylooligosaccharides & $\begin{array}{l}\text { Polizeli et al. (2017); Heinen } \\
\text { et al. (2017); Pasin et al. }\end{array}$ \\
\hline$\beta$-D-xylosidase (EC 3.2.1.37) & $\begin{array}{l}\beta-1,4-D-x y l a n \\
\text { xylooligosaccharides, xylobiose } \\
\text { bonds in nonreducing end }\end{array}$ & Xylose & $(2020)$ \\
\hline Arabinanase (EC 3.2.1.99) & $\alpha-1,5$-arabinofuranosidic bonds & Arabinose or arabino oligomers & \\
\hline Arabinofuranosidase (EC 3.2.1.55) & $\begin{array}{l}\alpha-1,2-, \alpha-1,3-\text {, and } \alpha-1,5--1 \\
\text { arabinofuranosidic bonds }\end{array}$ & Arabino furanose residues & \\
\hline $\begin{array}{l}\text { Endo-1,4-3-mannosidase (EC } \\
3.2 .1 .78 \text { ) }\end{array}$ & $\begin{array}{l}\text { 1,4- } \beta \text {-Mannan, glucomannan, } \\
\text { galactomannan bonds }\end{array}$ & Mannose & \\
\hline$\beta$-mannosidase (EC 3.2.1.25) & Nonreducing end from mannan & Mannose & \\
\hline $\begin{array}{l}\text { Pectin methyl esterase } \\
\text { (EC 3.1.1.11) }\end{array}$ & Methoxyl groups from pectin & Methanol and pectic acid & $\begin{array}{l}\text { Polizeli et al. (2013); Pinheiro } \\
\text { et al. (2017) }\end{array}$ \\
\hline $\begin{array}{l}\text { Polymethylgalacturonase } \\
\text { (EC 4.2.2.10) }\end{array}$ & $\alpha-1,4$ pectin bonds & 6-methyl-D-galacturonate & \\
\hline Polygalacturonase (EC 3.2.1.15) & $\alpha-1,4$ pectic acid bonds & D-galacturonate & \\
\hline Pectin Lyase (EC 4.2.2.10) & $\alpha-1,4$ pectin bonds & 6-methyl- $\Delta-4,5-\mathrm{D}$-galacturonate & \\
\hline Pectate Lyase (EC 4.2.2.2) & $\alpha-1,4$ pectic acid bonds & $\Delta-4,5-\mathrm{D}$-galacturonate & \\
\hline$\alpha$-amylase (EC 3.2.1.1) & $\begin{array}{l}\alpha-1,4 \text { amylose and amylopectin } \\
\text { bonds }\end{array}$ & Malto-oligosaccharides & $\begin{array}{l}\text { Polizeli et al. (2016); Almeida } \\
\text { et al. }(2017,2018)\end{array}$ \\
\hline$\alpha$-glucosidade (EC 3.2.1.20) & $\begin{array}{l}\alpha-1,4 \text { amylolytic bonds in } \\
\text { nonreducing ends }\end{array}$ & D-glucose & \\
\hline$\beta$-amylase (EC 3.2.1.2) & $\begin{array}{l}\alpha-1,4 \text { amylolytic bonds in } \\
\text { nonreducing ends }\end{array}$ & Maltose & \\
\hline Isoamylase (EC 3.2.1.68) & $\alpha-1,6$ amylolytic branching & Glucose, maltose, trehalose & \\
\hline Glucoamylase (EC 3.2.1.3) & $\begin{array}{l}\alpha-1,4 \text { and } \alpha-1,6 \text { amylolytic } \\
\text { bonds in nonreducing ends }\end{array}$ & $\beta$-D-glucose & \\
\hline Nonspecific lipases (EC 3.1.1.-) & Triacylglycerol & Fatty acids and glycerol & Pérez et al. (2019) \\
\hline Specific lipases (EC 3.1.1.3) & $\begin{array}{l}\text { 1- and 3-positions of } \\
\text { acylglycerols }\end{array}$ & $\begin{array}{l}\text { 1,2(2,3)-diacylglycerols, } \\
\text { 2-monoacylglycerols }\end{array}$ & \\
\hline
\end{tabular}

(Bryant, 1979; Smith, 1966; Shah et al., 2014). Table 10.1 summarizes the important groups of extracellular enzymes and their released products.

The soluble monomers are formed by hydrolysis, when inside the cells of acidogenic bacteria or some fungi, larger 
compounds are converted to compounds of one to five carbon units. The typical products of acidogenesis are short-chain volatile fatty acids (VFAs), propionic, butyric and, valeric acid, but other products, such as alcohol, carbon dioxide, ammonia, and hydrogen can be generated depending on the substrate.

Product formation in acidogenesis is limited by the partial pressure of hydrogen. The favorable pathway of fermentative bacteria is an acetate production via pyruvate (with the production of hydrogen). However, if the environmental conditions are not desirable, the partial hydrogen pressure can become high, and more intermediates, such as other VFAs and alcohols are produced (Schink, 1997; Robles et al., 2018). Acidogenesis generally proceeds at a faster rate than all other stages in $\mathrm{AD}$ (Deublein \& Steinhauser, 2008). With its rapidity, VFA acidification is widely reported to be a cause of digester failure (Akuzawa et al., 2011).

The next stage is the acetogenesis. Obligatory hydrogenproducing bacteria convert VFAs and alcohols to acetate, hydrogen, and carbon dioxide (Schink, 1997; Bryant, 1979). However, acetogens can also directly convert products from hydrolysis (sugars and amino acids) and even pyruvate to acetate (Drake et al., 2008; Worm et al., 2010).

Many reactions in acetogenesis, such as oxidation of organic acids and LCFA, only proceed under low hydrogen partial pressure due to thermodynamics (Schink, 1997). A central syntrophic association between the hydrogen-producing bacteria and methane-producing archaea has been reported. Hydrogenotrophic methanogens can rapidly consume the hydrogen produced by the acetogenic microorganisms, and as a consequence, the partial pressure of hydrogen is maintained at a favorable level for acetogenesis, and the system is not interrupted (Robles et al., 2018; Wang et al., 2018a; Li et al., 2020a).

Methanogenesis characterizers the final stage of AD. Intermediates, that is, acetate, $\mathrm{CO}_{2}$, or methylated compounds, are consumed by methanogenic archaea and result in methane production (Ferry, 2010). Acetoclastic methanogenesis split acetate into methyl groups and $\mathrm{CO}_{2}$. The former is reduced to methane using an electron provided by the carboxyl group. The $\mathrm{CO}_{2}$ in turn is reduced to methane by hydrogenotrophic methanogens, using $\mathrm{H}_{2}$ or formate as electron donors. Methylated compounds have the methyl group reduced to methane during methanogenesis by methylotrophic methanogens, which obtain the electron from the oxidation of methyl groups to $\mathrm{CO}_{2}$ (Liu and Whitman, 2008; Costa and Leigh, 2014). 


\subsection{Microbial community in AD}

The biomass decomposition occurs due to specific metabolic pathways involving microbial enzymatic machinery. Although $\mathrm{AD}$ is an established technology, the stability and highperformance of the digester is still a challenge on account of the complexity of the microorganisms involved in the process.

Technical advances aiming to explore microbial communities have been conducted. A central understanding of $\mathrm{AD}$ has been developed with recent progress in culture-independent techniques and the development of meta-omics approaches, that is, metagenomics, metatranscriptomics, metaproteomics, and metabolomics (Sikora et al., 2019; Nguyen et al., 2019a).

Corresponding to the four phases in $\mathrm{AD}$, the microorganisms are categorized into hydrolyzers, acidogens, acetogens, and methanogens (Nguyen et al., 2019a). The first step, hydrolysis, can be the limiting stage of $\mathrm{AD}$ when there are lots of solid and complex substrates fed into the digester (Li et al., 2011; Wang et al., 2018a).

Organisms that are active during the hydrolysis of polysaccharides in $\mathrm{AD}$ processes include various bacteria and fungi (Azman et al., 2015; Kazda et al., 2014).

The presence of a lot of cellulose and starch-degrading microorganisms has been reported during the hydrolysis step. Within the phyla found, there are, Firmicutes, Bacteroidetes, Spirochetes (Nguyen et al., 2019a), Proteobacteria (Nguyen et al., 2019a; Koeck et al., 2014), Cloacimonetes (Limam et al., 2014), and Actinomyces (Wang et al., 2016). Among the anaerobic fungi, there are the phylum Neocallimastigomycota (Dollhofer et al., 2015; Cheng et al., 2018), and the facultative ones from the subphyla Agaricomycotina, Mucoromycotina (Mucor circinelloides, Mucor rouxii), Pucciniomycotina, and Saccharomycotina (Kazda et al., 2014). The species Mucor rouxii was reported as producing yeast-like cells under anaerobic conditions (Lucio et al., 2000).

When it comes to protein degradation in $\mathrm{AD}$, it has been proposed that the microbial community involves, for example, members of the phyla Bacteroidetes, Cloacimonetes, Fusobacteria (Stolze et al., 2018), and Firmicutes (Westerholm and Schnürer, 2019).

Last, but not least, lipolytic bacteria in $\mathrm{AD}$ were reported by $\mathrm{Li}$ et al. (2013) and Petropoulos et al. (2018) as belonging to the families Bacteroidaceae and Caldilineaceae, and genera Trichococcus and Psycrobacter.

Most acidogenic bacteria are considered strict anaerobes, however, approximately $1 \%$ of them consist of facultative ones, 
which can oxidase organic matter using molecular oxygen, eventually present as an electron acceptor (Bohrz, 2010). Species found in acidogenesis belong to the phyla Firmicutes, Bacteroides, Proteobacteria, and Actinobacteria (Lucena et al., 2011; Nguyen et al., 2019a). A few species have been isolated, i.e., Clostridium (Shiratori et al., 2006), Desulfovibrio (Nanninga \& Gottschal, 1987; Lucena et al., 2011), Peptococcus, Bifidobacterium, Corynebacterium, Lactobacillus, and Actinomyces (Metcalf and Eddy, 2003; Nguyen et al., 2019a).

Acetogenesis is often performed by bacteria belonging to the genera Clostridium, Acetobacterium (Worm et al., 2010; St-Pierre and Wright, 2014; Azman et al., 2015), and Syntrophomonas (Nguyen et al., 2019a).

Methanogenic community generally represents $2 \%-5 \%$ of the total microbial community in AD (Zakrzewski et al., 2012; Heyer et al., 2013; Maus et al., 2016). The methanogenic species can be grouped in the orders, that is, Methanobacteriales, Methanococcales, Methanomicrobiales, Methanosarcinales, and Methanopyrales. Methylotrophic methanogens are responsible for converting methyl and compounds of one carbon to $\mathrm{H}_{2}, \mathrm{CO}_{2}$, and acetate. Acetate is converted to $\mathrm{CH}_{4}$ through the activity of acetoclastic methanogenic archaea from the genera Methanosaeta and Methanosarcina, which usually accounts for $2 / 3$ of the methane production (Wang et al., 2018a; Nguyen et al., 2019a; Li et al., 2020a). In addition, $\mathrm{H}_{2}$ and $\mathrm{CO}_{2}$ are converted to methane by hydrogenotrophic methanogens from the genera Methanobacterium, Methanospirillum, and Methanobrevibacter (Nguyen et al., 2019a; Chen et al., 2020a).

When compared to the other steps in $\mathrm{AD}$, methanogenesis is characterized by higher $\mathrm{pH}$ (range of 6.6-7.5), lower redox potential and a microbial community with significantly slower regeneration time (5-16 days) (Deublein and Steinhauser, 2008).

Advances in molecular techniques are constantly updating the list of anaerobic microorganisms responsible for different degradation pathways in $\mathrm{AD}$ and its complexity of cooperation.

\subsection{The influence of different operating conditions on AD microbial community}

$\mathrm{AD}$ can be affected by different factors, which are related to the substrate, the characteristics of the biodigester, and operating conditions. Many studies are reporting the influence of environmental changes on the microbial community in $\mathrm{AD}$. Factors such as substrate and inoculum composition, $\mathrm{pH}$, temperature, presence of trace elements or inhibitors, hydraulic 
retention time (HRT) and organic loading rate (OLR), bioaugmentation, etc. can cause a shift in the community diversity and affect the whole digestion process.

\subsubsection{Inoculum sources}

The microbial diversity in the inoculum used for starting up an $\mathrm{AD}$ process has been reported as a strong influencer in the degradation rate, stress tolerance, and specific methane yield of microorganisms (De Vrieze et al., 2015; Han, et al., 2016; Satpathy et al., 2016). An inoculum with a high diversity of microorganisms can be favorable for $\mathrm{AD}$ because sensible species may be replaced by others with similar functions (Resenfeld, 2002).

Many studies disclosed the influence of inoculum source. Liu et al. (2017) observed differences in methane production when comparing the use of three inoculants (digested municipal sludge, digested stillage, and digested manure). This biotic parameter was shown to be important for starting up biogas reactors, since over time the reactors equalized in terms of performance and structure of the microbial community. Gu et al. (2014) reported that among the inocula, that is, digested dairy manure, digested municipal sludge, anaerobic granular sludge, digested swine manure, and digested chicken manure; the first one was the best in the digestion of rice straw.

De Vrieze et al. (2015) testified that the abundance of methanogenic community on the startup of a biogas process resulted in different biomethane potential. Li et al. (2020a) reported that the method of continuously domesticating inoculum can improve the stability of the system and improve the methane production due to the dominance of the species Methanobacterium and Methanosarcina and the extinction of other species.

\subsubsection{Substrate composition}

The chemical composition of biomass plays an important role in $\mathrm{AD}$, such as microbial community performance and viability. Biomass composition varies across the main three organic components, that is, carbohydrates, proteins, and lipids (Mozhiarasi et al., 2020).

Dairy wastewater stream, pig, cattle, and bird breeding wastes (containing manure, blood and feathers), and wastes from industries which process whey, cheese, casein, and certain vegetables are examples of protein-rich substrates available for 
AD process (Ramsay and Pullammanappallil, 2001). These materials are energy-rich; however, their digestion is liable to ammonia inhibition due to $\mathrm{NH}_{3}$ and $\mathrm{NH}_{4}^{+}$formation from protein degradation (Rasapoor et al., 2020).

Protein $\mathrm{AD}$ digesters generally embrace the genera Proteiniborus, a protein-specific utilizing bacterium (Niu et al., 2008) and Aminobacterium (Tan et al., 2012). Kovács et al. (2013) reported the classes Clostridia, Bacilli, and GammaProteobacteria as the majority bacteria groups present in the $\mathrm{AD}$ of casein, at the time that the phylum Euryarcheota dominates in the archaeal community (Methanomicrobia, Thermococci, and Methanococci classes were the most abundant).

The carbohydrate-rich materials when added to AD digesters or present in anaerobic composting systems also influence the digester community. Substrate composed of lignocellulosic material, such as fruit peel and bagasse, agricultural residues, grass silage, pulp, and paper mills waste, can cause challenges during $\mathrm{AD}$ hydrolysis due to low degradability (Bozan et al., 2017; Patinvoh et al., 2017; Abraham et al., 2020). Approximately $90 \%$ of plant cell walls consist of polysaccharides, that is, cellulose, hemicellulose, and pectin (McNeil et al., 1984). Cellulose forms the core portion of lignocellulose that is limited by a hemicellulose matrix and an external layer of lignin (Saini et al., 2015). The crystalline nature of cellulose added to lignin's physical barrier in this biomass increase the resistance to microbial degradation (Thomsen et al., 2014; Karimi and Taherzadeh, 2016). Along with its structural features, the high lignocellulosic biomass $\mathrm{C} / \mathrm{N}$ ratio also limits its efficient degradation in $\mathrm{AD}$ (Hagos et al., 2017). An appropriate nutrient balance is required for bacteria growth and maintenance of a stable environment, and generally, an optimum $\mathrm{C} / \mathrm{N}$ ratio range of $20-30$ for $\mathrm{AD}(\mathrm{Li}$ et al., 2011; Puyuelo et al., 2011).

Firmicutes and Bacteroidete are the main phyla outlined in the lignocellulosic AD process (Azman et al., 2015; Bozan et al., 2017), which suggests these groups to be the major producers of hydrolytic enzymes. Numerous reports specify these groups in digesters. Wongwilaiwalin et al., 2013 reported that Firmicutes was the most abundant phylum in consortia obtained from cow rumen fluid, sugarcane bagasse pile, and pulp mill activated sludge. Tsavkelova et al. (2018) accounted for $97 \%$ of the total community in the $\mathrm{AD}$ of waste papers belonging to Firmicutes. Weiß et al. (2016) highlighted Firmicutes, Bacteriodetes, Proteobacteria, and Spirochetes phyla as the most abundant microbial community in the $\mathrm{AD}$ of sludge with unprocessed crop substance, such as wheat straw and 
maple green cut. Liu et al. (2018) reported that the microbial population in four different digesters treating corn stover was composed by the phyla Firmicutes and Bacteroidetes. Wang et al. (2016), in turn, showed that Actinobacteria was the major phylum existing in the rice straw digestion.

$\mathrm{AD}$ involving carbohydrate-rich material can also be done with easily accessible carbohydrates, such as food waste. Depending on the composition of the wastes, it can undergo fast acidogenesis and cause acidification (Mu et al., 2017).

Jang et al. (2016) showed that Firmicutes and Actinobacteria are the most distinctive groups present in $\mathrm{AD}$ with the addition of food waste. Additionally, Xu et al. (2017a) reported that the increase of food waste amounts in $\mathrm{AD}$ caused a shift in the methanogenic community from the dominance of Methanosarcina to Methanosaeta.

The AD microbial community further manages fat-rich substrates from, for example, the food industry, restaurants, slaughterhouses, dairy industry, etc. The degradation of lipids mainly results in glycerol and LCFA (Nzila et al., 2019). A few studies have described the microbial community present in anaerobic digesters containing fatty substrates.

Ziels et al. (2016) showed that after the addition of fat, oil, and grease into anaerobic codigestion processes, the bacterial community reacted faster than the methanogenics, and the phylum Firmicutes and the genus Syntrophomonas were those that stood out in terms of enrichment during the processes. The genus Syntrophomonas was revealed to be one of the most abundant or most increased group during the digestion of lipidrich materials (Palatsi et al., 2011; Ziels et al., 2016; He et al., 2018; Nakazaki et al., 2020).

Nakazaki et al. (2020) also exposed that Anaerolineaceae was the most dominant group of bacteria in the experiments involving $\mathrm{AD}$ of oil, glycerol or LCFA, whereas Clostridium, Desulfovibrio, Rikenellaceae, and Treponema were observed in glycerol degradation and Leptospirales, Synergistaceae, Thermobaculaceae, and Syntrophaceae were reported as abundant groups in the $\mathrm{AD}$ of LCFA and oil mineralization.

Francisci et al. (2015) described the increasing relative abundance of the genus Megamonas (phylum Firmicutes) when oleate was added into animal manure AD. Jensen et al. (2014) and Razaviarani and Buchanan (2015) reported greater levels of the phyla Thermotogae and Cloacamonas, respectively, when glycerol/glycerin was added in the mesophilic $\mathrm{AD}$ of wastewater sludge. Regueiro et al. (2016) studied the codigestion using protein-rich and lipid-rich substrates, and high LCFA levels 
during $\mathrm{AD}$ provoked an increase in the Anaerobaculaceae and Peptococcaceae families.

When it comes to the methanogenic community, the Methanoculleus, Methanobacterium, and Methanospirillum have been shown as significant hydrogen-utilizing bacteria for LCFA-degradation (Treu et al., 2016; Souza et al., 2013). Furthermore, Ziels et al. (2016) and Yang et al. (2016) reported that the genus Methanosaeta (order Methanosarcinales) dominated the anaerobic codigestion of fat, oil, and grease, and Regueiro et al. (2016) and Nakazaki et al. (2020) reported the same dominance in LCFA AD.

\subsubsection{Pretreatment}

Due to the importance of hydrolysis in the kinetics of $\mathrm{AD}$, a great deal of methodologies have been turned toward accelerating and facilitating microbiological degradation. This happens when it involves substrates (1) rich in lignocellulose, that is, forest by-products, straw, peels, agro-industrial wastes; (2) rich in keratin, i.e., waste from meat, poultry, fish industries; or even (3) wastewater sludge (Patinvoh et al., 2017; Amin et al., 2017; Wagner et al., 2018).

Pretreatments are an approach to facilitate degradation of substrates through structure disruption, changes in the porosity, and particle size reduction. Common strategies include biological pretreatments such as the addition of fungi/bacteria/ enzymes (Lima et al., 2016; Michelin et al., 2012, 2014, 2015; Polizeli et al., 2017; Pasin et al., 2020); physical treatment sucha as heat and pressure at the same time, irradiation, ultrasonic; and chemical treatment such as the use of acids and/or bases, ozonation, and oxidation (Amin et al., 2017; Wagner et al., 2018; Westerholm and Schnürer, 2019).

Anaerobic microbial communities acquired after substrate pretreatments were described by distinct authors. Fu et al. (2015) reported that the performance of a thermophilic microaerobic pretreatment of corn straw before the $\mathrm{AD}$ caused an increase in the relative abundance of the phylum Firmicutes (especially class Bacilli, order Bacillales) during the anaerobic process. Mladenovska et al. (2006) analyzed the microbial community from two thermophilic continuously stirred tank reactors (CSTR), with (1) pretreated manure for $40 \mathrm{~min}$ at $140^{\circ} \mathrm{C}$ and (2) nontreated manure. The bacterial and archaeal populations identified were identical in both systems. However, the thermal pretreatment caused an increase in the abundance of the species present in the digester. Sanz et al. (2017) reported that the 
thermal pretreatment of microalgae biomass influenced the relative abundance of Rikenellaceae (phylum Bacteriodetes) and Anaerolineaceae (phylum Chloroflexi). At the same time, there was a decrease in the relative abundance of the phylum Proteobacteria during AD. Wang et al. (2018b), in turn, reported a small effect on the microbial community structure during $\mathrm{AD}$ conducted after thermal pretreatment of distilled grain waste.

Zuo et al. (2020) noted that ethanol prefermentation is one biological pretreatment available to convert more carbon to ethanol-a neutral substance. This pretreatment provided a suitable environment for $\mathrm{AD}$, which in turn, resulted in a greater concentration of hydrolytic bacteria, such as Sphaerochaeta, VadinBC27, and Treponema. Additionally, the relative concentrations of Methanobacterium, Methanosaeta, and Methanoculleus were increased in the digesters with pretreated substrates.

Zhang et al. (2016) reported that microwave pretreatment of food waste and sewage sludge caused the dominance of the genera Methanosphaera and Methanosarcina, respectively, during the active methane production phase.

Pretreatments mostly cause minor structural alterations in the $\mathrm{AD}$ microbial community, but still impact its activity and abundance. It is likely that the effect of pretreatment strongly depends on physical effects, prevailing operating conditions, the activity of the microorganisms, and solubilization of compounds (Westerholm and Schnürer, 2019).

\subsubsection{Trace elements}

Besides basic macronutrients such as carbon, nitrogen, phosphorus, and sulfur, the anaerobic microbial community requires trace elements at relatively lower concentrations (Choong et al., 2016). These elements must be present to support the metabolism of microorganisms, otherwise, the performance of $\mathrm{AD}$ will expressively decline (Xu et al., 2017b). Trace element deficiency can limit the activity of anaerobes and cause the accumulation of fatty acids, instability, and methane yield decrease (Schnürer and Jarvis, 2010). In this regard, it is important to ponder the level of, for example, cobalt, nickel, iron, molybdenum, manganese, and tungsten during $\mathrm{AD}$, since they have been shown as vital for the methanogenic community (Wintsche et al., 2016; Xu et al., 2018).

Comprehensive studies have investigated a wide range of trace elements that might be vital for the anaerobic community. Scherer et al. (1983) reported that trace elements in the order of $\mathrm{Fe}>>\mathrm{Zn}>\mathrm{Ni}>\mathrm{Cu} \approx \mathrm{Co} \approx \mathrm{Mo}>\mathrm{Mn}$, play crucial roles in 
the growth and metabolism of methanogens, such as the genera Methanobacterium, Methanothermobacter, Methanobrevibacter, and Methanosarcina. Iron is important in stimulating the formation of cytochromes and ferroxins (Fd) which are important for cell energy metabolism (Choong et al., 2016). Lin et al. (1990) reported that increasing $\mathrm{Fe}^{2+}$ in $\mathrm{AD}$ enhanced the rate of methane formation by Methanosarcina barkeri. Likewise, Yu et al. (2015) noted a faster hydrolysis and acidification steps with supplementation of $\mathrm{Fe}(\mathrm{III})$ during $\mathrm{AD}$. Besides, Wang et al. (2020a) confirmed the $\mathrm{Fe}^{2+}$ stimulatory effect on high-solid swine manure $\mathrm{AD}$. The dosing frequency of $400 \mathrm{mg} / \mathrm{L}$ every 5 days positively increased the abundances of Firmicutes and Euryarchaeota, which could enhance the hydrolysis-acidification and methanogenesis process.

$\mathrm{Ni}$-supplementation has been connected with the predominance of the genus Methanosarcina (Speece et al., 1983; Munk \& Lebuhn, 2014). At the same time, Cai et al. (2017) described the genus Methanobacterium as the most sensitive to nickel, since with low and high $\mathrm{Ni}$-supplementation in rice straw digestion, the amount of Methanobacterium increased and decreased, respectively.

Wintsche et al. (2016) observed that in the AD of distiller's grains, Methanosarcina and Methanoculleus dominated the methanogenic communities. However, Methanosarcina (acetoclastic methanogenesis pathway) dominated the well-supplied $\mathrm{AD}$ (with supplementation of the trace elements cobalt, manganese, nickel, tungsten, and zinc), though, Methanoculleus (hydrogenotrophic methanogenesis pathway) was favored in the process under trace elements deprivation.

Sulfide can be formed through protein degradation during $\mathrm{AD}$, and due to its capability of forming complexes with metals, it can decrease the bioavailability of trace elements (Thanh et al., 2016; Wintsche et al., 2016). Gustavsson et al. (2013) showed that only $10 \%-20 \%$ of cobalt remained dissolved when elevated sulfide concentrations were present in $\mathrm{AD}$.

\subsubsection{Inhibitors}

The degradation of organic compounds by any biological process depends on maintaining a favorable environment for microorganisms. Any compound present in the substrate can be toxic at sufficiently high concentrations. Therefore the toxicity of materials should be avoided in the process, remaining as tolerable to microbial growth. 
The organic acid accumulation or decrease of methane production during the $\mathrm{AD}$ process can be caused by inhibitory substances, which can prompt shifts in the microbial community or inhibition of bacterial growth (Li et al., 2020b).

Many studies have investigated a wide range of compounds that might influence or even severely inhibit the anaerobes during the $\mathrm{AD}$ process.

Ammonia is commonly accumulated in AD due to the biological degradation of proteins and urea, which are present in the wastewater, sludge, or substrates (Li et al., 2020b; Rasapoor et al., 2020). The hydrophobic ammonia can diffuse into the cell and affect proton balance, and/or cause potassium deficiency (Sprott and Patel, 1986; Gallert et al., 1998). Methanogens are the least tolerant of ammonia (Sung and Liu, 2003), being the acetoclastic group more sensitive than the hydrogenotrophs (Koster and Lettinga, 1984; Westerholm et al., 2012; Li et al., 2020b). According to Jarrell et al. (1984) the most ammonia sensitive strains, inhibited at $4.2 \mathrm{~g} / \mathrm{L}$, are Methanospirillum hungatei, Methanosarcina barkeri, Methanobacterium thermoautotrophicum, Methanobacterium formicicum, and Methanospirillum hungatei. Capson-Tojo et al. (2020) also showed the genera Methanosaeta and Methanosarcina as the most vulnerable to ammonia inhibition. However, $\mathrm{AD}$ microbial community can also present an ammonia-tolerant community, including the families Pseudomonadaceae, Carnobacteriaceae, and Clostridiadaceae (Regueiro et al., 2016), and according to Capson-Tojo et al. (2020) the genus Methanoculleus appeared as the most resistant archaea in $\mathrm{AD}$ systems working with high ammonia levels.

Low concentrations of chemical elements were observed to cause an enhancement in AD performance, however, high concentrations of them have been reported to negatively affect the microbial community (Choong et al., 2016; Rasapoor et al., 2020).

High levels of light metal ions (e.g., aluminum, sodium, potassium, calcium, and magnesium), added as $\mathrm{pH}$ adjustment chemicals or released by the breakdown of organic matter in $\mathrm{AD}$, have been reported to affect specific microbial growth rate, generally because of osmotic pressure alterations due to dehydration in bacterial cells (Chen et al., 2008).

Cabirol et al. (2003) reported inhibition of acetogenic and methanogenic communities due to high levels of aluminum during $\mathrm{AD}$ since this ion can compete with iron and manganese or can adhere to the microbial cell membrane inhibiting cell growth. High quantities of calcium in $\mathrm{AD}$ can lead to the 
precipitation of carbonate and phosphate causing the reduction of specific methanogenic activity, loss of buffer capacity, and essential nutrients for $\mathrm{AD}$. Ions of magnesium at high concentrations were shown to stimulate the production of single cells, which are sensitive to lysis and cause the loss of acetoclastic activity during anaerobioses (Chen et al., 2008). Liu and Boone (1991) reported that $\mathrm{NaCl}$ toxicity in reactors decreased in the order of lignocellulose-degrading $>$ acetate-utilizing $>$ propionate-utilizing $>\mathrm{H}_{2} / \mathrm{CO}_{2}$-utilizing microorganisms.

Moreover, heavy metal toxicity is another major cause of digester upset or failure during $\mathrm{AD}$. Nguyen et al. (2019b) reported $\mathrm{Cu}^{2+}$ as the most toxic metal ion followed by $\mathrm{Zn}^{2+}$, $\mathrm{Cr}^{2+}$, and $\mathrm{Pb}^{2+}$ (the least toxic). High amounts of heavy metals led to the disruption of enzyme structure and function which caused inefficient microbial activity.

\subsubsection{Temperature}

Among factors affecting microbial growth, temperature is one of the most important in species selection, due to the fact that microorganisms do not have the means to control their internal temperature, which is then determined by the external environmental temperature. In most biological processes, three temperature ranges can be associated with microbial growth, psychrophilic $\left(0^{\circ} \mathrm{C}-20^{\circ} \mathrm{C}\right)$, mesophilic $\left(30^{\circ} \mathrm{C}-40^{\circ} \mathrm{C}\right)$, or thermophilic $\left(45^{\circ} \mathrm{C}-60^{\circ} \mathrm{C}\right)$.

Temperature expressively influences the structure and richness of microbial community, and the stability and performance of $\mathrm{AD}$, once it impacts enzyme activity, rate of reactions, and $\mathrm{CH}_{4}$ yield (Bi et al., 2019; Lv et al., 2020; Cao et al., 2020). Therefore digesting temperature regulations, that is, mesophilic or thermophilic, is one main strategy in this process ( $\mathrm{Lv}$ et al., 2019; Wang et al., 2018a). As almost $80 \%$ of a microorganism's cell body content is water, most of them cannot grow in psychrophilic conditions, due to temperature loss to the environment and, consequently, the reduction of intracellular reactions speed.

Numerous reports have described the temperature as an important and influent environmental parameter on the microbial community structure. Operation at thermophilic temperature provides a higher level of Firmicutes compared to Bacteroidetes/Proteobacteria (Westerholm et al., 2018; Liu et al., 2018; Chapleur et al., 2016; Theuerl et al., 2018). A lower Bacteroidetes ratio decreases the hydrolysis rate due to the reduction of lignocellulolytic enzymes richness (Güllert et al., 2016). Likewise, higher dominance of the phylum Thermotogae 
has been reported under thermophilic conditions (Lv et al., 2020; Chapleur et al., 2016; Theuerl et al., 2018). Thermotogae phylum is responsible for degrading polysaccharides to ethanol, acetate, $\mathrm{CO}_{2}$, and $\mathrm{H}_{2}$, and alcohols to $\mathrm{CO}_{2}$ and $\mathrm{H}_{2}$ when in an association with hydrogen-consuming anaerobes (Stolze et al., 2018). Furthermore, Lv et al. (2020) also uncovered through statistical evidence that the Clostridiaceae dominated pathways linked closely with methanogenesis in thermophilic AD digesters, and Chen et al. (2020b), using high-throughput Illumina sequencing results, verified that thermophilic $\mathrm{AD}$ microbial community was mediated by thermophiles such as Coprothermobacter and Methanothermobacter.

In contrast, Chen et al., (2020b) found a more diverse microbial community in mesophilic digesters than thermophilic ones. These taxa mostly belonged to Bacteroidetes and relatively broad types of methanogens.

Microbial correlations, between increased ammonia level and high temperatures, were revised in Westerholm and Schnürer (2019). At higher temperatures, the ammonia inhibition is quicker because of the equilibrium shifts in the direction of ammonia formation and not ammonium. Therefore, an enhanced relative abundance of Methanobacteriales (regularly Methanothermobacter) and/or Methanomicrobiales (generally Methanoculleus) was seen when there were temperature increases and ammonia accumulation. Ammonia inhibition is one of the most common causes of failures in $\mathrm{AD}$ digesters at thermophilic temperature (Cao et al., 2020).

For the startup of full-scale thermophiles digesters, it can be necessary to alter mesophilic sludge to thermophilic, due to the lack of thermophilic inoculum (de la Rubia et al., 2005). Tian et al. (2015) showed that anaerobic digesters operating at $55^{\circ} \mathrm{C}$ can be started from a mesophilic system by increasing the temperature by one quick step. The rise in temperature guaranteed that thermophiles would grow under the preferred temperature from the earliest starting point. With the temperature increase there was a quick change in the dominant hydrogenotrophic methanogens from the genera Methanolinea to Methanoculleus and Methanothermobacter (Tian et al., 2015).

Shaw et al. (2019) used a mesophilic AD system of swine manure to explore the consequences of a long-term temperature disturbance on the dynamic of microbial communities. After the temperature disturbance, a shift of acetotrophic (Methanotrichaceae and Methanosarcinaceae) to methylotrophic methanogens (Methanomassiliicoccaceae and Methanobacteriaceae) was seen. Lv et al. (2019) also studied 
the $\mathrm{AD}$ microbial stability in response to temperature increment. Results showed that regarding temperature increase, there was a weakening of links between Firmicutes and Methanomicrobiaceae families, at the same time that Methanosarcinaceae and Methanobacteriaceae reinforced their links with numerous bacterial groups. These results suggested that temperature changes could collapse certain microbial interconnections, processing instability, but reinforce other microbial links, which reflect the syntrophic property of the microbial community.

Last, but not least, it was observed that temperature also influences the soil composting, which is the biological organic matter decomposition under controlled conditions. Mesophilic organisms multiply in the first days of composting. They generate heat by their own metabolism and raise the temperature to a point where their own activities become suppressed and then thermophilic fungi and bacteria grow and continue the process. Composting generally is an aerobic process, however, if the piles are huge, anaerobic zones can be formed near their center. These zones are characterized by slow and $\mathrm{AD}$, with subsequent production of methane, due to the anaerobes which grow in this condition (Sánchez et al., 2017).

\subsubsection{Hydraulic retention time and organic loading time}

HRT refers to the period in which a feedstock stays in a digester and it is related to digester capacity (Gould, 2015). Longer HRT enables the microorganisms to adapt to inhibiting substances, such as ammonia and sulfides (Schnürer and Jarvis, 2010), while shorter HRT increases the efficiency of the process and reduces the system costs (Chandra et al., 2012; Shi et al., 2017).

OLR refers to the number of volatile solids loaded into the digester under a unit of time. Both parameters, HRT and OLR, are closely related and there must be a balance between them. $\mathrm{AD}$ with higher OLRs should involve long HRTs to provide enough time to the anaerobes to degrade the substrate (Demirer and Chen, 2005; Robles et al., 2018).

Tonanzi et al. (2020) reported a test involving OLR and HRT in digesters. Under high OLR ( $1.7 \mathrm{~g} \mathrm{VS} / \mathrm{L} / \mathrm{d})$ and an HRT of 60 days, the digester showed a gradual instability over time, which culminated in the accumulation of soluble chemical oxygen demand (COD) and acetic, propionic, and butyric acids. Therefore there was a total system failure due to VFA inhibition 
and a fall in pH. Furthermore, it has been reported that changes in OLR/HRT ratio lead a response in most phyla dominating in $\mathrm{AD}$, such as Actinobacteria, Bacteroidetes, Firmicutes, and Euryarchaeota (Xu et al., 2018).

Under increased OLR during mesophilic AD of food waste, an enrichment of hydrolytic and acidogenic bacteria was noted, such as Firmicutes or Bacteroidetes, along with the genus Methanosarcina, robust stress-tolerant methanogenic group, and hydrogenotrophic Methanomicrobiales order. In contrast, increased HTR showed a dynamic succession in the bacterial phyla Firmicutes and Actinobacteria while increasing Euryarchaeota (Methanosarcinaceae and Methanosaetaceae) (Xu et al., 2018).

Ferguson et al. (2016) reported that rapid shocks in the loading rate during $\mathrm{AD}$ caused shifts and diversification in microbial populations, especially the methanogenic community, resulting in the tolerance of some species to higher OLRs (Chen et al., 2013).

Svensson et al. (2018) showed that an AD frequently fed (10fold a day) with steam exploded food waste produced $20 \%$ more methane than the daily fed digester, and this higher OLR shifted the dominance of the phylum Firmicutes to Tenericutes in the community.

Using waste cooking oil skimmed from food waste as carbon source, He et al. (2018) revealed the distinct microbial succession in $\mathrm{AD}$ under an OLR of $1.0 \mathrm{~g} \mathrm{VS} / \mathrm{L} / \mathrm{d}$. The amplicon pyrosequencing exposed the dominance of acetoclastic methanogens belonging to the genus Methanosaeta, and the genera Syntrophomona, Anaerovibrio, and Synergistaceae among the bacteria. Hence, redundancy analysis indicated that variations on OLR affected more the bacterial than archaeal communities.

Moreover, Wu et al. (2020) studied the influence of OLRs increment (1.0-1.3 and $1.5 \mathrm{~g} \mathrm{VS} / \mathrm{L} / \mathrm{d})$ during AD. Methane production was seen with rising resource availability, while a random matrix theory-based network analysis suggested that higher OLRs led to more intense microbial interactions and quicker responses to environmental changes. Besides, the taxa Methanothermus, Methanobacterium, Chlorobium, and Haloarcula were the keystone of the network.

\subsubsection{Bioaugmentation}

Bioaugmentation is the addition of specialized or mixed microbial community to a system aiming to improve process functions (Michalska et al., 2020), such as degradation of contaminants, reduction of COD, microbial adaptation, and 
improvement of methane yield (Herrero and Stuckey, 2015; De Vrieze and Verstraete, 2018).

Bioaugmentation can be performed with the addition into the system of (1) a preadapted pure microbial strain or community, (2) genetically engineered bacteria, or (3) a vector with relevant genes, which will be transferred by conjugation into microorganisms present in the biosystems (El Fantroussi and Agathos, 2005).

Several researchers have investigated the practice of adding exogenous culture into AD. Bocher et al. (2015) reported a functional improvement of propionate degradation after augmentation with the methanogenic community. Likewise, Lins et al. (2014) noted the rise of stability and activity from the methanogenic group after bioaugmentation with Methanosarcina sp. The addition of this specie can improve the digestion due to its dominance or shift in dominance with Methanosaeta sp. after stabilizing the conditions which initially caused the methanogenesis to cease (Conklin et al., 2006).

Lee et al. (2020) uncovered that a triple augmentation in the $\mathrm{AD}$ of cow grass increased methane production in $20.7 \%$. The bioaugmentation with Clostridium cellulolyticum, Mesotoga infera, and Methanosaeta concilii target the three stages in $\mathrm{AD}$, since the first one produces exopolysaccharide overflow, contributing to the nutrient carbon to other bacteria, $M$. infera is a heterotrophic acetogen that uses various substrates, and the methanogenic one has a high affinity for acetate.

Ferraro et al. (2019) applied a mathematical model to investigate and simulate the kinetics process from a bioaugmented $\mathrm{AD}$ with wheat straw. The bioaugmentation with a mixed inoculum of anaerobic ruminal fungi and hydrogen-producing fermenting bacteria led to greater $\mathrm{CH}_{4}$ production and higher Archaea fractions, especially Methanosarcina, which ensured a greater diversification of the metabolic pathways and supported the strength of the system performance.

Wang et al. (2020b) described the augment dominated by acetoclastic Methanothrix and hydrogenotrophic Methanolinea as a source for bioaugmentation of overloaded digestion recovery and acidic wastewater treatment since this is an acidtolerant methanogenic culture, which produces methane from propionate at $\mathrm{pH}$ 5.0.

Fungal bioaugmentation has also been performed. Anaerobic fungi play a crucial role in the lignocellulose-rich fiber degradation due to their high cellulolytic activity. The bioaugmentation with anaerobic fungus Orpinomyces sp. increased the methane 
yield by $15 \%-33 \%$ during anaerobic codigestion of cow manure and selected cereal crops/straws (Akyol et al., 2019).

Bioaugmentation has also been tested to attenuate ammonia inhibition during AD. An augment with the ammonia-tolerant Methanoculleus bourgensis improved community adaptation to mesophilic AD under high concentrations of ammonia (Fotidis et al., 2014).

\subsection{9 pH}

$\mathrm{pH}$ is a central environmental factor influencing $\mathrm{AD}$. Changes in $\mathrm{pH}$ significantly affect microorganisms involved in the digestion process. It can modify their structures and, consequently, make them lose their original characteristics, increase or decrease their toxicity and metabolism. Anaerobes require specific $\mathrm{pH}$ range to better complete normal physiological activities, and they are very sensitive to fluctuations in this variable. Acidogenic bacteria prefer a $\mathrm{pH}$ range of 5.5-8.5, while for methanogens the range is $6.6-7.5$. Therefore the optimal $\mathrm{pH}$ range for the $\mathrm{AD}$ system is between 6.5 and 7.8. (Li et al., 2020a, Lackner et al., 2020).

As $\mathrm{pH}$ is a critical parameter to maintain a balanced reaction rate among the $\mathrm{AD}$ steps, Lackner et al. (2020) uncovered the relative abundance of anaerobes in $\mathrm{AD}$ under different $\mathrm{pH}$ ranges. Their results showed that Firmicutes $(22 \%-67 \%)$ and Bacteriodetes $(4 \%-15 \%)$ were more abundant in neutral and alkaline systems. Firmicutes were inhibited at $\mathrm{pH}<7.0$, while Bacteroidetes decreased their relative abundance at $\mathrm{pH}<6.0$. In the $\mathrm{pH}$ range $5.5-6$, Thermotogae $(6 \%-39 \%)$ were the dominant phylum, being scarce at $\mathrm{pH}$ 7.0-8.5. Furthermore, the relative abundance of methanogenic members presented a $\mathrm{pH}$-dependent succession. From acidic to alkaline $\mathrm{pH}$, the dominant groups were Methanothermobacter, Methanosarcina, and Methanoculleus.

$\mathrm{AD}$ showed to decrease microbial diversity in digesters with alkalization. Zhou et al. (2020) disclosed that, with alkalization, Chloroflexi and Chlorobi decreased in the microbial community during $\mathrm{AD}$, which affected the original network system and inhibited the growth of other species such as Proteobacteria and Bacteroidetes.

Moreover, within AD steps, acidogenesis is generally the fastest one. A slow or inhibited acid utilization due to organic overload, toxicants, or rapid temperature change can lead to the accumulation of VFAs. High amounts of VFAs in the system have a direct impact on $\mathrm{pH}$, which affects the growth of 
microorganisms. Additionally, the $\mathrm{pH}$ fluctuation can influence the ratio of undissociated to dissociated forms of VFAs, and the first one is much more toxic to the microbial community, since it can diffuse across the cell membrane and cause an intracellular $\mathrm{pH}$ decrease leading to damage (Kadam and Boone, 1996; Venkiteshwaran et al., 2015).

\subsection{Concluding remarks and outlook}

$\mathrm{AD}$ is a relatively mature and widely applied technology in the treatment of wastewater, sewage sludge, animal manure, and food waste. This expertise provides multiple socioeconomic and environmental benefits, since it diverts organic wastes from landfills, reduces odors, and pathogens from livestock wastes, and produces biogas as a renewable fuel. It also reduces greenhouse gas emissions from the degradation of organic matter, generates a nutrient-rich fertilizer, removes organic pollutants from waste and wastewater, creates local job opportunities, and reduces energy costs due to the use of biogas.

Despite the potential benefits, AD still faces several technical, economic, and social challenges, such as foaming, VFA accumulation and process instability, low buffer capacity, restricted knowledge about the microbial community network, vast and unexplored substrates, and the high cost of operation and fuel transportation.

This chapter reviews recent literature in the field of linkages between microbial community and $\mathrm{AD}$ environmental variations. Abiotic factors have been reported as the ones responsible for affecting the microbial community diversity, structure, and stability. These factors affect variables such as temperature, OLR, HRT, substrate composition, $\mathrm{pH}$, trace elements, and biotic factors, such as inoculum sources and bioaugmentation. In the last years, with considerable advances in molecular techniques, key microorganisms, and their richness, evenness and interactions under various environmental conditions have been ascertained. Among the reports in this field, at the same time that the phyla Firmicutes, Actinobacteria, and Bacteroidetes showed to dominate the $\mathrm{AD}$ microbial community, they also answer profoundly under changing conditions. Furthermore, the methanogenic community is shown to be the most sensitive group to environmental fluctuations, and many organisms remain unknown or unclassified into the phyla.

Therefore improvements on $\mathrm{AD}$ for a more sophisticated cultivation method rely on the linkage of physiological function to 
molecular datasets for species levels, prediction of microbial community performance under specific environmental parameters, bioprospection, and bioaugmentation of interesting and useful microorganisms to the $\mathrm{AD}$ community, use of different sources of substrates with the right proportions, and optimization of digester configuration.

So far, a more efficient and thus cheaper production of biogas as a product from $\mathrm{AD}$ (with regard to substrates and production techniques) give reasons to expect that it will continue as a substantial contributor to the production of renewable energies for electricity, heating, fuel, and gas grid.

\section{Acknowledgments}

We thank Fundação de Amparo à Pesquisa do Estado de São Paulo (FAPESP), process 2018/07522-6, Coordenação de Aperfeiçoamento de Pessoal de Nível Superior (CAPES) process 88887.368240/2019-00, and Conselho de Desenvolvimento Científico e Tecnológico (CNPq) process 142139/2017-3 for grants supporting the researches. The authors declare no conflicts of interest.

\section{References}

Abbasi, T., Tauseef, S.M., Abbasi, S.A., 2012. A brief history of anaerobic digestion and "Biogas". In: Abbasi, T., Tauseef, S.M., Abbasi, S.A. (Eds.), Biogas Energy. Springer Briefs in Environmental Science, vol. 2. Springer, New York, NY, pp. 11-23.

Abraham, A., Mathew, A.K., Park, H., Choi, O., Sindhu, R., Parameswaran, B., et al., 2020. Pretreatment strategies for enhanced biogas production from lignocellulosic biomass. Bioresour. Technol. 301.

Akuzawa, M., Hori, T., Haruta, S., Ueno, Y., Ishii, M., Igarashi, Y., 2011. Distinctive responses of metabolically active microbiota to acidification in a thermophilic anaerobic digester. Microb. Ecol, 61, 595-605.

Akyol, C., Ince, O., Bozan, M., Ozbayram, E.G., Ince, B., 2019. Fungal bioaugmentation of anaerobic digesters fed with lignocellulosic biomass: What to expect from anaerobic fungus Orpinomyces sp. Bioresour. Technol. 277, 1-10.

Allison, S.D., Martiny, J.B., 2008. Resistance, resilience, and redundancy in microbial communities. Proc. Natl Acad. Sci. U S A. 105 (Suppl 1), 11512-11519. Available from: https://doi.org/10.1073/pnas.0801925105.

Almeida, P.Z., Pereira, M.G., Carvalho, C.C., Heinen, P.R., Ziotti, L.S., Messias, J. M., et al., 2017. Bioprospection and characterization of the amylolytic activity by filamentous fungi from Brazilian Atlantic forest. Biota Neotropica 17 (3), $389-395$.

Almeida, P.Z., Messias, J.M., Pereira, M.G., Pinheiro, V.E., Monteiro, L.M.O, Heinen, P.R., et al., 2018. Mixture design of starchy substrates hydrolysis by an immobilized glucoamylase from Aspergillus brasiliensis. J. Biocatalysis Biotransform. 36 (5).

Amin, F.R., Khalid, H., Zhang, H., Rahman, S., Zhang, R., Liu, G., et al., 2017. Pretreatment methods of lignocellulosic biomass for anaerobic digestion. 
AMB. Express 7 (72). Available from: https://doi.org/10.1186/s13568-0170375-4.

Appels, L., Baeyens, J., Degreve, J., Dewil, R., 2008. Principles and potential of the anaerobic digestion of waste-activated sludge. Prog. Energy Combust. Sci. 34 (6), 755-781.

Azman, S., Khadem, A.F., Van Lier, J.B., Zeeman, G., Plugge, C.M., 2015. Presence and role of anaerobic hydrolytic microbes in conversion of lignocellulosic biomass for biogas production. Crit. Rev. Environ. Sci. Technol. 45 2523-2564. Available from: https://doi.org/10.1080/10643389.2015.1053727.

Bi, S.J., Qiao, W., Xiong, L.P., Ricci, M., Adani, F., Dong, R.J., 2019. Effects of organic loading rate on anaerobic digestion of chicken manure under mesophilic and thermophilic conditions. Renew. Energy 139, 242-250. Available from: https://doi.org/10.1016/j.renene.2019.02.083.

Bocher, B.T.W., Cherukuri, K., Maki, J.S., Johnson, M., Zitomer, D.H., 2015. Relating methanogen community structure and anaerobic digester function. Water Res. 70, 425-435. Available from: https://doi.org/10.1016/j. watres.2014.12.018.

Bohrz, G.I., 2010. Generation of methane in anaerobic pond: a case study in cattle slaughterhouse . 2010. 153 pp, Dissertation (Master in Process Engeneering) Federal University of Santa Maria, Technology Center, Santa Maria.

Bozan, M., Akyol, C., Ince, O., Aydin, S., Ince, B.K., 2017. Application of next generation sequencing methods for microbial monitoring of anaerobic digestion of lignocellulosic biomass. Appl. Microbiol. Biotechnol. 101 (18), 6849-6864. Available from: https://doi.org/10.1007/s00253-017-8438-7.

Bryant, M., 1979. Microbial methane production: theoretical aspects. J. Anim. Sci. 48 (1), 193-201.

Cabirol, N., Barragán, E.J., Durán, A., Noyola, A., 2003. Effect of aluminum and sulphate on anaerobic digestion of sludge from wastewater enhanced primary treatment. Water Sci. Technol. 48 (6), 235-240.

Cai, Y., Hua, B., Gao, L., Hu, Y., Yuan, X., Cui, Z., et al., 2017. Effects of adding trace elements on rice straw anaerobic mono-digestion. Bioresour. Technol. 239, 454-463. Available from: https://doi.org/10.1016/j.biortech.2017.04.071.

Cao, L., Keener, H., Huang, Z., Liu, Y., Ruan, R., Xu, F., 2020. Effects of temperature and inoculation ratio on methane production and nutrient solubility of swine manure anaerobic digestion. Bioresour. Technol. 299 (122552). Available from: https://doi.org/10.1016/j.biortech.2019.122552.

Capson-Tojo, G., Moscoviz, R., Astals, S., Robles, Á., Steyer, J.-P., 2020. Unraveling the literature chaos around free ammonia inhibition in anaerobic digestion. Renew. Sustain. Energy Rev. 117. Available from: https://doi.org/ 10.1016/j.rser.2019.109487.

Chandra, R., Takeuchi, H., Hasegawa, T., 2012. Methane production from lignocellulosic agricultural crop wastes: a review in context to second generation of biofuel production. Renew. Sustain. Energy Rev. 16 (3), 1462-1476. Available from: https://doi.org/10.1016/j.rser.2011.11.035.

Chapleur, O., Mazeas, L., Godon, J., Bouchez, T., 2016. Asymmetrical response of anaerobic digestion microbiota to temperature changes. Appl. Microbiol. Biotechnol. 100, 1445-1457. Available from: https://doi.org/10.1007/s00253015-7046-7.

Chen, Y., Cheng, K.J., Creamer, K.S., 2008. Inhibition of anaerobic digestion process: a review. Bioresour. Technol. 99, 4044-4064. Available from: https:// doi.org/10.1016/j.biortech.2007.01.057.

Chen, Y., Stevens, M.A., Zhu, Y., Holmes, J., Xu, H., 2013. Understanding of alkaline pretreatment parameters for corn stover enzymatic saccharification. 
Biotechnol. Biofuels 6 (8). Available from: https://doi.org/10.1186/1754-6834$6-8$

Chen, Y., Yanga, Z., Zhang, Y., Xiang, Y., Xu, R., Jia, M., et al., 2020a. Effects of different conductive nanomaterials on anaerobic digestion process and microbial community of sludge. Bioresour. Technol. 304.

Chen, Z., Li, W., Qin, W., Sun, C., Wang, J., Wen, X., 2020b. Long-term performance and microbial community characteristics of pilot-scale anaerobic reactors for thermal hydrolyzed sludge digestion under mesophilic and thermophilic conditions. Sci. Total. Environ. 720 (137566). Available from: https://doi.org/10.1016/j.scitotenv.2020.137566.

Cheng, Y.F., Shi, Q.C., Sun, R.L., Liang, D., Li, Y.F., Li, Y.Q., et al., 2018. The biotechnological potential of anaerobic fungi on fiber degradation and methane production. World J. Microbiol. Biotechnol. 34 (155). Available from: https://doi.org/10.1007/s11274-018-2539-z.

Choong, Y.Y., Norli, I., Abdullah, A.Z., Yhaya, M.F., 2016. Impacts of trace element supplementation on the performance of anaerobic digestion process: a critical review. Bioresour. Technol. 209, 369-379. Available from: https:// doi.org/10.1016/j.biortech.2016.03.028.

Conklin, A., Stensel, H.D., Ferguson, J., 2006. Growth kinetics and competition between Methanosarcina and Methanosaeta in mesophilic anaerobic digestion. Water Environ. Res. 78 (5), 486-496. Available from: https:// doi. org/10.2175/106143006x95393.

Costa, K.C., Leigh, J.A., 2014. Metabolic versatility in methanogens. Curr. Opin. Biotechnol. 29, 70-75. Available from: https://doi.org/10.1016/j. copbio.2014.02.012.

de la Rubia, M.A., Romero, L.I., Sales, D., Perez, M., 2005. Temperature conversion (mesophilic to thermophilic) of municipal sludge digestion. AIChE J. 51 (9), 2581-2586. Available from: https://doi.org/10.1002/aic.10546.

De Vrieze, J., Verstraete, W., 2018. Perspectives for microbial community composition in anaerobic digestion: from abundance and activity to connectivity. Environ. Microbiol. 18 (9), 2797-2809. Available from: https:// doi.org/10.1111/1462-2920.13437.

De Vrieze, J., Gildemyn, S., Vilchez-Vargas, R., Jáuregui, R., Pieper, D.H., Verstraete, W., et al., 2015. Inoculum selection is crucial to ensure operational stability in anaerobic digestion. Appl. Microbiol. Biotechnol. 99, 189-199. Available from: https://doi.org/10.1007/s00253-014-6046-3.

Demirer, G.N., Chen, S., 2005. Two-phase anaerobic digestion of unscreened dairy manure. Process biochemistry 40 (11), 3542-3549.

Deublein, D., Steinhauser, A., 2008. Biogas from Waste and Renewable Resources: An Introduction. John Wiley \& Sons, Hoboken, ISBN 978-3-527-31841-4.

Dollhofer, V., Podmirseg, S.M., Callaghan, T.M., Griffith, G.W., Fliegerova, K., 2015. Anaerobic fungi and their potential for biogas production. In: Guebitz, G., Bauer, A., Bochmann, G., Gronauer, A., Weiss, S. (Eds.), Biogas Science and Technology. Advances in Biochemical Engineering/Biotechnology. Springer, Cham. Available from: http://doi.org/10.1007/978-3-319-21993-6_2.

Drake, H.L., Gossner, A.S., Daniel, S.L., 2008. Old acetogens, new light. Ann. N. Y. Acad. Sci. 1125, 100-128. Available from: https://doi.org/10.1196/annals. 1419.016.

El Fantroussi, S., Agathos, S.N., 2005. Is bioaugmentation a feasible strategy for pollutant removal and site remediation? Curr. Opin. Microbiol. 8, 268-275. Available from: https://doi.org/10.1016/j.mib.2005.04.011.

Feng, L., Chen, J., Wang, F., Chen, Y., Luo, J., 2019. Acidogenic fermentation facilitates anaerobic biodegradation of polycyclic aromatic hydrocarbons in waste activated sludge. ACS Sustain. Chem. Eng. 7 (5), 5404-5411. 
Ferguson, R.M.W., Coulon, F., Villa, R., 2016. Organic loading rate: a promising microbial management tool in anaerobic digestion. Water Res. 100, 348e356. Available from: https://doi.org/10.1016/j.watres.2016.05.009.

Ferraro, A., Massini, G., Miritana, V.M., Signorini, A., Race, M., Fabbricino, M. 2019. A simplified model to simulate bioaugmented anaerobic digestion of lignocellulosic biomass: Biogas production efficiency related to microbiological data. Sci. Total. Environ. 691, 885-895. Available from: https://doi.org/10.1016/j.scitotenv.2019.07.051.

Ferry, J.G., 2010. How to make a living by exhaling methane. Annu. Rev. Microbiol. 64 (1), 453-473. Available from: https://doi.org/10.1146/annurev. micro.112408.134051.

Fotidis, I.A., Wang, H., Fiedel, N.-R., Luo, G., Karakashev, D.B., 2014. Bioaugmentation as a solution to increase methane production from an ammonia-rich substrate. Environ. Sci. Technol. 48, 7669-7676. Available from: https://doi.org/10.1021/es5017075.

Francisci, D.D., Kougias, P.G., Treu, L., Campanaro, S., Angelidaki, I., 2015. Microbial diversity and dynamicity of biogas reactors due to radical changes of feedstock composition. Bioresour. Technol. 176, 56-64. Available from: https://doi.org/10.1016/j.biortech.2014.10.126.

Fu, S.F., He, S., Shi, X.S., Katukuri, N.R., Dai, M., Guo, R.-B., 2015. The chemical properties and microbial community characterization of the thermophilic microaerobic pretreatment process. Bioresour. Technol. 198, 497-502. Available from: https://doi.org/10.1016/j.biortech.2015.09.029.

Gallert, C., Bauer, S., Winter, J., 1998. Effect of ammonia on the anaerobic degradation of protein by a mesophilic and thermophilic biowaste population. Appl. Microbiol. Biotechnol. 50, 495-501.

Gould, M.C., 2015. Bioenergy and anaerobic digestion. In: Dahiya, A. (Ed.), Bioenergy, Biomass to Biofuels. Academic press, Boston, pp. 297-317. Available from: https://doi.org/10.1016/B978-0-12-407909-0.00018-3.

Gu, Y., Chen, X., Liu, Z., Zhou, X., Zhang, Y., 2014. Effect of inoculum sources on the anaerobic digestion of rice straw. Bioresour. Technol. 158, 149-155.

Güllert, S., Fischer, M.A., Turaev, D., Noebauer, B., Ilmberger, N., Wemheuer, B., et al., 2016. Deep metagenome and metatranscriptome analyses of microbial communities affiliated with an industrial biogas fermenter, a cow rumen, and elephant feces reveal major differences in carbohydrate hydrolysis strategies. Biotechnol. Biofuels 9 (121). Available from: https://doi.org/10.1186/s13068016-0534-x.

Gustavsson, J., Yekta, S.S., Sundberg, C., Karlsson, A., Ejlertsson, J., Skyllberg, U. et al., 2013. Bioavailability of cobalt and nickel during anaerobic digestion of sulfur-rich stillage for biogas formation. Appl. Energy 122, 473-477. Available from: https://doi.org/10.1016/j.apenergy.2013.02.009.

Hagos, K., Zong, J., Li, D., Liu, C., Lu, X., 2017. Anaerobic co-digestion process for biogas production: progress, challenges and perspectives. Renew. Sustain. Energy Rev. 76, 1485-1496.

Han, S., Liu, Y.F., Zhang, S.C., Luo, G., 2016. Reactor performances and microbial communities of biogas reactors: Effects of inoculum sources. Appl. Microbiol. Biotechnol. 100, 987-995. Available from: https://doi.org/10.1007/s00253015-7062-7.

He, J., Wang, X., Yin, X.-B., Li, Q., Li, X., Zhang, Y.-F., et al., 2018. Insights into biomethane production and microbial community succession during semicontinuous anaerobic digestion of waste cooking oil under different organic loading rates. AMB. Express 8 (92). Available from: https://doi.org/10.1186/ s13568-018-0623-2. 
Heinen, P.R., Betini, J.H.A., Polizeli, M.L.T.M., 2017. Xylanases. Reference Module in Life Sciences. Elsevier, Oxford, pp. 1-12.

Herrero, M., Stuckey, D.C., 2015. Bioaugmentation and its application in wastewater treatment: a review. Chemosphere 140, 119-128. Available from: https://doi.org/10.1016/j.chemosphere.2014.10.033.

Heyer, R., Kohrs, F., Benndorf, D., Rapp, E., Kausmann, R., Heiermann, M., et al. 2013. Metaproteome analysis of the microbial communities in agricultural biogas plants. N. Biotechnol. 30, 614-622. Available from: https://doi.org/ 10.1016/j.nbt.2013.01.002.

Jang, H.M., Ha, J.H., Kim, M.S., Kim, J.O., Kim, Y.M., Park, J.M., 2016. Effect of increased load of high-strength food wastewater in thermophilic and mesophilic anaerobic co-digestion of waste activated sludge on bacterial community structure. Water Resour. 99, 140-148.

Jarrell, K.F., Sprott, G.D., Matheson, A.T., 1984. Intracellular potassium concentration and relative acidity of the ribosomal proteins of methanogenic bacteria. Can. J. Microbiol. 30, 663-668. Available from: https://doi.org/ 10.1139/m84-099.

Jensen, P.D., Astals, S., Lu, Y., Devadas, M., Batstone, D.J., 2014. Anaerobic codigestion of sewage sludge and glycerol, focusing on process kinetics, microbial dynamics and sludge dewaterability. Water Res. 67, 355-366. Available from: https://doi.org/10.1016/j.watres.2014.09.024.

Kadam, P.C., Boone, D.R., 1996. Influence of pH on ammonia accumulation and toxicity in halophilic, methylotrophic methanogens. Appl. Environ. Microbiol. 62 (12), 4486-4492.

Karimi, K., Taherzadeh, M.J., 2016. A critical review of analytical methods in pretreatment of lignocelluloses: composition, imaging, and crystallinity. Bioresour. Technol. 200, 1008-1018.

Kazda, M., Langer, S., Bengelsdorf, F.R., 2014. Fungi open new possibilities for anaerobic fermentation of organic residues. Energy Sustainability Soc. 4 (6). Available from: https://doi.org/10.1186/2192-0567-4-6.

Koeck, D.E., Wibberg, D., Maus, I., Winkler, A., Albersmeier, A., Zverlov, V.V. et al., 2014. Complete genome sequence of the cellulolytic thermophile Ruminoclostridium cellulosi wild-type strain DG5 isolated from a thermophilic biogas plant. J. Biotechnol. 188, 136-137. Available from: https://doi.org/10.1016/j.jbiotec.2014.08.024.

Koster, I.W., Lettinga, G., 1984. The influence of ammonium-nitrogen on the specific activity of pelletized methanogenic sludge. Agric. Wastes 9, 205-216. Available from: https://doi.org/10.1016/0141-4607(84)90080-5.

Kovács, E., Wirth, R., Maróti, G., Bagi, Z., Rákhely, G., Kovács, K.L., 2013. Biogas production from protein-rich biomass: fed-batch anaerobic fermentation of casein and of pig blood and associated changes in microbial community composition. PLoS One 8 (10).

Kovalovszki, A., Treu, L., Ellegaard, L., Luo, G., Angelidaki, I., 2020. Modeling temperature response in bioenergy production: novel solution to a common challenge of anaerobic digestion. Appl. Energy 263. Available from: https:// doi.org/10.1016/j.apenergy.2020.114646.

Lackner, N., Wagner, A.O., Markt, R., Illmer, P., 2020. pH and phosphate induced shifts in carbon flow and microbial community during thermophilic anaerobic digestion. Microorganisms 8, 286. Available from: https://doi.org/ 10.3390/microorganisms8020286.

Lamed, R., Setter, E., Bayer, E.A., 1983. Characterization of a cellulose-binding, cellulase-containing complex in Clostridium thermocellum. J. Bacteriol. 156 $828-836$. 
Lee, J.T.E., Wang, Q., Lim, Q.E., Liu, Z., He, J., Tong, Y.W., 2020. Optimization of bioaugmentation of the anaerobic digestion of Axonopus compressus cowgrass for the production of biomethane. J. Clean. Prod. 258, 120932. Available from: https://doi.org/10.1016/j.jclepro.2020.120932.

Li, Y., Park, S.Y., Zhu, J., 2011. Solid-state anaerobic digestion for methane production from organic waste. Renew. Sustain. Energy Rev. 15 (1), 821-826.

Li, A., Chu, Y., Wang, X., Ren, L., Yu, J., Liu, X., et al., 2013. A pyrosequencingbased metagenomic study of methane producing microbial community in solid-state biogas reactor. Biotechnol. Biofuels 6 (3). Available from: https:// doi.org/ 10.1186/1754-6834-6-3.

Li, Y., Chen, Y., Wu, J., 2019. Enhancement of methane production in anaerobic digestion process: a review. Appl. Energy 240, 120-137. Available from: https://doi.org/10.1016/j.apenergy.2019.01.243.

Li, Y., Wang, Z., Li, T., Jiang, S., Sun, Z., Jiang, H., et al., 2020a. Changes in microbial community and methanogenesis during high-solid anaerobic digestion of ensiled corn stover. J. Clean. Prod. 242, 118479.

Li, J., Wang, H., Yi, Y., Gou, M., Nobu, M.K., Tang, Y.-Q., 2020b. Response of isovalerate-degrading methanogenic microbial community to inhibitors. Appl. Biochem. Biotechnol. Available from: https://doi.org/10.1007/s12010020-03234-9.

Lima, M.S., Damasio, A.R.L., Crnkovic, P.M., Pinto, M.R., Da Silva, A.M., Da Silva, J.C.R., et al., 2016. Co-cultivation of Aspergillus nidulans recombinant strains produces an enzymatic cocktail as alternative to alkaline sugarcane bagasse pretreatment. Front. Microbiol. (Online) 7, 1/10.3389/fmicb-9.

Limam, R.D., Chouari, R., Mazéas, L., Wu, T., Li, T., Grossin-Debattista, J., et al., 2014. Members of the uncultured bacterial candidate division WWE1 are implicated in anaerobic digestion of cellulose. Microbiol. Open. 3, 157-167. Available from: https://doi.org/10.1002/mbo3.144.

Lin, D., Kakinozo, T., Nishio, N., Nagai, S., 1990. Enhanced cytochrome formation and stimulate methanogenesis rate by the increased ferrous concentrations in Methanosarcina barkeri culture. FEMS Microbiol. Lett. 68, 89-92. Available from: https://doi.org/10.1111/j.1574-6968.1990. tb04128.x.

Lins, P., Reitschuler, C., Illmer, P., 2014. Methanosarcina spp., the key to relieve the start-up of a thermophilic anaerobic digestion suffering from high acetic acid loads. Bioresour. Technol. 152, 347-354. Available from: https://doi.org/ 10.1016/j.biortech.2013.11.020.

Liu, Y., Boone, D.R., 1991. Effects of salinity on methanogenic decomposition. Bioresour. Technol. 35, 271-273. Available from: https://doi.org/10.1016/ 0960-8524(91)90124-3.

Liu, F., Whitman, W.B., 2008. Metabolic, phylogenetic, and ecological diversity of the methanogenic archaea. Ann. N. Y. Acad. Sci. 1125, 171-189. Available from: https:// doi.org/10.1196/annals.1419.019.

Liu, T., Sun, L., Müller, B., Schnürer, A., 2017. Importance of inoculum source and initial community structure for biogas production from agricultural substrates. Bioresour. Technol. 245, 768-777.

Liu, C.M., Wachemo, A.C., Tong, H., Shi, S.H., Zhang, L., Yuan, H.R., et al., 2018. Biogas production and microbial community properties during anaerobic digestion of corn stover at different temperatures. Bioresour. Technol. 261, 93-103. Available from: https://doi.org/10.1016/j.biortech.2017.12.076.

Lucena, R.M., Gavazza, S., Florencio, L., Kato, M.T., Morais Jr, M.A., 2011. Study

of the microbial diversity in a full-scale UASB reactor treating domestic

wastewater. World J. Microbiol. Biotechnol. 27, 2893-2902. 
Lucio, A.K.B., Polizeli, M.L.T.M., Jorge, J.A., Terenzi, H.F., 2000. Stimulation of hyphal growth in anaerobic cultures of Mucor rouxii by extracellular trehalose. Relevance of cell wall-bound activity of acid trehalase for trehalose utilization. FEMS Microbiol. Lett. 182, 9-13.

Lv, Z.P., Wu, X.Y., Zhou, B.Q., Wang, Y., Sun, Y., Wang, Y.F., et al., 2019. Effect of one step temperature increment from mesophilic to thermophilic anaerobic digestion on the linked pattern between bacterial and methanogenic communities. Bioresour. Technol. 292, 121968. Available from: https://doi. org/10.1016/j.biortech.2019.121968.

Lv, Z., Wang, J., Chen, Z., Chen, X., Zhang, L., Li, C., et al., 2020. Temperature regulations impose positive influence on the biomethane potential versus digesting modes treating agricultural residues. Bioresour. Technol. 301, 122747. Available from: https:// doi.org/10.1016/j.biortech.2020.122747.

Maroun, R., El Fadel, M., 2007. Start-up of anaerobic digestion of source-sorted organic municipal solid waste in the absence of classical inocula. Environ. Sci. Technol. 41 (19), 6808-6814

Maus, I., Koeck, D.E., Cibis, K.G., Hahnke, S., Kim, Y.S., Langer, T., et al., 2016. Unraveling the microbiome of a thermophilic biogas plant by metagenome and metatranscriptome analysis complemented by characterization of bacterial and archaeal isolates. Biotechnol. Biofuels 9 (171). Available from: https://doi.org/10.1186/s13068-016-0581-3.

McNeil, M., Darvill, A.G., Fry, S.C., Albersheim, P., 1984. Structure and function of the primary cell walls of plants. Annu. Rev. Biochem. 53, 625-663.

Meegoda, J.N., Brian, L., Kush, P., Wang, L.B., 2018. Review of the processes, parameters, and optimization of anaerobic digestion. Int. J. Environ. Res. Public. Health 15, 2224. Available from: https://doi.org/10.3390/ ijerph 15102224

Metcalf \& Eddy, 2003. Wastewater Engineering: Treatment Reuse, fourth ed. Mc Graw Hill, Boston, p. 1819 .

Michalska, J., Pinski, A., Zur, J., Mrozik, A., 2020. Selecting bacteria candidates for the bioaugmentation of activated sludge to improve the aerobic treatment of landfill leachate. Water 12 (1). Available from: https://doi.org/10.3390/ w12010140.

Michelin, M., Polizeli, M.L.T.M., Ruzene, D.S., Silva, D.P., Vicente, A.A., Jorge, J.A., et al., 2012. Xylanase and ß-xylosidase production by Aspergillus ochraceus: new perspectives for the application of wheat straw autohydrolysis liquor. Appl. Biochem. Biotechnol. 166, 336-347.

Michelin, M., Polizeli, M.L.T.M., Ruzene, D.S., Silva, D.P., Teixeira, J.A., 2013. Application of lignocellulosic residues in the production of cellulase and hemicellulases from fungi. In: first ed. Polizeli, M.L.T.M., Mahendra, R. (Eds.) Fungal Enzymes, vol. 1. CRC Press Taylor \& Francis Group, Boca Raton, pp. $31-64$.

Michelin, M., Ruiz, H.A., Silva, D.P., Ruzene, D.S., Teixeira, J.A., Polizeli, M.L.T.M., 2014. Cellulose from lignocellulosic waste. In: Ramawat, K.G., Mérillon, J.-M. (Eds.), Polysaccharides, first ed. Basel, Springer International Publishing, Switzerland, pp. 1-33.

Michelin, M., Ximenes, E., Polizeli, M.L.T.M., Ladisch, M.R., 2015. Effect of phenolic compounds from pretreated sugarcane bagasse on cellulolytic and hemicellulolytic activities. Bioresour. Technol. 1 (1)

Mladenovska, Z., Hartmann, H., Kvist, T., Sales-Cruz, M., Gani, R., Ahring, B.K., 2006. Thermal pretreatment of the solid fraction of manure: impact on the biogas reactor performance and microbial community. Water Sci. Technol. 53 (8), 59-67. Available from: https://doi.org/10.2166/wst.2006.236. 
Monteiro, L.M., Pereira, M.G., Vici, A.C., Heinen, P.R., Buckeridge, M.S., Polizeli, M.L.T.M., 2019. Efficient hydrolysis of wine and grape juice anthocyanins by Malbranchea pulchella $\beta$-glucosidase immobilized on MANAE-agarose and ConA-Sepharose supports. Int. J. Biol. Macromolecules 136, 1133-1141.

Mozhiarasi, V., Raghul, R., Speier, C.J., et al., 2020. Composition analysis of major organic fractions of municipal solid waste generated from Chennai. In: Gosh, S.K. (Ed.), Sustainable Waste Management: Policies and Case Studies. Springer, Singapore, pp. 143-152.

Mu, H., Zhao, C., Zhao, Y., Li, Y., Hua, D., Zhang, X., et al., 2017. Enhanced methane production by semi continuous mesophilic co-digestion of potato waste and cabbage waste: performance and microbial characteristics analysis. Bioresour. Technol. 236, 68-76. Available from: https://doi.org/10.1016/j. biortech.2017.03.138.

Munk, B., Lebuhn, M., 2014. Process diagnosis using methanogenic Archaea in maize-fed, trace element depleted fermenters. Anaerobe 29, 22-28. Available from: https://doi.org/10.1016/j.anaerobe.2014.04.002.

Nakazaki, K., Nguyen, K.K., Ballesteros Jr., F.C., Maekawa, T., Koyama, M., 2020. Characterizing the microbial community involved in anaerobic digestion of lipid-rich wastewater to produce methane gas. Anaerobe Available from: https://doi.org/10.1016/j.anaerobe.2019.102082.

Nanninga, H.J., Gottschal, J.C., 1987. Properties of Desulfovibrio carbinolicus sp. nov, and other sulfate-reducing bacteria isolated from an anaerobicpurification plant. Appl. Environ. Microbiol. 53, 802-809.

Nguyen, L.N., Nguyen, A.Q., Nghiem, L.D., 2019a. Microbial community in anaerobic digestion system: progression in microbial ecology. In: Bui, X.T., Chiemchaisri, C., Fujioka, T., Varjani, S. (Eds.), Water and Wastewater Treatment Technologies. Energy, Environment, and Sustainability. Springer, Singapore.

Nguyen, Q.-M., Bui, D.-C., Phuong, T., Doan, V.-H., Nguyen, T.-N., Nguyen, M.V., et al., 2019b. Investigation of heavy metal effects on the anaerobic co-digestion process of waste activated sludge and septic tank sludge. Int. J. Chem. Eng. Available from: https://doi.org/10.1155/2019/5138060ID 5138060 .

Niu, L., Song, L., Dong, X., 2008. Proteiniborus ethanoligenes gen. nov. sp. nov. an anaerobic protein-utilizing bacterium. Int. J. Syst. Evolut. Microbiol. 58, $12-16$.

Nzila, A., Razzak, S.A., Sankara, S., Nazal, M.K., Al-Momani, M., Kang, G.U., et al., 2019. Characterisation and microbial community analysis of lipid utilising microorganisms for biogas formation. PLoS One 14 (11), e0224989. Available from: https://doi.org/10.1371/journal.pone.0224989.

Palatsi, J., Viñas, M., Guivernau, M., Fernandez, B., Flotats, X., 2011. Anaerobic digestion of slaughterhouse waste: main process limitations and microbial community interactions. Bioresour. Technol. 102, 2219-2227. Available from: https://doi.org/10.1016/j.biortech.2010.09.121.

Pasin, T.M., Almeida, P.Z., Scarcella, A.S.S., Infante, J.C., Polizeli, M.L.T.M., 2020 Bioconversion of agro-industrial residues to second-generation bioethanol. In: Nanda, S., Vo, N. D.-V., Sarangi, P. (Eds.), Biorefinery of Alternative Resources: Targeting Green Fuels and Platform Chemicals. Springer, Singapore.

Patinvoh, R.J., Osadolor, O.A., Chandolias, K., Horváth, I.S., Taherzadeh, M.J., 2017. Innovative pretreatment strategies for biogas production. Bioresour. Technol. 224, 13-24. 
Pérez, M.M., Gonçalves, E.C.S., Vici, A.C., Salgado, J.C.S., Polizeli, M.L.T.M., 2019. Fungal lipases: versatile tools for white biotechnology. In: Yadav, A., Mishra, S., Singh, S., Gupta, A. (Eds.), Recent Advancement in White Biotechnology Through Fungi. Fungal Biology. Springer, Cham.

Petropoulos, E., Dolfing, J., Yu, Y., Wade, M.J., Bowen, E.J., Davenporta, R.J., et al., 2018. Lipolysis of domestic wastewater in anaerobic reactors operating at low temperatures. Environ. Sci. Water Res. Technol. 4 (1002). Available from: https://doi.org/10.1039/c8ew00156a.

Pinheiro, V.E., Desagiacomo, C.C.V., Michelin, M., Maller, A., Monteiro, L.M.O., Jorge, J.A., et al., 2017. Neosartorya glabra polygalacturonase produced from fruit peels as inducers has the potential for application in passion fruit and apple juices. Braz. J. Food Technol. 20 (e2016163). Available from: https://doi. org/10.1590/1981-6723.16316.

Polizeli, M.L.T.M., Peixoto-Nogueira, S.C., Silva, T.M., Maller, A., Cabral, H., 2012. Gel electrophoresis for investigating enzymes with biotechnological application, first ed. Gel Electrophoresis, 2. InTech, Rijeka, pp. 97-110.

Polizeli, M.L.T.M., Damasio, A., Maller, A., Cabral, H., Polizeli, A.M., 2013. Pectinases produced by microorganism. In: first ed. Polizeli, M.L.T.M., Mahendra, R. (Eds.), Funfal Enzymes, vol. 1. CRC Press, Boca Raton, pp. $316-340$.

Polizeli, M.L.T.M., Carvalho, C.C., Polizeli, A.M., 2016. O sistema amilolítico. In: first ed. Polizeli, M.L.T.M., Silva, T.M. (Eds.), Amilases Microbianas, vol. 1. São Paulo: Editora da Universidade de São Paulo, pp. 23-52.

Polizeli, M.L.T.M., Somera, A.F., De Lucas, R.C., Nozawa, M.S.F., Michelin, M., 2017. Enzymes involved in the biodegradation of sugarcane biomass: challenges and perspectives. In: Buckeridge, M., De Souza, A. (Eds.), Advances of Basic Science for Second Generation Bioethanol from Sugarcane. Springer, pp. 55-79.

Puyuelo, B., Ponsá, S., Gea, T., Sánchez, A., 2011. Determining C/N ratios for typical organic wastes using biodegradable fractions. Chemosphere 85 , 653-659.

Ramsay, I.R., Pullammanappallil, P.C., 2001. Protein degradation during anaerobic wastewater treatment: derivation of stoichiometry. Biodegradation 12 (4), 247-257. Available from: https://doi.org/10.1023/A:1013116728817.

Rasapoor, M., Younga, B., Brarb, R., Sarmahc, A., Zhuangc, W.-Q., Baroutiana, S. 2020. Recognizing the challenges of anaerobic digestion: critical steps toward improving biogas generation. Fuel 261.

Razaviarani, V., Buchanan, I.D., 2015. Anaerobic co-digestion of biodiesel waste glycerin with municipal wastewater sludge: microbial community structure dynamics and reactor performance. Bioresour. Technol. 182, 8-17. Available from: https://doi.org/10.1016/j.biortech.2015.01.095.

Regueiro, L., Carballa, M., Lema, J.M., 2016. Microbiome response to controlled shifts in ammonium and LCFA levels in co-digestion systems. J. Biotechnol. 220, 35-44. Available from: https://doi.org/10.1016/j.jbiotec.2016.01.006.

Resenfeld, J.S., 2002. Functional redundancy in ecology and conservation. Oikos 98, 56-162. Available from: https://doi.org/10.1034/j.16000706.2002.980116.x.

Robles, G., Nair, R.B., Kleinsteuber, S., Nikolausz, M., Horváth, I.S., 2018. Biogas production: microbiological aspects. In: Tabatabaei, M., Ghanavati, H. (Eds.), Biogas Biofuel and biorefinery technologies, vol. 6. Springer, pp. 163-198.

Saini, J.K., Saini, R., Tewari, L., 2015. Lignocellulosic agriculture wastes as biomass feedstocks for second-generation bioethanol production: concepts and recent developments. Biotechnology 5, 337-353. 
Sánchez, Ó.J., Ospina, D.A., Montoya, S., 2017. Compost supplementation with nutrients and microorganisms in composting process. Waste Manag. 69, $136-153$.

Sanz, J.L., Rojas, P., Morato, A., Mendez, L., Ballesteros, M., Gonzáles-Fernández C., 2017. Microbial communities of biomethanization digesters fed with raw and heat pre-treated microalgae biomasses. Chemosphere 168, 1013-1021. Available from: https://doi.org/10.1016/j.chemosphere.2016.10.109.

Satpathy, P., Steinigeweg, S., Cypionka, H., Engelen, B., 2016. Different substrates and starter inocula govern microbial community structures in biogas reactors. Environ. Technol. 37, 1441-1450. Available from: https://doi.org/ 10.1080/09593330.2015.1118559.

Scherer, P., Lippert, H., Wolff, G., 1983. Composition of the major elements and trace elements of 10 methanogenic bacteria determined by inductively coupled plasma emission spectrometry. Biol. Trace Elem. Res. 5, 149-163. Available from: https://doi.org/10.1007/BF02916619.

Schink, B., 1997. Energetics of syntrophic cooperation in methanogenic degradation. Microbiol. Mol. Biol. Rev. 61 (2), 262-280.

Schnürer, A., Jarvis, $\AA ., 2010$. Microbiological handbook for biogas plants. Swedish Waste Management U2009:03. Swed. Gas. Cent. Rep. 207, 1-138.

Shah, F.A., Mahmood, Q., Shah, M.M., Pervez, A., Asad, S.A., 2014. Microbial ecology of anaerobic digesters: the key players of anaerobiosis. Sci. World J. ID 183752.21 .

Shaw, G.T.-W., Weng, X.-Y., Chen, C.-Y., Weng, F.C.-H., Wang, D., 2019. A systematic approach re-analyzing the effects of temperature disturbance on the microbial community of mesophilic anaerobic digestion. Sci. Rep. 9 (6560), 1. Available from: https://doi.org/10.1038/s41598-019-42987-0.

Shi, X.-S., Dong, J.-J., Yu, J.-H., Yin, H., Hu, S.-M., Huang, S.-X., et al., 2017. Effect of hydraulic retention time on anaerobic digestion of wheat straw in the semicontinuous continuous stirred-tank reactors. BioMed. Res. Int. Available from: https://doi.org/10.1155/2017/2457805. ID 2457805.

Shiratori, H., Ikeno, H., Ayame, S., Kataoka, N., Miya, A., Hosono, K., et al., 2006. Isolation and characterization of a new Clostridium sp. that performs effective cellulosic waste digestion in a thermophilic methanogenic bioreactor. Appl. Environ. Microbiol. 72, 3702-3709.

Sikora, A., Detman, A., Mielecki, D., Chojnacka, A., Błaszczyk, M., 2019. Searching for metabolic pathways of anaerobic digestion: a useful list of the key enzymes. In: Banu, J.R. (Ed.), Anaerobic Digestion. IntechOpen. Available from: http://doi.org/10.5772/intechopen.81256.

Smith, P., 1966. The microbial ecology of sludge methanogenesis. Dev. Ind. Microbiol. 7, 156-161.

Souza, D.Z., Salvador, A.F., Ramos, J., Guedes, A.P., Barbosa, S., Stams, A.J.M., et al., 2013. Activity and viability of methanogens in anaerobic digestion of unsaturated and saturated long-chain fatty acids. Appl. Environ. Microbiol. 79, 4239-4245. Available from: https://doi.org/10.1128/ aem.00035-13.

Speece, R.E., Parkin, G.F., Gallagher, D., 1983. Nickel stimulation of anaerobic digestion. Water Res. 17, 677-683. Available from: https://doi.org/10.1016/ 0043-1354(83)90237-3.

Sprott, G.D., Patel, G.B., 1986. Ammonia toxicity in pure cultures of methanogenic bacteria. Syst. Appl. Microbiol. 7, 358-363. Available from: https://doi.org/10.1016/S0723-2020(86)80034-0.

Stolze, Y., Bremges, A., Maus, I., Pühler, A., Sczyrba, A., Schlüter, A., 2018. Targeted in situ metatranscriptomics for selected taxa from mesophilic and 
thermophilic biogas plants. Microb. Biotechnol. 11, 667-679. Available from: https://doi.org/10.1111/1751-7915.12982.

St-Pierre, B., Wright, D.G., 2014. Comparative metagenomic analysis of bacteria populations in three full scale mesophilic anaerobic manure digesters. Appl. Microbiol. Biotechnol. 98, 2709-2717. Available from: https://doi.org/ 10.1007/s00253-013-5220-3.

Sung, S., Liu, T., 2003. Ammonia inhibition on thermophilic anaerobic digestion. Chemosphere 53, 43e52. Available from: https://doi.org/10.1016/S0045-6535 (03) 00434-X.

Svensson, K., Paruch, L., Gaby, J.C., Linjordet, R., 2018. Feeding frequency influences process performance and microbial community composition in anaerobic digesters treating steam exploded food waste. Bioresour. Technol. 269, 276-284. Available from: https://doi.org/10.1016/j. biortech.2018.08.096.

Tan, H.Q., Li, T.T., Zhu, C., Zhang, X.Q., Wu, M., Zhu, X.F., 2012. Parabacteroides chartae sp. nov., an obligately anaerobic species from wastewater of a paper mill. Int. J. Syst. Evolut. Microbiol. 62, 2613-2617. Available from: https://doi. org/10.1099/ijs.0.038000-0.

Thanh, P.M., Ketheesan, B., Yan, Z., Stuckey, D., 2016. Trace metal speciation and bioavailability in anaerobic digestion: a review. Biotechnol. J. 34, 122-136. Available from: https://doi.org/10.1016/j.biotechadv.2015.12.006.

Theuerl, S., Klang, J., Heiermann, M., De, Vrieze, J., 2018. Marker microbiome clusters are determined by operational parameters and specific key taxa combinations in anaerobic digestion. Bioresour. Technol. 263, 128-135. Available from: https://doi.org/10.1016/j.biortech.2018.04.111.

Thomsen, S.T., Spliid, H., Østergård, H., 2014. Statistical prediction of biomethane potentials based on the composition of lignocellulosic biomass. Bioresour. Technol. 154, 80-86.

Tian, Z., Zhang, Y., Li, Y., Chi, Y., Yang, M., 2015. Rapid establishment of thermophilic anaerobic microbial community during the one-step startup of thermophilic anaerobic digestion from a mesophilic digester. Water Resour. 1 (69), 9-19. Available from: https://doi.org/10.1016/j.watres.2014.11.001.

Tonanzi, B., Braguglia, C.M., Gallipoli, A., Montecchio, D., Pagliaccia, P., Rossetti, S., et al., 2020. Anaerobic digestion of mixed urban biowaste: the microbial community shift towards stability. N. Biotechnol. 55, 108-117. Available from: https://doi.org/10.1016/j.nbt.2019.10.008.

Treu, L., Campanaro, S., Kougias, P.G., Zhu, X., Angelidaki, I., 2016. Untangling the effect of fatty acid addition at species level revealed different transcriptional responses of the biogas microbial community members. Environ. Sci. Technol. 50, 6079-6090. Available from: https://doi.org/10.1021/acs.est.6b00296.

Tsavkelova, E., Prokudina, L., Egorova, M., Leontieva, M., Malakhova, D. Netrusov, A., 2018. The structure of the anaerobic thermophilic microbial community for the bioconversion of the cellulose-containing substrates into biogas. Process. Biochem. 66, 183-196.

Venkiteshwaran, K., Bocher, B., Maki, J., Zitomer, D., 2015. Relating anaerobic digestion microbial community and process function. Microbiol. Insights 8 (S2), 37-44. Available from: http://doi.org/10.4137/MBI. S33593.

Vermelho, A.B., Melo, A.C.N., Sá, M.H.B., Santos, A.L.S., D'avila-Levy, C.M., Couri, S., et al., 2008. In: Bon, E.P.S., Ferrara, M.A., Corvo, M.L. (Eds.), Enzimas Proteolíticas: Aplicações biotecnológicas. Enzimas em Biotecnologia-Produção, Aplicações e Mercado, pp. 273-287.

Wagner, A.O., Lackner, N., Mutschlechner, M., Prem, E.M., Markt, R., Illmer, P., 2018. Biological pretreatment strategies for second-generation lignocellulosic 
resources to enhance biogas production. Energies 11 (1797). Available from: https://doi.org/10.3390/en11071797.

Wang, C., Dong, D., Wang, H., Mueller, K., Qin, Y., Wang, H., et al., 2016.

Metagenomic analysis of microbial consortia enriched from compost: new insights into the role of Actinobacteria in lignocellulose decomposition. Biotechnol. Biofuels 9 (22). Available from: https://doi.org/10.1186/s13068-016-0440-2.

Wang, P., Wang, H., Qiu, Y., Ren, L., Jiang, B., 2018a. Microbial characteristics in anaerobic digestion process of food waste for methane production-a review. Bioresour. Technol. 248, 29-36. Available from: https://doi.org/10.1016/j biortech.2017.06.152.

Wang, T.T., Sun, Z.Y., Huang, Y.L., Tan, L., Tang, Y.Q., Kida, K., 2018b. Biogas production from distilled grain waste by thermophilic dry anaerobic digestion: pretreatment of feedstock and dynamics of microbial community. Appl. Biochem. Biotechnol. 184, 685-702. Available from: https://doi.org/ 10.1007/s12010-017-2557-6.

Wang, S., Yuan, R., Liu, C., Zhou, B., 2020a. Effect of $\mathrm{Fe}^{2+}$ adding period on the biogas production and microbial community distribution during the dry anaerobic digestion process. Process. Saf. Environ. Prot. 136, 234-241. Available from: https://doi.org/10.1016/j.psep.2019.12.031.

Wang, C., Li, Y., Sun, Y., 2020b. Acclimation of acid-tolerant methanogenic culture for bioaugmentation: strategy comparison and microbiome succession. Acs Omega 5, 6062-6068. Available from: https://doi.org/ 10.1021/acsomega.9b03783.

Weiß, S., Somitsch, W., Klymiuk, I., Trajanoski, S., Guebitz, G.M., 2016. Comparison of biogas sludge and raw crop material as source of hydrolytic cultures for anaerobic digestion. Bioresour. Technol. 207, 244-251. Available from: https://doi.org/10.1016/j.biortech.2016.01.137.

Westerholm, M., Schnürer, A., 2019. Microbial responses to different operating practices for biogas production systems. In: Banu, J.R. (Ed.), Anaerobic Digestion. IntechOpen. Available from: http://doi.org/10.5772/ intechopen.82815.

Westerholm, M., Levén, L., Schnürer, A., 2012. Bioaugmentation of syntrophic acetate-oxidizing culture in biogas reactors exposed to increasing levels of ammonia. Appl. Environ. Microbiol. 78 (21), 7619-7625. Available from: https://doi.org/10.1128/AEM.01637-12.

Westerholm, M., Isaksson, S., Karlsson, O.L., Schnurer, A., 2018. Microbial community adaptability to altered temperature conditions determines the potential for process optimization in biogas production. Appl. Energy 226, 838-848. Available from: https://doi.org/10.1016/j.apenergy.2018.06.045.

Wintsche, B., Glaser, K., Sträuber, H., Centler, F, Liebetrau, J., Harms, H., et al., 2016. Trace elements induce predominance among methanogenic activity in anaerobic digestion. Front. Microbiol. Available from: https://doi.org/ 10.3389/fmicb.2016.02034.

Wongwilaiwalin, S., Laothanachareon, T., Mhuantong, W.,

Tangphatsornruang, S., Eurwilaichitr, L., Igarashi, Y., et al., 2013.

Comparative metagenomic analysis of microcosm structures and lignocellulolytic enzyme systems of symbiotic biomass-degrading consortia. Appl. Microbiol. Biotechnol. 97, 8941-8954. Available from: https://doi.org/10.1007/s00253-013-4699.

Worm, P., Müller, N., Plugge, C.M., et al., 2010. Syntrophyin Methanogenic Degradation. In: Hackstein, J.H.P. (Ed.), (Endo)Symbiotic Methanogenic Archaea. Springer-Verlag, Berlin, pp. 143-173.

Wu, L., Shan, X., Chen, S., Zhang, Q., Qi, Q., Qin, Z., et al., 2020. Progressive microbial community networks with incremental organic loading rates 
underlie higher anaerobic digestion performance. Msystems 5 (e00357-19). Available from: https://doi.org/10.1128/mSystems.00357-19.

Xu, R., Yang, Z.H., Zheng, Y., Zhang, H.B., Liu, J.-B., Xiong, W.P., et al., 2017a. Depth-resolved microbial community analyses in the anaerobic co-digester of dewatered sewage sludge with food waste. Bioresour. Technol. 244, $824-835$.

Xu, R., Zhang, K., Liu, P., Khan, A., Xiong, J., Tian, F., et al., 2017b. A critical review on the interaction of substrate nutrient balance and microbial community structure and function in anaerobic co-digestion. Bioresour. Technol. 247, 1119-1127. Available from: https://doi.org/10.1016/j. biortech.2017.09.095.

Xu, R., Yang, Z--H., Zheng, Y, Liu, J.-B., Xiong, W.-P., Zhang, Y.-R, et al., 2018. Organic loading rate and hydraulic retention time shape distinct ecological networks of anaerobic digestion related microbiome. Bioresour. Technol. 262, 184-193. Available from: https://doi.org/10.1016/j.biortech.2018.04.083.

Yang, Z.H., Xu, R., Zheng, Y., Chen, T., Zhao, L.J., Li, M., 2016. Characterization of extracellular polymeric substances and microbial diversity in anaerobic codigestion reactor treated sewage sludge with fat, oil, grease. Bioresour. Technol. 212, 164-173. Available from: https://doi.org/10.1016/j. biortech.2016.04.046.

Yu, B., Lou, Z., Zhang, D., Shan, A., Yuan, H., Zhu, N., et al., 2015. Variations of organic matters and microbial community in thermophilic anaerobic digestion of waste activated sludge with the addition of ferric salts. Bioresour. Technol. 179, 291-298.

Zakrzewski, M., Goesmann, A., Jaenicke, S., Jünemann, S., Eikmeyer, F., Szczepanowski, R., et al., 2012. Profiling of the metabolically active community from a production-scale biogas plant by means of highthroughput metatranscriptome sequencing. J. Biotechnol. 158, 248-258. Available from: https://doi.org/10.1016/j.jbiotec.2012.01.020.

Zehnder, A.J.B., 1978. Ecology of methane formation. In: Mitchell, R. (Ed.), Water Pollution Microbiology, 2. Wiley, New York, pp. 349-376.

Zhang, J., Lv, C., Tong, J., Liu, J., Liu, J., Yu, D., et al., 2016. Optimization and microbial community analysis of anaerobic co-digestion of food waste and sewage sludge based on microwave pretreatment. Bioresour. Technol. 200, 253-261. Available from: https://doi.org/10.1016/j.biortech.2015.10.037.

Zhou, L., Gao, Y., Yu, K., Zhou, H., De Costa, Yi, S., et al., 2020. Microbial community in in-situ waste sludge anaerobic digestion with alkalization for enhancement of nutrient recovery and energy generation. Bioresource Technology 295, 122277.

Ziels, R.M., Karlsson, A., Beck, D.A.C., Ejlertsson, J., Yekta, S.S., Bjorn, A., et al., 2016. Microbial community adaptation influences long-chain fatty acid conversion during anaerobic codigestion of fats, oils, and grease with municipal sludge. Water Res. 103, 372-382. Available from: https://doi.org/ 10.1016/j.watres.2016.07.043.

Zou, H., Gao, M., Yu, M., Zhang, W., Zhang, S., Wu, C., Tashiro, Y., Wang, Q., 2020. Methane production from food waste via mesophilic anaerobic digestion with ethanol pre-fermentation: Methanogenic pathway and microbial community analyses. Bioresource Technology 297, 122450. 


\title{
Apêndice 2
}

\section{Original Article}

\section{BBiofpr}

\section{Screening and cocktail optimization using experimental mixture design: enzymatic saccharification as a biological pretreatment strategy}

\author{
Vanessa Elisa Pinheiro, Ribeirão Preto Medical School, São Paulo University, Ribeirão Preto, Brazil; \\ Swedish Centre for Resource Recovery, University of Borås, Borås, Sweden \\ llona Sárvári Horváth, Magnus Lundin, Swedish Centre for Resource Recovery, University of Borås, \\ Borås, Sweden \\ Maria de Lourdes Teixeira de Moraes, Polizeli $\odot$, Ribeirão Preto Medical School, São Paulo \\ University, Ribeirão Preto, Brazil; Faculty of Philosophy, Sciences and Letters at Ribeirão Preto, \\ São Paulo University, Ribeirão Preto, Brazil
}

Received February 23 2021; Revised April 29 2021; Accepted May 14 2021; View online at Wiley Online Library (wileyonlinelibrary.com); DOI: 10.1002/bbb.2251; Biofuels, Bioprod. Bioref. (2021)

\begin{abstract}
Biofuels contribute environment-friendly, renewable energy, minimizing dependence on fossil energy. The pretreatment of biomass is a practical step that accelerates and facilitates the hydrolysis of complex materials. This work aimed to screen, select, and study cocktail formulations for biomass hydrolysis, where the enzymes were provided both from a commercial source (Trichoderma reesei, Novozymes $($ ) and through the cultivation of Aspergillus brasiliensis and Aspergillus tamarii Kita. Experimental mixture designs were used to optimize the enzymatic conversion of substrates into simple sugars. A crude extract rich in amylase (AAB) had a significant favorable influence on cornmeal hydrolysis by maximizing the yield of reducing sugars (RS) $\left(173 \mu \mathrm{molmL}^{-1}\right)$. Celluclast ${ }^{\mathrm{TM}}$, rich in cellulase, significantly affected the hydrolysis of banana peel, maximizing the RS yield $\left(175 \mu \mathrm{molmL}^{-1}\right)$. Variable degrees of enzyme synergism were evident from statistical analysis of the biomass hydrolysis. (C) 2021 Society of Chemical Industry and John Wiley \& Sons, Ltd
\end{abstract}

Key words: biomass; enzymatic hydrolysis; experimental mixture design; banana peel; cornmeal; sorghum grain bran

\section{Introduction}

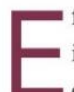
fforts to achieve sustainable bioenergy production have increased tremendously over the years due to a high demand for energy and to environmental concerns as the world's population has expanded.

\footnotetext{
First-generation biofuels (bioethanol and biodiesel) and advanced biofuels (biohydrogen, biogas, bio-oil, biochar, and syngas) can be produced from renewable materials like plants, which convert solar energy into biomass through photosynthesis. Agriculture residues, waste papers from chemical pulps, forest wood, and food / municipal wastes
}

Correspondence to: Maria de Lourdes Teixeira de Moraes Polizeli, Faculty of Philosophy, Sciences and Letters at Ribeirão Preto - São Paulo University. Bandeirantes, Av. 3.900, 14040-901 Ribeirão Preto, São Paulo, Brazil. E-mail: polizeli@ffclrp.usp.br 
are among other fractions belonging to this category. These materials are sustainable, environmentally friendly, and promising alternatives to fossil resources. ${ }^{2,3}$

However, innovative technologies and methodologies are needed to remove barriers and to make these substrates easily accessible for biofuel production by microorganisms. Different pretreatment methods have been developed and have been investigated to facilitate the hydrolysis of sugar sources. ${ }^{1,4,5}$ Balanced enzyme cocktails are among the most promising approaches to optimize the hydrolysis reaction. ${ }^{6,7}$

The objective of using enzymes is to break the recalcitrant structure of biomass. A pool of enzymes - that is xylanases, cellulases, amylases, and ligninases - can synergistically contribute to substrate degradation, resulting in the formation of monosaccharides. The main hemicellulose is xylan, a branched polysaccharide consisting of xylose residues linked by $\beta-1,4$ glycosidic bonds. ${ }^{8}$

The xylanolytic system is composed of endoxylanase (EC 3.2.1.8), $\beta$-xylosidase (EC 3.2.1.37), $\alpha$-glucuronidase (EC 3.2.1.139), and $\alpha$-arabinofuranosidase (EC 3.2.1.55), which cooperatively convert xylan into simple sugars. ${ }^{5,9,10}$ Cellulases include endoglucanases (EC 3.2.1.4), cellobiohydrolases (CBH I and CBH II, EC 3.2.1.91), and $\beta$-glucosidases (EC 3.2.1.21), which work together to release glucose. ${ }^{5,11}$ Amylases act on starches or on the oligosaccharides derived from them. $\alpha$-Amylase (EC 3.2.1.1), $\beta$-amylase (EC 3.2.1.2), and $\gamma$-amylase (glucan 1,4- $\alpha$-glucosidase, EC 3.2.1.3) hydrolyze different glycosidic linkages on starch polymers, leading to the release of glucose residues. ${ }^{12-14}$

Distinct substrates require different enzymatic mixtures to maximize hydrolysis. ${ }^{15}$ The relative proportions of the enzymes may depend on the protein load in the reaction. The enzymatic synergism will rely on the accessibility of the target surface area by their cooperative action. ${ }^{6,16}$

Several studies have applied response surface design systematically to optimize multiple factors affecting experimental performance. ${ }^{17,18}$ Mixture design is a method that inspects mixture-related elements. ${ }^{19}$ In this study, efficient degrading enzyme systems were evaluated to enhance biomass hydrolysis before biofuel production. It is necessary to investigate and optimize enzyme systems systematically to degrade different types of lignocellulosic biomass to improve their conversion into fermentable sugars. This is the first step in any industrial process towards producing value-added chemicals or fuels from these renewable raw materials. Twenty-three different biomass types were included in screening and separately treated with three different types of crude enzyme extracts, either produced on site or commercially. Three of the best performing biomass types were then selected for further investigation using an experimental mixture design to investigate synergy when treated in different combinations with enzyme cocktails.

\section{Material and methods}

\section{Production of enzyme extracts}

The fungi Aspergillus brasiliensis and Aspergillus tamarii Kita were selected from the Mycology Collection of the Microbiology and Cell Biology Laboratory of Biology Department from Faculty of Philosophy, Science and Letters of Ribeirão Preto - USP (São Paulo, Brazil), where they were maintained on potato dextrose agar (PDA) - (Himedia $\%$ Brazil) slants at $4{ }^{\circ} \mathrm{C}$.

The crude extract optimized for amylase production (AAB) was prepared according to Almeida et al. ${ }^{12}$ with modifications. A volume of $25 \mathrm{~mL}$ Segato Rizzatti (SR) medium ${ }^{20}$ containing $1 \%(\mathrm{w} / \mathrm{v})$ of cornmeal as a carbon source was poured into $125 \mathrm{~mL}$ Erlenmeyer flasks and then sterilized in an autoclave at $127^{\circ} \mathrm{C}$ and $1.0 \mathrm{~atm}$ for $15 \mathrm{~min}$. Cultures of $A$. brasiliensis were obtained by inoculation of $1.0 \mathrm{~mL}$ of a conidia solution ( $10^{6}$ conidia) into each flask, incubated at $30^{\circ} \mathrm{C}$ for $120 \mathrm{~h}$ under static conditions.

The crude extract optimized for xylanase production (XAT) by $A$. tamarii Kita was prepared according to Heinen et al. ${ }^{10}$ The strain A. tamarii Kita was grown in $125 \mathrm{~mL}$ Erlenmeyer flasks with $2.5 \%(\mathrm{w} / \mathrm{v})$ of barley bagasse as carbon source, in $15 \mathrm{~mL}$ of Adams' medium, ${ }^{21}$ and $10 \mathrm{~mL}$ of distilled water. Cultures were obtained by inoculation of $1.0 \mathrm{~mL}$ of a conidia solution $\left(10^{6}\right.$ conidia) into each flask, previously sterilized for $15 \mathrm{~min}$ at $127^{\circ} \mathrm{C}$ and $1.0 \mathrm{~atm}$, incubated for $129 \mathrm{~h}$ at $28^{\circ} \mathrm{C}$ under static conditions. After cultivation, cultures were harvested by vacuum filtration using Whatman no. 1 filter paper, and the enzyme activity in the filtrates (extracellular crude extracts) was determined.

Commercial cellulase extract from Trichoderma reese $i$ was obtained from Novozymes ${ }^{\circ}$ (Celluclast" ${ }^{\mathrm{*}}$ ). In this study, the commercial extract was diluted ten times and then named CTR.

\section{Enzyme activity}

The polysaccharide-degrading activity of amylases, xylanases, pectinases, carboxymethylcellulases (CMCases), and arabinanases was analyzed based on the amount of released reducing sugar (RS) using the 3,5-dinitrosalicylic acid (DNS) method. ${ }^{22}$

The activity of amylases, xylanases, pectinases, and arabinanases was determined using their natural substrates - soluble potato starch, carboxymethylcellulose medium viscosity, beechwood xylan, polygalacturonic acid, sodium salt, and linear arabinan, respectively. The mixtures of $50 \mu \mathrm{L}$ 
of the substrate (1\%) in sodium acetate buffer $\left(100 \mathrm{mmol} \mathrm{L}^{-1}\right.$, $\mathrm{pH} 5.0$ ) and $50 \mu \mathrm{L}$ of enzyme extract were kept in a water bath at $50^{\circ} \mathrm{C}$ for $10 \mathrm{~min}$ in case of amylases, xylanases, pectinases, and arabinanases, and $60 \mathrm{~min}$ for the assays of CMCases. After that, the tube assays were boiled at $100^{\circ} \mathrm{C}$ for $5 \mathrm{~min}$, cooled, and $100 \mu \mathrm{L}$ DNS was added to all samples. Finally, $1 \mathrm{~mL}$ of distilled water was added to each mixture, and the concentration of RS was determined by measuring the color intensities in a spectrophotometer at $540 \mathrm{~nm}$. The activity unit (U) was defined as the amount of enzyme capable of releasing $1 \mu \mathrm{mol}$ of RS per minute.

$\beta$-Glucosidase activity was determined by $p$-nitrophenyl$\beta$-D-glucopyranoside (pNPG) hydrolysis. The assay was initiated by adding $15 \mu \mathrm{L}$ of the crude extract to $10 \mu \mathrm{L}$ of Mcllvaine buffer (pH 6.0) and $25 \mu \mathrm{L}$ of pNPG $\left(4 \mathrm{mmol} \mathrm{L}^{-1}\right.$ in $\mathrm{H}_{2} \mathrm{O}$ ) and incubated for $5 \mathrm{~min}$ at $50^{\circ} \mathrm{C}$. The reaction was stopped by the addition of $50 \mu \mathrm{L} 0.2 \mathrm{~mol} \mathrm{~L}^{-1} \mathrm{Na}_{2} \mathrm{CO}_{3}$ solution. The measurement was performed in a Microplate Readers (Molecular Devices, SpectraMax, San Jose, CA, USA), at $405 \mathrm{~nm}$. The enzymatic activity unit (U) was defined as the amount of enzyme required to hydrolyze one $\mu \mathrm{mol}$ of the substrate per minute.

\section{Biomass hydrolysis}

\section{Biomass}

The different types of biomass used in the screening were as follows: barley bagasse (Hordeum vulgare), kindly supplied by 'Colorado’ brewery of Ribeirão Preto, São Paulo, Brazil $\left(21.1704^{\circ} \mathrm{S}, 47.8103^{\circ} \mathrm{W}\right.$ ); sugarcane bagasse (Saccharum officinarum), grounded and washed, provided by the Guarani Mill (São Paulo, Brazil - $23.5505^{\circ} \mathrm{S}, 46.6333^{\circ} \mathrm{W}$ ); elephant grass (Pennisetum purpureum), obtained 120 days after the planting of seeds in moist soil in the city of Leme, São Paulo, Brazil $\left(22.1892^{\circ} \mathrm{S}, 47.3978^{\circ} \mathrm{W}\right)$ and then dried in an oven at $50^{\circ} \mathrm{C}$, for $24 \mathrm{~h}$, and finally milled to achieve a particle size of $1 \mathrm{~mm}$. The orange pies with thick and average pieces were wastes obtained from a local orange juice industry in Riberão Preto city. The orange peel (Citrus sinensis var. Bahia) and banana peel (Musa spp. Var. Prata), both obtained after the fruits were consumed, were oven dried at $50^{\circ} \mathrm{C}$ for $24 \mathrm{~h}$ and milled in a knife mill to a particle size of $1 \mathrm{~mm}$. Wheat bran (Triticum sp.) was obtained commercially (Macrozen - whole foods). Coffee grounds (Coffea sp.) were collected at the kitchen of the Department of Microbiology and Cell Biology, Sao Paulo University. White sludge was supplied by International Paper, Luiz Antônio, São Paulo, Brazil $\left(21.5528^{\circ} \mathrm{S}, 47.6987^{\circ} \mathrm{W}\right)$. This sludge sample was autoclaved to prevent the proliferation of microorganisms and was stored in polyethylene bags in a cold chamber $\left(4^{\circ} \mathrm{C}\right)$. The vinasse used was supplied by Biosev Plant - Leme, São Paulo, Brazil. Corn straw (Zea mays), sorghum (Sorghum bicolor) stem and grain, and cotton bran (Gossypium hirsutum L.) were obtained from plantations in the Leme, São Paulo, Brazil region. In contrast, cassava (Manihot esculenta) peel and tuberous root were obtained from a supermarket in the city of Ribeirão Preto, São Paulo, Brazil. All these residues were oven-dried at $50^{\circ} \mathrm{C}$ for $24 \mathrm{~h}$ and then milled to a particle size of $1 \mathrm{~mm}$. SJC Bioenergia donated the wet distiller grains (WDG). The soybean bran (Glycine max) and soy straw came from the Três Pinheiros Farm in Planaltina, Brazil (15.6216 ${ }^{\circ}$ $\left.\mathrm{S}, 47.6522^{\circ} \mathrm{W}\right)$. All materials were subjected to pretreatment by autoclaving at $121^{\circ} \mathrm{C}$ for $2 \mathrm{~h}$. After that, they were washed and dried in an oven at $60^{\circ} \mathrm{C}$ for $48 \mathrm{~h}$. Finally, they were also milled in a knife mill to a final particle size of $1 \mathrm{~mm}$ for soybean bran and $5 \mathrm{~mm}$ for soy straw. The cornmeal used was Fubá Mimoso Yoki ${ }^{\circ}$, enriched with folic iron and fiber, and bought in the supermarket.

\section{Screening assays}

The screening was performed by applying each extract - that is XAT, AAB, or CTR - with different biomass types for enzymatic hydrolysis. In each case, $50 \mathrm{mg}$ of biomass and $1 \mathrm{~mL}$ of extract buffered in sodium acetate $\left(100 \mathrm{mmol} \mathrm{L}^{-1}\right.$, $\mathrm{pH} 5.0)(1: 20 \mathrm{w} / \mathrm{v})$ were added to $2 \mathrm{~mL}$ Eppendorf tubes, which were then kept at $50^{\circ} \mathrm{C}$ for $24 \mathrm{~h}$ for the hydrolysis to occur. The results from the biomass hydrolysis were analyzed by RS dosage $\left(\mu \mathrm{mol} \mathrm{mL}^{-1}\right)$ using the methodology described by Miller, ${ }^{22}$ in which a standard curve of glucose and xylose $\left(1 \mathrm{mg} \mathrm{mL}^{-1}\right)$ was used.

\section{Experimental mixture design}

Six experimental designs were carried out. They comprised three simplex centroid mixture designs, consisting of pure fractions and mixtures of two and three components as presented in Tables 1 and 2.

The three first designs aimed to define an optimal formulation of enzyme mixture for the hydrolysis of investigated substrates, that is cornmeal, banana peel, or sorghum grain bran hydrolysis. Thus, three enzyme extracts, that is AAB (A), XAT (B), and CTR $(C)$, were the independent variables tested affecting the hydrolysis of each biomass (Table 1).

The following three designs in this study were focused on how these three biomass types and their different mixtures could be hydrolyzed by each of the enzyme extracts tested. Hence, cornmeal, banana peel, and sorghum grain bran were the independent variables in these designs (Table 2).

Furthermore, the RS yield $\left(\mu \mathrm{mol} \mathrm{mL} \mathrm{L}^{-1}\right)$ obtained at the end of the experiments was used as the response variable in all these assays. 


\begin{tabular}{|c|c|c|c|c|c|c|}
\hline \multirow[t]{2}{*}{ Assay } & \multicolumn{3}{|c|}{ Variable (mL) } & \multicolumn{3}{|c|}{$\mathrm{RS}\left(\mu \mathrm{molL}^{-1}\right)$ released } \\
\hline & XAT & AAB & CTR & Cornmeal & Banana peel & $\begin{array}{l}\text { Sorghum grain } \\
\text { bran }\end{array}$ \\
\hline 1 & $1(1)$ & $0(0)$ & $0(0)$ & 169.03 & 93.22 & 70.16 \\
\hline 2 & $0(0)$ & $1(1)$ & $0(0)$ & 174.19 & 131.45 & 97.09 \\
\hline 3 & $0(0)$ & $0(0)$ & $1(1)$ & 78.54 & 143.54 & 61.29 \\
\hline 4 & $0.5(0.5)$ & $0.5(0.5)$ & $0(0)$ & 153.38 & 144.67 & 155.64 \\
\hline 5 & $0.5(0.5)$ & $0(0)$ & $0.5(0.5)$ & 113.87 & 153.22 & 68.06 \\
\hline 6 & $0(0)$ & $0.5(0.5)$ & $0.5(0.5)$ & 140.48 & 97.58 & 142.09 \\
\hline $7^{\circ}$ & $0.33(0.33)$ & $0.33(0.33)$ & $0.33(0.33)$ & 105.80 & 139.51 & 190.16 \\
\hline $8^{\circ}$ & $0.33(0.33)$ & $0.33(0.33)$ & $0.33(0.33)$ & 136.77 & 155 & 166.12 \\
\hline $9^{*}$ & $0.33(0.33)$ & $0.33(0.33)$ & $0.33(0.33)$ & 138.38 & 157.09 & 160.64 \\
\hline
\end{tabular}

Table 2. Mixture design: Mixture among biomass (cornmeal, banana peel, and sorghum grain bran) using XAT, AAB, and CTR enzymatic extracts. The yields of RS ( $\left.\mu \mathrm{molmL}^{-1}\right)$ were evaluated.

\begin{tabular}{|c|c|c|c|c|c|c|}
\hline \multirow[t]{2}{*}{ Assay } & \multicolumn{3}{|c|}{ Variable (mg) } & \multicolumn{3}{|c|}{$\mathrm{RS}\left(\mu \mathrm{mol} \mathrm{L}^{-1}\right)$ released } \\
\hline & Cornmeal & Banana peel & $\begin{array}{l}\text { Sorghum grain } \\
\text { bran }\end{array}$ & $A A B$ & XAT & CTR \\
\hline 1 & $50(1)$ & $0(0)$ & $0(0)$ & 170 & 135.96 & 88.06 \\
\hline 2 & $0(0)$ & $50(1)$ & $0(0)$ & 155.64 & 117.90 & 175.32 \\
\hline 3 & $0(0)$ & $0(0)$ & $50(1)$ & 126.77 & 72.74 & 101.61 \\
\hline 4 & $25(0.5)$ & $25(0.5)$ & $0(0)$ & 159.67 & 72.41 & 129.83 \\
\hline 5 & $25(0.5)$ & $0(0)$ & $25(0.5)$ & 158.54 & 70.80 & 93.22 \\
\hline 6 & $0(0)$ & $25(0.5)$ & $25(0.5)$ & 159.03 & 111.77 & 142.41 \\
\hline $7^{\circ}$ & $0.167(0.33)$ & $0.167(0.33)$ & $0.167(0.33)$ & 155.80 & 110.32 & 118.22 \\
\hline 8 & $0.167(0.33)$ & $0.167(0.33)$ & $0.167(0.33)$ & 155.80 & 108.54 & 136.45 \\
\hline $9^{*}$ & $0.167(0.33)$ & $0.167(0.33)$ & $0.167(0.33)$ & 157.74 & 109.67 & 122.09 \\
\hline
\end{tabular}

The assays were performed in $2 \mathrm{~mL}$ Eppendorf tubes containing $50 \mathrm{mg}$ of biomass, $1 \mathrm{~mL}$ of enzyme extract buffered in sodium acetate $\left(100 \mathrm{mmolL}^{-1}, \mathrm{pH} 5.0\right)$, as well as $15 \mathrm{mmol} \mathrm{L}^{-1}$ sodium azide to prevent bacterial contamination. Enzymatic hydrolysis was then carried out at $50^{\circ} \mathrm{C}$ and $50 \mathrm{rpm}$ in a dry shaking bath. After $24 \mathrm{~h}$ of hydrolysis, aliquots of $10 \mu \mathrm{L}$ were taken out from each tube and immediately boiled for $5 \mathrm{~min}$ to inactivate the enzymes, and the RS were quantified $\left(\mu \mathrm{molmL} L^{-1}\right)$.

\section{Statistical analysis}

The biomass screnning was conducted in triplicate, and the mean and standard deviation values were reported.
The effect of tertiary mixture compositions of (i) biomass, that is cornmeal, banana peel, and sorghum grain bran, and (ii) enzyme extracts, that is AAB, XAT, and CTR, was investigated employing simplex centroid designs. This type of design has $2^{\mathrm{q}-1}$ points, where $\mathrm{q}=3$ represents the numbers of components in each system and xi represents the proportion of $i$ th constituent in the mixture. The ratio of the components in each design varied between 0 and 1 , according to Eqn (1):

$$
\sum_{i=1}^{3} x i=x_{1}+x_{2}+x_{3}=1 ; 0 \leq x i \geq 1
$$

(C) 2021 Society of Chemical Industry and John Wiley \& Sons, Ltd | Biofuels, Bioprod. Bioref. (2021); DOI: 10.1002/bbb.2251 
The experimental mixtures ratios for each design performed have been given in Tables 1 and 2. As described above, the first part of the experimental design investigated enzyme extract mixtures and the second part investigated substrate proportions. To predict the response variable $Y$ as a function of the three components, polynomial models were employed to link the response with the composition of the mixtures. The first-order coefficients, shown in Eqn (2), measure the relative effect of pure substrates, and the quadratic (Eqn (3)) and special cubic (Eqn (4)) terms measure the synergistic or antagonistic interactions between fractions, that is: linear model:

$$
Y=\beta_{1} x_{1}+\beta_{2} x_{2}+\beta_{3} x_{3}
$$

quadratic model:

$$
Y=\beta_{1} x_{1}+\beta_{2} x_{2}+\beta_{3} x_{3}+\beta_{12} x_{1} x_{2}+\beta_{13} x_{1} x_{3}+\beta_{23} x_{2} x_{3}
$$

special cubic model:

$$
\begin{aligned}
Y= & \beta_{1} x_{1}+\beta_{2} x_{2}+\beta_{3} x_{3}+\beta_{12} x_{1} x_{2}+\beta_{13} x_{1} x_{3} \\
& +\beta_{23} x_{2} x_{3}+\beta_{123} x_{1} x_{2} x_{3}
\end{aligned}
$$

where $Y$ is the dependent variable (RS yield $\left(\mu \mathrm{mol} \mathrm{mL}^{-1}\right), \beta_{i}$ is the regression coefficient (calculated from experimental data), and $x_{i}$ is the independent variable (factors). ${ }^{23-25}$ All models were fitted for each response variable by means of regression methods and analyzed with ANOVA. The significance of the regression models was evaluated at a significance level of 5 or $10 \%(P$-values $\leq 0.05$ or $\leq .1)$ depending on the experiment. The lack of fit verified the hypothesis that the selected model was adequate to describe all of the experimental data. Statistica v.13.0 software (StatSoft, Inc, Tulsa, OK, USA) was used for analyses.

\section{Results and discussion}

\section{Enzyme activity}

The determination of enzyme activity showed that xylanases were the main enzymes present in the XAT extract $\left(23.75 \pm 0.63 \mathrm{U} \mathrm{mL}^{-1}\right)$, and amylases in the $\mathrm{AAB}$ extract $\left(6.0 \pm 0.1 \mathrm{U} \mathrm{mL}^{-1}\right)$. As both these enzyme extracts produced on site were crude, several other enzymes could be found in their composition (Table 3 ).

Celluclast $^{\text {tw }}$ was used as a cellulase-rich extract. The CMCase

\begin{tabular}{|c|c|c|c|}
\hline $\begin{array}{l}\text { Enzyme } \\
\text { extract }\end{array}$ & Enzyme & $\begin{array}{l}\text { Activity } \\
\left(\mathrm{UmL}^{-1}\right)\end{array}$ & Reference \\
\hline \multirow[t]{6}{*}{ AAB } & Amylase & $6.0 \pm 0.100$ & \multirow[t]{6}{*}{ This work } \\
\hline & Pectinase & $0.89 \pm 0.050$ & \\
\hline & Xylanase & $1.00 \pm 0.180$ & \\
\hline & Arabinanase & $0.80 \pm 0.290$ & \\
\hline & CMCase & $0.68 \pm 0.140$ & \\
\hline & $\beta$-Glucosidase & $0.02 \pm 0.003$ & \\
\hline \multirow[t]{6}{*}{ XAT } & Xylanase & $23.75 \pm 0.630$ & \multirow[t]{6}{*}{ Heinen et al. ${ }^{10}$} \\
\hline & Pectinase & $0.19 \pm 0.020$ & \\
\hline & Amylase & $6.50 \pm 0.160$ & \\
\hline & $\begin{array}{l}\text { Endo-1,4- } \beta \text { - } \\
\text { glucanase }\end{array}$ & $0.15 \pm 0.014$ & \\
\hline & $\begin{array}{l}\text { Exo-1,4- } \beta \text { - } \\
\text { glucanase }\end{array}$ & $0.25 \pm 0.015$ & \\
\hline & $\beta$-Glucosidase & $0.04 \pm 0.003$ & \\
\hline
\end{tabular}
activity in the commercial extract was $78.66 \pm 2.3 \mathrm{U} \mathrm{mL}^{-1}$. However, as this commercial extract was diluted ten times for the investigations in this study, the actual activity was
$7.8 \mathrm{U} \mathrm{mL}^{-1}$. Suwannarangsee et al., ${ }^{18}$ and Abdullah et al. ${ }^{26}$ also reported the activity profile of Celluclast ${ }^{\mathrm{ts}}$ using a proteomic analysis with liquid chromatography-tandem mass spectrometry (LC/MS/MS). They found that among 20 enzymes present in Celluclast ${ }^{\mathrm{ri}}$, $35 \%$ counts for cellulases (two cellobiohydrolases (CBH I and CBH II) and five endoglucanases), and $40 \%$ counts for hemicellulases (two xylanases, two $\beta$-xylosidases, one xyloglucanase, one swollenin, one Cip1, and one Cip2). However, no $\beta$ glucosidase was detected. Cip1 and Cip2 are non-hydrolytic proteins, which contain a fungal-type cellulose-binding domain and a signal sequence. Cip1 is very similar to an unassigned putative hydrolase secreted by Streptomyces coelicolor, ${ }^{27}$ and Cip2 is very similar to multidomain esterase from Ruminococcus flavefaciens. ${ }^{28}$

\section{Screening for biomass hydrolysis}

The selection of a suitable pretreatment has a significant effect on the economic feasibility of producing biofuels. Hence it is essential to select both pretreatment methods and suitable substrates resulting in higher concentrations of liberated sugars (which can be utilized in the following steps of biofuel production) during the hydrolysis. ${ }^{29,30}$

In this screening, crude enzyme extracts - that is XAT, $\mathrm{AAB}$, and CTR - were individually applied for the hydrolysis of 23 different biomass samples. The results - the amount of $\mathrm{RS}\left(\mu \mathrm{mol} \mathrm{mL} \mathrm{m}^{-1}\right)$ released after $24 \mathrm{~h}$ of hydrolysis at $50^{\circ} \mathrm{C}$ - are shown in Fig. 1(A-C).

During hydrolysis with $\mathrm{AAB}$, cornmeal, banana peel, orange peel, barley bagasse, sorghum grain bran, 

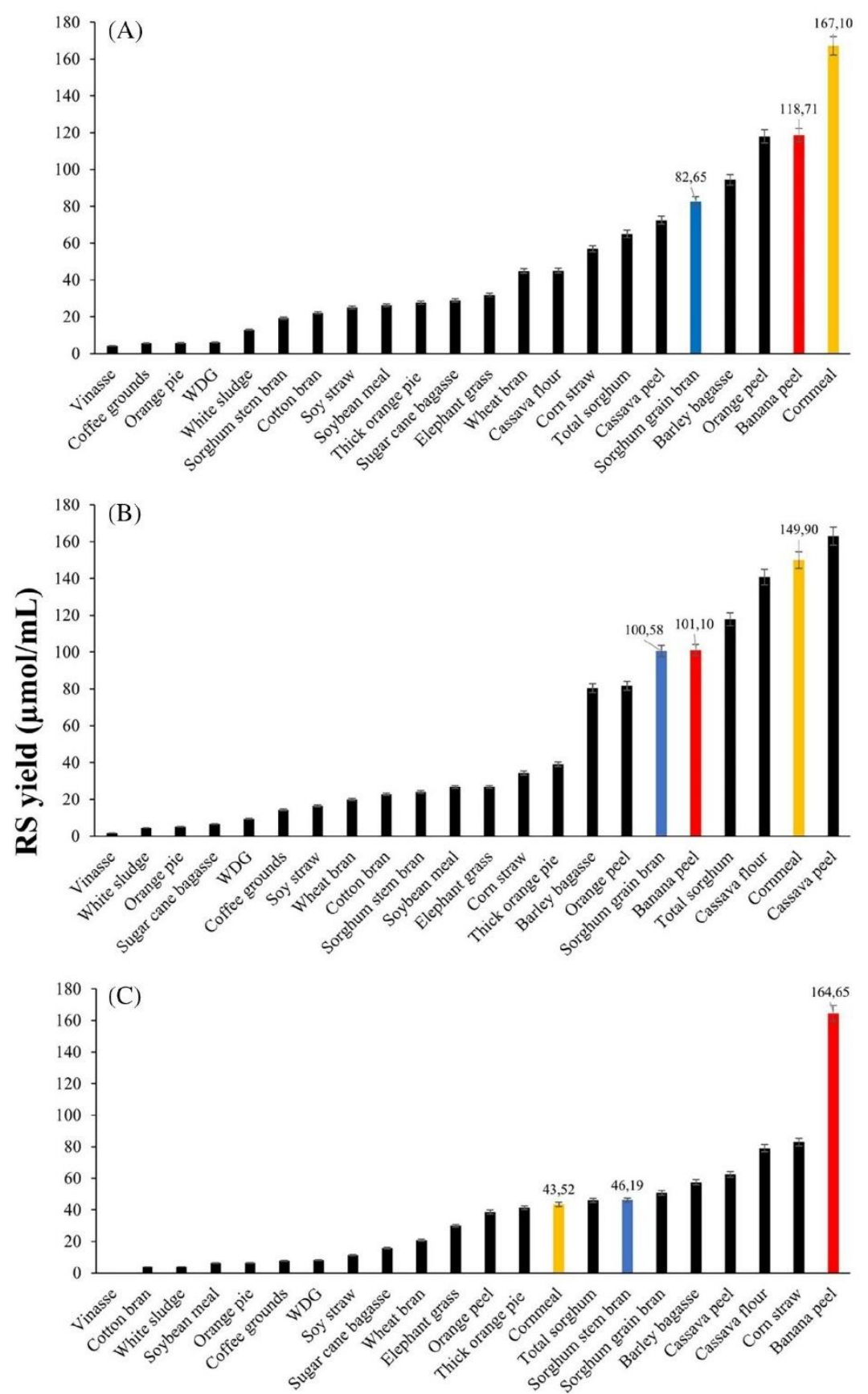

Biomass

Figure 1. Screening of biomass. RS yield $\left(\mu \mathrm{molmL}^{-1}\right)$ obtained after $24 \mathrm{~h}$ of hydrolysis at $50^{\circ} \mathrm{C}, \mathrm{pH} 5.0$ with enzymatic extracts of $A A B(A)$, XAT $(B)$, and CTR (C).

C 2021 Society of Chemical Industry and John Wiley \& Sons, Ltd | Biofuels, Bioprod. Bioref. (2021); DOI: 10.1002/bbb.2251 
and cassava peel showed relatively high RS yields of $167.1 \pm 5.01 ; 118.71 \pm 3.5 ; 118.0 \pm 3.5 ; 94.38 \pm 2.8 ; 82.65 \pm 2.4$ and $72.45 \pm 2.17 \mu \mathrm{molmL}^{-1}$, respectively (Fig. 1 (A)). Furthermore, the treatment with XAT resulted in relatively high hydrolysis levels in the cases of cassava peel, cornmeal, cassava flour, total sorghum, banana peel, and sorghum grain bran with corresponding RS yields of $162.97 \pm 4.98$; $149.9 \pm 4.5 ; 140.71 \pm 4.22 ; 117.76 \pm 3.53 ; 101.1 \pm 3.0$ and $100.58 \pm 3.0 \mu \mathrm{mol} \mathrm{mL}^{-1}$, respectively (Fig. 1(B)). Considering the six best biomasses hydrolyzed by AAB or XAT, the cornmeal, banana peel, and sorghum grain flour were those that exhibited greater efficiency in both settings with RS yields higher than $80 \mu \mathrm{mol} \mathrm{mL} L^{-1}$.

Cornmeal $\left(\right.$ Yoki $\left.^{\circ}\right)$ is biomass rich in starch $(80 \%)$, with $8 \%$ protein and $3 \%$ of lipids. Likewise, sorghum grains have similar composition, although with a higher protein content of $13-15 \%{ }^{31}$ The ratio of fermentable / nonfermentable components in cornmeal and sorghum grain may contribute to their high potential to form RS during hydrolysis by $\mathrm{AAB}$ and XAT. Both are rich in amylases. Banana peel has also been reported to contain lignin, hemicellulose, and cellulose, comprising up to $9.82 \%, 25.52 \%$, and $11.45 \%$ of the biomass, respectively. ${ }^{32}$ Each crude enzyme extract of $\mathrm{AAB}$ and XAT contains many hemicellulases (especially XAT), leading to a substantial RS release.

The cellulose content in the biomass can be hydrolyzed into cellobiose and glucose through the action of numerous enzymes, such as cellobiohydrolases (EC 3.2.1-), endoglucanases (EC 3.2.1.4), $\beta$-glucosidases (EC 3.2.1.21), and accessory enzymes. Furthermore, although the hemicellulose structure is more complex than cellulose, the polysaccharides forming this polymer do not form tightly packed crystalline structures. Consequently, they are more accessible to enzymatic hydrolysis. The hydrolysis of hemicellulose occurs through the action of several enzymes that work in cooperation or synergism. The two most important xylan-degrading enzymes are endo- $\beta$-1,4-xylanase (EC 3.2.1.8) and $\beta$-D-xylosidase (EC 3.2.1.37). ${ }^{33,34}$

Moreover, when applying the CTR (Fig. 1(C)), the highest RS release was observed for banana peel, yielding $164.65 \pm 4.9 \mu \mathrm{mol} \mathrm{RS} \mathrm{mL} L^{-1}\left(29.52 \mathrm{~g} \mathrm{RSL}^{-1}\right)$, which was $50 \%$ higher than the quantity obtained in the case of the two following best biomasses that were hydrolyzed, that is corn straw and cassava flour. The CTR is a cellulase-rich extract with significant quantities of hemicellulases, including swollenin, Cip1, and Cip2 ${ }^{18}$ The synergistic activity among the different enzymes present in CTR extract could have led to biomass degradation. Hence, the product of the cip2 gene was demonstrated to exhibit glucuronyl esterase activity, which might be related to the breakdown of ester linkages between hemicellulose and lignin, ${ }^{35}$ improving the banana peel hydrolysis, which is a lignocellulolytic waste.

Considering the RS yields obtained during the screening and considering the value-added products for biorefineries, cornmeal, banana peel, and sorghum grain bran were selected for further investigation using three-factor simplex centroid experimental design tests.

Banana is widely cultivated in over 130 countries worldwide, making it the second-largest tropical fruit produced in the world. ${ }^{36,37}$ In general, banana peel $(30-40 \%$ of the total fruit weight) is discarded as solid waste; however, when the peel is decomposed, it produces noxious gases, for example hydrogen sulfide and ammonia. ${ }^{37}$ Hence, sustainable management of this highly organic waste would involve its application as a bio-sorbents and also as a substrate for bioethanol, ${ }^{38-40}$ biodiesel, ${ }^{36}$ and biogas. ${ }^{37,41,42}$

So far, only a few studies have been found in the literature focusing on the production of fermentable sugars through enzymatic treatment of banana peel. Oberoi et al. ${ }^{43}$ showed that optimized hydrolysis of banana peel using commercial enzymes would lead to a production of 28.2 and $48 \mathrm{gL}^{-1}$ glucose and RS, respectively. Rehman et al. ${ }^{44}$ used banana peel as substrate in solid-state fermentation to produce enzymes by Aspergillus niger MS23 and Aspergillus terreus MS105, and the crude enzyme extracts obtained were applied for the hydrolysis of the same substrate, that is banana peel. Martínez-Trujillo et al. ${ }^{45}$ performed hydrolysis of banana peel using oxidases and hydrolases in a $1 \mathrm{~L}$ bioreactor, which resulted in a release of $18 \mathrm{~g} \mathrm{RSL}^{-1}$ ( $60 \%$ of which was glucose) after $24 \mathrm{~h}$ of treatment. In agreement with our findings, these results also show the potential of banana peel for utilization as a rich source of fermentable sugars.

Sorghum is the fifth most important cereal crop in the world. It is a food security crop in several countries, mainly in Africa and Asia, where this plant is consumed as food. However, the production area in these countries is declining due to the lack of established markets, social pressures, and consumer preferences. One way to increase sorghum market opportunities is to promote its multiple use, for example food, livestock feed, and biofuel. The dilemma of food grain crops being used for biofuel production is critical.

Nevertheless, certain types of sorghum species or genotypes, suited explicitly for bioenergy production, can generate a large amount of biomass with economic benefits - that is, lower input of nutrients, fertilizers, and water. ${ }^{46-48}$ Several studies considered sorghum grain as an energy crop for producing biogas and bioethanol. ${ }^{3,49-51}$ Corredor et al. ${ }^{52}$ investigated the use of sorghum bran (a mixture of the pericarp, germ tissue, and residual starch from the endosperm extracted during the decortication process) as a 
potential feedstock for low-cost ethanol production. It was found that using a combination of starch degradation, hot water treatment, and optimized enzymatic hydrolysis (by the application of cellulases and hemicellulases) resulted in a maximum total sugar yield of $75 \%$ of the theoretical yield.

Last but not least, corn is another widely grown and essential grain crop worldwide. Ethanol, refined from corn, is the primary fuel additive in the USA. ${ }^{53}$ Corn production in the USA was estimated to a volume of 345.89 million metric tons in 2019/2020, followed by China and Brazil with 260.77 and 101 million metric tons, respectively. ${ }^{54}$ The land areas devoted to corn cultivation have increased substantially in recent years, and now there is greater production in the USA. ${ }^{55}$ Due to the carbohydrate-rich composition, excess corn grains can produce various value-added products, such as biofuels. Besides, saccharification by enzymes (pretreatment) before the primary step (fermentation) is essential to make the conversion procedure more realistic and cost-effective. ${ }^{56}$ Since the hydrolysis of corn starch is the first and critical step in corn processing, the central role of this step is to provide the conversion of the two major starch components, namely amylose and amylopectin, effectively. Amylases can depolymerize these polymers. $\alpha$-Amylase (EC 3.2.1.1) acts exclusively on $\alpha-1,4$ bonds within the chains, delivering maltooligosaccharides, whereas $\beta$-amylase (EC 3.2.1.2) hydrolyzes the $\alpha-1,4$ bonds at the non-reducing ends of the starch chain, releasing maltose units. The third one, glucoamylase (EC 3.2.1.3), acts on both $\alpha-1,4$, and $\alpha-1,6$ bonds on non-reducing-starch-ends, removing monomers of glucose.

Leach and Schoch ${ }^{57}$ found that raw corn starch is more susceptible to the action of $\alpha$-amylase than high amylose corn starch. Furthermore, it has been shown that the application of a two-step enzymatic process, that is $\alpha$-amylase followed by glucoamylase, was more efficient than using just one type of enzyme. ${ }^{58}$ Similarly, Karakatsanis and LiakopoulouKyriakides $^{59}$ reported a very efficient conversion of corn starch, leading to a release of more than $96 \%$ of fermentable sugars after $24 \mathrm{~h}$ of hydrolysis, using the simultaneous action of $\alpha$-amylase and glucoamylase. Mojović et al. ${ }^{58}$ investigated the two-step enzymatic hydrolysis of cornmeal by using commercially available $\alpha$-amylase and glucoamylase, and found that the highest (93.8\%) conversion of cornmeal starch was achieved after $48 \mathrm{~h}$ of hydrolysis with the combined enzymatic action. Furthermore, Dettori-Campus et al. ${ }^{60}$ obtained up to $80 \%$ of starch conversion when hydrolyzing corn starch granules by amylase produced by Bacillus stearothermophilus. Similarly, Kimura and Robyt ${ }^{61}$ achieved $80 \%$ of corn starch conversion through one-step enzymatic hydrolysis using glucoamylase. Arasaratnam and
Balasubramaniam ${ }^{62}$ also reported a glucose yield of $76 \%$ when corn flour was treated with a combination of amylase and glucoamylase.

The application of crude enzymatic extracts can compete for acidic or alkali saccharification steps as well as heat treatments. ${ }^{63}$ Enzymatic saccharification is also advantageous for lower generation inhibitors and / or toxic compounds, such as organic acids, phenols, and furfurals..$^{64,65}$

\section{Mixture designs}

The enzyme extracts mixtures were studied through simplex centroid mixture designs. Six different designs were performed following the biomass selection in the previous screening. First, the effects of using the three different enzyme extracts (XAT, AAB, and CTR) and their mixtures on the hydrolysis of biomass samples were investigated. Second, the hydrolysis of biomass mixtures - that is, cornmeal, banana peels, and sorghum grain bran - was studied using individual crude extracts (XAT, AAB, and CTR). The RS yield ( $\mu \mathrm{mol} /$ $\mathrm{mL}$ ) after $24 \mathrm{~h}$ of hydrolysis was used as a response variable for all designs.

\section{Enzyme extracts mixture designs}

Mixtures of crude enzyme extracts - that is, XAT, AAB, and CTR - were applied to biomass hydrolysis. The experimental data for the dependent variable (RS yield) evaluated during each experiment are present in Table 1. The response data were analyzed sequentially using a multiple regression analysis from the linear to the special cubic model to find the fitted model. The linear model was found to be the best suited for cornmeal hydrolysis $\left(R^{2}=81.3 \%, p_{\text {model }}=0.0065\right)$, while for banana peel and sorghum grain bran the quadratic model was the best suitable option $\left(\mathrm{R}^{2}=90.3 \%\right.$, $\left.p_{\text {model }}=0.09\right)$, $\left(\mathrm{R}^{2}=87.2 \%, p_{\text {model }}=0.04\right.$, respectively). The $P$-values were higher than 0.05 for the lack of fit test for all selected models (Table 4).

The models fitted for the response variable RS yield ( $\mu \mathrm{mol} /$ $\mathrm{mL})$ in the case of the three biomasses investigated, are described by Eqns (5) (cornmeal), (6) (banana peel), and (7) (sorghum grain bran):

$$
\begin{aligned}
R S(\mu \mathrm{mol} / m L)= & 155.42(A)+170.19(B)+77.86(C) \\
R S(\mu \mathrm{mol} / \mathrm{mL})= & 91.41(A)+129.64(B)+141.73(C) \\
& +165.52(A B)+175.54(A C)
\end{aligned}
$$


Table 4. Analysis of variance (ANOVA) for the mixtures design involving the yields of RS ( $\mu \mathrm{molmL}^{-1}$ ) obtained by enzymatic hydrolysis of different types of biomass (cornmeal, banana peel, and sorghum grain bran) using mixtures of enzyme crude extracts (AAB, XAT and CTR).

\begin{tabular}{|c|c|c|c|c|c|c|c|c|c|}
\hline \multirow[t]{2}{*}{ Biomass } & \multirow[t]{2}{*}{ Model } & \multirow{2}{*}{$\begin{array}{l}\text { Source of } \\
\text { variation }\end{array}$} & \multirow{2}{*}{$\begin{array}{l}\text { Sum } \\
\text { Square }\end{array}$} & \multirow{2}{*}{$\begin{array}{l}\text { Degree of } \\
\text { freedom }\end{array}$} & \multirow{2}{*}{$\begin{array}{l}\text { Mean } \\
\text { square }\end{array}$} & \multicolumn{2}{|c|}{ Teste F } & \multirow[t]{2}{*}{$P$} & \multirow[t]{2}{*}{$\mathrm{R}^{2}$} \\
\hline & & & & & & F calc & $F$ tab & & \\
\hline \multirow[t]{5}{*}{ Cornmeal } & \multirow[t]{5}{*}{ Linear } & Model & 6148.44 & 2 & 3074.22 & 13.06 & $5.14^{\mathrm{a}}$ & .0065 & 0.81 \\
\hline & & Total error & 1412.41 & 6 & 235.40 & & & & \\
\hline & & Lack of fit & 738.02 & 4 & 184.50 & 0.55 & $19.25^{b}$ & .72 & \\
\hline & & Pure error & 674.40 & 2 & 337.20 & & & & \\
\hline & & Total & 7560.85 & 8 & 945.11 & & $\alpha=0.05$ & & \\
\hline \multirow{5}{*}{$\begin{array}{l}\text { Banana } \\
\text { peel }\end{array}$} & \multirow[t]{5}{*}{ Quadratic } & Model & 4125.33 & 5 & 825.07 & 5.63 & $5.3^{a}$ & .09 & 0.9 \\
\hline & & Total error & 439.81 & 3 & 146.60 & & & & \\
\hline & & Lack of fit & 255.35 & 1 & 255.35 & 2.77 & $8.52^{b}$ & .23 & \\
\hline & & Pure error & 184.45 & 2 & 92.23 & & & & \\
\hline & & Total & 4565,14 & 8 & 570.64 & & $\alpha=0.1$ & & \\
\hline \multirow{5}{*}{$\begin{array}{l}\text { Sorghum } \\
\text { grain bran }\end{array}$} & \multirow[t]{5}{*}{ Quadratic } & Model & 14467.26 & 4 & 3616.82 & 6.87 & $4.10^{a}$ & .04 & 0.87 \\
\hline & & Total error & 2106.08 & 4 & 526.52 & & & & \\
\hline & & Lack of fit & 1612.96 & 2 & 806.48 & 3.27 & $9^{b}$ & .23 & \\
\hline & & Pure error & 493.13 & 2 & 246.56 & & & & \\
\hline & & Total & 16573.35 & 8 & 2071.67 & & $\alpha=0.1$ & & \\
\hline
\end{tabular}

$$
\begin{aligned}
R S(\mu \mathrm{mol} / \mathrm{mL})= & 69.24(A)+92.13(B)+90.37(C) \\
& +379.09(A B)+282.63(B C)
\end{aligned}
$$

where $\mathrm{A}, \mathrm{B}$, and $\mathrm{C}$ correspond to encoded values for XAT, $\mathrm{AAB}$, and $\mathrm{CTR}$, respectively.

The mathematical models were evaluated by analyzing variance (ANOVA) (Table 4) and the F test. For statistically significant models, the calculated $\mathrm{F}$ value should be higher than the critical (tabulated) $\mathrm{F}$ value.

Upon obtaining the reduced equation for each model, the responses of the relative RS yield concerning the component combinations were represented graphically as ternary contour plots (Figs 2(A)-(C)).

From the fitted models and the data presented in Table 1 (columns 5 to 7), it was possible to deduce the individual performance of pure enzyme extracts and their mixtures. For cornmeal hydrolysis, AAB and XAT's individual performance had better hydrolysis effects, that is RS yield of 174.19 and $169.03 \mu \mathrm{mol} \mathrm{mL}^{-1}$, respectively. According to the fitted model and as displayed in the contour plot, the beta or tertiary coefficients were not significant (Fig. 2(A)). Both of the extracts $(\mathrm{AAB}$ and $\mathrm{XAT})$ are rich in amylase $\left(6 \pm 0.5 \mathrm{UmL}^{-1}\right)$, contributing to the hydrolysis of amylose, which is the main component in cornmeal (70\%).
In the case of banana peel hydrolysis, the two binary blends, that is XAT with CTR and XAT with AAB, exhibited significant synergistic effects $(P$-value $=0.04$ and 0.05 , respectively). As shown in the sixth column in Table 1, the RS yields of these binary combinations were 153.22 and $144.67 \mu \mathrm{mol} \mathrm{mL}^{-1}$, respectively. These results are in agreement with the synergistic effects displayed in Fig. 2(B). Banana peel has been reported to have $25 \%$ hemicellulose and $11.45 \%$ cellulose in its composition. ${ }^{32}$ As the xylanase activity is high in XAT $\left(23 \pm 0.63 \mathrm{U} \mathrm{mL}^{-1}\right)$, the enzyme's action resulted in greater accessibility of cellulose present in the waste, which probably explains why the two binary blends involved in this extract performed well.

The sorghum grain bran hydrolysis showed that the two binary blends - that is, XAT with $\mathrm{AAB}$ and $\mathrm{AAB}$ with CTR - displayed significant synergistic effects $(P$-values $=0.01$ and 0.04 , respectively). As shown in column 7 in Table 1, the RS yields of the binary combinations were $153.22 \mu \mathrm{mol} \mathrm{mL}^{-1}$ and $142.09 \mu \mathrm{mol} \mathrm{mL}^{-1}$, respectively. These results are in agreement with the size of synergistic effects displayed in Fig. 2(C). Sorghum grains present a similar composition as corn, containing $70 \%$ of starch. ${ }^{31} \mathrm{XAT}$ and $\mathrm{AAB}$ are amylaserich extracts $\left(6 \pm 0.5 \mathrm{U} \mathrm{mL}^{-1}\right)$, which could have provided the higher starch saccharification when both of them were applied in the mixture. 
(A)

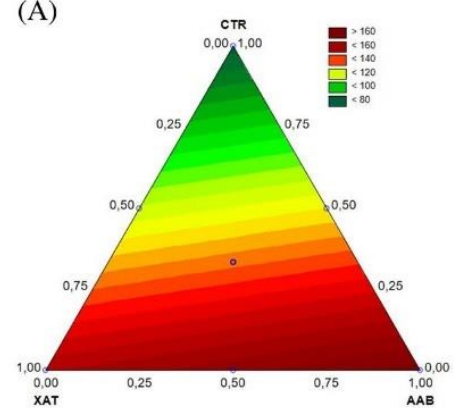

(B)

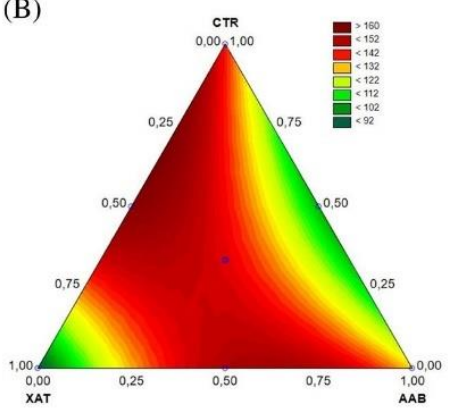

(C)

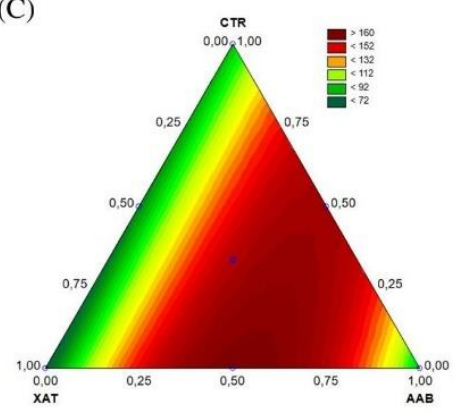

Figure 2. Ternary contour plots using mixtures of three enzyme extracts for the hydrolysis of cornmeal (A), banana peel (B), and sorghum grain bran (C). The independent variables were the enzyme extracts: AAB, XAT, and CTR. The dependent variable was: $\mathrm{RS}$ yield $\left(\mu \mathrm{mol} \mathrm{mL} \mathrm{m}^{-1}\right.$ ) obtained after hydrolyses at $50^{\circ} \mathrm{C}$ and $50 \mathrm{rpm}$ for $24 \mathrm{~h}$.

\section{Biomass mixture designs}

Tertiary mixtures of biomass - that is cornmeal, banana peel, and sorghum grain bran - were subjected to hydrolysis using enzyme extracts of AAB, XAT, and CTR, respectively. The experimental setups, as well as the response variables obtained, are presented in Table 2. Linear, quadratic, and special cubic models were used to obtain least-squares fits for the response variable. Table 5 shows the variance analysis (ANOVA) of the best model fitted for AAB, XAT, and CTR.

The special cubic model was found to be the best suited for biomass hydrolysis by AAB $\left(\mathrm{R}^{2}=99.1 \%, p_{\text {model }}=0.002\right)$ and XAT $\left(\mathrm{R}^{2}=99.9 \%, p_{\text {model }}=0.001\right)$. In the hydrolysis with CTR, the linear model was the most suitable $\left(R^{2}=96 \%\right.$, $\left.p_{\text {model }}=0.00005\right)$. Estimated regression coefficients and standard errors for each model are presented in Table 5

The fitted models for the response variable (RS yield $\left(\mu \mathrm{mol} \mathrm{mL} L^{-1}\right)$ for each enzyme extract used for the hydrolyses are described by Eqns (8) (AAB), (9) (XAT), and (10) (CTR):

$$
\begin{aligned}
R S(\mu \mathrm{mol} / \mathrm{mL})= & 168.95(A)+154.59(B)+126.77(C) \\
& +42.72(A C)+73.4(B C)-177.0(A B C)
\end{aligned}
$$

$$
\begin{aligned}
R S(\mu \mathrm{mol} / \mathrm{mL})= & 135.96(A)+117.9(B)+72.74(C)-218.08(A B) \\
& -134.2(A C)+65.8(B C)+876.81(A B C)
\end{aligned}
$$

$$
R S(\mu \mathrm{mol} / \mathrm{mL})=87.90(\mathrm{~A})+177.38(\mathrm{~B})+103.77(\mathrm{C}) .
$$

where $\mathrm{A}, \mathrm{B}$, and $\mathrm{C}$ correspond to encoded values for cornmeal, banana peel, and sorghum grain bran, respectively.
The relative RS yield responses according to the component combinations were also graphically represented as ternary contour plots (Figs 3(A)-(C)).

By analyzing the results from the mixture design for the application of $\mathrm{AAB}$, the individual performance of pure cornmeal showed the highest coefficient for RS yield $\left(170 \mu \mathrm{mol} \mathrm{mL}^{-1}\right)(P$-value 0.000002$)$, followed by the performance of pure banana peel ( $P$-value 0.000002$)$. On the other hand, the ternary blend of the three biomasses exhibited a significant antagonistic effect ( $P$-value 0.02$)$ on RS yield. These results are in accordance with the sizes of synergistic and antagonistic effects displayed in Fig. 3(A).

When the biomass hydrolysis using XAT was studied, the ternary blend of the three biomasses showed a significant synergistic effect ( $P$-value 0.0007$)$ on RS yield. This result can also be seen in the size of synergistic and antagonistic effects displayed in Fig. 3(B), showing the excellent effect of XAT performance during pure cornmeal hydrolysis $(P$-value $=0.00004) . \mathrm{XAT}$ is a crude extract rich in xylanases $\left(23 \pm 0.63 \mathrm{U} \mathrm{mL}^{-1}\right)$, with the occurrence of other enzymes, such as amylases $\left(6.5 \pm 0.15 \mathrm{UmL}^{-1}\right)$. Cornmeal, banana peel, and sorghum grain are three biomasses with different compositions, as mentioned above. However, when mixed together in the ternary mixture, it was advantageous when XAT was applied.

Finally, the effects of CTR application were better fitted by the linear model (Table 5 and Fig. $3(\mathrm{C})$ ). The pure banana peel had better hydrolysis effects $(P$-value $\leq 0.000)$ - that is, a RS yield of $175.32 \mu \mathrm{mol} \mathrm{mL}^{-1}$. According to the fitted model, the beta or the tertiary coefficients were not significant.

The different mixture designs performed using (i) three different enzyme extracts or (ii) three different biomasses showed two high RS yield zones. Both of them were located towards one side of the triangles, with (i) cornmeal hydrolyzed by $\mathrm{AAB}$, and (ii) banana peel hydrolyzed by 
Table 5. Analysis of variance (ANOVA) for the mixtures design involving the yields of RS ( $\mu \mathrm{molmL}^{-1}$ ) obtained by hydrolyses of mixtures of selected biomass (cornmeal, banana peel, and sorghum grain bran) using enzyme extracts of AAB, XAT, and CTR.

\begin{tabular}{|c|c|c|c|c|c|c|c|c|c|}
\hline \multirow{2}{*}{$\begin{array}{l}\text { Enzyme } \\
\text { extract }\end{array}$} & \multirow[t]{2}{*}{ Model } & \multirow{2}{*}{$\begin{array}{l}\text { Source of } \\
\text { variation }\end{array}$} & \multirow{2}{*}{$\begin{array}{l}\text { Sum } \\
\text { Square }\end{array}$} & \multirow{2}{*}{$\begin{array}{l}\text { Degree of } \\
\text { freedom }\end{array}$} & \multirow{2}{*}{$\begin{array}{l}\text { Mean } \\
\text { square }\end{array}$} & \multicolumn{2}{|c|}{ Teste F } & \multirow[t]{2}{*}{$P$} & \multirow[t]{2}{*}{$r^{2}$} \\
\hline & & & & & & F calc & F tab & & \\
\hline \multirow[t]{5}{*}{$\mathrm{AAB}$} & \multirow{5}{*}{$\begin{array}{l}\text { Special } \\
\text { cubic }\end{array}$} & Model & 1070.81 & 5 & 214.16 & 70.41 & $9.01^{a}$ & .002 & 0.99 \\
\hline & & Total error & 9.12 & 3 & 3.04 & & & & \\
\hline & & Lack of fit & 6.61 & 1 & 6.61 & 5.27 & $18.5^{\mathrm{b}}$ & .14 & \\
\hline & & Pure error & 2.50 & 2 & 1.25 & & & & \\
\hline & & Total & 1079.94 & 8 & 134.99 & & & & \\
\hline \multirow[t]{5}{*}{ XAT } & \multirow{5}{*}{$\begin{array}{l}\text { Special } \\
\text { cubic }\end{array}$} & Model & 4369.98 & 6 & 728.16 & 897.52 & $19.32^{\mathrm{a}}$ & .001 & 0.99 \\
\hline & & Total error & 1.623 & 2 & 0.81 & & & & \\
\hline & & Lack of fit & 0 & 0 & 0 & 0 & 0 & 0 & \\
\hline & & Pure error & 1.62 & 2 & 0.81 & & & & \\
\hline & & Total & 4370.60 & 8 & 542.32 & & & & \\
\hline \multirow[t]{5}{*}{ CTR } & \multirow[t]{5}{*}{ Linear } & Model & 5699.18 & 2 & 2849.59 & 73.90 & $5.14^{\mathrm{a}}$ & .000 & 0.96 \\
\hline & & Total error & 231.35 & 6 & 38.56 & & & & \\
\hline & & Lack of fit & 46.85 & 4 & 11.71 & 0.12 & $19.2^{b}$ & .95 & \\
\hline & & Pure error & 184.50 & 2 & 92.25 & & & & \\
\hline & & Total & 5930.53 & 8 & 741.31 & & & & \\
\hline $\begin{array}{l}\text { 1. } R^{2}=0 . \\
\text { 2. } R^{2}=0.7 \\
\text { 3. } R^{2}=0 .\end{array}$ & $\begin{array}{l}=95 \% .5 .3 \\
=95 \% .3 .5 \\
=95 \% .2 .6\end{array}$ & $\begin{array}{l}=95 \% .1 .2 . \\
=95 \% .3 .2 \\
=95 \% .4 .2\end{array}$ & & & & & & & \\
\hline
\end{tabular}

(A)

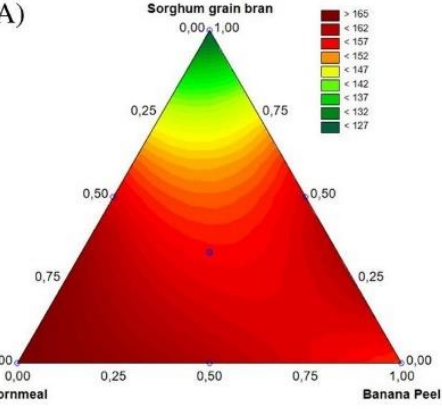

(B)

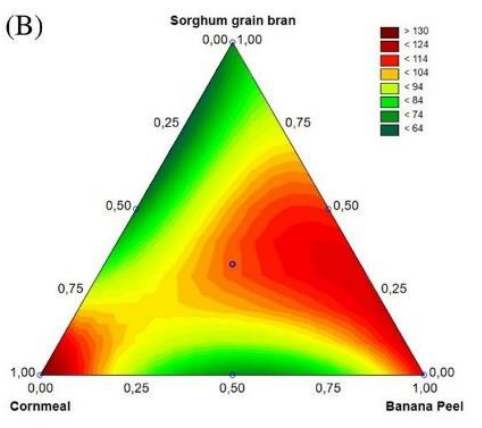

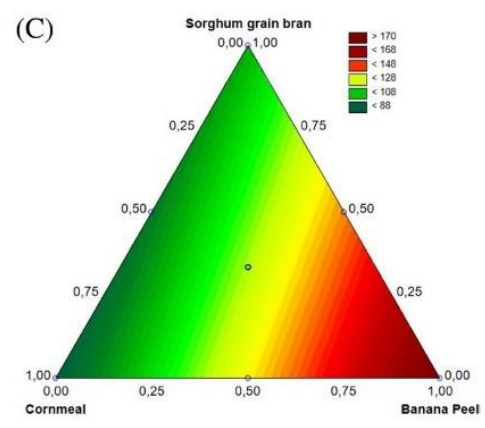

Figure 3. Ternary contour plots were determined during hydrolysis of mixtures of three different biomass using enzyme extracts of AAB (A), XAT (B), and CTR (C). Independent variables were the biomass: Cornmeal, banana peel, and sorghum grain bran. The dependent variable was: RS yield $\left(\mu \mathrm{mol} \mathrm{mL}^{-1}\right)$ obtained after hydrolyses at $50^{\circ} \mathrm{C}$ and $50 \mathrm{rpm}$ for $24 \mathrm{~h}$.

CTR. However, variable degrees of enzyme synergism were exhibited by each biomass. The ternary mixture for substrate hydrolysis could be due to the differences in their structures and compositions ${ }^{66}$ together with the enzymatic synergism. Many studies have demonstrated synergism among various cellulases and hemicellulases, and between these groups. ${ }^{67}$
Banerjee et al.$^{68}$ have reported a useful synergism among $\mathrm{CBHs}(\mathrm{CBH} 1$ and $\mathrm{CBH} 2$ from $T$. reesei), $\mathrm{EG}(\mathrm{EG} 1), \beta$ glucosidase, GH10 endo- $\beta$-1,4-xylanase, and $\beta$-xylosidase. Development and knowledge in the field of enzyme synergism therefore lie in establishing optimal enzyme combinations for the specific pretreatment required for each particular biomass application.

CC 2021 Society of Chemical Industry and John Wiley \& Sons, Ltd | Biofuels, Bioprod. Bioref. (2021); DOI: 10.1002/bbb.2251 


\section{Conclusions}

This study applied a systematic screening of biomass substrates followed by mixture design assays with the aim of optimizing the application of enzyme cocktails for biomass saccharification as a biological pretreatment in biofuel production processes. The objective was to identify optimized enzyme cocktails and / or optimized biomass combinations for the saccharification and the determination of synergetic or antagonistic effects. However, this seemed to be neither simple nor straightforward. Consequently, further investigations with several combinations of assays are needed with the aim of designing practical and economically feasible bioconversion processes.

\section{Acknowledgements}

The authors are grateful to Mariana Cereia and Maurício de Oliveira for their technical assistance. This work was supported by Fundação de Amparo à Pesquisa do Estado de São Paulo (FAPESP) (processes 10/52322-3; 2014/50884-5; 2018/07522-6), and Conselho Nacional de Desenvolvimento Científico (CNPq) (processes 563260/2010-6 and 465319/2014-9). V.E.P. was the recipient of a CNPq fellowship (process 142139/2017-3) and M.L.T.M.P. received CNPq Productivity scholarship (process 301963/2017-7).

\section{Conflict of interest}

The authors report no conflicts of interest. The authors alone are responsible for the content and writing of the manuscript.

\section{References}

1. Patinvoh RJ, Osadolor OA, Chandolias K, Horváth IS and Taherzadeh MJ, Innovative pretreatment strategies for biogas production. Bioresour Technol 224:13-24 (2017).

2. Bauer W, Biogas beats bioethanol. Asia Pacific Biotech News 19(8):16-17 (2015).

3. Stamenković OS, Siliveru K, Veljković VB, Banković-Ilić IB, Tasić MB, Ciampitti IA et al., Production of biofuels from sorghum. Renew Sustain Energy Rev 124:109769 (2020).

4. Taherzadeh MJ and Karimi K, Pretreatment of lignocellulosic wastes to improve ethanol and biogas production: a review. Int J Mol Sci 9(9):1621-1651 (2008).

5. Polizeli MLTM, Somera AF, de Lucas RC, Nozawa MSF and Michelin M, Enzymes involved in the biodegradation of sugarcane biomass: challenges and perspectives, in Advances of Basic Science for Second Generation Bioethanol From Sugarcane, ed. by Buckeridge MS and De Souza AP. Springer, New York, pp. 55-79 (2017).

6. Bussamra BC, Freitas S and da Costa AC, Improvement on sugar cane bagasse hydrolysis using enzymatic mixture designed cocktail. Bioresour Technol 187:173-181 (2015).
7. Gao D, Chundawat SPS, Krishnan C, Balan V and Dale BE, Mixture optimization of six core glycosyl hydrolases for maximizing saccharification of ammonia fiber expansion (AFEX) pretreated corn Stover. Bioresour Technol 101(8):27702781 (2010).

8. Polizeli MLTM, Rizzatti A, Monti R, Terenzi H, Jorge JA and Amorim D, Xylanases from fungi: properties and industrial applications. Appl Microbiol Biotechnol 67(5):577-591 (2005).

9. Pasin TM, Almeida PZ, Scarcella ASA, Infante JC and Polizeli MLTM, Bioconversion of agro-industrial residues to secondgeneration bioethanol, in Biorefinery of Alternative Resources: Targeting Green Fuels and Platform Chemicals, ed. by Nanda S, Vo D-VN and Sarangi PK. Springer, Singapore, pp. 23-47 (2020).

10. Heinen PR, Pereira MG, Rechia CV, Almeida PZ, Monteiro LM, Pasin T et al., Immobilized endo-xylanase of Aspergillus tamarii Kita: an interesting biological tool for production of xylooligosaccharides at high temperatures. Process Biochem 53:145-152 (2017).

11. Monteiro LMO, Vici AC, Messias JM, Heinen PR, Pinheiro VE, Rechia CG et al., Increased Malbranchea pulchella $\beta$ glucosidase production and its application in agroindustrial residue hydrolysis: a research based on experimental designs. Biotechnol Rep 30:e00618 (2021).

12. Almeida PZ, Messias JM, Pereira MG, Pinheiro VE, Monteiro LMO, Heinen PR et al., Mixture design of starchy substrates hydrolysis by an immobilized glucoamylase from Aspergillus brasiliensis. Biocatal Biotransformation 36(5):389-395 (2018)

13. Gupta VK, New and Future Developments in Microbial Biotechnology and Bioengineering: Aspergillus System Properties and Applications. Elsevier, Amsterdam (2016)

14. Mander L and Liu H-W, Comprehensive Natural Products II: Chemistry and Biology. Elsevier, Amsterdam (2010).

15. Meyer AS, Rosgaard $L$ and Sørensen HR, The minimal enzyme cocktail concept for biomass processing. J Cereal Sci 50(3):337-344 (2009).

16. Lynd LR, Laser MS, Bransby D, Dale BE, Davison B, Hamilton $\mathrm{R}$ et al., How biotech can transform biofuels. Nat Biotechnol 26(2):169-172 (2008).

17. Anderson-Cook CM, Borror CM and Montgomery DC Response surface design evaluation and comparison. J Stat Plan Infer 139(2):629-641 (2009).

18. Suwannarangsee S, Bunterngsook B, Arnthong J, Paemanee $A$, Thamchaipenet A, Eurwilaichitr L et al., Optimisation of synergistic biomass-degrading enzyme systems for efficient rice straw hydrolysis using an experimental mixture design. Bioresour Technol 119:252-261 (2012).

19. Dejaegher B and Vander HY, Experimental designs and their recent advances in setup, data interpretation, and analytical applications. J Pharm Biomed Anal 56(2):141-158 (2011).

20. Rizzatti A, Jorge J, Terenzi H, Rechia C and Polizeli MLTM, Purification and properties of a thermostable extracellular $\beta$-D-xylosidase produced by a thermotolerant Aspergillus phoenicis. J Indus Microbiol Biotechnol 26(3):156-160 (2001).

21. Adams $P$, Mycelial amylase activities of thermophilic species of Rhizomucor, Humicola and Papulaspora. Mycopathologia 112(1):35-37 (1990)

22. Miller GL, Use of dinitrosalicylic acid reagent for determination of reducing sugar. Anal Chem 31(3):426-428 (1959).

23. Cornell JA, Experiments with Mixtures: Designs, Models, and the Analysis of Mixture Data. John Wiley \& Sons, New Jersey (2011).

24. Giese EC, Dekker RF, Scarminio IS, Barbosa AM and da Silva R, Comparison of $\beta-1,3$-glucanase production by Botryosphaeria rhodina MAMB-05 and Trichoderma harzianum Rifai and its optimization using a statistical mixture-design. Biochem Eng J 53(2):239-243 (2011). 
25. Neto BB, Scarminio IS and Bruns RE, Como Fazer Experimentos-: Pesquisa e Desenvolvimento na Ciência e na Indústria. Bookman Editora, Porto Alegre (2010).

26. Abdullah R, Nisar K, Aslam A, lqtedar M and Naz S, Enhanced production of xylanase from locally isolated fungal strain using agro-industrial residues under solid-state fermentation. Nat Prod Res 29(11):1006-1011 (2015).

27. Redenbach M, Kieser HM, Denapaite D, Eichner A, Cullum $\mathrm{J}$, Kinashi $\mathrm{H}$ et al., A set of ordered cosmids and a detailed genetic and physical map for the $8 \mathrm{Mb}$ Streptomyces coelicolor A3 (2) chromosome. Mol Microbiol 21(1):77-96 (1996).

28. Aurilia V, Martin JC, McCrae SI, Scott KP, Rincon MT and Flint HJ, Three multidomain esterases from the cellulolytic rumen anaerobe Ruminococcus flavefaciens 17 that carry divergent dockerin sequences. The GenBank accession numbers for the sequences reported in this paper are AJ238716 (cesA) and AJ272430 (xynE). Microbiology 146(6):1391-1397 (2000).

29. Jafari $\mathrm{Y}$, Amiri $\mathrm{H}$ and Karimi $\mathrm{K}$, Acetone pretreatment for improvement of acetone, butanol, and ethanol production from sweet sorghum bagasse. Appl Energy 168:216-225 (2016).

30. Shafiei M, Karimi K and Taherzadeh MJ, Techno-economical study of ethanol and biogas from spruce wood by NMMOpretreatment and rapid fermentation and digestion. Bioresour Technol 102(17):7879-7886 (2011).

31. Wall JS and Blessin CW, Composition of sorghum plant and grain, in Sorghum Production and Utilization, ed. by Wall JS, Ross WM. AVI Publishers, Westport, pp. 118-166 (1970).

32. Orozco RS, Hernández PB, Morales GR, Núñez FU, Villafuerte JO, Lugo VL et al., Characterization of lignocellulosic fruit waste as an alternative feedstock for bioethanol production. BioResources 9(2):1873-1885 (2014).

33. Pandey A, Soccol CR, Economic utilization of crop residues for value addition: A futuristic approach. J Sci Ind Res 59:12-22 (2000).

34. Polizeli MLTM, Vici A, Scarcella A, Cereia M and Pereira M, Enzyme system from Aspergillus in current industrial uses and future applications in the production of second-generation ethanol, in New and Future Developments in Microbial Biotechnology and Bioengineering, ed. by Gupta V. Elsevier, Amsterdam, pp. 127-140 (2016).

35. Li X-L, Špániková S, de Vries RP and Biely P, Identification of genes encoding microbial glucuronoyl esterases. FEBS Lett 581(21):4029-4035 (2007).

36. Jitjamnong J, Thunyaratchatanon C, Luengnaruemitchai A, Kongrit N, Kasetsomboon N, Sopajarn A et al., Response surface optimization of biodiesel synthesis over a novel biocharbased heterogeneous catalyst from cultivated (Musa sapientum) banana peels. Biomass Convers Biorefin 1-17 (2020).

37. Pisutpaisal N, Boonyawanich S and Saowaluck H, Feasibility of biomethane production from banana peel. Energy Procedia 50:782-788 (2014).

38. Betiku E and Ajala SO, Modeling and optimization of Thevetia peruviana (yellow oleander) oil biodiesel synthesis via Musa paradisiacal (plantain) peels as heterogeneous base catalyst: a case of artificial neural network vs. response surface methodology. Ind Crops Prod 53:314-322 (2014).

39. Betiku E, Akintunde AM and Ojumu TV, Banana peels as a biobase catalyst for fatty acid methyl esters production using Napoleon's plume (Bauhinia monandra) seed oil: a process parameters optimization study. Energy 103:797-806 (2016)

40. Gohain M, Devi A and Deka D, Musa balbisiana Colla peel as highly effective renewable heterogeneous base catalyst for biodiesel production. Ind Crops Prod 109:8-18 (2017).
41. Clarke WP, Radnidge P, Lai T, Jensen P and Hardin M, Digestion of waste bananas to generate energy in Australia. Waste Manag 28(3):527-533 (2008).

42. Achinas S, Krooneman J and Euverink GJW, Enhanced biogas production from the anaerobic batch treatment of banana peels. Engineering 5(5):970-978 (2019).

43. Oberoi HS, Vadlani PV, Saida L, Bansal S and Hughes JD, Ethanol production from banana peels using statistically optimized simultaneous saccharification and fermentation process. Waste Manag 31(7):1576-1584 (2011).

44. Rehman S, Aslam H, Ahmad A, Khan SA and Sohail $M$, Production of plant cell wall degrading enzymes by monoculture and co-culture of Aspergillus Niger and Aspergillus terreus under SSF of banana peels. Braz J Microbiol 45(4):1485-1492 (2014).

45. Martínez-Trujillo MA, Bautista-Rangel K, García-Rivero M, Martínez-Estrada A and Cruz-Díaz MR, Enzymatic saccharification of banana peel and sequential fermentation of the reducing sugars to produce lactic acid. Bioprocess Biosyst Eng 43(3):413-427 (2020).

46. Almodares A, Hatamipour M, Planting sweet sorghum under hot and dry climatic condition for bioethanol production. World Renewable Energy Congress-Sweden; 8-13 May; 2011; Linköping; Sweden; 2011: Linköping University Electronic Press.

47. Briand C, Geleta S and Kratochvil R, Sweet sorghum (Sorghum bicolor [L.] Moench) a potential biofuel feedstock: analysis of cultivar performance in the mid-Atlantic. Renew Energy 129:328-333 (2018).

48. Sipos B, Réczey J, Somorai Z, Kádár Z, Dienes D and Réczey $\mathrm{K}$, Sweet sorghum as feedstock for ethanol production: enzymatic hydrolysis of steam-pretreated bagasse. Appl Biochem Biotechnol 153(1-3):151-162 (2009).

49. Almodares $A$ and Hadi MR, Production of bioethanol from sweet sorghum: a review. Afr J Agric Res 4(9):772-780 (2009).

50. Matsakas $L$ and Christakopoulos $P$, Fermentation of liquefacted hydrothermally pretreated sweet sorghum bagasse to ethanol at high-solids content. Bioresour Technol 127:202-208 (2013).

51. Ostovareh S, Karimi K and Zamani A, Efficient conversion of sweet sorghum stalks to biogas and ethanol using organosolv pretreatment. Ind Crops Prod 66:170-177 (2015).

52. Corredor D, Bean S and Wang D, Pretreatment and enzymatic hydrolysis of sorghum bran. Cereal Chem 84(1):61-66 (2007).

53. Gilbert $\mathrm{CL}$ and Mugera HK, Competitive storage, biofuels and the corn price. J Agric Econ 71(2):384-411 (2020).

54 . Shahbandeh M. Corn production worldwide $2018 / 2019$, by country Statista2020. Available: https://www.statista.com/ statistics/254292/global-corn-production-by-country/.

55. Irmak $S$ and Tiryaki ON, Is it economical and beneficial to produce hydrogen from excess corn kernels? Fuel 272:117747 (2020).

56. Tiryaki ON, Irmak S, Ramchandran D, Subbiah J and Morton $\mathrm{M}$, Utilization of excess corn kernels for hydrogen gas biofuel production. Int J Hydrogen Energy 44(57):29956-29963 (2019).

57. Leach $\mathrm{H}$ and Schoch $\mathrm{T}$, Structure of starch granule. II. Action of various amylases on starches. Cereal Chem 38:318-327 (1963).

58. Mojović L, Nikolić S, Rakin M and Vukasinović M, Production of bioethanol from corn meal hydrolyzates. Fuel 85(1213):1750-1755 (2006)

59. Karakatsanis A and Liakopoulou-Kyriakides M, Comparative study of hydrolysis of various starches by alpha-amylase and glucoamylase in PEG-dextran and PEG-substrate aqueous two phase systems. Starch-Stärke. 50(8):349-353 (1998).

60. Dettori-Campus B, Priest F and Stark J, Hydrolysis of starch granules by the amylase from Bacillus stearothermophilus NCA 26. Process Biochem 27(1):17-21 (1992). 
61. Kimura A and Robyt JF, Reaction of enzymes with starch granules: kinetics and products of the reaction with glucoamylase. Carbohydr Res 277(1):87-107 (1995)

62. Arasaratnam $V$ and Balasubramaniam K, Synergistic action of $\alpha$-amylase and glucoamylase on raw corn. Starch-Stärke 45(6):231-233 (1993).

63. Chantawongsa $\mathrm{N}$ and Kongkiattikajorn J, Pretreatment methods for banana peel as a substrate for the bioproduction of ethanol in SHF and SSF. Int J Comput Internet Manag 21:15-19 (2013).

64. Dos Santos AC, Ximenes E, Kim Y and Ladisch MR, Ligninenzyme interactions in the hydrolysis of lignocellulosic biomass. Trends Biotechnol 37(5):518-531 (2019).

65. Martín C, Galbe M, Nilvebrant N-O and Jönsson LJ, Comparison of the fermentability of enzymatic hydrolyzates of sugarcane bagasse pretreated by steam explosion using different impregnating agents, in Biotechnology for Fuels and Chemicals, ed. by Finkelstein $\mathrm{M}$ and Davison $\mathrm{BH}$. Humana Press, New Jersey, pp. 699-716 (2002).

66. Berlin A, Maximenko V, Gilkes $\mathrm{N}$ and Saddler J, Optimization of enzyme complexes for lignocellulose hydrolysis. Biotechnol Bioeng 97(2):287-296 (2007).

67. Malgas S, Mkabayi L, Mathibe BN, Thoresen M, Mafa MS, Le Roes-Hill $\mathrm{M}$ et al., Enzymatic path to bioconversion of lignocellulosic biomass, in Recent Advances in Bioconversion of Lignocellulose to Biofuels and Value Added Chemicals within the Biorefinery Concept, Vol. 5, ed. by Ximenes E, Filho F, de Souza Moreira LR, de Aquino Ximenes E and Farinas SC. Elsevier, Amsterdam (2020)

68. Banerjee G, Car S, Scott-Craig JS, Borrusch MS and Walton JD, Rapid optimization of enzyme mixtures for deconstruction of diverse pretreatment/biomass feedstock combinations. Biotechnol Biofuels 3(1):22 (2010).

Vanessa Elisa Pinheiro
Vanessa Elisa Pinheiro has a bachelor's
degree and licentiate in biology
from São Paulo University. She has
completed her master degree in
biochemistry at Ribeirão Preto Medical
School - São Paulo University, and
she is working on her PhD at the same
institution.
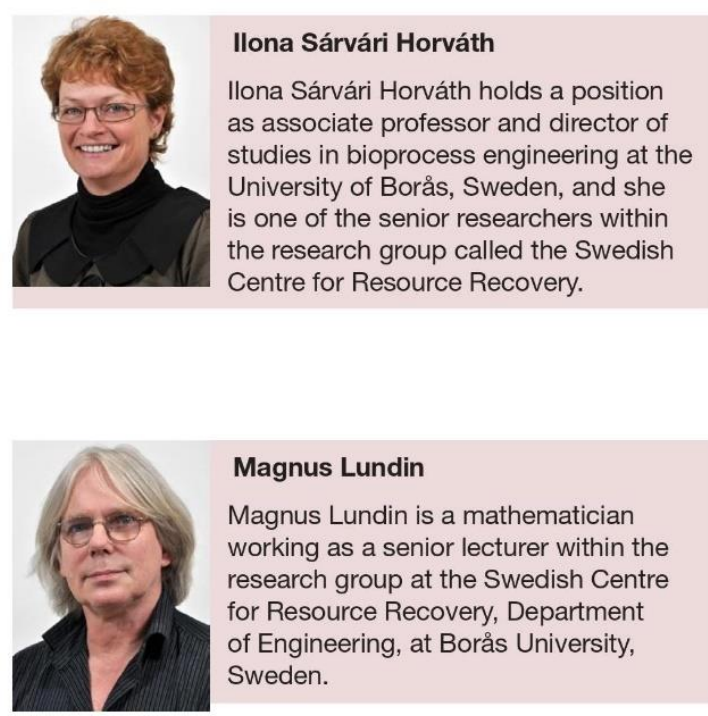

\section{Magnus Lundin}

Magnus Lundin is a mathematician working as a senior lecturer within the research group at the Swedish Centre for Resource Recovery, Department of Engineering, at Borås University, Sweden.

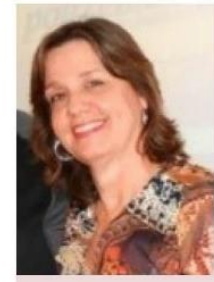

Maria de Lourdes Teixeira de Moraes Polizeli

Maria de Lourdes Teixeira de Moraes Polizeli graduated in pharmacy and biochemistry (1982) from the Faculty of Pharmaceutical Sciences of Ribeirão Preto, University of São Paulo. Her master's degree and PhD in biological sciences (biochemistry) were from Ribeirão Preto Medical School, São Paulo University. Currently, she is a full professor at the Department of Biology at the Faculty of Philosophy, Sciences and Letters of Ribeirão Preto. 


\section{Apêndice 3}

\section{Statistical optimization of cornmeal saccharification using various hydrolases}

Vanessa Elisa Pinheiro ${ }^{1,2}$, Paula Zaghetto de Almeida ${ }^{1}$, Maria de Lourdes Teixeira de Moraes Polizeli $^{1,2^{*}}$

${ }^{1}$ Ribeirão Preto Medical School - São Paulo University. Bandeirantes Av., 3.900, 14049-900, Ribeirão Preto, Brazil

${ }^{2}$ Faculty of Philosophy, Sciences and Letters at Ribeirão Preto - São Paulo University. Bandeirantes Av., 3.900, 14040-901, Ribeirão Preto, Brazil

*Correspondence to: Maria de Lourdes Teixeira de Moraes Polizeli Faculty of Philosophy, Sciences and Letters at Ribeirão Preto - São Paulo University. Bandeirantes, Av. 3.900, 14040-901. Ribeirão Preto, São Paulo, Brazil Phone: +55-16-3315 $4680 \quad$ FAX: +55-16-3315 4886 E-mail: polizeli@ffclrp.usp.br 


\begin{abstract}
Corn represents one of the most significant available biomass sources. Here, cornmeal, a product made of grounded corn, was hydrolyzed by three different enzymatic cocktails: (a) extract rich in Aspergillus brasiliensis amylases (AAB), (b) rich extract in Aspergillus tamari Kita xylanases (XAT), and (c) rich commercial extract in Trichoderma reesei cellulases (CTR). The mixture design results, containing the three different cocktails, showed that AAB action on cornmeal does not require XAT or CTR supplementation, being considered the most efficient. The optimum $\mathrm{pH}$ and temperature for amylolytic activity were investigated, and the $\mathrm{pH} 3.75$ 4.6 and $60-70{ }^{\circ} \mathrm{C}$ ranges were the best conditions for amylase activity. The cornmeal hydrolysis optimization showed that $5 \%$ substrate and 48 hours of incubation with AAB were the best parameters for cornmeal conversion into simple sugars. The central composite design enabled an adequate and reliable measurement of cornmeal hydrolysis, $\mathrm{pH} 4.0-4.5$ and $40-45^{\circ} \mathrm{C}$ ranges resulted in 32.4-37.8 g/L of reducing sugar release.
\end{abstract}

Keywords Green-hydrolysis, Aspergillus brasiliensis, cornmeal, mixture design, central composite design 


\section{Introduction}

Strategies for converting renewable raw materials into value-added products are being developed due to the increasing concerns about global energy shortages and environmental pollution. Various grains, such as corn, mainly used for food and animal feed, have now been targeted as material for biofuels, biochemicals, and biopolymer productions [1].

Corn (Zea mays) is a domesticated grass that originated more than 7000 years ago in Central America. This grain has different biotypes with adaptations ranging from the tropics to the temperate zone [2]. Corn is grown in every state of Brazil, and given the large country size and geographic diversity, this grain is produced during several different periods. The abundant supplies and competitive prices combined with strong foreign demand have sharply improved Brazil's corn production. The initial forecast for the market year 2020/21 show (March 2021 February 2022) is at 105 million metric tons (MMT), representing a 3\% increase over the recent season. Planting area 2020/21 is also estimated to expand by 1 million hectares (MHa), reaching 19.5 MHa. The Brazilian productivity trend conjectures the average yield to grow to 5.57 metric tons/hectare $(\mathrm{MT} / \mathrm{Ha})$ in this market year $[3,4]$.

In $2017,46 \%$ of US corn grain was used to feed livestock and poultry, while $29 \%$ was utilized for fuel ethanol production, $12 \%$ for food, and $10 \%$ for other industrial applications [5, 6]. Twenty and seven percent of all ethanol production comes from corn, and in the USA, 95\% of this fuel comes from this grain [6].

Starch is the main component in the corn grain (70\%) [7], which may be depolymerized by enzymatic hydrolysis, specifically by glycoside hydrolases (EC 3.2.1.). $\alpha$-Amylase (EC 3.2.1.1) acts exclusively on $\alpha-1,4$ bonds within the amylose and amylopectin chain, liberating maltooligosaccharides. $\beta$-Amylase (EC 3.2.1.2) hydrolysis $\alpha-1,4$ bonds at the non-reducing ends of the starch chain by releasing maltose units; and glucoamylase (EC 3.2.1.3) acts on $\alpha$ 1,4 bonds and at a slower rate on $\alpha-1,6$ bonds on non-reducing of starch ends by hydrolyzing glucose monomers [8].

These enzymes are produced by a large number of microorganisms, including Aspergillus brasiliensis. This species is described in the Aspergillus section Nigri, closely related to A. niger, an organism deemed harmless and grown under acceptable industrial largescale practices [9].

Swine and poultry diets are based primarily on corn grain and soybean meals [5]. The application of enzymes during feed production is helpful to improve the corn assimilation by the animals. Amylase helps in starch digestion, and xylanases break down the fiber-rich cell walls found in feed ingredients, releasing enclosed nutrients. In other words, enzymes can work 
in combination to improve nutrient digestibility and reduce anti-nutrient levels, thereby increasing energy and protein availability in corn-based diets [10].

Moreover, biofuel production also requires pretreatment. In the dry milling process, the corn grain is milled, and the starch is hydrolyzed with enzymes and fermented with yeast to produce ethanol [5]. Furthermore, when the subject is biogas production, enzyme application is also required. The most efficient approach to improve digestion efficiency is to disrupt the chemical bonds in the material prone to enzymatic hydrolysis [11]. Thus, the objective of this study was to examine the best conditions for enzymatic hydrolysis of milled corn using as tools a mixture design and a central composite design to optimize the effect of different enzyme preparations, the influence of $\mathrm{pH}$, temperature, time of hydrolysis, and the source concentration influencing the simple sugars yield, a value product.

The designing of a series of experiments results in an adequate and consistent measurement of the response. It develops a mathematical model with the best fittings, finds the optimal set of experimental parameters, and represents process parameters' direct and interactive effects.

\section{Material and methods}

\subsection{Materials}

PDA medium was purchased from Himedia (Brazil). Barley bagasse was kindly supplied by "Colorado" brewery of Ribeirão Preto/SP/Brazil. Fubá Mimoso Yoki® (cornmeal) composed $(\mathrm{g} / 100 \mathrm{~g})$ by fatty 2 ; carbohydrate 82 ; fiber 5.4 ; and protein 7.4 , was bought in the supermarket. Corn grain has a high starch content (70\%).

\subsection{Microorganisms}

Aspergillus tamarii Kita and Aspergillus brasiliensis were provided by the Mycology Collection of the Microbiology and Cell Biology Laboratory of Biology Department from Faculty of Philosophy, Sciences and Letters at Ribeirão Preto - USP (SP, Brazil). Both fungi were maintained in the laboratory on PDA medium slants at $4^{\circ} \mathrm{C}$. The fungi A. brasiliensis was isolated from the Brazilian Atlantic Forest in Peruíbe - SP [12]. Stock culture is being preserved under the register number of CFF124. Aspergillus tamarii Kita was isolated from an Atlantic Forest soil sample (Bela Vista biological refuge, Foz do Iguaçu - Brazil). A partial sequence of the ITS1-5,8S-ITS2 region of A. tamarii Kita is deposited in the National Center for Biotechnology Information (NCBI) by the access number: KJ995575.1 [13]. 


\subsection{Enzyme production}

The crude extract optimized for amylase production (AAB) was cultivated according to Almeida et al. [12] with modifications. A. brasiliensis was grown in $125 \mathrm{~mL}$ Erlenmeyer flasks containing $1 \%(\mathrm{w} / \mathrm{v})$ of cornmeal as carbon source, in $25 \mathrm{~mL}$ of SR (Segato Rizzatti) medium [14]. Cultures were obtained by inoculation of $1.0 \mathrm{~mL}$ of a conidia solution $\left(1.0 \times 10^{6}\right)$ into each flask, previously sterilized at $127{ }^{\circ} \mathrm{C}$ and 1.0 atm, for 15 minutes, and incubated at $30{ }^{\circ} \mathrm{C}$ for $120 \mathrm{~h}$ under static conditions.

The crude extract optimized for xylanase production (XAT) was cultivated according to Heinen et al. [13]. The strain A. tamarii Kita was grown in $125 \mathrm{~mL}$ Erlenmeyer flasks containing $2.5 \%(\mathrm{w} / \mathrm{v})$ of barley bagasse as carbon source, $10 \mathrm{~mL}$ of distilled water, and $15 \mathrm{~mL}$ of Adams medium [15]. Cultures were obtained by inoculation of $1.0 \mathrm{~mL}$ of a conidia solution $\left(1.0 \times 10^{6}\right)$ into each flask, previously sterilized at $127{ }^{\circ} \mathrm{C}$ and $1.5 \mathrm{~atm}$ for 15 minutes, and incubated at $28^{\circ} \mathrm{C}$ for $129 \mathrm{~h}$ under static conditions.

After cultivations, the cultures were harvested by vacuum filtration using Whatman no 1 filter paper, and the filtrates (extracellular crude extracts) were used for enzymatic activity quantification.

Commercial cellulase extract from Trichoderma reesei was obtained from Novozymes ${ }^{\circledR}$ (CelluclastTM). In this study, the commercial extract was 10 -fold diluted and named as CTR.

\subsection{Enzymatic assays and protein determination}

Enzymes present in the crude extracts were evaluated: amylases, xylanases, pectinases, arabinanases, xyloglucanases, CMCases, mannanases, FPases, avicelases, arabinofuranosidases, $\beta$-xylosidases, $\beta$-glucosidases and lipases. The conditions for each assay are in Table S1.

Amylases, xylanases, pectinases, arabinanases, xyloglucanases, CMCases, mannanases, FPases, and avicelases were measured from their natural substrates (Table S1). Each assay was initiated with $50 \mu \mathrm{L}$ of the crude extract added to $50 \mu \mathrm{L}$ of the respective substrate diluted in sodium acetate buffer (100 mM, pH 5.0) (Table S1). The substrates were diluted in the concentration of $1 \%$ for amylases, xylanases, pectinases, arabinanases, xyloglucanases, CMCases, and avicelase, $0.5 \%$ for mannanase and $0.044 \mathrm{~g} / \mathrm{mL}$ for FPase. The mixtures (substrate plus crude extract) were kept in a water bath at $50{ }^{\circ} \mathrm{C}$. After incubation, the mixtures were boiled at $100{ }^{\circ} \mathrm{C}$ for 5 minutes, then $1 \mathrm{~mL}$ of distilled water was added to each mixture, and an aliquot of $100 \mu \mathrm{L}$ was quantified at $540 \mathrm{~nm}$. The reducing sugars (RS) released were 
quantified with the Miller method [16]. The enzyme activity unit was defined as the amount of enzyme capable of releasing $1 \mu \mathrm{mol}$ of RS per minute. A time zero blank was prepared to each enzymatic assay. The blank mixtures containing buffer, substrate and enzyme extract were not incubated, they were directly boiled at $100{ }^{\circ} \mathrm{C}$ for 5 minutes.

Arabinofuranosidase, $\beta$-xylosidase, $\beta$-glucosidase, and lipase activities were determined through their artificial substrate's hydrolysis i.e., p-nitrophenyl- $\alpha$-arabinofuranoside, $p$ nitrophenyl- $\beta$-D-xilopiranoside, and p-nitrophenyl- $\beta$-D-glucopyranoside, $\quad p$ nitrophenylpalmitate, respectively. Each assay was initiated with $25 \mu \mathrm{L}$ of the crude extract and $25 \mu \mathrm{L}$ of substrate diluted in Mcllvaine buffer $\mathrm{pH} 6.0$ and incubated for 5 minutes at $50{ }^{\circ} \mathrm{C}$. Each substrate was diluted in the respective concentration as showed in Table S1. The reactions were stopped by adding $50 \mu \mathrm{L}$ of $0.2 \mathrm{M} \mathrm{Na}_{2} \mathrm{CO}_{3}$ solution. The measurement was performed in a spectrophotometer at $405 \mathrm{~nm}$. The unit (U) was defined as the amount of enzyme required to hydrolyze one $\mu \mathrm{mol}$ of the substrate per minute. An appropriate blank was prepared to each enzymatic assay. The blank mixtures containing buffer, substrate and enzyme extract were immediately inactivated by adding $50 \mu \mathrm{L}$ of $0.2 \mathrm{M} \mathrm{Na}_{2} \mathrm{CO}_{3}$ solution.

Proteins were measured with the Bradford method [17], using a standard curve of 0 $200 \mu \mathrm{g}$ of bovine serum albumin with intervals of $20 \mu \mathrm{g}$ among the points. The values of protein were expressed as $\mathrm{mg}$ of protein per $\mathrm{mL}$ of solution.

\subsection{Effect of $\mathrm{pH}$ and temperature on crude amylase activity from $A A B$}

The influence of temperature on the amylase activity was determined by carrying out the enzyme assay at different temperatures $30,35,40,45,50,60,70$, and $80{ }^{\circ} \mathrm{C}$.

After determining the optimum temperature, the influence of $\mathrm{pH}$ on the crude amylase activity was evaluated in sodium acetate buffer with different $\mathrm{pH}$ values $3.75 ; 4.0 ; 4.6 ; 5.2$, and 5.45 at the concentration of $100 \mathrm{mM}$.

\subsection{Cornmeal hydrolysis}

\subsubsection{Mixture design between three enzymatic extracts}

AAB (A), XAT (B), and CTR (C) enzymatic extracts were used to hydrolysis of cornmeal. The hydrolysis was performed with a final volume of $1 \mathrm{~mL}$. It was composed of 0.05 $\mathrm{g}$ of cornmeal and enzymatic extract buffered in sodium acetate, $\mathrm{pH}$ 5.0, with $15 \mathrm{mM}$ sodium azide, to prevent bacterial contamination (Table 1). The hydrolysis was carried out at $50{ }^{\circ} \mathrm{C}$ in a dry bath with stirring of $50 \mathrm{rpm}$. Aliquots of $10 \mu \mathrm{L}$ were taken out in time zero (blank) and 
after 4 hours of hydrolysis, and they were immediately boiled for 5 minutes to inactivate the enzymes. Reducing sugars were quantified with the Miller method (Miller, 1969).

Models for mixture design consisting of three components include linear, quadratic, and special cubic models. The models for the case of three variables are:

$Y=\beta_{1} x_{1}+\beta_{2} x_{2}+\beta_{3} x_{3}$

Equation 1. Linear model

$Y=\beta_{1} x_{1}+\beta_{2} x_{2}+\beta_{3} x_{3}+\beta_{12} x_{1} x_{2}+\beta_{13} x_{1} x_{3}+\beta_{23} x_{2} x_{3}$

Equation 2. Quadratic model

$Y=\beta_{1} x_{1}+\beta_{2} x_{2}+\beta_{3} x_{3}+\beta_{12} x_{1} x_{2}+\beta_{13} x_{1} x_{3}+\beta_{23} x_{2} x_{3}+\beta_{123} x_{1} x_{2} x_{3}$

Equation 3. Special cubic model

where $Y$ is the dependent variable, that is, the expected response, $\beta_{i}$ is the regression coefficient (calculated from experimental data), and $x_{i}$ are the independent variables (components). Each parameter was presented by a model that helps to explain the variability [18-20].

The mixture models considered adequate and satisfactory were chosen based on the results of variance analysis (ANOVA) (Table S2). They were chosen based on the lack of fit, a high percentage of explained variation $\left(\mathrm{R}^{2}\right)$, and the $\mathrm{F}$ test's calculated value, which must be greater than the tabulated value (in the degrees of freedom considered). Since the model was predictive, it was possible to generate the respective contour curves and the response surfaces (Figure S1). The linear model was determined using only the pure components' measured responses (vertices of the triangle). The quadratic model was determined using the pure components' measured responses and for the binary mixtures represented by the midpoints of the three sides of the triangle. The cubic model was determined using the inclusion of a central point (Figure S1) [20].

Statistica v.13.0 (StatSoft, USA) was used to analyze the experimental regression and graphical analysis data. Analysis of variance was performed at the significance levels of $5 \%$.

\subsubsection{Best substrate concentration and time of hydrolysis}

The best concentration of cornmeal for hydrolysis was tested at $50{ }^{\circ} \mathrm{C}$ in a dry bath with $50 \mathrm{rpm}$ agitation for 4 hours, with the best enzymatic cocktail previously selected (AAB). The final substrate concentration varied from $1,2,3,4,5,6$, and $7 \%$.

Subsequently, to analyze the best time for hydrolysis, tests were performed at $50{ }^{\circ} \mathrm{C}$ in a dry bath with $50 \mathrm{rpm}$ agitation during with the best enzymatic cocktail (AAB) selected 
previously. Aliquots of $10 \mu \mathrm{L}$ were taken out in time zero (blank) and after 4, 24, 48, and 72 hours of hydrolysis. The amount of RS was measured by the DNS method.

\subsubsection{Optimization by central composite design and response surface analysis}

$A 2^{2}$ central composite design (CCD) and response surface analysis were performed to assess the effect of the temperature and $\mathrm{pH}$ on cornmeal hydrolysis.

Independent variable levels were defined according to a complete experimental design (Table 2), and a set of 11 experiments was carried out, three of which were central point repetitions. The answer to the variables, where $\mathrm{Y}$ is the RS production, can be approximated by the quadratic polynomial (Equation 4).

$Y=\beta_{0}+\beta_{1} X_{1}+\beta_{2} X_{2}+\beta_{11} X_{1}^{2}+\beta_{22} X_{2}^{2}+\beta_{12} X_{1} X_{2}$

\section{Equation 4.}

where: $\beta_{0}$ is the intercept, $\beta_{1}$ and $\beta_{2}$ are the first-order model coefficients, $\beta_{12}$ is the ratio between products, $X_{1}$ is the variable temperature and $X_{2}$ is the variable $\mathrm{pH}$. A Student $t$-test was used to assess the statistical significance of the regression coefficients. Regression coefficient $\left(\mathrm{R}^{2}\right)$ was used to express the fit quality of the polynomial model, and its statistical significance was determined by the $\mathrm{F}$ test (Fisher's test). Analysis of variance was performed at the significance levels of $10 \%$. The software Statistica v.13.0 (StatSoft, USA) was used to analyze the experimental data using residual error.

Treatments were performed in $2 \mathrm{~mL}$ Eppendorf for 48 hours under $50 \mathrm{rpm}$ agitation in a dry bath. For each $50 \mathrm{mg}$ of cornmeal, it was used $1 \mathrm{~mL}$ of crude enzymatic extract (AAB) with $15 \mathrm{mM}$ of sodium azide and buffered with sodium acetate $50 \mathrm{mM}$. Aliquots of $10 \mu \mathrm{L}$ were taken out in time zero (blank) and after 48 of hydrolysis. The amount of RS released was measured by the DNS method.

The $\mathrm{pH}$ and temperature of each test varied according to the respective experiment (Table 2).

\subsubsection{Thermal hydrolysis control}

Thermal hydrolysis tests of cornmeal were also performed. The experiments were done under the same temperatures as the experimental design $\left(33,35,40,45\right.$, and $\left.47^{\circ} \mathrm{C}\right)$; however, instead of enzymatic extract, $1 \mathrm{~mL}$ of distilled water and $15 \mathrm{mM}$ sodium azide were added for each $50 \mathrm{mg}$ of cornmeal. The tests were performed on $2 \mathrm{~mL}$ Eppendorf's in a dry bath with 50 
rpm agitation for 48 hours. After the hydrolysis time, the amount of RS was measured by the DNS method.

\subsubsection{Hydrolysis of cornmeal pretreated with A. brasiliensis cultivated in solid-state fermentation}

Erlenmeyer flasks of $125 \mathrm{~mL}$ were added of $2 \mathrm{~g}$ of cornmeal, $3 \mathrm{~mL}$ of SR salt solution, and $1 \mathrm{~mL}$ of spore solution $\left(10^{6}\right)$ of the fungus A. brasiliensis. This solid-state fermentation (FES) was incubated for 120 hours at $30^{\circ} \mathrm{C}$ in static condition. After the microorganism growth time, the cultures (cornmeal + A. brasiliensis mycelia) were macerated in porcelain mortar and oven-dried at $50{ }^{\circ} \mathrm{C}$ overnight resulting in the pretreated cornmeal. The hydrolysis occurred in $2 \mathrm{~mL}$ Eppendorf, where $50 \mathrm{mg}$ of pretreated cornmeal was brought into contact with $1 \mathrm{~mL}$ of enzymatic extract (AAB) added $15 \mathrm{mM}$ sodium azide. The incubation occurred at $50^{\circ} \mathrm{C}$, for 48 hours, in a dry bath under stirring of $50 \mathrm{rpm}$. After that, the formation of RS was analyzed by Miller's methodology.

\section{Results and Discussion}

Corn grain has a high starch content (70\%), and the cornmeal from Yoki® used in this study shows a centesimal composition of (in $\mathrm{g} / 100 \mathrm{~g}$ ) fatty 2; carbohydrate 82; fiber 5.4 and protein 7.4. Due to this composition, corn has been converted into ethanol for thousands of years. Since the past century, its use as fuel has expanded. The conversion to biofuels includes grinding, hydrolysis with enzymes, fermentation with yeast, and distillation [21]. Additionally, research has proven the best nutrient digestibility within the small intestine of birds when the corn is treated with enzymes [10].

On account of the demand for corn as a resource for energy production and animal feed, this research was developed aiming at the enzymatic hydrolysis optimization of corn.

\subsection{Production and analysis of enzyme extracts}

Three different enzymatic extracts were selected to hydrolyze the cornmeal. The crude enzymatic extract produced by A. brasiliensis (AAB) had been optimized for amylase production by Almeida et al. [12] using maltose as an inducer. In this work, cornmeal was used as carbon source to the submerged fermentation since this enzymatic production was aimed at a corn resource. The crude enzymatic extract optimized for xylanase production (XAT) [13] used barley bagasse as a carbon source, showing sustainability and lower process operational costs [22]. 
The determination of enzyme activities showed that amylases were the main enzymes present in the AAB extract $(6.0 \pm 0.1 \mathrm{U} / \mathrm{mL})$ and xylanases in the XAT extract $(23.75 \pm 0.63$ $\mathrm{U} / \mathrm{mL}$ ). These two extracts produced on-site were crude, on account of this other enzymes could be found in their composition [23].

It was also tested the cornmeal hydrolysis by cellulase extract (CTR) from Novozymes $®$ (Celluclast ${ }^{\mathrm{TM}}$ ), which originally showed a CMCases activity of $78.66 \pm 2.30 \mathrm{U} / \mathrm{mL}$, and 7.8 CMCase $\mathrm{U} / \mathrm{mL}$ during the hydrolysis tests since it was 10 -folds diluted.

\subsection{Mixture design}

A mixture design was used to analyze the hydrolysis since this type of experiment can show the interaction and even the influence of each cocktail itself. The RS ( $\mu \mathrm{mol} / \mathrm{mL})$ produced, the ANOVA values and the model used are shown in Figure 1 and Table S2. These results indicate that XAT, AAB, and CTR had affected the hydrolysis of cornmeal $(p \leq 0.05)$. The linear model obtained for the RS ( $\mu \mathrm{mol} / \mathrm{mL})$ is expressed in Equation 5.

Reducing sugar $(m g / m L)=83.47(\mathrm{~A})+117.92(\mathrm{~B})+34.5(\mathrm{C})$

\section{Equation 5.}

where $\mathrm{A}, \mathrm{B}$, and $\mathrm{C}$ correspond to encoded values for XAT, AAB, and CTR, respectively.

The linear model showed that AAB's cornmeal hydrolysis (assay number 2) promoted a more significant amount of reducing sugars in 4 hours of hydrolysis $(118.70 \mu \mathrm{mol} \mathrm{RS} / \mathrm{mL})$. The first and fourth assays have also stood out as good for cornmeal hydrolysis. In assay number 4, there was a mixture between $\mathrm{AAB}$ and XAT, which resulted in $89.19 \mu \mathrm{mol} \mathrm{RS} / \mathrm{mL}$, and assay number 1 with XAT extract showed the formation of $81.93 \mu \mathrm{mol}$ RS/mL. Table 1 shows this result, and it can also be seen in the contour curve and Pareto chart (Figure 1A and B).

There was no lack of adjustment in the degrees of freedom used. The correlation coefficient value $\left(\mathrm{R}^{2}\right)$ was 0.75 , and $F_{\text {calculated }}(8.94)$ for the model was more significant than the $F_{\text {listed }}$ (5.14), which means that the model is statistically significant and predictive, at a confidence level of $95 \%$ (Table S2).

The linear model was enough to describe the $\mathrm{AAB}$ crude extract as the best extract to cornmeal hydrolysis, with no need of XAT or CTR supplementation.

In the world, corn is one of the most significant starch sources, therefore, the first and critical step in corn processing is the starch saccharification procedures [24]. This procedure 
provides the conversion of amylose and amylopectin, the two major starch components, into simple sugars. Various amylases have the capability of hydrolyzing these different starches. Therefore, as the cornmeal has a rich carbohydrate content (82\%), the crude enzymatic extract rich in amylases was the one that promoted the maximum hydrolysis. Karakatsanis and Liakopoulou-Kyriakides [25] reported that more than $96 \%$ of simple sugars were released after $24 \mathrm{~h}$ of corn starch hydrolysis using $\alpha$-amylase and glucoamylase simultaneously. Furthermore, the application of a two-step enzymatic process, $\alpha$-amylase followed by glucoamylase, was more efficient than applying just one type of enzyme [26].

$\alpha$-Amylases are the oldest and multipurpose starch hydrolysing enzymes that can substitute chemical hydrolysis of starch in industries [27]. Additionally, the Aspergillus species produce a large variety of extracellular enzymes, and amylases are the ones with the most significant industrial importance [28], constituting a class covering approximately $25 \%$ of the world enzyme market $[29,30]$. The fungal amylases are preferred over other microbial sources because of their accepted GRAS (Generally Recognized As Safe) status [31]. A. brasiliensis is described within the Aspergillus section Nigri. It is closely related to A. niger, which has been granted the GRAS [9].

\subsection{Crude extract $(A A B)$ characterization}

Enzymatic dosages were performed to quantify some enzymes present in the crude extract AAB. Table 3 shows the specific activity (units per mg of protein) when the enzymatic activities were done in buffer sodium acetate $50 \mathrm{mM} \mathrm{pH} 5.0$ and $50^{\circ} \mathrm{C}$. Amylases were present and showed the highest amount among the tested enzymes, $35.27 \mathrm{U} / \mathrm{mg}$ (Table 3).

Amylases have numerous applications in industry, and each bioprocess requires enzymes with assorted characteristics of $\mathrm{pH}$ and temperature. The enzymes characterization lies to discovery the best conditions for application which can contribute and lead to a more efficient process. To characterize the best temperature (Figure 2A) and $\mathrm{pH}$ for dosage (Figure 2B) of $\mathrm{AAB}$ amylase, some experiments were carried out using an ample range of the parameters. The results showed that the $60-70{ }^{\circ} \mathrm{C}$ and the $\mathrm{pH} 3.75-4.6$ are the best for this enzyme. Amylase activity at $60-70^{\circ} \mathrm{C}$ range was $55 \%$ higher than that found at $50{ }^{\circ} \mathrm{C}$. At $80^{\circ} \mathrm{C}$, there was a decline of $68 \%$ due to denaturation. The optimal $\mathrm{pH}$ range of amylase dosage was between 3.75 and 4.6. In a $\mathrm{pH}$ superior to this range, the amylolytic activity decreased by 6 and $15 \%$, respectively, in pH 5.2 and 5.45. Almeida et al. [12] described an amylase from A. brasiliensis incubated in submerged fermentation using the commercial carbon source, maltose. Both amylolytic extracts produced from an expensive commercial (maltose) and biomass source (cornmeal in this work) 
showed the similar range of optimum $\mathrm{pH}$ (4.5 and 3.75-4.6, respectively) and optimum temperature (70 and $60-70{ }^{\circ} \mathrm{C}$, respectively). Additionally, Table 4 shows the optimal temperature and $\mathrm{pH}$ from amylases produced by other Aspergillus groups. The data analysis shows that amylases have suitable activities in a wide range of $\mathrm{pH}$ and temperatures. At the same time, it can be produced using different resources as inducers.

After the characterization's tests, it was found that $6.0 \pm 0.2 \mathrm{U} / \mathrm{mL}$ of amylase was presented in the AAB. In other words, this means that in the hydrolysis tests, it was applied 6 units per $\mathrm{mL}$ of crude extracts of this enzyme, which corresponds with a specific activity of 166.66 U/mg. This production of amylase from A. brasiliensis using cornmeal as a carbon source was significantly valuable. Varalakshmi et al. [32] compared the amylase production by A. niger using different sources as substrates. They showed that when glucose was used as an inducer, it was found in the crude extract approximately $20 \mathrm{U}$ of amylase per mg of protein, sucrose $30 \mathrm{U} / \mathrm{mg}$, maltose $35 \mathrm{U} / \mathrm{mg}$, and soluble starch $40 \mathrm{U} / \mathrm{mg}$.

\subsection{Cornmeal concentration and time of hydrolysis}

Tests were done to analyze the best cornmeal concentration for hydrolysis. Different concentrations of this source $(1,2,3,4,5,6$, and $7 \%)$ were placed for hydrolysis with AAB extract. Figure 3A shows that the concentrations of 5, 6, and 7\% were promising to form simple sugars. There was the maximum RS production with $5 \%$ cornmeal. On account of this, the following tests were performed with this percentage.

The best hydrolysis time was also studied. Hydrolysis tests were done at $50^{\circ} \mathrm{C}$ with cornmeal 5\% for 4, 24, 48, and 72 hours. The RS ( $\mu \mathrm{mol} / \mathrm{mL})$ results are shown in Figure 3B. The highest amount of RS produced was within 48 hours of hydrolysis.

\subsection{Hydrolysis optimization by central composite design (CCD) and response surface analysis}

Temperature and $\mathrm{pH}$ were investigated jointly by a CCD since that they had a strong influence on enzymatic activity and subsequently in cornmeal hydrolysis. The temperature study ranged from 33 to $47^{\circ} \mathrm{C}$, and the established $\mathrm{pH}$ range was 3.75 to 5.45. The best CCD results can be observed in assay 2 (Table 2), with the temperature $45^{\circ} \mathrm{C}$ and $\mathrm{pH} 4$. The Pareto chart (Figure 4A) showed variable effects, where temperature and $\mathrm{pH}$ presented the linear and quadratic effects on the RS production. By the t-test (Table S3), this was confirmed since the null hypothesis $\left(\mathrm{H}_{0}\right)$ could be rejected $\left(-3.18 \leq \mathrm{t}_{\text {calc }}\right.$ value $\left.\leq 3.18\right)$ for the calculated degrees of freedom. Thus, the model obtained for RS production $(\mu \mathrm{mol} / \mathrm{mL})$ is expressed in Equation 6. 
$R S$ production $(\mu \mathrm{mol} / m L)=184.86+22.49(T)-28.88(T)^{2}-21.97(p H)-15.09(p H)^{2}$

\section{Equation 6.}

where $\mathrm{T}$ and $\mathrm{pH}$ correspond to temperature and $\mathrm{pH}$, respectively.

Equation 6 reveals how individual variables affected RS production. The positive sign for the linear term of temperature indicates that, in principle, this independent variable intensifies the hydrolysis of the biomass under study. However, the presence of a quadratic term in the model means that the effect of this variable changes when it is increased. Thus, the negative sign for the quadratic temperature term indicates a concave curve in the model, which means that this parameter will start to negatively affect the dependent variable. In addition, the negative coefficient value for the linear $\mathrm{pH}$ term means that increasing this factor it will reduce the treatment performance, just as the negative value for the quadratic term indicates a concave curve in the model.

The terms of the significant model were evaluated by analysis of variance (ANOVA) and $\mathrm{F}$ test (Table S3) $(p$-value $\leq 0.1)$. The correlation coefficient value $\left(\mathrm{R}^{2}\right)$ was 0.89 , and $F_{\text {calculated }}(12.72)$ was more significant than the listed $F_{\text {listed }}(3.18)$, which means that the model is statistically significant at a confidence level of $90 \%$. In this way, the model was adequate to describe the data and build a response surface. Figures $\mathbf{4 B}$ and $4 \mathrm{C}$ show the response surface contours for the RS production $(\mu \mathrm{mol} / \mathrm{mL})$ obtained by the reduced model of second order.

From the results presented, the temperature $40-45^{\circ} \mathrm{C}$ and $\mathrm{pH} 4.0-4.5$ are advantageous parameters for cornmeal hydrolysis by $\mathrm{AAB}$ crude enzymatic extract, achieving an RS production of 180-210 $\mu \mathrm{mol} / \mathrm{mL}$ (32.4-37.8 $\mathrm{g} / \mathrm{L}$ ), which corresponds to the hydrolysis of 79$92 \%$ of the carbohydrates present in the cornmeal since $82 \%$ of this biomass corresponds to this macronutrient. Liakopoulou-Kyriakides et al. [33] showed that at 5 hours of hydrolysis, the mixture of B. licheniformis $\alpha$-amylase with Rhizopus sp. glucoamylase at $50^{\circ} \mathrm{C}$ achieved $76 \%$ crude corn conversion. Apar \& Özbek [34] obtained 90\% of corn starch hydrolysis applying the commercial $\alpha$-amylase produced by Bacillus sp in the temperature of $65^{\circ} \mathrm{C}$.

Experimental design $2^{2}$ has been used to optimize production, products and reduce production costs [35-37]. Interestingly, with the aid of this technique, it was possible to increase the cornmeal hydrolysis considerably. CCDs are very efficient since we can provide much information on experiment variable effects and overall experimental error in a minimum number of required runs [38].

In this work, we could describe cornmeal hydrolysis with an amylase-rich extract using 
lower temperatures $40-45^{\circ} \mathrm{C}$ and acid $\mathrm{pH}$, making these conditions suitable for industrial production.

\subsection{Thermal hydrolysis control and hydrolysis of cornmeal pretreated with fungus growth}

Thermal hydrolysis and hydrolysis of cornmeal with the fungus biomass were developed to analyze and compare the RS production standardized in this work. Distilled water was put in contact with cornmeal (5\%) for $48 \mathrm{~h}$, under $50 \mathrm{rpm}$, at temperatures of 33, 35, 40, 45, and $47{ }^{\circ} \mathrm{C}$. The RS produced $(\mu \mathrm{mol} / \mathrm{mL})$ after the hydrolysis was $11.45,10.64,14.03,17.74$, and 18.54, respectively. Regardless of the temperatures employed, the formation of RS in the presence of distilled water was insignificant. The quantity was much lower than that one found when the AAB crude enzymatic extract was applied to cornmeal (180-210 $\mu \mathrm{mol} \mathrm{RS} / \mathrm{mL})$ under the optimized temperature $\left(40-45^{\circ} \mathrm{C}\right), \mathrm{pH}(4.0-4.5)$, concentration $(5 \%)$ and time conditions (48h). The performance of enzymes was essential for breaking down the complex sugars of cornmeal.

Another test performed was the hydrolysis of cornmeal pretreated with A. brasiliensis growth by AAB. A. brasiliensis was cultivated during 4 days on cornmeal at $30^{\circ} \mathrm{C}$. After it, the resulting substrate (cornmeal + mycelium) was hydrolyzed by AAB in the optimized conditions. The RS produced was $60 \%$ higher when the cornmeal did not contain the microorganism grown on it. The fungus A. brasiliensis may have consumed much of the bran sugars for its metabolism and growth, making less available sugar for hydrolysis.

Additionally, it can also be inferred that when hydrolyzing cornmeal added with mycelium there was a smaller amount of bran as substrate. The fungal cell wall is mainly composed of chitin [39], so there was a smaller amount of useful material for hydrolysis by the enzymatic extract optimized for amylase production.

\section{Conclusion}

This research was encouraged on account of development in the field of biorefining strategies for converting renewable raw materials into value-added products. This work studied the enzyme production using cornmeal and the hydrolysis of this source through the enzyme extract produced with it. A mixture design using three different extracts (XAT, AAB, and CTR), the enzyme cocktail secreted by A. brasiliensis stood out (linear model) as the best for cornmeal hydrolysis. This cocktail was rich in amylase, $166.66 \mathrm{U} / \mathrm{mg}$, which presented $\mathrm{pH}$ 3.75-4.6 and temperature $60-70{ }^{\circ} \mathrm{C}$ ranges as the best enzyme activity. The optimization of cornmeal hydrolysis showed that $5 \%$ of the substrate and 48 hours were parameters essentials for RS 
$(\mu \mathrm{mol} / \mathrm{mL})$ formation and the CCD. The experiments showed that the $\mathrm{pH} 4.0-4.5$ and the temperature $40-45^{\circ} \mathrm{C}$ were greater for cornmeal hydrolysis. The best hydrolysis in acid $\mathrm{pH}$ and low temperature makes it suitable for industrial production, such as hydrolysis steps on fuel and feed production.

\section{Acknowledgements}

The authors are grateful to Mariana Cereia and Maurício de Oliveira for their technical assistance. This work was supported by Fundação de Amparo à Pesquisa do Estado de São Paulo (FAPESP, processes 10/52322-3; 2014/50884-5; 2018/07522-6), and Conselho Nacional de Desenvolvimento Científico (CNPq, processes 563260/2010-6 and 465319/2014-9). V.E.P. was CNPq fellowship recipient (Process 142139/2017-3) and M.L.T.M.P. received CNPq Productivity scholarship process 301963/2017-7.

\section{Conflict of interest}

The authors report no conflicts of interest. The authors alone are responsible for the content and writing of the manuscript.

\section{References}

1. Makanjuola O, Greetham D, Zou X, Du C (2019) The development of a sorghum branbased biorefining process to convert sorghum bran into value added products. Foods 8: 279. 2. Arias S, Bhatia SK (2015) Medical applications for biomaterials in Bolivia, SpringerBriefs in Public Health.

3. GAIN (2021) Grain and Feed Update. Report Number: BR2021-0004, 2021 Ed., Global Agricultural Information Network,

https://apps.fas.usda.gov/newgainapi/api/Report/DownloadReportByFileName?fileName=Gra in+and+Feed+Update_Brasilia_Brazil_01-28-2021.pdf

4. GAIN (2020) Grain and Feed Update. Report Number: BR2020-0010. 2020, 2020 Ed.,

Global Agricultural Information Network, https://usdabrazil.org.br/wpcontent/uploads/2020/06/grain-and-feed-annual-2020.pdf

5. Klopfenstein T, Erickson G, Berger L (2013) Maize is a critically important source of food, feed, energy and forage in the USA. Field Crops Research 153: 5-11.

6. Mohanty SK, Swain MR (2019) Bioethanol production from corn and wheat: food, fuel, and future. Bioethanol production from food crops. Academic Press 45-59. 
7. Patzek TW (2006) A statistical analysis of the theoretical yield of ethanol from corn starch. Natural Resources Research 15: 205-212.

8. Pandey A, Soccol CR (2000) Economic utilization of crop residues for value addition: A futuristic approach. JSIR 59:12-22.

9. Varga J, Kocsube S, Toth B, Frisvad JC, Perrone G, Susca A, Meijer M, Samson RA (2007) Aspergillus brasiliensis sp. nov., a biseriate black Aspergillus species with world-wide distribution. International Journal of Systematic and Evolutionary Microbiology 57: 19251932.

10. Partridge G, Giménez-Rico RD, Rosa EA (2007) Danisco Animal Nutrition: una fitasa de nueva generación con termoestabilidad elevada. Albéitar: publicación veterinaria independiente, 64-65.

11. Karuppiah T, Azariah VE (2019) Biomass pretreatment for enhancement of biogas production. Anaerobic Digestion. IntechOpen, London, UK.

12. Almeida PZ, Messias JM, Pereira MG, Pinheiro VE, Monteiro LMO, Heinen PR, Cardoso GC, Jorge JA, Polizeli MLTM (2018) Mixture design of starchy substrates hydrolysis by an immobilized glucoamylase from Aspergillus brasiliensis. Biocatalysis and Biotransformation 36: 389-395.

13. Heinen PR, Pereira MG, Rechia CV, Almeida PZ, Monteiro LM, Pasin TM, Messias JM, Cereia M, Kadowaki MK, Jorge JA, Polizeli MLTM (2017) Immobilized endo-xylanase of Aspergillus tamarii Kita: an interesting biological tool for production of xylooligosaccharides at high temperatures. Process Biochemistry 53: 145-152.

14. Rizzatti ACS, Jorge JA, Terenzi HF, Rechia CV, Polizeli MLTM (2001) Purification and properties of a thermostable extracellular $\beta$-D-xylosidase produced by a thermotolerant Aspergillus phoenicis. Journal of Industrial Microbiology and Biotechnology 26: 156-160. 15. Adams P (1990) Mycelial amylase activities of thermophilic species of Rhizomucor, Humicola and Papulaspora. Mycopathologia 112: 35-37.

16. Miller GL (1959) Use of dinitrosalicylic acid reagent for determination of reducing sugar. Analytical chemistry 31: 426-428.

17. Bradford MM (1976) A rapid and sensitive method for the quantitation of microgram quantities of protein utilizing the principle of protein-dye binding. Analytical biochemistry 72: $248-254$.

18. Cornell JA (2011) Experiments with mixtures: designs, models, and the analysis of mixture data, John Wiley \& Sons, New York, USA. 
19. Giese EC, Dekker RF, Scarminio IS, Barbosa AM, da Silva R (2011) Comparison of $\beta-1$, 3-glucanase production by Botryosphaeria rhodina MAMB-05 and Trichoderma harzianum Rifai and its optimization using a statistical mixture-design. Biochemical Engineering Journal 53: 239-243.

20. Neto BB, Scarminio IS, Bruns RE (2010) Como fazer experimentos: Pesquisa e desenvolvimento na ciência e na indústria, Bookman Editora, Porto Alegre, BR.

21. Hay FJ (2019) Corn for biofuel production. FARM ENERGY. Available: https://farmenergy.extension.org/corn-for-biofuel-production/. Accessed: 27-03-2021

22. Timko M (2019) Determining the effect of ultrasonic pretreatment on anaerobic digestion of barley bagasse. Doctoral dissertation, Worcester Polytechnic Institute.

23. Pinheiro VE, Horváth IS, Lundin M, Polizeli MLTM (2021) Screening and cocktail optimization using experimental mixture design: enzymatic saccharification as a biological pretreatment strategy. Biofuels, Bioproducts and Biorefining 10.1002/BBB.2251.

24. Sudan SK, Kumar N, Kaur I, Sahni G (2018) Production, purification and characterization of raw starch hydrolyzing thermostable acidic $\alpha$-amylase from hot springs, International Journal of Biological Macromolecules, 117: 831-839.

25. Karakatsanis A \& Liakopoulou-Kyriakides M (1998) Comparative study of hydrolysis of various starches by alpha-amylase and glucoamylase in PEG-dextran and PEG-substrate aqueous two phase systems. Starch-Stärke 50(8): 349-353.

26. Mojović L, Nikolić S, Rakin M and Vukasinović M (2006) Production of bioethanol from corn meal hydrolyzates. Fuel 85(12-13): 1750-1755.

27. Paul JS, Gupta N, Beliya E, Tiwari S, Jadhav SK (2021) Aspects and recent trends in microbial $\alpha$-amylase: a review. Applied Biochemistry and Biotechnology (2021).

28. Hernández MS, Rodríguez MR, Guerra NP, Rosés RP (2006) Amylase production by Aspergillus niger in submerged cultivation on two wastes from food industries. Journal of food engineering 73: 93-100.

29. Rajagopalan G, Krishnan C (2008) $\alpha$-Amylase production from catabolite derepressed Bacillus subtilis KCC103 utilizing sugarcane bagasse hydrolysate. Bioresource technology 99: 3044-3050.

30. Reddy N, Nimmagadda A, Rao KS (2003) An overview of the microbial $\alpha$-amylase family. African Journal of Biotechnology 2: 645-648.

31. Gupta R, Gigras P, Mohapatra H, Goswami VK, Chauhan B (2003) Microbial $\alpha$-amylases: a biotechnological perspective. Process biochemistry 38: 1599-1616. 
32. Varalakshmi K, Kumudini B, Nandini B, Solomon J, Suhas R, Mahesh B, Kavitha A (2009) Production and characterization of a-amylase from Aspergillus niger JGI 24 isolated in Bangalore. Polskie Towarzystwo Mikrobiologów Polish Society of Microbiologists 58: 2936.

33. Liakopoulou-Kyriakides M, Karakatsanis A, Stamatoudis M, Psomas S (2001) Synergistic hydrolysis of crude corn starch by $\alpha$-amylases and glucoamylases of various origins. Cereal Chemikstry 78(5): 603-607.

34. Apar D, Özbek B (2004) $\alpha$-Amylase inactivation by temperature during starch hydrolysis. Process Biochemistry 39 (9): 1137-1144.

35. Rajendran R, Kanimozhi B, Prabhavathi P, Kumar DS, Santhanam P, Abirami M, Sundaram KS, Manikandan A (2015) A method of central composite design (CCD) for optimization of biodiesel production from Chlorella vulgaris. Journal of Petroleum \& Environmental Biotechnology 6:1.

36. Speranza B, Racioppo A, Sinigaglia M, Corbo MR, Bevilacqua A (2015) Use of central composite design in food microbiology: a case study on the effects of secondary phenols on lactic acid bacteria from olives. International journal of food sciences and nutrition 66: 520525 .

37. Nadh-Benarji D (2016) Statistical optimizations of fermentation factors on bioethanol production from Mahua Flower (Madhuca indica) with Saccharomyces cerevisiae by response surface methodology in batch bioreactor. Journal of Microbiology and Biomedical Research 2: 1-7.

38. Verseput R (2001) Digging into DOE Selecting the right central composite design for response surface methodology applications. Quality Digest 21: 33-36.

39. Ruiz-Herrera J (1991) Fungal cell wall: structure, synthesis, and assembly. CRC press, 2 ed., pp. 203.

40. Uguru G, Akinyanju J, Sani A (1997) The use of yam peel for growth of locally isolated Aspergillus niger and amylase production. Enzyme and microbial technology 21: 48-51.

41. Jin B, Van Leeuwen H, Patel B, Yu Q (1998) Utilisation of starch processing wastewater for production of microbial biomass protein and fungal $\alpha$-amylase by Aspergillus oryzae. Bioresource technology 66: 201-206.

42. Goto CE, Barbosa EP, Kistner LsC, Moreira FG, Lenartovicz V, Peralta RM (1998) Production of amylase by Aspergillus fumigatus utilizing $\alpha$-methyl-D-glycoside, a synthetic analogue of maltose, as substrate. FEMS microbiology letters 167: 139-143. 
43. Kajiwara Y, Takeshima N, Ohba H, Omori T, Shimoda M, Wada H (1997) Production of acid-stable $\alpha$-amylase by Aspergillus kawachii during barley shochu-koji production. Journal of fermentation and bioengineering 84: 224-227. 


\section{Figure Legends}

Figure 1. Response surface (A) and Pareto chart (B) from the mixture design (with three components) using XAT, AAB, and CTR for cornmeal hydrolysis. Dependent variable: RS $(\mu \mathrm{mol} / \mathrm{mL})$. After 4 hours of hydrolysis under $50 \mathrm{rpm}$, aliquots were analyzed for the reducing sugar content $(\mu \mathrm{mol} / \mathrm{mL})$.

Figure 2. Relative amylase activity. The effect of temperature $(\mathbf{A})$ and $\mathrm{pH}(\mathbf{B})$ on amylase activity. $\mathrm{AAB}$ crude extract produced at $30^{\circ} \mathrm{C}$, with $\mathrm{SR}$ salt solution, 120 hours static, supplemented with cornmeal $(1 \%)$ as carbon source. The temperature test was done in sodium acetate buffer $\mathrm{pH} 5.0$, and the $\mathrm{pH}$ test was done at $70^{\circ} \mathrm{C}$.

Figure 3. RS relative production in different cornmeal concentrations (A) and time of hydrolysis $(\mathbf{B})$. Tests of concentrations were done at $50^{\circ} \mathrm{C}, 4$ hours under $50 \mathrm{rpm}$. Tests of time were done at the same conditions, but aliquots were analyzed for the reducing sugar content $(\mu \mathrm{mol} / \mathrm{mL})$.

Figure 4. CCD response. Pareto chart showing the significant effects (A), contour curve (B), and response surfaces $(\mathbf{C})$. Dependent variables: temperature and $\mathrm{pH}$. After 48 hours of hydrolysis under $50 \mathrm{rpm}$, aliquots were analyzed for the reducing sugar content $(\mu \mathrm{mol} / \mathrm{mL})$ by the Miller method. 
Table 1. Mixture design: cornmeal hydrolysis during $4 \mathrm{~h}$ through XAT, AAB, and CTR enzymatic extracts. It was evaluated the yields of reducing sugars $(\mu \mathrm{mol} / \mathrm{mL})$

\begin{tabular}{|c|c|c|c|c|}
\hline \multirow{2}{*}{ Assay } & \multicolumn{3}{|c|}{ Variables $(\mathrm{mL})$} & \multirow{2}{*}{$\begin{array}{c}\text { RS } \\
(\mu \mathrm{mol} / \mathrm{mL})\end{array}$} \\
\hline & $X A T$ & $A A B$ & $C T R$ & \\
\hline $1^{a}$ & $1(1)$ & $0(0)$ & $0(0)$ & 81.93 \\
\hline $2^{a}$ & $0(0)$ & $1(1)$ & $0(0)$ & 118.70 \\
\hline $3^{a}$ & $0(0)$ & $0(0)$ & $1(1)$ & 28.38 \\
\hline $4^{a}$ & $0.5(0.5)$ & $0.5(0.5)$ & $0(0)$ & 89.19 \\
\hline $5^{a}$ & $0.5(0.5)$ & $0(0)$ & $0.5(0.5)$ & 61.29 \\
\hline $6^{a}$ & $0(0)$ & $0.5(0.5)$ & $0.5(0.5)$ & 73.87 \\
\hline $7^{b}$ & $0.33(0.33)$ & $0.33(0.33)$ & $0.33(0.33)$ & 69.35 \\
\hline $8^{b}$ & $0.33(0.33)$ & $0.33(0.33)$ & $0.33(0.33)$ & 72.25 \\
\hline $9^{b}$ & $0.33(0.33)$ & $0.33(0.33)$ & $0.33(0.33)$ & 112.74 \\
\hline
\end{tabular}

${ }^{a}$ Experimental points in the mixture design (Figure 1). The sum of all components in the assays was always $100 \%$. ${ }^{b}$ Replicates from assay number 7 or central point. $100 \%$ or $1=1 \mathrm{~mL}$ of enzymatic extract. Analysis performed by Miller method. Hydrolysis was developed at $50^{\circ} \mathrm{C}$, for 4 hours under $50 \mathrm{rpm}$. 
Table 2. CCD to evaluate the effect of temperature and $\mathrm{pH}$ on cornmeal hydrolysis

\begin{tabular}{cccc} 
Assay & \multicolumn{2}{c}{ Variables } & $R S(\mu \mathrm{mol} / \mathrm{mL})$ \\
\cline { 2 - 3 } $1^{\mathrm{a}}$ & $-1(35)$ & $-1(4.0)$ & 135.96 \\
$2^{\mathrm{a}}$ & $1(45)$ & $-1(4.0)$ & 210 \\
$3^{\mathrm{a}}$ & $-1(35)$ & $1(5.2)$ & 114.51 \\
$4^{\mathrm{a}}$ & $1(45)$ & $1(5.2)$ & 144.83 \\
$5^{\mathrm{b}}$ & $-1.41(33)$ & $0(4.6)$ & 90.32 \\
$6^{\mathrm{b}}$ & $1.41(47)$ & $0(4.6)$ & 143.54 \\
$7^{\mathrm{b}}$ & $0(40)$ & $-1,41(3.75)$ & 175.80 \\
$8^{\mathrm{b}}$ & $0(40)$ & $1,41(5.45)$ & 112.90 \\
$9^{\mathrm{c}}$ & $0(40)$ & $0(4.6)$ & 190.80 \\
$10^{\mathrm{c}}$ & $0(40)$ & $0(4.6)$ & 181.29 \\
$11^{\mathrm{c}}$ & $0(40)$ & $0(4.6)$ & 182.74
\end{tabular}

The encoded values of the variables are in parentheses. ${ }^{a}$ Assays from the Factorial planning. ${ }^{b}$ Axial points. ${ }^{\mathrm{c}}$ Central points. Analysis performed by Miller method. Hydrolysis was developed with cornmeal (5\%) for 48 hours under $50 \mathrm{rpm}$. 
Table 3. Enzymes present in the AAB crude extract

\begin{tabular}{ccc} 
Enzyme & U/mL & Specific activity (U/mg of protein) \\
\hline Amylase & 1.27 & 35.27 \\
Xylanase & 1.00 & 27.9 \\
Pectinase & 0.89 & 24.9 \\
Arabinanase & 0.80 & 22.46 \\
Xyloglucanase & 1.02 & 28.39 \\
CMCase & 0.68 & 19.13 \\
Mananase & 0.74 & 20.61 \\
Fpase & 0.66 & 18.39 \\
Avicelase & 0.88 & 24.56 \\
Arabinofuranosidase & 0 & 0 \\
$\beta$-xylosidase & 0 & 0 \\
$\beta$-glucosidase & 0.027 & 0 \\
Lipase & 0 & 0
\end{tabular}

Enzymatic activity at $50^{\circ} \mathrm{C}, \mathrm{pH} 5.0$ (sodium acetate buffer $50 \mathrm{mM}$ ) 
Table 4. Properties of fungal amylases

\begin{tabular}{|c|c|c|c|c|}
\hline Microorganism & $\begin{array}{l}\text { Fermentation } \\
\text { (inducer) }\end{array}$ & $\begin{array}{c}\text { Optimum } \\
\text { pH }\end{array}$ & $\begin{array}{c}\text { Optimum } \\
\text { temperature }\left({ }^{\circ} \mathbf{C}\right)\end{array}$ & Reference \\
\hline Aspergillus niger & SSF (Yam peel) & 5.5 & 70 & {$[32]$} \\
\hline Aspergillus oryzae & $\mathrm{SmF}\left(\mathrm{SPW}^{\mathrm{a}}\right)$ & $5.0-9.0$ & $25-35$ & {$[33]$} \\
\hline $\begin{array}{l}\text { Aspergillus } \\
\text { fumigatus }\end{array}$ & $\begin{array}{c}\text { SmF } \\
(\alpha-\text {-methyl-D- } \\
\left.\text { glycoside }^{\mathrm{b}}\right)\end{array}$ & 6.0 & 30 & {$[34]$} \\
\hline Aspergillus kawachii & $\begin{array}{c}\text { SmF (barley shochu- } \\
\text { koji) }\end{array}$ & 3.0 & 30 & {$[35]$} \\
\hline $\begin{array}{l}\text { Aspergillus } \\
\text { brasiliensis }\end{array}$ & SmF (maltose) & 4.5 & 70 & {$[12]$} \\
\hline $\begin{array}{l}\text { Aspergillus } \\
\text { brasiliensis }\end{array}$ & SmF (cornmeal) & $3.75-4.6$ & $60-70$ & This work \\
\hline
\end{tabular}

${ }^{a}$ Starch processing wastewater

${ }^{\mathrm{b}}$ Synthetic analog of maltose 
Figure 1.

A

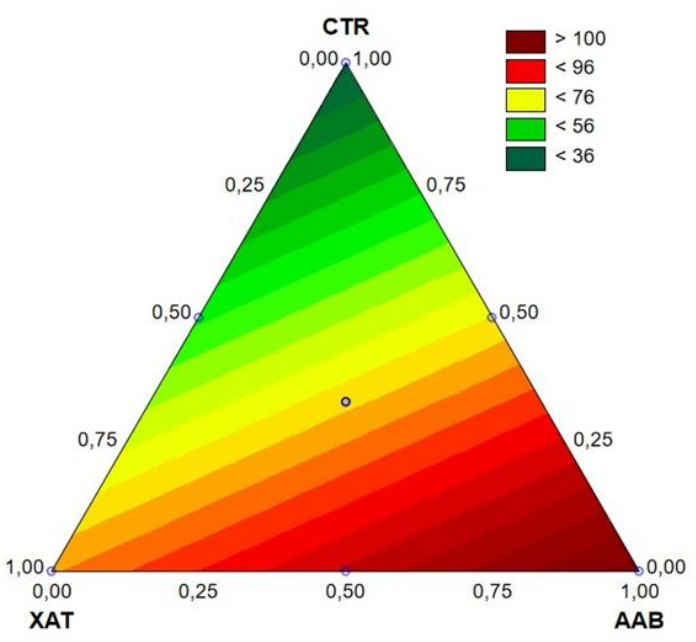

B

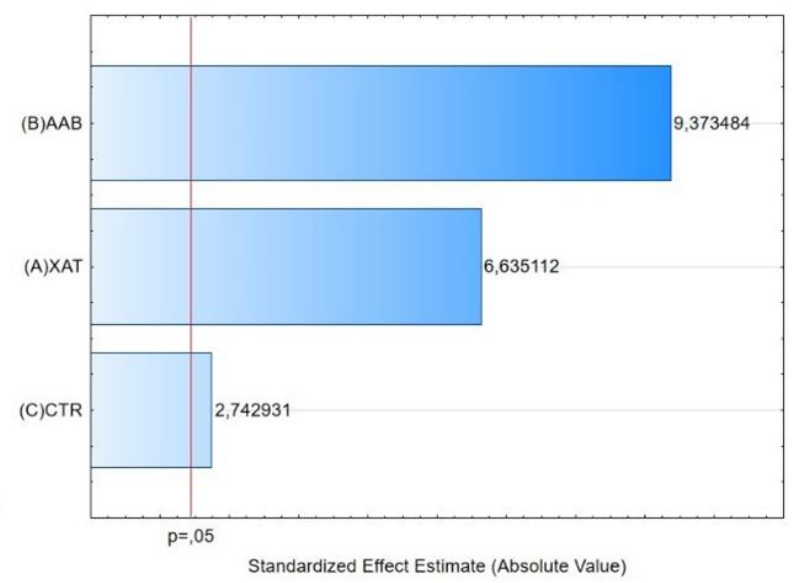

Figure 2.

A

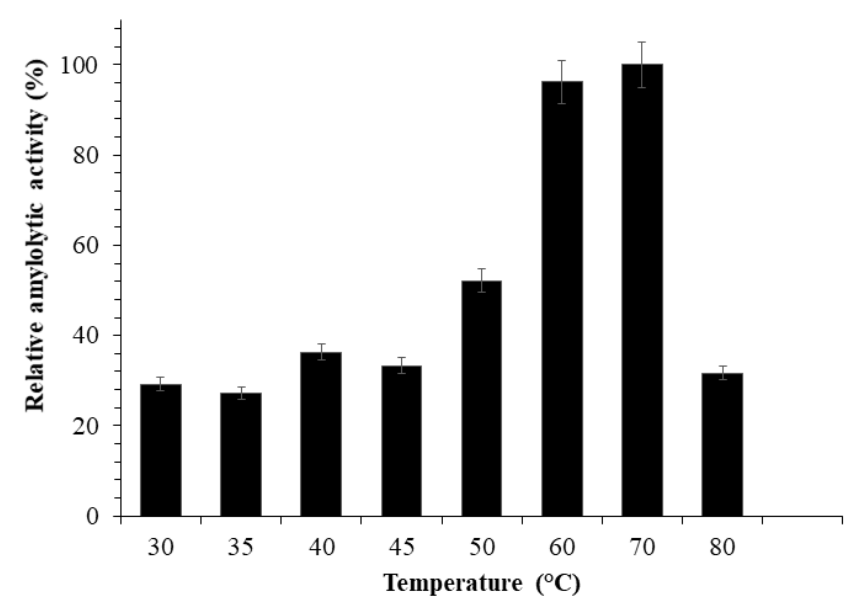

B

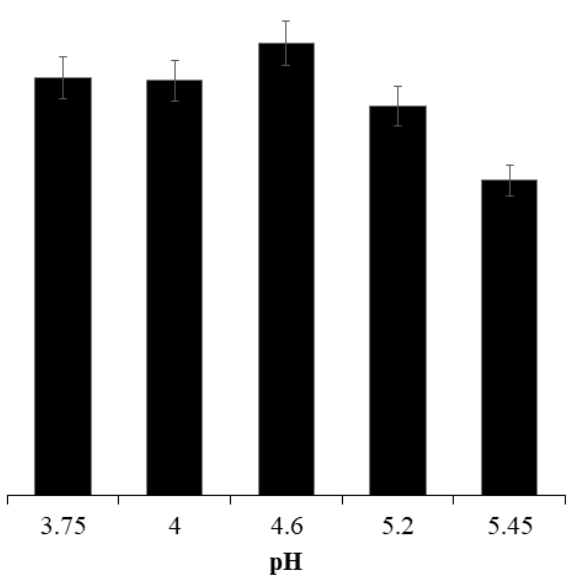


Figure 3.

A

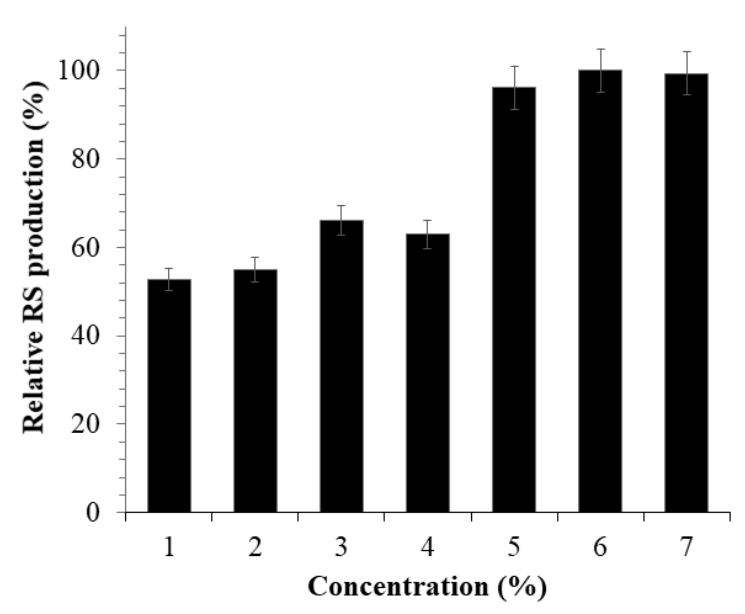

Figure 4.

A

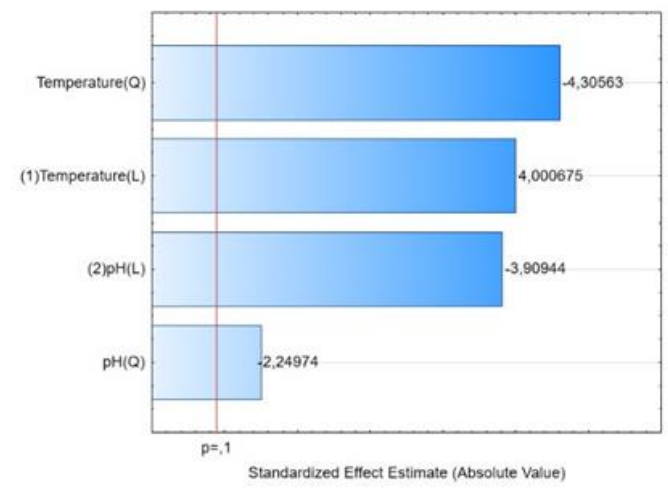

C
B

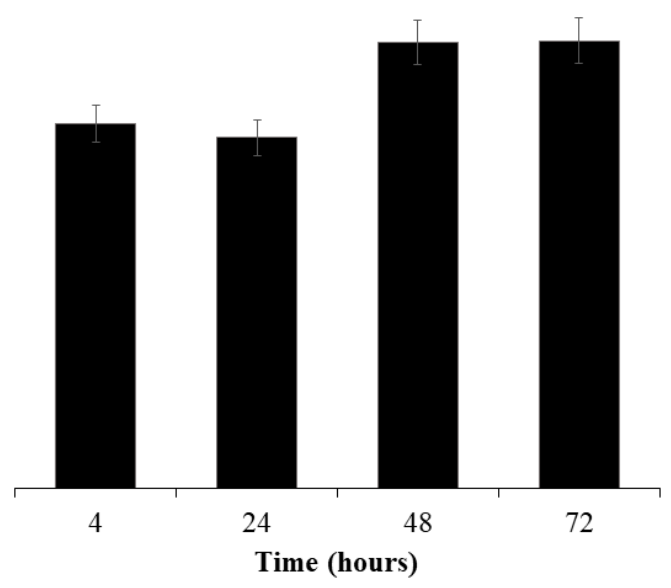

B

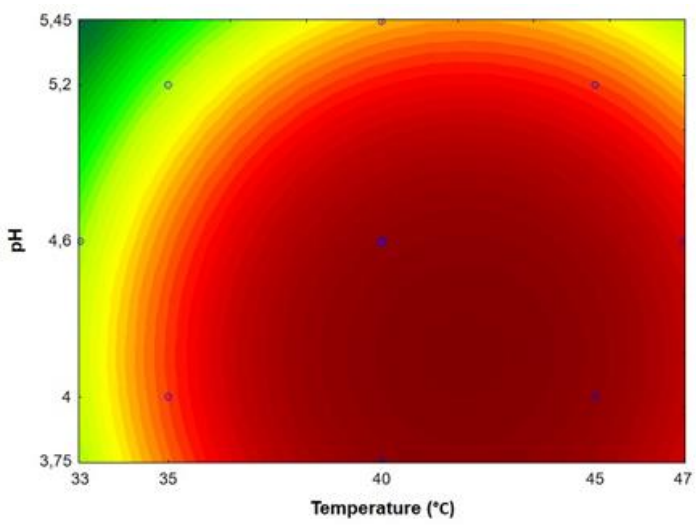

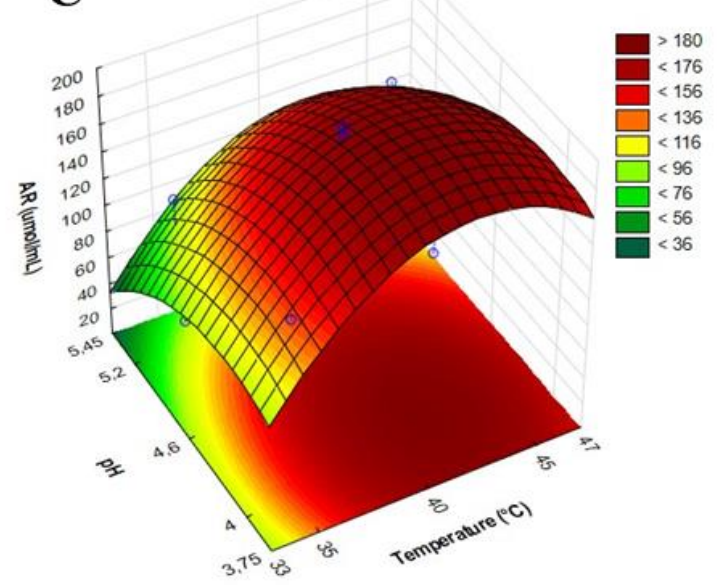

Faculdade de Medicina de Ribeirão Preto, Universidade de São Paulo, Ribeirão Preto, 2021 


\section{Supplementary Material}

Table S1. Summary of enzymatic assays

\begin{tabular}{|c|c|c|c|c|}
\hline Enzyme & Substrate & $\begin{array}{c}\text { Substrate } \\
\text { concentration }\end{array}$ & $\begin{array}{c}\text { Substrate } \\
\text { volume }(\mu L)\end{array}$ & $\begin{array}{c}\text { Assay time } \\
(\text { min })\end{array}$ \\
\hline Amylase ${ }^{a}$ & soluble potato starch & $1 \%$ & 50 & 10 \\
\hline$X_{\text {Xylanase }}^{a}$ & beechwood xylan & $1 \%$ & 50 & 10 \\
\hline Pectinase $^{a}$ & polygalacturonic acid sal sodic & $1 \%$ & 50 & 10 \\
\hline Arabinanase ${ }^{a}$ & linear arabinan & $1 \%$ & 50 & 10 \\
\hline Xyloglucanase $e^{a}$ & xyloglucan & $1 \%$ & 50 & 10 \\
\hline CMCase $^{a}$ & $\begin{array}{l}\text { medium viscosity } \\
\text { carboxymethylcellulose }\end{array}$ & $1 \%$ & 50 & 60 \\
\hline Mannanase $^{a}$ & Locust Bean Gun & $0.5 \%$ & 10 & 5 \\
\hline FPase $^{a}$ & $\begin{array}{l}\text { Whatman filter paper No. } 1 \\
\text { (cellulose) }\end{array}$ & $0.044 \mathrm{~g} / \mathrm{mL}$ & - & 60 \\
\hline Avicelase $^{a}$ & Avicel & $1 \%$ & 50 & 60 \\
\hline Arabinofuranosidase $^{b}$ & $\mathrm{pNPA}^{\mathrm{c}}$ & $2 \mathrm{mM}$ & 25 & 5 \\
\hline$\beta$-xylosidase ${ }^{b}$ & $\mathrm{pNPX}^{\mathrm{d}}$ & $18 \mathrm{mM}$ & 25 & 5 \\
\hline$\beta$-glucosidase ${ }^{b}$ & $\mathrm{pNPG}^{\mathrm{e}}$ & $4 \mathrm{mM}$ & 25 & 5 \\
\hline Lipase $^{b}$ & $\mathrm{pNPP}^{\mathrm{f}}$ & $8 \mathrm{mM}$ & 25 & 5 \\
\hline
\end{tabular}

${ }^{a}$ Enzymes measured from Miller methodology (1959)

${ }^{b}$ Enzyme measured from its artificial substrates

${ }^{c} p$-nitrophenyl- $\alpha$-arabinofuranoside

${ }^{d} p$-nitrophenyl- $\beta$-D-xilopiranoside

e $p$-nitrophenyl- $\beta$-D-glucopyranoside

${ }^{\mathrm{f}} p$-nitrophenylpalmitate

Table S2 - Analysis of Variance (ANOVA) for the Mixtures Design involving the yields of reducing sugar $(\mu \mathrm{mol} / \mathrm{mL}$ ) obtained by enzymatic hydrolysis (XAT, AAB, and CTR)

\begin{tabular}{cccccccc}
\multirow{2}{*}{ Model } & Source of variation & Sum Square & Degree of Freedom & Mean Square & \multicolumn{2}{c}{ F test } \\
\hline \multirow{3}{*}{ Linear } & & & & & & \\
\multirow{3}{*}{ calc } & $\mathbf{F}_{\text {tab }}$ \\
& Model & 4393.14 & 2 & 2196.57 & 8.94 & 5.14 \\
& Total error & 1473.66 & 6 & 245.61 & & \\
& Lack of fit & 297.06 & 4 & 74.26 & 0.12 & 19.25 \\
& Pure error & 1176.60 & 2 & 588.30 & & \\
& Total & 5866.81 & 8 & 733.35 & $\alpha=0.05$ \\
\hline
\end{tabular}


Table S3 - Analysis of variance (ANOVA) for Central Composite Design (CCD) - second order model - for RS production $(\mu \mathrm{mol} / \mathrm{mL})(p \leq 0.1)$.

\begin{tabular}{|c|c|c|c|c|c|}
\hline \multirow{2}{*}{$\begin{array}{l}\text { Source of } \\
\text { variation }\end{array}$} & \multirow{2}{*}{$\begin{array}{l}\text { Sum Square } \\
\quad(S S)\end{array}$} & \multirow{2}{*}{$\begin{array}{c}\text { Degree of freedom } \\
(D F)\end{array}$} & \multirow{2}{*}{$\begin{array}{c}\text { Mean Square } \\
\quad(M S)\end{array}$} & \multicolumn{2}{|c|}{ F test } \\
\hline & & & & $\mathbf{F}_{\text {calc }}$ & $\mathbf{F}_{\text {tab }}$ \\
\hline Regression (R) & 12834.7 & 4 & 3208.67 & 12.72 & 3.18 \\
\hline Residue (r) & 1512.64 & 6 & 252.10 & & \\
\hline Total $(\mathrm{T})$ & 14347.34 & 10 & & & \\
\hline
\end{tabular}

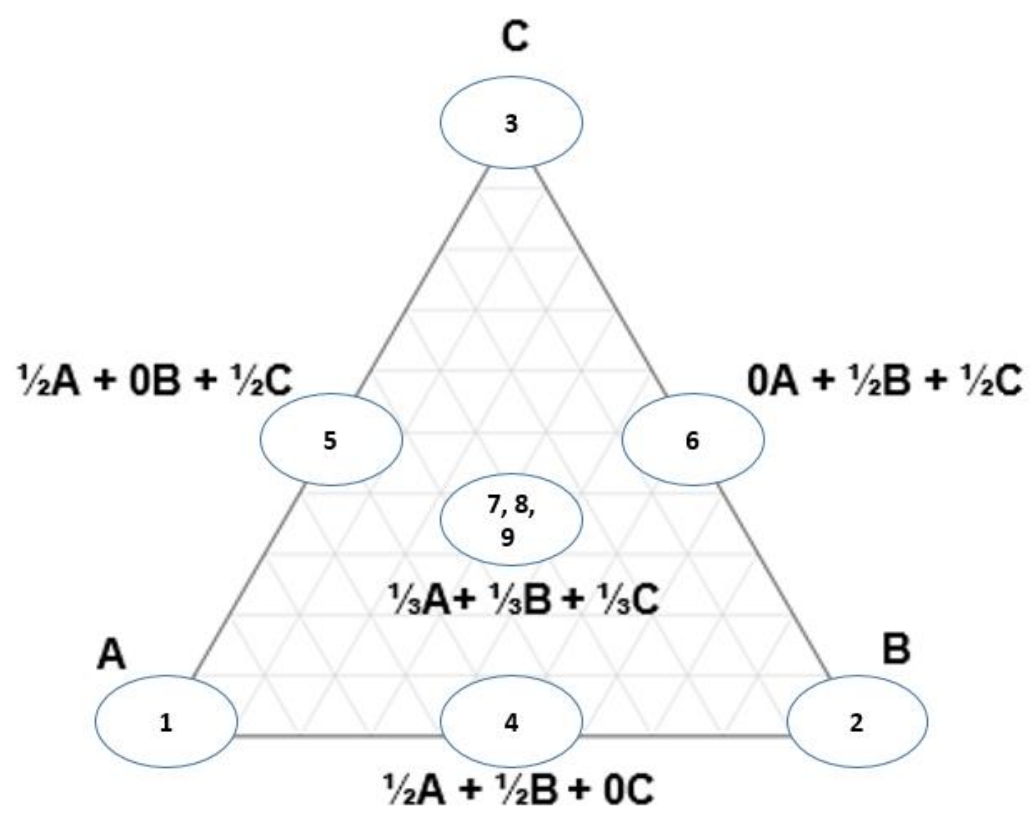

Figure S1 - Simplex Design. Mixtures among the three wastes for Simplex Centroid Design aiming to evaluate the interactions effect in order to obtain monosaccharides by the action of the optimized enzyme extract. $\mathrm{A}=$ sugarcane bagasse, $\mathrm{B}=$ soybean hulls and $\mathrm{C}=$ barley bagasse. The total amount of wastes in each point was always equal to $50 \mathrm{mg}=100 \%$. The vertices 1, 2 and 3 represent each pure component and the other points (4, 5, 6, 7, 8 and 9) represent their respective mixtures (according to the equations). 


\section{Graphical Abstract}
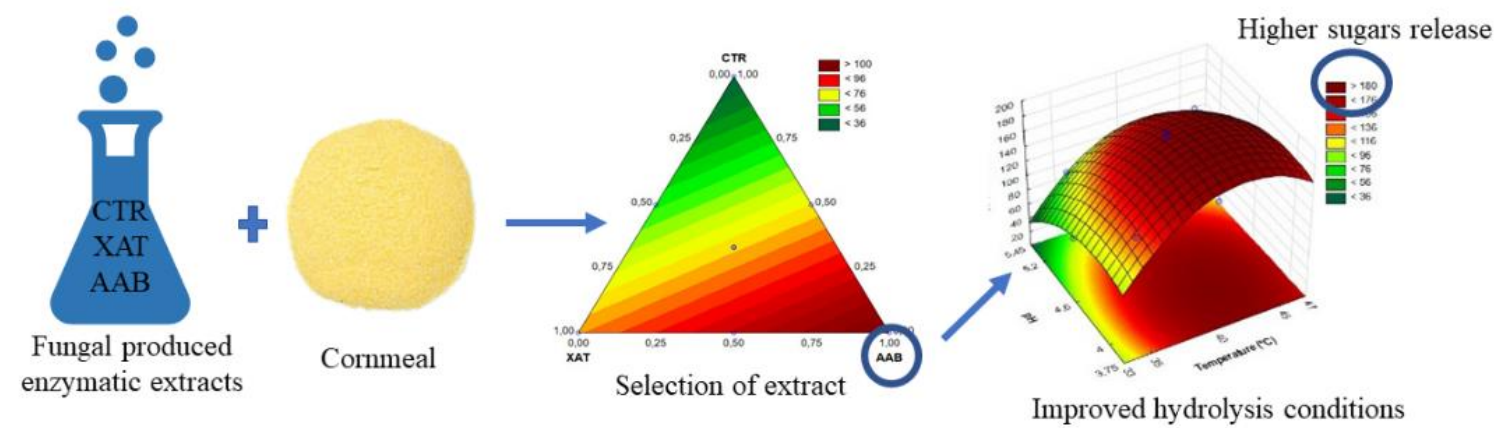

Faculdade de Medicina de Ribeirão Preto, Universidade de São Paulo, Ribeirão Preto, 2021 


\section{Apêndice 4}

\section{Anaerobic digestion of cornmeal - The effect of crude enzyme extract and co-digestion with cow manure}

Vanessa Elisa Pinheiro ${ }^{1,2}$, Steven Wainaina ${ }^{2}$, Maria de Lourdes Teixeira de Moraes Polizeli ${ }^{1,3}$, Ilona Sárvári Horváth ${ }^{2}$

${ }^{1}$ Ribeirão Preto Medical School - São Paulo University. Bandeirantes Av., 3.900, 14049-900, Ribeirão Preto, Brazil

${ }^{2}$ Swedish Centre for Resource Recovery, University of Borås, SE 50190 Borås, Sweden

${ }^{3}$ Faculty of Philosophy, Sciences and Letters at Ribeirão Preto - São Paulo University. Bandeirantes Av., 3.900, 14040-900, Ribeirão Preto, Brazil

*Correspondence to: Maria de Lourdes Teixeira de Moraes Polizeli

Faculty of Philosophy, Sciences and Letters at Ribeirão Preto - São Paulo University.

Bandeirantes, Av. 3.900, 14040-900. Ribeirão Preto, São Paulo, Brazil

Phone: +55-16-3315 $4680 \quad$ FAX: $+55-16-33154886$

E-mail: polizeli@ ffclrp.usp.br 


\section{Abstract}

The hydrolytic effect of a crude enzyme extract, containing mainly starch-degrading enzymes, was studied for cornmeal (Zea mays) hydrolysis, followed by investigating the effect of enzymatic treatment regarding the anaerobic digestion of this biomass. Additionally, codigestion of cornmeal and cow manure was also conducted, and both batch and semi-continuous experiments were performed. Enzymatic pretreatment of cornmeal resulted in a yield of $79 \pm$ $5 \%$ reducing sugars released, with $1: 10 \mathrm{w} / \mathrm{v}$ ( $\mathrm{g}$ of the dry weight of substrate/ $\mathrm{mL}$ of enzyme extract added) enzyme load at $45^{\circ} \mathrm{C}$ for $48 \mathrm{~h}$. Furthermore, there was a significant enhancement in the specific methane production observed during the batch assays, both when cornmeal hydrolysate was digested or when enzymes were directly added to the digester. Moreover, synergetic effects were found when co-digesting cornmeal and cow manure leading to higher methane yield $(280 \mathrm{NmL} / \mathrm{gVS})$ than that $(200 \mathrm{NmL} / \mathrm{gVS})$ calculated based on the methane potential of the individual substrates. Regarding long term effects, the laboratory-scale semicontinuous experiments also demonstrated that the co-digestion of cornmeal and cow manure (1:1 volatile solid (VS) basis) led to a stable process reaching an organic loading rate of $3 \mathrm{~g}$ $\mathrm{VS} / \mathrm{L} /$ day and achieving a daily methane production of $1280.12 \pm 99.4 \mathrm{NmL} \mathrm{CH}_{4} / \mathrm{day}$. However, when cornmeal was investigated in mono-digestion and when the enzyme extract was directly added during semi-continuous digestion of cornmeal, VFA accumulation was observed, leading to a decrease in $\mathrm{pH}$.

Keywords: enzymatic hydrolysis, cornmeal, anaerobic digestion, co-digestion, cow manure 


\section{Introduction}

Anaerobic digestion (AD) of organic materials, such as energy crops and organic waste, increases interest in environmental sustainability. This is because $\mathrm{AD}$ contributes to the production of renewable energy and high-value metabolites, reduces the emission of gases that cause the greenhouse effect, and also allows the treatment of otherwise harmful organic waste. 1, 2 The $\mathrm{AD}$ process consists of four interdependent degradation steps, i.e., hydrolysis, acidogenesis, acetogenesis, and methanogenesis, ${ }^{3}$. Several groups of facultative and strict anaerobes are taking part in the degradation of complex organic compounds. ${ }^{4-6}$ The final product is the biogas, mainly composed of methane $\left(\mathrm{CH}_{4}\right)$ and carbon dioxide $\left(\mathrm{CO}_{2}\right) .{ }^{7,8}$ The remaining digestate residue can be used as organic fertilizer and recycled to agricultural land.

Biogas production is a vital sector for the entire bioenergy industry; it supplies various uses and markets, including electricity, heating, and transportation. Brazil has one of the most significant bioenergetic potentials due to the high volume of organic biomass available. From the incentives brought by RenovaBio, New National Biofuel Policy, biogas has been gaining value since 2018. It has an added value to the low-emission renewable matrix (along with ethanol and biodiesel). ${ }^{9}$ According to Centro Internacional De Energias Renováveis - Biogás (CIBIOGÁS), Brazil has 521 biogas generation plants in operation, of which $86 \%$ works with treating residues generated from agricultural activities (pig, beef, cattle, agricultural, sugar and alcohol residue). ${ }^{10}$

Over the past decade, Brazil became the third-largest global corn producer and the second-largest corn exporter. ${ }^{11}$ Companhia Nacional de Abastecimento (CONAB) estimated that Brazil would produce 112.9 million metric tons of corn (Zea mays) in the market year 2020/21, and the cultivated area is estimated at 19.776 million hectares. ${ }^{12}$ Corn is a grain with strong domestic demand, mainly from animal feed producers and corn-based bioethanol plants. 
${ }^{13}$ Moreover, due to its carbohydrate-rich composition, the exacerbated cornmeal production (grounded dry maize) can also be utilized as substrate for biogas production. ${ }^{14}$

Substrate composition and biodegradability are critical factors for the methane yield from energy crops like cornmeal. ${ }^{15}$ Pretreatments, aiming at the disruption of structures, changes in porosity, and reduction of particle size of substrates, can be applied to increase biodegradability. ${ }^{16-18}$ Among common strategies, biological pretreatment by adding enzymes is preferred, as it is considered environmentally friendly compared to other pretreatment methods. ${ }^{19-24}$ The application of hybrid technology (enzymatic pretreatment associated with digestion) is an essential resource for optimizing digestion, ${ }^{25-27}$ since it hydrolyzes the substrates, allowing better performance of the microbial population in the later stages of AD. 28-30 The central role of cornmeal hydrolysis is to convert the two major starch polymer components, i.e., amylose and amylopectin, into fermentable sugars (glucose) by the action of $\alpha$-amylases and glucoamylases. ${ }^{31}$

Another alternative, which has been studied to improve biogas production, is the anaerobic co-digestion (CoAD). Since cow manure itself has a low biogas yield potential, its utilization as a co-substrate within the digestion of crop material is perceived as a promising approach to boost biogas production. Cow manure can provide good buffering capacity and a wide range of nutrients, while the energy crop increases the energy yield of the process. ${ }^{14}$ Additionally, the CoAD can lead to synergistic effects regarding the activity of microorganisms,' and due to the mixing of substrates with different characteristics, it can decrease the amount of recalcitrant or inhibitory substances in the feedstock. ${ }^{32,33}$

A limited number of studies are available to investigate the potential of using cornmeal (the specific, grounded dry maize) as a substrate for biogas production. Most of these studies address the methane production from maize in general, such as Cornell et al. ${ }^{34}$, Seppälä et al. ${ }^{14}$ and Banks and Heaven ${ }^{35}$, who have performed some of the few studies that describe the co- 
digestion of maize and manure with different shares of substrates, hydraulic retention time (HRT) and organic loading rate (OLR). Two of the few studies that report biogas production from cornmeal specifically are conducted by Garuti et al. ${ }^{36}$ and Kolbl et al. ${ }^{37}$ The first one investigated this substrate as a supplementary energy source. The second one considered the methane yields derived from 5 L Automatic Methane Potential Test Systems in batch or semicontinuous tests using different substrates, including the cornmeal. Thus, there is a lack of research investigating optimal conditions aiming to improve AD's performance utilizing cornmeal. Therefore, the objective of this work was to explore different scenarios for directing cornmeal into the usual methane production lines by performing batch and semi-continuous AD experiments. Firstly, the enzymatic pretreatment of cornmeal for methane production was studied. Secondly, long-term effects were investigated during semi-continuous operations. There mono and co-digestion of cornmeal was carried out with the addition of crude enzyme extract and/or cow manure.

\section{Material \& Methods}

\subsection{Substrates and inoculum}

Cornmeal Risenta® composed of in $\mathrm{g} / 100 \mathrm{~g}$ : fat 1.20 , carbohydrate 73 , fiber 4.10 , and protein 8 , was bought in the supermarket (Borås, Sweden). The cow manure was collected from a cattle farm - Hushållningssällskapet Sjuhärad (Rådde Gård, Länghem, Sweden). The manure was filtered through a $2 \mathrm{~mm}$ porosity sieve to remove grass and stored in plastic containers at $-20{ }^{\circ} \mathrm{C}$ to prevent biodegradation. Sludge used as inoculum was obtained from a full-scale thermophilic $\left(55 \pm 1^{\circ} \mathrm{C}\right)$ co-digestion plant (Borås Energy and Environment $\mathrm{AB}$, Borås, Sweden) treating household waste. The sludge was also filtered through a $2 \mathrm{~mm}$ porosity sieve to remove sand, plastic, and other unwanted particles, after which it was acclimated for five days in an incubator at $55^{\circ} \mathrm{C}$ before use. The sludge parameters were $\mathrm{pH} 8.4$, volatile fatty acids 
(VFA) $1500 \mathrm{mg} / \mathrm{L}, \mathrm{NH}_{4} 2700 \mathrm{mg} / \mathrm{L}$, bicarbonate alkalinity $7800 \mathrm{mg} / \mathrm{L}$, and total alkalinity 9 $500 \mathrm{mg} / \mathrm{L}$.

\subsection{Enzyme extract production and cornmeal hydrolysis}

\subsection{Enzyme extract production and cornmeal hydrolysis}

The crude enzyme extract, optimized for amylase production by Aspergillus brasiliensis, was produced according to Almeida et al. ${ }^{38}$ with modifications. Erlenmeyer flasks of $125 \mathrm{~mL}$ containing $25 \mathrm{~mL}$ Segato Rizzatti (SR) medium ${ }^{39}$ and 1\% (w/v) of cornmeal as carbon source were inoculated with $1.0 \mathrm{~mL}$ of conidia solution $\left(10^{6}\right.$ spores $\left./ \mathrm{mL}\right)$. The cultures were incubated at $30^{\circ} \mathrm{C}$ for $120 \mathrm{~h}$ under static conditions. The enzyme extract obtained is referred to as $\mathrm{AAB}$ in the following.

The optimal enzyme dosage for cornmeal hydrolysis was investigated in $15 \mathrm{~mL}$ Falcon tubes immersed in a water bath at $45^{\circ} \mathrm{C}$, and $100 \mathrm{rpm}$ for 48 hours. The pretreatments were carried out at a solid loading of $10 \%(\mathrm{w} / \mathrm{v})$, and the proportion between substrate and enzyme extract varied among $1: 0.25 ; 1: 0.5 ; 1: 1 ; 1: 2 ; 1: 4 ; 1: 6 ; 1: 8$ and $1: 10$ (g cornmeal/ $\mathrm{mL} \mathrm{AAB})$. The hydrolysis performance was followed up by determining the concentration $(\mathrm{g} / \mathrm{L})$ of reducing sugars (RS) released by the end of the incubation period.

\subsection{Batch experimental set-up}

Experiments were carried out using thermophilic sludge as inoculum. In addition, enzymatically pretreated and untreated cornmeal were tested as substrates, and the biomethane potential of each was determined. Furthermore, the methane potential of cow manure, as a cosubstrate for CoAD, was also investigated. Figure S1 in supplementary material shows a schematic overview of the experimental setup, and Table $\mathbf{1}$ shows the applied experimental design. 
Thermophilic $\left(55 \pm 1^{\circ} \mathrm{C}\right)$ batch digestion assays were carried out with serum glass bottles of $118 \mathrm{~mL}$ used as reactors. Substrate load of $0.4 \mathrm{~g}$ of volatile solids (VS) was used, together with inoculum added, keeping a substrate-to-inoculum (S/I) ratio of 1:2 (on VS basis). Additionally, co-digestion of cornmeal and cow manure was also performed with a substrate mixture ratio of 1:1 (VS basis), keeping the same overall substrate load of $0.4 \mathrm{~g}$ VS. Blank assays were also prepared with only the inoculum without adding any substrate, while microcrystalline cellulose of $50 \mu \mathrm{m}$ particle size (Sigma Aldrich, Darmstadt, Germany) was used as a positive control. All experimental setups were performed in triplicates and the experiments were carried out without any $\mathrm{pH}$ adjustment since the inoculum had a high $\mathrm{pH}$ of 8.4 .

Each reactor was sealed with a rubber septum and an aluminum cap; then, the headspace was flushed with $\mathrm{N}_{2}$ for 2 min to achieve anaerobic conditions. The reactors were manually shaken every day to enable sufficient mixing. Gas samples were regularly taken from the headspace using a pressure-tight syringe to keep the samples' actual pressure. To avoid an overpressure inside the bottles, the gas was released after each measurement occasion utilizing a needle (Sterican ${ }^{\circledR} \varnothing 0.4 \times 20 \mathrm{~mm}$ B. Braun, Germany). Then, the gas composition in the headspace was measured again. The cumulative methane production was calculated from the data obtained by gas chromatography (GC), using the ideal gas law and assuming ideal gas mixtures as described by Hansen et al. ${ }^{40}$ and Teghammar et al. ${ }^{41}$. All of the methane volumes are reported at normal conditions $\left(0^{\circ} \mathrm{C} ; 101.3 \mathrm{kPa}\right)$ according to ISO 10780:1994.

\subsection{Semi-continuous digestion}

The semi-continuous trials were performed using six CSTRs (continuous stirred-tank reactors) with an active volume of 2-litre each. Each bottle was equipped with a mechanical agitator, which runs in a continuous mode $(10 \mathrm{rpm})$ to avoid mass transfer limitations. Pure 
nitrogen was used to flush the headspace of each bottle for 2 minutes to create anaerobic conditions before starting. All bottles were then incubated in a thermostatic water bath at 55 ${ }^{\circ} \mathrm{C}$.

Three different trials were performed. First, one pair of the reactors was used for digesting only cornmeal (mono-digestion) (reactors $\mathrm{C} 1$ and $\mathrm{C} 2$ ). Then, the second pair of reactors were used to digest cornmeal with direct addition of the enzyme extract $\mathrm{AAB}(10 \%$ w/v) regularly (reactors $\mathrm{Ce} 1$ and $\mathrm{Ce} 2$ ). Finally, the third pair of the reactors digested cornmeal and cow manure in a mixing ratio of 1:1 (VS basis) (co-digestion) (reactors Co1 and Co2). Table S1 in supplementary material summarizes the details of the experimental setup during the semi-continuous AD.

The vessels were started up by filling them with $2 \mathrm{~L}$ of inoculum. The initial organic loading rate (OLR) was $0.5 \mathrm{~g} \mathrm{VS} / \mathrm{L} / \mathrm{day}$, and then it increased to 1.0, 2.0, and $3.0 \mathrm{~g} \mathrm{VS} / \mathrm{L} /$ day, while the hydraulic retention time (HRT) was kept at 20 days.

The performance of the $\mathrm{AD}$ process was followed up by measuring methane production of each reactor as well as $\mathrm{pH}$ in the digestate residue daily. In contrast, the digestate collected from each semi-continuous trial was analyzed weekly regarding volatile solids (VS), total solids (TS), volatile fatty acids (VFA), and total alkalinity (TA), making it possible to determine the VFA/TA ratio regularly.

\subsection{Analytical Methods}

Amylase activity was determined as described in Almeida et al. ${ }^{38}$ and the RS released was quantified using the Miller method. ${ }^{42}$

The TS and the VS were determined as described by Sluiter et al. ${ }^{43}$ and the $\mathrm{pH}$ of the digestate was measured according to the VDI-4630 guidelines. ${ }^{44}$ The VFA/TA ratio was determined as described by HACH-COMPANY. ${ }^{45}$ 
The methane produced in batch trials was determined using GC (PerkinElmer Clarus 590, PerkinElmer Inc., Waltham, MA, USA) equipped with a packed column $(60 \times 1.8$ " OD, 80/100, Mesh, PerkinElmer Inc., Waltham, MA, USA), and a thermal conductivity detector (PerkinElmer Inc., Waltham, MA, USA), with an injection temperature of $150{ }^{\circ} \mathrm{C}$. The carrier gas was nitrogen operated with a flow rate of $20 \mathrm{~mL} / \mathrm{min}$ at $60^{\circ} \mathrm{C}$. The gas samples were taken from the headspace of the batch reactors and injected directly in the GC using a $250-\mu \mathrm{L}$ pressure-lock gas syringe (VICI, Precision Sampling Inc., Baton Rouge, LA, USA).

The daily methane production from each reactor during the semi-continuous operation was monitored with the $\mu$-flow online instrument - Automatic Methane Potential Testing System (AMPTS, Bioprocess Control AB, Lund, Sweden). The generated biogas was forced to pass through a separate bottle filled with a solution of $3 \mathrm{M} \mathrm{NaOH}$ in order to trap $\mathrm{CO}_{2}$ and $\mathrm{H}_{2} \mathrm{~S}$ before the gas reached the flow-detecting unit.

\subsection{Data processing}

\subsubsection{Kinetics}

The modified Gompertz model (Equation 1) ${ }^{46}$ was fitted to the experimental data obtained from the batch trials.

$$
\mathrm{G}(\mathrm{t})=\mathrm{Gmax} \cdot \exp \left\{-\exp \left[\frac{\mathrm{Rm} \cdot \mathrm{e}}{\mathrm{Gmax}}(\lambda-\mathrm{t})+1\right]\right\}
$$

\section{Equation 1.}

where $\mathrm{G}(\mathrm{t})$ is the cumulative methane yield $\left(\mathrm{NmL} \mathrm{CH}_{4} / \mathrm{g}\right.$ VS) during the digestion time (t), Gmax is the maximum methane yield $\left(\mathrm{NmL} \mathrm{CH}_{4} / \mathrm{g}\right.$ VS) at the infinite time, $\mathrm{Rm}$ is the maximum methane production rate $\left(\mathrm{NmL} \mathrm{CH}_{4} / \mathrm{g} \mathrm{VS} /\right.$ day $), e$ is the Euler constant $=2.7183, \lambda$ is the length of the lag phase, and $t$ is the fermentation time (day). 


\subsubsection{Degree of substrate degradation}

The degree of substrate degradation (DD) during semi-continuous $\mathrm{AD}$ was determined using a calculation used in full-scale Swedish installations where the volume of substrate added and the volume of digestate removed are assumed to be equal (Equation 2). Thus, the TS is expressed as \% of wet weight and VS as \% of TS.

$$
\mathrm{DD}=\frac{(\text { TSsubstrate } \mathrm{x} \text { VSsubstrate })-(\text { TSdigestate } \times \text { VSdigestate })}{(\text { TSsubstrate } \times \text { VSsubstarte })} \times 100
$$

\section{Equation 2.}

\subsubsection{Statistical Analysis}

Hydrolysis tests and the batch $\mathrm{AD}$ experiments were designed in triplicates and the semi-continuous digestion tests in duplicate. Statistical analyses were performed using the software Statistica 13. One-way ANOVA and Tukey's HSD multiple comparison tests were carried out to verify statistical significance in the datasets at a $95 \%$ confidence interval.

\section{Results \& Discussion}

\subsection{Enzymatic pretreatment}

The degree of hydrolysis of natural starch from the cornmeal depends on several factors, such as the substrate concentration and type, concentration of the enzyme as well as the applied process conditions. The first set of experiments was conducted in order to determine the proportion of substrate and enzyme extract for appropriate hydrolysis of the cornmeal. Therefore, an enzyme extract, $\mathrm{AAB}$, with an amylase activity of $3.4 \mathrm{U} / \mathrm{mL}$, was used. The pretreatment performance was tested at different proportions of enzyme extract added to the substrate using a solid loading of $10 \%$. Figure 1 shows the concentration of RS $(\mathrm{g} / \mathrm{L})$ released in each experiment obtained at different enzyme loads of $\mathrm{w} / \mathrm{v}$, i.e., g dry weight substrate / $\mathrm{mL}$ 
of enzyme extract added. Enzyme loads of 1:10 and 1:8 (w/v) resulted in the highest amount of RS released. Enzyme load of 1:10 (w/v), corresponding to $34 \mathrm{U}$ of amylase per gram of cornmeal, resulted in a release of $52.65 \mathrm{~g} / \mathrm{L}$ of RS, counting up to a hydrolysis yield of $79 \pm 5 \%$ (based on the presence of the starch in the system). On the other hand, the enzyme load of 1:8 (w/v), containing $27.2 \mathrm{U}$ of amylase per gram of cornmeal, released $54.31 \mathrm{~g}$ of RS/L (corresponding to a starch hydrolysis yield of $81 \pm 5 \%$ ). However, considering the standard deviation of $5 \%$, there is no significant difference between these results.

$\mathrm{AAB}$ is a crude extract that beside its amylolytic activity has also activities of xylanase $(1.00 \pm 0.18 \mathrm{U} / \mathrm{mL})$, pectinase $(0.89 \pm 0.05 \mathrm{U} / \mathrm{mL})$, CMCase $(0.68 \mathrm{U} / \mathrm{mL} \pm 0.14)$, arabinanase $(0.80 \pm 0.29 \mathrm{U} / \mathrm{mL})$, and $\beta$-glucosidase $(0.02 \pm 0,003 \mathrm{U} / \mathrm{mL}) .{ }^{47}$ The higher concentration of enzymes used, played a major role in the hydrolysis since the yield increased with increasing $\mathrm{AAB}$ concentration. Higher amounts of enzymes in the system enabled greater sugar production, and no product inhibition was observed. The hydrolysis of corn starch consists of converting amylose and amylopectin, the two major starch polymer components, to glucose. The amylases present in $\mathrm{AAB}$ extract exhibited high efficiency in the conversion, and these results were comparable with the results obtained previously by other researchers. Arasaratnam and Balasubramaniam ${ }^{48}$ reported a glucose yield of $76 \%$ on cornflour by using a combination of amylase and glucoamylase. A similar yield, i.e., lower than $80 \%$, was obtained when starch granules were hydrolyzed by glucoamylase. ${ }^{49}$ Differences in the hydrolysis results may be originated from different substrate concentrations and/or disparate experimental conditions applied, as well as dissimilar compositions of the original substrates.

Therefore, the following AD assays were carried out by applying the operating condition obtained with a solid loading of $10 \%$ and with the addition of $\mathrm{AAB}$ in a proportion of $1: 10 \mathrm{~g}$ of cornmeal/ $\mathrm{mL}$ of $\mathrm{AAB}$ ), which corresponds to an enzyme load of $34 \mathrm{U}$ of amylase per gram of cornmeal. 


\subsection{Characterization of substrates and inoculum}

The substrate/inoculum ratio is a highly important factor in AD. ${ }^{50,51}$ Table 2 shows the obtained TS and VS content of the substrates, cornmeal, cornmeal hydrolysate, and cow manure, as well as the thermophilic sludge used as inoculum in the assays. The VS content of the cornmeal and hydrolysate was $100 \%$ of the TS content, while the cow manure had $77 \%$ VS in its TS content. Thus, a high VS content in the substrate means great bioavailability of organic matter. ${ }^{52}$ The thermophilic sludge had a TS content of 3,8\% and a VS content of 2,5\%, i.e., $65 \%$ of its TS.

\subsection{Batch AD of individual substrates and mixtures}

The biomethane potential of cornmeal was determined. Furthermore, the effects of enzymatic pretreatment and the addition of cow manure as co-substrate were evaluated. Figure 2 shows the accumulated methane production per gram VS of substrate added to the system. During the initial phase, at the third and fifth day of digestion, the cornmeal hydrolysate showed accumulated methane of $100 \pm 5$ and $138 \pm 6.5 \mathrm{NmL} / \mathrm{g} \mathrm{VS}$, respectively, which was correspondingly $43 \%$ and $23 \%$ higher than that obtained for the untreated cornmeal at the same days.

When achieving the plateau of the gas production, i.e., after around 12 days of incubation, the accumulated methane productions from cornmeal substrates were somewhat higher than that achieved from cellulose, i.e., the positive control (296 $\pm 15 \mathrm{NmL} / \mathrm{g} \mathrm{VS})$ and the methane yield from the cornmeal hydrolysate was $11 \%$ higher than that observed for the untreated sample $\left(323 \pm 15 \mathrm{NmL} \mathrm{CH}_{4} / \mathrm{g}\right.$ VS $)$ at day 12 . However, towards the end of the incubation period, the methane yield of cornmeal was $358 \mathrm{NmL} \mathrm{CH}_{4} / \mathrm{g} \mathrm{VS}$, which is in agreement with other authors. Kolbl et al. ${ }^{37}$ reported a $\mathrm{CH}_{4}$ production of $319 \pm 33.9 \mathrm{NmL}$ $\mathrm{CH}_{4} / \mathrm{g}$ VS when investigating the same substrate in batch trials. 
The highest accumulated methane production was achieved with cornmeal hydrolysate, as well as when $\mathrm{AAB}$ was directly added to cornmeal prior to the digestion, reaching methane yields of around $390 \mathrm{NmL} / \mathrm{g} \mathrm{VS}$ at day 26, and it was $8 \%$ higher than that of untreated cornmeal (Figure 2). The crude extract $\mathrm{AAB}$ is rich in amylases $(3.4 \mathrm{U} / \mathrm{mL})$, which catalyze the hydrolysis of internal $\alpha$-D-(1-4)-glycosidic linkages in starch, and also in glucoamylases catalyzing the hydrolysis of $\alpha$-D-(1-4) and $\alpha$-D-(1-6)-glycosidic bonds of starch from the nonreducing ends ${ }^{37}$. The use of cornmeal hydrolysate or even the direct addition of AAB into the batch trials enabled the release of fermentable sugars and thus resulted in higher methane yields.

Direct application of enzymes has been previously described by several authors when investigating methane production from different energy crops in batch assays, showing levels of improvement. Kaiser ${ }^{53}$, for example, has reported significant improvements in biogas production from maize silage with the addition of enzymes. However, no enhancements in biogas production were observed by Oliva-Merenci et al. ${ }^{54}$ when performing direct enzyme addition to $\mathrm{AD}$ of maize silage. Therefore, the effects of using enzyme addition should be investigated in each particular case.

The digestion of cow manure itself resulted in the lowest methane accumulation during the studied period. The methane yield was not higher than $11 \pm 0.5 \mathrm{NmL} / \mathrm{g}$ VS when manure was applied as mono-substrate. However, comparing the observed data of $\mathrm{CH}_{4}$ accumulation and the calculated $\mathrm{CH}_{4}$ yield based on the results achieved from each individual substrate, synergetic effects were observed when mixing these substrates for co-digestion, leading to $40 \%$ higher methane yield than that calculated based on the methane yields observed for the individual substrates. The accumulated methane yield of cornmeal was $390 \mathrm{NmL} / \mathrm{g} \mathrm{VS}$, while the corresponding value of $65 \mathrm{NmL} / \mathrm{g}$ VS was observed for cow manure after 26 days of digestion in the batch assays. Considering the count of a mixing ratio of 1:1 on VS basis, it 
would result in a calculated value of $200.5 \mathrm{NmL} / \mathrm{g} \mathrm{VS}$, which can be compared to the experimental value of $280 \mathrm{~mL} / \mathrm{gVS}$ (Figure 2).

The co-digestion comprises mixing two or more feedstocks in an appropriate proportion to get complementary characteristics for digestion. Hence, co-digestion can have distinct advantages, including dilution of inhibitory substances that might be presented in the wastes, supplementation of sufficient, diversified, and balanced nutrients, positive synergism leading to enhancement of biogas production, consequently system economics improvements. ${ }^{55-61}$ Song and Zhang ${ }^{62}$ showed that the methane yield was higher with the co-digestion of cattle manure and $\mathrm{H}_{2} \mathrm{O}_{2}$-treated wheat straw than with the mono-digestion of each substrate alone (untreated wheat straw, cattle manure, or $\mathrm{H}_{2} \mathrm{O}_{2}$-treated wheat straw). Moreover, many researches improved the $\mathrm{AD}$ performance through the concomitant use of different organic wastes, such as cow manure with kitchen waste and water hyacinth, ${ }^{63}$ cow manure and tea

waste, ${ }^{64}$ cow manure with sugar beet by-product, ${ }^{65}$ goose manure with wheat straw, ${ }^{66}$ dairy manure with corn stover and tomato residues, ${ }^{67}$ chicken and pig manure with apple pulp and corn stover, ${ }^{68}$ cow dung with barley, ${ }^{69}$ and sheep manure with waste paper. ${ }^{70}$

\subsubsection{Statistical analysis and kinetics from batch trials}

A statistical analysis of $\mathrm{CH}_{4}$ accumulation obtained when the plateau was reached, i.e., after the $12^{\text {th }}$ day of fermentation, revealed that there was a difference between the methane productions from the different substrates $(p$-value $(\leq 0,000)<\alpha(0.05) ; \mathrm{F}(865.47)>\mathrm{f}(31.64))$. Moreover, the results of Tukey's simultaneous tests indicated that the accumulation of $\mathrm{CH}_{4}$ from the $12^{\text {th }}$ to the $26^{\text {th }}$ day of digestion with cornmeal, cornmeal hydrolysate, and cornmeal with the addition of $\mathrm{AAB}$ was statistically different from that obtained in co-digestion with cow manure ( $p$-value $<0.02 ;<0.007$ and $<0.001$, respectively). 
The modified Gompertz model, a mathematical model based on a sigmoid function that shows a degradation profile considering a lag phase period, is a useful model investigating how much time is needed for the microorganisms to adapt to the substrate. The model can predict the maximum methane yield (Gmax), the maximum production rate $(\mathrm{Rm})$, and the length of the lag phase $(\lambda) .{ }^{46}$ Table 3 shows the corresponding kinetic parameters, Gmax, Rm, and $\lambda$, predicted by the model based on the experimental data obtained during the batch digestion assays in this study.

According to this model, the highest maximum accumulated methane yields of 399 $\mathrm{NmL} / \mathrm{g}$ VS could rich when cornmeal hydrolysate or cornmeal with the addition of AAB were digested. Regarding the lag phase, this was lower in mono-digestions, corresponding to 4-5 days, before the methane production started. On the other hand, Co-digestion showed a more extended lag phase period, i.e., 15-17 days, probably because of the presence of cow manure and its recalcitrant structure.

\subsection{Semi-continuous AD trials}

Batch trials are commonly used to identify suitable digestion substrates during digestion and their methane potential. ${ }^{71-73}$ However, the stability indicators for anaerobic digesters and the long-term effects can preferably be assessed through continuous experiments ${ }^{74,75}$. Methane production, $\mathrm{pH}$, and VFA to alkalinity ratio are some of the stability indicators used to follow up the performance of the digesters. ${ }^{61,75,76}$ These parameters have been studied in the following experiments of semi-continuous AD using CSTRs, with an active volume of 2-litre each. Three different trials were performed, e.g., one pair of reactors was used digesting only cornmeal (reactors $\mathrm{C} 1$ and $\mathrm{C} 2$ ). In contrast, the second pair of reactors digested cornmeal with direct addition of the enzyme extract, $\mathrm{AAB}(10 \%$ w/v) (reactors Ce1 and Ce2). Finally, in the third 
pair of reactors, cornmeal and cow manure (1:1 VS basis) was co-digested (reactors Co1 and $\mathrm{Co} 2)$.

\subsubsection{Process stability and methane production in the initial stages}

The process stability was controlled by determining the VFA/TA ratio and $\mathrm{pH}$. There is a direct relationship between alkalinity variations and VFA accumulation in AD processes. Keeping a VFA/TA ratio of around 0.08 is recommended in order to ensure a stable process, and an increase in this ratio above 0.35 indicates process failure. ${ }^{77,78}$

At the beginning of fermentation, all six reactors showed a VFA/TA ratio of 0.012 . During this first week, the OLR in all the six reactors was $0.5 \mathrm{~g} \mathrm{VS} / \mathrm{L} /$ day, resulting in VFA/TA ratios between 0.016-0.019 at the end of the week (Figure 3A, B and C). In the second week of $\mathrm{AD}$, the OLR was increased to $1 \mathrm{~g} \mathrm{VS/L/day,} \mathrm{and} \mathrm{it} \mathrm{was} \mathrm{kept} \mathrm{at} \mathrm{this} \mathrm{level} \mathrm{for} 2$ weeks. By the end of this period, i.e., the end of the third week, the VFA/TA ratios obtained were 0.35 , 0.45; 0.25, 0.25; and 0.75, 0.92 in reactors C1, C2 (Figure 3A); Ce1, Ce2 (Figure 3B); and Co1, Co2 (Figure 3C), respectively. During the fourth week of fermentation, the OLR was additionally increased to $2 \mathrm{~g}$ VS/L/day. However, the reactors C1 and C2 (Figure 3A) with cornmeal as substrate and the reactors $\mathrm{Ce} 1$ and $\mathrm{Ce} 2$ (Figure $3 \mathrm{~B}$ ) with cornmeal $+\mathrm{AAB}$ as substrates showed instability, as is indicated by the high VFA/TA ratios and a large decrease in the methane production. Previous studies reported that low OLR, ranging from 0.7-1.4 $\mathrm{g}$ $\mathrm{VS} / \mathrm{L} /$ day, is recommended for stable biogas production in small reactors during AD of food residues rich in organic matter. ${ }^{79}$ Cornmeal is an easily degradable substrate; hence, the application of higher OLR can lead to overloading of the system. The rate of hydrolysis and acidogenesis, the first steps of anaerobic degradation, performs faster than that of the following steps. Hence, the last step, methane production, is the rate-limiting step of the degradation. 
Cornmeal applied here has a high surface area promoting a high rate of hydrolysis. The monomers produced by the hydrolysis can then rapidly be converted to VFAs by the action of acidogenic bacteria characterized by fast growth rates. ${ }^{2}$ On the other hand, VFA-consuming methanogens have a lower growth rate compared to that of acidogens. This will lead to the accumulation of VFAs since these are produced faster than they can be consumed, which eventually can result in a process failure. The importance of the particle size in connection to high VFA production was previously reported when digestion of food waste, also an easily degradable substrate, was investigated. ${ }^{80}$ This increased production of VFA in AD can be turned from a challenge into an opportunity. VFAs produced as intermediary degradation products of $\mathrm{AD}$ have a high market value and can be applied as building blocks in several chemical processes. Moreover, the VFA can be utilized as substrates in biological processes, like synthesizing bioplastics, growing protein-rich fungal biomass, or producing liquid biofuels.

${ }^{28}$ Further investigations are therefore recommended to shed more light on the potential of possible optimization strategies aiming at production and recovery of VFAs as the main product from a cornmeal-fed $\mathrm{AD}$ process.

\subsubsection{Strategies aiming to restore the cornmeal mono-digestion process}

Considering the instability in reactors C1, C2 (Figure 3A) after the first 4 weeks of AD investigations, attempts were carried out to be able to rescue the process. In the $5^{\text {th }}$ week, the OLR decreased back to $1 \mathrm{~g} \mathrm{VS/L/day,} \mathrm{followed} \mathrm{by} \mathrm{an} \mathrm{additional} \mathrm{decrease} \mathrm{to} 0.5$ during the $6^{\text {th }}$ week. Then from the $7^{\text {th }}$ week, it was increased again to $1 \mathrm{~g} \mathrm{VS} / \mathrm{L} /$ day and was kept at that level.

The reactors, $\mathrm{C} 1$ and $\mathrm{C} 2$ digesting cornmeal showed low daily methane production and a high VFA/TA ratio between the $5^{\text {th }}$ and $8^{\text {th }}$ weeks. Additional attempts were made to safe the reactors, so at the beginning of the 9th week, the feed was changed to a mixture of cornmeal and cow manure with a VS ratio of 1:1 while still keeping the OLR of $1 \mathrm{~g}$ VS/L/day. Going 
over to co-digestion resulted in decreased VFA/TA ratio (Figure 3A), while the daily methane production was still low. Consequently, 1 liter of the reactor volume in both reactors was then changed to a new inoculum in the $11^{\text {th }}$ week, while the feed was kept as earlier, i.e., a mixture of cornmeal and cow-manure with VS ratio of 1:1 and at OLR of $1 \mathrm{~g} \mathrm{VS/L/day.} \mathrm{After} \mathrm{these}$ strategies, the reactors showed a stable daily methane production, reaching an average methane production of $405.62 \pm 76 \mathrm{NmL} \mathrm{CH}_{4} /$ day and an optimal VFA/TA ratio of around 0.2 in the following weeks, i.e., between week 13 and 17 (Figure 3A).

Several researchers have investigated the effects of adding exogenous culture to AD (bio-augmentation). Bocher et al. ${ }^{81}$ reported a functional improvement in propionate degradation after the increase with the methanogenic community. Likewise, Lins et al. ${ }^{82}$ observed an increase in the stability and activity of the methanogenic group after bioaugmentation with Methanosarcina sp. The addition of this species improved the digestion process due to its domain or change of domain with Methanosaeta sp. stabilizing the conditions that initially caused the cessation of methanogenesis ${ }^{83}$. Ferraro et al. ${ }^{84}$ bio-increased the process performance during $\mathrm{AD}$ of wheat straw with an addition of a mixed inoculum of anaerobic ruminal fungi and hydrogen-producing bacteria. This addition led to a higher production of $\mathrm{CH}_{4}$ and higher fractions of Archaea, especially Methanosarcina, which guaranteed a greater diversification of the metabolic pathways and better performance and resistance of the system.

Likewise, it can be concluded that the amendment of the digestion process by the addition of new inoculum to reactors $\mathrm{C} 1$ and $\mathrm{C} 2$ led to better performance due to the presence of metabolically active microbiota triggering a better degradation and reestablishment of stable methane production. 


\subsubsection{The effect of the addition of enzyme extract in semi-continuous AD of cornmeal}

Considering the instability in reactors $\mathrm{Ce} 1, \mathrm{Ce} 2$ obtained after the first 4 weeks of $\mathrm{AD}$; similar efforts were carried out as in the case of reactors $\mathrm{C} 1$ and $\mathrm{C} 2$ described above.

The reactors $\mathrm{Ce} 1$ and $\mathrm{Ce} 2$ kept a constant daily methane production of $239.16 \pm 63 \mathrm{NmL}$ $\mathrm{CH}_{4} /$ day from week 5 to 8 and moreover, they showed an improvement in the average daily production to $545.07 \pm 109.2 \mathrm{NmL} \mathrm{CH}_{4} /$ day during the $9^{\text {th }}$ and $10^{\text {th }}$ weeks (Figure 3B). However, after that, the methane production started to decrease, while the VFA/TA ratio started to increase in both of these reactors digesting cornmeal with the addition of crude AAB extract, and then at the $12^{\text {th }}$ week, the methane production stopped (Figure 3B).

Some strategies reported in the literature prevent reactor loss and promote methanogenesis and drastic reduction of VFA/TA ratio, like the addition of alkaline reagents, such as $\mathrm{NaHCO}_{3}$ and $\mathrm{CaO} .{ }^{85,86}$ The addition of sodium bicarbonate was therefore applied in this study from week 6 to 12 , aiming to keep the $\mathrm{pH}$ of the reactors $\mathrm{Ce} 1$ and $\mathrm{Ce} 2$ around 7.0 (Figure 3B). However, this action could not stabilize the process.

Concerning AD of cornmeal, the results of the batch assays in this study showed that higher methane yields could be achieved with enzymatically pretreated cornmeal (i.e., cornmeal hydrolysate) as well as cornmeal with the addition of AAB then that of untreated cornmeal (Figure 2). However, when cornmeal with the addition of enzyme extract was digested under semi-continuous operation, no improvement in the methane production could be obtained. On the contrary, the methane production stopped after 12 weeks of operation, despite efforts taken to safe the process. As discussed above, methanogenesis acts as the rate-limiting step for the AD during long-term operation when digesting highly degradable substrates. On the other hand, the addition of the enzyme extract made the substrate even more highly degradable. Hence a balance between the metabolic degradation steps could not be achieved. Consequently, the higher rate of the first steps led to an excessive formation of VFAs. 


\subsubsection{The influence of co-digestion}

Reactors Co1 and Co2, where the digestion of cornmeal was tested in the presence of cow manure as co-substrate, performed better and achieved higher methane production rates due to increased OLRs, which were possible to apply (Figures 3C). As mentioned above, the OLR was increased to $2 \mathrm{~g} \mathrm{VS/L/day} \mathrm{at} \mathrm{week} \mathrm{4,} \mathrm{keeping} \mathrm{a} \mathrm{high} \mathrm{and} \mathrm{stable} \mathrm{methane} \mathrm{production}$ with low VFA/TA ratios all the way towards week 9, when the OLR was additionally increased to $3 \mathrm{~g} \mathrm{VS} / \mathrm{L} /$ day and then kept at this level until the end of the experiment (Figure 3C). Nevertheless, after week 15, one of these reactors (Co1) started to show instability with decreasing methane production rates followed by a sharp increase in the VFA/TA ratio during the last weeks of fermentation (17-20) (Figure 3C).

Cow manure is one of the most interesting residues used as a co-substrate in CoAD. ${ }^{87}$, ${ }^{88}$ This organic waste has been widely studied in AD processes and has been characterized by easy access, high energy density, and high nutrient content ${ }^{89}$. Thus, the use of this manure as a co-substrate in AD offers buffering capacity and acts as a second source of microorganisms in order to additionally increase the enzyme capacity within the anaerobic process ${ }^{90,91}$.

The Municipal Livestock Survey, released by IBGE (Brazilian Institute of Geography and Statistics), showed that there were 214.7 million cattle in Brazil in 2019. ${ }^{92}$ This large number of animals generates large quantities of manure, which need to be handled. Hence, the utilization of manure in CoAD processes would help mitigate the negative effects on climate change, which would otherwise occur due to greenhouse gas emissions during storage and processing. ${ }^{91} \mathrm{Li}$ et al. ${ }^{93}$ investigated the co-digestion of rice straw with cow manure (S/I 1:1 g VS) and obtained an improvement in the yield of methane by $9.6 \%$ compared to that achieved when only rice straw was digested. Likewise, Akyol et al. ${ }^{69}$ reported that co-digestion of cow manure and barley was more efficient in all studied mixing ratios $(1: 1,2: 1$, and 1:2) compared 
to mono-digestion of barley. In another study there co-digestion of tomato and corn residues with cow manure was investigated. It was found that mixtures containing $13 \%, 33 \%$, and $54 \%$ of cow manure had, respectively, 10.2; 0.9 , and 0.5 times greater methane yields, than those obtained by digestion of individual substrates. ${ }^{67}$ Montoro et al. ${ }^{94}$ also reported positive synergistic effects, i.e., increased buffering capacity and a better nutrient balance in the system, leading to an improvement in the biodegradation of the substrates, during co-digestion of cattle manure and sweet potatoes.

Accordingly, even this study showed that CoAD of cornmeal with cow manure provided a high buffering capacity in the system, preventing rapid drop of $\mathrm{pH}$ due to VFAs build-up and consequently avoiding system acidification, making it possible to apply higher OLRs and hence achieving higher methane productivities (Figure 3A and 3C).

\subsubsection{Enzyme addition into the stable reactors working with co-digestion}

During the final stage of the experiment, i.e., between weeks 17 to 20 , AAB crude extract was added once a week to the reactors $\mathrm{C} 1, \mathrm{C} 2$, and $\mathrm{Co} 1$ and $\mathrm{Co} 2$, aiming to study the long-term effects of the addition of enzymes. As mentioned above, even reactors $\mathrm{C} 1$ and $\mathrm{C} 2$ were working as co-digestion reactors at this stage, however, at lower OLR. Therefore, the addition of enzymes was calculated based on obtaining $10 \%$ of the daily loading in each reactor. Hence, reactors $\mathrm{C} 1$ and $\mathrm{C} 2$, which were operating at OLR of $1 \mathrm{~g} \mathrm{VS} / \mathrm{L} /$ day, received $\mathrm{AAB}$ corresponding to $117 \mathrm{U}$ of amylase ( $34.4 \mathrm{~mL}$ of $\mathrm{AAB})$. On the other hand, compared to reactors Co1 and Co2 operating at OLR of $3 \mathrm{~g}$ VS/L/day, AAB counting up to $175.4 \mathrm{U}$ of amylase (51.6 $\mathrm{mL}$ of $\mathrm{AAB}$ ) was added once in a week. As a result, three of these four reactors showed a stable operation, with a persistent daily methane flow, i.e., $358.94 \pm 60,61 \mathrm{NmL} \mathrm{CH}_{4} /$ day in reactors $\mathrm{C} 1$ and $\mathrm{C} 2$ (Figure 3A), and $1280.12 \pm 99.4 \mathrm{NmL} \mathrm{CH}_{4} /$ day in reactor $\mathrm{Co} 2$, while the process was instable and consequently low methane production of $369.66 \mathrm{NmL} \mathrm{CH}_{4} /$ day could only be 
achieved in reactor Co1 at week 17 (Figure 3C).

As shown in the Figure 3A and $\mathbf{C}$, the addition of exogenous enzymes did not cause a significant increase in the daily production of methane. The system in the three reactors $(\mathrm{C} 1$, $\mathrm{C} 2$, and Co2) performed stable, and the enzyme addition did not affect the performance. The substrate degradation degree was already around $99 \pm 0.5 \%$ in reactors $\mathrm{C} 1, \mathrm{C} 2$ and $72.08 \pm$ $4.4 \%$ in reactor Co2. Consequently, most of the available substrates were already broken down. Once the systems were equilibrated, the substrates added were rapidly consumed by the microorganisms. No significant enhancements in the degradation and conversion into methane were observed when enzymes were directly added (Figure 2).

Several studies found in the literature dealing with the direct application of enzymes to continuous digestion processes report contradictory results. Brulé et al. ${ }^{95}$ suggested that the degradation of exogenous enzymes can be carried out by endogenous bacteria present in the inoculum when different substrates are treated. Binner et al. ${ }^{96}$ observed a partial and complete degradation of five different commercial enzyme mixtures within the first hour after direct enzyme supplementation during AD of corn silage. Nevertheless, Garcia et al. ${ }^{97}$ showed significant enhancements of substrate degradation and conversion into methane when enzymes were supplied to the digestion of sorghum (Sorghum bicolor L. Moench) silage, straw, or corn cob flour. Hence, these reported results demonstrate that the feasibility of the enzyme addition depends on the characteristic of individual substrates and the enzymes applied, and has to be determined in each specific case.

\section{Conclusions}

This study showed that although enhancements of the methane potential could be observed after enzymatic pretreatment of cornmeal or with direct addition of enzymes to the cornmeal digestion process, the subsequent investigations using semi-continuous digestion 
trials, to be able to investigate long term effects, did not support these findings. At semicontinuous operation conditions, a stable process could not be achieved at higher loading rates than $1 \mathrm{~g} \mathrm{VS/L/day,} \mathrm{due} \mathrm{to} \mathrm{the} \mathrm{substrate's} \mathrm{high} \mathrm{degradability,} \mathrm{which} \mathrm{was} \mathrm{further} \mathrm{improved} \mathrm{by} \mathrm{the}$ enzyme addition. During these conditions, the high rate of the initial degradation steps, i.e., hydrolysis and acidogenesis, led to an accumulation of high concentrations of VFAs, disturbing the balance within the different degradation steps and finally resulting in low methane production or, in some cases, process failure in the end. However, the accumulation of VFAs observed at these conditions will also open new possibilities for the application of enzymes creating a VFA platform for producing new value-added products beside or instead of producing biogas.

\section{Acknowledgements}

This work was developed as part of Pinheiro, V.E. sandwich doctorate at Borås University (Sweden) with the fellowship from CAPES (Coordenação de Aperfeiçoamento de Pessoal de Nível Superior) PRINT - n 41/2017 (Process 88887.368240/2019-00). This work was also supported by Fundação de Amparo à Pesquisa do Estado de São Paulo (FAPESP 2014/50884-5; 2018/07522-6), and CNPq (Conselho Nacional de Desenvolvimento Científico e Tecnológico) - Processes 142139/2017-3; 301963/2017-7; 465319/2014-9.

\section{Conflict of interest}

The authors report no conflicts of interest. The authors alone are responsible for the content and writing of the manuscript.

\section{References}

1. Bocci E, Di Carlo A, McPhail SJ, Gallucci K, Foscolo PU, Moneti M, Villarini M, Carlini M. Biomass to fuel cells state of the art: A review of the most innovative technology solutions. International journal of hydrogen energy 39:21876-21895 (2014). 
2. Wainaina S, Lukitawesa, Awasthi KM, Taherzadeh MJ. Bioengineering of anaerobic digestion for volatile fatty acids, hydrogen or methane production: a critical review. Bioengineered 10:437-458 (2019).

3. Deublein D and Steinhauser A. Biogas from waste and renewable resources: an introduction. John Wiley \& Sons (2011).

4. Ren Y, Yu M, Wu C, Wang Q, Gao M, Huang Q, Liu Y. A comprehensive review on food waste anaerobic digestion: Research updates and tendencies. Bioresource technology 247:1069-1076 (2018).

5. Schattauer A, Abdoun E, Weiland P, Plöchl M, Heiermann M. Abundance of trace elements in demonstration biogas plants. Biosystems engineering 108:57-65 (2011).

6. Zhang Q, Chen J and Wang T. Effects of nitrilotriacetic acid on anaerobic co-digestion of food waste and sludge. Waste and Biomass Valorization 9:1731-1734 (2018).

7. Barnea J and Schlegel HG. Microbial Energy Conversion: The Proceedings of a Seminar Sponsored by the UN Institute for Training and Research (UNITAR) and the Ministry of Research and Ministry for Research and Technology of the Federal Republic of Germany Held in Göttingen, October 1976. Elsevier (2013).

8. Buswell A and Mueller H. Mechanism of methane fermentation. Industrial \& Engineering Chemistry 44:550-552 (1952).

9. Ministério. Brasil institui Política Nacional dos Biocombustíveis (RenovaBio). http://www.mme.gov.br/web/guest/todas-as-noticias/-

/asset_publisher/pdAS9IcdBICN/content/brasil-institui-politica-nacional-dosbiocombustiveis-renovabio-

/pop_up?_101_INSTANCE_pdAS9IcdBICN_viewMode=print\&_101_INSTANCE_pdAS9Ic dBICN_languageId=pt_BR2017[accessed 12-05-2021]

10. CIBIOGÁS. Nota Técnica: Nº 002/2010 - Panorama do Biogás no Brasil em 2019. https://biblioteca.cibiogas.org/biblioteca/notatecnica/pdf/panorama-do-biogas-no-brasil-em2019.pdf2020[accessed 12-05-2021]

11. Allen E and Valdes C. Brazil's corn industry and the effect on the seasonal pattern of US corn exports. United States Department of Agriculture, Economic Research Service (2016).

12. CONAB. Perspectives for the Brazilian grain harvest 2020/21. In: Ministry of agriculture las, (ed.). www.conab.gov.br: Conab - Companhia Nacional de Abastecimento (2021).

13. Gomes JR. Viewpoint: Brazil 2020-21 corn outlook uncertain. Argus Media (2020).

14. Seppälä M, Pyykkönen V, Väisänen A, Rintala J. Biomethane production from maize and liquid cow manure - Effect of share of maize, post-methanation potential and digestate characteristics. Fuel 107: 209-216 (2013).

15. Amon T, Amon B, Kryvoruchko V, Zollitsch W, Mayer K, Gruber L. Biogas production from maize and dairy cattle manure - influence of biomass composition on the methane yield. Agriculture, Ecosystems \& Environment 118: 173-182 (2007).

16. Amin FR, Khalid H, Zhang H, Rahman S, Zhang R, Liu G, Chen C. Pretreatment methods of lignocellulosic biomass for anaerobic digestion. Amb Express 7:1-12 (2017).

17. Patinvoh RJ, Osadolor OA, Chandolias K, Horváth IS, Taherzadeh MJ. Innovative pretreatment strategies for biogas production. Bioresource technology 224:13-24 (2017).

18. Wagner AO, Lackner N, Mutschlechner M, Prem EM, Markt R, Illmer P. Biological pretreatment strategies for second-generation lignocellulosic resources to enhance biogas production. Energies 11:1797 (2018).

19. Pasin TM, Almeida PZ, Scarcella ASA, Infane JC, Polizeli MLTM. Bioconversion of agroindustrial residues to second-generation bioethanol. Biorefinery of Alternative Resources: Targeting Green Fuels and Platform Chemicals. Springer pp.23-47 (2020).

20. Lima MS, Damasio ARL, Crnkovic PM, Pinto MR, Silva AM, Silva JC, Segato F, Lucas RC, Jorge JA, Polizeli MLTM. Co-cultivation of Aspergillus nidulans recombinant strains 
produces an enzymatic cocktail as alternative to alkaline sugarcane bagasse pretreatment. Frontiers in Microbiology 7:583 (2016).

21. Michelin M, Polizeli MLTM, Ruzene DS, Silva DP, Vicente AA, Jorge JA, Terenzi HF, Teixeira JA. Xylanase and $\beta$-xylosidase production by Aspergillus ochraceus: new perspectives for the application of wheat straw autohydrolysis liquor. Applied biochemistry and biotechnology 166:336-347 (2012).

22. Michelin M, Ruíz HA, Silva DP, Ruzene DS, Teixeira J, Polizeli MLTM. Cellulose from lignocellulosic waste. In Ramawat KG, Mérillon JM. Polysaccharides - Bioactivity and Biotechnology, Berlin: Springer International Publishing pp.1-33 (2015). ISBN: 978-3-31903751-6.

23. Michelin M, Ximenes E, Polizeli MLTM, Ladisch MR. Effect of phenolic compounds from pretreated sugarcane bagasse on cellulolytic and hemicellulolytic activities. Bioresource technology 199:275-278 (2016).

24. Polizeli MLTM, Somera AF, Lucas RC, Nozawa MSF, Michelin M. Enzymes involved in the biodegradation of sugarcane biomass: challenges and perspectives. Advances of Basic Science for Second Generation Bioethanol from Sugarcane. Springer, pp.55-79 (2017).

25. Mendes AA, Pereira EB, Furigo Jr A, Castro HFD. Anaerobic biodegradability of dairy wastewater pretreated with porcine pancreas lipase. Brazilian Archives of Biology and Technology 53:1279-1284 (2010).

26. Valladão A, Torres A, Freire D, Cammarota M. Profiles of fatty acids and triacylglycerols and their influence on the anaerobic biodegradability of effluents from poultry slaughterhouse. Bioresource Technology 102:7043-7050 (2011).

27. Soares JL, Cammarota MC, Gutarra MLE, Volschan I. Reduction of scum accumulation through the addition of low-cost enzymatic extract in the feeding of high-rate anaerobic reactor. Water Science and Technology 80:67-74 (2019).

28. Wainaina S, Kisworini AD, Fanani M, Wikandari R, Millati R, Niklasson C, Taherzadeh MJ. Utilization of food waste-derived volatile fatty acids for production of edible Rhizopus oligosporus fungal biomass. Bioresource technology 310:123444 (2020).

29. Robles G, Nair RB, Kleinsteuber S, Nikolausz M, Horváth IS. Biogas production: microbiological aspects. Biogas. Springer pp.163-198 (2018).

30. Wang P, Wang H, Qiu Y, Ren L, Jiang B. Microbial characteristics in anaerobic digestion process of food waste for methane production - A review. Bioresource technology 248:29-36 (2018).

31. Mojović L, Nikolić S, Rakin M, Vukasinović M. Production of bioethanol from corn meal hydrolyzates. Fuel 85:1750-1755 (2006).

32. Kangle K, Kore S, Kore V, Kulkarni G. Recent trends in anaerobic codigestion: a review. Universal Journal of Environmental Research and Technology 2:210-219 (2012).

33. Rabii A, Aldin S, Dahman Y, Elbeshbishy E. A review on anaerobic co-digestion with a focus on the microbial populations and the effect of multi-stage digester configuration. Energies 12:1106 (2019).

34. Cornell M, Banks C and Heaven S. Effect of increasing the organic loading rate on the codigestion and mono-digestion of cattle slurry and maize. Water Science and Technology 66:2336-2342 (2012).

35. Banks $C$ and Heaven S. Impact of the addition of maize on the anaerobic digestion of cattle slurry. 5th IWA International Symposium on Anaerobic Digestion of Solid Wastes and Energy Crops (2008).

36. Garuti M, Langone M, Fabbri C, Piccinini S. Monitoring of full-scale hydrodynamic cavitation pretreatment in agricultural biogas plant. Bioresource technology 247:599-609 (2018). 
37. Kolbl S, Paloczi A, Panjan J, Stres B. Addressing case specific biogas plant tasks: Industry oriented methane yields derived from 5 L Automatic Methane Potential Test Systems in batch or semi-continuous tests using realistic inocula, substrate particle sizes and organic loading. Bioresource technology 153:180-188 (2014).

38. Almeida PZ, Messias JM, Pereira MG, Pinheiro VE, Monteiro LMO, Heinen PR, Cardoso GC, Jorge JA, Polizeli MLTM. Mixture design of starchy substrates hydrolysis by an immobilized glucoamylase from Aspergillus brasiliensis. Biocatalysis and Biotransformation 36:389-395 (2018).

39. Rizzatti A, Jorge J, Terenzi H, Rechia C, Polizeli MLTM. Purification and properties of a thermostable extracellular $\beta$-D-xylosidase produced by a thermotolerant Aspergillus phoenicis. Journal of Industrial Microbiology and Biotechnology 26:156-160 (2001).

40. Hansen TL, Schmidt JE, Angelidaki I, Marca E, Jansen JC, Mosbæk H, Christensen TH. Method for determination of methane potentials of solid organic waste. Waste management 24:393-400 (2004).

41. Teghammar A, Yngvesson J, Lundin M, Taherzadeh MJ, Horváth IS. Pretreatment of paper tube residuals for improved biogas production. Bioresource technology 101:1206-1212 (2010). 42. Miller GL. Use of dinitrosalicylic acid reagent for determination of reducing sugar. Analytical chemistry 31:426-428 (1959).

43. Sluiter A, Ruiz R, Scarlata C, Sluiter J, Templeton D. Determination of extractives in biomass. Laboratory analytical procedure (LAP) 1617 (2005).

44. VDI, Verein Deutcher Ingenieure. Fermentation of organic materials-Characterisation of the substrate, sampling, collection of material data, fermentation tests. Gesellschaft, Energietechnik (2006).

45. HACH-COMPANY. Determination of FOS/TAC Value in Biogas Reactors. Hach Lange GmbH. DOC316.52.93087. www.hach.com46 (2005).

46. Lay J-J, Li Y-Y and Noike T. Effect of moisture content and chemical nature on methane fermentation characteristics of municipal solid wastes. Doboku Gakkai Ronbunshu 1996:101108 (1996).

47. Pinheiro VE, Horváth IS, Lundin M, Polizeli MLTM. Screening and cocktail optimization using experimental mixture design: enzymatic saccharification as a biological pretreatment strategy. Biofuels, Bioproducts and Biorefining (2021). DOI: 10.1002/BBB.2251.

48. Arasaratnam V and Balasubramaniam K. Synergistic action of $\alpha$-amylase and glucoamylase on raw corn. Starch-Stärke 45:231-233 (1993).

49. Kimura A and Robyt JF. Reaction of enzymes with starch granules: kinetics and products of the reaction with glucoamylase. Carbohydrate research 277:87-107 (1995).

50. Brown D, Shi J and Li Y. Comparison of solid-state to liquid anaerobic digestion of lignocellulosic feedstocks for biogas production. Bioresource technology 124:379-386 (2012). 51. Cui Z, Shi J and Li Y. Solid-state anaerobic digestion of spent wheat straw from horse stall. Bioresource technology 102:9432-9437 (2011).

52. Wang Z, Jiang Y, Wang S, Zhang Y, Hu Y, Hu Z-h, Wu G, Zhan X. Impact of total solids content on anaerobic co-digestion of pig manure and food waste: Insights into shifting of the methanogenic pathway. Waste Management 114:96-106 (2020).

53. Kaiser F. Untersuchungen der wirkung von MethaPlus S100 auf die vergärung von maissilage in laborfermentern. Report of Bayerische Landeanstalt für Landwirtschaft (2004). 54. Oliva-Merencio D, Pereda-Reyes I, Schimpf U, Koehler S, Silva AJ. Cellulase effect on anaerobic digestion of maize silage under discontinuous operation. Engenharia Agrícola 35:951-958 (2015).

55. Arnell M, Astals S, Åmand L, Batstone DJ, Jensen PD, Jeppsson U. Modelling anaerobic co-digestion in Benchmark Simulation Model No. 2: parameter estimation, substrate characterisation and plant-wide integration. Water Research 98: 138-146 (2016). 
56. Bora BJ, Saha UK, Chatterjee S, Veer V. Effect of compression ratio on performance, combustion and emission characteristics of a dual fuel diesel engine run on raw biogas. Energy conversion and management 87:1000-1009 (2014).

57. Kim S-H, Han S-K and Shin H-S. Feasibility of biohydrogen production by anaerobic codigestion of food waste and sewage sludge. International Journal of Hydrogen Energy 29:16071616 (2004).

58. Pavan P, Bolzonella D, Battistoni E, Cecchi F. Anaerobic co-digestion of sludge with other organic wastes in small wastewater treatment plants: an economic considerations evaluation. Water Science and Technology 56: 45-53 (2007).

59. Stroot PG, McMahon KD, Mackie RI, Raskin L. Anaerobic codigestion of municipal solid waste and biosolids under various mixing conditions - I. Digester performance. Water research 35:1804-1816 (2001).

60. Zaher U, Li R, Jeppsson U, Steyer J.-P, Chen S. GISCOD: general integrated solid waste co-digestion model. Water research 43:2717-2727 (2009).

61. Cook SM, Skerlos SJ, Raskin L, Love NG. A stability assessment tool for anaerobic codigestion. Water research 112: 19-28 (2017).

62. Song $\mathrm{Z}$ and Zhang $\mathrm{C}$. Anaerobic codigestion of pretreated wheat straw with cattle manure and analysis of the microbial community. Bioresource technology 186:128-135 (2015).

63. Tasnim F, Iqbal SA and Chowdhury AR. Biogas production from anaerobic co-digestion of cow manure with kitchen waste and Water Hyacinth. Renewable Energy 109:434-439 (2017). 64. Khayum N, Anbarasu S and Murugan S. Biogas potential from spent tea waste: A laboratory scale investigation of co-digestion with cow manure. Energy 165:760-768 (2018).

65. Aboudi K, Álvarez-Gallego CJ and Romero-García LI. Evaluation of methane generation and process stability from anaerobic co-digestion of sugar beet by-product and cow manure. Journal of bioscience and bioengineering 121:566-572 (2016).

66. Hassan M, Ding W, Umar M, Rasool G. Batch and semi-continuous anaerobic co-digestion of goose manure with alkali solubilized wheat straw: a case of carbon to nitrogen ratio and organic loading rate regression optimization. Bioresource technology 230:24-32 (2017).

67. Li Y, Li Y, Zhang D, Li G, Lu J, Li S. Solid state anaerobic co-digestion of tomato residues with dairy manure and corn stover for biogas production. Bioresource technology 217:50-55 (2016).

68. Li K, Liu R, Cui S, Yu Q, Ma R. Anaerobic co-digestion of animal manures with corn stover or apple pulp for enhanced biogas production. Renewable Energy 118:335-342 (2018).

69. Akyol Ç, Ozbayram EG, Ince O, Kleinsteuber S, Ince B. Anaerobic co-digestion of cow manure and barley: Effect of cow manure to barley ratio on methane production and digestion stability. Environmental Progress \& Sustainable Energy 35:589-595 (2016).

70. Li W, Siddhu MAH, Amin FR, He Y, Zhang R, Liu G, Chen C. Methane production through anaerobic co-digestion of sheep dung and waste paper. Energy Conversion and Management 156:279-287 (2018).

71. Callaghan F, Wase D, Thayanithy K, Forster C. Continuous co-digestion of cattle slurry with fruit and vegetable wastes and chicken manure. Biomass and bioenergy 22: 71-77 (2002). 72. Murto M, Björnsson L and Mattiasson B. Impact of food industrial waste on anaerobic codigestion of sewage sludge and pig manure. Journal of environmental management 70:101-107 (2004).

73. Patinvoh RJ, Lundin M, Taherzadeh MJ, Horváth IS. Dry anaerobic co-digestion of citrus wastes with keratin and lignocellulosic wastes: batch and continuous processes. Waste and Biomass Valorization 11: 423-434 (2020).

74. Ferrer I, Vázquez F and Font X. Long term operation of a thermophilic anaerobic reactor: process stability and efficiency at decreasing sludge retention time. Bioresource technology 101:2972-2980 (2010). 
75. Schoen MA, Sperl D, Gadermaier M, Goberna M, Franke-Whittle I, Insam H, Ablinger J, Wett B. Population dynamics at digester overload conditions. Bioresource technology 100:5648-5655 (2009).

76. Lukitawesa, Patinvoh RJ, Millati R, Horváth IS, Taherzadeh MJ. Factors influencing volatile fatty acids production from food wastes via anaerobic digestion. Bioengineered; 11: 39-52 (2020).

77. Gerardi MH. The microbiology of anaerobic digesters. John Wiley \& Sons (2003).

78. Switzenbaum MS, Giraldo-Gomez E and Hickey RF. Monitoring of the anaerobic methane fermentation process. Enzyme and Microbial Technology 12: $722-730$ (1990).

79. Zhang C, Su H, Baeyens J, Tan T. Reviewing the anaerobic digestion of food waste for biogas production. Renewable and Sustainable Energy Reviews 38: 383-392 (2014).

80. Izumi K, Okishio Y-k, Nagao N, Niwa C, Yamamoto S, Toda T. Effects of particle size on anaerobic digestion of food waste. International biodeterioration \& biodegradation 64: 601608 (2010).

81. Bocher BT, Cherukuri K, Maki J, Johnson M, Zitomer D. Relating methanogen community structure and anaerobic digester function. Water research 70:425-435 (2015).

82. Lins P, Reitschuler C and Illmer P. Methanosarcina spp., the key to relieve the start-up of a thermophilic anaerobic digestion suffering from high acetic acid loads. Bioresource technology 152: 347-354 (2014).

83. Conklin A, Stensel HD and Ferguson J. Growth kinetics and competition between Methanosarcina and Methanosaeta in mesophilic anaerobic digestion. Water Environment Research 78: 486-496 (2006).

84. Ferraro A, Massini G, Miritana VM, Signorini A, Race M, Fabbricino M. A simplified model to simulate bioaugmented anaerobic digestion of lignocellulosic biomass: Biogas production efficiency related to microbiological data. Science of The Total Environment 691:885-895 (2019).

85. Beyer E, Neumann J, Awe D, Pfeiffer W, Tränckner J. Anaerobic treatment of residuals from tanks transporting food and fodder. Environmental Science and Pollution Research 26:32698-32707 (2019).

86. Li L, Peng X, Wang X, Wu D. Anaerobic digestion of food waste: A review focusing on process stability. Bioresource technology 248:20-28 (2018).

87. Xing B-S, Cao S, Han Y, Wen J, Zhang K, Wang XC. Stable and high-rate anaerobic codigestion of food waste and cow manure: Optimisation of start-up conditions. Bioresource Technology 123195 (2020).

88. Xu H, Yun S, Wang C, Wang Z, Han F, Jia B, Chen J, Li B. Improving performance and phosphorus content of anaerobic co-digestion of dairy manure with aloe peel waste using vermiculite. Bioresource Technology 301:122753 (2020).

89. Zhou J, Zhang Y, Khoshnevisan B, Duan N. Meta-analysis of anaerobic co-digestion of livestock manure in last decade: Identification of synergistic effect and optimization synergy range. Applied Energy 282:116128 (2021).

90. Dai X, Chen Y, Zhang D, Yi J. High-solid anaerobic co-digestion of sewage sludge and cattle manure: the effects of volatile solid ratio and pH. Scientific reports 6:35194 (2016).

91. Li Y, Zhao J, Krooneman J, Euverink GJW. Strategies to boost anaerobic digestion performance of cow manure: Laboratory achievements and their full-scale application potential. Science of The Total Environment 142940 (2020).

92. IBGE. Produção da Pecuária Municipal 2019. In: Diretoria de Pesquisas CdA, Pesquisa da Pecuária Municipal 2019., https://biblioteca.ibge.gov.br/visualizacao/periodicos/84/ppm_2019_v47_br_informativo.pdf: Instituto Brasileiro de Geografia e Estatística (2019)[accessed 12-05-2021] 
93. Li D, Liu S, Mi L, Yu Q, Ma R. Effects of feedstock ratio and organic loading rate on the anaerobic mesophilic co-digestion of rice straw and cow manure. Bioresource Technology 189: 319-326 (2015).

94. Montoro S, Lucas Jr J, Santos D, Costa M. Anaerobic co-digestion of sweet potato and dairy cattle manure: a technical and economic evaluation for energy and biofertilizer production. Journal of Cleaner Production 226:1082-1091 (2019).

95. Brulé M, Oechsner H, Fischer L, Lemmer A, Jungbluth T. Effect of enzymatic substrate preparation on the biogas yield of energy crops. Landtechnik 62:414-415 (2007).

96. Binner R, Menath V, Huber H, Thomm M, Bischof F, Schmack D, Reuter M. Comparative study of stability and half-life of enzymes and enzyme aggregates implemented in anaerobic biogas processes. Biomass conversion and biorefinery 1:1-8 (2011).

97. Garcia NH, Benedetti $\mathrm{M}$ and Bolzonella D. Effects of enzymes addition on biogas production from anaerobic digestion of agricultural biomasses. Waste and Biomass Valorization 10:3711-3722 (2019). 


\section{Figure Legends}

Figure 1. The concentration of RS $(\mu \mathrm{mol} / 11 \mathrm{~mL})$ released during hydrolysis of cornmeal after $48 \mathrm{~h}$, at $45^{\circ} \mathrm{C}$ and $100 \mathrm{rpm}$, at different proportions of crude enzyme extract added.

Figure 2. Accumulated methane production (NmL/g VS) of different substrates obtained during batch $\mathrm{AD}$ assays performed at $\mathrm{S} / \mathrm{I}$ ratio of 0.5 .

Figure 3. Experimental results $(\mathrm{pH}, \mathrm{VFA} / \mathrm{TA}$ ratio, and daily methane production expressed in $\mathrm{NmL} \mathrm{CH}_{4}$ /day) obtained following up the performance at the semi-continuous operation during anaerobic digestion of $(\mathbf{A})$ cornmeal $(\rightarrow-\mathrm{C} 1$ and $\cdots \cdot \mathrm{C} 2),(\mathbf{B})$ cornmeal with the addition of crude enzyme extract $(-\mathrm{Ce} 1$ and $\cdots \cdot \mathrm{Ce} 2)$ and $(\mathbf{C})$ co-digestion of cornmeal and cow manure $(-\mathrm{Co} 1$ and $\cdot \cdot \mathrm{O} \cdot \mathrm{Co} 2)$ 
Table 1. Experimental set up for the batch anaerobic digestion assays performed at S/I ratio of 1:2 (g VS basis).

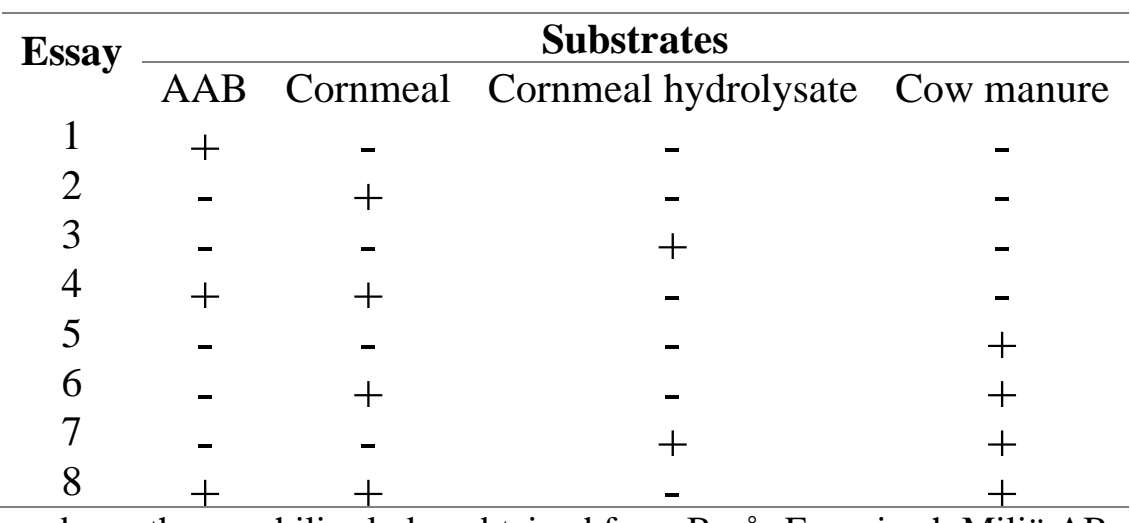

The inoculum used was thermophilic sludge obtained from Borås Energi och Miljö AB.

Table 2. Total solids (TS) and Volatile Solid (VS) content of the substrates as well as inoculum used in the investigations

\begin{tabular}{cccc}
\hline Material & TS $(\mathbf{g} / \mathbf{K g})$ & VS $(\mathbf{g} / \mathbf{K g})$ & VS (\%) of TS \\
\hline Cornmeal hydrolysate & $862.76 \pm 4.0$ & $861.69 \pm 4.0$ & 99.88 \\
Cornmeal & $889.8 \pm 3.5$ & $889.8 \pm 3.5$ & 100 \\
Cow Manure & $67.35 \pm 2.0$ & $51.51 \pm 2.0$ & 77 \\
Thermophilic sludge & $37.85 \pm 2.0$ & $24.9 \pm 2.0$ & 65 \\
\hline
\end{tabular}

Table 3. Kinetic data obtained using the Gompertz model

\begin{tabular}{|c|c|c|c|c|}
\hline SUBSTRATE & $\begin{array}{c}\text { HMAX }^{\mathbf{A}} \\
\text { (ML/ G } \\
\text { VS) }\end{array}$ & $\begin{array}{c}\mathbf{R M}^{\mathbf{B}} \\
(\mathbf{M L / G} \mathbf{V S} / \\
\text { DAY) }\end{array}$ & $\Lambda^{\mathrm{C}}(\mathbf{D A Y})$ & $\mathbf{R}^{2}$ \\
\hline $\mathrm{AAB}$ & 64.19 & 5.37 & 4.82 & 0.98 \\
\hline Cornemal & 377.64 & 43.16 & 5.44 & 0.98 \\
\hline Cornmeal hydrolysate & 399.10 & 38.94 & 4.78 & 0.99 \\
\hline Cornmeal hydrolysate $+\mathrm{AAB}$ & 399.34 & 40.39 & 5.51 & 0.99 \\
\hline Cellulose & 373.03 & 33.88 & 6.14 & 0.99 \\
\hline Cow manure & 6.76 & 2.27 & 1.36 & 0.93 \\
\hline Cornmeal + cow manure & 310.23 & 17.75 & 7.95 & 0.97 \\
\hline Cornmeal hydrolysate + cow manure & 383.66 & 15.55 & 14.47 & 0.94 \\
\hline Cornmeal hydrolysate $+\mathrm{AAB}+$ cow manure & 326.26 & 15.84 & 10.48 & 0.95 \\
\hline
\end{tabular}




\section{Figure 1.}

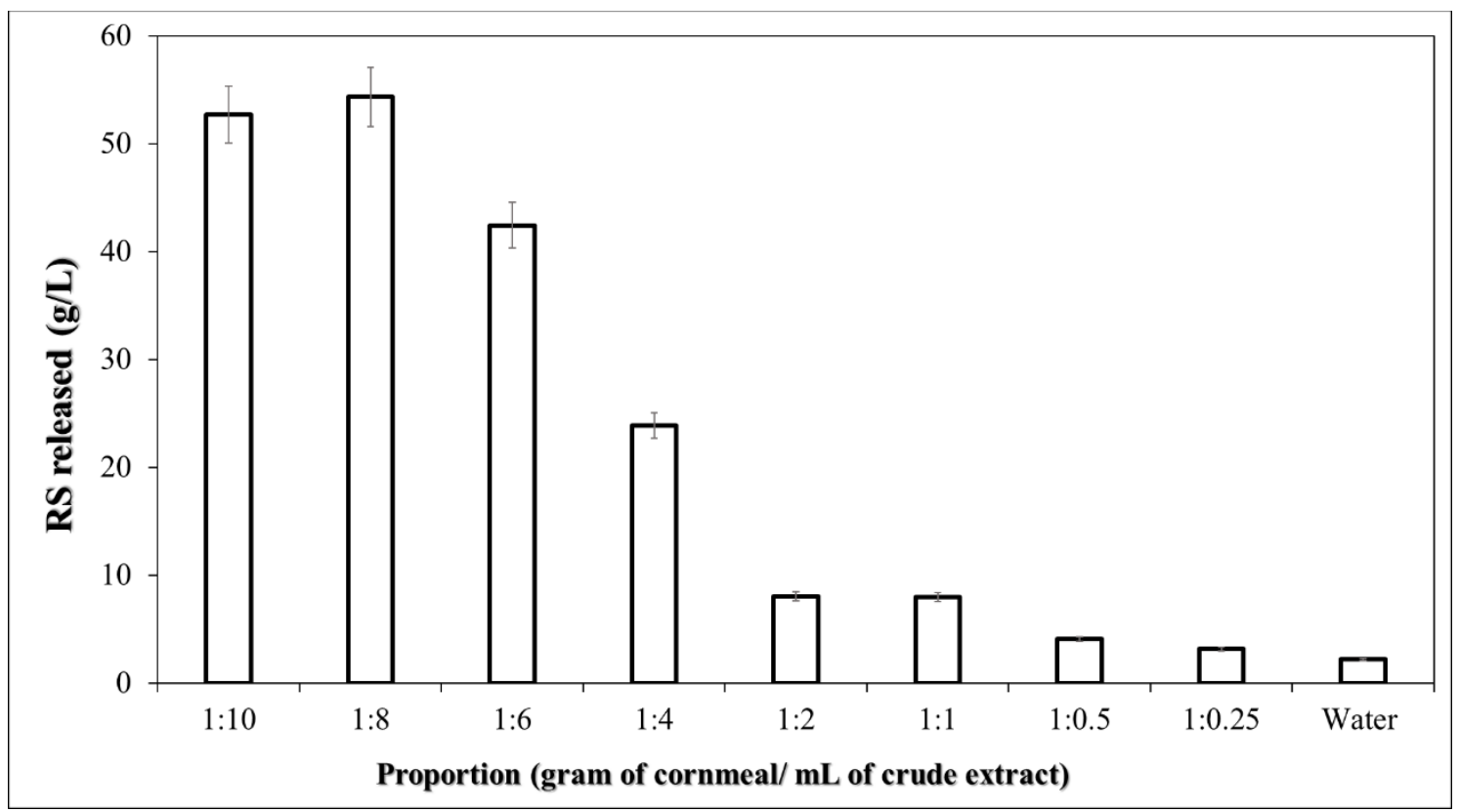

Figure 2.

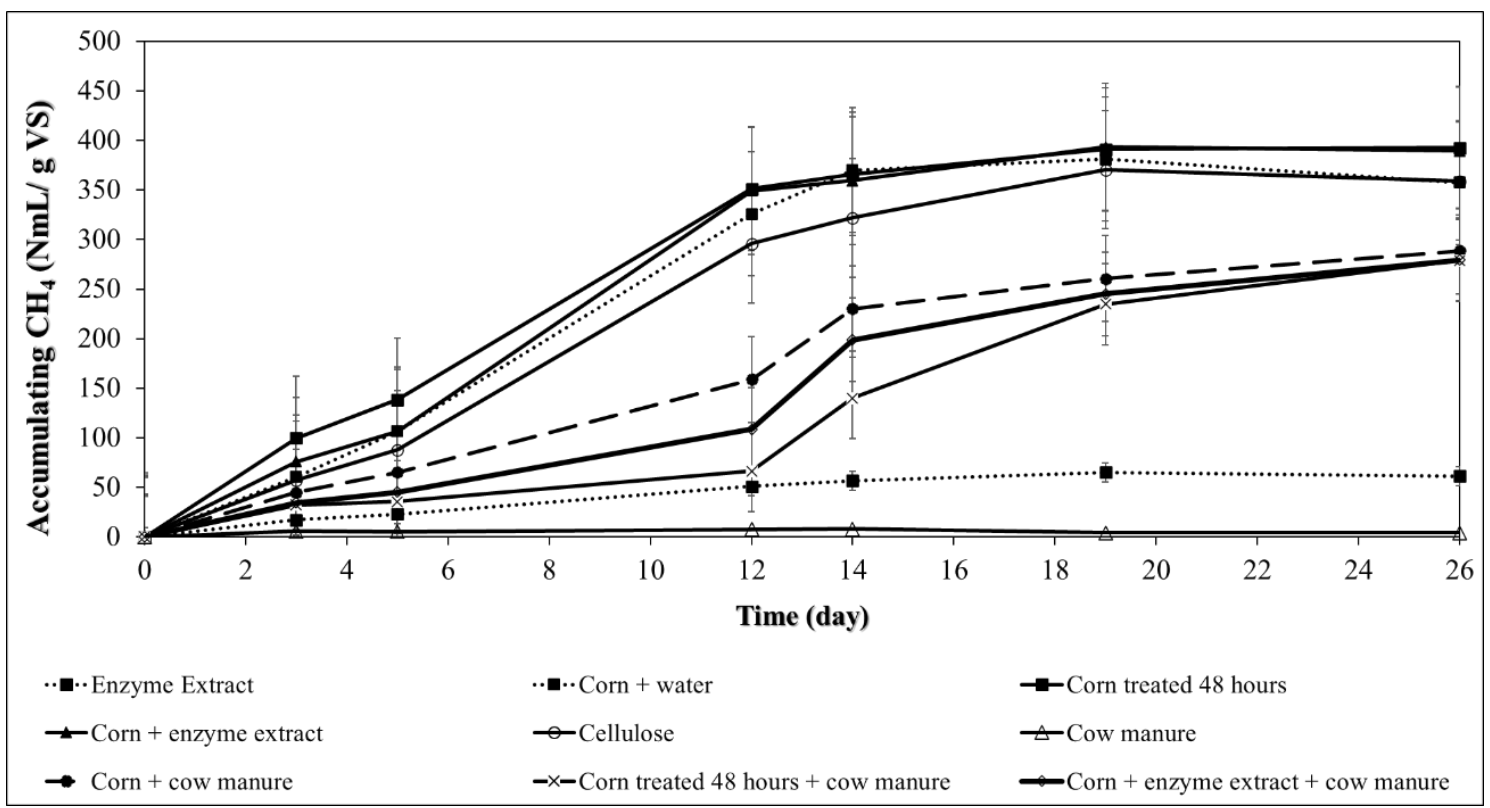




\section{Figure 3.}

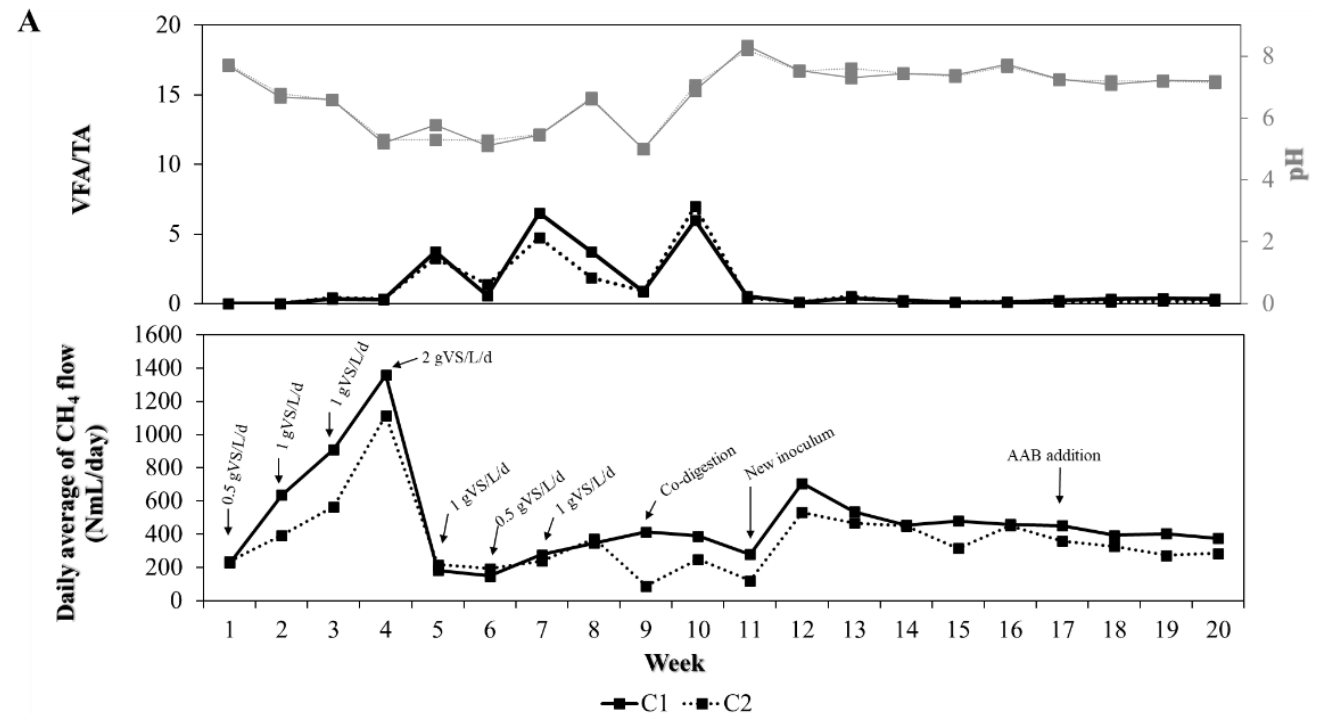

B
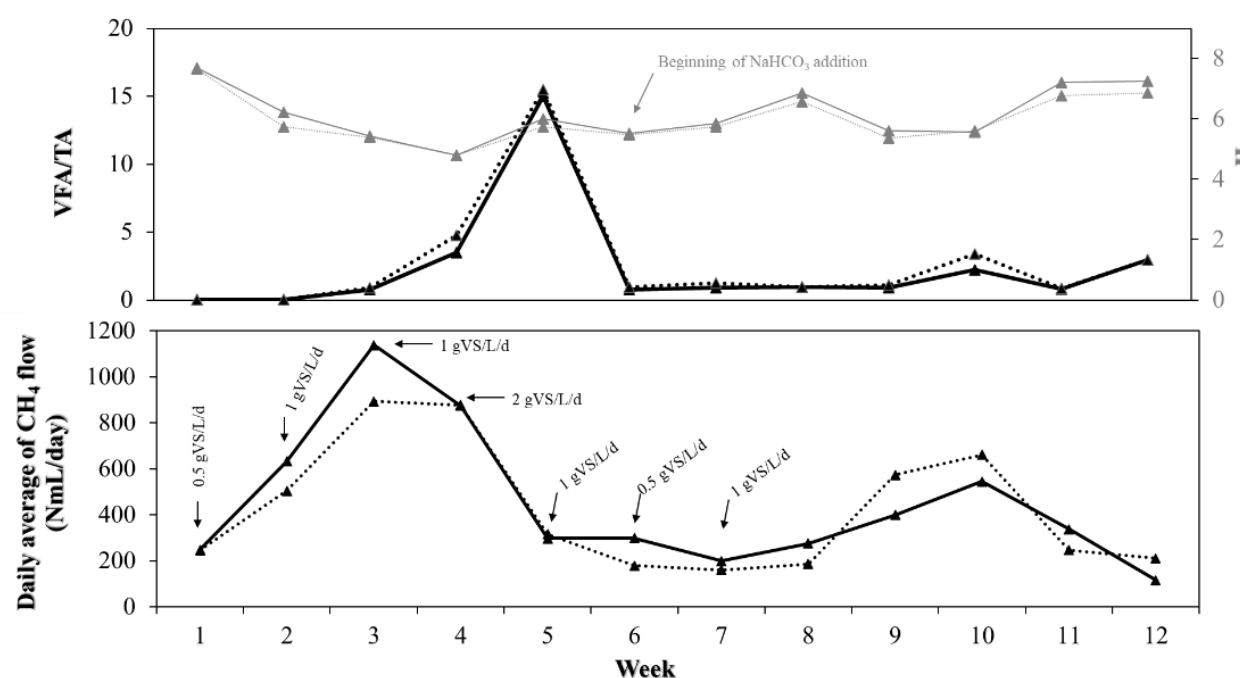

$\leftarrow \mathrm{Ce} 1 \quad \cdots \cdots \cdot \mathrm{Ce} 2$

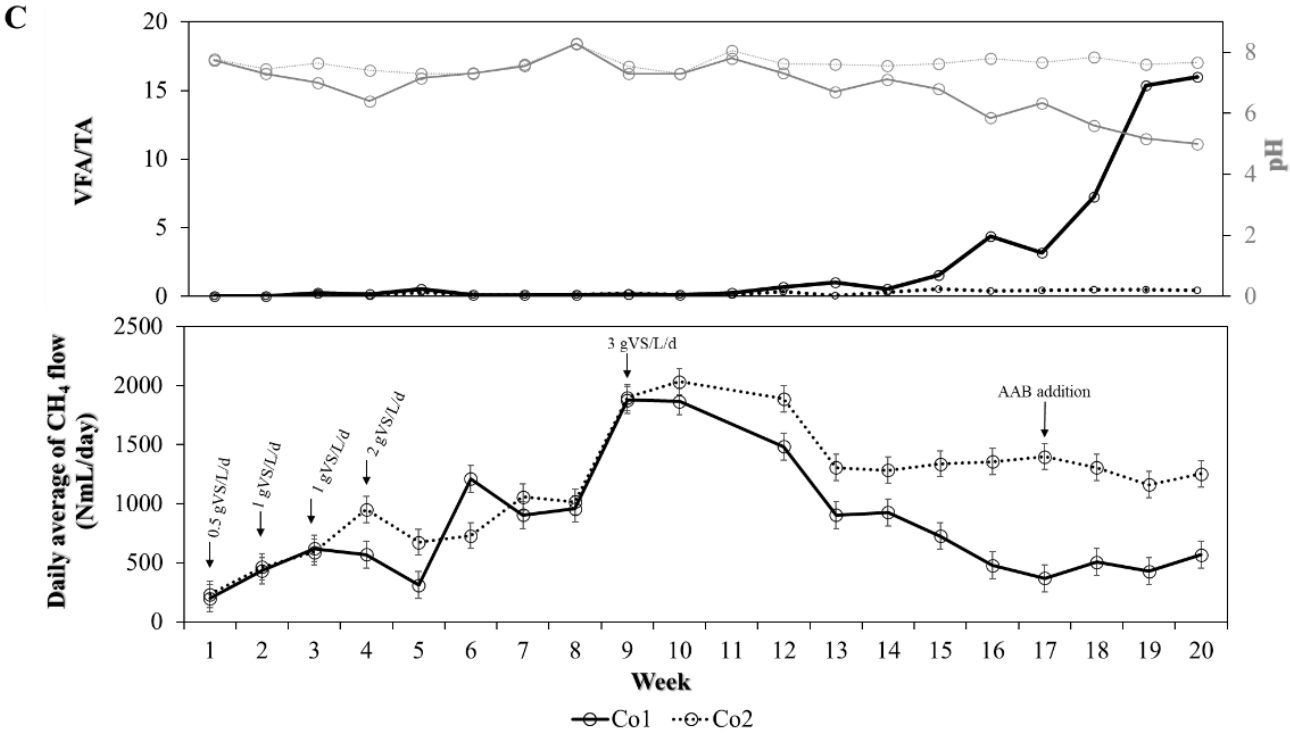

Faculdade de Medicina de Ribeirão Preto, Universidade de São Paulo, Ribeirão Preto, 2021 


\section{Supplementary Material}

Table S1. Experimental set up for substrate addition during semi-continuous operation.

\begin{tabular}{|c|c|c|c|}
\hline WEEK & REACTOR & $\begin{array}{c}\text { OLR } \\
(\mathrm{GVS} / \mathrm{L} / \mathrm{D})\end{array}$ & SUBSTRATE \\
\hline 1 & $\begin{array}{c}\mathrm{C} 1 / \mathrm{C} 2 \\
\mathrm{Ce} 1 / \mathrm{Ce} 2 \\
\mathrm{Co} 1 / \mathrm{Co} 2\end{array}$ & 0.5 & $\begin{array}{c}\text { cornmeal } \\
\text { cornmeal }+\mathrm{AAB}^{\mathrm{a}} \\
\text { cornmeal + cow manure }(1: 1 \mathrm{~g} \text { VS basis })\end{array}$ \\
\hline 2 AND 3 & $\begin{array}{c}\mathrm{C} 1 / \mathrm{C} 2 \\
\mathrm{Ce} 1 / \mathrm{Ce} 2 \\
\mathrm{Co} 1 / \mathrm{Co} 2\end{array}$ & 1.0 & $\begin{array}{c}\text { cornmeal } \\
\text { cornmeal }+\mathrm{AAB}^{\mathrm{a}} \\
\text { cornmeal }+ \text { cow manure }(1: 1 \mathrm{~g} \mathrm{VS} \text { basis })\end{array}$ \\
\hline 4 & $\begin{array}{c}\mathrm{C} 1 / \mathrm{C} 2 \\
\mathrm{Ce} 1 / \mathrm{Ce} 2 \\
\mathrm{Co} 1 / \mathrm{Co} 2\end{array}$ & 2.0 & $\begin{array}{c}\text { cornmeal } \\
\text { cornmeal }+\mathrm{AAB}^{\mathrm{a}} \\
\text { cornmeal }+ \text { cow manure }(1: 1 \mathrm{~g} \text { VS basis })\end{array}$ \\
\hline 5 & $\begin{array}{c}\mathrm{C} 1 / \mathrm{C} 2 \\
\mathrm{Ce} 1 / \mathrm{Ce} 2 \\
\mathrm{Co} 1 / \mathrm{Co} 2\end{array}$ & $\begin{array}{l}1.0 \\
1.0 \\
2.0\end{array}$ & $\begin{array}{c}\text { cornmeal } \\
\text { cornmeal }+\mathrm{AAB}^{\mathrm{a}} \\
\text { cornmeal + cow manure }(1: 1 \mathrm{~g} \text { VS basis })\end{array}$ \\
\hline 6 & $\begin{array}{c}\mathrm{C} 1 / \mathrm{C} 2 \\
\mathrm{Ce} 1 / \mathrm{Ce} 2 \\
\mathrm{Co} 1 / \mathrm{Co} 2\end{array}$ & $\begin{array}{l}0.5 \\
0.5 \\
2.0\end{array}$ & $\begin{array}{c}\text { cornmeal } \\
\text { cornmeal }+\mathrm{AAB}^{\mathrm{a}} \\
\text { cornmeal }+ \text { cow manure }(1: 1 \mathrm{~g} \text { VS basis })\end{array}$ \\
\hline 7 AND 8 & $\begin{array}{c}\mathrm{C} 1 / \mathrm{C} 2 \\
\mathrm{Ce} 1 / \mathrm{Ce} 2 \\
\mathrm{Co} 1 / \mathrm{Co} 2\end{array}$ & $\begin{array}{l}1.0 \\
1.0 \\
2.0\end{array}$ & $\begin{array}{c}\text { cornmeal } \\
\text { cornmeal }+\mathrm{AAB}^{\mathrm{a}} \\
\text { cornmeal }+ \text { cow manure }(1: 1 \mathrm{~g} \text { VS basis })\end{array}$ \\
\hline 9 AND 10 & $\begin{array}{c}\mathrm{C} 1 / \mathrm{C} 2 \\
\mathrm{Ce} 1 / \mathrm{Ce} 2 \\
\mathrm{Co} 1 / \mathrm{Co} 2\end{array}$ & $\begin{array}{l}1.0 \\
1.0 \\
3.0\end{array}$ & $\begin{array}{c}\text { cornmeal + cow manure (1:1 g VS basis) } \\
\text { cornmeal + } \mathrm{AAB}^{\mathrm{a}} \\
\text { cornmeal + cow manure (1:1 g VS basis })\end{array}$ \\
\hline 11 & $\begin{array}{c}\mathrm{C} 1 / \mathrm{C} 2 \\
\mathrm{Ce} 1 / \mathrm{Ce} 2 \\
\mathrm{Co} 1 / \mathrm{Co} 2\end{array}$ & $\begin{array}{l}1.0 \\
1.0 \\
3.0\end{array}$ & $\begin{array}{c}\text { cornmeal + } \\
\text { cow manure }(1: 1 \text { g VS basis })^{\mathbf{b}} \\
\text { cornmeal + AAB }{ }^{\text {a }} \\
\text { cornmeal + cow manure }(1: 1 \text { g VS basis })\end{array}$ \\
\hline 12 & $\begin{array}{c}\mathrm{C} 1 / \mathrm{C} 2 \\
\mathrm{Ce} 1 / \mathrm{Ce} 2 \\
\mathrm{Co} 1 / \mathrm{Co} 2\end{array}$ & $\begin{array}{l}1.0 \\
1.0 \\
3.0\end{array}$ & $\begin{array}{c}\text { cornmeal + cow manure (1:1 g VS basis) } \\
\text { cornmeal + } \mathrm{AAB}^{\mathrm{a}} \\
\text { cornmeal + cow manure (1:1 g VS basis })\end{array}$ \\
\hline $\begin{array}{l}13,14, \\
15,16\end{array}$ & $\begin{array}{c}\mathrm{C} 1 / \mathrm{C} 2 \\
\mathrm{Co} 1 / \mathrm{Co} 2\end{array}$ & $\begin{array}{l}1.0 \\
3.0\end{array}$ & $\begin{array}{l}\text { cornmeal + cow manure (1:1 g VS basis) } \\
\text { cornmeal + cow manure (1:1 g VS basis) }\end{array}$ \\
\hline $\begin{array}{l}17,18 \\
19,20\end{array}$ & $\begin{array}{c}\mathrm{C} 1 / \mathrm{C} 2 \\
\mathrm{Co} 1 / \mathrm{Co} 2\end{array}$ & $\begin{array}{l}1.0 \\
3.0\end{array}$ & $\begin{array}{l}\text { cornmeal + cow manure (1:1 g VS basis })+\mathrm{AAB}^{\mathrm{a}} \\
\text { cornmeal + cow manure (1:1 g VS basis })+\mathrm{AAB}^{\mathrm{a}}\end{array}$ \\
\hline
\end{tabular}

${ }^{a}$ Enzyme extract added once a week following 10\% of the daily loading in each reactor.

${ }^{\mathrm{b}}$ Replacement of culture medium (1L) for new fresh inoculum 


\section{Figure S1.}

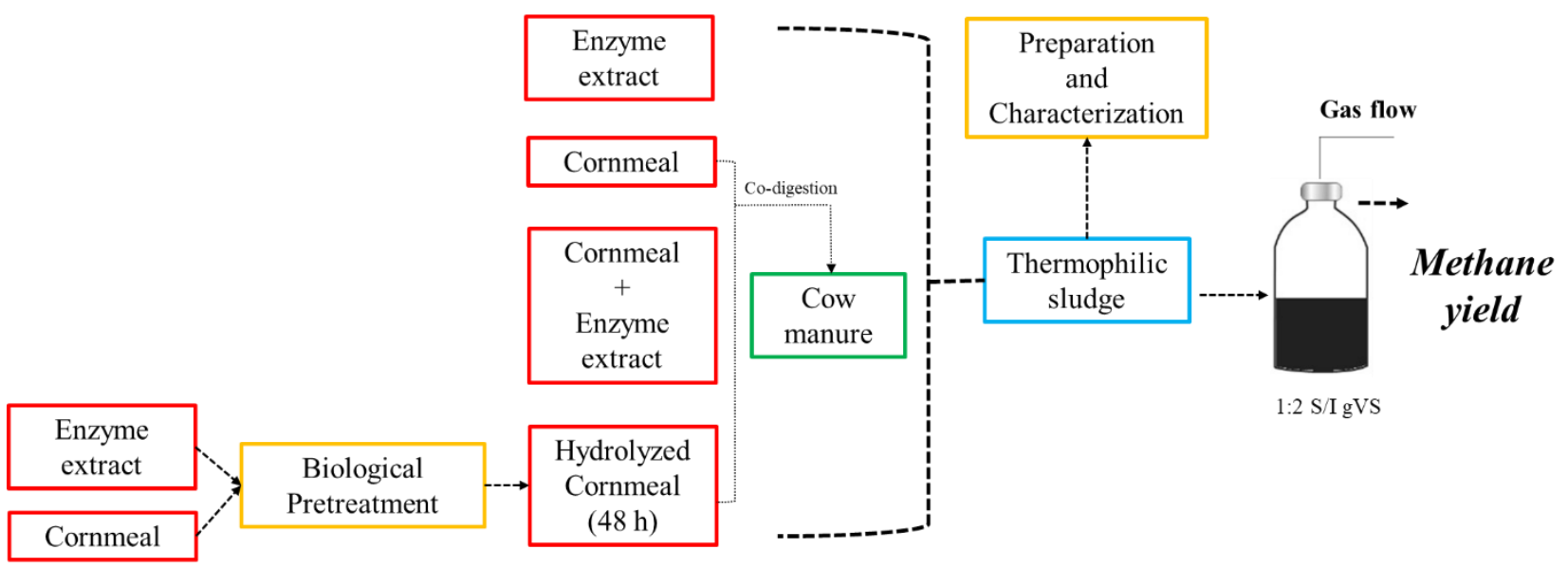

Figure S1. Schematic diagram showing the experimental set up for the batch digestion assays at a substrate to inoculum ratio (S/I) of 1:2. 